OH

70

U6211279

$1085 X$

CRLSSI 

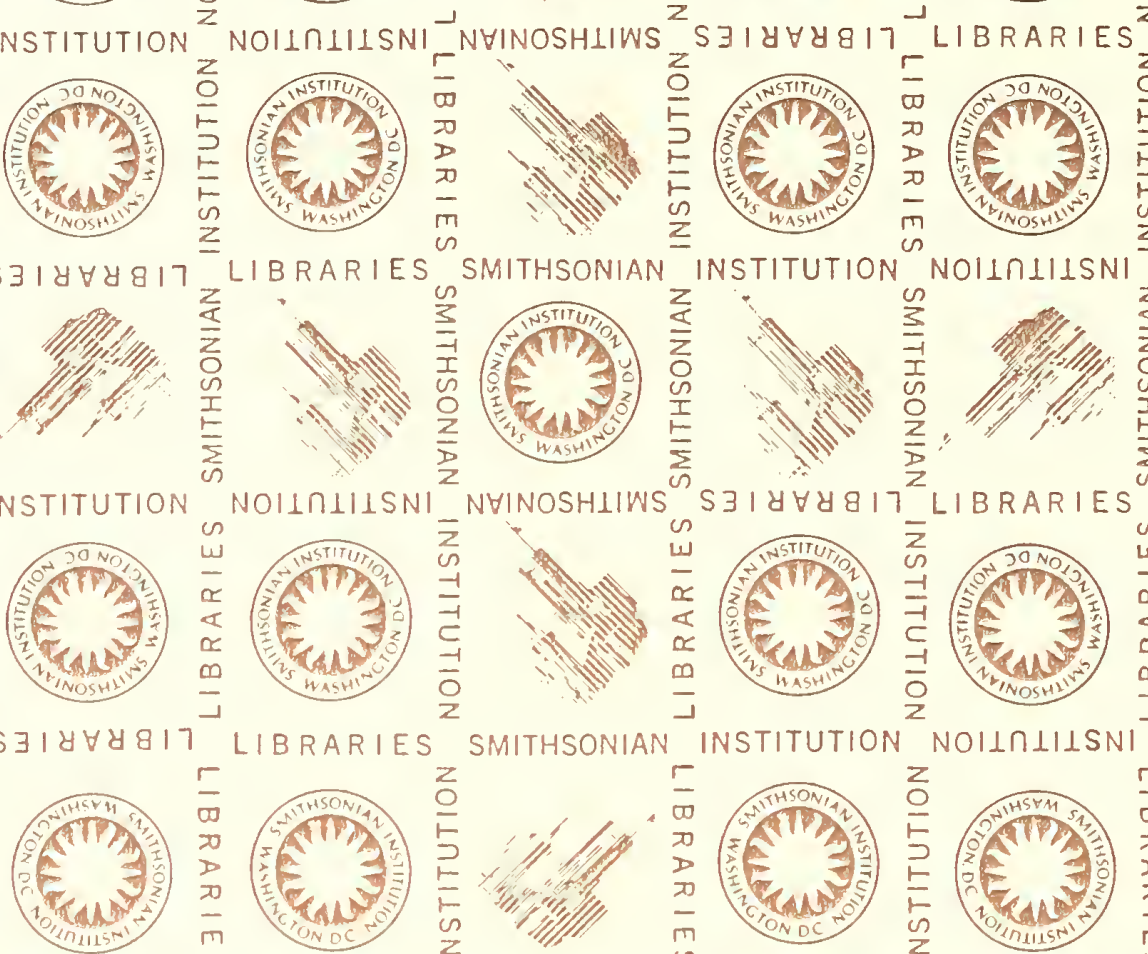

NSTITUTION
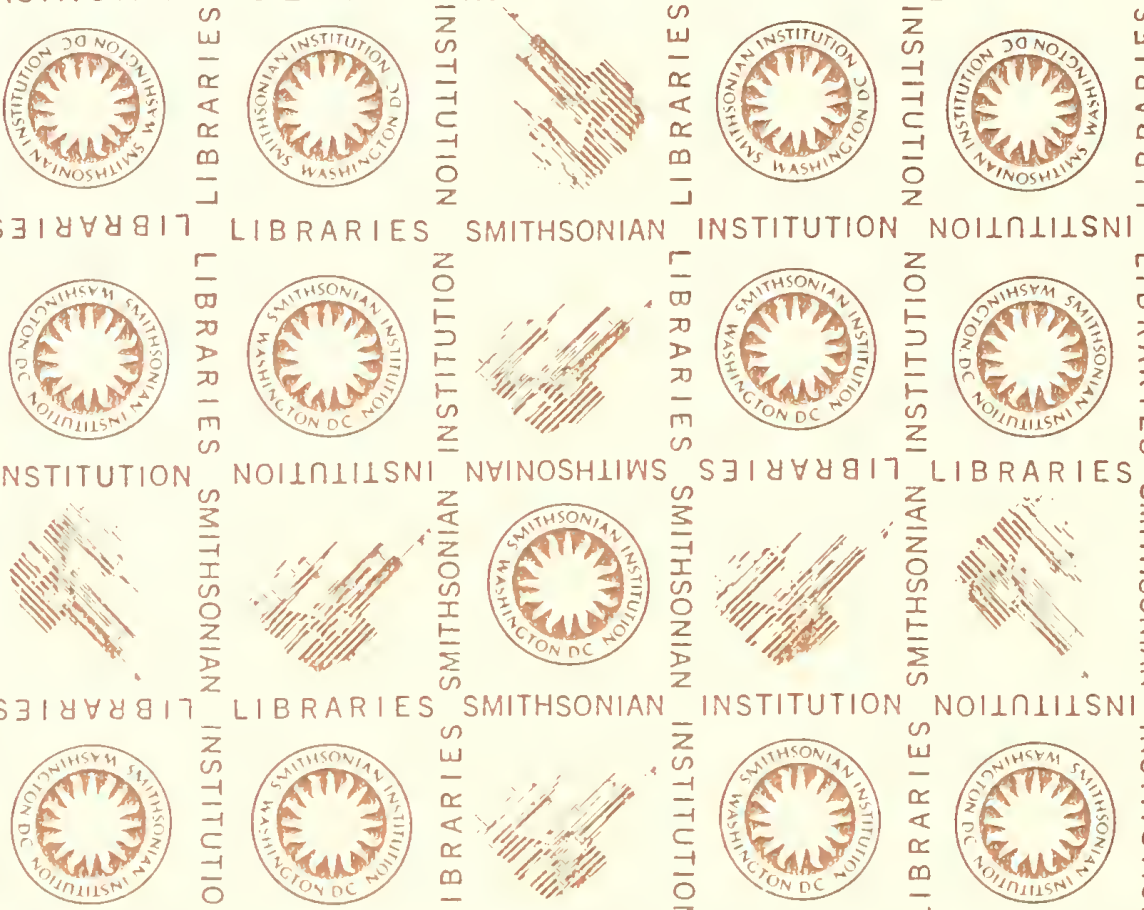
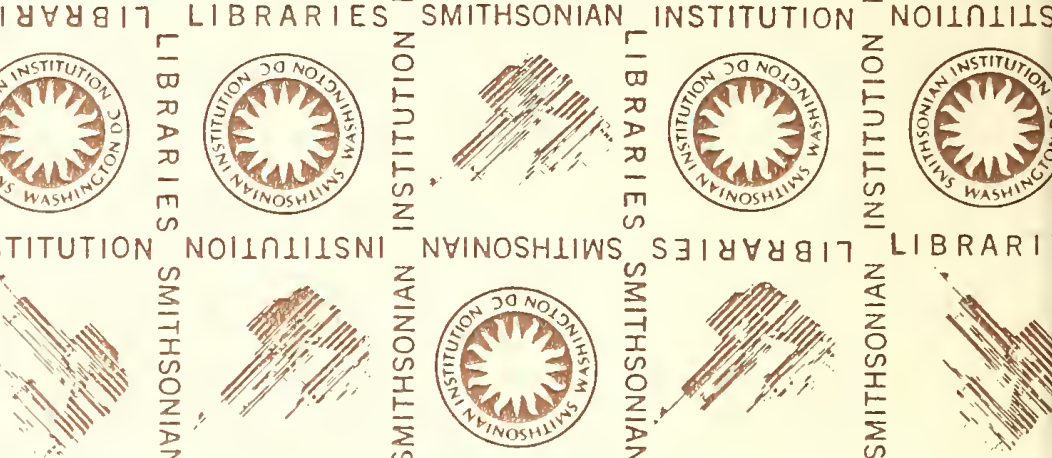

LIBRAR I
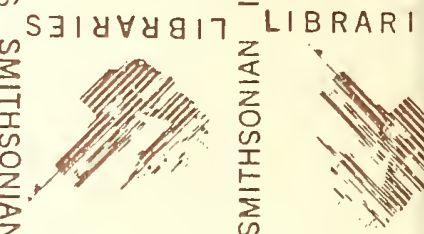

NOSH
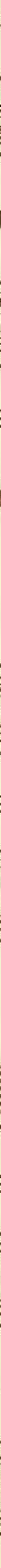

LI BRAR I
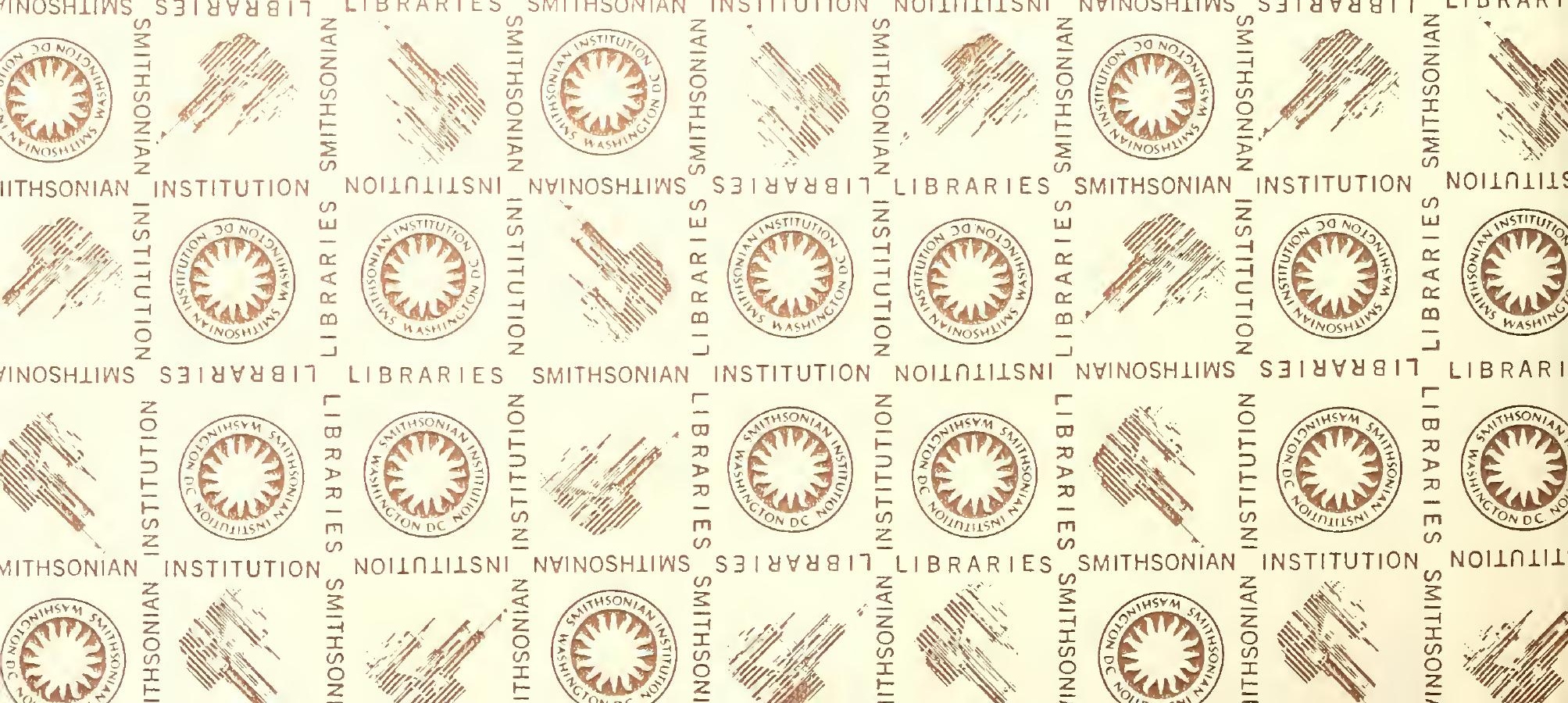


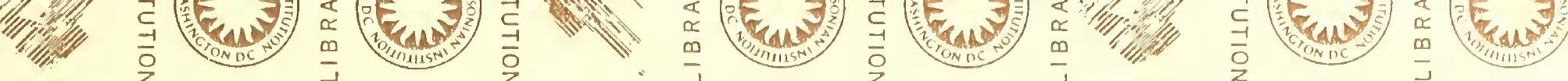

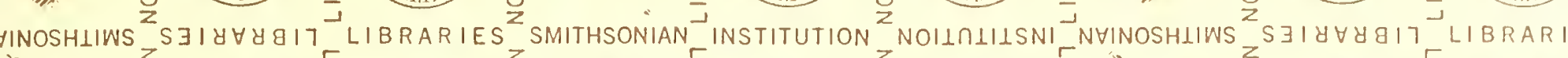
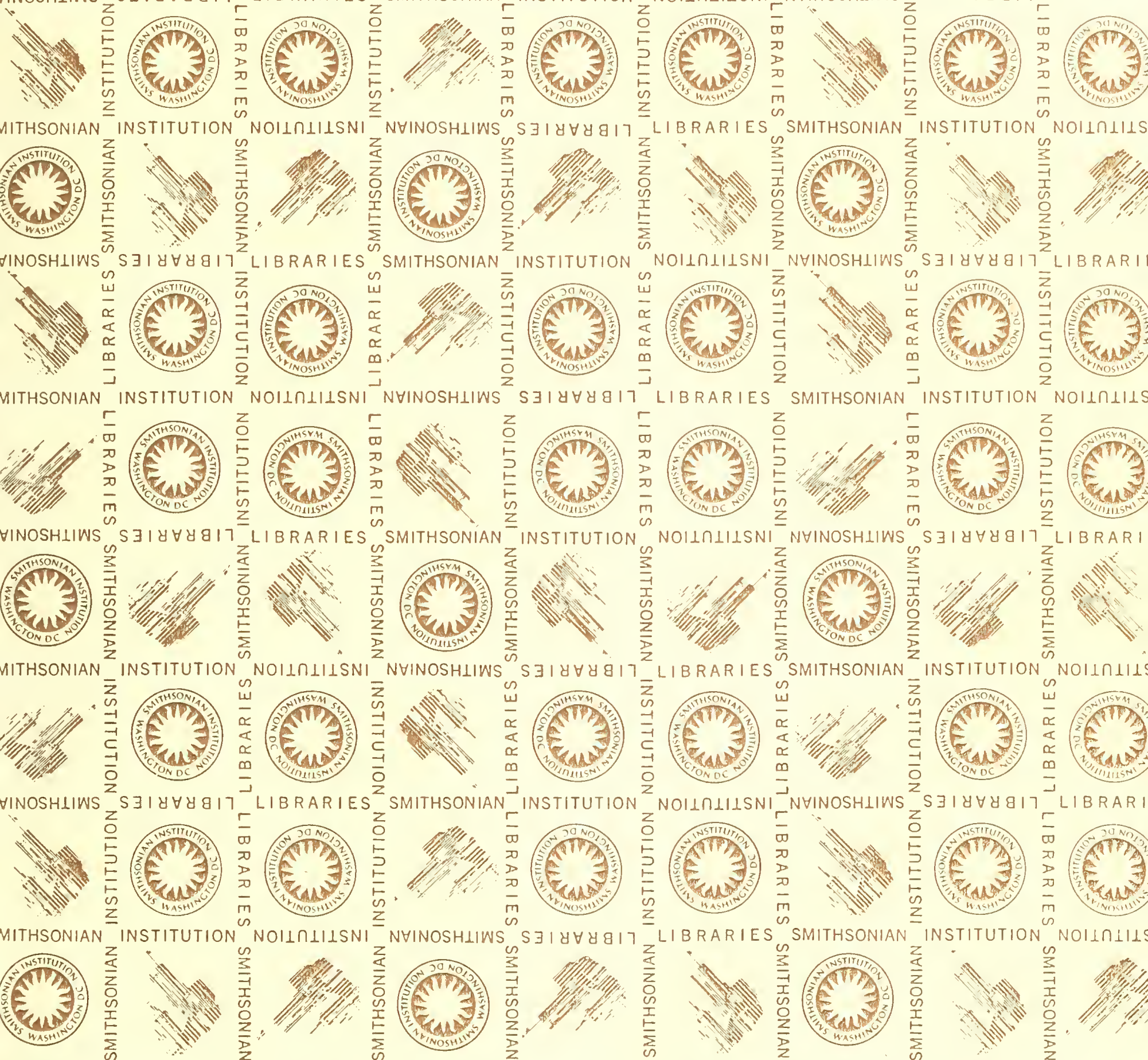

INSTITUTION

NOILIILS
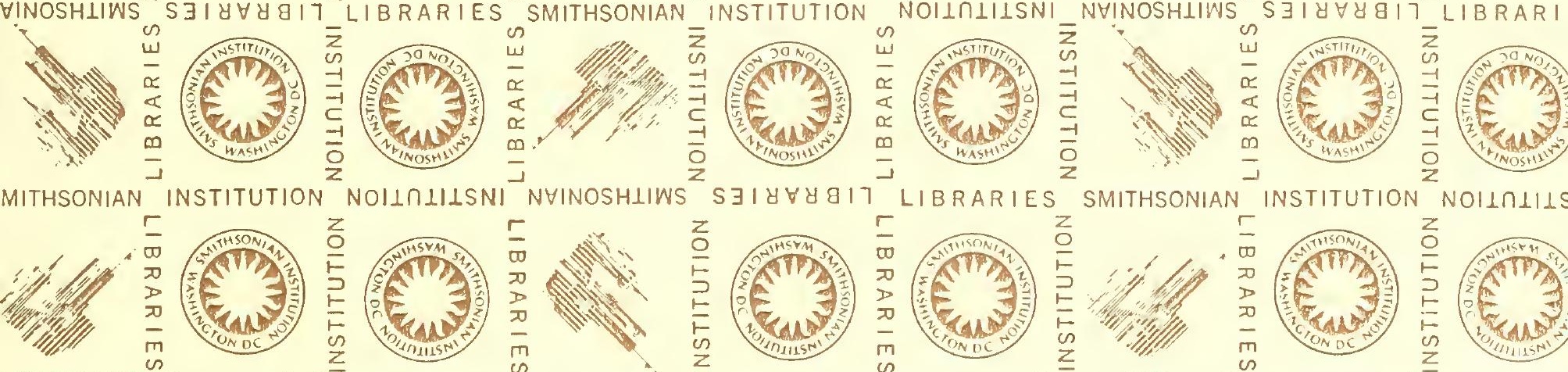

SIIYZYG17 LIBRARIES "SMITHSONIAN 



\section{The National Museum of Natural History}

OH

70)

U6? $198(55) \times$

CRLSSI

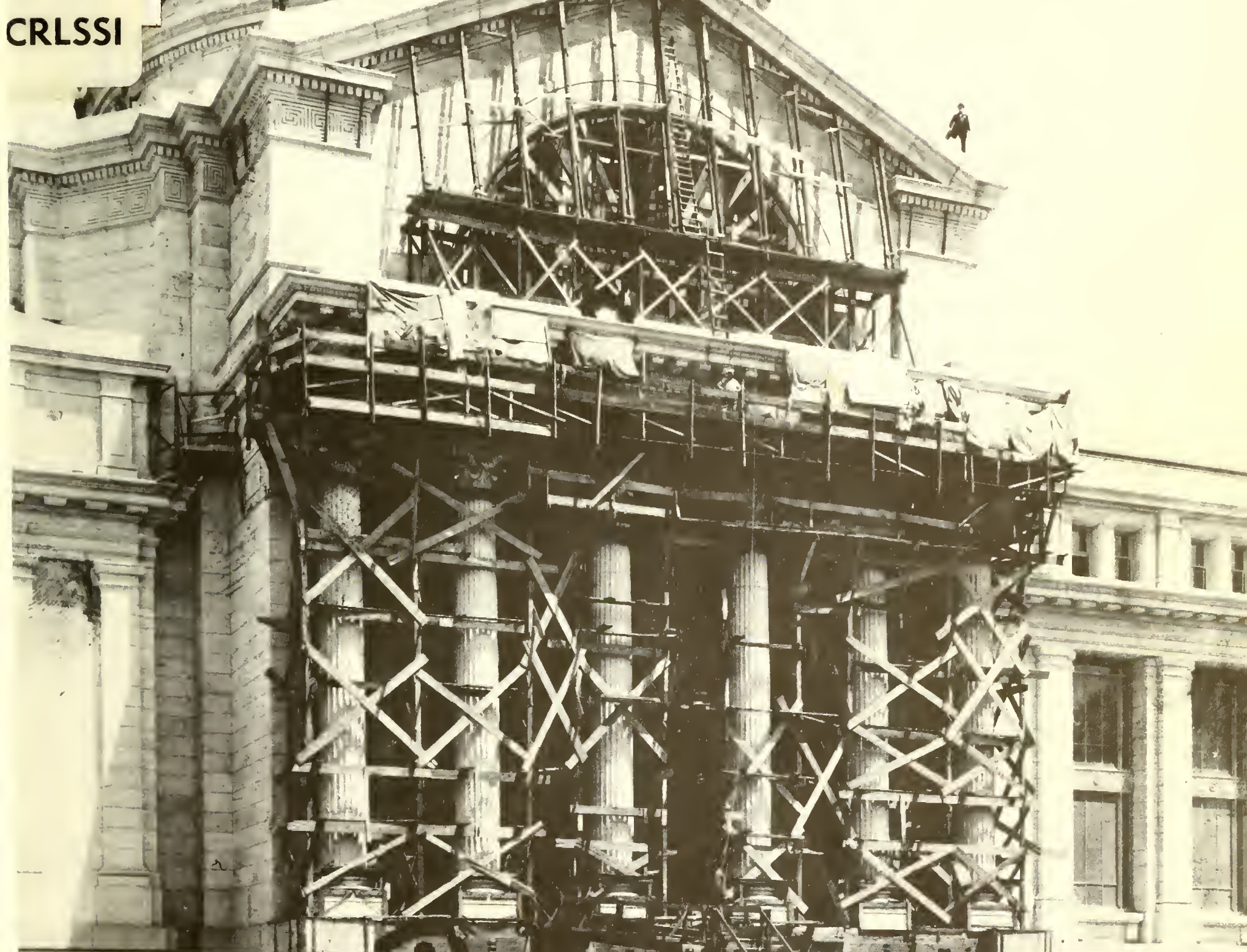

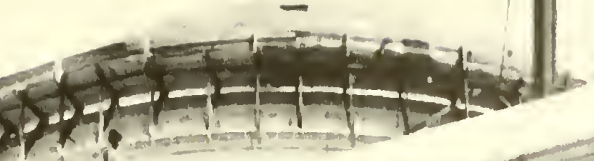

in

Ellis L. Yochelson

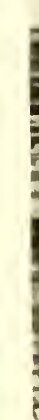

11.

a. $1.2=2$

$x=-$ 



\section{The National Museum of Natural History}

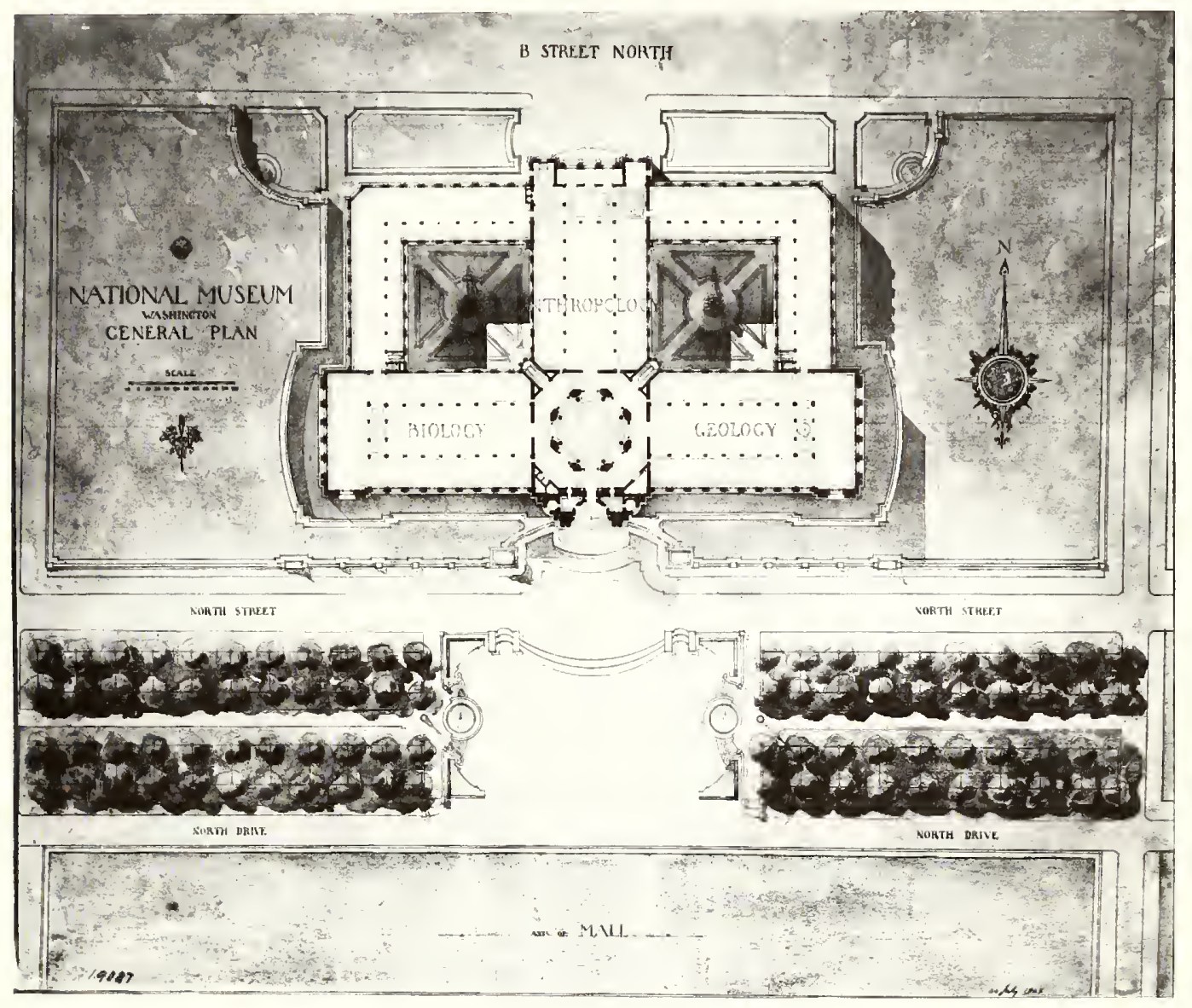

75 Years in the Natural History Building 


\section{The National Museum of Natural History}

Published on the occasion of the Diamond Jubilee of the Natural History Building (1910-1985) for the National Museum of Natural History, Smithsonian Institution, by the Smithsonian Institution Press City of Washington, 1985 


\section{Years in the Natural History Building}

Ellis L. Yochelson, U.S. Geological Survey

Edited by Mary Jarrett

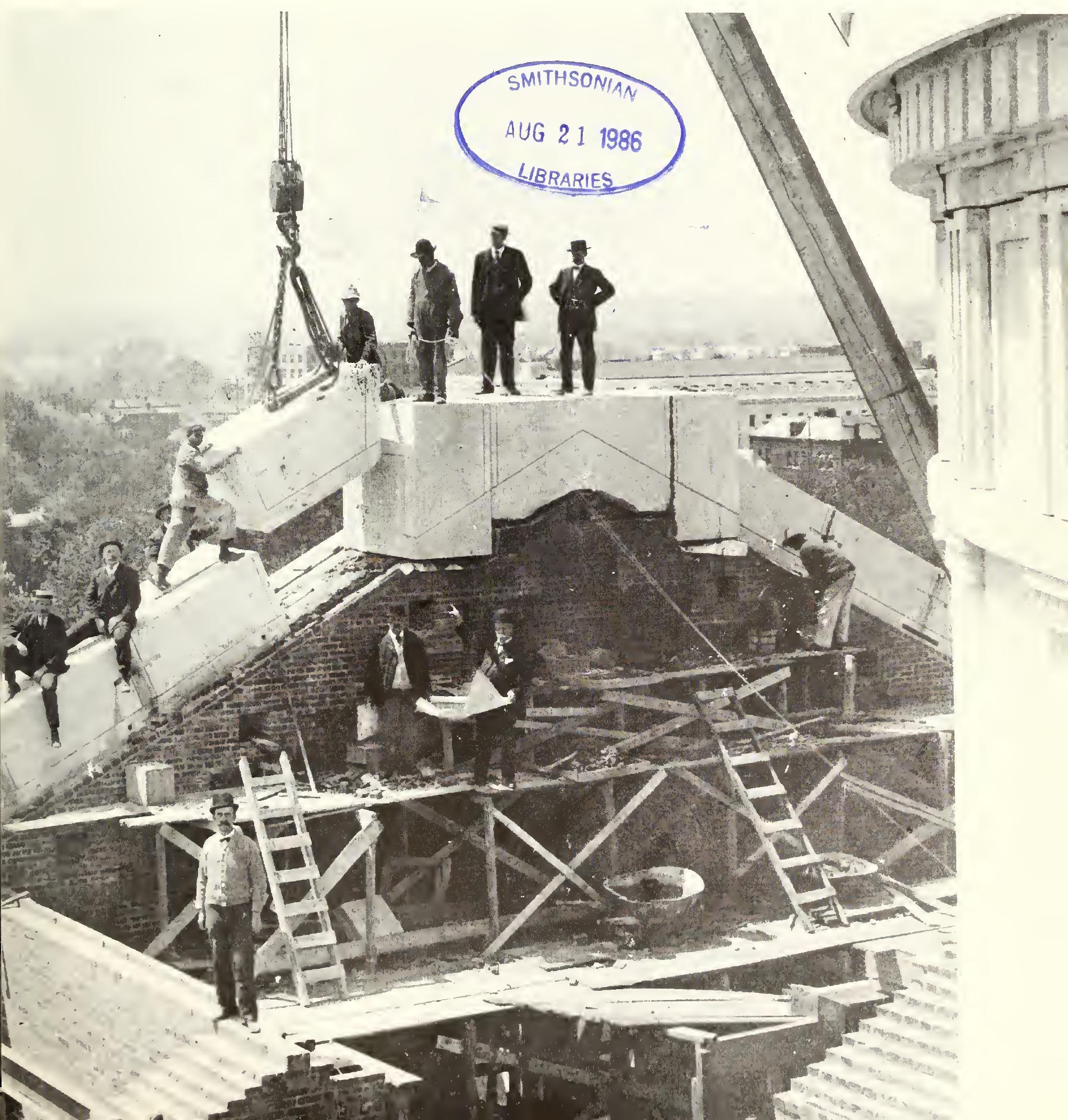


FRONI covtr: Looking north from the Mall at /1:0I A.M.

May II, I909, just after the last stour was set on the south porch of the Natural Histony Building.

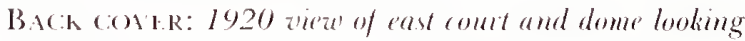
northuest.

HAH - 1111 F PAG: Sketch of building showing three main wings and smaller ronges, enelosing the courts. The exhibits atere assigued essentially as suggested here, but the grounds when completed were far less claborate.

11+1. PAot: Setfing the last stone on the south porde at 11:00 A.14. May 11, 1909. This completed the heany comstraction on the new brileling.

PAR I I OPENER: Dome and south porch of the newe National Musemm still under constrution. About six months later, in the summer of 1970 , the collections started being moved across the Mall.

PAR 12 OPE NER: The Fenthöri elephant Loxodontus on its operning night, 110) 6, 1959

PAR I 3 oPr.NR: The Natural I Listory Bnilding today, looking west along the Mall and Constitution Azemue. Photo by J. Tiusley, July 1985.

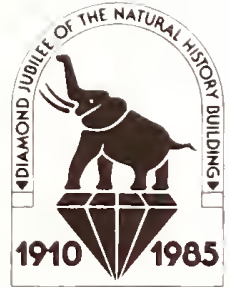

(1) 1985 by Smithsonian Institution. All rights reserved printed in the United States of America

\section{Library of Congress Cataloging-in-Publication Data}

Yochelson, Ellis Leon, 1928-

The National Museum of Natural History: 75 years in the Natural History Building.

Bibliography: p.

Supt. of Docs. no.: SI 3.2: N21/2

1. National Museum of Natural History-History.

I. Jarrett, Mary: II. Title.

QH70.U62W279 I985 507.4'0153 85-600I80

ISIBN $87474-989-1$

$\infty$ "The paper in this book meets the guidelines for permanence and durability of the Committee on Production Guidelines for Book Longevity of the Council and Library Resources. 


\section{Contents}

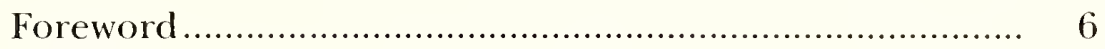

Preface

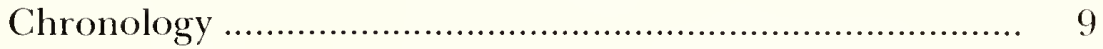

Part One: The Structure

Chapter 1 The United States National Museum ................................. 15

Chapter 2 The New Building ....................................................... 23

Chapter 3 Building the Building ........................................................ 29

Chapter 4 Moving into Valhalla ...................................................... 35

Chapter 5 The National Gallery of Art .......................................... 41

Chapter 6 Affiliated Organizations .................................................. 47

\section{Part Two: The Exhibits}

Chapter 7 New Exhibits, New Offices................................................ 57

Chapter 8 The Great War and Its Lingering Aftermath..................... 65

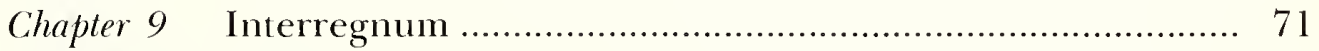

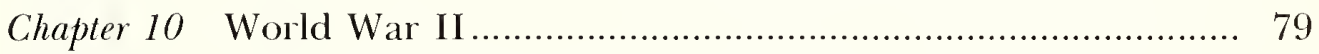

Chapter 11 New Faces, New Funds, New Exhibits .............................. 85

Chapter 12 New Wings and a New Elephant ...................................... 99

Chapter 13 Big Science: Deep Space, Deep Waters ................................ 111

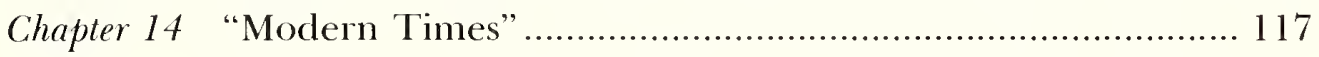

\section{Part Three: The Museum}

Chapter 15 Museum Administration.................................................... 129

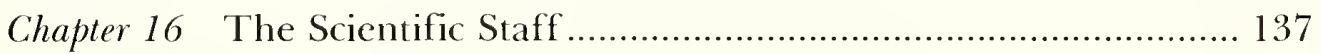

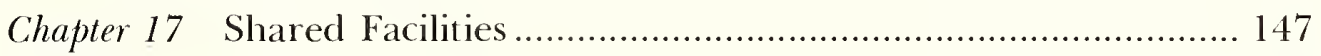

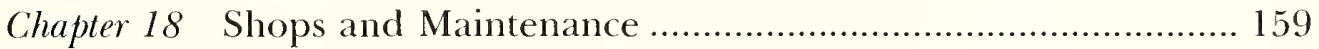

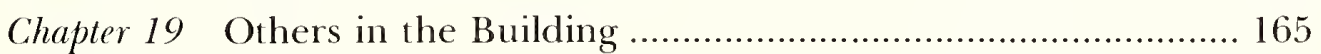

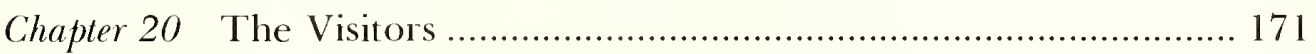

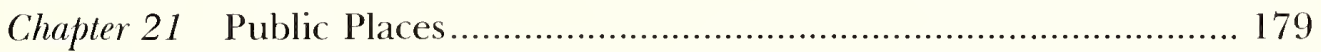

Chapter 22 Outside the Building ......................................................... 191

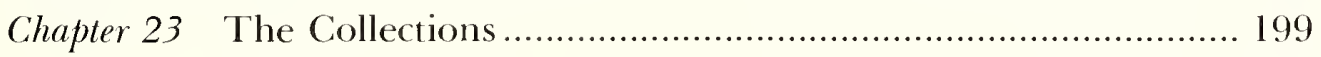

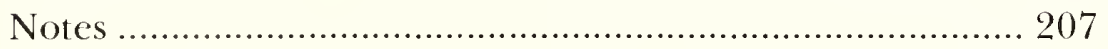

Index of Personal Names.................................................. 214

Sources of Illustrations..................................................... 216 


\section{Foreword}

$\mathrm{T}$ his year we are celebrating the Diamond Jubilee of the Natural History Building, which first opened its doors to the public on March I7, 1910. The new building represented a major advance for the Smithsonian Institution, vastly expanding its space and opportunities for collection storage, exhibition, and research, and it ushered in a whole new era in the life of on already well-established musemm, known today as the National Museum of Natural History (NMNH). During the past seventy-five years, the Natural History Building, familiarly called the "NHB" by its residents, has undergone many changes to keep pace with the growth of its at tivities, whic have expanded and changed constantly to stay abreast of the extratordinary advances in science and the ever-expanding need for public displays and antivities. Thus the building and its life have been inextricably bound to each other through the years. Over these seventy-five years we have seen upwards of 150 mithion visitors come through onr doors, 50 million in the last ten years alone, and we expect more than six million in 1985. Our collections for research and display now number about 100 million.

The irlea for this book first took shape in a chance conversation that I had with the author, Dr. Ellis L. Yochelson, at our Museum's Christmas Party in December 1983. While discussing wats to celebrate the seventy-fifth anniversary of the NHB in 1985, Ellis, who has always had a keen interest in and sense of history, suggested that a book be written on the history of the building since 1910. I immediately seized on the suggestion, and a project was born-with Ellis himself as author. As a long-time resident of the building who not only knew much of the history himself but also was a scientific colleague and personal friend of several of the NHB's oldest citizens, Ellis was an ideal choice. Furthermore, as a member of the resictent paleontological staff of the Geological Survey of the United States Department of the Interior, one of the longestrunning scientific affiliates with the $\mathrm{NMNH}$, he could bring a unique perspective to bear on the history of the buikling. Although always a loyal advocate of the Museum, he coult take a more detached view than one of our own staft, and at the same time he understood implicitly the symbiotic relationships that have always characterized the associations between the scientists of the NMNH and of the several affiliated agencies that have long had research units in the building.

We all are enormously indebted to Ellis Yochelson for the Herculean job that he did in writing this book within virtually impossible deadlines. From the outset, he wisely decided that he could not bring the building to life without telling the story of the people who worked here and of the activities and events that have punctuated the history of the building. It is, therefore, much more than a history of the building: it is a history of the Museum. 
Dr. Yochelson has given us a charming book, full of fascinating anecdotes and his own dry wit. He would be the first to point out that it is written from his own perspective as a personal chronicle. He was not asked to write an official history, and the book should not be read on that assumption. Many, but by no means all, of the guiding figures in the Museum's history appear in these pages, and the author does not pretend to emphasize each in proportion to his or her importance. It was never our intention that the book would incorporate all employees past or present, and Ellis has had complete freedom to emphasize personalities as he saw fit. In a companion volume to this book, the pictorial Directory published in March 1985, all present NMNH staff and associated employees-about 1,250-are featured.

I am indebted to many persons for their help in making this book possible, including some, no doubt, of whom I am unaware. Certain persons deserve special mention. Without the full cooperation of Richard Z. Poore, Chief of the Geological Survey's Branch of Paleontology and Stratigraphy, this book never could have been written by Dr. Yochelson, a U.S.G.S. employee under his charge. Many present staff members reviewed all or parts of the manuscript. I am grateful to the departmental chairmen for soliciting these reviews. The chairmen at the time were: Robert F. Fudali (Mineral Sciences), W. Ronald Heyer (Vertebrate Zoology),
Leslie W. Knapp (Smithsonian Oceanographic Sorting Center), Mark M. Littler (Botany), Ian G. Macintyre (Paleobiology), Wayne N. Mathis (Entomology), Clyde F. E. Roper (Invertebrate Zoology), and Douglas H. Ubelaker (Anthropology). Especially detailed and thorough reviews were prepared by Frederick M. Bayer, Fenner A. Chace, Jr., Joseph Ewan, Pamela M. Henson, Karl V. Krombein, Curtis W. Sabrosky, and Victor G. Springer. Essential technical work in the preparation of the final copy was performed by Anne Curtis, Barbara Gautier, T. Gary Gautier, Ella Giesey, Carole Lee Kin, and Joan B. Miles. Patricia Geeson, Victor E. Krant/, and James H. Wallace, Jr., rendered indispensable help in the process of gathering pictures for the book. Ann Rossilli designed the Diamond Jubilee logo.

Finally, I an especially indebted to Stanwyn G. Shetler, Assistant Director for Programs, for reviewing the entire manuscript in detail and guiding the book through the many stages of editing to publication on my behalf; to Mary Jarrett, for her painstaking and exemplary final editing of the book; to Hope G. Pantell of the Smithsonian Institution Press, for her vital editorial guidance during production; and to Christopher Jones, for his pleasing design of the book.

RICHARD S. Fiske, Director

National Museum of Natural History Smithsonian Institution

July 1985 


\section{Preface}

$\mathrm{O}$

LD-TIME TOUR GUIDES IN WASHINGTON used to like to say, "On the north side of the Mall, opposite the Smithsonian Castle, the large granite building with the green dome on top is the United States National Mausoleum." In a way the building did look like an oversize cemetery monument, and it does contain many deat objects, but there is nothing funereal about the place. Since March 17, 1910, when the public was first invited to see the inside of a not-yet-completed building, people have been enjoying, more or less continuously, this national museum and its exhibits.

Over the years a varicty of names have been applied to the structure. "The United States National Museum," "the New National Museum," "the National Museum of Natural Historv," and "the Natural History Building" have much in common, yet each is a shade different, indicating a stage in the development of the nation's museums. The building itself has changed through time. It has housed trivial and significant objects, minspired and lascinating exhibits, and, always, dedicated people. I have tried to write a little about all these subjects-that is, about space and time and some of the people who occupied both dimensions.

One seldom finds an opportmity to use the word "concatenation." But had the United States Geological Survey not hiret me in 1952 to work at the Natural History Building of the United States National Museum, and had I not been involved with the Geological Survey centennial in 1979 , and had I not met National Musem of Natural History director Richard Fiske at the Invertebrate Zoology Christmas party in 1983, and had the present Chief Geologist, Robert Hanilton, not worked with Fiske when both were on the Geological Survey, I would never have heard of the anniversary of the Museum building, nor would l have been given the time to write about its history. When it became evident that the time allotted was not going to be enough, my branch chief, Richard Z. Poore, permitted me to maintain the Geological Survey tradition of meeting a commitment.

William Massa, with the aid of his colleagues in the Smithsonian Archives, invariably brought me the papers or photograplis 1 requested, and then searched around on his own to find the items he knew I really needed. Without the help of Victor Kranz and, through him, a whole host of people in photographic services throughout the Institution, there would be no illustrations.

Because the Museum has no central photographic archive, tracking down negatives and identifications for old pictures posed special problems. Prints for which negatives could not be found were copied, but some of them, of course, may have been derived from even earlier copies. Photo negative numbers are given at the end of the book.

Almost none of the Smithsonian's photographs are captioned, and before 1975 scarcely any bore a date. If the information given for a picture seems vague or incomplete, it is because no further data were available.

Honesty forces me to say that I enjoy talking. In past years I have had the privilege of speaking with Secretaries Abbot, Wetmore, Carmichael, and other fine gentlemen and ladies no longer present. During a sixmonth period, I conversed with about a quarter of the people currently on the staff of the Museum and its affiliated agencies in an attempt to determine how the Museum has run and is running. It was far more stimulating and informative than reading eighty-five years' worth of annual reports. In particular I owe a major debt to Ed Henderson and to "Coop" for advice and recollections, and for first paying attention to me in 1944. If 1 did not get it right after all this assistance, the fault lies with me. 


\section{Chronology}

Date

May 13,1878

May 17,1878

1879

1881

August 19, 1887

November 18, 1887

September 6, 1896

January 27, 1897

July 1, 1897

July 1898

January 30, 1903

June 15, 1904

February 22, 1906

January 23, 1907

August 11, 1909

October 15, 1909

March 17, 1910

June 1, 1910

June 1, 1911

June 20, 1911

October 8, 1911

October, 1917

July 16, 1918

November 1, 1918

April, 1919

July 1, 1920

April 1, 1925
Event

Joseph Henry, first Secretary of Smithsonian Institution, dies.

Spencer Fullerton Baird appointed second Secretary.

Name "United States National Museum" first used by

Congress.

National Museum (Arts and Industries) building opens after use for Cleveland Inaugural Ball.

Secretary Baird dies.

Samuel Pierpont Langley appointed third Secretary.

Assistant Secretary George Brown Goode dies.

Charles Doolittle Walcott appointed Acting Assistant

Secretary in charge of U.S. National Museum.

National Museum organized into three departments:

Anthropology, W. H. Holmes, head; Biology, F. W.

True, head; and Geology, G. P. Merrill, head.

Richard Rathbun appointed Assistant Secretary in charge of U.S. National Museum.

Funds for new building appropriated by Congress.

Ground broken for New National Museum.

Secretary Langley dies.

Charles Doolittle Walcott appointed fourth Secretary.

Staff begins to move collections into new building.

Heating boilers fired.

New National Museum opened to public.

Holmes again appointed head of Anthropology.

Leonhard Stejneger appointed second head of Biology.

Building formally completed.

Sunday-afternoon visiting hours begin.

Bureau of War Risk Insurance moves into building.

Building closed for use by Bureau of War Risk

Insurance. Richard Rathbun dies.

W. de C. Ravenel appointed assistant to the Secretary, in charge of U.S. National Museum.

Building reopened to public.

National Gallery of Art formed, with Holmes as director.

Alexander Wetmore appointed Assistant Secretary. 
February 9, 1927

Fall 1927

January 10, 1928

1929

October 29, 1929

June 19, 1930

1930

April 1931

June 30, 1934

1940

December 7, 1941

June 30, 1944

January 12, 1945

October 23, 1946

July 31,1947

May 26, 1948

1949 (?)

December 1952

January 2, 1953

Fall 1955

July 1, 1957

February 4, 1958

August 1958

May 13, 1960

January 1962

1960

1963

July I, 1963

October 15, 1963

January 31, 1964

February 1, 1964

February 1, 1965

July 1, 1965

July 1, 1965

Summer 1965

September 16-19, 1965

March 1966

March 24, 1969
Secretary Walcott dies.

Rotunda closed.

Charles Greeley Abbot appointed fifth Secretary.

Decking put in east range, ground floor.

Rotunda reopened.

Wings authorized by Congress.

War Collection moved to Arts and Industries.

Decking of west range and west north range begins.

Heating and electrical plants cease operations.

Conversion to alternating current begins.

America enters World War II.

Secretary Abbot retires.

Alexander Wetmore appointed sixth Secretary.

100th anniversary of Smithsonian Institution noted.

Department of Biology divided into departments of Botany and Zoology.

A. Remington Kellogg appointed Director, U.S. National Museum.

Ice plant ceases operation.

Secretary Wetmore retires.

Leonard Carmichael appointed seventh Secretary.

Junior League begins docent tours in Museum.

U.S. National Museum divided into Museum of History and Technology and Museum of Natural History.

A. Remington Kellogg appointed Assistant Secretary.

A. C. Smith appointed Director, Museum of Natural History.

Funds for east wing construction appropriated by Congress.

T. Dale Stewart appointed Director, Museum of Natural History.

Construction begins on east wing.

Construction begins on west wing.

Department of Entomology formed from Division of Entomology.

Department of Geology divided into departments of Paleobiology and Mineral Sciences.

Secretary Carmichael retires.

S. Dillon Ripley appointed eighth Secretary.

Bureau of American Ethnology and Department of Anthropology merge to form Smithsonian Office of Anthropology.

Smithsonian Office of Ecology formed.

Department of Zoology divided into departments of Invertebrate and Vertebrate Zoology.

Department of Botany moved to Museum from Castle.

200th anniversary of birth of James Smithson celebrated.

Richard S. Cowan appointed Director, Museum of Natural History.

Official name becomes National Museum of Natural History. 
September 26, 1971

November 16, 1971

January 15, 1973

1973

September 16, 1973

December 17, 1973

March 5, 1974

1975

1975

October 1975

August (?) 1975

July 1976

1976

December 1976

Fall 1978

May 30, 1979

December 7, 1979

January 1980

August 1980

February 9, 1981

March 1981

July 15, 198 I

May 16, 1983

September 17, 1984

July 10,1985 125th anniversary of Smithsonian Institution.

Baird Auditorium dedicated.

Porter M. Kier appointed Director, National Museum of Natural History.

"Rearticulation" returns building management, exhibits, and educational activities to directorship of Museum.

Former Secretary Carmichael dies.

Former Secretary Abbot dies.

Discovery Room opens.

Smithsonian Oceanographic Sorting Center becomes part of Museum.

Office of Anthropology abolished; Department re-

established.

Escalator installed in foyer.

Osteo-Preparation Laboratory built in cast courtyard.

West Court building completert.

Greenhouse built in east courtyard.

Naturalist Center opens in West Court building.

Inventory program begins in Museum.

Kier leaves directorship; James F. Melto appointed Acting Director.

Former Secretary Wetmore dies.

Richard C. Fiske appointed Director, National Museum of Natural History.

Constitution Avenue entrance modified for physically handicapped.,

Work begins on Museum Support Center.

Link Port facility, in Fort Pierce, Floricla, becomes part of National Museum of Natural History.

Evans Gallery opens in foyer.

Museum Support Center dedicated.

Secretary Ripley retires; Robert McCormick Adams takes office as ninth Secretary.

Fiske leaves directorship; James C. Tyler appointed Acting Director. 



\section{The \\ Structure}

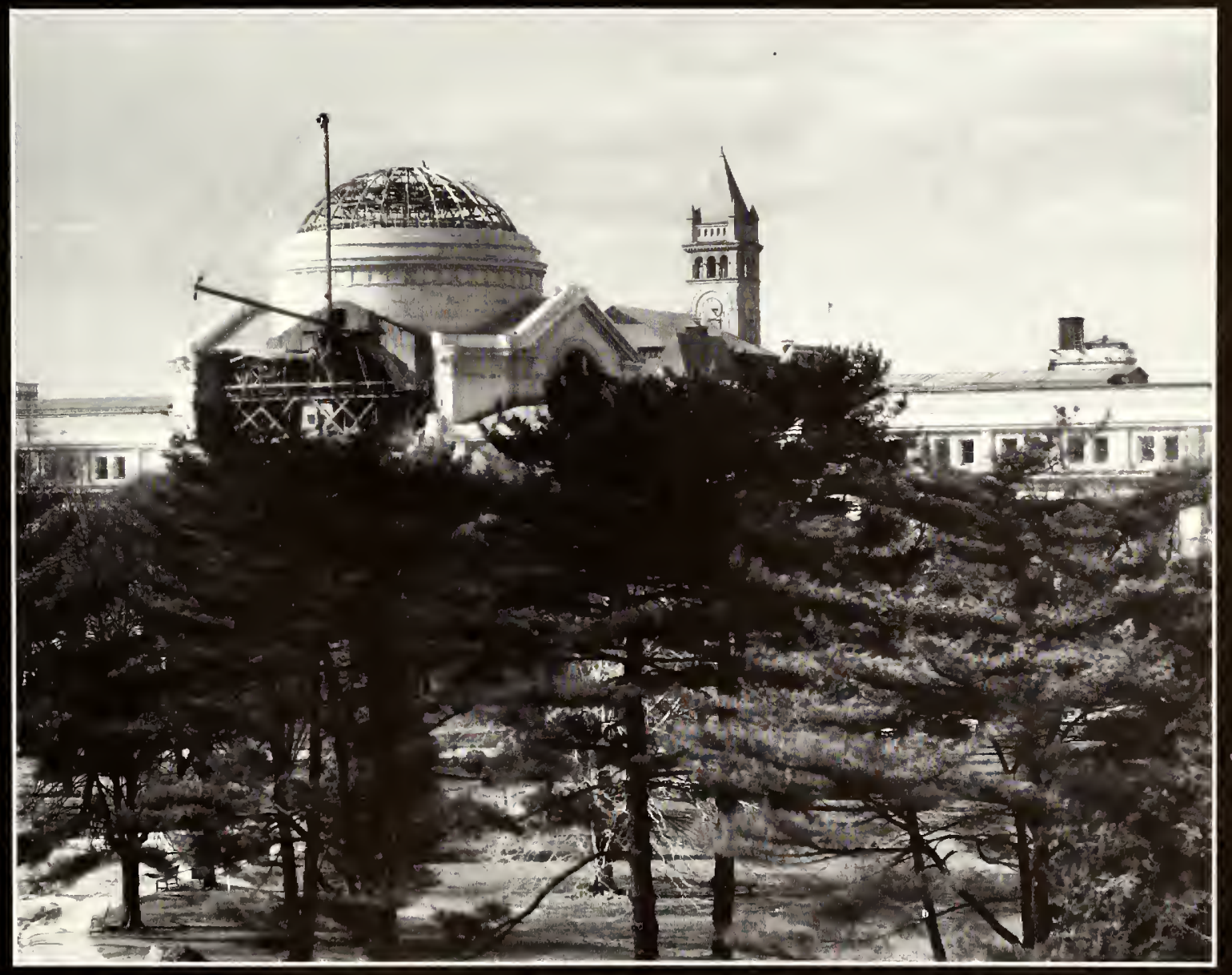




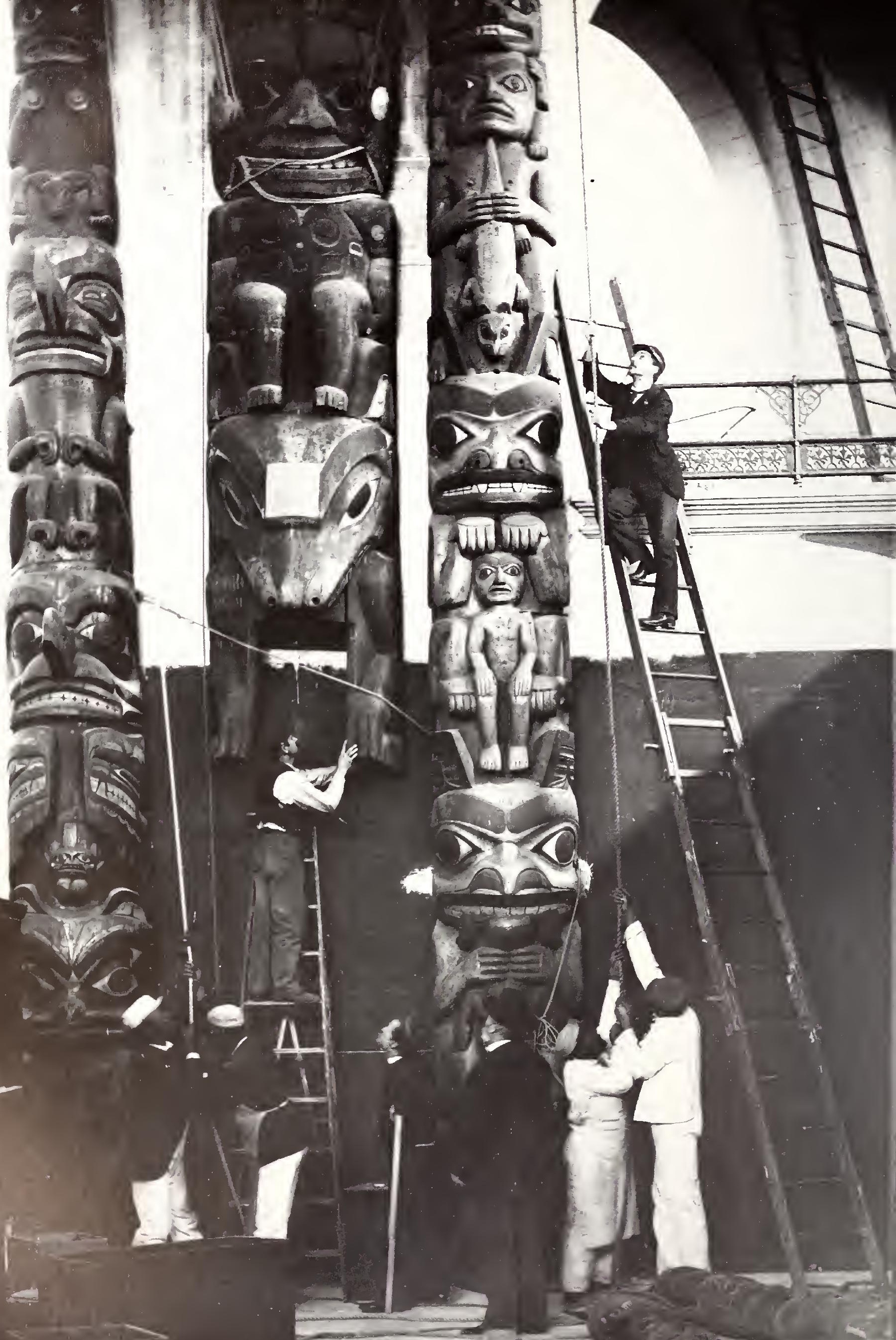




\section{United States National Museum}

A LTHOUGH THE STORY OF THE SMITHSONIAN has been told many times, it is a good story that deserves retelling from a slightly different angle. In brief, the Institution was created by an Act of Congress in 1846 to execute the will of the English chemist and mineralogist James Smithson, who had bequeathed his entire fortune to the United States "to found at Washington ... an establishment for the increase and diffusion of knowledge among men." Although Congress had settled on science, art, and history as the areas of knowledge to be pursued, the outline was a vague one. The Institution's first Secretary, Joseph Henry, wanted to support research and publications, but not to have the Institution actively involved in gathering collections or developing a public museum. The Board of Regents did insist upon an impressive Smithsonian building, and in 1847 construction began on "the Castle," located on the south side of the Mall with its main entrance centered on Tenth Street.

Three years later, the overworked Henry hired young and energetic Spencer F. Baird as his assistant. In Baird, natural history found a powerful advocate. He was a prodigious collector as well as a master at persuading others to collect for him. Historians argue as to whether Henry's original objections to a museum were swayed by the force of Baird's arguments or by the weight of his collections.

There was no formal founding of the United States National Museum, but in 1858 large government-owned collections from the moribund National Institute were transferred to the Castle from the Patent Office building (now the National Portrait Gallery and National Museum of American Art). One of Henry's concerns was guarding the Smithsonian endowment; he was aware

Installing totem poles in the United States National Museum (now the Arts and Industries Building), possibly in the early 1880s. The onlookers may be Samuel P. Langley and Otis T. Mason. Donated from the Philadelphia Centennial exhibit, the totem poles were accessioned in 1876. The one in the center is currently on display at the north end of Hall 8. of what a financial drag a museum could be, having seen the cost of collection maintenance lead to the ruin of the National Institute. 'Before agreeing to accept the collections, Henry had made certain that federal money would be available for their maintenance. In 1857 (and every year since) Congress appropriated the funds. A Guide to the Smithsomian Institution and National Museum was published in 1859 , but it was not until 1870 that Henry used the name National Museum in the Annual Report, and not until four years later that Congress used the term in an appropriations bill. ${ }^{2}$

Henry's insistence on federal support for federal collections had several interesting consequences. The Smithsonian continues as a semiprivate institution, but because it administers government funds, its museum employees are civil servants just like employees of the Agriculture, Commerce, or Interior departments, with the same rules and regulations to follow. Perhaps the most important point is that the museum is public property: Anyone may enter to see the exhibits; anyone may enter without paying a fee. Henry's recognition that the federal government should maintain a museum, in the same sense that the government should make a survey of the coasts or investigate how to make crops grow better, was a major development whose ramifications continue to this day.

\section{Centennial Exposition Exhibits}

The approaching 1876 Centennial Exposition at Philadelphia was to be a great event. Because there was no working space in the Castle, a small, temporary brick building was constructed to the west of it in 1875 , near where the Freer Gallery of Art now stands. There Baird assembled a crew-including his protégé George Brown Goode-to help plan and build exhibits. The Smithsonian had a noteworthy display in Philadelphia, and Baird coaxed many of the other exhibitors to donate their materials to the federal government.

As might be expected, these donations changed the problem of getting more material into the enormously crowded Castle from difficult to impossible. Temporary storage space had to be obtained by taking over a 
pre-Civil War armory situated in a neighborhood long since eradicated by urban renewal, between Sixth and Seventh on B Street, SW. ${ }^{3}$

Without too much prodding, Congress agreed to give the National Museum a building of its own. Ground was broken on the east side of the Castle on April 17, 1879. The square brick structure was a cheap one, costing only $\$ 315,400$. Familiar now as the Arts and Industries Building, it houses a facsimile of the $1876 \mathrm{Ex}$ position put together for the nation's Bicentennial. A reconstruction of the Smithsonian Institution display may be seen on the east side of the south hall.

On March 4, 1881, the nearly completed United States National Musemm building was used for James A. Garfield's Inaugural Ball. After the bunting was taken down, the floors swept, and a few minor repairs made, the building was opened to the public. For the first time there was some additional space for permanent exhibits.

\section{George Brown Goode}

Meanwhile, Secretary Henry had died. In 1878 Baird succeeded him and eventually promoted George Brown Goode 10 Assistant Secretary, in charge of the National Museum. Goode, who had come to the Institution in 1873, was by training an ichthyologist. While he never put the fishes entirely behind him, he rapidly becane a "museum man." When the Centennial Exposition inspired a whole series of major fairs and shows, Goode sent exhibits to them. In his time he was widely regarded as the New World's leading specialist in museum administration and in exhibit preparation, which he developed into a field in itself. Atter Baird's death in 1887, Samuel Pierpont Langley, an astronomer, became Secretary of the Smithsonian. He was not particularly interested in collections, but Goode, being steeped in the Baird tradition, continued to acquire material.

Most of it went into the National Museum, but the Castle retained a sizeable display, described in a contemporary account:

Case after case through one of its great halls is filled with birds of all feathers, mounted so skillfully that they exhibit not only the

characteristic poses of the birds but in many cases their habits in life. They vary in size from the smallest humming bird to the largest ostrich. ... Another large hall is devoted to insects collected from an equally-wide area and presenting as great a diversity in size and color... . Here also is a marvelous collection of birds' eggs, varying in size all the way from the hemeopathic pellet to a football. The collection of shells, of sponges, of coral, and other curious organisms of the sea is enormous.

Goode as administrator delineated three roles he saw for a museum. He recognized that, first, it served as a museum of record; and if material is to serve as a standard of comparison, it must be kept safely. Today we might refer to this as a data bank of objects. Second, Goode noted the museum of research; and people who work in science, just as in any other field, must have the proper facilities. Today we might refer to this as a research institute, but Goode made clear in his various writings that study of the collections, not abstract theorizing, was what he referred to as research. Finally, there was the museum of education; and without collections, museums have no objects to exhibit. Today as always, the display halls are what the average visitor considers a museum.

There are examples of museums that, without any collections, do well at one or another of these various functions. As Goode saw it, however, the basic reason for a museum was to accumulate and maintain collections. Collections were like the platform of a stool, with the three functions Goode distinguished acting as the legs. The trick was-and still is-to keep these "legs" in perfect balance. Because this is almost impossible, one aspect of the history of the Smithsonian Institution has been the emphasis on different museum functions at different times. None of the three approaches has ever been ignored.

Goode knew that this new building was incapable of showing the diversity of nature and the handiwork of man in a colierent manner, let alone storing the mountains of natural-history specimens that kept piling up in Washington. In his Anmual Report of 1882, Secretary Baird acknowledged "the inadequacy of the Museum building, then scarcely more than a year old, to house the rapidly increasing national collections. ${ }^{16}$ One of the basic facis of museology is that there is never sufficient space to house the collections. Regardless of this, the dedicated museum worker brings them in.

In the course of his day-to-day work, Goode developed many of the techniques still used in the Museum. He improved the accessioning and cataloguing procedures, standardized case and drawer sizes, issued instructions on collecting methods, and oversaw a myriad of other seldom-considered details. Goode died at the age of forty-five, almost certainly from overwork. ${ }^{7}$

"The death of Secretary Baird in 1887, while a serious blow ... was felt less by the Museum force in general than was that of Dr. Goode in 1896," the head of the Department of Geology wrote in the 1920s. "The loss of the last named was seemingly quite irreparable and for a time created a panic among those who had been looking forward to a life profession in Museum work under his guidance and with his cooperation." 8

George Brown Goode summed up his lifetime of experience in a one-sentence aphorism that to this day is quoted by museum authorities seeking increases in their budgets. He wrote, in capitals: "A FINISHED MUSEUM IS A DEAD MUSEUM AND A DEAD MUSEUM IS A USELESS MUSEUM."9 


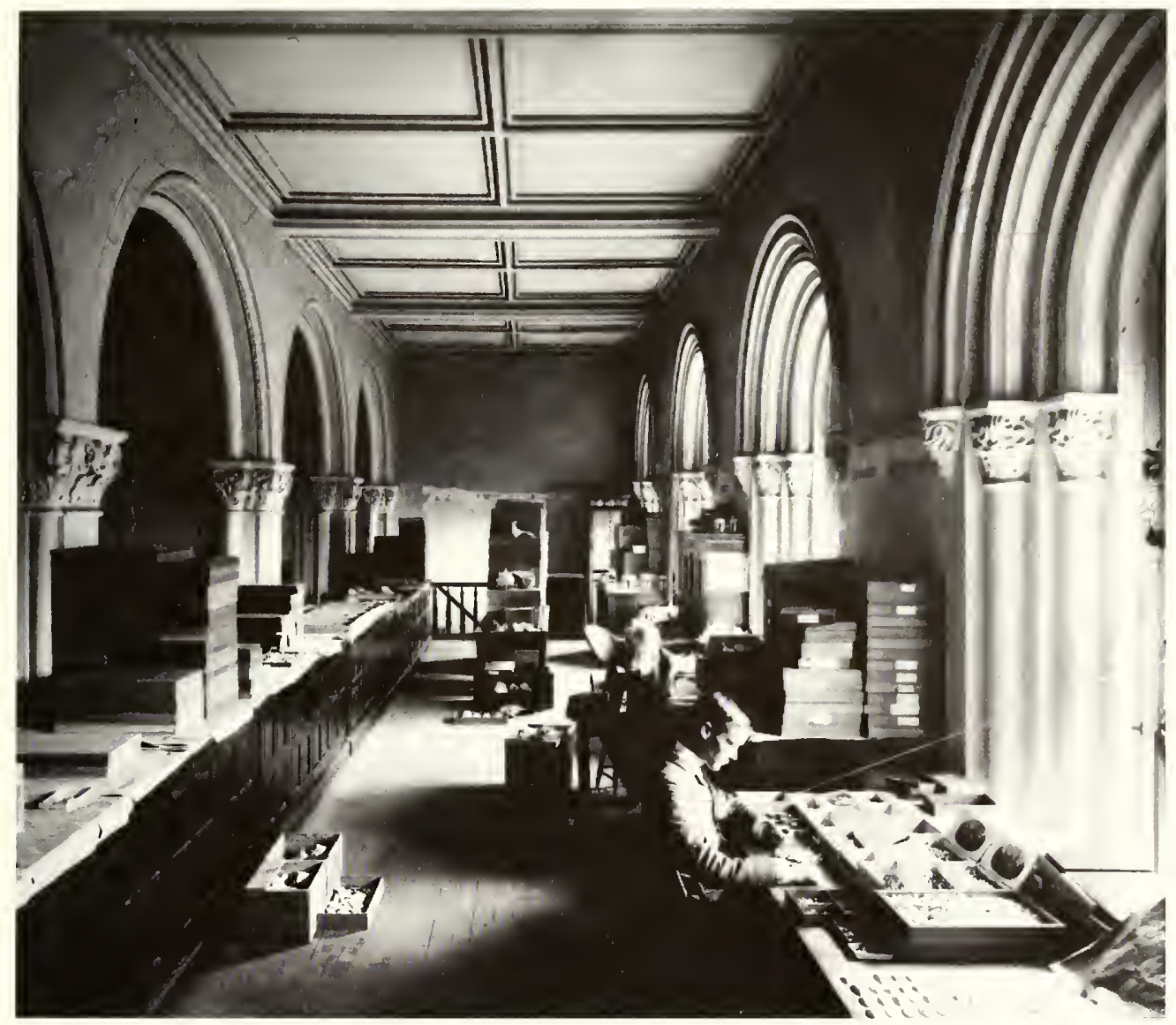

Office spare in the balcomy of the Smilhsomian Castle's

Great IJall, probably well before 1910. The specimens being studied are mollust shells.

Hall of Fisheries in the Smillasonian Castle, somewhere between 1880 and 1910. The life-size models of the octopus and the giamt squid were moved to the new

National Museum, where lliey remained on exlubit until the 1950s. Later they were transferred to storage at Silver Hill, Maryland, but they lost some plaster in moving and eventually were discarded.

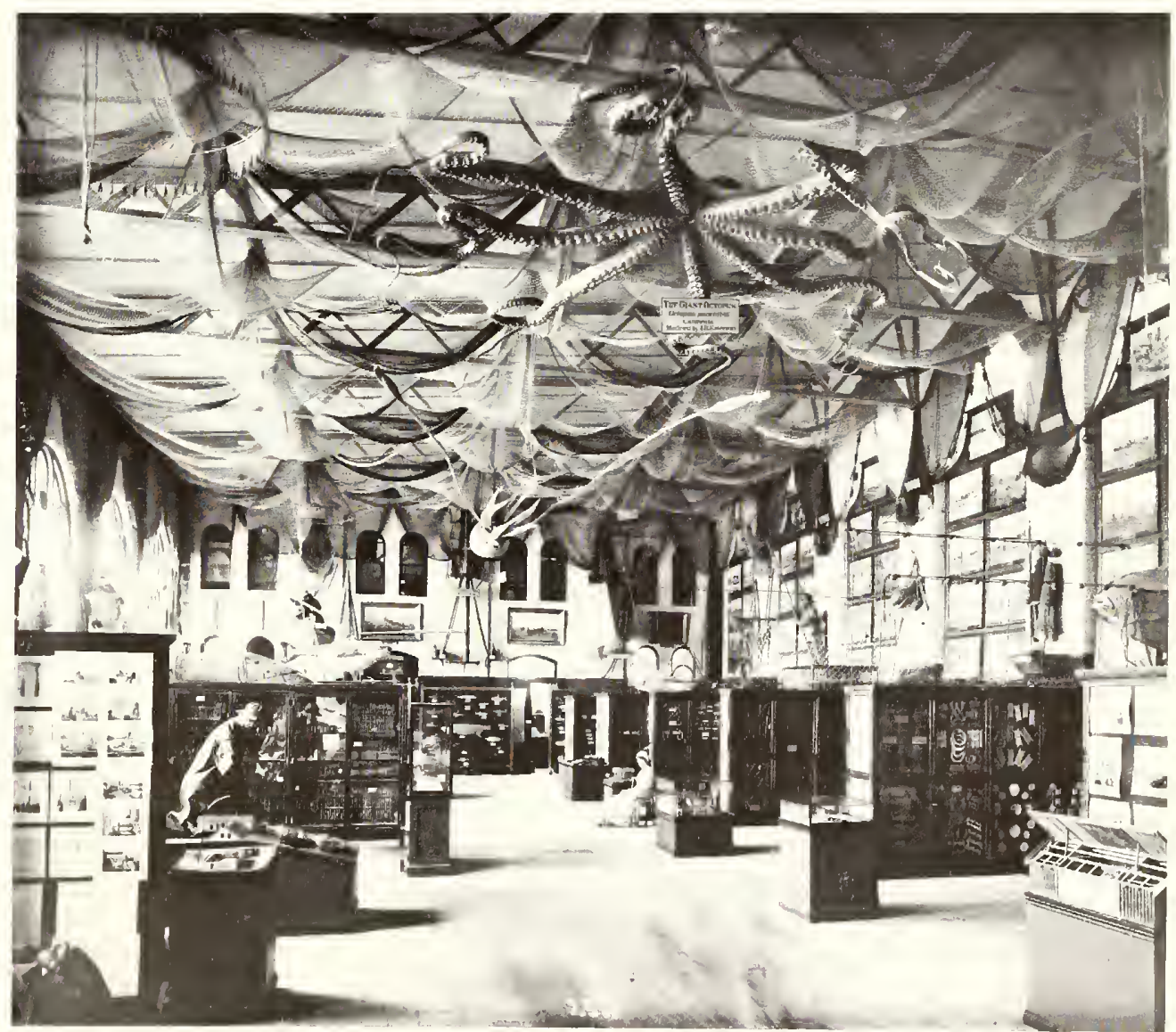




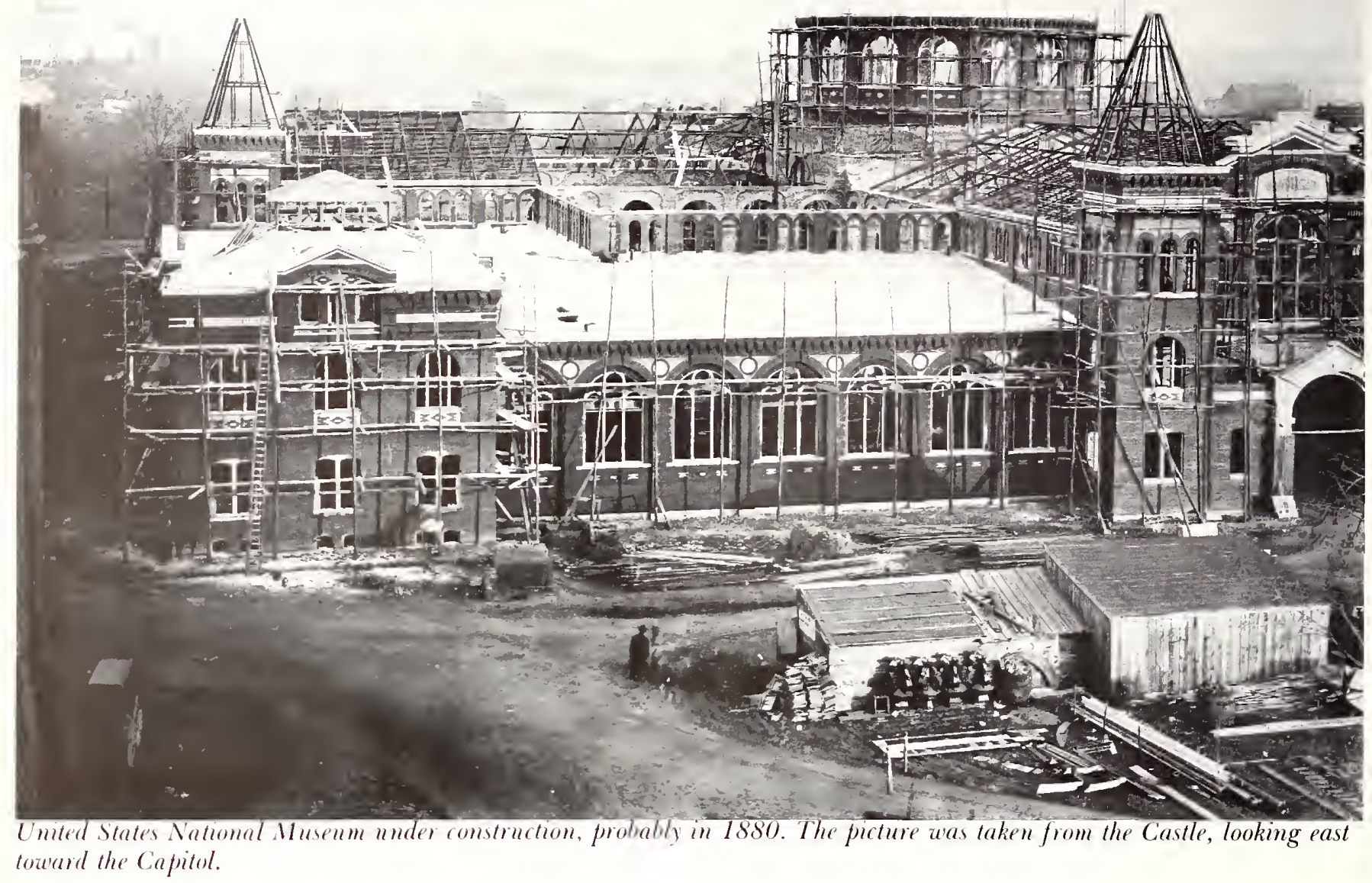

\section{Charles Doolittle Walcott}

Following Goode's death, Charles Doolittle Walcott served as Acting Assistant Secretary, in charge of the United States National Museum, for eighteen months in 1897 and 1898. Walcott was a paleontologist who hald risen through the ranks to become director of the United States Geological Survey in 1894. That organization had run afoul of Congress, but made a comeback under Walcot's leadership. Not only had he persuaded Congress to restore the budget to its former levels in order to study geology and make topographic maps; he convinced them that his organization should be studying the national forests.

Walcott continued to head the Geological Survey and to publish papers on paleontology while he was Assistant Secretary, but his close contacts with Congress now benefited the National Museum as well. The Museum had long planned to build side galleries in the four main exhibit halls, and in 1897 Congress appropriated $\$ 8,000$ for the first of these galleries. ${ }^{10}$ Goode had been requesting funds without success since 1893 .

Walcott inherited an administrative hodgepodge, for Goode had designated innumerable divisions and sec-
Iions within the United States National Museum. There was virtually no paid staff; whenever a volunteer appeared, a special niche was carved out for him as an honorary curator or some such title. Although Walcott was unable to increase the staff, he clarified the organization by setting up three departments: Anthropology, Biology, and Geology. Each had a head curator, with curators in charge of subdivisions. For the first time a chain of command was established. The various internal divisions have changed over the years. While the Department of Anthropology survives intact, the departments of Botany, Entomology, Invertebrate Zoology, and Vertebrate Zoology represent the original Biology Department; and Mineral Sciences and Paleobiology, Geology.

As Acting Assistant Secretary, Walcott performed one further, inestimable behind-the-scenes task for the $\mathrm{Mu}$ seum. "During his administration," the geologist Bailey Willis relates, "Uncle Joe' Cannon was Speaker of the House, and it was [Cannon's] habit after a fatiguing session to walk up Pennsylvania Avenue. Walcott, as if by chance, would draw up beside the curb with a faststepping bay and a light buggy and suggest a drive in 
Installing the Easter Island images in the National Museum, 1888. George

Brown Goode is to the left,

Secretary Langley stands with hat in hand, and to the right is Otis T. Mason, later to be second head of the

Department of Anthropology. Copied from a print in William Henry Holmes's "Random Records."

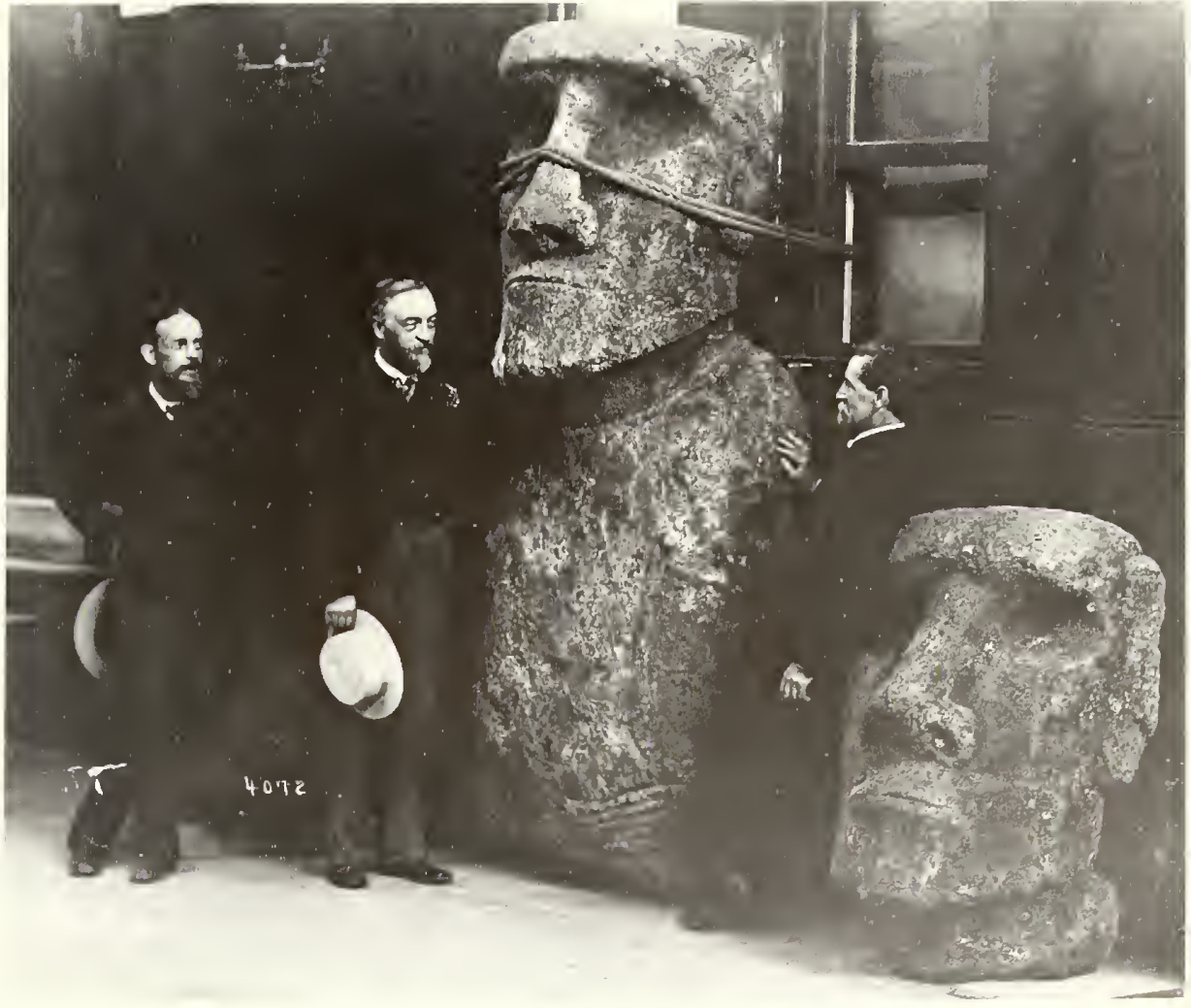

Rock Creek Park, but during these rides he never mentioned business. On one occasion 'Uncle Joe' paused, his foot on the step, and said: 'Walcott, you may have a building for the Survey or one for the National Museun, but you can't have both.' And Walcott took the Museum." 11

\section{Richard C. Rathbun}

In 1898 Richard C. Rathbun was named Assistant Secretary, in charge of the United States National Museum, and Walcott returned full-time to the Geological Survey. Rathbun had started his career as a geologist, but under Baird's spell he had become enamored of fish and, like Goode, soon developed a compulsive concern for collections and museums. It is to him that we owe our clear account of the first National Museum building and the various attempts to persuade Congress to build a new one. After Walcott left, it was Rathbun who kept up congressional interest, for Secretary Langley was preoccupied with developing a man-carrying aircraft, and, to put it gently, was not known for either his administrative or political skills. In 1903 Congress finally authorized the building, at a cost not to exceed $\$ 3,500,000$ - a figure attained through some political shufflings with several proposals. Before midyear a firm of Washington architects, Hornblower and Marshall, had been selected to draw the final plans. It was expected that construction would take about four or five years. ${ }^{12}$

In the 1880 s the general idea of a second museum had been a brick building similar to the United States National Museum, but two stories high. The World Columbian Exposition of 1893 in Chicago set the stage for a change from high Victorian style to neoclassic architecture. It also inspired what became the McMillan Commission to beautify the city of Washington. The proposed museum was to be the first building constructed according to the dictates of the Commission, and plans for it became increasingly elaborate. For a time the anticipated building was one-third larger again than the one that actually was constructed.

Langley led the ground-breaking on June 14, 1904, but faded from the scene and died early in 1906. The Board of Regents offered the secretaryship to Henry Fairfield Osborn, who declined to leave the American Museum of Natural History in New York City. At last, in 1907, Walcott became the fourth Secretary of the Smithsonian Institution.

For several years Rathbun bore the burdens of the Museum and its new building. As Acting Secretary after Langley's death, he oversaw all of the Smithsonian's increasing activities, and while the new Secretary was settling into office and going off to Canada to search for fossils, Rathbun planned the new exhibits and the horrendous job of moving the collections. When all was finished, Rathbun described the building. There is much architectural terminology to digest and perhaps more detail than one wants in this account, but one cannot help feeling that Rathbun loved every bolt and brick in his lovely new building. 


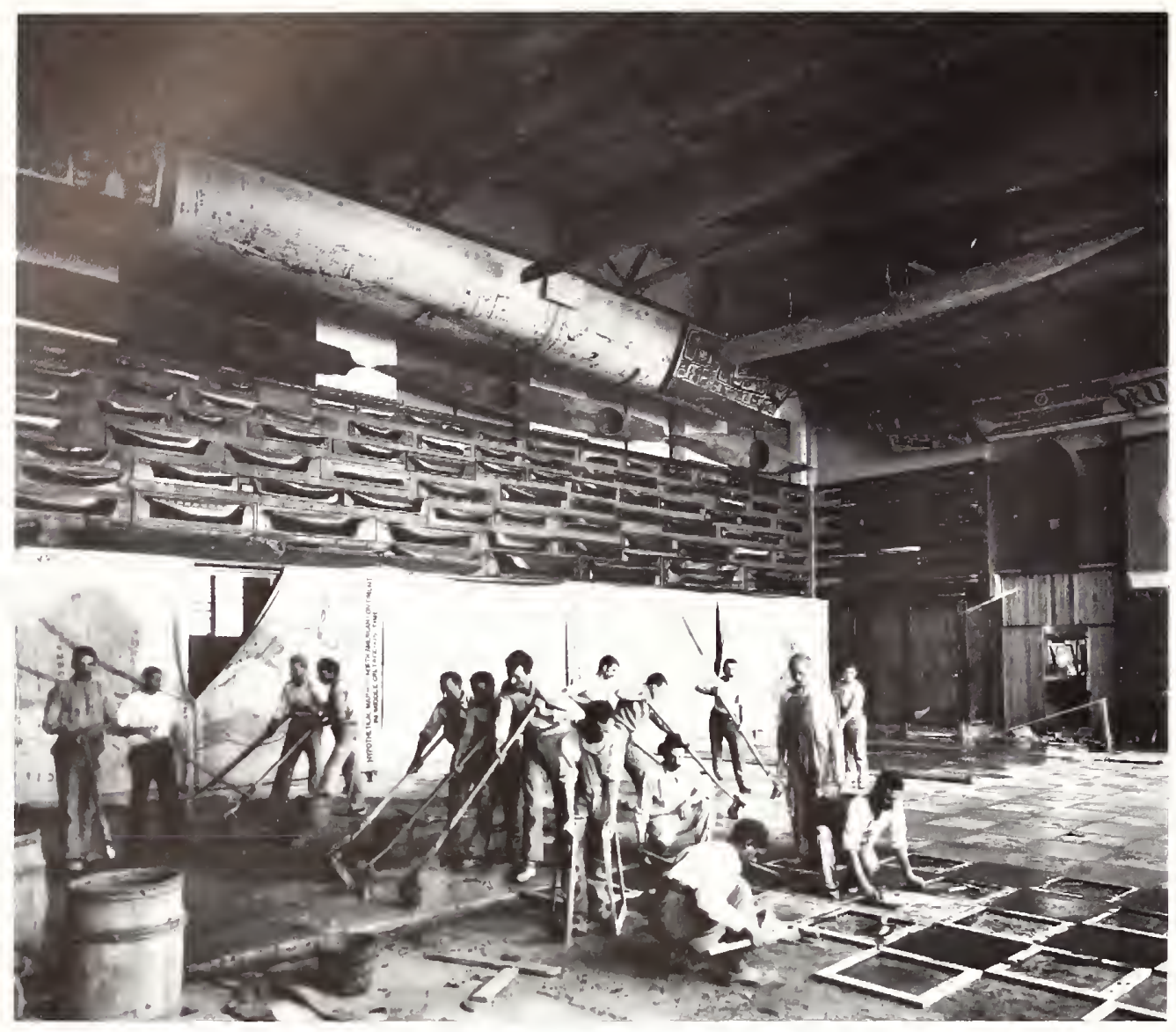

Cement floor being put in at the United States National Museum, with Pacific Northwest Indian canoes hanging above. This was probably taken in the late 1880 s to 1890 after the original wooden floor rotted away.

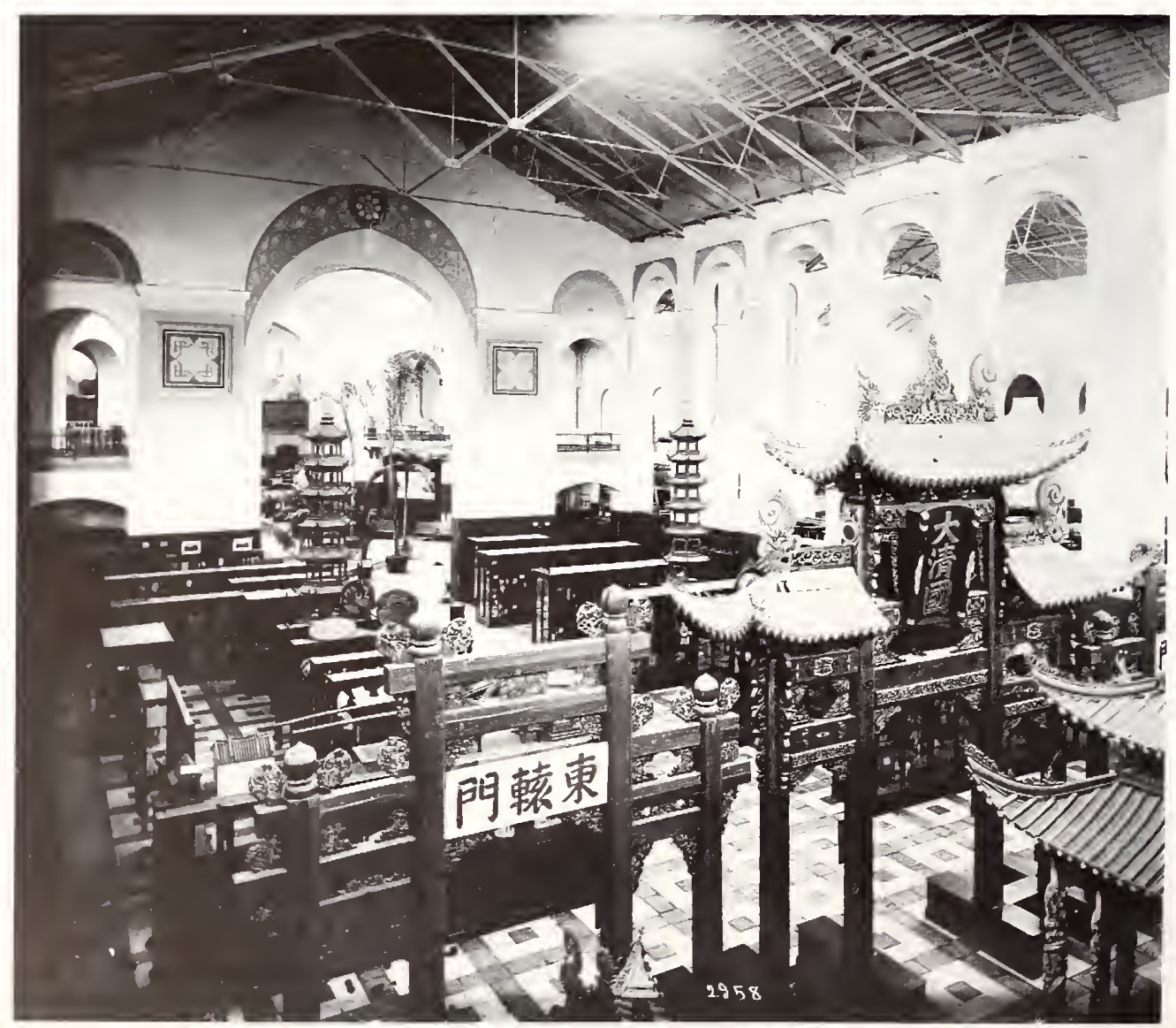

States National Museum. 


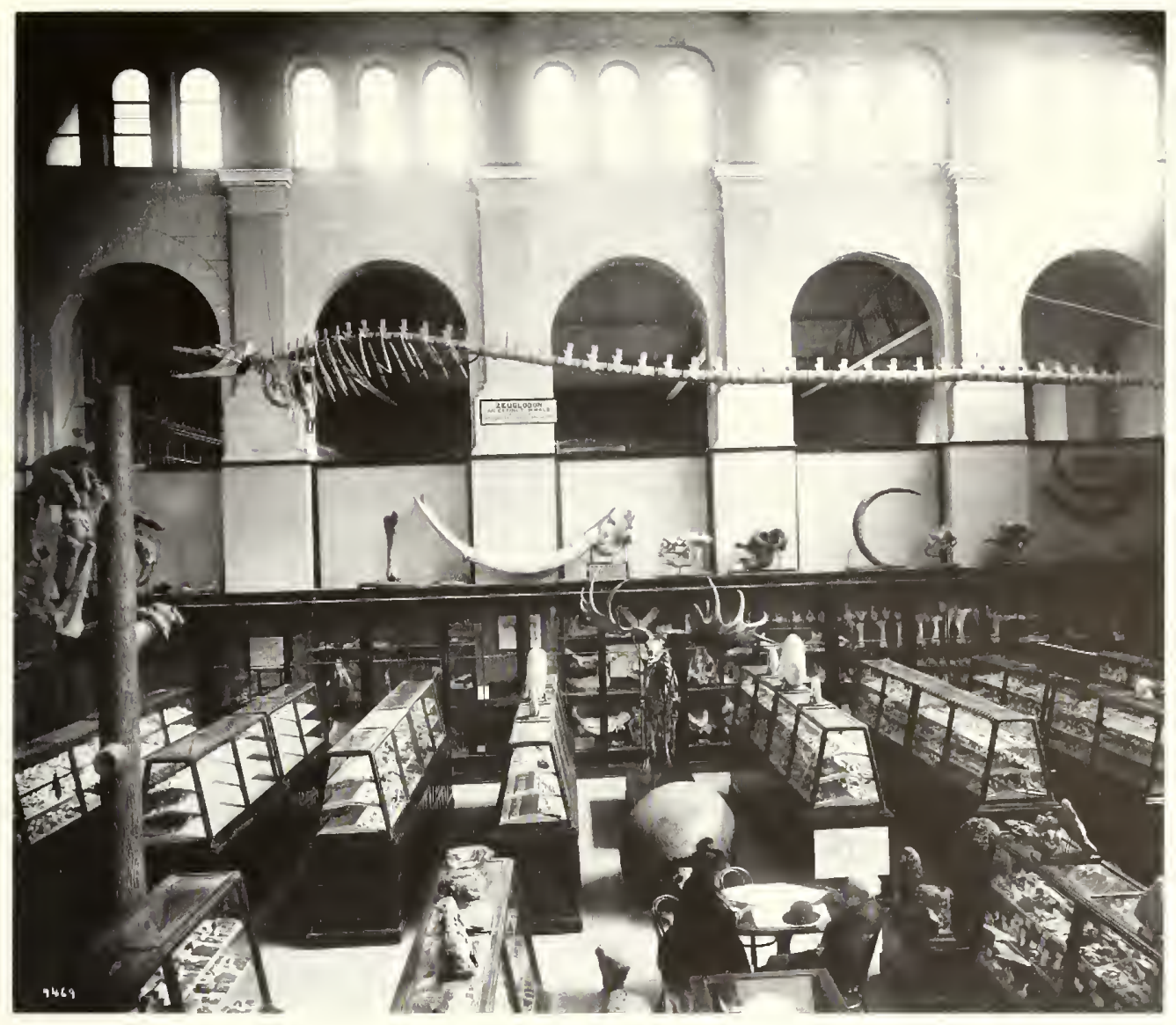

Above, plaster cast of toothed whale Zeuglodon (now more correctly referred to as Basilosaurus); below, Irish elk (Megaloceros); and extreme left, ground sloth (Eremotherium), in the Uniled States Natronal Museum. The Irish elk has been remoumted at least three times, and is now in Hall 6. This ground sloth is not the Panamanian specimen currently on exhibit. The Zeuglodon was not collected until the 1890s, so the photograph call be dated within aboul a fifteen-year interval near the lurn of the century.

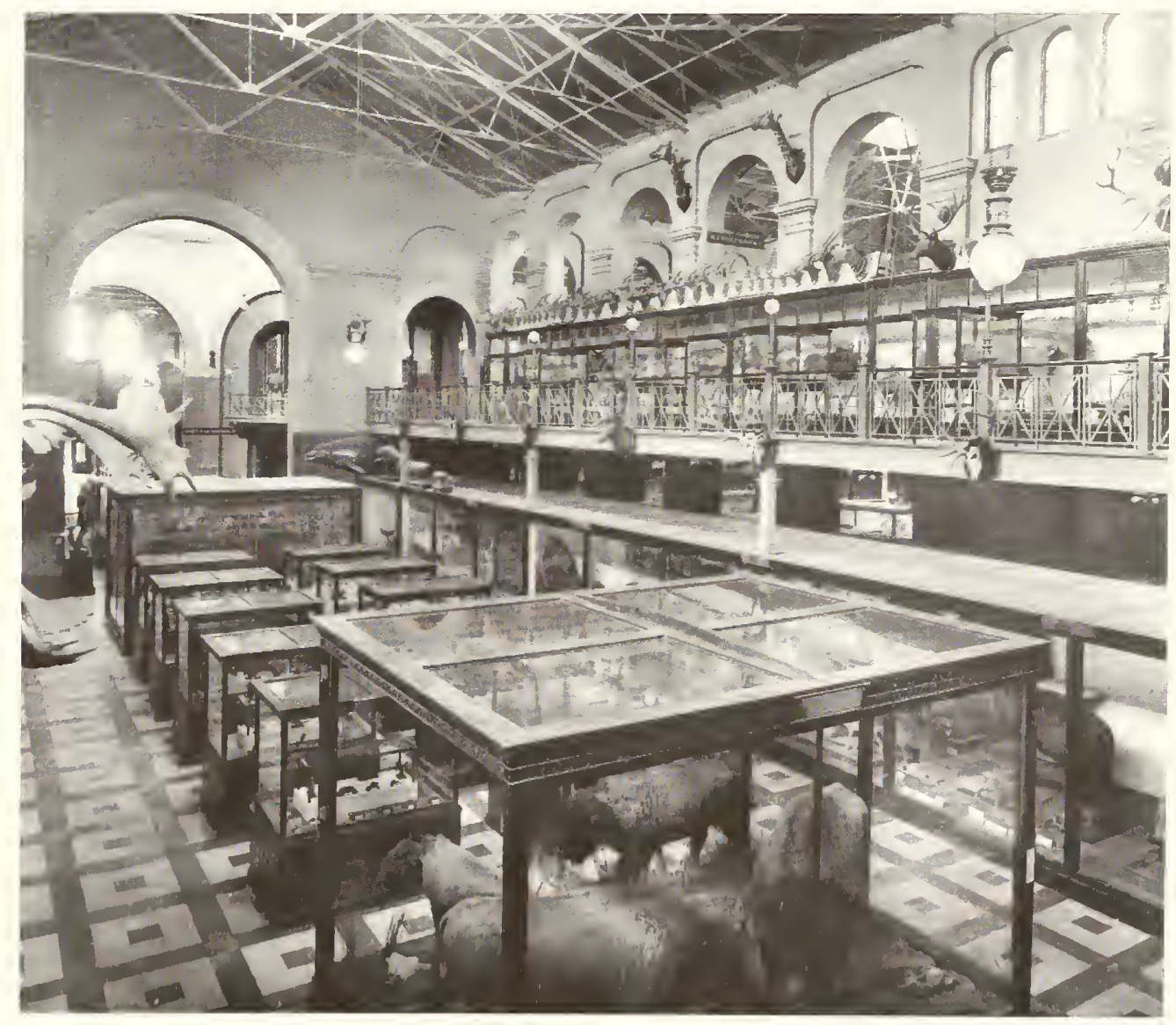

Mammal exhibit in the United States National Museum around 1900 showing the Horraday buffalo (Bison) group in the foreground. 


\section{The New Building}

"I N THE DESIGNING OF THE BUILDING," Rathbun wrote, "two principal objectives were kept in view, first, to secure the largest possible amount of available space and second, to produce a substantial and dignified structure. . . Planned as a great shell . . the building contains few permanent walls, and by giving exceptional width to the main mass an unusual extent of floor area as compared to the extent of the outer walls has been obtained. Other notable features are the absence of the customary monumental staircase, and the minimizing of dark spaces as also of distracting architectural details in the interior. The construction is entirely fireproof." 1

Although it is impossible to get from one place to another within its walls without getting lost, the basic plan of the building is simple. Picture an inverted, fat $T$ having the horizontal member twice the length of the vertical. This is the south side of the building, facing the Castle across the Mall, with the Capitol to the east of it and the Washington Monument to the west. The shorter, vertical member of the $T$ points north. From the north or Constitution Avenue entrance, two narrower segments called ranges extend eastward and westward parallel to the Mall. Each range then turns a right angle and runs south to join the main wings, thus enclosing a hollow rectangle on each side of the northsouth segment. The rotunda marks the intersection of this north with the east-west wings at the front of the building. Even with this plan in mind, it is not particularly easy to visualize locations such as, say, the south side of the north range, no matter how many years one walks around inside the two-square-block structure.

The two open courts, each 128 feet square, were a vital part of the building's design. They provided two commodities seldom spoken of today-fenestration and ventilation. Electric lights were in fairly common use by the turn of the century, but no intelligent person

July 9, 1904: Digging the foundation for the new National Museum on the east side of the building, using an authentic steam-powered steam shovel and mulepower to haul the dirt. would have expected them to take the place of daylight, especially if one wanted to see the true colors of objects. The courts were a necessity if the inner part of the Muscum were to be light enough for the exhibits to be seen and the staff to work. In addition, everyone knows that cross-ventilation is far better than just opening a window. Windows on both sides of the building were one way to ameliorate the Washington summer heat. The courtyard walls are faced with light-colored brick, and the windows are framed with granite from Woodstock, Maryland.

The exterior walls of the Museum are built of solid red brick, hidden from view by a facing of granite blocks ten inches or more thick. The exterior walls are quite massive; on the east side they measure seven feet in thickness. The new Museum was built to last, and it is strong. For twenty years the east attic contained several hundred 500-pound steel cases full of fossils, giving a total weight of approximately half a ton per square yard, yet there was never any doubt that the building could support such a load.

The McMillan Commission had decreed that government buildings were to have a light-colored exterior, a reaction against the red-brick style that had dominated Washington during the last quarter of the nineteenth century. The Patent Office and Tariff buildings, two early govermment structures (one occupied, and one soon to be, by the Smithsonian) were of limestone and local sandstone. They had not stood up well. That left granite as the logical facing material.

Three different kinds of granite were used on the outside of the building. The ground-floor stone is from Milford, Massachusetts; this is called pink granite, but the color is light gray, the stone developing a pinkish cast when wet with rain. The first and second floors and the dome are built of white granite from Bethel, Vermont. The third floor uses another white granite of a different hue, from Mount Airy, Nortl Carolina. (Perhaps, half a century after the Civil War, it was good politics to have some stone from north and some from south.) Had any cost/benefit ratio been seriously consiclered, it is unlikely that granite would have been se- 


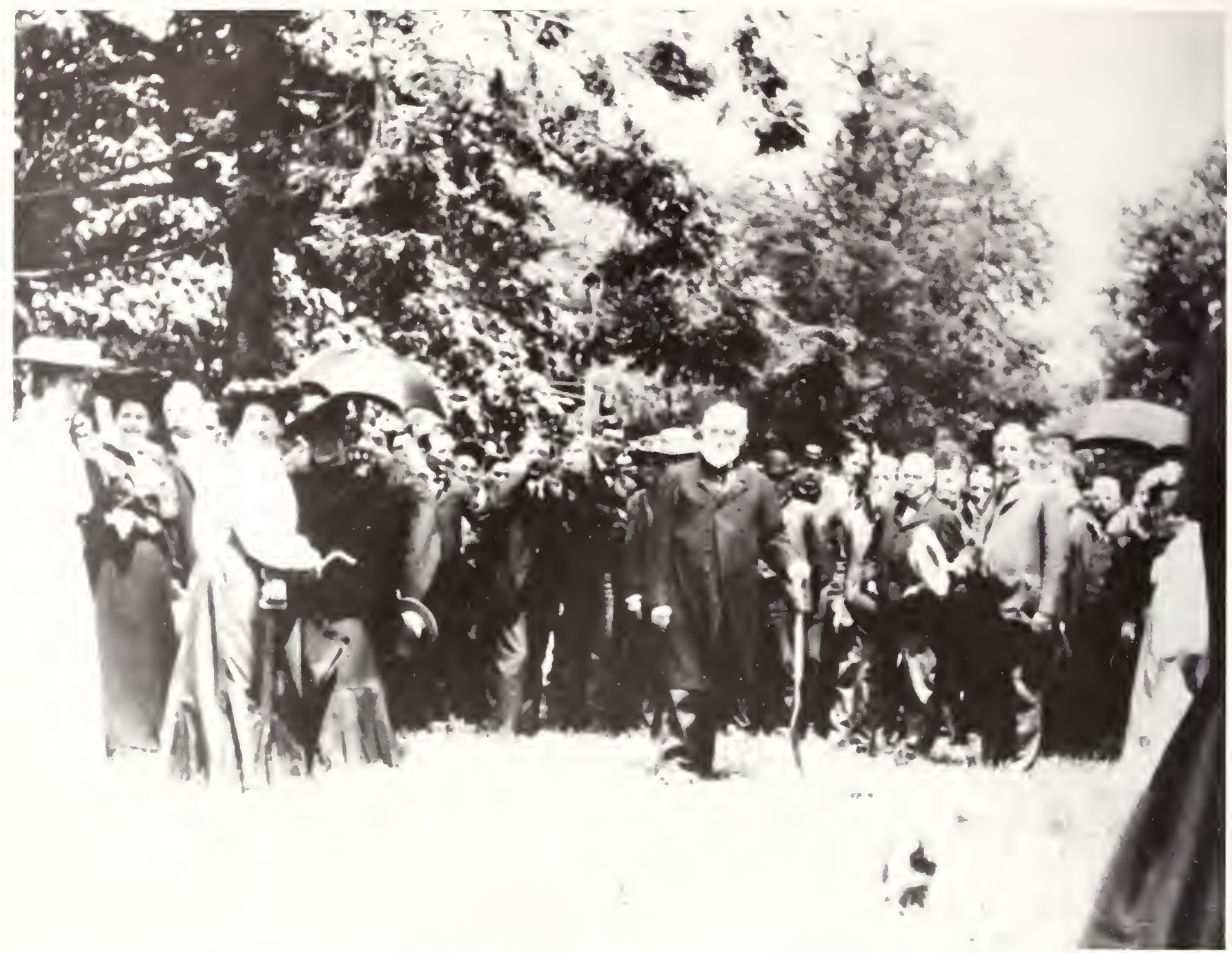

Breaking ground for the nea National Musemm, Jume It, 1907. Servetary Langley holds the showel. To the left, midatay between him and the lady with the umbrella, is Assistaml Secretary Ralhbun. To the right of Secretary
Langley, hat in hand, is J.D. Hormblower, archilect, and belind the hat is Bernard L. Green, superintendent of construction. lected even in the early 1900s, for the need to cur each stone to size before setting it in the proper position outside the bricksturned the granite facing into a major logistic problem. Labor and material were inexpensive, howerer, and the new Museum did not exceed its projected cost. This was in the tradition of the first National Museum building, which had been built for less than was appropriated by the Congress and had opened ahead of schedule.

\section{New Building Vs. Old}

The differences between the new building and the old were manifold. One gets an idea of what was thought of the old National Museum from George Perkins Merrill, head curator of geology and an expert on building stones, who had joined the staff in 1881 : "It was a square squatty affair of red, blue, and yellow brick, exteriorly an architectural horror, interiorly a barren waste. It presented one redeeming feature-space; and as it was space that Baird was after, I presume it may at first thought have been considered a success. One may here be reminded of the reply made by a high official after being shown through the then newly finished Pension Office building. 'Well,' it was asked, 'have you any criticism?' 'Yes,' was the reply, 'it is fireproof.",2

Yet no one except Rathbun seemed excited by the appearance of the new building, which, though handsome and solid, is hardly dramatic. The British Museum of Natural History building, with its various terra-cotta animals decorating both exterior and interior walls, is far more interesting. ${ }^{3}$ The National Museum's architects and some of the staff had toured European museums before final plans were made, and original plans did include terra-cotta facing. But that idea soon disappeared in favor of an exterior whose classic style has remained in harmony with neighboring buildings. To 

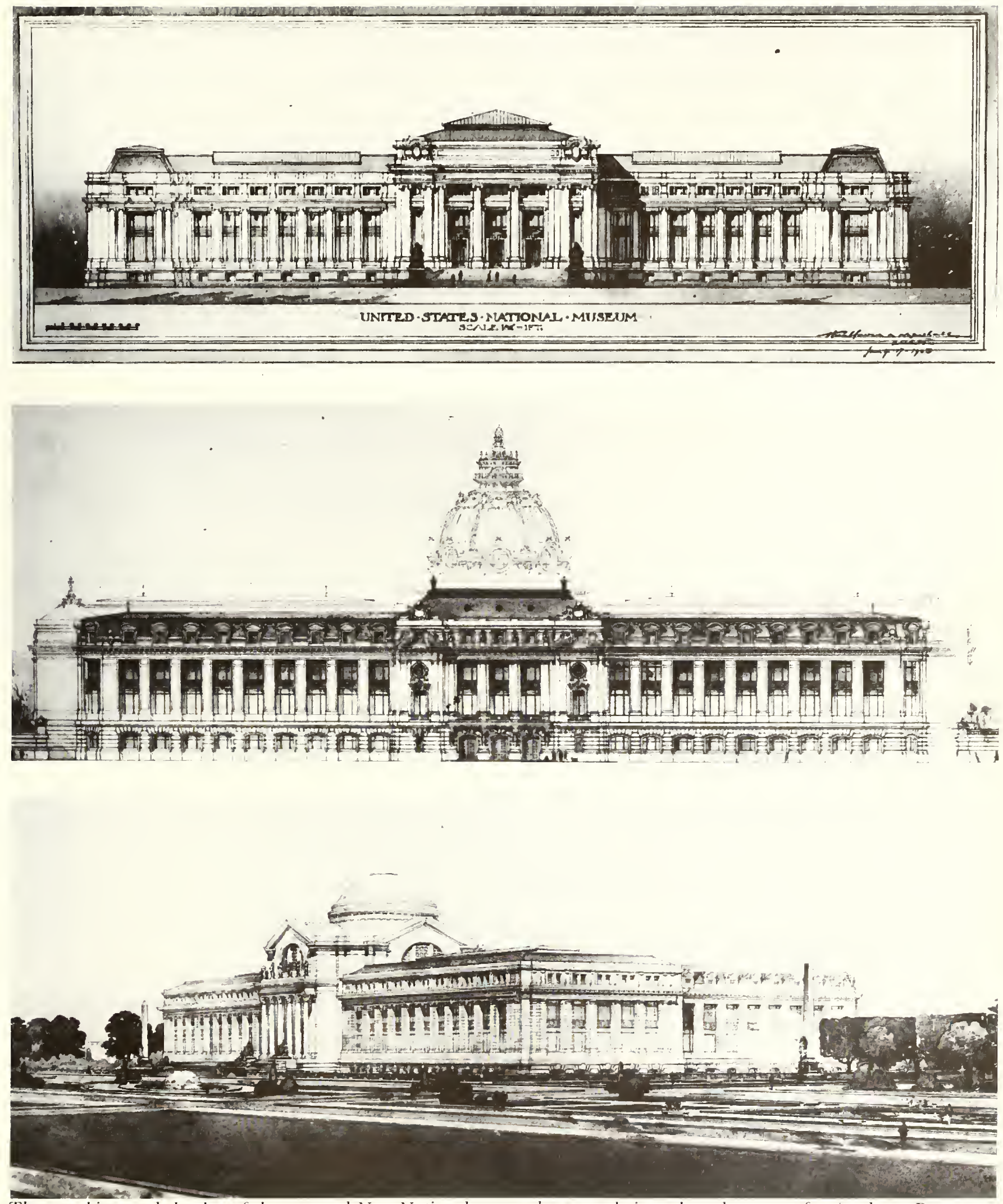

Three architectural sketches of the proposed New National Museum. Top, with a low marsard roof and a skylight aroumd the central areas, as planned in July 1903. Middle, with the elaborate dome projected in 1904; subsequent designs showed an even fancier dome. Bottom, the building with a simple Roman-style dome, essentially as it was consiructed except for the obelisks at either end. This sketch was pullished in the Annual Report for 1909. 


\section{BUILding for National Museum RULES FOR WORKMEN}

1. Working hours 8 to 12 and 12.30 to 4.30 .

2. Come and go through middle gate.

3. Each man will receive a check by which his time will be kept.

4. Checks must be taken care of and deposited with the watchman at the gate before 8 o'clock. Late men must first report at the office.

5. Men who lose checks must replace them with new ones before going to work or receiving pay.

6. Checks will be distributed to the men before quitting timie.

7. Men leaving work earlier must first report to the foreman and then get their checks at the office.

8. Men absent for three days will be laid off unless a satisfactory excuse is promptly given.

9. Men laid off or quilting work will receive a card to the pay clerk at the Library Building.

10. No smoking during working hours.

11. Use water closets and commit no nuisance about the building.

12. Return all tools at end of day to places as directed by foreman.

13. Nobody allowed to carry anything but his own property away from the building. Packages will be examined whenever thought proper by foreman or watchman.

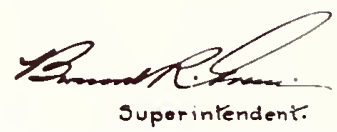

Rules for workmen as loid down by Bernord L. Green. The soperintendent of buildngs and gromnds for the Library of Congress, he knew how to $\mathrm{rmm}$ a major construction job.

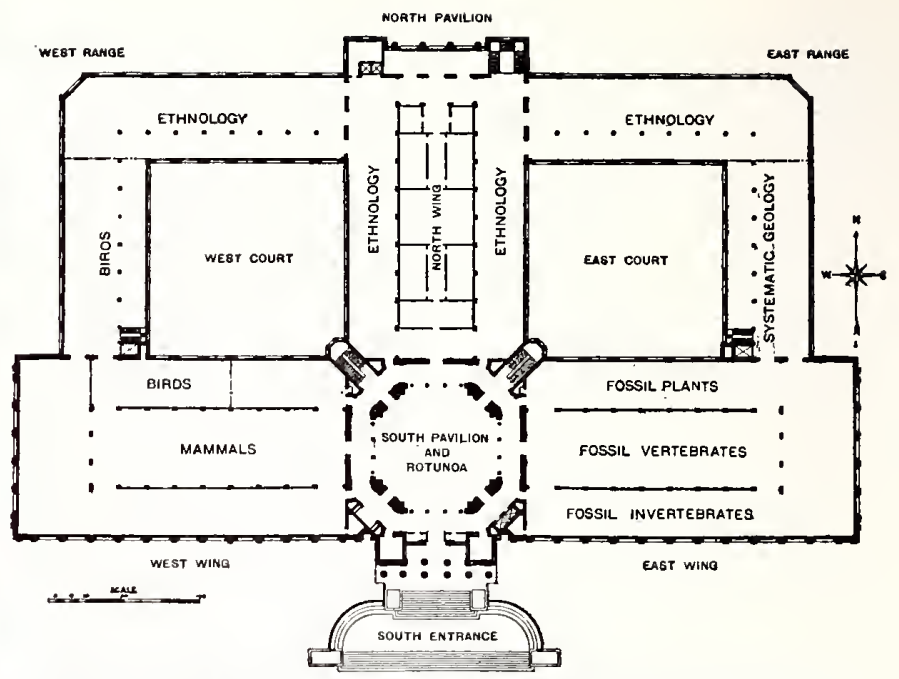

"Plon of first story of new building, showing distribution of exhibition collections." This illustration from the Annual Report for 1913 shows clearly the three wings, each comnected with two ranges to make the two courts. One hall in the eost wing and several halls in the west wing still were not open to the public at this time.

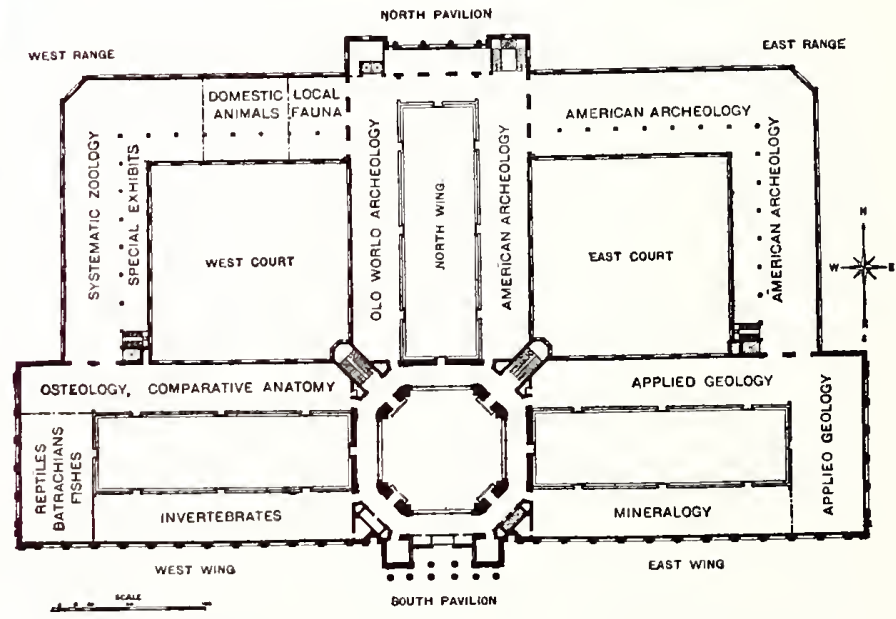

"Plan of second story of new building, showing distribution of exhibition collections," from the 1913 Annual Report. The black dots denote supporting pillars. In the west north range (Hall 26), the local-fauna exhibit included the birds of the District of Colmmbia now on display by the Baird Auditorium. 
some viewers it looks even newer than the fifty-yearold Federal Triangle buildings on the north side of Constitution Avenue.

While the Museum building is not the Parthenon or even the Lincoln Memorial, likewise it is not a characterless modern-clay office building, and the dedicated student of architectural history can spend an hour looking at the exterior. There is some detail to be discerned. The window ledges of the ground floor are formed by the upper surface of the massive lower course of monoliths, whose rusticated surface contrasts with the smooth blocks above. Each vertical pair of windows on the two exhibit floors is treated as essentially one window, strengthening the vertical lines of the building.

On the third story, the roof line is set back along the ranges but is entirely vertical on the wings. The thirdfloor ranges have more granite decoration than the wings, with alternating half-circles and triangles above the windows. The roof and dome are covered with light gray-green slate from Poulney, Vermont, and choice ledges and crevices all over the building - the south portico in particular-are covered with pigeons. The birds are conditioned by many years' worth of attempts to harass them into leaving, and nothing affects them. Like the granite, they are permanent.

\section{Dome, Stately Entrance, Rotunda}

The building's most pleasing aesthetic feature is probably the dome, best seen from the Mall side. The entrance from the Mall is stately, with two runs of steps to the south portico. The north entrance is architecturally the least satisfactory part of the building. Both sides have massive bronze doors. If there is one single criticism to be leveled against the architects, these grandlooking, heavy doors are it. Several generations of mechanics have oiled them, tinkered with them, and cursed them, but since the day the Museum opened, the public has had difficulty heaving them open.

The interior of the building is only slightly more detailed than the exterior. The easiest way to see its best features is to go to the second floor and walk around the rotunda, looking both down, to the floor of 'Tennessee marble, and up. The view of the dome and the large windows is even better from the third floor, but this contains offices and collections and is off-limits to tourists. Few of the staff visit the fourth-floor rotunda unless their collections are stored there.

The rotunda is eight-sided, with the four sides directly facing the wings and the portico being much wider than the four sides in between. Each of these four longer sides has a screen of pillars made of polished brecciated marble. The first-story columns are Doric in style, and the second- and third-story columns are Roman Ionic. As one continues to look upward above the third screen of columns, the four semicircular

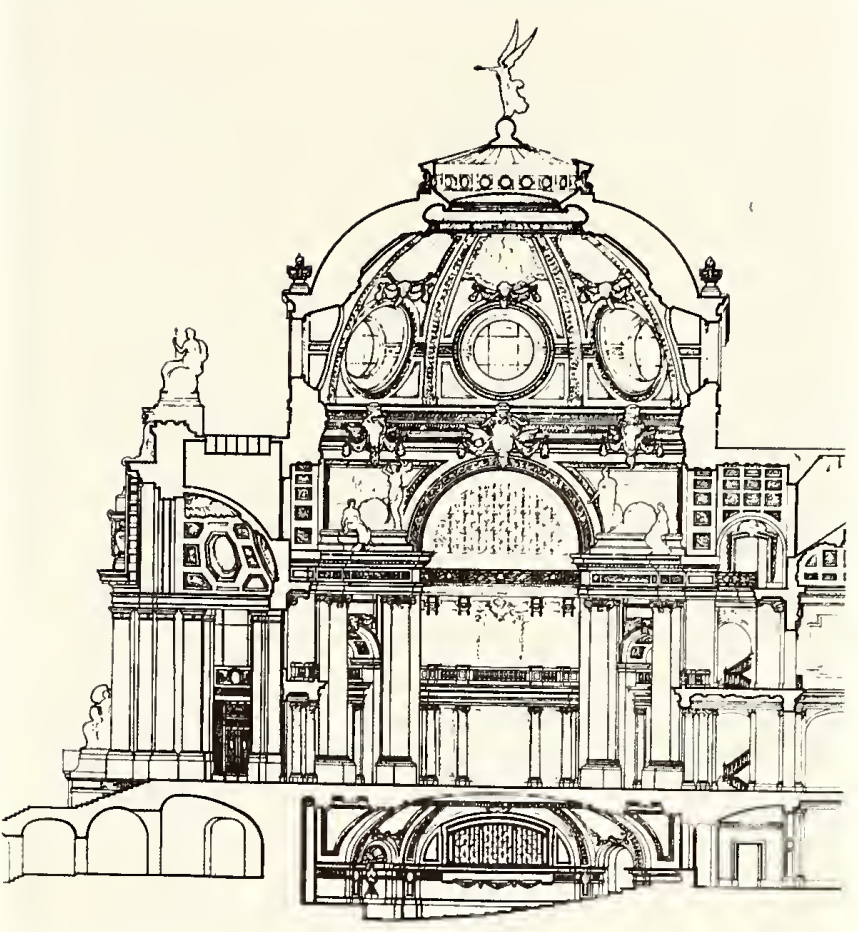

In this proposal for the rotunda, drawn in section, enormous bull's-eye windows let light into the area, the interior is adorned with figures, and the dome is surmounted by a winged statue. To the left are additional statues at the south entrance, and an exedra-an enormous semicircular entrance befitting a palace. The auditorium, in this fanciful sketch, is placed under the rotunda, indicating a date after 1904-after construction had begun.

clerestory windows and the arches containing them can be seen. Craning one's neck, it is possible to see the tiled interior of the dome and the skylight. This is almost as impressive a view as looking into the dome of the Capitol.

There are three exhibit halls to the north, east, and west on the first floor, and two each on the second floor. By Rathbun's measure, the new building had 468,000 square feet (ten and three-quarters acres), of which 220,000 square feet (five acres) was exhibit space. The central hall of each of the three wings has an enormously high ceiling, most of which is roofed by a long, wide skylight. This high ceiling is best seen today from the center of the north hall. A balcony on the second floor, added in the 1960 s to Hall 10 , permits a better view of the skylight and the plaster molding than tourists in the early days could have had. Still, one wonders why even this relatively simple ornamental detail was put in, for the truth of the matter is that no one looks at it. People come to a museum to see the exhibits, not the shell that contains them. 


\section{Building The Building}

W

Hen CONSTRUCTION BEGAN, on June 14, 1904, "the lateness of the season precluded the holding of a formal ceremony on the occasion, but the first spadeful of earth was turned by Secretary Langley in the presence of the superintendent of construction, the architects, and the employees of the Museum and Institution." Langley said a few words, a board fence was erected, and the digging started. The remark about the lateness of the season is a reflection of the era when Congress departed for the summer. What is perhaps more interesting was that it was considered still "too early to discuss the details of the plans." There were not many major museum buildings in the country, and in spite of their examination of foreign buildings, the architects really did not have a grasp of what was needed, or how best to put the parts together.

Clearly the plans were not engraved on stone; they shifted repeatedly and sometimes wildly. Plans of 1902 show a nearly flat roof having a great skylight over the rotunda. Part of the roof was modified to a mansard style, covering pavilions on the east and west ends of the structure. As late as 1904, the auditorium was placed in the foyer, not under the rotunda. The south entrance was designed as an exedra-a semicircular entryway befitting a palace. The entire south facade was to be adorned with statuary. The formerly flat roof suddenly sprouted a dome in the style of the French Second Empire.

In its time the Museum was the largest building in the city apart from the Capital, covering nearly four acres. Completing the excavations and having the massive concrete foundations in by November 9, 1904, was an excellent start. The contracts for the granite were let during these first several months. Early in the winter, "the scheme of correcting any possible mistake of line and effect as practiced at the Union Station by erection of a wooden fascimile of a section was tried at the $\mathrm{Mu}$ -

Northwest corner of the building before completion of the ground floor, looking south touard the Castle on Nowember 22, 1905. The office at this corner is now occupied by the Travel Service. seum. A complete bay, or window, from basement to attic was constructed, and it provert so serviceable that a complete change was made in the elevation of the structure. It was discovered that a certain lack of height prevented a convergence of lines. The question was answered by raising the foundation three feet." This alteration "also permits the transfer of the lecture room to the rotunda basement, removing it from the center wing, which will become available for exhibition purposes." Denizens of museums are supposedly attracted to the basements, which by tradition are expected to be dark and cramped. At least now it is clear why the Museum basement, or ground floor, has such a high ceiling. It is another tribute to the strength of the building that the architects could add extra height without any concern.

\section{Laying the First Stone}

The first stone was laid August 21, 1905-a large block near the north entrance, on the east side. The northern side of the building site required less excavation than the Mall side, so apparently it was easier to start there. The cornerstone is on the northeast corner of the Constitution Avenue entrance. Things were moving well on the construction except that, as Rathbun noted in 1906, "the failure of one of the quarries to furnish stone within the time agreed upon has been the cause of some delay and had retarded the completion of the building until about two years hence."

The top of the building caused major problems. Hornblower and Marshall, not content with their dome of 1904, envisioned in 1905 an even more elaborate one surmounted by a great winged statue. The construction superintendent, Bernard L. Green, who was also the superintendent of buildings and grounds of the Library of Congress, was sympathetic toward a dome but consulted another architect, who greatly modified the Hornblower and Marshall concept. In one of his last major decisions, Langley got rid of the elaborate dome and the statuary. Thus the neoclassical building came to be surmounted by a simple Roman-style dome.

By October 1906, the Washington Post was writing, 


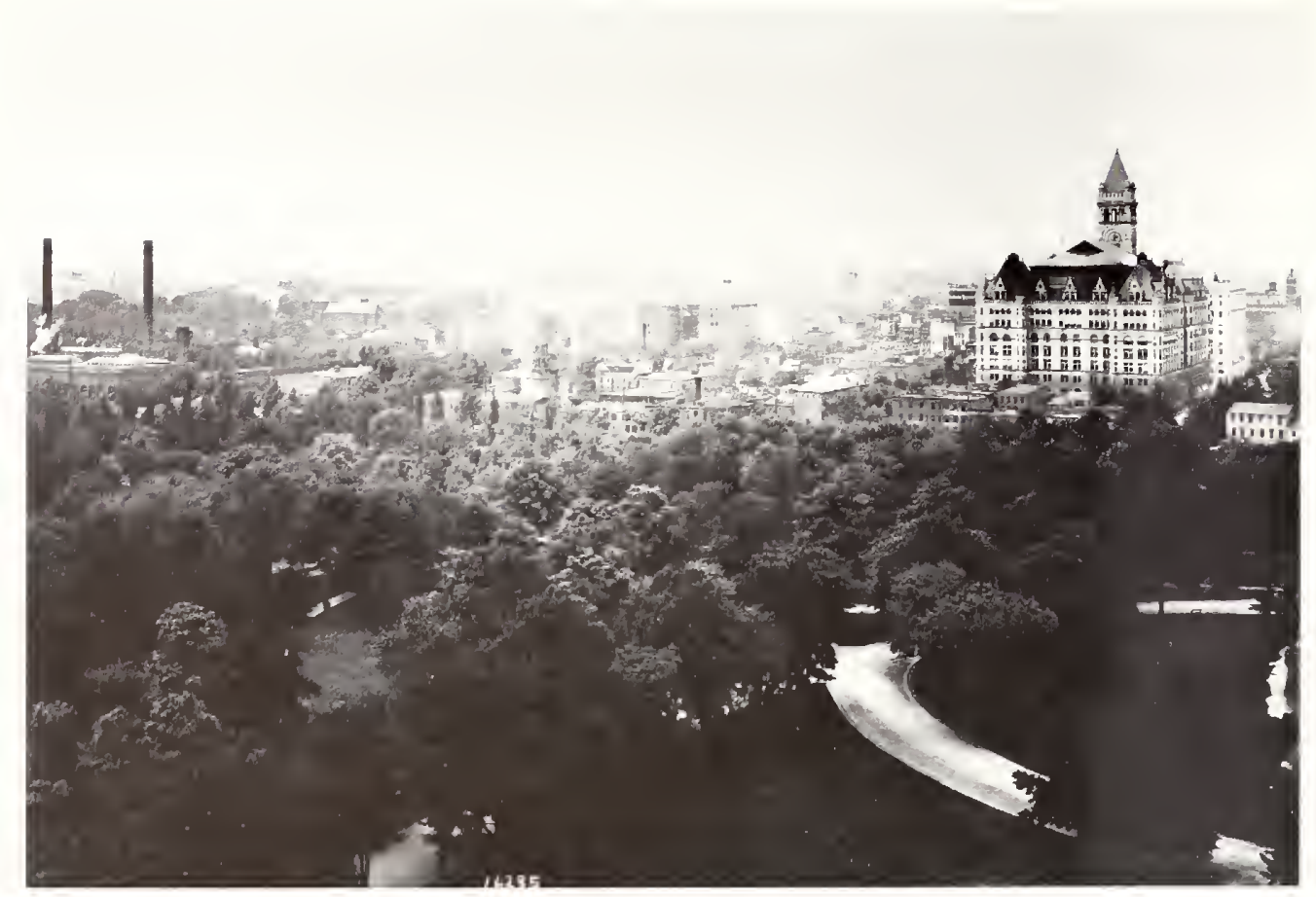

The Mall before construction of the new National Museum, as viewed from the tower of the Castle. To the right is the Post Office Building, a massive granite structure completed in the 1890 s; the museum site is farther to the right, just out of the picture. June 1, 1904.

"Looming up amidst the trees which skirt the northern edge of the Mall, near Tenth Street, the walls of the new Lnited States National Museum are now beginning to assume tangible proportions."

\section{Delays in Construction}

However, it was not going all that smoothly. "Work on the new building has not progressed as rapidly as was expected, owing to delays in the delivery of the granite which was to compose the greater part of the outer wall," Rathbun complained again in 1907. "The fault has lain both with the quarry and with the railroad leading therefrom, the former have already violated the time limit of its contract by a considerable amount, and the latter having neglected to furnish necessary cars when called upon to do so. This delay has not only caused annoyance, but is resulting in pecuniary loss to the Government through the deterioration of large collections held in storage, and in other ways."7

Annoyed as he was, Rathbun did overemphasize the deterioration of the collections. This was in large measure material from the 1904 Louisiana Purchase Exposition in St. Louis. Once again, as at Philadelphia in 1876, a great deal of material was available and the Smithsonian took it, knowing full well that storage space was inadequate. ${ }^{8}$ Still, Rathbun could report there had been some progress, with the east side completed to the second story and work on the west side ready to go as soon as the granite arrived.

In the summary of 1908 Rathbun wrote:

At the close of the [fiscal] year the exterior walls, except those enclosing the south pavilion and the dome, for which the stone had not been received, were finished, and the construction of the roofs was well underway. The interior structural walls and piers were also completed in the rough, and many of the metal window frames of the first and second stories were in place. Some of the latter likewise had been glazed. So much work still remains to be done in the interior, however, such as the building of partitions, the laying of floors, the plastering, the installation of the heating, ventilating, and lighting plants with their immense ramifications of pipes and wires, the completion of the windows, and countless lesser details, that the expectation held forth of being able to make some use of the building by January, 1909, has had to be abandoned. ${ }^{9}$

For once Rathbun was wrong, for the building was used earlier than anticipated_-"as the meeting place of the Sixth International Tuberculosis Congress, held in the early autum of 1908 . . . A large part of the first and second floors, as well as the basement, was given over to the Congress and while the progress of construction of the building was thereby much retarded, this delay may be regarded as fully sanctioned by the exceptionally important nature of the event which occasioned it." $" 10$

In his next report Rathbun fired another blast at the granite quarry and the railroad, this time including the stonecutters, and remarked that a monumental stairway had been dropped from the plans because it would take up too much space. Actually he had a great deal to be pleased about, even though the building was still not finished. "The entire stonework of the outer walls of the building, including the porch, columns, and front 


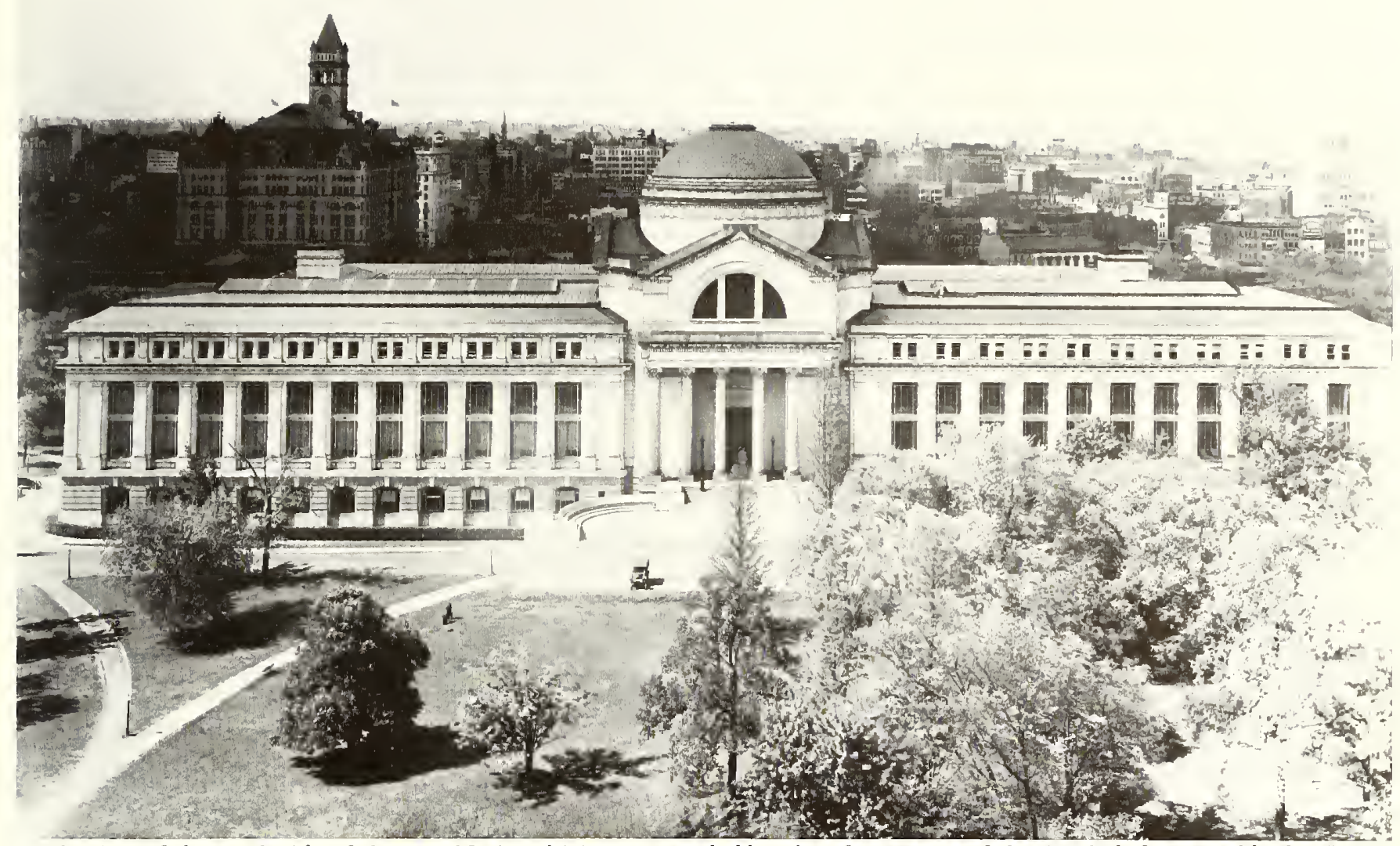

Early view of the south side of the new National Museum, probably taken from tower of the Castle before World War 1 .

of the south pavilion in which the main entrance is located, was, however, completed, as were also the roofs and the skylights of the building generally... .Good progress was made in the preparation and construction of furniture for the new building, more especially for the storage rooms and laboratories, in which it is intended, so far as possible, to utilize the best quality of fireproof material."

Of course, nothing goes easily. The optimists who had assumed that the building would be completed by June 1909 had not renewed the lease on rented storage space, and the bulk of the stored collections had to be moved into several of the new exhibit halls. Although Rathbun complained that "this summary action prevented the assorting and proper assignment of material ... and will necessarily cause some inconvenience in the final adjustment of the collections," ${ }^{12}$ it does seem clear from this remark that he was a patient, longsuffering man, slow to anger-at least in his official writings.

Rathbun's report continued:

On August 10, 1909, occupation of the third story, which is divided into rooms for laboratories, reserve collections, and offices, was obtained from the superintendent of construction, although at the time the story was unprovided with doors, and temporary expedients had to be adopted for the protection of such property as was first moved. On November 9 following, the remaining stories of the main building were turned over to the Museum, and while constructive work of a subordinate character continued to be carried on during most of the rest of the year, it cannot be said to have materially interfered with Museum operations. The mechanical plant was completed in ample time to meet the requirements of the winter season, the boilers being put into permanent service on October 15, $1901 .^{13}$

Congress came up with a supplemental appropriation to allow for grading and construction of roads on the outside and to paint the walls on the inside.

The last construction work on the new National Museum was finished on June 20,1911 . The annual reports for the next several years discuss problems of leaks in the new roofs and how a great amount of metal flashing had to be taken up and replaced; but like the delivery of granite, this too was ultimately completed. 


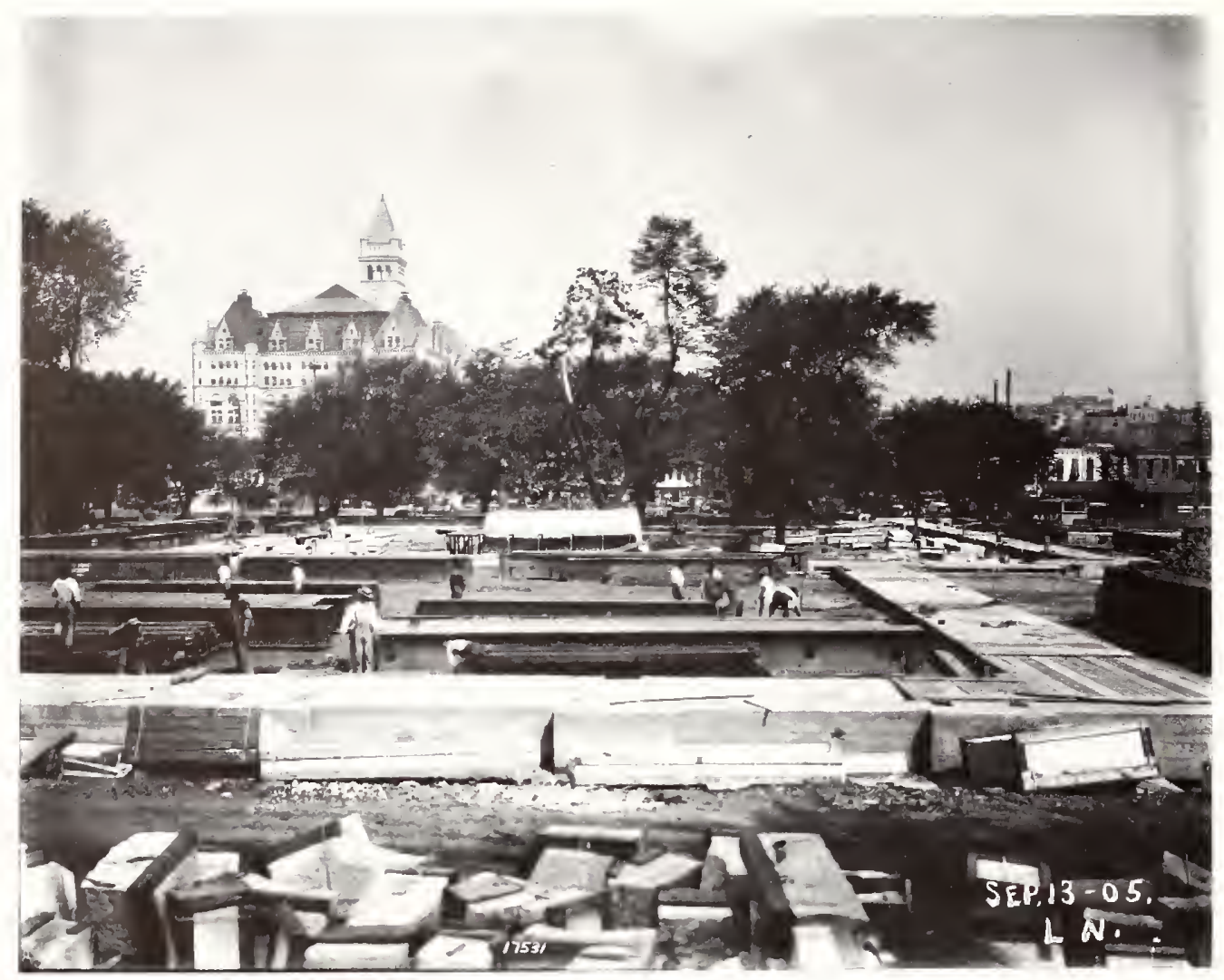

Construction on the ground floor at the west side of the building, looking north toward the Post Office. September 13, 1905.

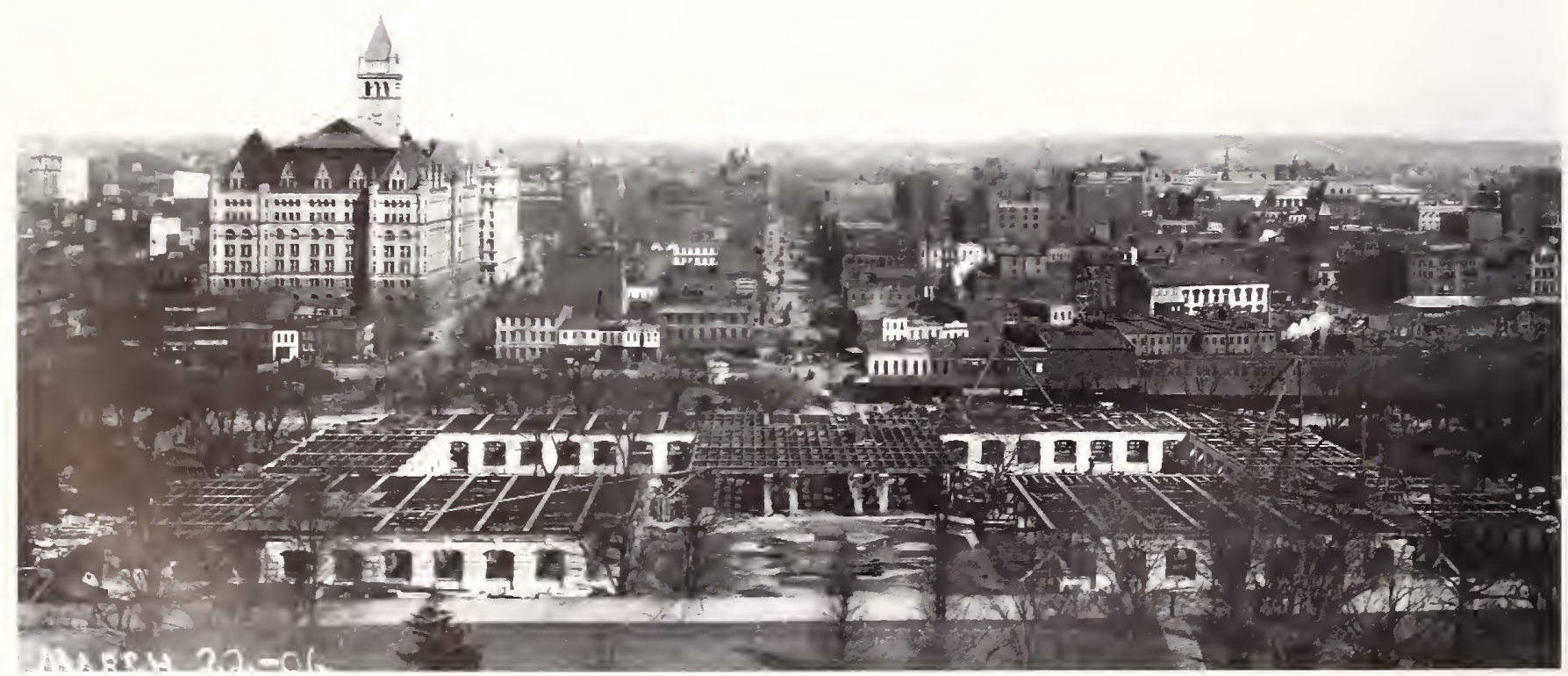

Foundation of the new National Museum, probably taken from the tower of the Smithsonian Castle. The low area in the center is the site of the Baird Auditorium. March 22, 1906. 


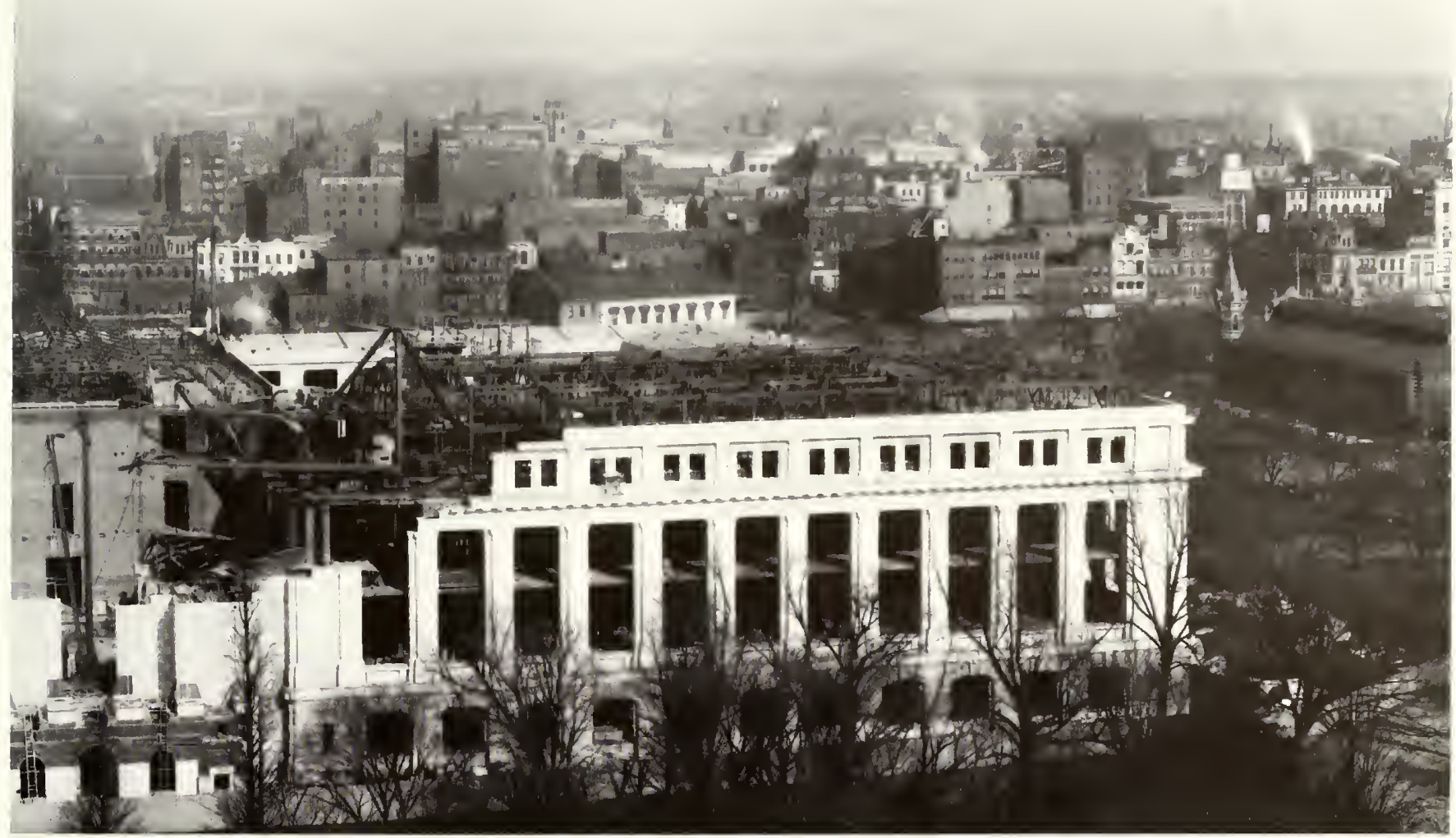

Construction of the east wing to the thind-floor level and the votunda to the fonth-floot (attic) level; probably taken in 1907 from the tower of the Castle. In the middle distance is the Old Patent Office building, the curcent site of the National Museum of American Art and the National Portiait Gallery.

Aerial view of the new National Museum looking north-northwest; the farmers' market is on the north side of

$B$ Street and there is no construction for the Federal

Triangle of government buildings. The projections on the south side of each courtyard house the freight elevators, which were nu by direct electric curtent until the 1960s.

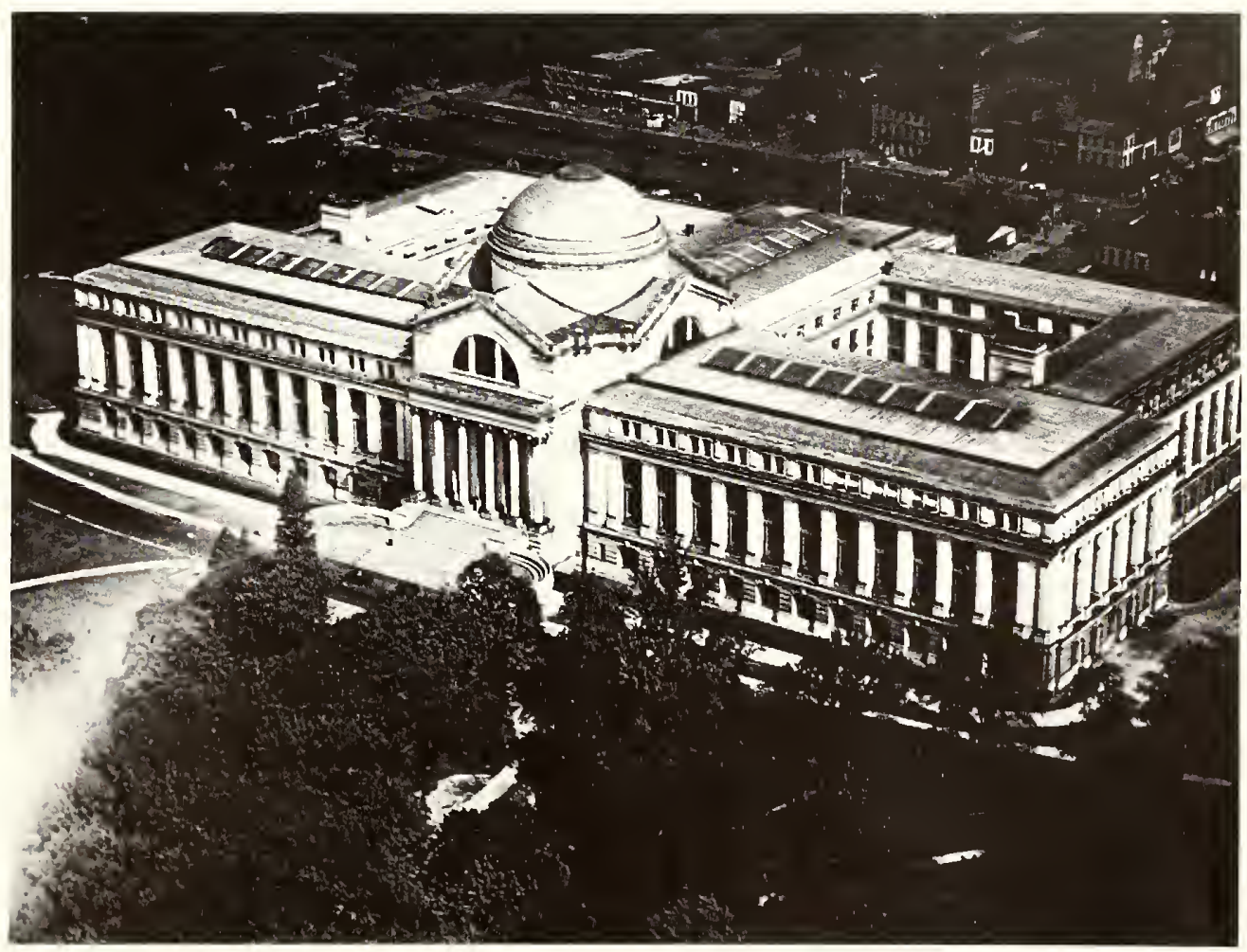



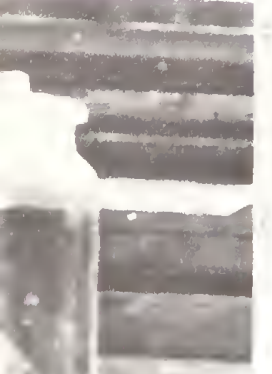

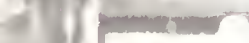

$\sqrt{x}$

d)

i

1
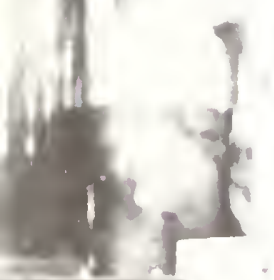

-

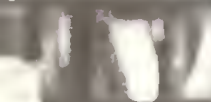

a.s.

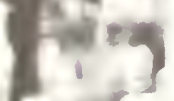

pres

ats

r.
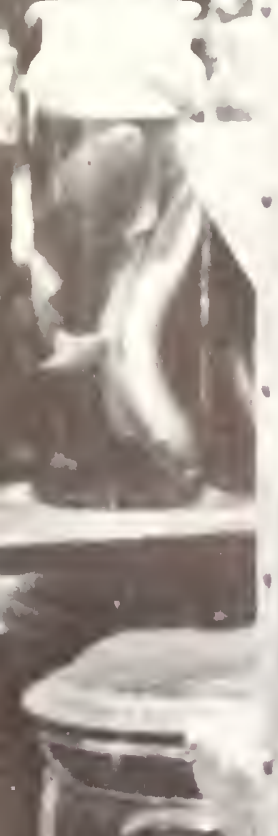

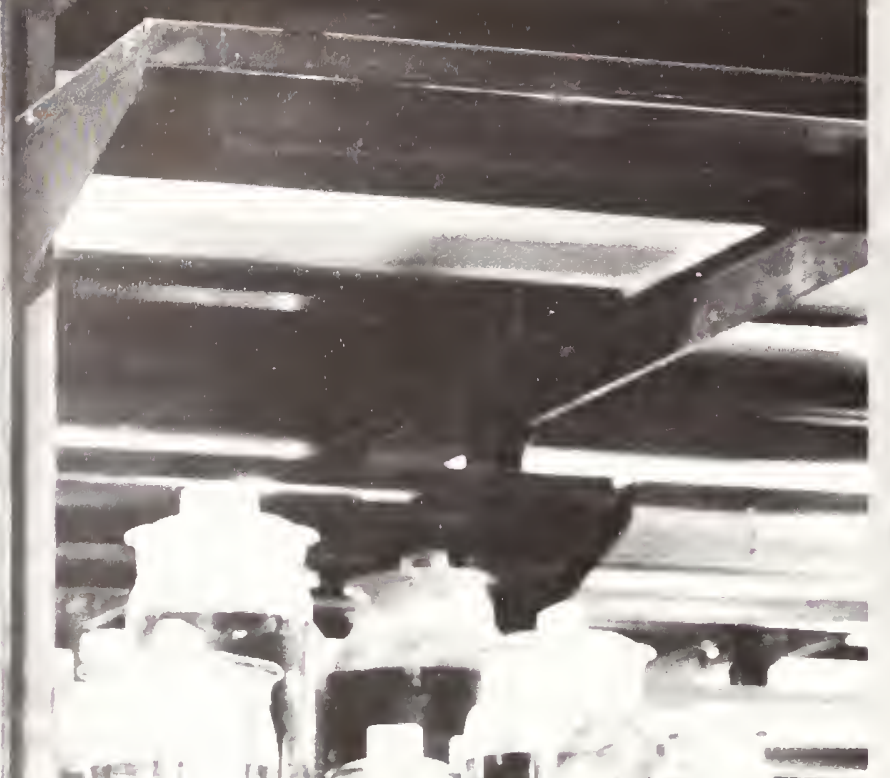

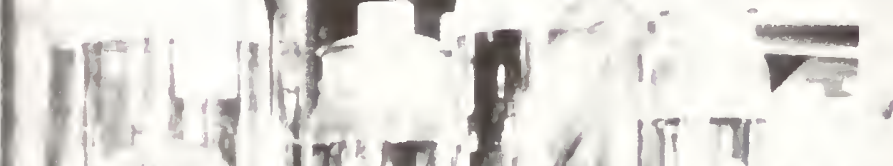

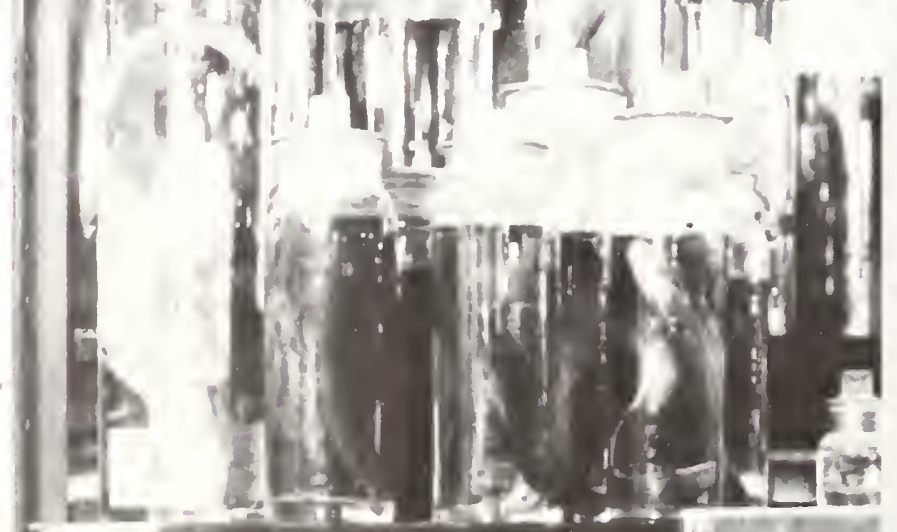
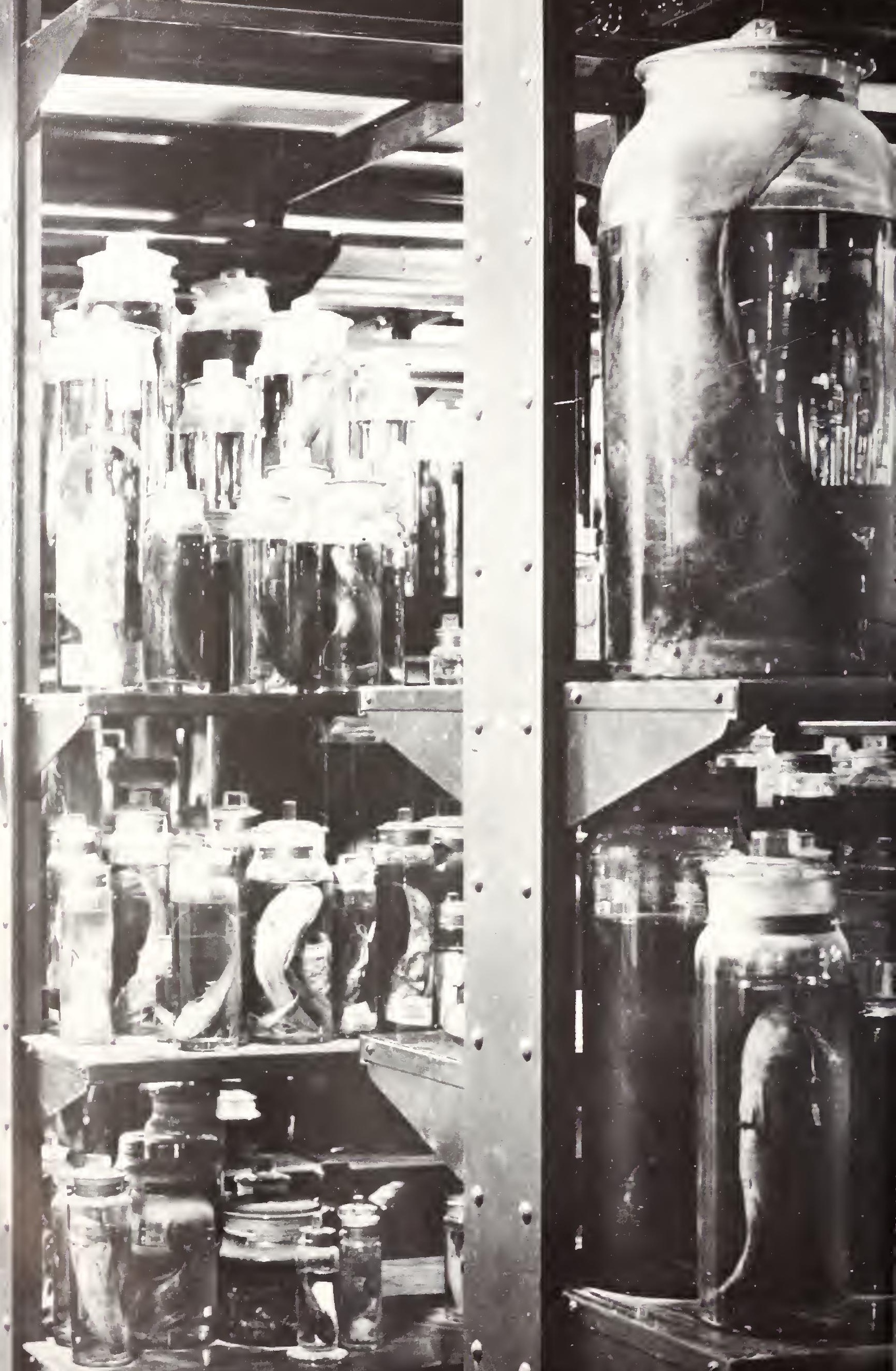


\section{Moving Into Valhalla}

L ITTLE DETAIL IS PRESERVED as to the actual mechanics of the move to the north side of the Mall. Loaded on wagons, specimens and cases scattered among the Smithsonian Castle, the old National Museum, and temporary storage facilities were transported to their new home. While the east side of the building had been the first to be built, the west side, facing the Washington Monument, was the first to start filling up.

On August 11, 1901, the day after permission to occupy the third floor was obtained, the mollusk collections began to be moved in. The division's curator, William Healy Dall, measured the floor plans ("a hopeless muddle")' late in May, but soon went off to Maine for the summer, leaving assistant curator Paul Bartsch to supervise the move. A long-time preparator in the Department of Biology, John A. Mirguet, had a vivid recollection of bringing a case full of mollusks from the balcony and the north tower of the Castle to the third floor of the new building and positioning it on a piece of flooring newly laid clown by the carpenter. The time it took him to go back to the Castle and return with another load was just sufficient for the carpenter to lay another piece of flooring. These cases were awkward pieces to move-six feet high and about ten feet wide, with space for four stacks of drawers.

When Dall returned in the fall he spent a month unpacking his books and office collections, and by midNovember was settled in his new quarters, actively pursuing his research. Not only was he an important figure at the Museum, but his career casts some light on the often-curious arrangement of research collections.

In 1865 Dall, then twenty, came to Washington for the first time, leaving shortly thereafter for more than three years in Alaska. Upon his return he lived in the south tower of the Castle, working on the collections without pay. As there was no prospect of employment, he joined the Coast Survey in 1871 and went back to Alaska for three more years, this time to study the

"Alcoholic specimen room, middle part of groumd story, west wing," from United States National Museum Bulletin 80 (1913). This area is now used for preparation of exhibits.
Aleutian Islands. While working in the Castle after his return, he continued to be paid by the Coast Survey until 1884. Then he joined the United States Geological Survey, but still remained in his Smithsonian office, now in the north tower. While the recent mollusks were moved to the west range of the new National Museum, the collection of Cenozoic lossils was moved there also. As part of this work for the Geological Survey, Dall curated these fossils and wrote a study of the fossils of Floricla.

Dall was a friend of $T$. Wayland Vaughan, another Geological Survey employee and a specialist on corals. Thus modern and Cenozoic corals were also housed with the mollusks at first. Modern brachiopods were an interest of Dall's, so they too were "mollusks"; and because Paul Bartsch taught courses in economic parasitology at a local university, parasitic worms were" mollusks" for years. ${ }^{2}$

\section{An Orderly Transfer}

Under Rathbun's direction, the move into the new Museum was fairly orderly. "As it was desirable at first to establish the scientific staff and the general collections in the building, the construction of the storage and laboratory furniture was taken up and mostly finished before work on the exhibition cases was begun," he reported in 1910.3

Fire is one of the persistent worries of any museum administrator. As a safeguard, cases for specimen storage, formerly made of wood, were to be of steel or at least covered with metal; covers on these cases inhibited the pervasive dust. Steel shelving and steel racks were also the ideal. Sulphur-tipped, strike-anywhere matches were forbidden in the building, and several signs posted in the attic proclained in large letters that smoking there was grounds for instant dismissal.

Rathbun's account of fiscal year 1910 went on:

The moving of the reserve collections was commenced in August, 1909, and by [July, 1910] not only had it been practically completed, but the systematic arrangement of the specinens in their new quarters, either permanently or tentatively, 


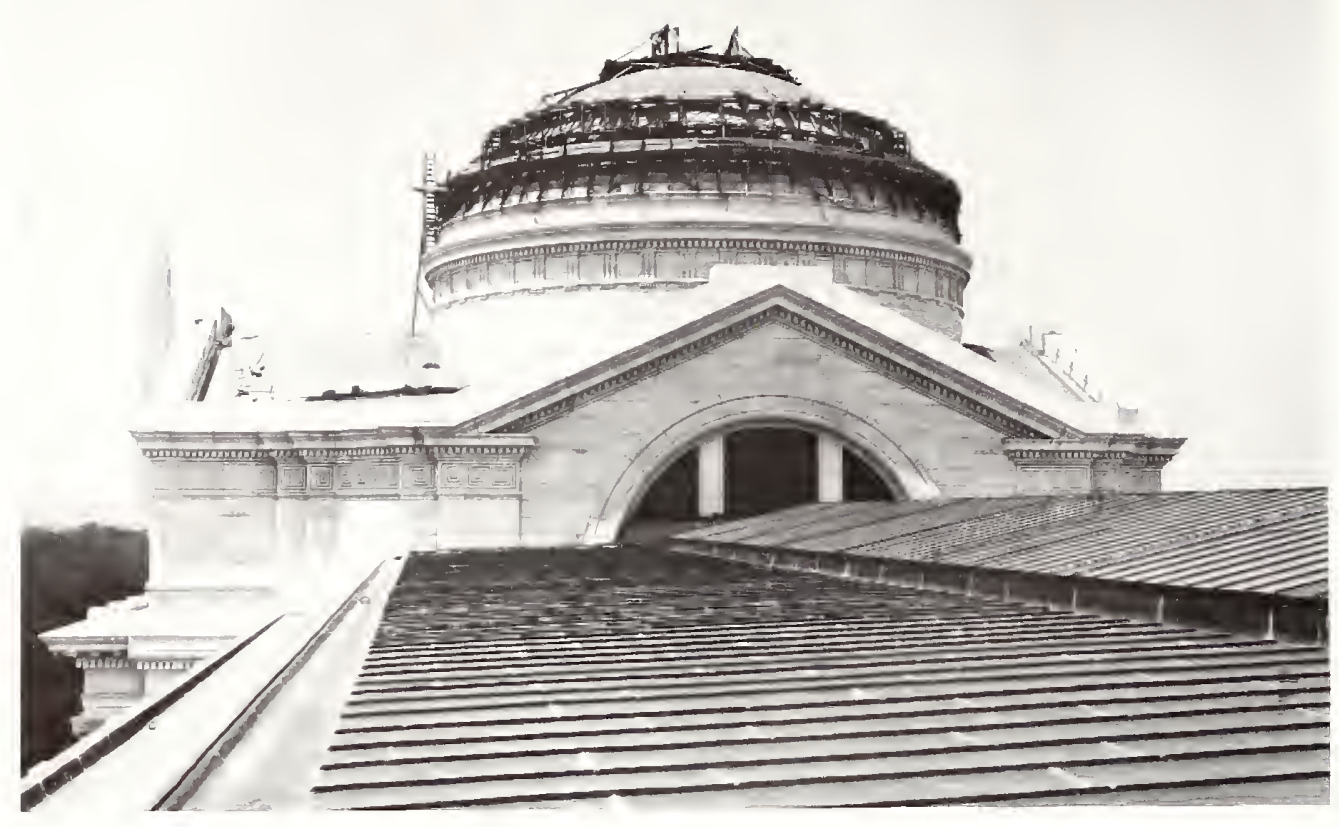

Final stages of work on the exterior of the dome, looking west from the roof of the east wing.

had also been accomplished. While the new installation had not been perfected to the same extent in all of the divisions, yet, as a whole, it was so far advanced as 10 produce conditions vastly superior to those existing at any previous time. Such a result was only made possible by the greatly increased and more convenient accommodations. which permitted the spreading out in an accessible and orderly manner all of the material belonging to each division, and by the employment of temporary help exceptional progress was made in the work of recording and cataloging specimens. The mechanical and scientific workshops and the offices generally were among the first in the new quarters to be furnished."

Writing in 1941, the rertebrate paleontologist Charles Gilmore looked back on the transition:

At the time of $m y$ affiliation with the National Museum in 1903, the bulk of the [O.C.] Marsh collection was stored in rented buildings in southwest Washington. The first floor of a threestory brick building on the west side of 10 th street near C street, SW. was then in use as a paleontological laboratory, the cellar and the two upper floors being completely occupied by boxes and crated trays of vertebrate material. The study collections of this period were kept in standard trays arranged in tiers of the balcony in the southeast corner of the present Arts and lndustries Building and in the lower part of Atopped exhibition cases in use at that time. These collections in storage from 1903 on were rapidly reducel in bulk through preparation and condennation of worthless material, so that in 1910, with the occupancy of the New Natural History Building, the widely scattered storage collections were assembled as a unit. ... For the first time the preparators were provided with a well-lighted, well-equipped, roomy laboratory (27 by 77 feet). These improvements in facilities were almost immediately reflected in an improved quality as well as quantity of output. ${ }^{5}$

The process of moving took a few years, for after the transferring of the study collections, the exhibits had to be taken down and reinstalled. While this opened up some space in the Castle, the greatest positive impact was on the old National Museum building. A Department of Mineral Technology had been established in 1904, but lack of space and staff made it a paper organization until natural history left the building. Independent divisions of Textiles and Medicine also were created, taking some of the hodgepodge out of the Department of Anthropology. These divisions coalesced during fiscal year 1918-19 to form the Department of Arts and Industries. Precisely when the red brick building came to be known as the Arts and Industries Building is not clear, but by the 1920s and 1930 s most people referred to the buildings as "the Museum" and "the A \& I." During the ten years it took Arts and Industries to come into its own as a tourist attraction, the notion of a new and old National Museum disappeared. 


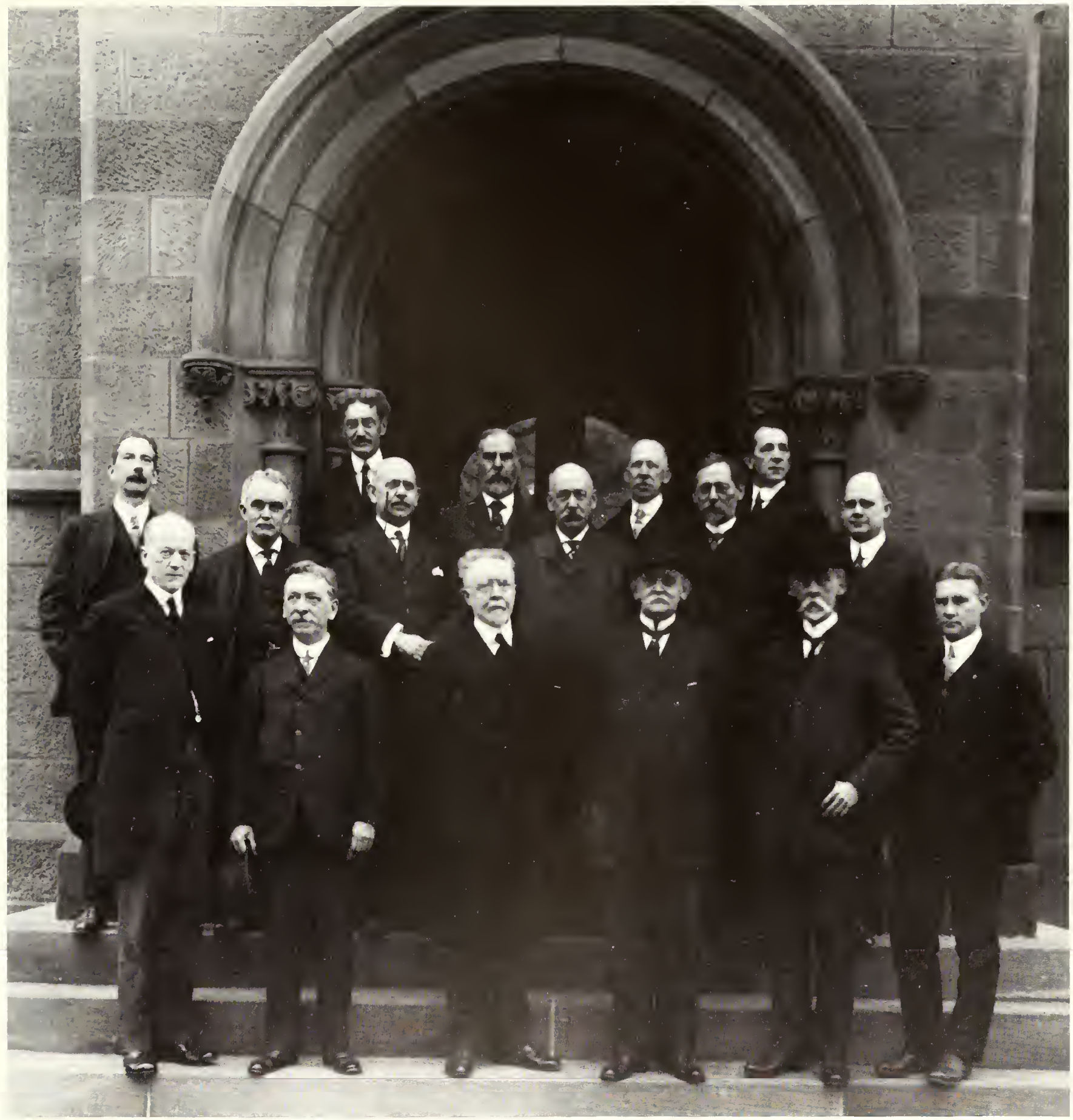

Those who led the Institution and the Museum during this period, plotographed on the steps of the Castle in Jamuary 1915. Front row, left to right: Dr. Charles D. Walcott, Secretary, Smithsonian Institution; Dr. Richard Rathbun. Assistant Secretary in Charge, United States National Museum: Dr. George P. Merrill, Head curator, Geology; Dr. Frank Baker, Superintendent, National Zoological Park; Dr. William H. Holmes, Head Curator, Anthropology, and Curator, National Gallery; Mr. Harry W. Dorsey, Chief Clerk. Back row, left to right: $D r$.
Charles G. Abbot, Director, Astrophysical Obsereatory; Dr. Leonard C. Gumnell, Assistant in Charge, Burean of International Catalogue of Scientific Literature. Mr.J. H. Hill, Property Clerk; Mr. James G. Traylor, Appointment Clerk; Mr. C. W. Shoemaker, Chief Clerk, Exchange Service; Mr. W. I. Adams, Disbursing Agent; Mr. A. Howard Clark, Editor; Dr. Leonhard Stejneger, Head Curator, Biology; Mr. F. W. Hodge, Ethnologist in Charge, Burean American Ethnology; Mr. Panl Brockett, Assistant Librarian. 


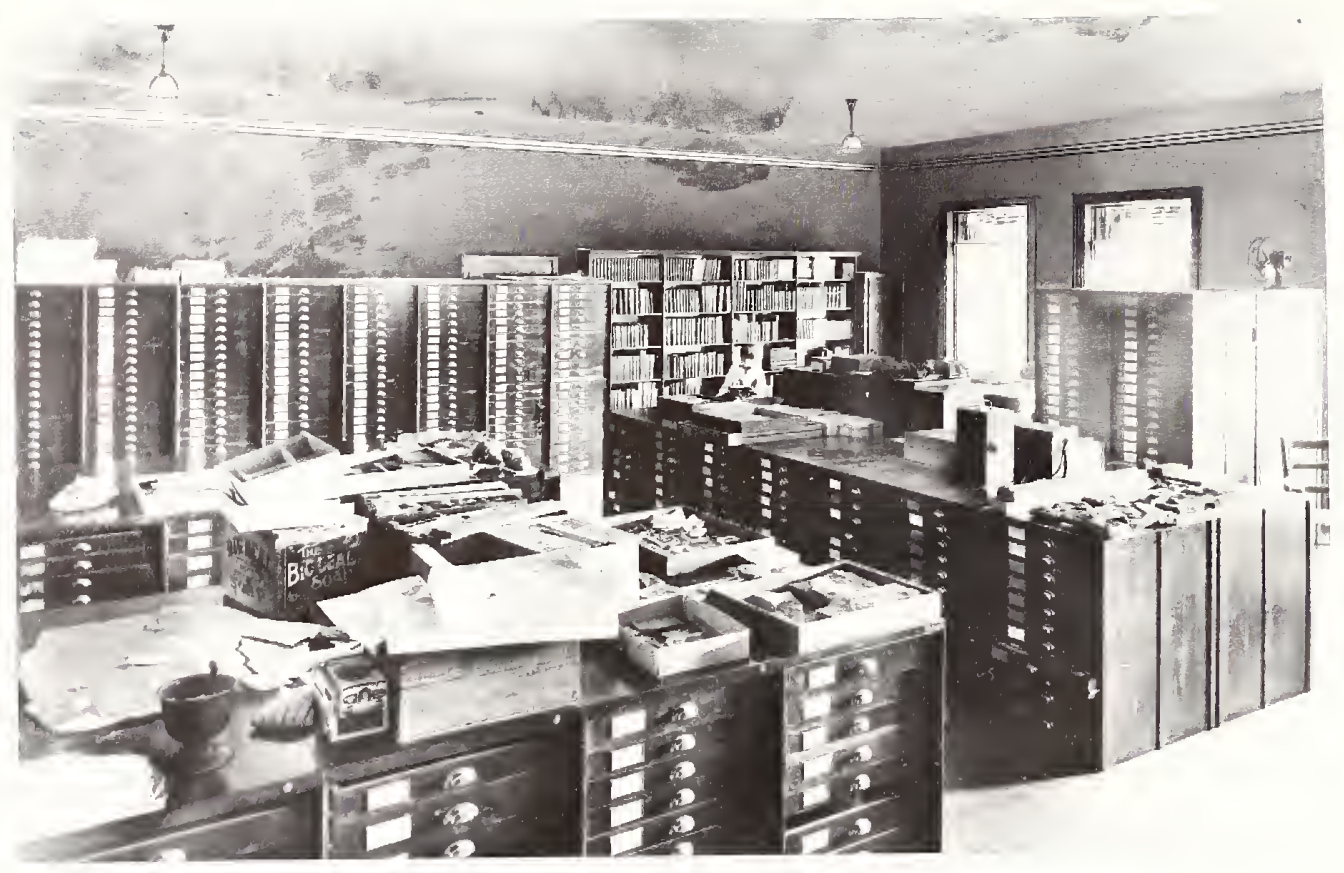

"East wing, third story," from United States National Museum Bulletin 80 (1913). This laboratory of invertebrate paleontology cannot be precisely located, but the general area, now occupied by archeologists, lies more or less under the section of roof shown in picture on page 36. The negative is stained, and the effect seen on the wall is not that of a leaking roof. The woman using the typewriter, barely visible behind cabinets, may be Margaret Moodey, secretary of the Department of Geology.

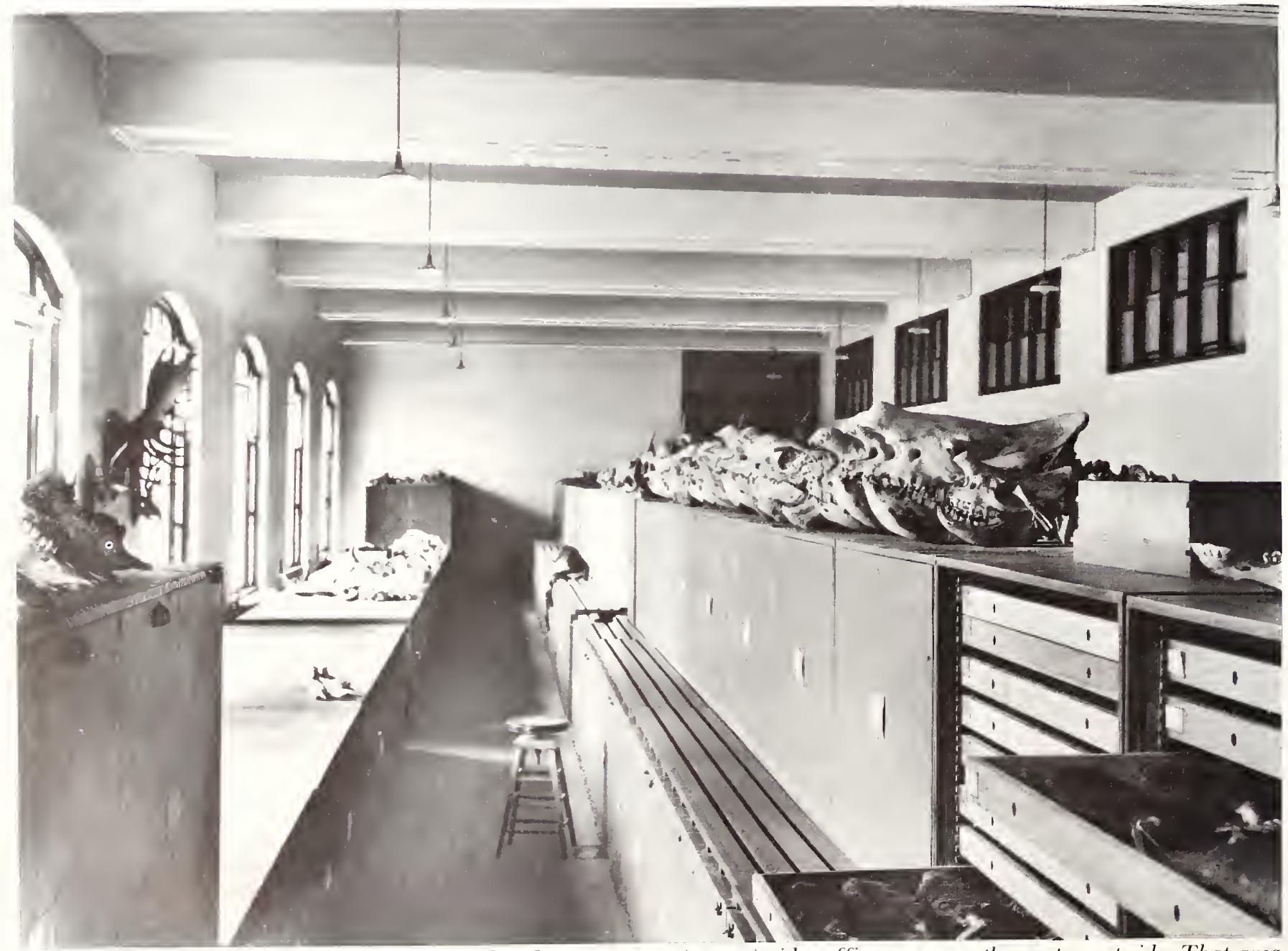

"West range, ground story, storage of mammals," from United States National Museum Bulletin 80 (1913). The working area shown is on the B Street (Constitution
Avenue) side; offices were on the west court side. That area was occupied by the Bureau of the Biological Survey, and is now occupied by the National Anthropological Archives. 


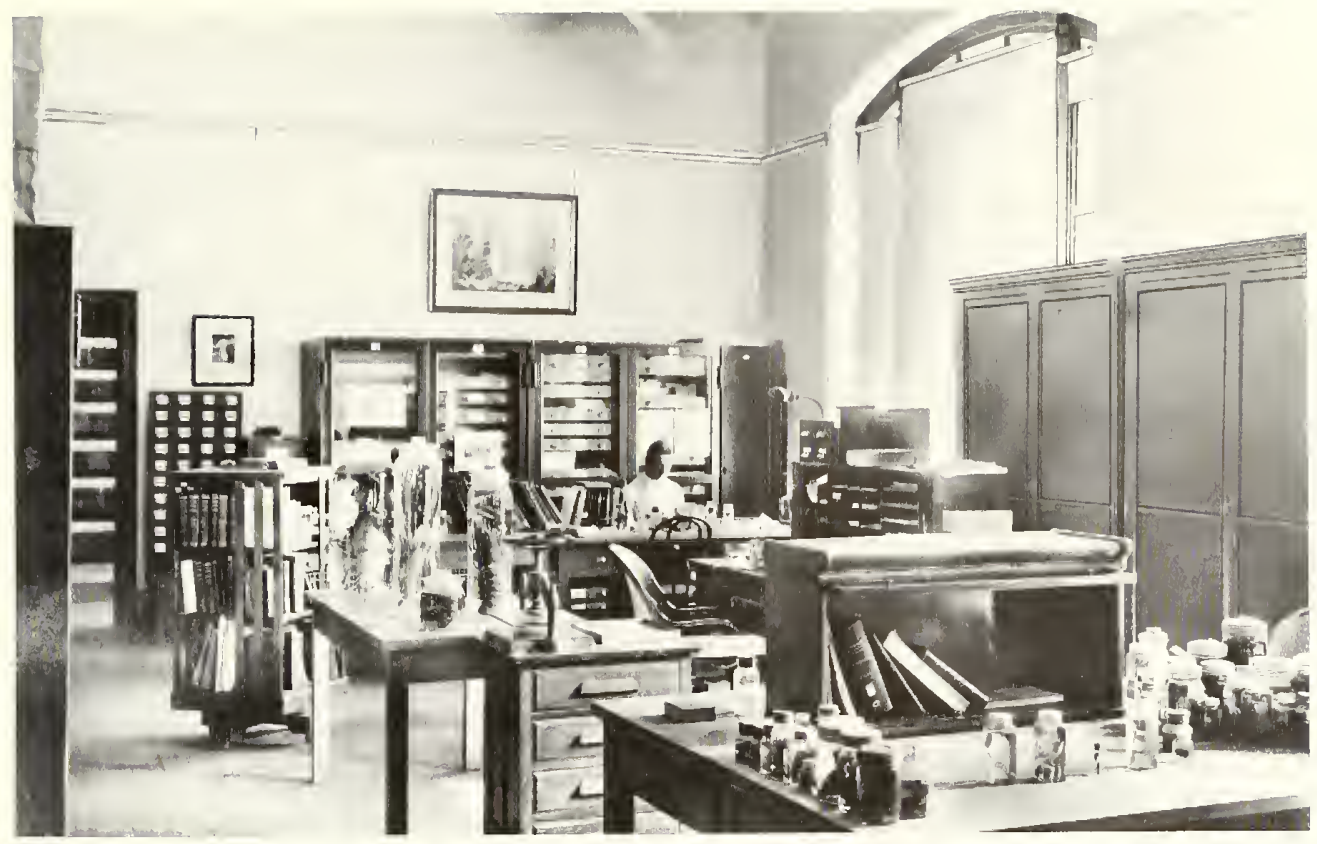

"West wing, ground story, laboratory of marine invertebrates," from United States National Muscum Bulletin 80 (1913). This office on the south side of the building originally belonged to Mary Jane Rathbur, and it is probably she who is sitting by the table. The area is now used for offices by the exhibits staff.

"East range, third story," from United States National Museum Bulletin 80 (1913). This area continues to be occupied by Physical Anthropology, but the cases to the left side of the hall have been replaced by racks holding deeper drawers on both sides. On the right in the distance is the site of the research office of Secretary Robert Mc C. Adams; immediately behind where the photographer was standing is the office of $S$. Dillon Ripley. The wooden

floor has been replaced by terrazzo, and the lighting has been improved.

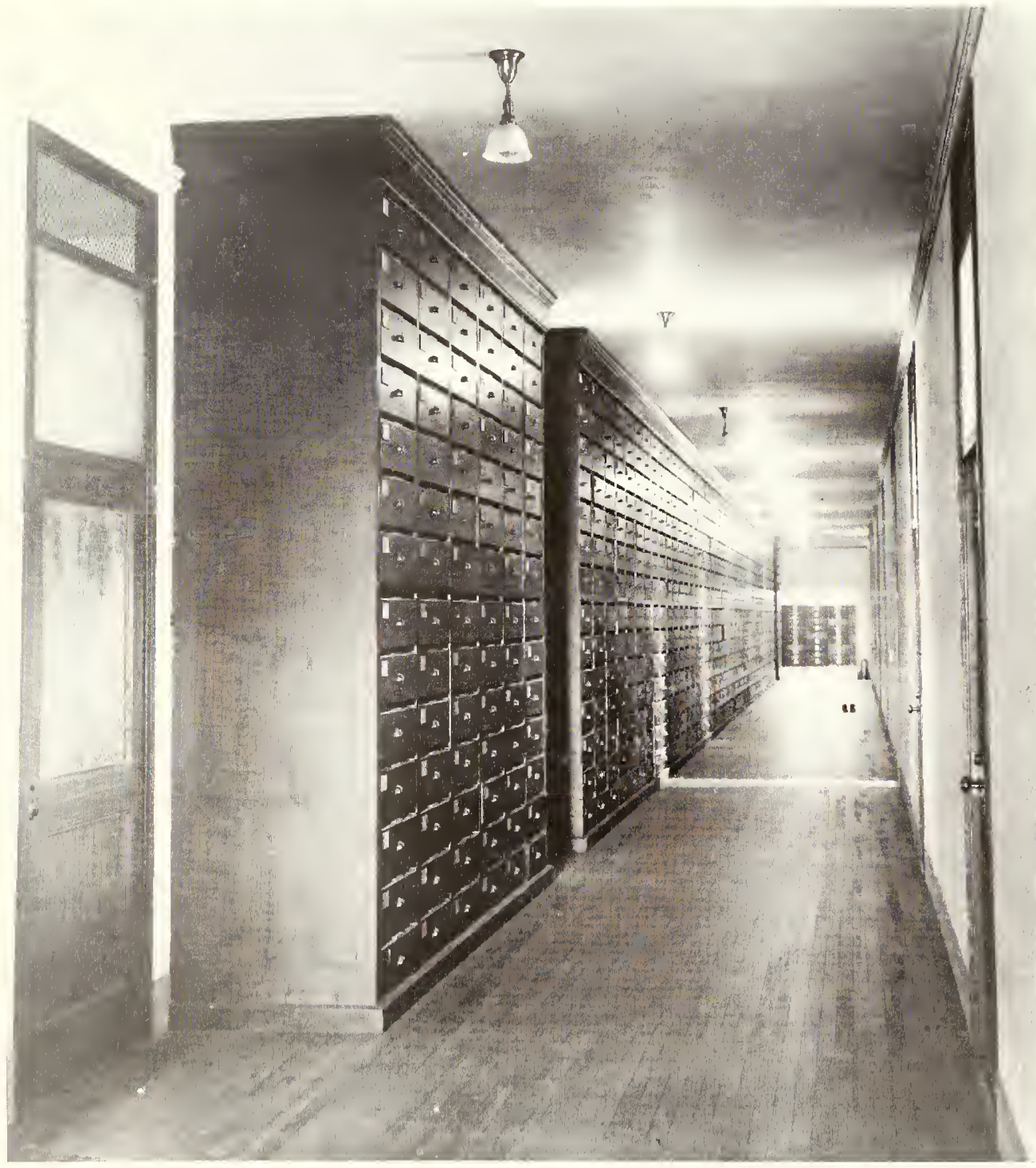





\section{The National Gallery of Art}

A LTHOUGH ART MAY SEEM INCONGRUOUS with natural history, it did play a significant role in the history of the Museum and its buildings. Just as much as the National Museum, the National Gallery of Art was a creature of circumstance. In 1903 Harriet Lane Johnston, niece of President Buchanan, left an important collection to the Corcoran Gallery of Art in Washington, with the proviso that it be transferred to a national gallery of art, should one be established. Because of certain requirements of the bequest, the Corcoran Gallery declined the Johnston collection.

The Smithsonian had acquired some etchings, paintings, and sculptures in the early days of Joseph Henry's regime, and while much of the material had been lent, works of art had always been on display in the Castle. So, with a number of paintings in the Johnston collection essentially available for the asking, the lawyers decided that the Smithsonian Institution, with its openended charter, was the national gallery of art; the name was acquired through this friendly court suit.' To implement the will, a National Gallery of Art was established within the administrative structure of the $\mathrm{Na}$ tional Museum. ${ }^{2}$ Somehow space was found for paintings and art objects to be placed on display in the brick building of the National Museum in the fall of 1906. This action did ensure that legally there was a National Gallery, though the jumbled surroundings were far from inspiring.

Since art works continued to be shown in the Castle, a logical next step would have been to refurbish part of the Castle as an art gallery. As the new National Museum building neared completion, the National Gallery's first curator wrote: "The new building ... in accordance with the understanding with Congress, has been planned and constructed for the great collections

Wooden pillars from the Johm Gellatly bequest, surmounted by candle-carrying angels. The chest in the center supports a wooden frame in which various stained-glass windows are exhibited. The totem pole looming over the display indicate's that this is near the south side of Hall 10, facing sonth toward the rotunda. Post-1933. of natural history-geology, zoology, botany, ethnology, and archeology. It has neither the room, nor the proper lighting for paintings." 3 But Congress did not see the situation quite the same way, and no money was appropriated for construction in the Castle.

The new Murseum, as noted, did not have proper lighting, but it did have room, and the center skylighted hall of the north wing was given over to art. The pictures were installed between "some of the more interesting ethnological groups and historical exhibits" that is, the Indians to the west in Hall 9 and the Oriental civilizations to the east in Hall 8. It was an uncomfortable alliance. For lack of a better display area, a miscellaneous lot of statuary was placed in the ambulatory around the rotunda, and some pieces were stationed in the ground-floor lobby. Later, the walls on the second floor of the rotunda were hung with paintings that could not possibly blend with the mounted animal heads that decorated the two stairwells. The admixture gives an excellent example of the National Museum's being one concept and the Natural History Building's being another.

This sounds entirely negative, but the other side of the coin is that Hall 10 in the center of the north wing was the first Museum display to be installed. Although it is not easy to hang an art exhibit, it is infinitely faster than installing a natural history display. In the final analysis, as poorly suited as the building was for art, the National Gallery must have been a godsend to Assistant Secretary Rathbun, enabling him to open some exhibits in a relatively short time.

\section{Formal Opening}

On March 17, 1910, from noon until five in the afternoon, the National Gallery of Art, and thus the new Natural History Building, was formally opened to the public. "Admission was by card, partly to prevent undue crowding, and partly to bring the event specially to the attention of Congress, the official body in Washington, and all other persons known to be interested in the promotion of art at the Nation's Capital." On Friday, March 18, the building was open to the public, and 


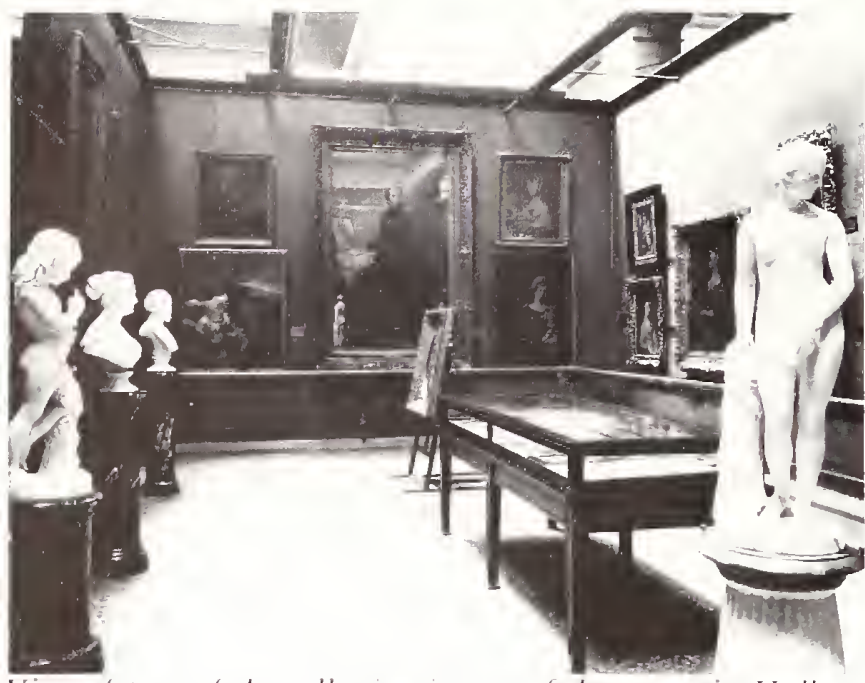

Virwe of part of the follection in one of the rooms in Hall 10. Hiram Powers's The Greek Slave is to the right; to the left is one of the items in the Harriet Lane Johnston bequest, a pestrait of her son as Cupid Stringing His Bow. In the renter is one of the rartiest art arquistions of the Institution, G. P. A. Heaty's painting Francis Pierre Guilmane Guirot. This wets presented to President John Tyter, whe gaze it to the Natronal Institute, from which it wess transferred to the Smithomion.

"hundreds" of people took the opportunity to see the show. Thereafter, halls were opened as completed. In spite of the time and effort that had gone into the new Natural History Building, there was never any formal dedication.

The publicity regarding the establishment of a National Gallerv had stirred interest within the art world and resulted in additional donations. Early in 1904, Charles Freer offered his collection of Oriental art and American paintings to the Institution; whether he was influenced by the Johnston bequest or had decided on this step earlier is not known. As a matter of record, the Board of Regents-after some hemming and hawing-accepted the initial Freer gift in January 1906, before the legal tangle involving the Johnston bequest and the National Gallery was resolved. Until the opening of the Freer Gallery in 1923, the only display in Washington of some of the treasures in this collection took place as a temporary exhibit of 175 paintings and objects in the new National Museum from April 15 to June 15, 1912.5 (A life-size model of the great blue whale now is suspended where Whistler's paintings once hung.) The Freer collection, and later the Freer building, were part of the United States National Museum until 1920.

\section{William Henry Holmes}

The person chosen to direct the Smithsonian's initiative into the arts was William Henry Holmes. Holmes had

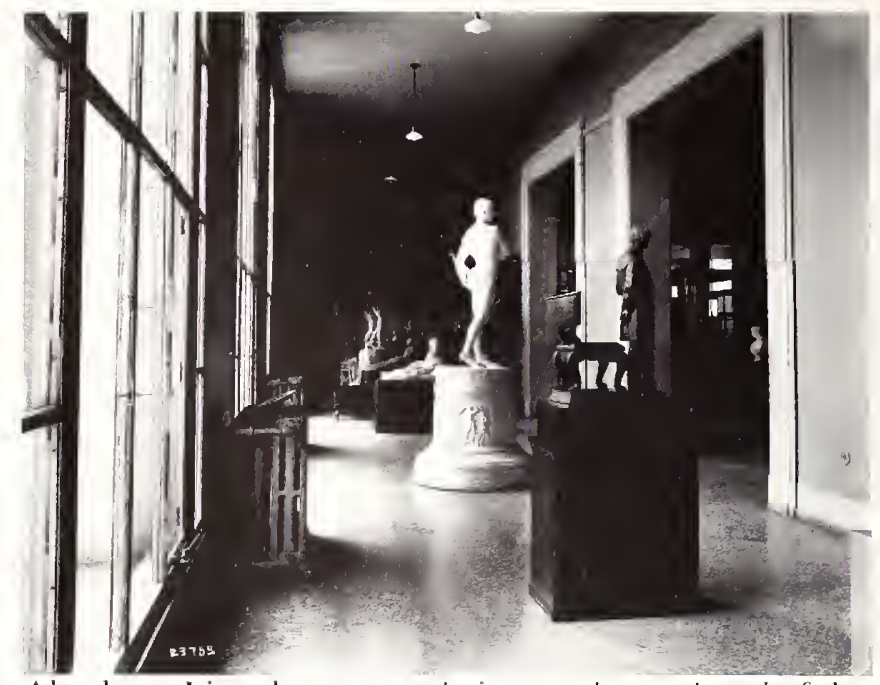

Abraham Lincoln, contemplating, at the north end of the north wing on the second floor. This area, near the north elevators, is now occupied by docents. The exhibits can hardly be seen by the light of the widely spaced incandescent bulbs, but someone left his straw hat on the steam radiator, suggesting that summer light was coming in. The Orpheus behind Lincoln is a plaster cast made in 1915 for the Francis Srotl Koy Memorial at Fort McHenry, Baltimore. It was later bronzed and shown in the rotunda. The light fixtures suggest a date before 1930.

first come to the Institution in the 1870s, and began his career as a scientific illustrat or under Fielding Bradford Meek; Meek lived in the Castle for nearly twenty years and was Joseph Henry's star boarder. Holmes had worked for the Hayden Territorial Survey and had been one of the first to explore the Indian ruins of Mesa Verde; he had also described the buried fossil forests of Yellowstone Park. Later he became a member of the U.S. Geological Survey and accompanied Captain C. E. Dutton to the Grand Canyon. Two mountains, one in the Gallatin Range in Yellowstone National Park of Wyoming and one in the Henry Mountains of Utah, are named for him, along with a pinnacle in the Grand Canyon-an indication of the esteem in which he was held by his geological colleagues.

Holmes was an excellent artist and particularly liked watercolors. He prepared outstanding perspective landscape views to illustrate reports for Hayden and the U.S. Geological Survey; his line drawings of the Grand Canyon are unequalled. Investigations by Holmes of Indian stone tools during the early 1890s opened new vistas in American anthropology. Because of his skill in both anthropology and art, he was heavily involved in preparing exhibits for the 1893 Columbian Exposition in Chicago. While there he was induced to transfer to the new Field Museum, but the director of the Field Museum and Holmes clashed early and often.

In 1897, when Walcott formed the Department of Anthropology, Holmes returned to the Museum as de- 
Part of the Gellatly collection, looking north in Hall 10, post-1933 and pre-1948.

The center piece is now the desk of the director of the

National Museum of American Art.
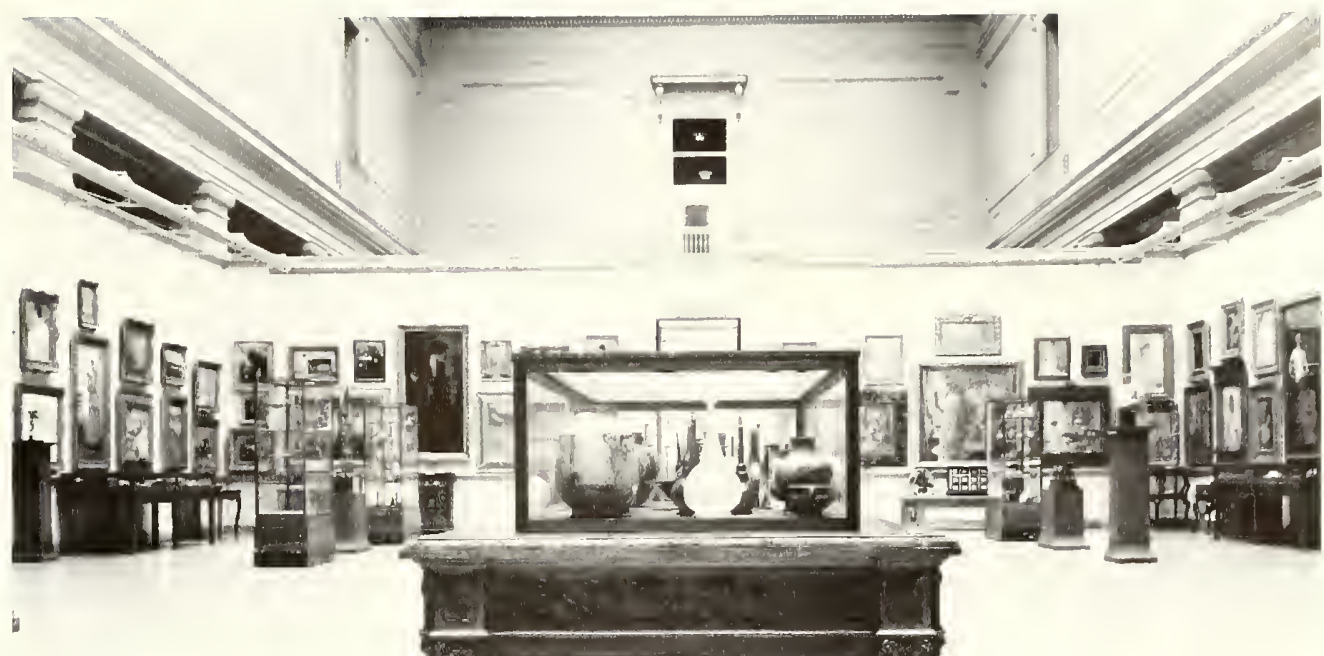

partment head. He was also the curator of prehistoric archeology, for all department heads held other positions and were expected to continue their research. Holmes was responsible for the founding in 1902 of the Division of Physical Anthropology, which brought Aleš Hrdlička to the Museum staff. That same year, Secretary Langley called Holmes away from the Museum to be chief of the Smithsonian's separate Bureau of American Ethnology; Holmes continued his work as curator of prehistoric archeology. Starting in August 1906, his new title as curator of the National Gallery added to his many duties, although not to his salary. In July 1909 Holmes relinquished his position as chief of the Bureau of American Ethnology in order to resume the head curatorship of the Department of Anthropology.

It took a long time for a National Gallery of Art to be officially recognized by Congress, but on July 1 , 1920, Holmes became the full-time head of this new Smithsonian bureau. His name disappeared from the annual reports of the National Museum, and the Department of Anthropology was run by Walter Hough. Holmes kept the same office on the Constitution Avenue side of the Museum building, just to the east of the elevators, that he had occupied as head of the Department of Anthropology.

Holmes made a determined effort to establish a real art gallery, writing articles and creating committees of support, and by 1923 space had been reserved on the
Mall for a major new building. A design contest was won by Eero Saarinen, who later designed the terminal at Dulles International Airport, but his plans were voted down by the regents as too modern.

Unfortumately, all efforts to obtain construction funds from Congress collapsed when rumors began to circulate that Andrew Mellon might donate a building for an art gallery. This was a setback to Holmes, for although nothing came of this rumor during his lifetime, it effectively stopped all other public support. By 1930 the gallery staff consisted of only himself and three assistants. In 1926 his left leg had to be amputated, but Holmes returned to his office. A few years later he was permitted to take a Civil Service examination and to continue on the government payroll long after most employees retire. On June 30, 1932, the day when Holmes finally did retire, he wrote in his "Random Records": "In his 85th year he is still at his desk in the National Gallery of Art." ${ }^{, 7}$ Ruel P. Tolman succeeded him; ten months iater Holmes was dead.

\section{Andrew Mellon's Offer}

Eventually Andrew Mellon did offer the nation both money and paintings for a National Gallery of Art. This resulted in the impressive domed building that stretches from Fourth to Seventh streets on Constitution Avenue, vaguely resembling the Natural History Building but built of light marble rather than somber granite. To make sure that nothing complicated the offer from 
A temporary exhibit in Hall 10 , hung on low screens in front of the permanent collection. This could be a show of local artists, possibly from the 1930 s or 1940 s.

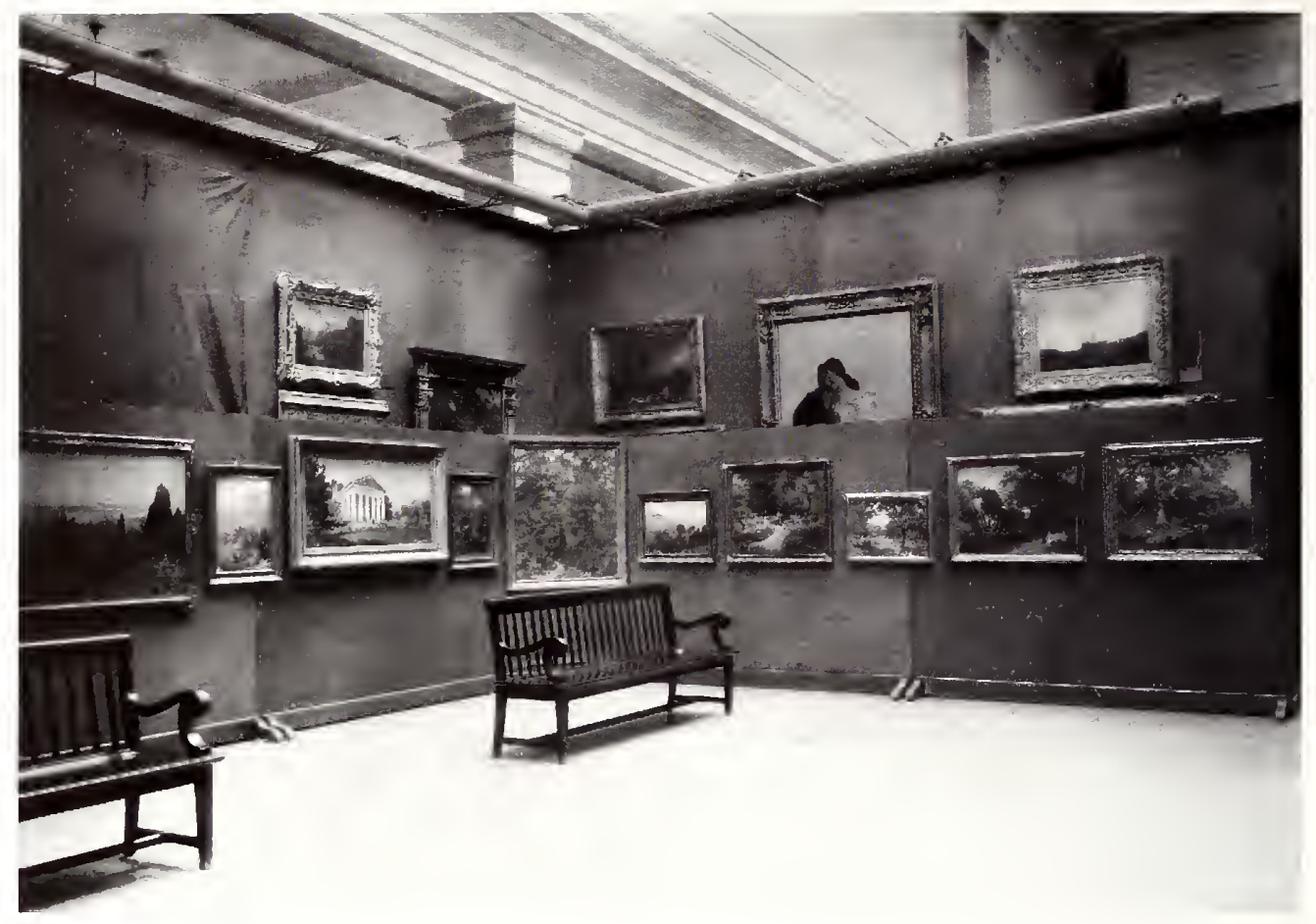

Mellon, the art holdings of the Smithsonian were renamed the National Collection of Fine Arts (NCFA) in 1937.

During the first decade of Holmes's tenure, in spite of restricted space, the Nitional Gallery developed a series of temporary exhibits and continued to receive chonations; at one point a sculptor worked publicly as a special exhibit. "The accumulating art more than filled the "art hall" off the rotunda. By 1930 it included, in part, the Alfred Duane Pell collection of "art objects of varied types and nutch interest," and several groups of historical portraits.

"The visitor finds himself face to face with many of the outstanding personages of the great war," Holmes wrote of one group, "kings, queens, presidents, soldiers, statesmen, and others-whose faces and achievements are familian to the peoples of every civilized nation." There were also a "collection of portraits of survivors of the Civil War painted from life by Walter Beck 50 years after the close of the war $[;]$. . . the John Elliot collection of portraits of young Americans who entered the air service of France before the United States had decicled to take part in the struggle [World War [] . . . and a very interesting collection of sketches of prominent World War personages made by John C. Johansen for use in executing his great work, the 'Signing of the Peace Treaty, June 28, 1919"," which occupied the west wall of the lobby. The lobby also contained many pieces of sculpture and some other paintings.

For those interested in origins, the work of the National Portrait Committee in assembling paintings of World War I personages marked the dim beginnings of the National Portrait Gallery. The Pell collection, with its numerous glass and porcelain objects, gave a real stimulus to what eventually became the Division of Ceramics and Glass in the National Museum of History and Teclinology. Meanwhile, for a natural history building, the new National Museum became increasingly eclectic. The sculpture-crammed lobby scarcely hinted of natural history, and since 1923 war portraits had intruded into one of the second-floor halls. ${ }^{10}$

In 1929 the National Gallery obtained the John Gellatly collection, which in 1933 was moved to Washington to be displayed intact as it had been in the donor's New York home. The collections grew at a slower rate after this major bequest, and while the gallery and later the National Collection sponsored temporary exhibits in the ground-floor foyer, the main exhibits changed very lit tle. In the spring of 1956 the National Collection held a fiftieth-anniversary show of turn-of-the-century paintings from the important William T. Evans collection. But despite their best efforts, the staff of the $\mathrm{Na}$ tional Collection had not made much progress toward becoming a real gallery.

\section{The Catlin Paintings}

By 1963 the National Collection of Fine Arts, with a total staff of ten people, still had little official contact with the Museum. However, the National Collection was the keeper of the Catlin paintings, perhaps the single most important collection of western Indian ethnography in the world. Catlin paintings were on exhibit in several halls; they hung above the elevator doors, and all over the third-floor walls wherever there was a small empty space. Wherever there was a large empty space, something romantic in a gilt frame was hung. 
Exhibit of the Ranger

Collection, 1929, in the

National Gallery-National

Museum, north hall. Director William Henry Holmes holds onto a bench to support his single leg. Louise Rosenbusch, research, is also standing. The other two employees of the National Gallery of Art are the clerks Helen Hogen and Glenn Martin, seated at the desk.

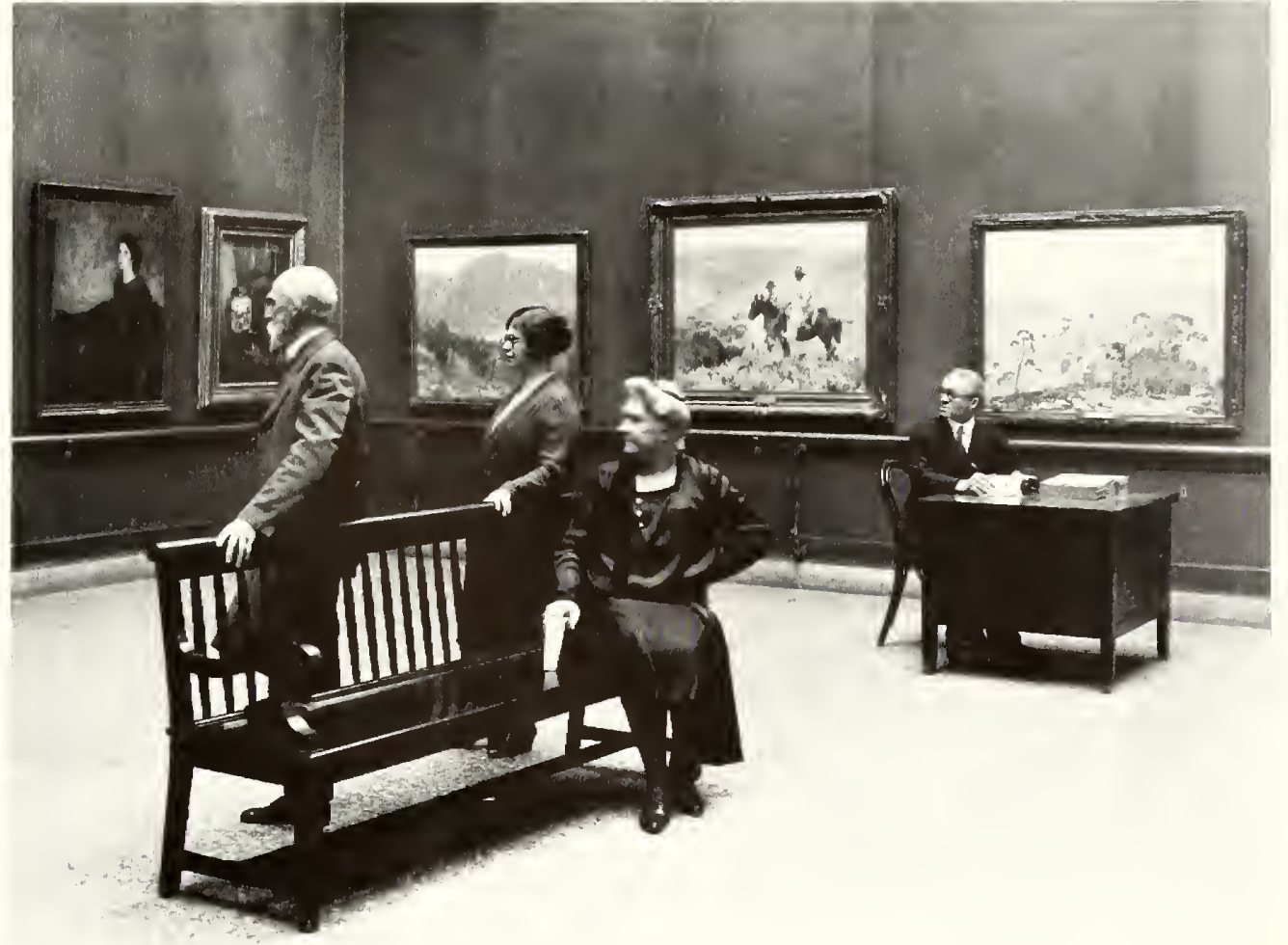

The storage area in the east north range was also overflowing, and anyone in the Museum who had office wall space and wanted a painting could have one. Several people had original Holmes drawings on loan. During the 1930 s, the building superintendent had a nude hanging in his office. For about twenty years J.H.F. van Lerius's melodramatic Death Preferred, now the centerpiece of the Renwick Gallery, was in the paleobotanical library of the Geological Survey. The diaphanouslyclad maiden jumping from a window to escape the clutches of ruffians attracted a number of visitors not interested in plants.

\section{Three Buildings Acquired}

After half a century, change was in the air. The old Patent Office Building, a few blocks northeast of the Museum, was turned over to the Smithsonian in 1958 as a gallery site. ${ }^{11}$ Barney Studio House, on Massachusetts Avenue, became an outlying part of the NCFA in 1960. In 1962 the National Portrait Gallery was formed, and in 1968 both art museums were installed in their new home in the Old Patent Office building. Next, the NCFA acquired the building at Seventeenth Street and Pennsylvania Avenue, NW, near the White House, now known as the Renwick Gallery. As the final step of this story, the NCFA was retitled the National Museum of American Art in 1980.

During the mid-1960s, the displays in the north wing of the Natural History Building were gradually dismantled and transferred to the newly renovated Patent
Office Building, between Seventh and Ninth streets on F and G streets, NW. For several years temporary exhibits were still hung in the foyer of the National $\mathrm{Mu}$ seum, and there were several special exhibitions in Hall 10 , the last being in 1969. Thereafter, the whole building reverted to natural history. Yet after all, there was nothing so strange in the long cohabitation of natural history and art. Many major museums, for example the National Museum of Wales, have objects of natural history and objets d'art under the same roof; and no one has ever been able to draw a precise line between art and ethnography.

In spite of some objections by the anthropologists, the Catlin paintings left the building, for by official decision they are art, even though the Department of Anthropology holds title to them. By contrast, John Elliott's Diana of the Tides remained behind. This is a huge painting, one of the original holdings of the old National Gallery of Art. For years it occupied the east wall of the dinosaur hall because there was no other place to hang it. When the hall was refurbished, the mural was boxed over and hidden from view. When the hall was modified again in the 1970 s, rediscovery of the forgotten mural provided a minor sensation. Diana is still hanging in the same place, again hidden from view. Perhaps the National Museum of American Art hopes the National Museum of Natural History will forget where it is or who owns it. Aesthetics aside, the practical fact is that murals twenty-five feet high and very long are awkward to display. 

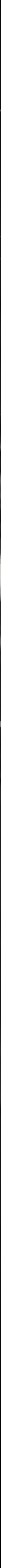


\section{Affiliated Organizations}

I T IS WELL KNOWN THAT THE Smithsonian Institution helped focus scientific endeavors that eventually resulted in the founding of various government scientific agencies. The Weather Service is cited as the classic example, but similar developments occurred in natural history. The "museum community" includes many individuals who are in the Museum but not of it, and for the first fifty years at least, about half of the scientists and support staff in the new building were paid by other government organizations.

Most people both inside and outside the building are still unaware of any distinction between Museum members and those of associated agencies, the primary difference often being the day on which they are paid. The ultimate confusion occurred a few years ago when an assistant secretary of the Department of the Interior wrote the Secretary of the Smithsonian, congratulating him on a staff publication that would be of considerable use to his department. The item, it turned out, was one prepared by Interior Department employees within the Museum.

\section{Geological Survey}

The easiest administrative history to follow is that of the U.S. Geological Survey. After the Civil War, the tradition of government-supported exploration of the western United States resulted in four simultaneous territorial surveys. ${ }^{1}$ In addition to making maps and studying the rocks, they followed the pattern of earlier government explorations by examining, to varying degrees, other aspects of natural history. Eventually several of the survey parties crossed paths in the field. Congress rectified what was judged to be duplication of effort by discontinuing three of the surveys; the fourth, a survey of the fortieth parallel, had been finished.

John Wesley Powell in his office in the Bureau of Ethnology on F Street, 1894 or earlier. Explorer of the Grand Canyon, first director of the Bureau of Ethnology, and second director of the Geological Survey, Powell is representative of all the American scientists who were and are affiliated with the Museum.
In March 1879, the United States Geological Survey was created, under the Department of the Interior, to carry on the geological facets of this work in a more systematic manner. The same act, the Sundry Civil Expense Bill, also created the Bureau of Ethnology and placed it under the jurisdiction of the Smithsonian.2 John Wesley Powell, who had explored the Colorado River and had headed one of the four territorial surveys, became the director of the bureau. The U.S. Geological Survey was organized with Clarence King as director, but within two years he left. Powell became director of that agency as well, and rode both horses for thirteen years.

Within the section of the act establishing the Geological Survey appears the following sentence: "And all collections of rocks, minerals, soils, and fossils, and objects of natural history, archaeology, and ethnology, made by the Coast and Interior Survey, the Geological Survey, or by any other parties for the Government of the United States, when no longer needed for investigations in progress, shall be deposited in the National Museum." This is potentially a powerful piece of lawmaking; tradition ascribes its wording to Powell. Assistant Secretary Baird had always maintained-an arguable point-that the congressional action establishing the Smithsonian had made it the keeper of the nation's collections. The wording of the 1879 law expunged doubt as to the final destination of all federal collections. It also established tangible bonds between the Museum and a group of other organizations.

The Geological Survey made its headquarters in the National Museum when the brick building opened in 1881 , but in a few years the director moved to the Hooe Iron Building, on F Street between Thirteenth and Fourteenth. Laboratories had been set up in the northeast tower of the National Museum, so the chemists and physicists stayed a few years longer. But the paleontologists in residence at the Museum stayed put, with their ever-increasing collections, because of the difficulty of moving so many fossils. As the Survey grew, more paleontologists were added to the staff in the Hooe Building, and their collections were kept there because of tight quarters in the National Museum. As 


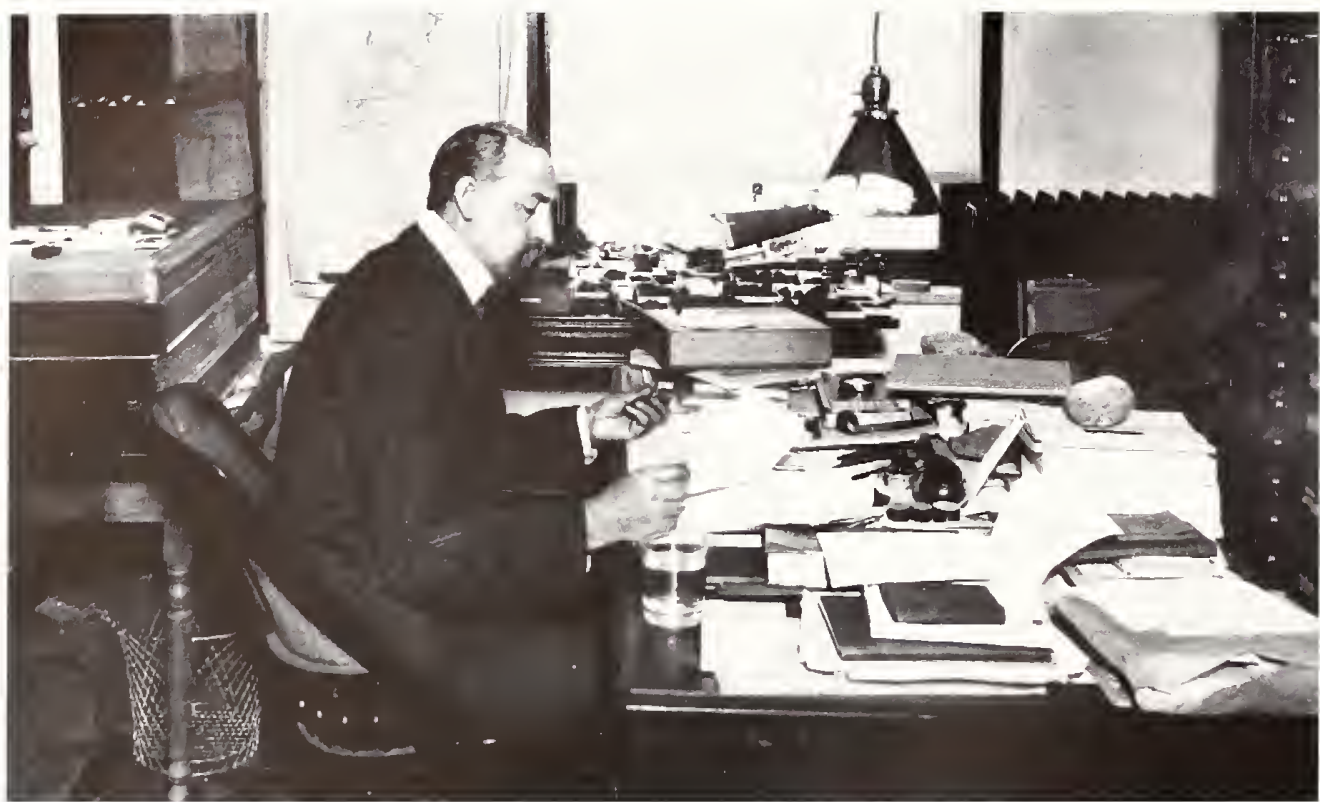

E. O. Ulrich, paleontologist of the U.S. Geological Survey, in his first office in the Hooe Building, 1901.

soon as the new National Museum opened, some of the Geological Survey paleontologists moved into it from the brick building and the Hooe Building. To this day, more than a dozen Geological Survey paleontologists remain in the Museum.

\section{Commission on Fish and Fisheries}

In 1871, eight years before the Geological Survey took shape, the U.S. Commission on Fish and Fisheries was organized. This was a brainchild of Secretary Baird, who ran it at no extra salary until his death. He settled the commission in the former armory at Seventh and B streets, SW, and developed additional laboratories in other parts of the country, the most famous of which was at Woods Hole, Massachusetts. The Armory building, which continued to be used for storage of Museum collections for decades, lay in a line with the Army Medical Museum, the original National Museum, and the Castle, so there was plenty of communication between the Smithsonian buildings and the Commission.

Shortly after the turn of the century, the Fish Commission became the Bureau of Fisheries under the Department of Commerce and Labor. "Technical studies yield valuable data for the fishing industry," a later article explained. "The life habits of fish and the changes in the abundance of various kinds of fish are studied. An efficient fish ladder for the upstream migrations of the salmon and other fish was developed in cooperation with the states and the industry. The Bureau's aid to the pearl button and goldfish industries will long be remembered." ${ }^{\circ 5}$ Smile though one may at the last sentence, the scientists of the bureau performed many economically useful investigations. In the course of their activities, the staff of the commission and the bureau collected numerous fishes, most of which were saved for the collections.
In 1939 the Bureau of Fisheries was transferred to the Interior Department, joining the Biological Survey, transferred to Interior from Agriculture the same year. In 1940 both were absorbed into the Fish and Wildlife Service, which in 1956 became the U.S. Fish and Wildlife Service. The former Fish Commission was partitioned into the Bureau of Sports Fisheries and the Bureau of Commercial Fisheries, with the latter eventually returning to the jurisdiction of the Department of Commerce.

As the events of World War II disrupted Washington, the Old Armory was torn down to make room for temporary buildings. (The west end of the National Air and Space Museum now occupies the site.) In 1942 the collections of fish and a few ichthyologists were moved into the north side of the south wing on the ground level of the National Museum. Part of the area was temporarily decked over to make more office space, and one bureau employee was placed in a former latrine. The fisheries collections were integrated with those of the Division of Fishes-the bureau collections were substantially larger.

Today the Commerce Department is represented in the Museum building by a few people on the ground floor who do a great deal of scientific work affecting what food we gather from the seas. They enjoy the dubious pleasure of walking on the only original wooden floors remaining in the building. Just to complicate things a little more, or perhaps to show the breadth of the applied-science community, the National Systematics Laboratory of the Department of Commerce used to include a malacologist (a student of the clams and snails), housed on the third floor in the Division of Mollusks. Currently this organization includes, in addition to fish specialists, a "shrimp woman" and a "crab man" with offices in the Division of Crustacea. 


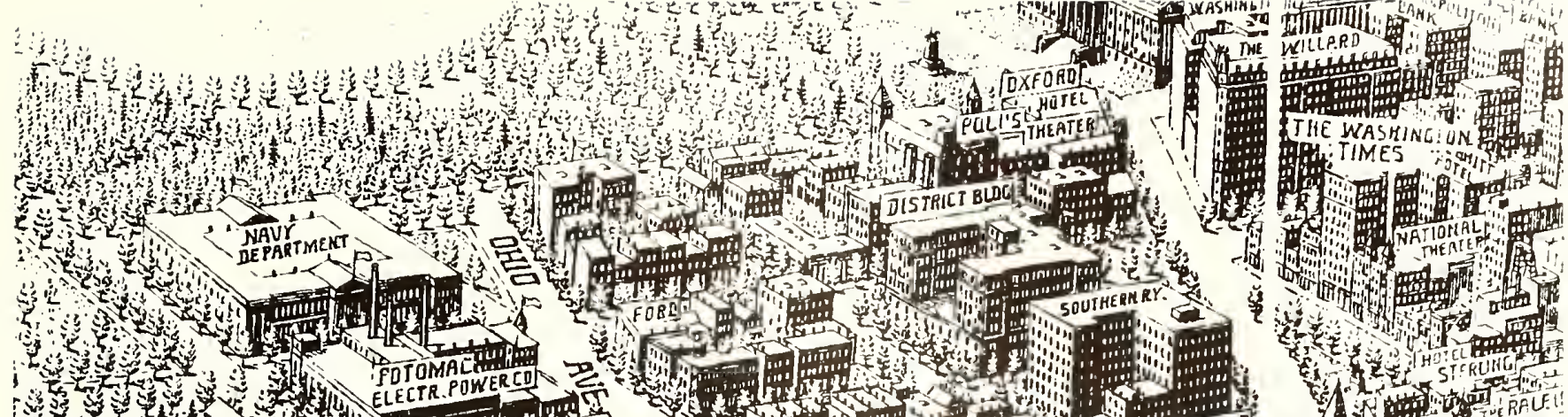

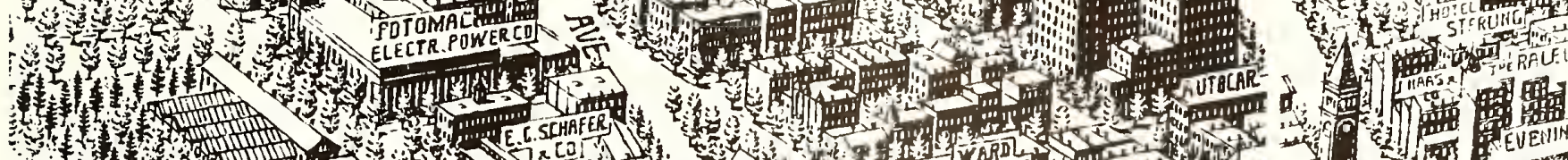

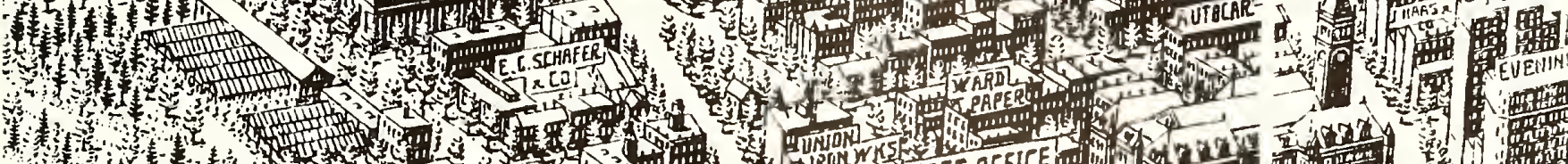

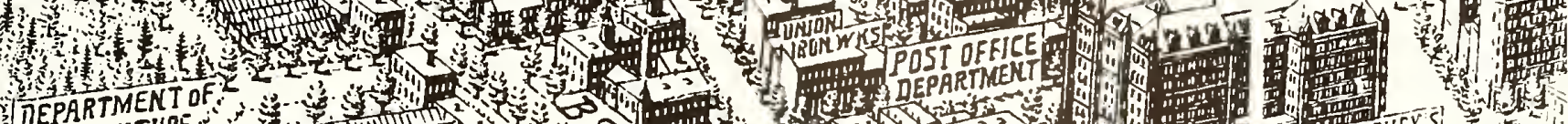

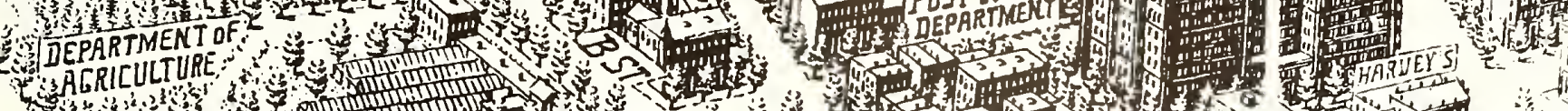
tor

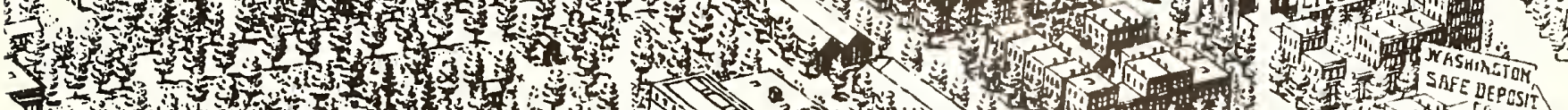
IE 2020 .

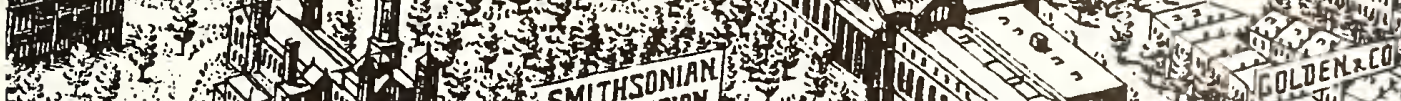
2.5.

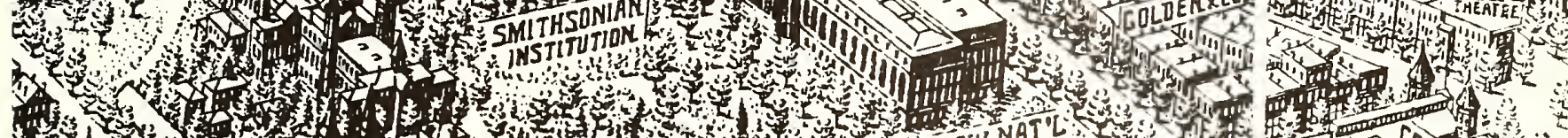

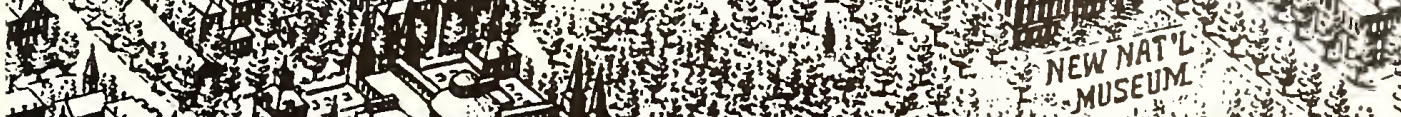

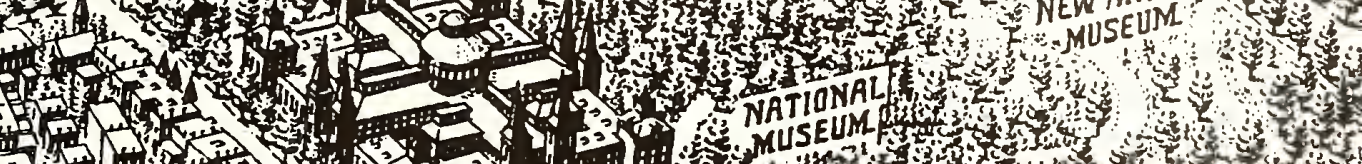

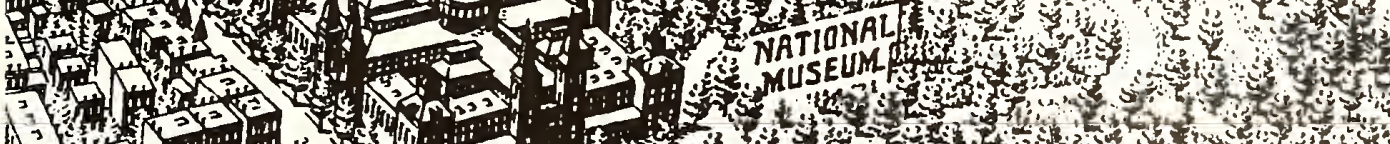
(1)

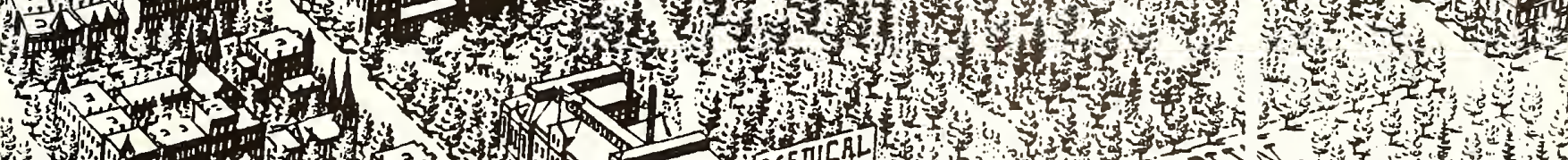
tor IHE ET E ERT X AN (5) 等A An oblique view of the Mall area, drawn in 192I. On the south side of the Mall, the Army Medical Museum (now replaced by the Hirshhorn Museum) stood on the site of the Armory, used for storage. The Burean of Fisheries site is compiler has left ont the courtyards of the Natural History Building, while towers and turrets on the Arts and Industries Building and on the Castle have been extended considerably. To the north of the Caslle, the Freer Gallery, as yet unopened, also lacks a contyard. Still farther Department of Agriculture, with experimental planting where the National Musenm of American History now lid have far more tress than today. (From Washington, the Beautiful Capital of the Nation, coppright 1922 by William Olsen, National Aero-View Publishing Company, Washington, D.C. 


\section{Department of Agriculture}

The relationships of the Department of Agriculture to the Smithsonian Institution and to the National $\mathrm{Mu}$ seum have been even more involved. For many years the United States National Herbarium was in the Smithsonian Castle, and scientific papers generated by those who studied the collection were published by the Museum. However, at that time the employees in the herbarium were mostly from the Department of Agriculture. All other Smithsonian plant collections and the few paid Museum botanists were jammed into the herbarium space, perhaps the most crowded area of a crowded institution. That remarkable student of the grasses Agnes Chase, in whom the Smithsonian took just pricle for many years, was an employee of the Department of Agriculture, as was A. S. Hitchcock, whom she came to assist.

Although the new Natural History Building was "commortious," for some reason the plant collections were not moved to new quarters there. If it was thought advantageous for the herbarium to remain in the Casthe, just east of the Department of Agriculture, perhaps it seemed just as well for the Museum's botanical material and staff to stay there too. In 1947 the Museum's Department of Biology was divided into departments of Botany and Zoology. But even so, the staff of Botany and their collections were not transferred. They and the Department of Agriculture botanists remained somewhat isolated until the west wing was added to the Natural History Building in the 1960s.

\section{Government Entomology}

The Department of Agriculture, founded in 1862, not only predated the Fish Commission but had a far broader mission in the natural history realm. The relationship of insects to crops is so obvious that Townsend Glover, the first govemment entomologist, was on the scene in the 1840 s, as an employee of the Patent Office. However, government entomology did not really become noticeable until 1878, when its few practitioners were organized into a Division of Entomology and C. V. Riley arrived from Missouri. A most forceful personality, Riley was compelled to leave office once, but with a change in administration he returned to run the organization until 1894, when he was given the option of resigning or being fired.

The insect collection of the Museum had been widely distributed to various specialists throughout the country. Riley offered his Department of Agriculture collections to the Museum on the condition that it establish a position for someone to study insects; the Museum complied. A few years later Riley donated his private collection. These two actions were the key building blocks of the insect collections of the Museum. Both Riley and his successor, L. O. Howard, were honorary curators in the Department of Biology. ${ }^{6}$

In 1894 the old brick Beiber Building, behind and to the east of Department of Agriculture headquarters, became vacant. Entomology moved there, along with the Biological Survey. ${ }^{7}$ This location, to the west of the Castle, was only a few minutes' walk from the National Museum. It is not clear whether any entomologists were housed in the brick Museum, but with space so limited there, it seems unlikely.

At the turn of the century, much of the work of the Bureau of Entomology was directed toward control of economically harmful insects. Later, Howard wrote, "work on even more fundamental aspects was begun, such as the physiology of insects and their reactions. And it was found necessary to enlarge the facilities of the Bureau in its taxonomic work. This work, consisting of the accurate identification of insects, has ... been of the most important help to the more strictly economic workers of the Department of Agriculture; and ... of the different State Experiment Stations and Agricultural Colleges. . . . Demands have been [so] great from institutions throughout the States, [that the] Museum force of the Bureau will undoubtedly be enlarged."

Howard's annual reports do not mention the location of staff members, but according to C. F. W. Muesebeck, a long-retired specialist on parasitic wasps, Department of Agriculture entomologists-not including Howard-were in residence in the Museum by 19I0. Not everyone was happy with the arrangements. A. A. Girault grumbled in a paper, "This work was done in Bedlam, that is, the Insect Section, U.S. National Museum at Washington, a place unfit for scholarship." ${ }^{9}$ At peak staffing, in 1942, the systematic entomologists of the Department of Agriculture numbered twenty-eight specialists, twenty-one aides, and four typists. ${ }^{10} \mathrm{Al}$ though most of the systematic entomologists have remained at the Museum, some moved first to the main building of the Department of Agriculture and later to the Agricultural Research Center at Beltsville, Maryland.

\section{Biological Survey}

The Biological Survey originally came into the Department of Agriculture in 1885 as the Economic Ornithology section of Riley's Entomology Division. Started through the efforts of yet another scientific entrepreneur, C. Hart Merriam, the enterprise was promoted one year later to Division of Economic Ornithology and Mammalogy. In 1896 it became the Division of Biological Survey, and in 1905 the Biological Survey attained bureau status. Under Merriam its work was mostly on systematics, distribution, and life history of animals, for although he had begun as an ornithologist, Merriam devoted increasing amounts of time to mammals. The Biological Survey eventually did a few studies of reptiles, but its strength was in birds and mammals, with a particular concern toward developing the concept of animal and plant distribution by climatic life zone. 


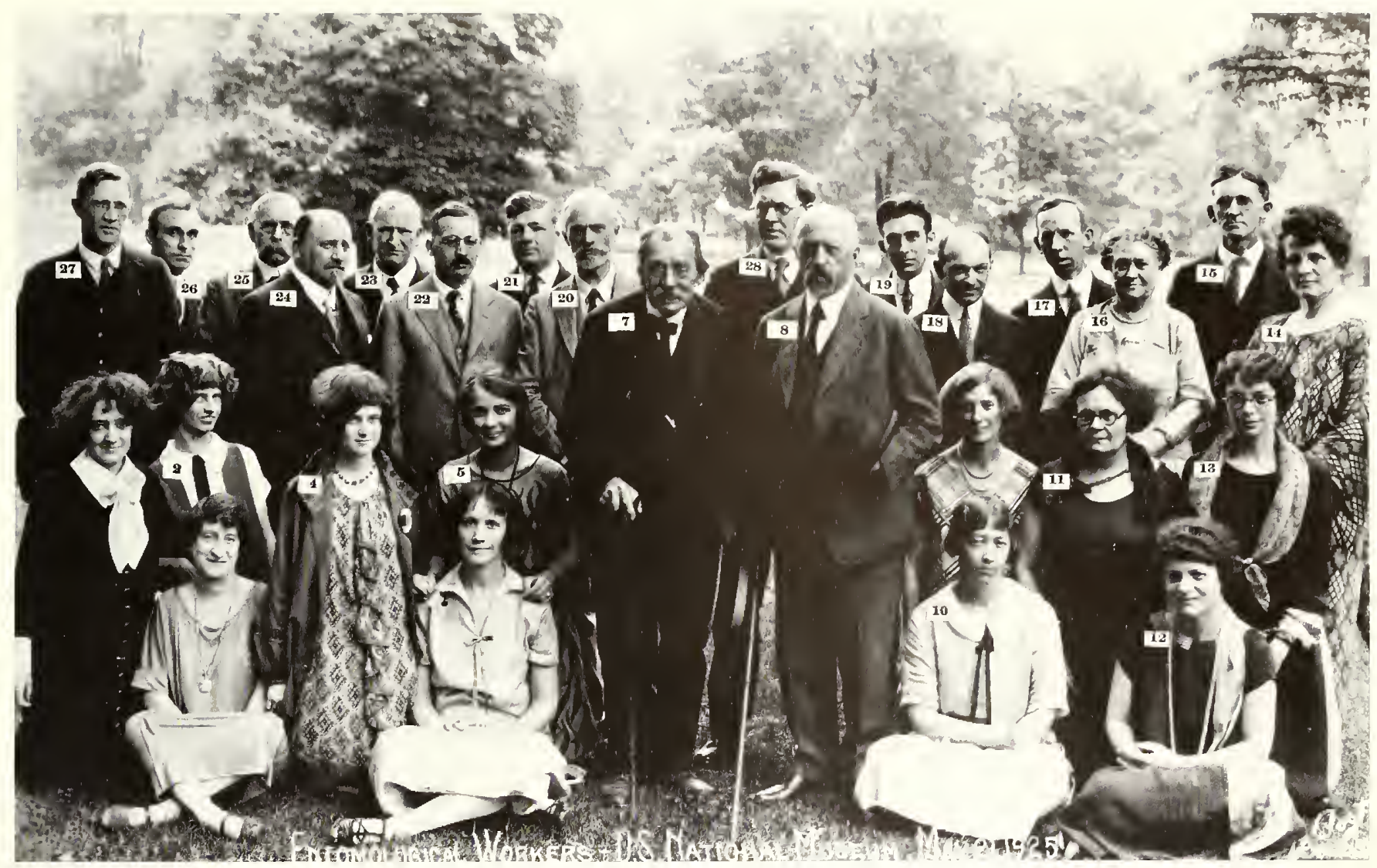

Entomological workers, U. S. National Museum, May 21, 1925. Number 8 is L. O. Howard, chief of the Bureau of Entomology. Of the twenty-eight people shown, apparently none was paid by the Museum.

Merriam never got on well with Congress or with most of his subordinates, and in 1910 he retired. When the new Museum building was occupied, the Biological Survey ornithologists moved to the third floor of the north wing and the mammalogists to the west range on the ground floor. The collections of the Biological Survey since its inception had been stored in the Museum, but were maintained as a separate series until the 1940s.

The major objectives of the Biological Survey were changed. Studies of bird-insect relationships were discontinued. Game management and predator control became more important, and the taxonomic work received less emphasis. Like the Fish Commission, the Biological Survey changed in name and moved from one government department to another. However, taxonomy still has its place; today the U.S. Fish and Wildlife Service of the Department of the Interior includes a Museum section to support such work at the Museum of Natural History. ${ }^{11}$ It is administered out of Denver, but that is hardly more illogical than administering the systematic entomologists from a Beltsville, Maryland, office, or the Commerce Department taxonomists from Woods Hole, Massachusetts.

If other agencies did not mention having employees in the Museum, the annual reports of the National Museum, by the same token, almost never mentioned the activities of others in the building, except the museum work of those who were honorary staff members. There seems to be no written agreement that the Museum would provide space for these other scientists, yet the arrangement has worked well for more than a century. Washington bureaucracy is replete with fights over turf and office space, but one cannot tell from the size, location, or quality of an individual Museum office who works for which federal agency.

\section{Bureau of Ethnology}

Although the Bureau of Ethnology was uncler the Smithsonian Institution, it functioned independently, and never had employees in the new Natural History Building. Founded in 1877, it flourished for some years in the Adams Building on F Street, NW, just across from the Geological Survey. Offices became available in the Castle as a result of transfers to the new Museum building, and in 1910 the bureau, which had been retitled the Bureau of American Ethnology (BAE) in 1894, moved to the Mall.

Because the bureau had a separate budget and because ethnographic material was popular with Congress, many outstanding publications were produced. Perhaps the best known was BAE Bulletin 30, Handbook of American Indians North of Mexico, which was edited by 


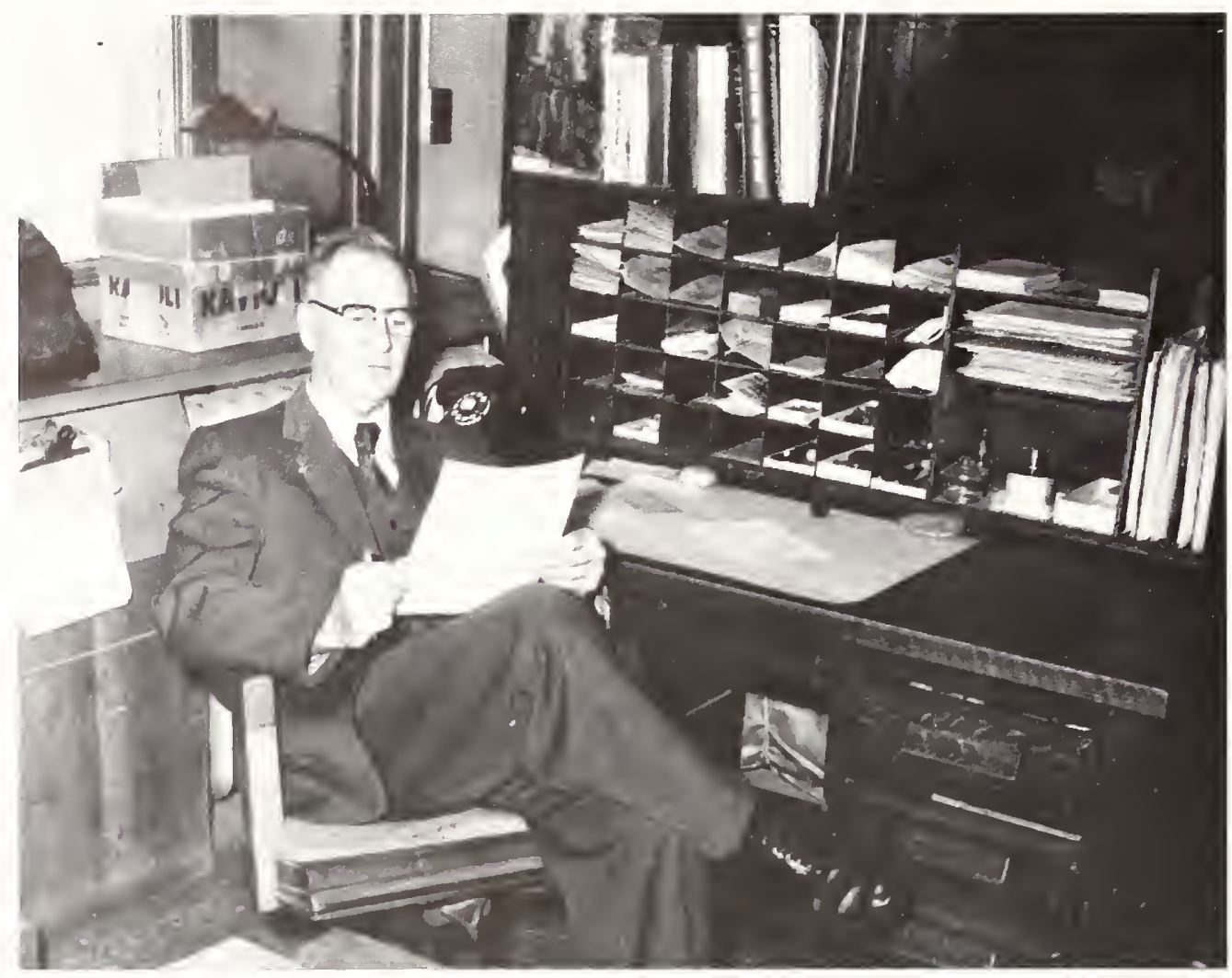

Roland W. Brown, a paleobotanist with the U.S. Geological Survey, at his desk in "Stone Hall" in December 1958. The wooden desk and gooseneck lamp were standard equipment of the time; above are Sears Roebuck catalogues into which Dr. Broun pasted newspaper clippings of interest. Brown owned only a single pair of shoes, shown here, which he cobbled himself. The manuscript of his book The Composition of Scientific Words is on the windowsill.

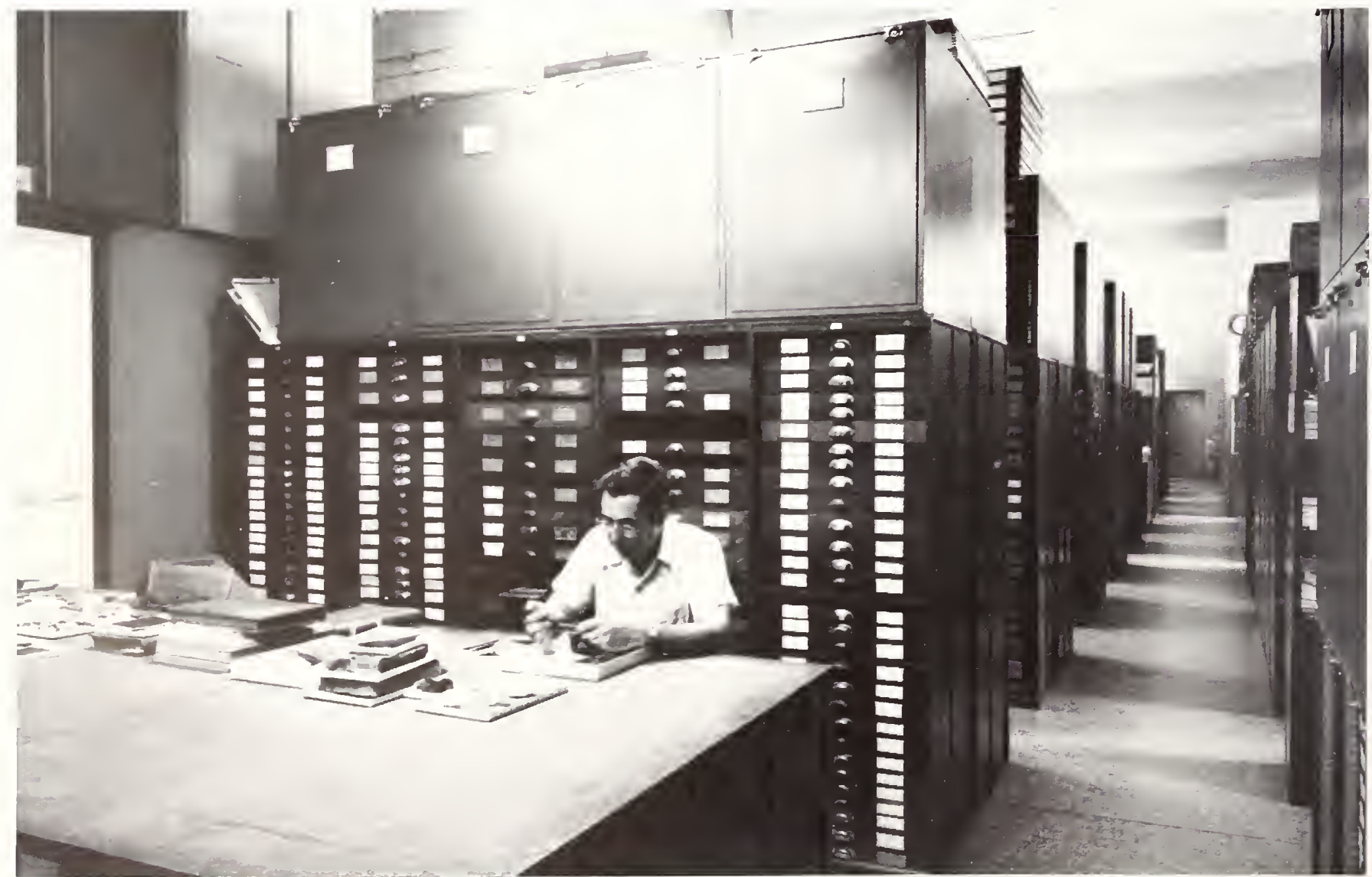

S.H. Mamav, a paleobotanist with the U.S. Geological Survey, working in "Stone Hall," probably in the mid1950s. Behind him are three-foot wooden cases atop six-foot steel cases. Stone slabs about two inches thick and up to eight feet long are attached to the wall and extend above the top of the cases. 


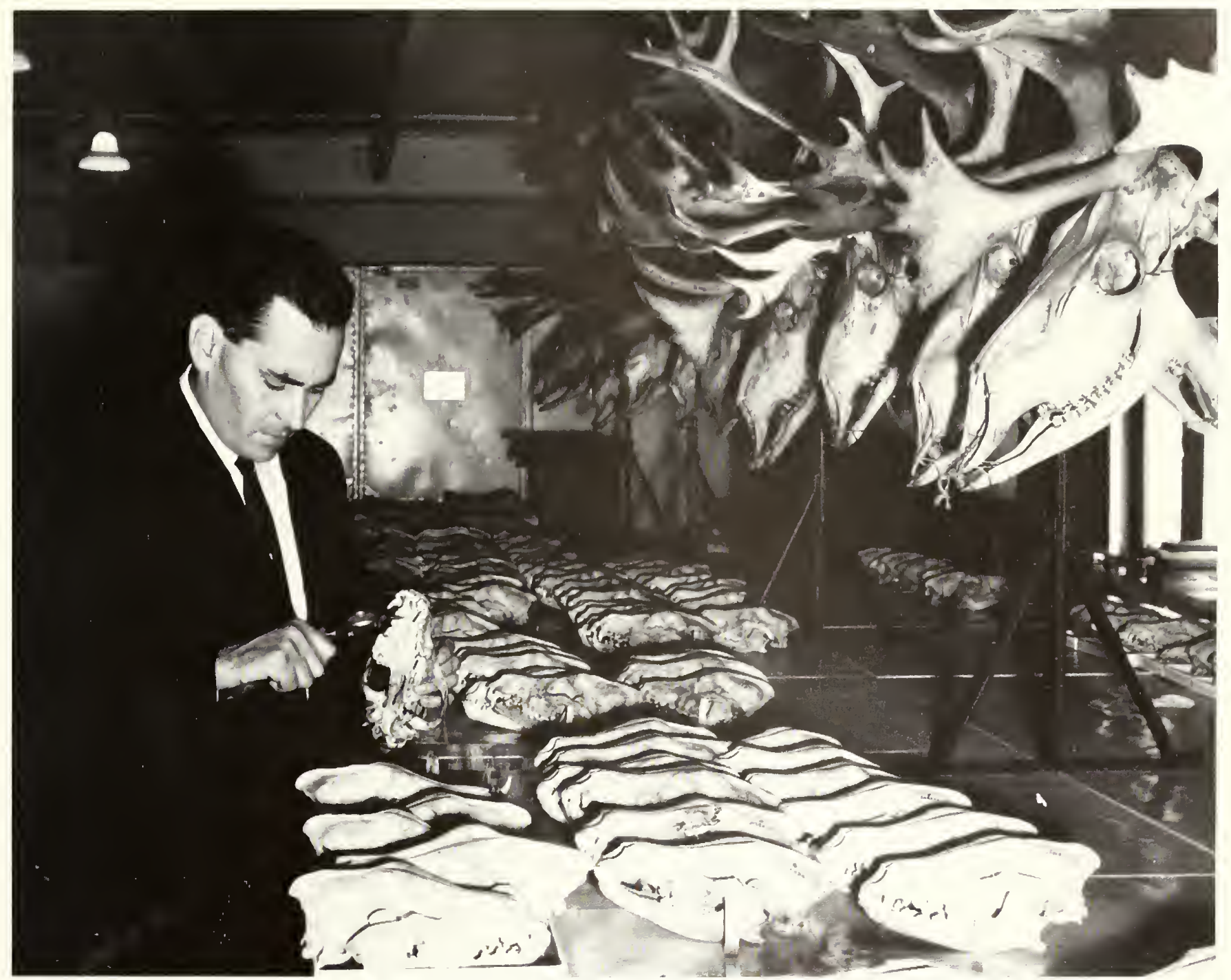

John Paridoso, a biologist with the Fish and Wildlife Service, measuring wolf skulls (Canis), with caribou (Rangifer) hanging above. The photograph was taken before 1964 in the Fish and Wildlife area of the west range, ground floor.

F. W. Hodge during the first decade of this century. More than a third of a century later, Bulletin 143, the Handbook of South American Indians, was completed.

Although relationships between the Department of Anthropology and the BAE had been strong when Holmes ran both, they gradually became less satisfactory. In addition, for the last half of its lifetime the staff of the bureau dwindled, and in July, 1964, it was merged with the Museum's Department of Anthropology to form the Smithsonian's Office of Anthropology. ${ }^{12}$ At that time its scientific staff of three anthropologists moved to the Museum of Natural History. During the early 1970s, a major revision of the Handbook of American Indians North of Mexico was undertaken. William Sturtevant, one of the last former BAE employees on the departmental staff, is in charge of the project, whose budget is distinct from that of the department.

\section{Systematics Continues}

In the current government science community, systematics-the differentiation of species, their naming and classification-is given less significance than in the past, in spite of its obvious application to the nation's environment, food, and fuel. There have been staff increases for natural history positions in the Departments of Agriculture, Commerce, and the Interior, but they are slight compared to total growth of these agencies.

However, the old tradition of the Museum as the place to do systematics for the federal government remains. During the early 1960s the Department of the Army joined the club of associated agencies by housing a Southeast Asia Mosquito Project in the Museum. The outside world still confuses the staff members of the affiliated agencies with those of the Museum, and the Museum continues to provide space for these allied scientists and their valuable collections. 



\section{The \\ Exhibits}

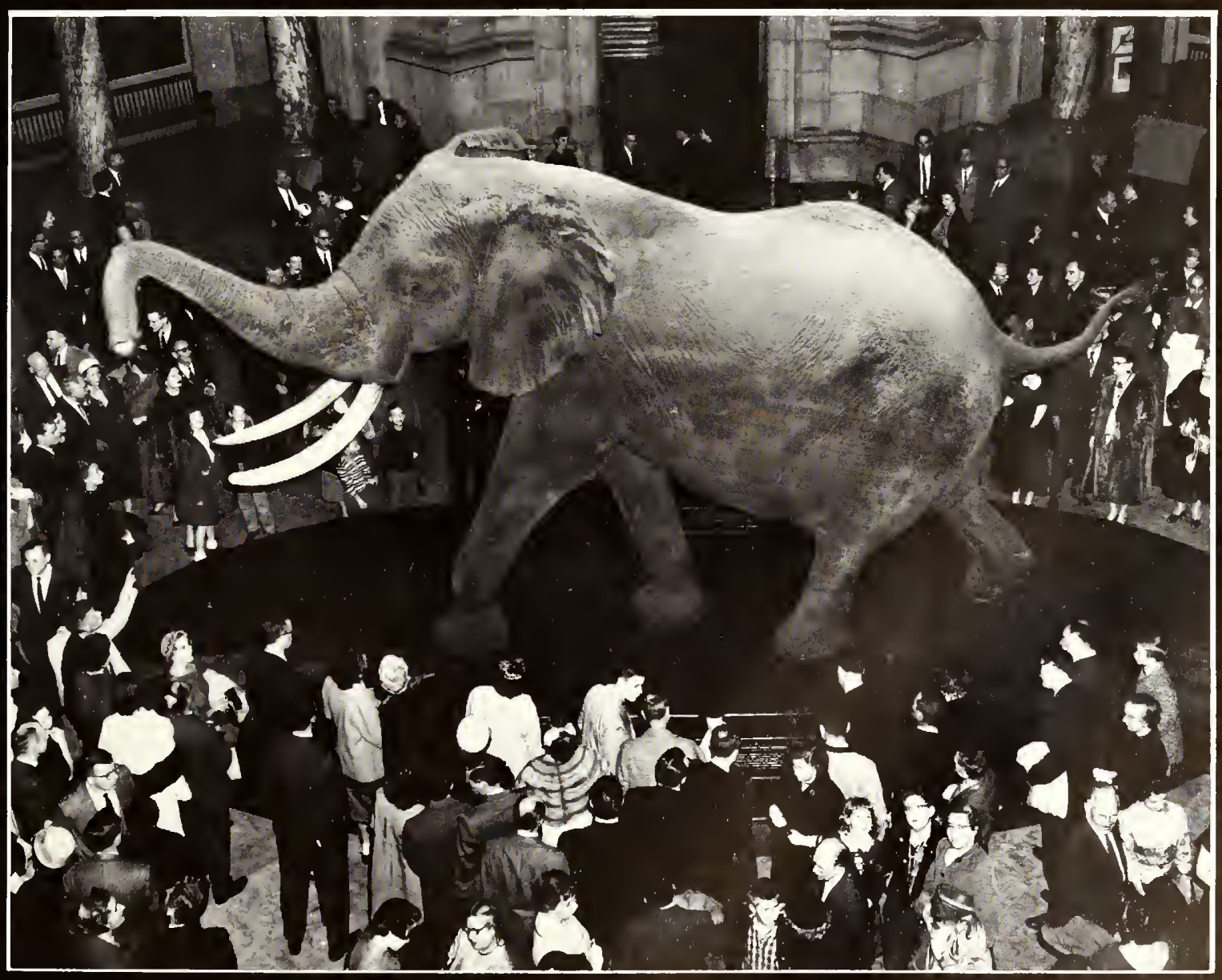




\section{New Exhibits, New Offices}

$\mathrm{E}$ XACTLY WHEN THE NEW NATIONAL MUSEUM opened is a minor point for clebate, since the building first served as a meeting place in 1908; collections were first stored in unfinished halls early in 1909; and the main floor of the north wing was first opened to visitors on March 17, 1910. This last date, marking its public debut, seems the best one to pick as the building's official birthday.

Over the next year, "only the remaining part of the space allotted to ethnology and consisting of the northern sections of the east and west ranges on the same floor were made accessible," but in 1911 and 1912 "much greater progress was shown," especially in the area of exhibits. While safety dictated steel- or metal-covered storage cases as soon as they could be obtained, aesthetics, in the head curator's view, dictated wooden display cases. These were traditional for more than half a century, and because the Museum provided plans and specifications for many other new or changing museums, similar display cases were seen throughout the country.

Although much of the work had to be contracted out, many of the new display cases were built by the carpentry and cabinet shops in the new National Museum. Mr. Cole, who had been chief carpenter for Secretary Langley's effort to build a man-carrying aircraft, moved in to take charge, and the sawing of mahogany and pine wafted a pleasant smell through a large part of the ground floor. Dark mahogany was standard for all

Hall of Archeology of Mexico, Central and South America on the second floor (Hall 26), taken from the stairs looking south. Those are calendar stones in the foreground and on the wall to the right. The glyphs on that wall are Mayan, and the cases contain Aztec pottery. Behind the calendar stone is a model of the Castillo at Chichén Itzá, and behind that, partly in the shadow, is Coatlique, main mother goddess of the Aztecs. The Mayan stele behind it is from Capan, Honduras. Because the models of the Serpent columns, which were at the door of the Castillo, are not included in the hall, this view probably was taken before 1924. display cases in all the halls. When these were completer, the shop spent decades building wooden storage cases that were then covered in the sheet-metal shop and sent off to the curators, who could never get enough of them. By 1912 the three Smithsonian buildings contained "2,724 exhibition cases of all kinds and sizes, 5,990 storage cases and pieces of laboratory furniture, 2,800 pieces of office and miscellaneous furniture, 32,976 unit specimen drawers of wood, 4,712 unit specimens drawers of steel, 6,839 insect drawers, and 13,253 miscellaneous specimens drawers and boxes of various sizes."2

About a year after the building opened, the new Museum experimented with the concept of opening for half a day on Sundays, and the public loved it. On October 15, 1911, a local paper reported: "The New National Museum will have its second Sunday opening today. The program is a more inviting one than that which attracted 15,000 to the institution at the initial Sunday opening a week ago for two new exhibits have been installed and several of the old ones have been repaired and rearranged. The museum's corps of taxidermists, preparators and cabinet makers have been busily engaged since Monday transferring and completing the exhibits.

"Zoology and paleontology," the article continued, "is the subject matter of the two new exhibits, which have been located on the first and second floors of the buildings. It is announced that the rotunda on the first floor will be open, as will the east hall of that floor and the northern part of the west range on the second floor. $1 \mathrm{t}$ is in these rooms that the zoological and paleontological exhibits will be displayed."3

Installing the new exhibits was hard work, and George Perkins Merrill remarked: "At best the head of a clepartment or division has not been able to depend on more than a moiety of each clay for research, and in times when exhibits are in preparation he has been obliged to dispense with even that. There are few forms of literary work, it must be added, that require greater care than that of label writing. To be able to state concisely and clearly the essential facts concerning an object 
Part of the Hall of Building Stomes (Hall 20), on the north side of the east wing secornd floor, showing two

exhibit cases with a slab allached to the wall between them. The cases were about eight feet tall, so that it was

difficult to see the upper shelf. In the early days, the paint shop was in charge of removing the glass if a cura tor had to get into a case.

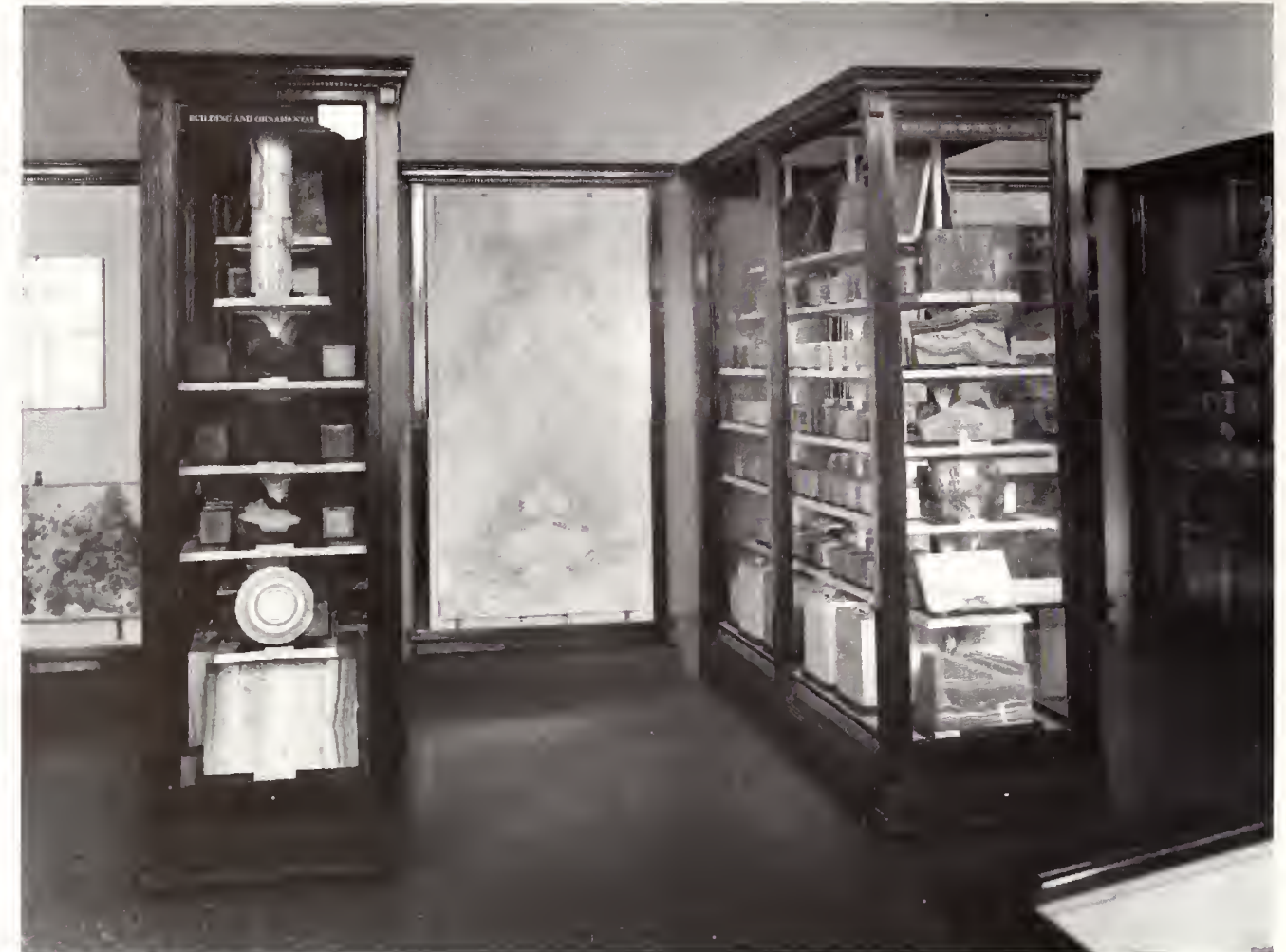

is by no means an easy task as everyone knows who has marle the attempt. If the label is too long it will not be read; if too short it is not sufficiently explicit."-

Menill noted that the Department of Geology, unlike Biology or Anthropology, was tending "toward open installation with the main aisle through the center of each hall, or it utilized for display of objects, only such as can readils be seen over and around. In short the aim laab becen to so arrange the cases and isolated objects, that a visitor can, in making continuous progress through the hall see readily on either hand every individual objece on clisplay." He added that "1he paleobotanical exhibit has proven with us as is almost miversally the case with other musemms, the most difficult of all to make interesting and atractive."

\section{Exhibit Challenges-and Problems}

A 1913 document chronicled the concerns of the Division of Mineralogy and Petrology. There and elsewhere in the Museum, exhibit technique was not nearly so sophisticated as today. ("The labels employed are on herbarium board. Gray board was preferred by the Assistant Curator, but was not adopted because twothirds of the labels had been previousty printed on the herbarim board.") But the problems that the curators faced with tourists and exhibit maintenance were comparable to those of later generations:

The average visitor spends so little time in each hall, that every effort must be made to secure his attention and the exhibition has been designed to attract attention and create interest, as well as supply information. . . The cases are fairly dust proof and thus far the specimens have remained clean; in the course of time, however, sufficient dust will filter in to cause the specimens to require cleaning. This period can be deferred somewhat by care on the part of the one in charge to secure adequate cleaning of the cases with the vacuum cleaner. .. Every effort should be made also to force the operators to keep the tops of the cases clean, a difficult task as they are apt to overlook all points not directly visible. The tops of the cases should be inspected also to note if the top glass becomes loosened, in which event special opportunity for access will be given the dust.

The enormously popular gen collection, which could not "be given too great prominence, or too much attention," was arranged

in seven table top cases down the center of the hall. It is believed that the sage-green velours lining to the cases is the most suitable that can be secured. Unfortunately it fades; this objection would hold for any other fabric or color. The white silk pads are also satisfactory but those now employed were used in the old building and are not especially fresh and clean, and in a few years will have to be renewed. ${ }^{8}$

Not all exhibits were simple. William Henry Holmes did a great cleal more than install the National Gallery of Art, and in some ways was the star of the new Mu- 
West end of Hall of Geology and Meteoritics (Hall 6) in the 1920s or 1930s. In the cases to the left are igneous rocks, most trimmed to uniform rectangular shapes. The meteorites are to the right, but the largest specimen, in the foreground, is a plaster cast of a Mexican specimen.

Tourists would touch the cast and then chip a piece away, so that it continually had to be repaired with black paint. Eventually director Wetmore was persuaded to discard the cast.

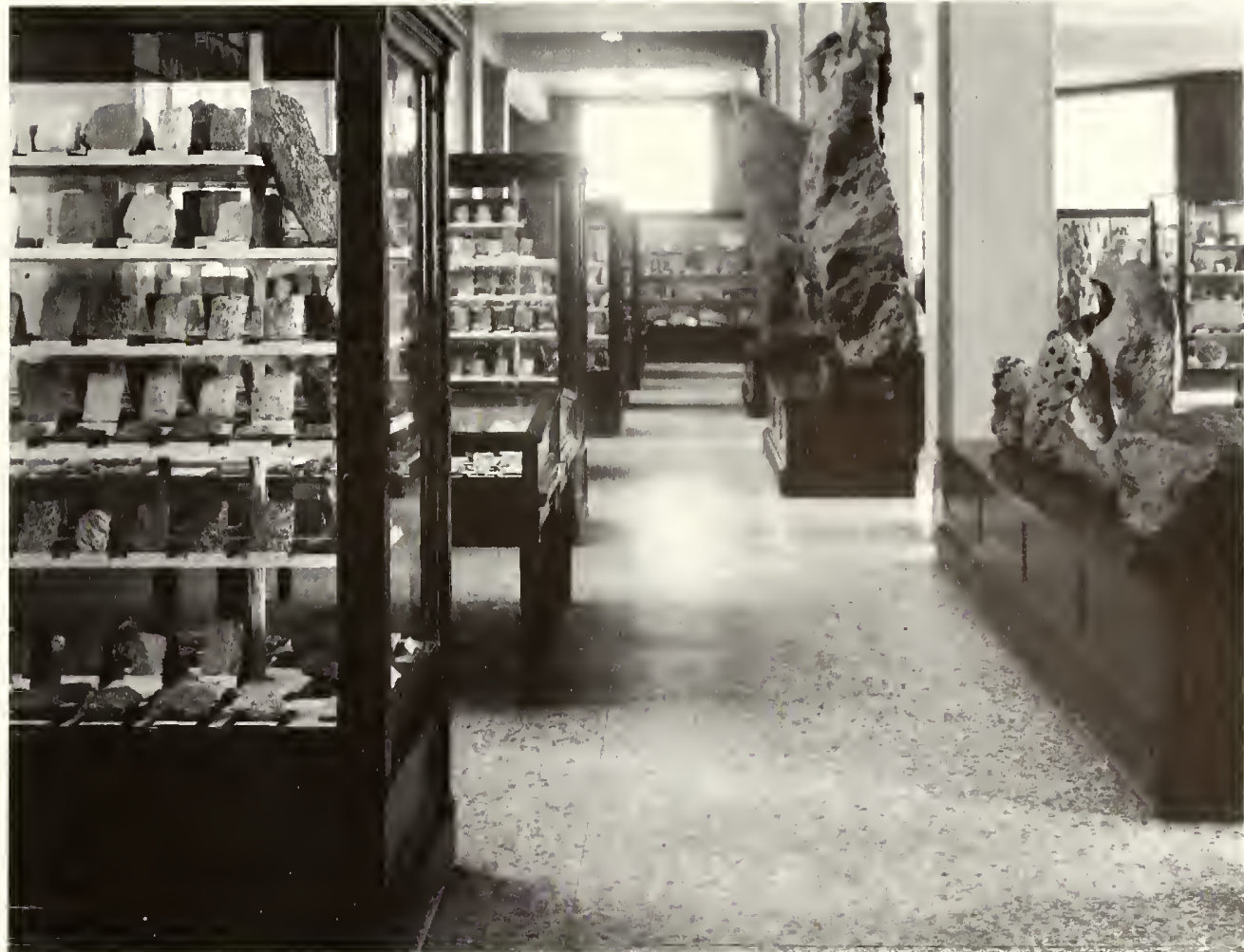

seum's show, earning accolades for his ingenuity with ethnological exhibits. His "scheme for getting these changing peoples on record," as a Washington newspaper article observed, had first been displayed at the 1893 World's Fair at Chicago, and is now in use in practically all the great museums of the world. This new idea of the American ethnologist was to crystallize into permanent form a family group of all the important people. This group should be cast, life size, into some permanent material. The members that go to make up the group should be shown at their customary activities. They should be clad as when seen at home. The scene should be set as though the pages of history were turned back to the time when the people lived untrammeled by a higher civilization and foreshadowed by higher peculiarities of the time and place they formerly occupied. ... Dr. Holmes is a scientist and an artist. He is one of the great men in ethnology in America. ${ }^{9}$

Rathbun described the arrangement of the exhibits in detail:

Many paintings of Indians from the Catlin collection and other sources were hung, and a large series of transparencies of Indian subjects were placed in the windows of the halls. The totem poles and other carvings and paintings of the northwest coast tribes, with the exception of the Haida house front and its associated totem poles, were installed at the south end of the middle hall, where they make a striking display. In the arrangement of the collection from the Pueblo region it was found advisable to separate the antiquities from the ethnological material proper, with which they have heretofore been associated, and they have been transferred to the division of prehistoric archeology. The construction of lay figure groups progressed rapidly, and seven fullsized groups of this character were added to the exhibition.

The exhibits of this division are assembled primarily by geographic area, and the peoples and their cultures, so far as represented, may be thus studied in much the same order that the peoples themselves might be visited by the traveler. Under these headings the classification is by nations or tribes, and by special exhibition units ilhustrating culture as follows: tribal area, synoptic series of artifacts, family groups, industrial groups,

individual figures, pictorial exhibits, and sculptural exhibits. Of the 16 full sized lay figure groups that have been planned the following 12 are finished and on view, namely the Eskimo, Chilkat, Hupa, Cocopa, Zuñi, Sioux, Virginia, Tehuelche, Samoan, Negrito, the arrow makers, and the snake dance. ${ }^{10}$

Neil M. Judd, newly hired in 1911 as an aide in ethnology, remembered the exhibits well from a different perspective.

The new building with over ten acres of floor space had been completed externally in 1910, but the interior plaster was not yet dry when orders 


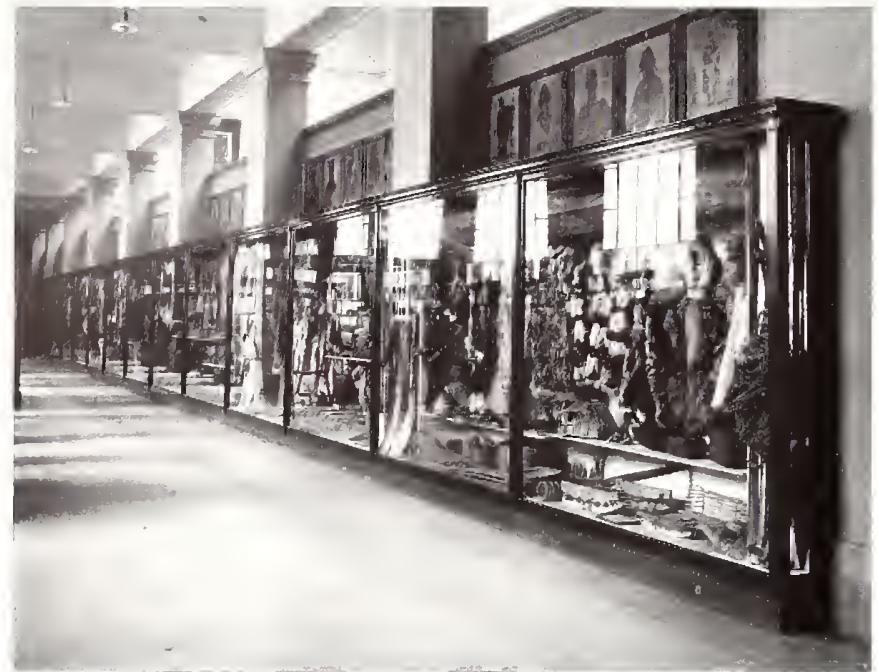

Holl of Eskimo and Indion Groups (Hall 9). Indion poimtings by George Cattrin are on the woll above the cases; Eskimo chothing in in the foregromend and Indian clothing is in the distance. Probobly post-1930, judging from the light fixtures.

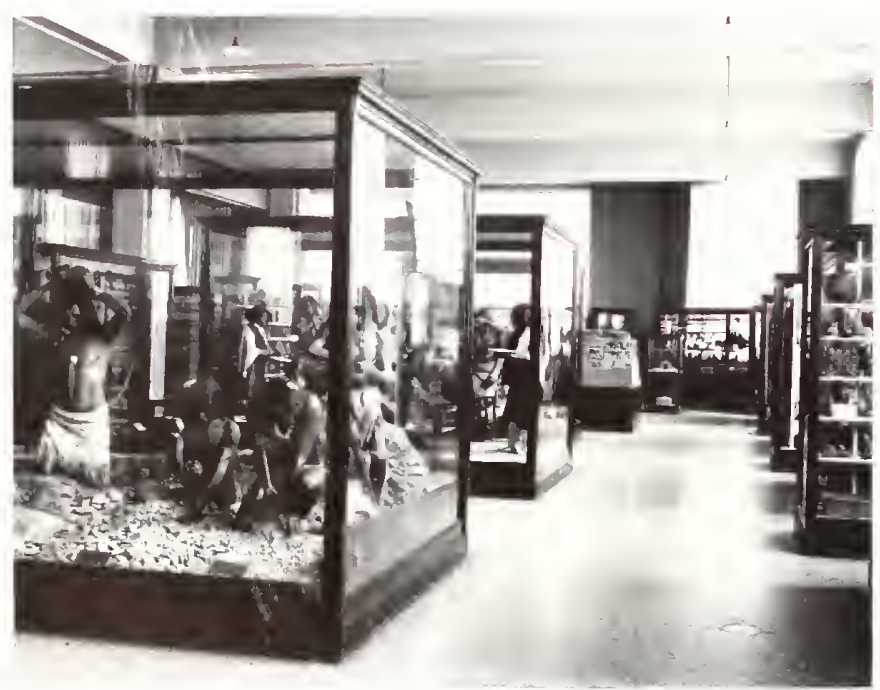

The Prme Bronch Quarry Indian group, to the left, is discussed and illhustroted in the Smithsomion Institution Annual Report for 1920. The case behind, moinly hidden, holds the Hopi snoke doncers. Holmes's work at this quarry in Whashingtom, D.C., brought him world fome and cast new hight on the mom factmre of stone took. In his "Rondom Records" is another photograph of this group, with a notation that someone had moved it to the second floor without consulting him. After the move, furthermore, the area surrounding the figures was strewn with waterworn cobbles rather than flakes of broken stone. Holmes was furrous. came to rush the exhibits... .

The "new" National Museum was individualistic, unlike any other. It was entirely up to date. With larger-than-usual exhibition spaces, special furniture had to be designed. In archaeology, for halls with twenty-foot ceilings and windows on both sides, four kinds of cases were provided: those fixed in position against a wall; casterequipped "floor" cases four feet wide by eight feet long and eight feet high; "clouble-slope-top" cases with storage drawers beneath; and "narrow flattop" cases, likewise on rollers and with storage facilities. Each was precisely like every other of its kind, and each was allotted a predetermined space, row upon row. Wall cases and floor cases were equipped with adjustable shelves, but it took two strong men to lift their great plate-glass fronts. They were all very modern. And every glass-front case was a mirror reflecting every other case and its contents. Those were parsimonious times at the National Museum. We lacked competent assistants and adequate equipment. But somehow the work was done. . . As the task progressed, we begged from colleagues in other halls and improvised when other means failed. From sheer necessity we continued to use handmade pasteboard boxes and trays, salvaged from the "old" museum [and] redstained wood trays marle to fit the old walnut exhibition cases. . .

Three halls with 216 exhibition cases on nearly 35,000 square feet of floor space were reserved for Western Hemisphere archaeology-from the Arctic to the Antarctic. Under Prof. Holmes' supervision those 2 I 6 cases were my responsibility; filling them in a hurry my job. ... There was no time to mark and describe individual specimens. They were unpacked and immediately put in exhibition cases, and the contents of those cases became visible storage not to be changed appreciably for forty years. ${ }^{11}$

\section{Biology Exhibits}

The Department of Biology encountered the most challenges in installing material, for the subject matter to be exhibited was far more diverse than that of Geology or even Anthropology. Display of specimens was also more difficult-there were serious problems of protection against pests and deterioration. After the building opened, an unanticipated change had to be made in the halls themselves when the ground window glass proved insufficient to protect the colors of the specimens from sunlight. The enormous windows, each containing two movable panes that had to be kept open in warm weather, were fitted with a complicated system of curtains. "The main curtains on the first floor, of unbleached muslin, reach from the window top to the upper level of the ventilating openings and are followed 


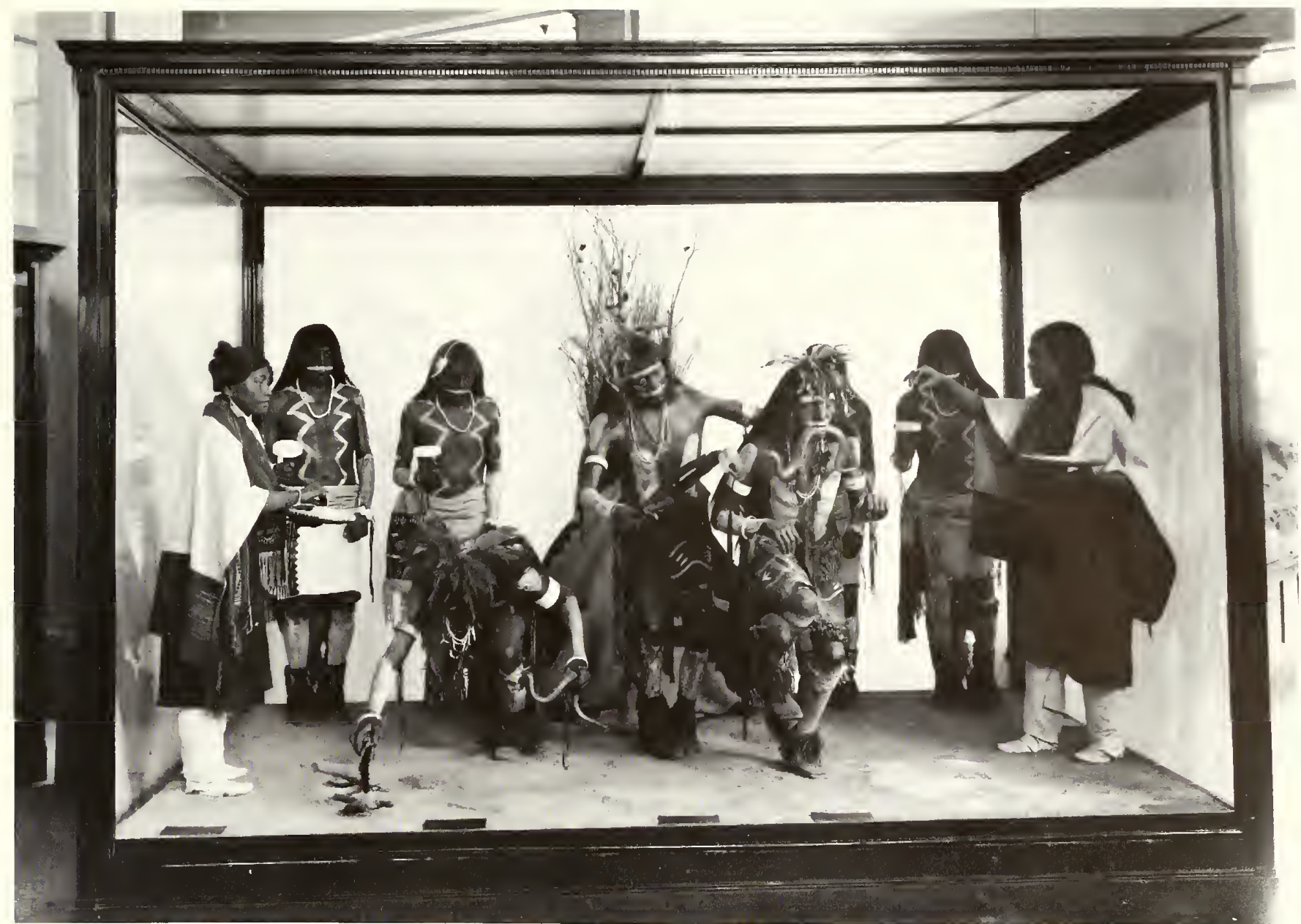

Indian exhibit-Hopi snake dance. This group too is discussed and illustrated in the Annual Report for 1920. To take the photograph-probably in the 1910s or 1920s, for the model behind this case is not on a stand-the sides and back of the case were covered with fabric to cut down on reflection and to mask adjacent cases. The display is in Hall 11 in the west north range, first floor. by shorter curtains." ${ }^{12}$ A third set of curtains, black, was drawn after closing time as extra protection for the mammal and bird exhibits.

Shortly after the exhibits work began, F. W. True, the head of Biology, was promoted by Secretary Walcott to Assistant Secretary in charge of library and exchanges, and on June 1, 1911 , Leonhard Stejneger took over. Stejneger had had less experience with expositions than Holmes and Merrill, who in a sense had stockpiled some displays, but he kept things moving. Because "a satisfactory display of plant life present[s] difficulties which have not yet been worked out," ${ }^{13}$ (to this day the Museum has not developed a major botanical display), Biology's exhibits related to zoology only. Even without botany, they occupied a large number of halls.

"The first story is devoted to the mounted skins of mammals and birds arranged faunally," Rathbun wrote, "the latter group occupying the [west] range and a portion of the north hall of the [west] wing. . . The American nammals, consisting principally of North Amer- ican representatives, have been assigned to the large skylighted hall, the African mammals to the outer end of the wing, and the Australian and oriental mammals the south hall, while the palearctic fauna will share the north hall with the birds. Pending their arrangement a few large mammals mounted separately on pedestals have been exhibited in the rotunda." 14

\section{William T. Hornaday}

One of the major items transferred to the central skylighted Hall 16 of the west wing-the site of the temporary Freer exhibit-was the group of six buffalo that William T. Hornaday had mounted in 1888. One of the finest taxidermists of his generation and the person most to be credited for the founding of the National Zoological Park, Hornaday had personally shot three of the specimens in one of the last buffalo hunts in the United States. He was one of the first, if not the first, to develop the notion of placing specimens in natural settings, and he had brought back sufficient material from Montana to provicle a realistic environment. ("The 
group, with its accessories, has been prepared so as to tell . . the general visitor . . the story of the buffalo, but care has been taken ... to secure an accuracy of detail that will satisfy the critical scrutiny of the most technical naturalist." $)^{15}$ Unfortunately, Hornaday had clashed with Langley and left in 1897; the new exhibits could have used him. Taxidermy was so important to the department that for a few years there was a departmental position of chief of exhibits, at that time the only official recognition of exhibition design within the establishment.

Graced by Hornaday's newly mounted specimens, an African buffalo group, and some individual African specimens Theodore Roosevelt had collected after leaving the White House, the mammal hall was formally opened on April 22, 1913. Some of the biological exhibits on the second floor had already opened the previous year; others were still being worked on. By the end of June the entire area allotted to natural historythe wings and ranges in the first and second storieswas open to the public.

During the following year, Rathbun noted, "the division of plants has for the first time been represented to the public by an exhibition of flower stuclies in water color ... embrac[ing] a wide range of domestic and foreign plants as well as cultivated varieties." There still were many cases to be installed, but the dramatic pliase of opening new halls was over. Because a great deall of space was now open in the old brick Museum, much of the Annual Repont was devoted to the change of exhibits there.

It was a phenomenal achievement for the reference collections to have been moved, and for so many new display halls to have been opened, in a relatively short time. Bv way of comparison, the Freer building did not open until two years after it was completed. and that was a fir smaller operation. A published plan of the Museum's exhibil halls indicates that all five acres of display space was filled by $1917 .{ }^{17}$ By any criteria one cares wo apply, the staff had done a remarkable job. and deserved at least to pause on their laurels.

\section{Offices and Storage Space}

There was a vast amount of space in the massive new building apart from what the exhibits occupied. Most of the ground floor, except in the north wing, remained to be filled, and the third floor provided acres of new offices and seemingly unlimited storage space. As head curator of geology. Merrill rated a large office on the southeast corner, the same size as the office of the director on the southwest corner, except that Merrill's was full of steel cases that divided it into several cubbyholes. The remainder of the Geology Department had adjacent offices facing the Mall, and the large mineral collection was at the north side of the east wing. The chemical laboratory overlooked the east court.
Paleontologists of the Geological Survey filled most of the offices on the third floor of the east range, convenient to the Geology Department. E. O. Ulrich and a young J. B. Reeside were among those who moved from the Hooe Building to share an office overlooking the east courtyard. Late one afternoon Ulrich was studying the fossil brachiopods in a large collection and dividing them into three piles, each a different species. Reesicle arrived early the next morning and was there to see Ulrich come in and begin shouting that someone had mixed up the piles during the night. Deciding and then changing one's mind as to how much variation there is within a species continues to be a major preoccupation of a large number of people in the building.

The vertebrate paleontologists were on the ground floor, partly because they needed more space and high ceilings to assemble large specimens, and partly because they needed ironwork from time to time to mount a skeleton; this could be obtained from the nearby machine shop. Charles W. Gilmore had the northeast corner office. The library, on the east north range between his office and the lobby, did not even occupy all the space of that range. The saw for meteorites and the stone-cutting and polishing equipment were also on the east sicke adjacent to the shops and the east court. The shops occupied most of the east wing.

Holmes had his office on the Constitution Avenue side of the thind floor, adjacent to the elevators in the north wing. It was not as spacious as Rathbun's and Merrill's south-sicle rooms, and on windy days there was a racket from the halyard whipping back and forth on the flagpole outside the window. But Holmes as an artist liked the north light of the office, which also chanced to have a marble-lined private bathroom. Several other ethnologists were in the east north range; Aleš Hrdlička and the physical anthropology collections occupied the courtyard side. They were separated from another group of ethnologists scattered in the east side of the north wing closer to the rotunda. Anthropology had a potsherd and casting laboratory in the north range on the ground floor, around the corner from the vertebrate paleontology laboratory; since both operations used a fair amount of plaster in restoring missing fragments of bones or pots, the association was convenient.

The Department of Biology was both the most splitup and the largest in staff. The entomologists-that is, the Department of Agriculture employees-were in the west side of the north wing and in the west wing. Mollusks were in the west range, along with a few Geological Survey folk who worked on fairly young fossils. The Museum's bird division and the ornithologists of the Biological Survey were in the west north range and the courtyard side of the west wing. In later years the head curator of biology had the first office in the east wing nearest the rotunda. It is not a particularly distin- 
Hall of Archeology of Europe and Asia (Hall 23), on the second floor of the north wing, looking north to the elevator doors in the distance; a model of the Parthenon is to the right. The windows on the left open onto the west court, and the openings on the right ozerlook Hall 10. Probably 1910-1940.

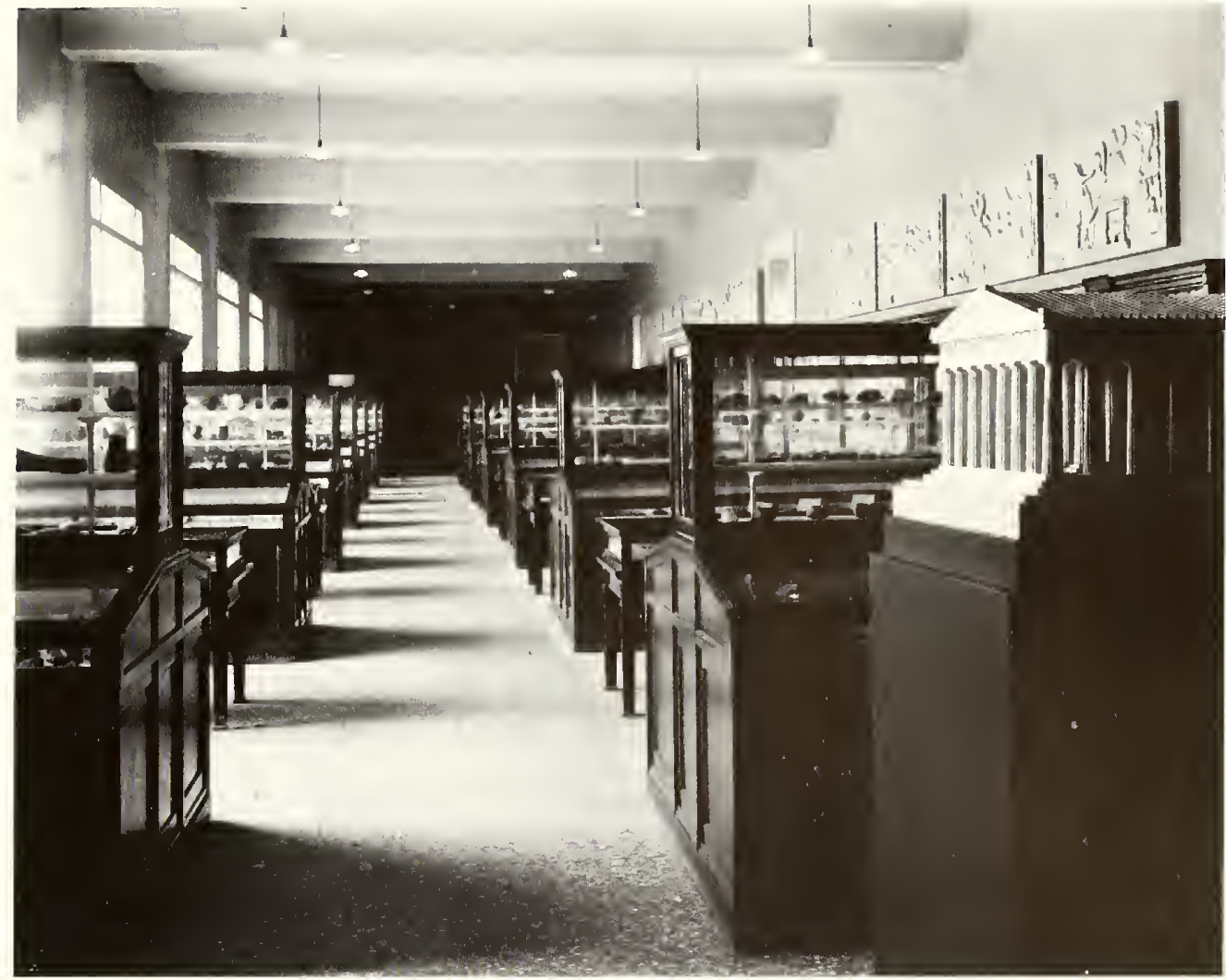

guished one, but does have a large closet at one end, an uncommon feature. Most of fices had clothes trees or lockers, for the thickness of the Museum's walls precluded the sort of thin partitions used for conventional closets.

On the ground floor, the mammalogists held sway in both the west north range and the west range. Most of the west range was occupied by mammalogists of the Biological Survey, while the Division of Mammals had the Constitution Avenue side of the building. The Matl side of the west wing was occupied by the invertebrate zoologists, and the Museum fish people had the north side, looking out into the west courtyard. Botany remained in the Castle.

\section{Few New Staff Members}

In spite of the large new quarters, few new members were added to the scientific staff; most of the expansion was from associated agencies. Neil Judd, in Anthropology, was one of the few new junior staff members, and his position probably came about because Holmes was so busy with the National Gallery. Waldo Schmitt, in invertebrate zoology, was another. A native of Washington, D.C., he had been a scientific aide in the Division of Marine Invertebrates before joining several cruises in Bureau of Fisheries vessels. After a year in California, he returned to the Museum as an assistant curator. ${ }^{18}$ In order to provide a paid position for him, Mary Jane
Rathbun, the sister of the Assistant Secretary, gave up her staff appointment. Schmitt's devotion to her, through the next thirty years of her career, was less an expression of gratitude than a true scientific love story. Miss Rathbun was the specialist on crabs.

Compared to the brick buikling, the new National Museum was a palace. All the offices, which were steamheated, had windows, giving plenty of daylight to work by. For those on the ground floor, lavatories were in the lobby; there were two on the third floor near the rotunda. It may give some notion of the building's size to point out that from a remote office to the nearest bathroom was close to a 500 -foot walk.

There seems to be a general rule of thumb today that it takes about five years after a major move for an organization to function with its former efficiency. It takes time to settle in and fit new members into the staff, to remember where materials have been moved, to get a grasp of how the library has been rearranged. Yet the disruption of research at the Museum was minimal. Judging from lists in the annual reports of the published papers of the staff, there was no noticeable slackening of publication as a result of the move and the new exhibits program. Certainly by 1913 the Museum staff was pursuing research at a more active pace than ever. But the tranquility and order that had been earned by hard work were not to last. 



\section{The Great War and Its Lingering Aftermath}

$\mathrm{T}$ HE FIRST HINT OF COMING DIFFICULTIES was recorded in an annual report: "The auditorium was used on June 1, I9I7, for an address to the employees of the Institution and its branches by Eugene $\mathrm{E}$. Thompson, secretary of the Washington Liberty Loan Committee, who explained the object of the Liberty Loan, how the bonds could be purchased, and the desire of Federal officials having the matter in charge that the first loan of the United States receive as great a number of individual subscriptions as clid the last loan in Great Britain." The weekly "Local Notes" that Secretary Walcott had instituted the year before record that the staff was paid in advance so that they could participate in the loan drive. Later the "Notes" record the sponsoring of a Red Cross ambulance by the staff. Benjamin Walcott, the Secretary's youngest son, went off to fly for the French and died in 1917.

The Great War impinged upon the Mall in increasingly real ways. "From the first evidence of trouble, the [geology] department was subject to call for material for experimental purposes, particularly along the lines of electricity, radioactivity, light and sound transmission, from alt branches of the government, the Geophysical Laboratory, and numerous private investigators." Later, for a period of several months, Merrill "was detailed by the Council of National Defense to find a sufficient supply of quartz for naval supersonic purposes for not only his own country but for France and England as well." Biological effects of gas warfare and peat as a fuel source were investigated. The Division of Physical Anthropology furnished data on the human races of the Balkans, and other parts of the Museum supplied esoteric information now vital to the nation.

On October 13, I917, President Wilson called to Secretary Walcott's attention the urgent need for space to house the Bureau of War Risk Insurance, a new agency under the Treasury Department. He asked if part of the Arts and Industries building could be used. Insteact,

Wartime rally in fromt of the Museum, looking north from the Mall. space was made in "the foyer on the ground floor of the natural history building with the adjoining rooms, and shortly after, the west north and west ranges, by removing the collections of the division of mammals and of the Biological Survey to the same ranges on the second floor. The space thus provided amounted to approximately 25,000 square feet."

While accepting, as his colleagues did, the necessity of this sacrifice, Stejneger was quite clear as to the upheaval it caused within the Museum:

when late in the calendar year of 1917 the division of mammals and the Biological Survey were called upon to give up their laboratory and storage space in the west and west north ranges, ground [floor], it was decided to move the cases containing these collections up into the corresponding exhibition space on the second floor. In these ranges were exhibited the District of Columbia fauna, the domestic animal series, all the invertebrates including the insects, the whole synoptic series, the special exhibits of color aberrations, hybricts, birds eggs and nests, the destructive work of insects, the historical exhibit of the corals of the Wilkes Exploring Expedition, etc. The bulk of the exhibition cases were placed in adjacent alcoves containing the special exhibits, but a large number had to be given shelter in the whate hall, which thereby became unduly crowded with a very heterogeneous assembly of exhibits. Some of the large cases could nol be thus accommodated and, like that containing the zebu and the yak, were transferred to the south side of the south hatl on the first floor, where the original arrangement ... had to be disturbed and the cases crowded together. Toward the end of the fiscal year it became necessary to give up more space for the same purpose, in consequence of which both the big halls on either side of the great skylight hall on the first floor for the west wing had to be cleared of their exhibits....5

On November 23, the President again wrote to the secretary [Walcot1] asking that the Board of 


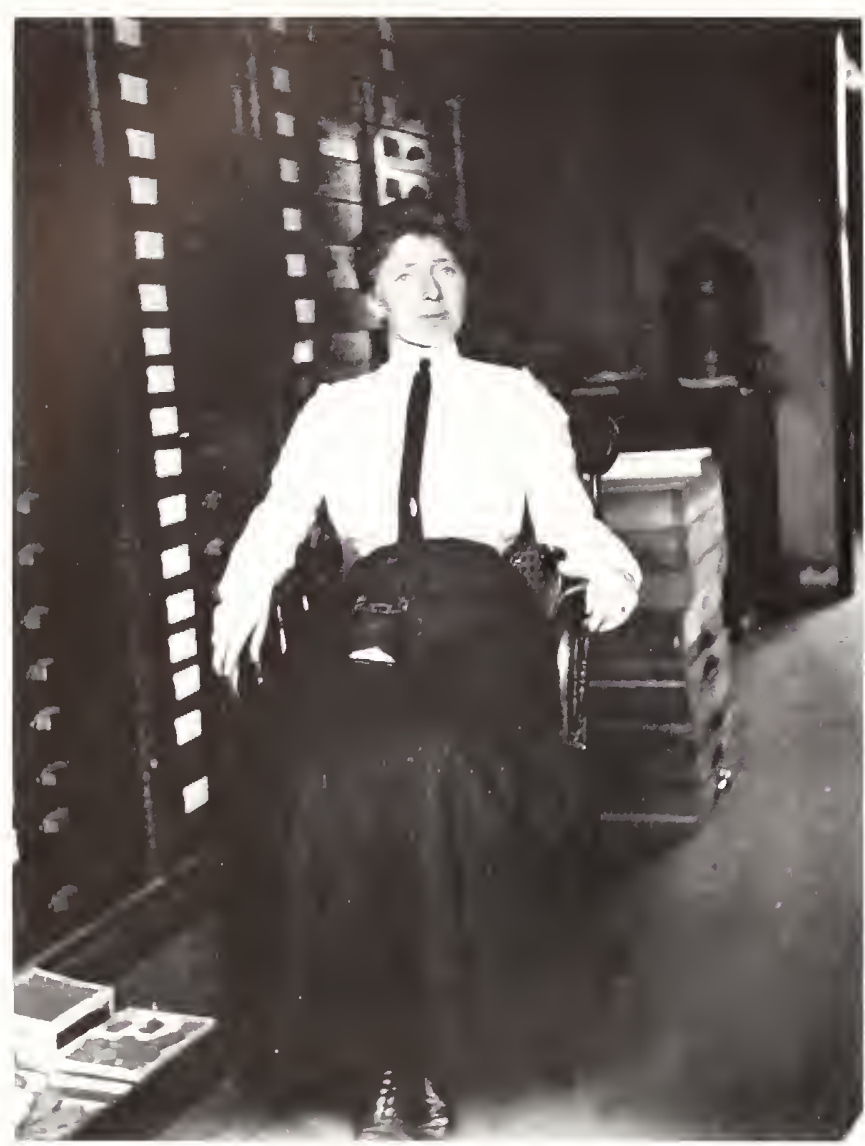

Margaret 11 . Moodes. 1910. Miss Moodey uas secretary in the Department of Geology, and probably this was laken in the southeast commer office of the thind floor.

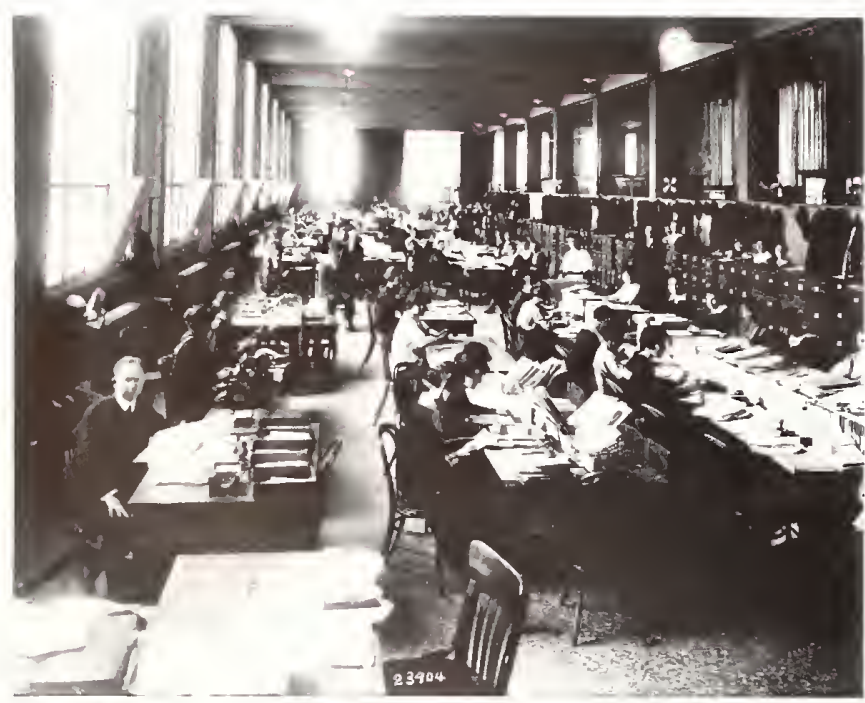

Clerks on the first floor of the Museum, probably in 1918. The scene is one of the ranges-the exhibits camol be idenlified.
Regents place at the disposal of this bureau from 60,000 to 80,000 additional feet in the exhibition hall ... which was provided by concentrating the cases in parts of eacli hall and protecting them by means of partitions, thereby leaving large areas available....

As the force increased additional space was granted, so that at the close of the fiscal year, the bureau occupied 69,286 square feet in the foyer, auditorim, and ranges on the ground floor; the rotunda, and portions of the exhibition halls on the first floor extending from the center of the north hall around east through the southern section of the west hall, thereby providing accommodations for 3,059 employees.

On July 16, 1918, at the further request of the President, the Board of Regents closed the natural history building to the public, thereby making available for the Bureau of War Risk Insurance on the ground and two exhibition floors a total of 138,600 square feet. ${ }^{6}$

This conversion to office space was a remarkable incident, probably unparalleled in the history of American musemms. The building is large, but the concept of thousands upon thousands of clerks at their desks brings that point home dramatically.

\section{Museum Reopened}

In late March 1919 the Bureau of War Risk Insurance moved to quarters of its own at the corner of Vermont Avenue and H Street, NW, but its funds were so depleted that it was unable to honor its agreemnt to renovate the Natural History Building. The Museum thus had to be reopened unrepaired-the first floor on April 11 and the second floor on April 22. In the next fiscal year the Musem received sufficient funds to repair the dimaged plaster walls and repaint the exhibit halls.

For years, a footnote to the annual attendance figure of 132,859 for fiscal 1918-19 indicated that it reflected only the three months the building was open that yearApril, May, and June, 1919. Attendance was strikingly heavy, suggesting that visitors had sorely missed the Museum during the long time it was closed. Attendance during the previous fiscal year, 1917-18, represented a great increase over annual figures for the first few years the Museum was open. More than 401,000 visitors came to the Natural History Building during the twelve months of that year. The relatively heavy attendance, in spite of the fact that some exhibits were closed, showed the swelling of population in wartime Washington and the lack of other entertainment facilities.

During World War II the Museum remained open and functioned about as normally as any agency did at that time. When there was talk of closing it again, it was successfully argued that the educational and entertainment value of the Museum, for people assigned 
Clerks on the first floor of the Museum. This may be Hall 12 in the west range, looking south; before World

War I, it housed a bird exhibit. Another hall, in the distance, is blocked off for offices. The 125 or so people shown gize some indication of how crowded the building must have been with desks for 3,000 clerks. Fans provided all the climate control that was available.

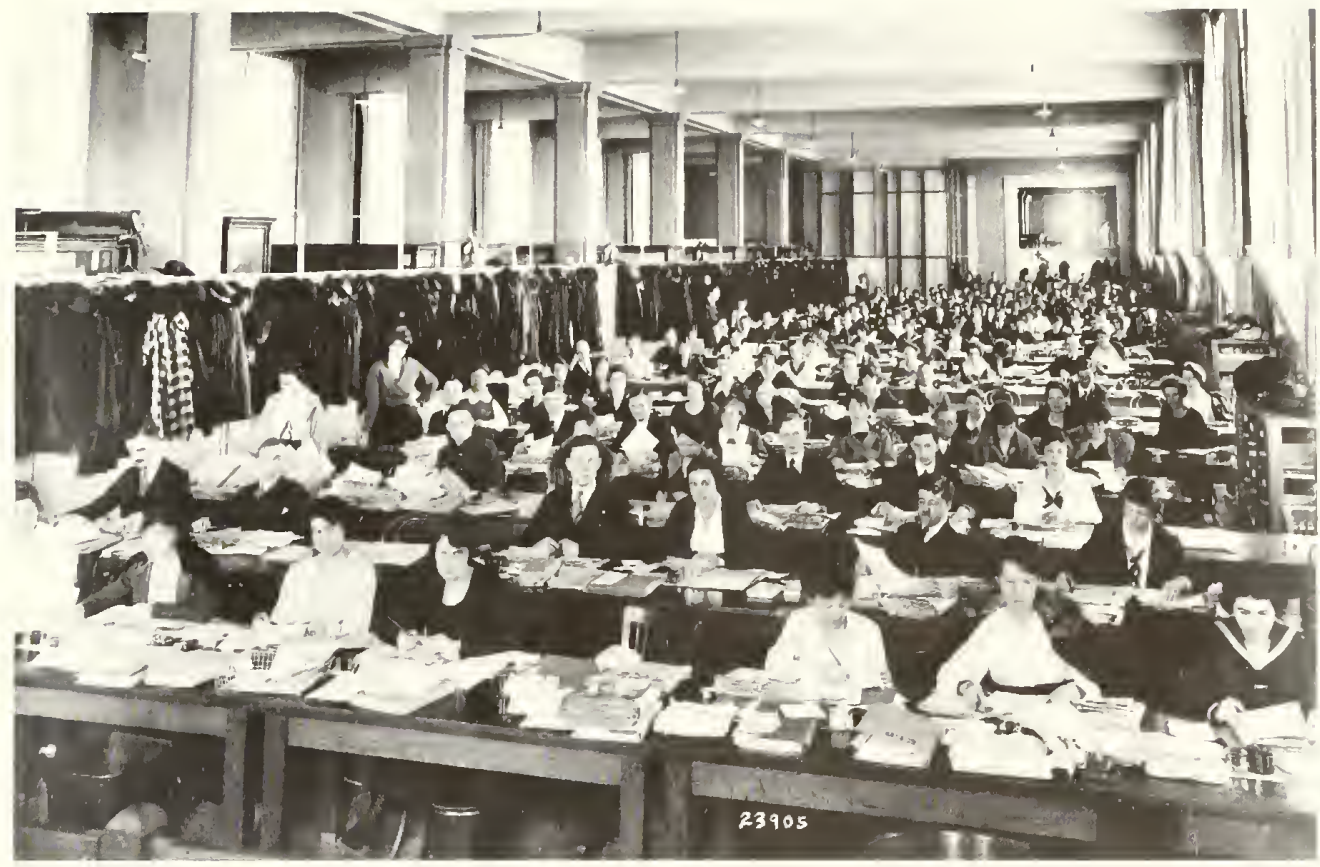

to war work in the city, far outweighed any minor savings in fuel or labor.

One aftermath of the First World War was a huge accumulation of uniforms, weapons, medical instruments, and a host of miscellaneous materials that came to be known as the War Collection and stayed in the building for more than a decade. Partly as a result of this great growth in the collections, in $192 \mathrm{l}$ a Department of History was split off from the Department of Anthropology; it was headquartered in the Arts and Industries Building. Another legacy of the war was a sheet-metal shed, behind the Castle, that had been erected by the Army Signal Corps. This became the Aircraft Building and the nucleus of the National Air and Space Museum.

\section{New Administration}

The Museum was under new administration, for on the same day that it had been closed to the publicJuly 16, 1918-Richard Rathbun died. There was no member of the scientific staff either willing or able to succeed him. Perhaps if the war had not disrupted matters so, one of the three head curators would have moved into the job, but that did not happen, and on November 1, 1918, the position of Assistant Secretary in charge of the United States National Museum was discontinued. Willian de C. Ravenel was placed in charge of the administrative affairs of the Museum, with the titles of Administrative Assistant to the Secretary and Director of Arts and Industries in the Museun.

It is hard to find out much about Ravanel, except that he was of the South Carolina Ravenels. A former official of the Fish Commission, as Rathbun had been, Ravenel was more a bureaucrat than a scientist. His personal interests lay in Arts and Industries and the historical collections. But he strongly asserted the right of natural history to occupy the entire Natural History Building, uncramped by the National Gallery of Art or-even more unmanageable at that time-the War Collection.

The rotunda was set aside for naval exhibits churing the latter half of 1919 , and the Navy soon filled it with signalling devices, a paravane, and various munitions. "During the month of June the large 6-inch naval gun which fired America's first shot in the World War was delivered at the building. Owing to its weight and the impossibility of getting it in the building it was placed on the east chriveway, where it makes a most impressive exhibit."

Early in 1920, according to the Anmual Report, the space assigned to the War Collections was increased by two large ranges on the ground floor. ... In one was installed the collection of foreign uniforms, insignia and decorations . . . and the collections of captured German military equipment... In the second range were placed the collections of chemical warfare and ordnance material. The west and central portion of the foyer ... was given over to the Corps of Engineers for its exhibit; a portion of the foyer and three rooms on the east to the exhibit of the Medical Department ... and the walls of three rooms on the west of the foyer to the pictorial material. ...

The public liked these new displays, but the staff had become deeply frustrated by the continued occupation of so much of their exhibit and storage space and the hindrance of their work. 


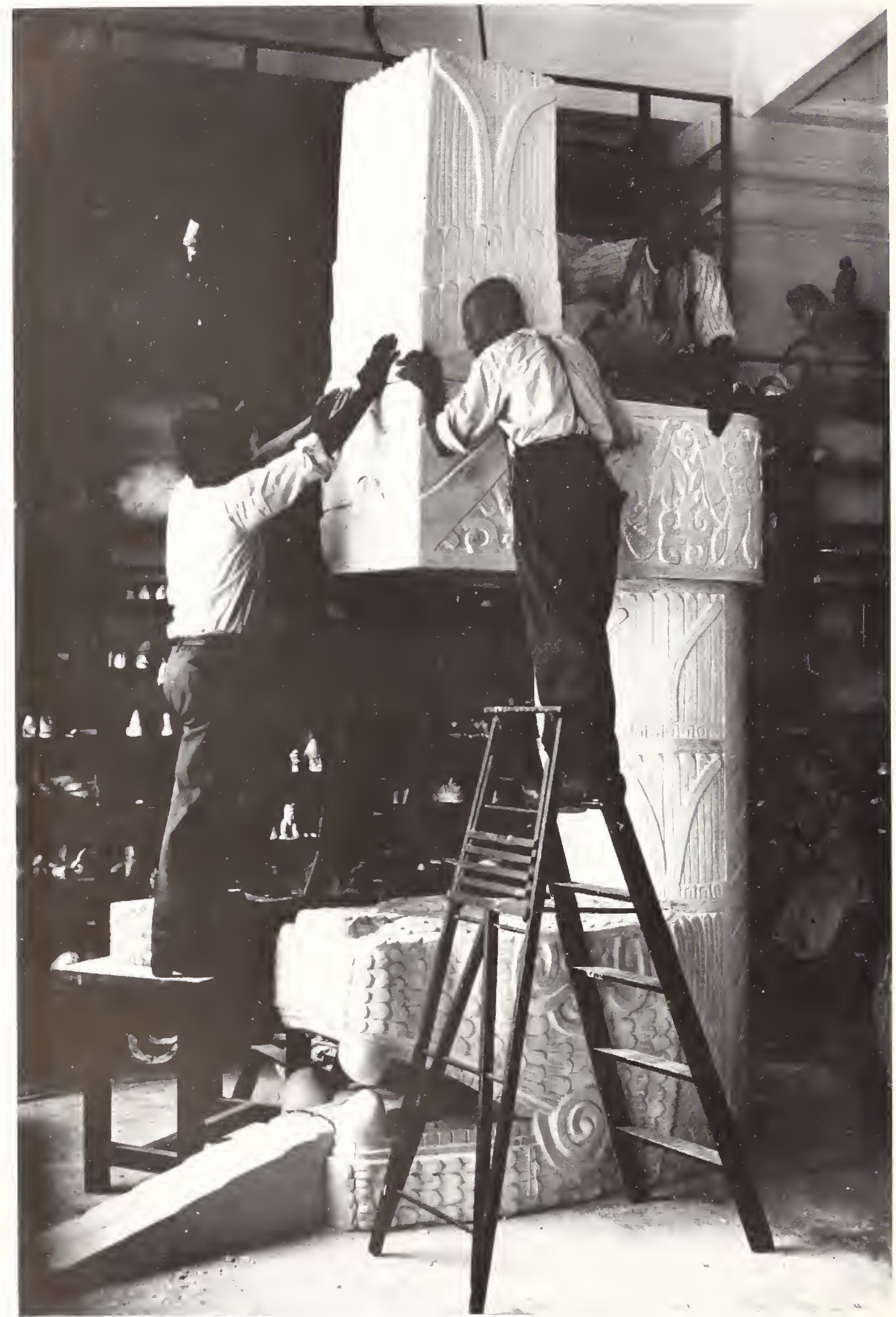

"Setting up the Serpent columns in the National Museum," a copy of a photograph in William Henry Holmes's "Random Records." Judging from the ceiling height, this was the second floor. The material behind does not appear to represent Central American anthropology, and these plaster

casts may have been placed near the north elevator before being moved into Hall 23. There was some work on the exhibit halls after they reopened in 1919, though it is difficult to document just how much was done. 


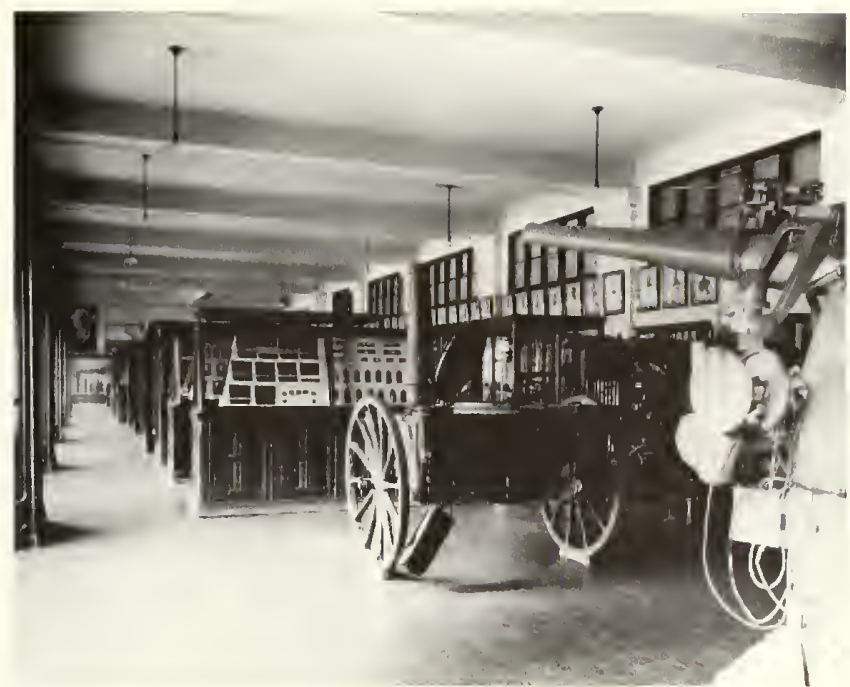

The War Collection in the west or west north range, 19191929. To the right is a naval gun with a sighting rifle on the barrel. The wheeled object is a field oven, and the foremost case contains boards of insignia. On the wall are drawings by J. C. Chace of various war heroes.

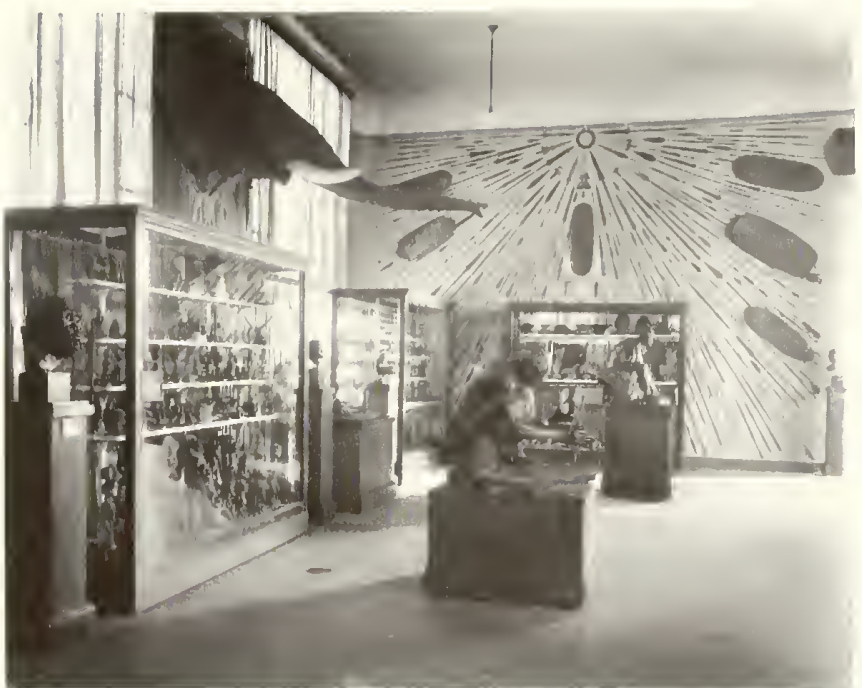

The Henry Ward African exhibit at the northeast comer of the first floor, at the juncture of Halls 6 and 7. This photograph was taken after 1922, when the Ward Collection was placed on exhibit. The African elephant head (Loxondontus) on the wall cammot be located, and may haze been deaccessioned when the display was revised.

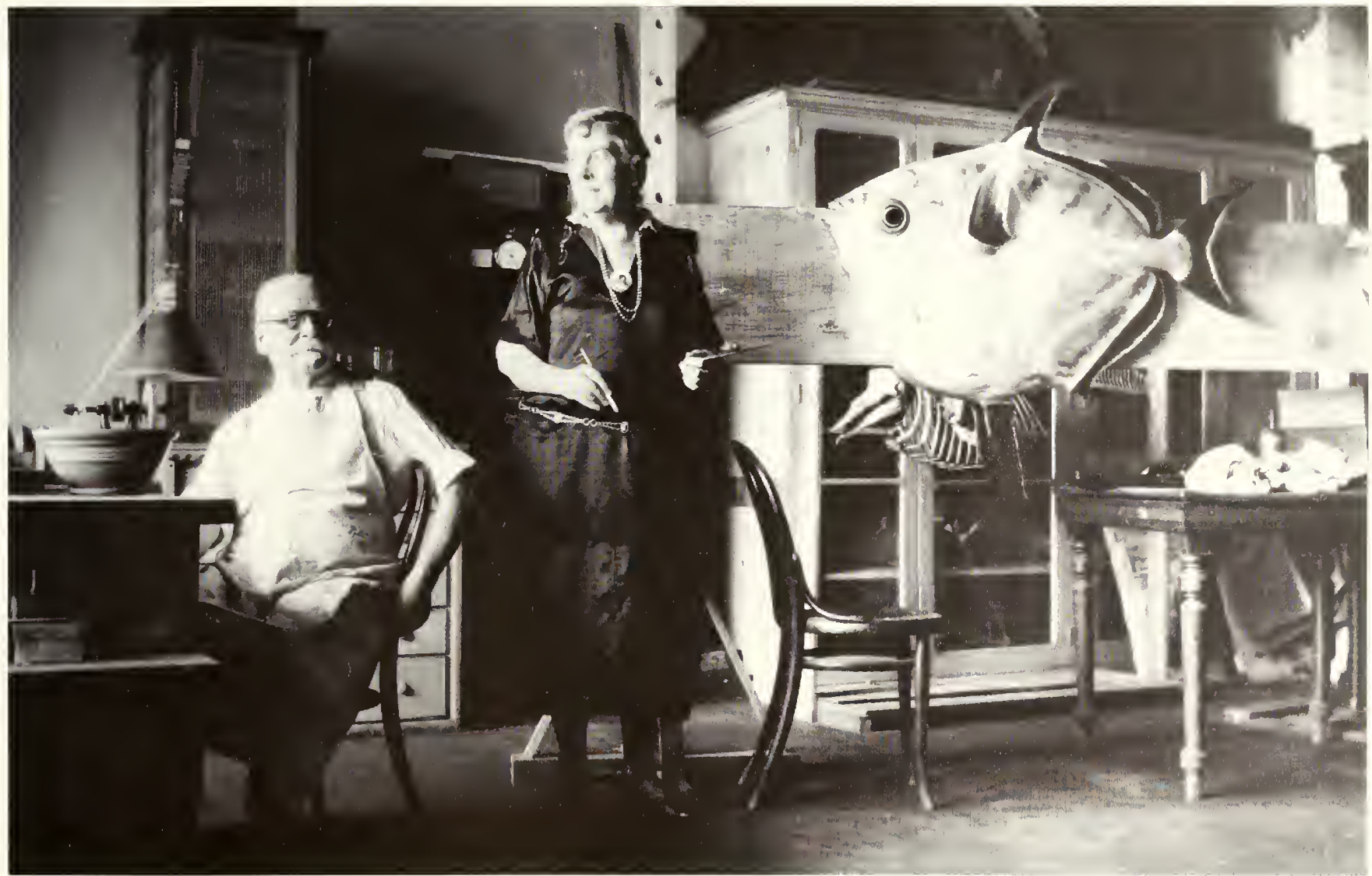

"W. E. Scollick and Doris Cochran's mother painting model of ocean sunfish, about 1928." There were two models made of Lampris; both were taken off exhibit in the early 1950s, when the fish hall was closed. 


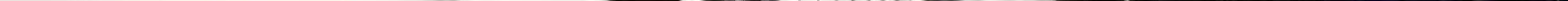




\section{Interregnum}

A FTER THE RECOVERY OF LOST SPACE, funding for the Museum was of first concern. Yet, Ravenel wrote, "the appropriations for the fiscal year ending June 30, I920, remained practically the same as for the past ten years-excepting those for heating and lighting and for furniture and fixtures, the former being increased to take care of the additional buildings, the latter being slightly reduced from the amount for several years just prior to the war-notwithstanding the fact that since the Natural History Building was constructed about ten years ago approximately three million species have been added to the collections. This alone ... should warrant a large increase in the appropriation for preservation of collections, from which the entire staff of scientific, administrative, and executive branches of the service are paid, and a considerable increase in the item for furniture and fixtures." The budget item for "preservation of collections" was $\$ 300,000$ that year.

A year later the appropriation was $\$ 312,650$, but the extra sum went entirely to the newly opened Freer Gallery. The United States National Museum now had four buildings: Arts and Industries; the still-new Natural History building; the tin shed behind the Castle, dignified by the name of Aircraft Building; and the Freer Gallery. In I923, with appropriations still virtually unchanged, the Museum reported "difficulty in making both ends meet. . . . It is only by rigid economy and by the omission of many things that should be clone that the year ends without a deficit."2

Though the comtry, under President Harding, had returned to normality in a very large way, the Smithsonian and its buildings were not prospering. The

Stairwell on north side of east wing, April 1984. The transparencies on the window into the east comt ore between the first ond second floors. These are the lost remmants of the old Hall of Geology and Meteoritics, dating from a time when this storivay was open to visitors who went to the second floor to see llo brilding stomes, minerols, and gems. Except for the light fixture, this wrew comld hove beer taken ary time since 1920. fledgling Bureau of the Budget was now charged with conducting the government's business, and while people were waiting to see how it would operate, it did constitute an immediate barrier between agency heads and Congress. Secretary Walcott was a past master of friendly relations with senators and congressmen, and had enjoyed easy entry to the White House since the time of President Cleveland, but none of that was working for him now.

\section{Grim Times for the Smithsonian}

With access to Congress cut off and an unsympathetic administration in power, times were grim. The year 1925-26 "marks a crisis in the affairs of the Institution," Walcott reported. "For several years it has grown more and more difficult to stretch the income from its meager endowment sufficiently to cover the steadily increasing costs of even the limited amount of research which can be undertaken and the administration of the eight growing Government bureaus. The cost of publishing is more than twice that of 10 years ago, which has resulted in materially decreasing the output of Smithsonian publications. .. . The Institution has for several years been undermanned, and the ordinary running expenses are met only by the exercise of rigid economy." Everyone seemed to use the phrase "rigid economy."

As one way of raising funds, Walcott instituted the Smillusonian Screntific Series; the butk of this encyclopedic work was written by staff members in the National Museum. Eventually the series produced some income for the Institution, as did the books of paintings of North American wildflowers by Mrs. Walcott, but not enough to help substantially. Secretary Walcott then made a serious attempt to increase the Smithsonian endowment. Consultants were hired, and Dwight Morrow agreed to head the first nationwide fund-raising drive in the history of the Institution. On February 1 1, 1927, a major meeting was held in the Castle to start this search for endownent funding. Sadly, Walcott had died only two days before, and it was only because of his deathbed wish that the conference went on as planned. 
What with Walcott's death, Morrow's appointment as ambassador to Mexico, the stock market crash and the subsequent depression, the drive was a failure.

\section{The Passing of the First Generation}

The whole first generation of naturalists who were established names in the old National Museum now began to chie off. Frank H. Knowlton, an eminent paleobotanist, died in 1926. Only a few weeks after Walcott's death, the mollusk expert William Healy Dall died. George Merrill of Geology died in 1929; W. H. Holmes, the artist-anthropologist, retired in 1932 and died in 1933. In evaluating carcers, one historical issue is whether a person is noteworthy simply because he was an early worker in a given area; but there is no doubt that all these people were first-rank scientists.

There were a few staff members added in the 1920s. William F. Foshag had become an assistant curator of mineralogy and petrology in 1919, and the following year Doris M. Cochran came on as an aide in the Division of Reptiles and Batrachians (amphibians). Later, Herbert W. Kreiger and Henry B. Collins came to the Division of Ethnology. Still later, Thomas D. Stewart is listed as an aide in the Division of Physical Anthropology; as T. Dale Stewart, he later played an important role in the history of the building. In 1928 Remington Kellogg transterred from the Biological Survey to become an assistant curator of mammals, and at the close of the decade, Edward Henderson transferred from the Ceological Survey to the Division of Physical and Chemic al Geology.

Since the Bureau of the Budget had reclassified all positions within the Museum in 1924, salary standards, especially for scientists, were higher, which helped the Museum to attract and retain a full staff. The new Secretary was Charles Greetev Abbot, who had been director of the Smithsonian Astrophysical Observatory.

\section{Alexander Wetmore}

The most noteworthy staff addition of the 1920s was the ornithologist Alexander Wetmore. As a member of the Biological Survey since 1911, he knew the Museum well. In 1924 the director of the National Zoo, Ned Hollister, died unexpectedly. W'etmore was appointed by Walcott to succeed him, but held this position for only a few months. "In accordance with a plan to develop and coordinate the scientific work of the various branches of the Smithsonian Institution," read the Anmal Report, "provision was made... for an additional assistant secretary, and on April 1, 1925, Dr. Alexander Wetmore was appointed to this post with general supervision over the Museum interests of the Institution-the United States National Museum, the National Gatlery of Art, and the National Zoological Park." "Wetmore was listed that year as Assistant Secretary, but the following year his title reverted to the classic one, last held by Rathbun, of "Assistant Secretary, Smithsonian
Institution, in charge United States National Museum."

Wetmore asked for assistance, and John Graf was added to the Museum staff as his administrative aide, although his office was in the Arts and Industries Building. On the rare occasions when Wetmore made an unreasonable decision, the staff member concerned would take it up with Graf. Of course, almost always everyone did what Wetmore advised. "A tall man of quietly distinguished presence and great natural modesty, ${ }^{5}$ he did not demand respect, but he commanded it. After World War 1, jackets were not worn at the desk, but somehow everyone put on a jacket to visit the director's office.

\section{Departmental Rearrangements}

Some internal rearrangements had been made in the Museun's departments. In 1920 a Division of Echinoderms (starfish, for example) was formed so that Austin H. Clark could become curator. Clark, who had been socially and politically active in the Museum circle for years, had assumed that after Watcott's death he might be made director. But that never happened, and Clark remained in his ground-floor office writing huge monographs. An active worker, Clark was famed for keeping the messiest office in the building. He never filed away reprints or accession slips, but could always find what he needed. Long after Clark's official retirement, a younger colleague went to his office to complain about not being able to obtain a typewriter. According to legend, Clark dug into the pile of reprints on one of his tables and extracted a standard model typewriter that had been completely hidden from view. Judging from the dates on the reprints hiding it, the machine had been covered for ten years.

The year after Clark got his division, the Division of Mollusks was formed. Paul Bartsch had already been promoted to the rank of curator, and this separation occurred more at the request of other departmental members than for any other reason. Bartsch was a womanizer, yet he also taught a Sunday-school class and helped instruct Boy Scouts. He wrote a great deal on mollusk's, and supposedly one can trace his romances by the new species bearing the names of various ladies. While there may not be any truth to the story that he once chased a secretary onto a ledge, he did pull up the skirts of one secretary, who ran screaming to Wetmore. One day in 1953 when Bartsch, then in his 80s, was said to be coming in for the day, an illustrator who hoped to meet him was advised to keep her back to the wall and her hands on her skirt.

\section{Lapses in the Work Ethic}

Most people worked conscientiously, but of course there were lapses. Edward Henderson tells of the "hat trick" of Barton Bean in the Division of Fishes. On occasional mornings Bean would go to his office, turn on the lights and hang up his hat and coat, and then stroll uptown 


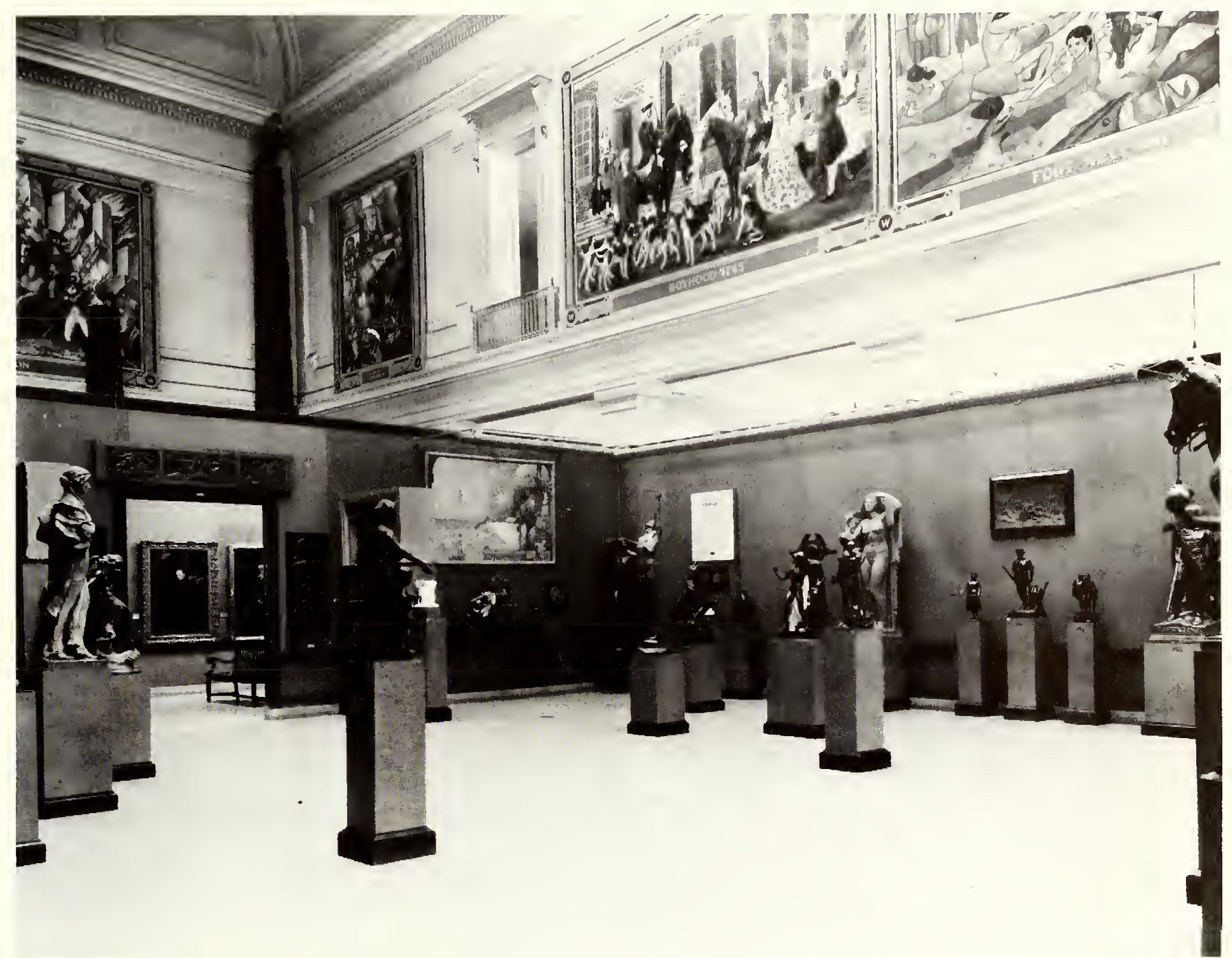

The National Gallery of Art during the George Washington Bicentennial in 1932. The large paintings on the walls were specially prepared by American artists, and a

to shoot a few games of pool, later returning to pick up his hat. Henderson also mentioned the technician in the ground-floor preparation room of the Department of Geology. He would come to the Museum each morning and telephone to Miss Moodey, the departmental secretary - everyone on the staff had to report in. Then he would turn on the large band saw used to cut meteorites and go off to the waterfront for hours. One day the band went off course and sawed into the steel table. The saw and the table with the two-inchdeep cut are still in use.

\section{The Staff and the Telephone}

The telephone office was at the northeast corner of the north range. The staff was allowed six private calls a month; all others were charged at a rate of three cents per call. Upon getting the operator, the first step was to state that this was an official call. The chief operator temporary exhibit of sculpture was installed. Below the picture of Fort Necessity is the statue by Daniel Chester French, The Minuteman.

had the habit of listening from time to time and then ringing the staff member after a call was completed, arguing that the business had been private, not official. One conversation was concluded by the outside party's saying that he had better hang up because the old bat might be listening in. The chief operator immediately rang the curator's office, incensed at being called an old bat by someone outside the Museum.

Although later telephone operators did not so obviously listen in, for years all long-distance calls had to be placed through an operator; it took a bit of effort to reach the point where the curators could place longdistance calls directly without first notifying the departmental secretary. Not until 1963, when a more elaborate telephone system was installed in the new Museum of History and Technology, did the staff have access to direct dialing throughout the country. Not until 1980 were push-button telephones installed. 


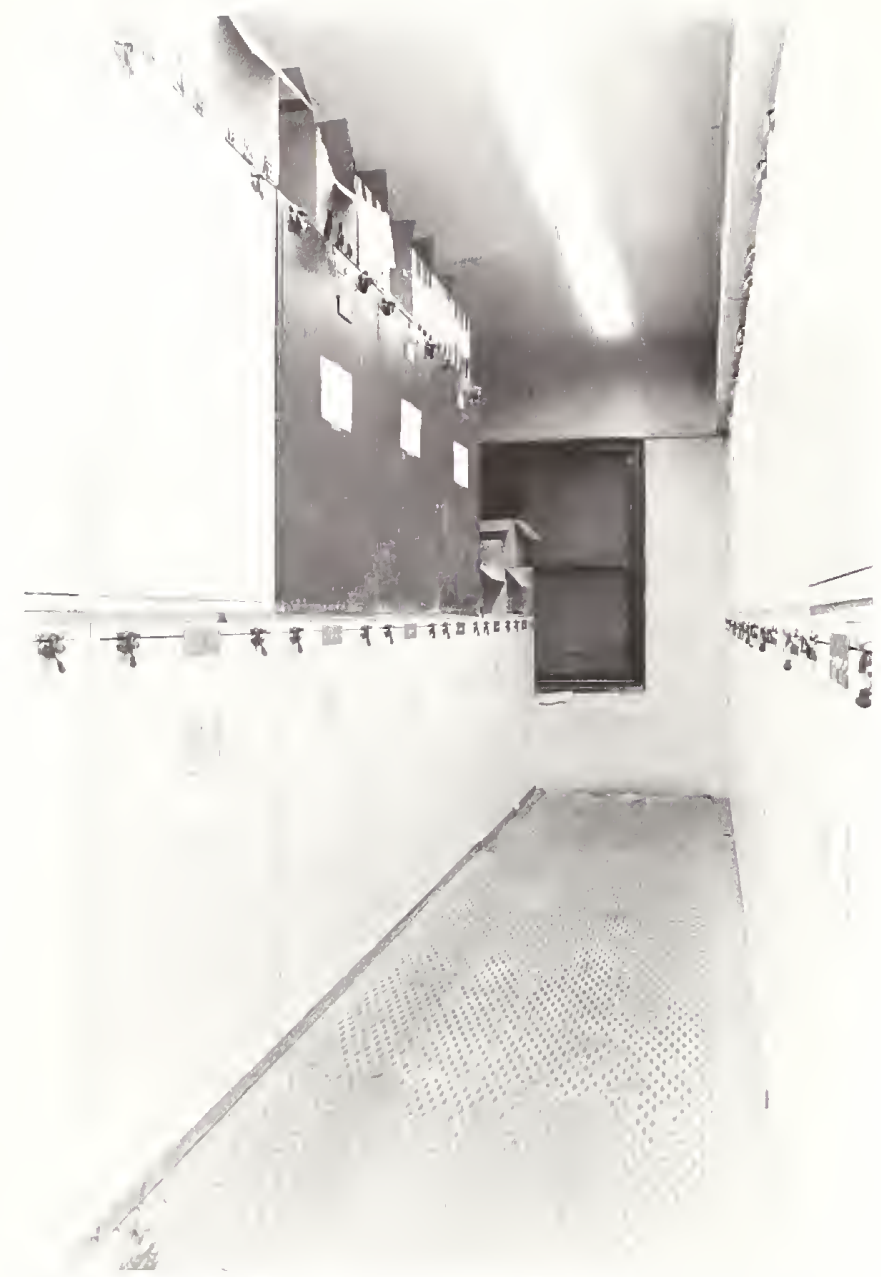

East range ground floor, April 1984, showing the steet decking and windows that ofen onto the corvidor but are plastered-ozer on the exterior. From the 1930, to the 1960, revtebrate fossils were stored here. The cases, cozered to ke'p ond dust, nowe contain inzertelorate fossits: the fluorescent lights are moderately new. The Scanning Electron Microseope Laboratory is directly beloa'.

Karl Krombein recalls that the library for entomology, which was along the west north range, also housed the secretary for the Department of Agriculture entomologists. The only USD A telephone in the building was in that office, and whenever a telephone call came in, the individual of fice would have to be buzzed through an elaborate code of short and long noises. The person buzzed would then run to the telephone, and as some of the offices were 300 feet away, this did not make for efficient communication.

\section{Musical Chairs}

Herbert Friedmann was listed as curator of birds in the Anmual Report for fiscal year I930; in the following report, G. Arthur Cooper was listed as assistant curator in the Division of Stratigraphic Paleontology. But these were not increases in the staff, for Friedmann replaced the deceased Robert Ridgeway, and R.S. Bassler had moved up to head curator of geology after Merrill's death, leaving a vacancy. Charles Resser handled the Cambrian fossil collections and Cooper was to look after everything else. In I934, Edward A. Chapin transferred from the Biological Survey of the Department of Agriculture to replace the deceased J. M. Aldrich in the Division of Insects. In number, if not in position, the staff was nearly static until the I940s.

T. Dale Stewart described the situation as a "game of musical chairs that goes on all the time in the Smithsonian." He turned to an especially sticky chapter on the history of this department:

Dr. Walter Hough, a long-time head curator of anthropo:sgy, had died ... in September, 1935.

Normally, he would have been succeeded by one of the three curators under him. In order of seniority, this would have been either Aleš Hrdlička in physical anthropology, Neil Judd in archeology, or Herbert Kreiger in ethnology. As it happened, however, these three were not on speaking terms with one another. Faced with this situation, Alexander Wetmore ... reached down to the next level in the hierarchy and picked Frank Setzler, Judd's assistant curator, to be acting head curator....

It has long been my opinion that Setzler's advancement to the head curator's office was due kargely to the fact that he macke a special effort to ingratiate himself with his elders. . . No one else had the temerity to call Wetmore "Alec", [or] Hrdlička "Ales"; yet Setzler did and apparently they liked it. Indeed, the three anthropological curators liked it so much that they acquiesced in Setzler's advancement over them. ${ }^{6}$

There were personal problems in other departments, too. In Geology, an emotionally unbalanced aide once threw a rock and hit James Benn, a quiet man who curated the minerals. Head curator Bassler almost always said no to any request, but if it were pursued to the point of going to see Dr. Wetmore, Wetmore would usually say that the request seemed reasonable and Bassler would immediately agree. Biology, apart from Bartsch, was calmer, though there is the true story of Miss Rathbun's throwing a glass of water in the face of a technician who became hysterical when finally dismissed for poor performance. In the latest oral version of the scene, the diminutive Miss Rathbun dragged over a chair to stand on while she poured a pitcher of water on the hysteric.

\section{The Thirties}

In 1935 no one publicly expressed any interest in celebrating the first twenty-five years in the new building. Even if it was not one big happy family, however, the Museum of the 1930 s was a scientifically rewarding 


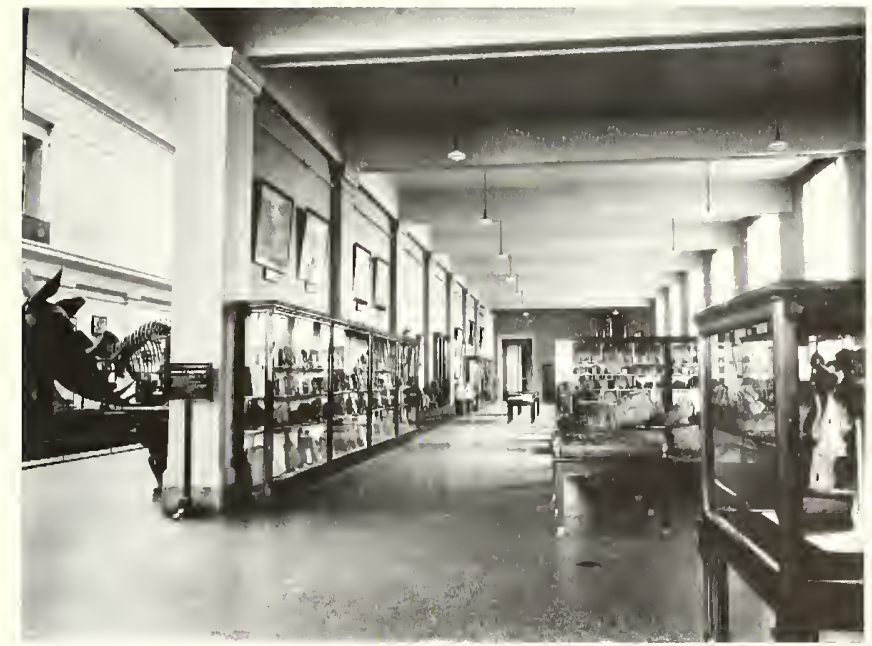

Later view of the Hall of Paleobotany on the first floor looking west to rotunda, 1930s. To the right is a fossil tree stump. To the left of Hall 5, in Hall 2, one can see the papier-mâché Stegosaurus made for the 1902 PanAmerican Exhibit in Buffalo, and the Triceratops skeleton to the right.

place. Most members of the scientific staff were turning out large tomes. In the exhibits field, the Museum installed, in 1931, the seventy-foot skeleton of the huge dinosaur Diplodocus longus, a fossil unearthed from the quarries at Dinosaur National Monument in Utah. Mounted so that visitors could walk under it between the shoulder and the hip, the skeleton reigned for twenty years as the Museum's single most impressive exhibit. The old A-frame cases, at Edward Henderson's suggestion, were partitioned so that people viewing a display from one side would not look into the faces of those on the other side. Henderson also introduced, in the 1930s, the first lighted case in the building, to illuminate the Star of Artaban sapphire. To make its alcove as dark as possible, he pushed the case so far back that the top of it could be glimpsed from the Dinosaur Hall below; for this Gilmore chided him.

Although money problems remained, space problems were partially resolved. Early in 1930 the naval collections that had filled the rotunda for ten years were moved to the Arts and Industries Building; over most of the year, the remainder of the War Collection followed piecemeal. That same year a steel-frame gallery, or mezzanine, was erected over rooms 18 to 20 on the ground floor, "increasing the storage facilities of the division of vertebrate paleontology by approximately 1,750 square feet of floor space." It is not clear what prompted this new construction, although there were attempts under President Hoover to use government construction as a way of promoting the economy.

Vacating "two large and finely lighted" second-floor exhibit halts that had been closed to the public since $1917,{ }^{8}$ the long-suffering mammalogists returned to the ground floor. There they too obtained additional

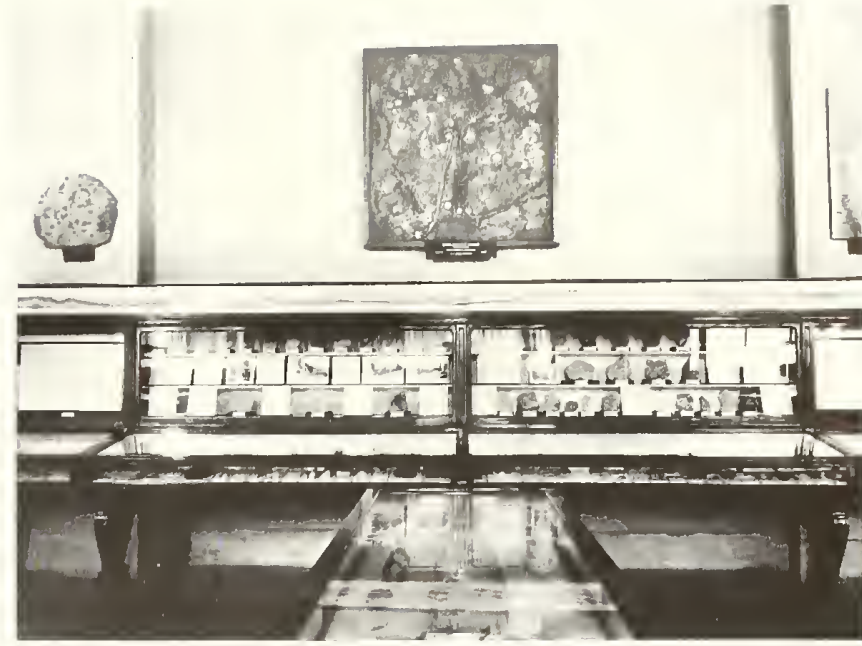

Stratigraphic section, Invertebrate Paleomtology. This was part of Panorama of Life on the north side of Hall t. which showed a cross-section of the United States, together with cases of fossils arranged by age. In the foreground is part of the biologic series of fossils.

space by decking: "The galleries in the two ranges propes will cover all the space between the exterior wall of the building and the partition walls enclosed the rooms in the two ranges; and, in addition, in rooms 51 to 53 and in the eastern half of room 57 . The western half of this latter room is already occupied by a steel gallery and steel shetves containing the alcoholic mammal collection." A synoptic display of marine invertebrates, partially installed on the ground-floor west north range, was abandoned in favor of the decking.

Today on the Constitution Avenue side of the building, in the windows of the west north range, one can see a horizontal line of steet l-beams. They ruin the appearance of the windows and certainly were not a feature that Rathbun would have approved. The upper deck consisted of loose steel plates that always rattled when someone walked on them, with the storage cases sitting directly on small cross-girders. There were plenty of gaps between the plates, just large enough for dropped pencits or books to fath through into the offices below. The yertical steel I-beam supports are in the halls, but they have been there for so long that even the oldest inhabitants of the buitding do not recall either the vertebrate paleontology or the mammal galleries' being installed. Unaesthetic as they may be-though made feasible by the aesthetic decision to raise the ground floor three feet in 1905-these decks were and are very useful. In addition, they were symbolic, a tangible indication that preoccupation was shifting from the exhibitions to research and reference collections.

\section{Crowding in Natural History}

The Museum staff was greatly relieved to see the War Collections disappear, but as usual there was a trade- 


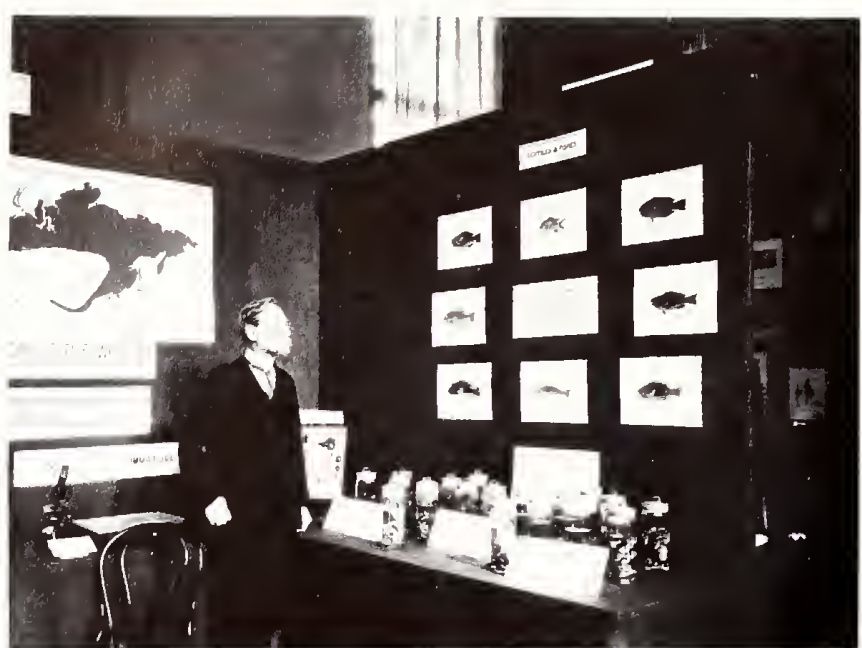

Leomhard Stejneger, head curator of zoology, standing by a special temporany exthibit in the Castle. The illustrations to the right, by a Japanese artist, were prepared before 1909, but never published; the fauna is cumently under study by Vittor C. Springer of the Dizision of Fishes. This display was prepared for the February 1927 endowment drive.

off to the disadvantage of natural history. Half of Hall 26 on the second floor became the site of a lace exhibit brought over from Arts and Industries. At first the Constitution Avenue side of the hall was used for lace and the south side for biology; it took nearly a decade to improve this to the point that the area nearest the elevators was devoted to lace and the western part to natural history: Case after dreary case of lace, Malcolm Watt kins, recalls, gave way at the dividing line to displays of chickens on one side and wasps on the other. The wasp case was strewn with crumpled newspaper in an attempt to communicate the idea that a newspaper and the material forming the nest of a paper wasp were fundamentally the same. Each year the nest got darker from dust and the newspaper got yellower. Within a few more years, several exhibit alcoves on the west side were converted into of fice space for entomologists. Not all the space that had been open in 1917 was ever recovered for public displays.

Even if the lace were ignored, the Natural History Building was still a long way from being fully devoted to natural history. In 1932, to commemorate the 200th anniversity of George Washington's birth-a major event in the Capital-"a special exhibition ... under the auspices of the National Sculpture Society, was installed in the National Gallery of Art, with extension into the rotunda of the Natural History Building. The rotunda will be kept free of ordinary exhibits that it may serve its proper purpose as an impressive entrance into the building. The greater part of the foyer was alloted for a temporary exhibit of the National Capital Park and Planning Commission dealing with the development and future plans for the city of Washington."10

At the close of the bicentennial year the foyer exhibit was removed, as were the twin stone lions that had temporarily graced the pedestals at either side of the south steps. But the rotunda received some "largesse" in the form of several of the plaster figures from the show. Having been presented to the National Gallery of Art, they remained in place, whether the Museum's curators liked it or not.

\section{The Great Depression}

By 1933 America was in the Roosevelt years and the Great Depression. This was a grim time, but for Washington civil servants, not so grim as elsewhere. Most Museum staff members were given a month's unsalaried furlough, but at least they had jobs to return to. Watson Perrygo, the taxidermist, like many others, continued to come in and work on the collections; eventually, the Smithsonian scraped up the money for back pay.

As times got worse, the Museum became the site of various emergency relief work projects instituted by the New Deal. A short-lived Civil Works Administration placed temporary help in the building between December I 5, 1933, and February 20, 1934. In all, 208 people shelved books, typed lists, wrote labels, and repaired equipment. "As our staff has been for a long time undermanned," Wetmore wrote in the Annual Report, "the C.W.A. work came at an opportune time, and not only provided employment but aided inaterially in placing our records and collections in proper condition for preservation and study. The assistance, though occupying much of the regular staff in supervision, was entirely worth while and much appreciated."

When the CWA project ended, in February 1934, the Museum applied to the District of Columbia government for similar assistance under the Federal Emergency Relief Administration (FERA). In November "33 women, and 43 men were so assigned. Supplies and materials required were purchased from the regular appropriations. As before, the work was concerned largely with ... the handling of the national collections and was limited to preserving specimens, book and records, and increasing their usefulness for study and scientific research." 12

\section{WPA Project}

This project closed one year later, but in May 1936 a WPA (Works Progress Administration) project to succeed it was initiated through the District of Columbia government. For that fiscal year, about 18,000 manhours of work was under FERA and about 6,500 under WPA. The Federal Art Project also allowed a bit of help for the art collections. In fiscal year 1937, temporary help increased to eighty-eight people, although some worked only briefly. By the close of the next fiscal year, 


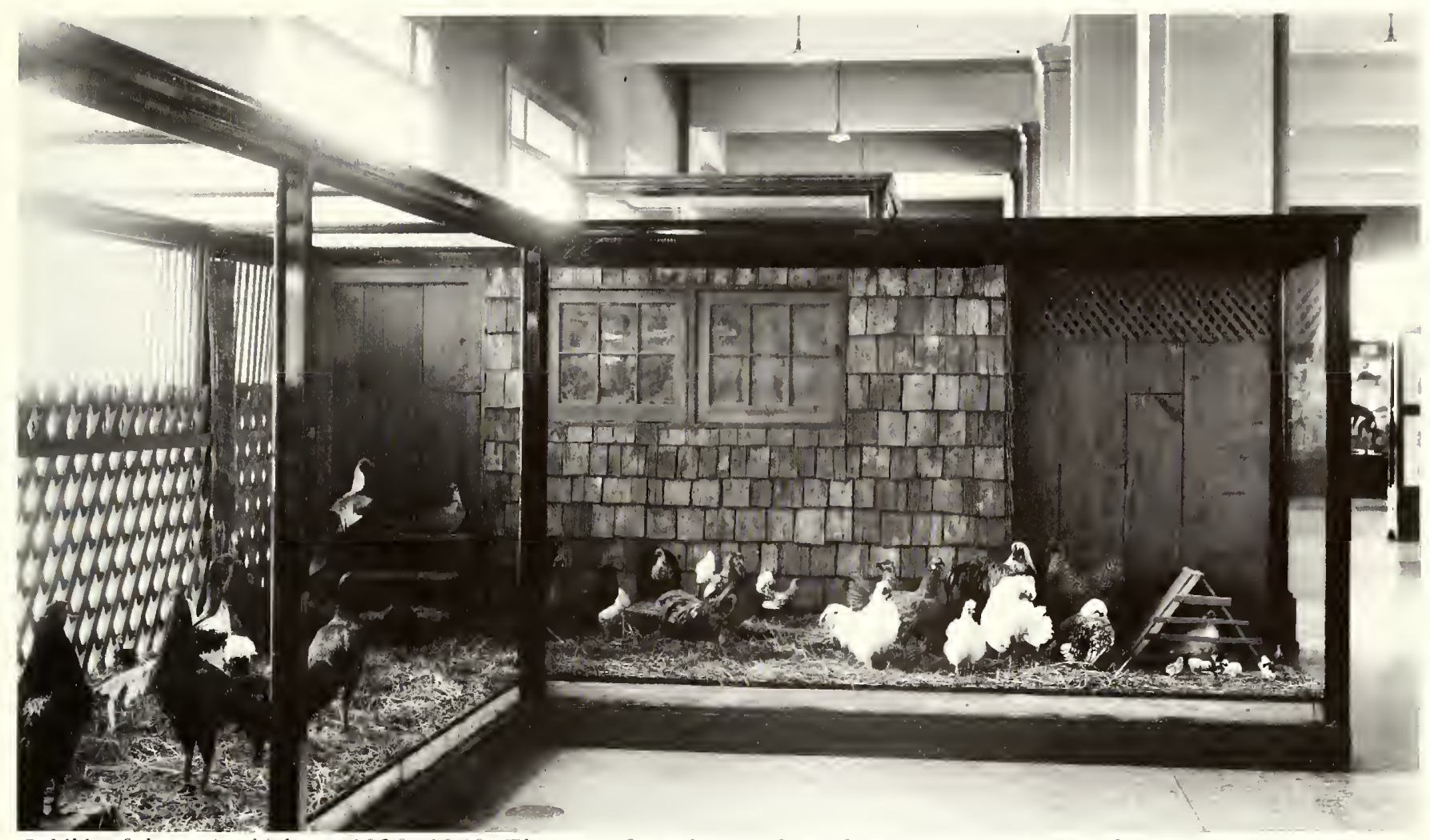

Exhibit of domestic chickens, 1920-1940. The case of monkeys to the right suggests Hall 13 in the west wing, a display area that was divided between birds and mammals. This is currently the bird hall.

167 temporary WPA employees were in the building. "The project proceeded smoothly, not only as a result of the efficient organization but also because many of the workers had gained experience from the previous year." 13

There continued to be fluctuations in numbers, and a gradual decrease the next year. In 1940 WPA help) ended, and was eulogized in the Annual Report: "The termination of this project on April 15 was felt in all departments of the Museum. Aside from the care given in arranging the study collections and conducting numerous other tasks related to the preservation of the material, the cataloguing and numbering of specimens were of direct aid to research, for the material thus handled became readily available for study by our own staff and other technical workers. The departure of these assistants brings loss to the Museum.... Their accomplishments were of permanent value, and it is hoped that their service at the Museum was of equal value to them in making them better fitted to take their places in the outside world." 14

There is no doubt that the use of temporary help was a mixed blessing. Some of the collections benefited from the extra attention; a card catalogue prepared for the meteorite collection and a picture file of decapod crustaceans are still in use. But Henry Collins remembered a terrible muddle made by an unemployed dressmaker who renumbered collections. T. Dale Stewart noted that the WPA employees could put a number on a bone when instructed, but then could do nothing more with it. Waldo Wedel recalled a drunken draftsman whose table was covered with newspaper; an inked line began along a straightedge and then angled off to follow a line between the columns of newsprint. Still, he remembered another WPA employee as the best typist he ever encountered. At best, keeping unskilled help occupied was a drain on the staff.

Late in the WPA period, before the free help ran out, the National Collection of Fine Arts made some renovations, replacing tons of weak plaster, painting, and covering the walls with a light-colored monk's cloth. Otherwise, little of this extra help was directed toward the exhibits. Coal clust was everywhere, and because the building shook slightly from the machinery on the ground floor under the geology halls, the dust moved off the specimens in the cases and accumulated in elongate windrows. The usual method of dealing with this was to open the top of the case and blow.

Just before the Second World War, the elevators in the lobby and the rotunda were replaced; after thirty years, it was high time. These were about the only major expenditures having anything to do with exhibitions. For two decades, work at the Museum had looked inward toward research and toward increase and maintenance of collections, not outward toward the general public. 


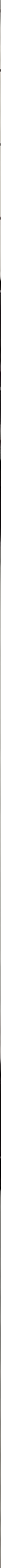




\section{World War II}

W ORLD WAR II WAS QUITE a different affair from World War I. The Great War had been a shock to most people, destroying what had been half a century of peace and tranquility. The second war was anticipated by many, and America's involvement was longer and deeper. To the National Museum community, the second had two distinctive effects. It caused fundamental modifications in the relationship of science to government. And on the practical side, there was real concern about destruction in Washington-a point never seriously considered in I9 I7, but one that had worried the Museum staff even before the bombing of Pearl Harbor on December 7, 1941.

"For the past year attention has been given to the designation of categories of specimens that were to be evacuated from Washington in case of entry into the War or should air raids come to Washington," read the $194 \mathrm{I}-42$ report. "The work of selecting and packing this material has occupied the staff for months, and part still remains to be accomplished. In some of the collections type series have been maintained separately for some time, while in others types were kept with other material so that it was necessary to segregate them, with many thousands of specimens concerned. . . Type specimens preserved in alcohol, which offer some difficulties in handling, were evacuated together with selections of insects. Other type material will go to a warehouse in another location." (A type specimen is the standard to which other organisms are referred to see if they are the same species.)

\section{Safeguarding Type Specimens}

Karl Krombein, newly on the staff of the Department of Agriculture, was given the task of separating insect types from the general collection in his charge. Looking back on it forty years later, he judged it to have been a worthwhile effort, for the separate type collections received more care and attention. Any nuseum curator worth his salt will be extremely protective of the types;

Triceratops in the early Dinosaur Hall, with

Stegosaurus behind. from a scientific standpoint, they are by far the most valuable part of any collection.

Little is said in the annual reports about this evacuation of material, and the few participants still on the staff do not dwell on it. Specimens were taken to Luray, Virginia, where they remained for three years. "It is with considerable relief that we were able during the year [1944] to bring back to Washington the thousands of valuable type specimens and other irreplaceable objects that early in the war had been removed from the Capital for safekeeping. . . Return of this material, which aggregated more than 60 tons, was completed in November, 1944, and by the end of that year most of the specimens had been reinstalled."2

The Museum had only a single great auk, so it was taken off exhibition, wrapped in paper, and sent away. The help was inexperienced and neglected to put moth balls in the package. As a result, many of the feathers were eaten and dropped off. Watson Perrygo ghued them back on one at a time. Eventually, the specimen was restored, but it looked so back until all the feathers were replaced that Wetmore told Perrygo to keep a cover over it at all times so that no one else would see it.

Unwrapping and returning the types to the collections was far worse than packing them. Inevitably some specimens were lost, and the packing and unpacking disrupted research for years. Like the similarly disruptive conversion of the building to office space during World War I, evacuation of the types was a unique event. Should a global conflict come again, with the Museum at ground zero in Washington, evacuating types and rare specimens would be futile.

Pearl Harbor spurred planning for the protection of the works of art in the National Collection of Fine Arts. A portion of the wall behind the mural Diana of the Tides was fortified to resist bomb fragments. Plans were made for the evacuation of some paintings, and others, including miniatures and part of the Gellatly collection, were assigned to the ground-floor lobby, which was considered safe from incendiary bombs.

An important safety measure was "the removal of 


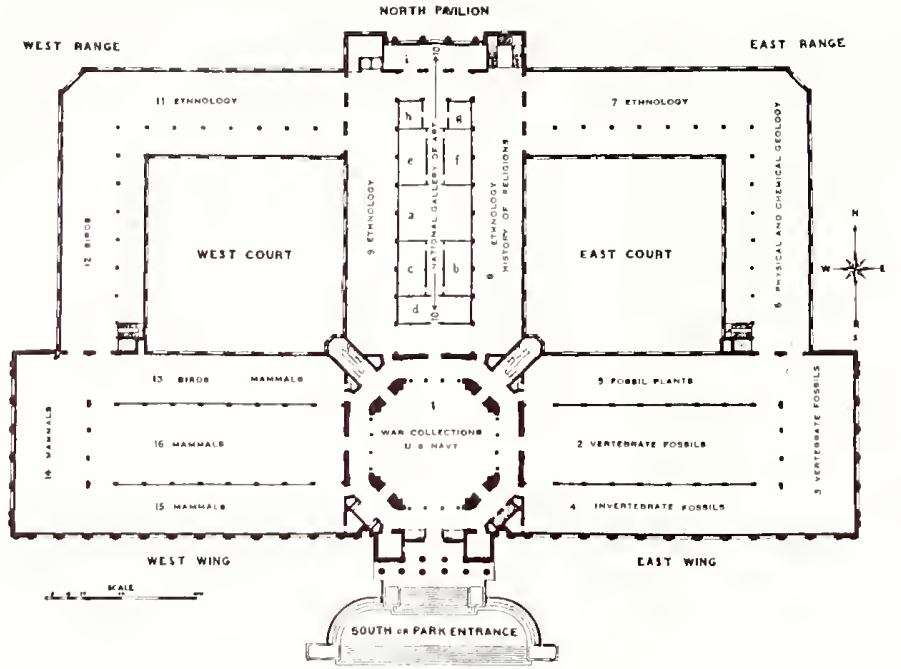

Plan of exhibits on the first floor as anticipated in 1919 , but not realized until the 1930s. From a 1919 brochnre containing ten pages of text describing the exhibits, plus floor plans.

many tons of heary storage racks containing geological and paleontological specimens from the fourth floom to the ground and second thoors of the Natural History Building. Also, storage cases and many specimens were taken from other sections of the fourth floor to the second floor 10 such an extent that allows free movement throughout the upper floor of the building in case of fire from incendiary bombs, the floor in question being directly under the roof; various items of inflammable material were eliminated."3

\section{Building-Stone Exhibit Closed}

Charged with securing storage space for these hefty collections, a committee recommended that the building-stone exhibit on the second floor be "reduced in size and that specimens that had outlived their usefulness be made avalable to other Govermment bureaus. As a result, a considerable portion of such material was accepted by the National Bureau of Standards for use in testing the weathering conditions of various types of building material. The space thus obtained made room for a portion of the rock series and all the Paleozoic invertebrate fossil collections. Then, the paleobotanical collections formerly occupying the northern half of the fourth floor were removed as a unit into iwo rows of cases 9 feet high lining both sides of the northeast basement hallway."

Hall 20, G. P. Merrill's old "Building Stone Hall," actually had been under scrutiny for years, with some nembers of the Geology Department wanting it closed. Not many visitors came to the Museum in the 1930s, and very few of them went in to see the slabs and cubes of stone, Merrill's pride and joy. Part of the exhibit consisted of a series of bottles from various mineral

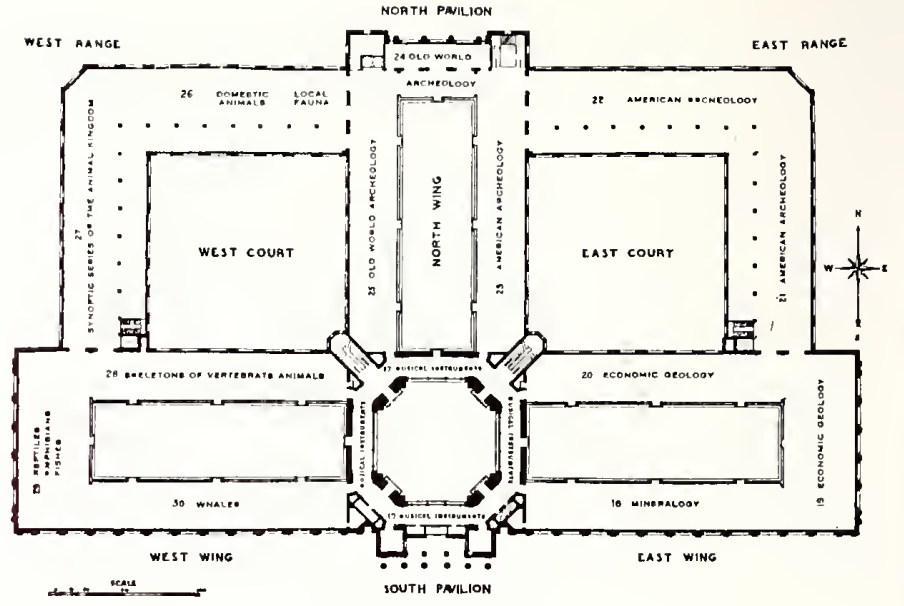

Plan of exhibits on the second floor as anticipated in 1919 but never realized, because of the moving-in of the lace collection in the west north range and the gradual encroachment of offices in the west range.

springs, but since the water had evaporated from some of them, they had to be refilled from the tap. Edward Henderson finally persuaded a friend at the National Bureau of Standards that the Bureau might build a wall of the various stones. Bassler as usual was against the idea until Wetmore approved.

The paleobotanical collections were placed in the east north range corridor outside the library, an area designated as an air-raid shelter. Yet the drawers of very heavy specimens, piled up nine feet high, would have been killers had they ever been tumbled by bomb blast. In later years, just climbing up to look into them was a lazard.

\section{Civil Defense Measures}

Frank Setzler, head curator of Anthropology, was in charge of air-raid precautions for the Mall buildings. Practice air-raid and blackout drills were described in the report for 1943: "Twice during the year our airraid defense organization, consisting of approximately 212 employees, was given instruction in the use of fire hoses, chemical fire extinguishers and the portable fire pumps. Numerous incidents were prescribed during the daytime air-raid drills which provided practice for the stretcher and first-aid squads."

For a number of years, wooden boxes filled with sand were scattered throughout the attics. Gradually the shovels and buckets disappeared and in the 1960s the sand boxes were discarded, except for some near locked doorways, to be used in case of fire. The measures that might have mitigated destruction by incendiary bombs would not have much impact in a nuclear age.

As might be expected, Museum attendance declined at the start of the war. Attendance was so low in early 
Looking south at the Feathered Serpent column and model of the Castillo at Chichen Itzá in the Hall of Archeology of Mexico, Central and South America

(Hall 23). The columns were moved about 1924, but were not originally placed in this hall; the light globes suggest a post-1930 date.

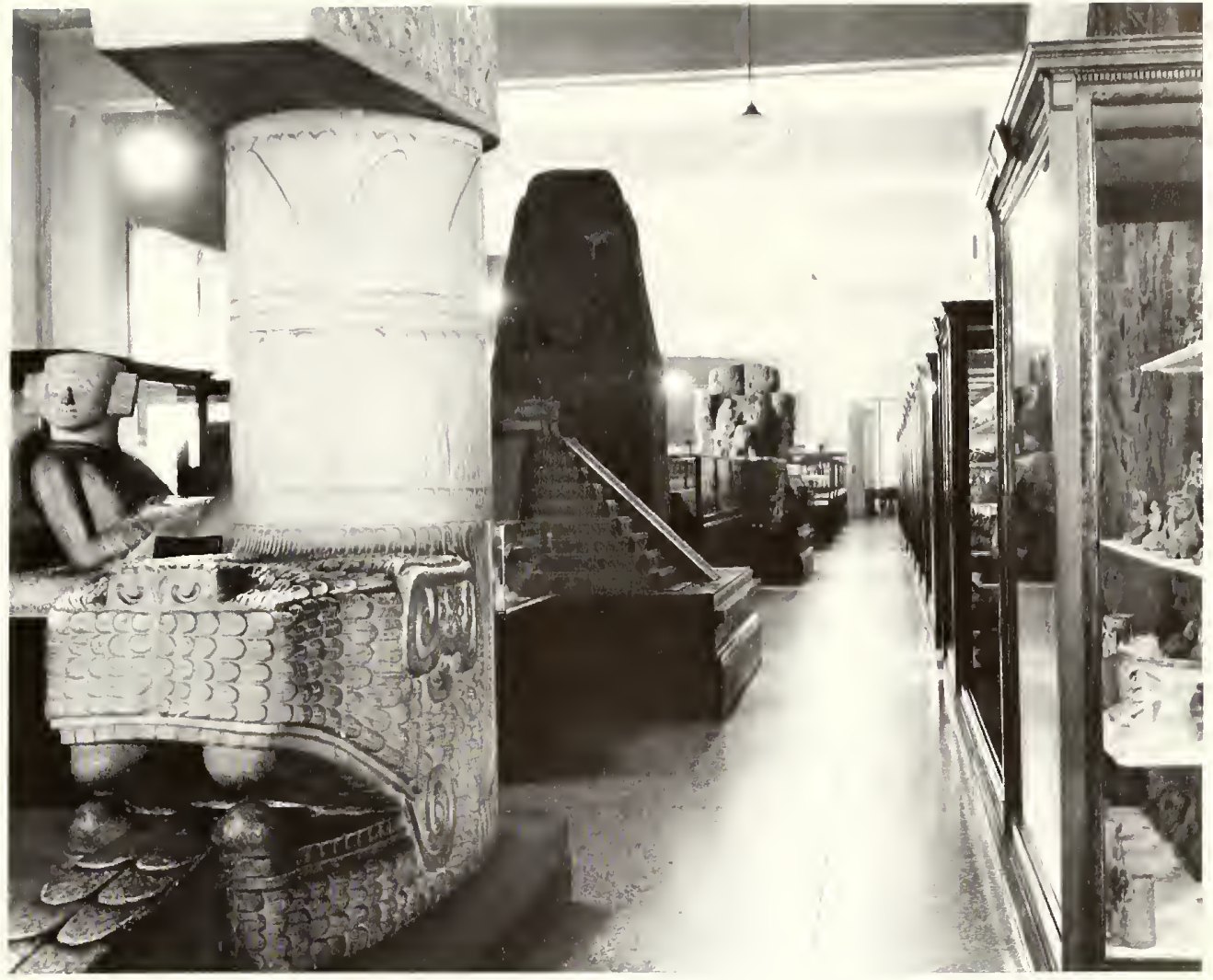

1942 that Perrygo used to visit the guards at the doors to ask how many visitors were trickling in. After a year attendance rose again. The Museum was open six and one-half days a week; when the half day was shifted to Monday, many people came on Sundays from 9:00 A.M. to $4: 30$ P.M. From late 1942 until mid-1943, 25 to 35 percent of the visitors were servicemen, and efforts were made to accommodate them. "In the Natural History Building a program of Sunday docent service for guiding parties through the Museum, was inaugurated. A number of women U.S.O. volunteers were especially trained to act as guides, and the "tours' conducted by them proved very popular. During the period covering the last 35 Sundays of the fiscal year [1944], over 5,000 members of the military personnel took advantage of this guide service."

\section{Wartime Service}

The scientists were by no means immune from wartime service. In the Department of Anthropology alone, 25 percent of the staff left. J. F. Gates Clarke, an entomologist then with the Department of Agriculture, held a reserve commission and was gone by February 1942. Karl Krombein, who later transferred from Agriculture to Museum, stayed in the Air Force Reserve even after the war and retired as a full colonel. T. Dale Stewart taught human anatomy in a medical college in Missouri. Others, like new assistant curator of birds S. Dillon Ripley, joined the Office of Strategic Services. The State Department recognized that it was important to strengthen ties with Latin America, and Waldo Schmitt was one of the first ambassadors of good will to be dispatched. "Uncle Waldo" returned successful-characteristically, bearing large collections of invertebrates.

The Museum's real effort was not in entertaining visitors or protecting specimens, but in providing information. For the first time the nation was heavily involved in Asia and the Pacific. Not many people had knowledge of the area, but a few staff members had collected specimens in these regions or knew them from the literature. The staff and the library were overwhelmed with requests for data on such topics as "camouflage plants; natural vegetation of specific regions ...; the use of land, fresh-water and marine animals for food, the palatability of the flesh thereof, and methods of capture; the serviceability of hides and skins for various purposes; disease transmission; ... marine fouling organisms, bibliographic surveys; recommendations regarding personnel."7 The list was more than half a page long, and there must be a story behind each of the requests for information.

The Museum staff was called upon for a great deal of on-the-spot instruction, some having to do with dangerous animals. "Assistance was given the Army Medical School and the National Naval Medical Center, as well as various Army and Navy training centers throughout the country, by supplying well-preserved material of insects and Acarina [mites and ticks] that are involved in human health probtems. About 1,200 specimens were specially mounted on pins, and ap- 


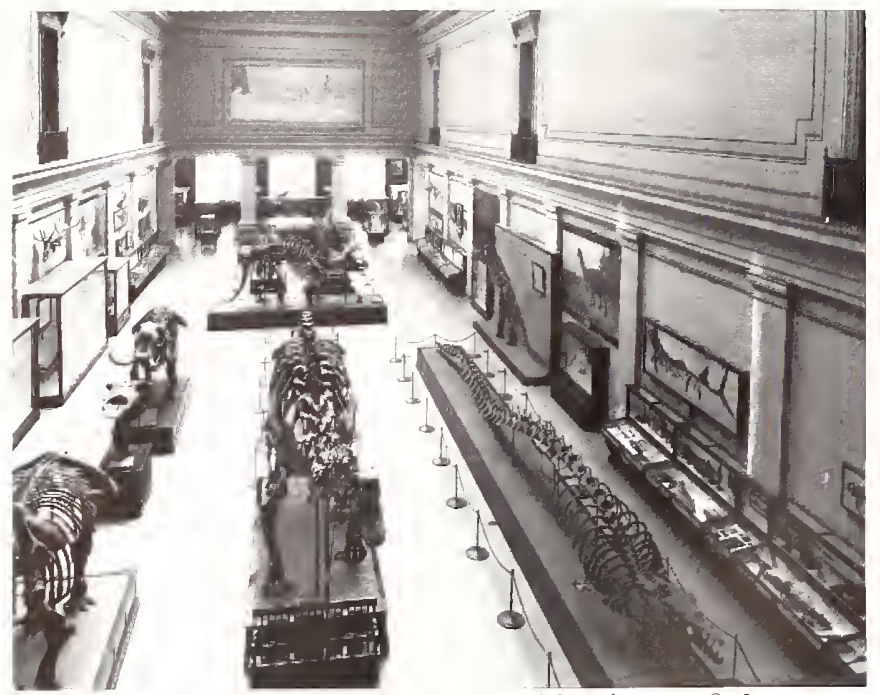

Hall of Extmet Monsters (Hall 2) with Diana of the Tides on the wall in the distance and ome of the few beuches in the building in the foreground. Taken after 1932 from the second-floor rotunda, looking rast. The Zeuglodon has been displaced frome center stage by the Diplodocus. Triceratops is behind Diplodocus, and behind it are both the sketeton and papier-mâché Stegosianiss.

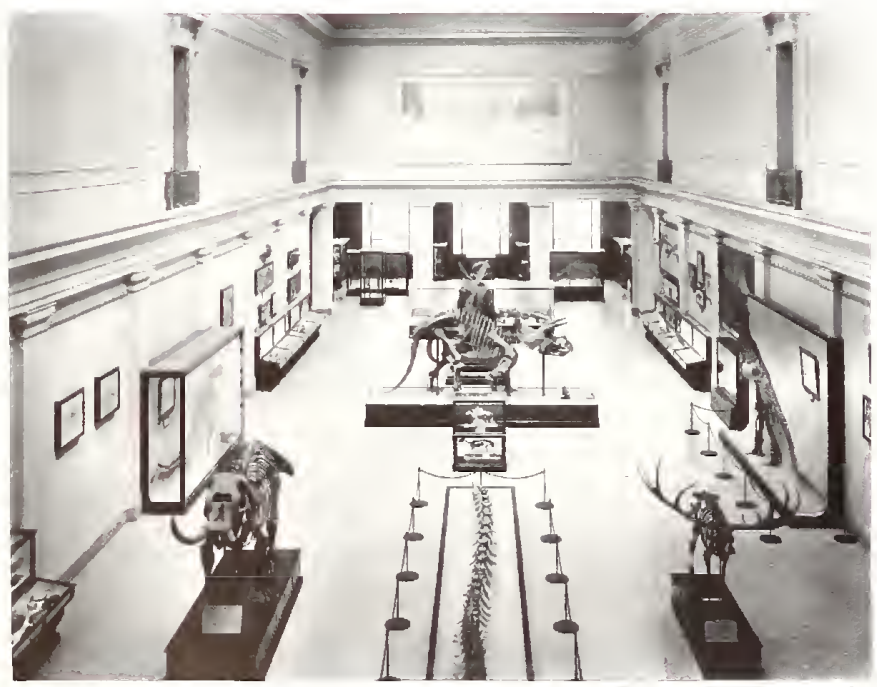

An early view of the Dinosan Hall with Triceratops and skeletoms of the toothed whale (foreground), flanked by a mastodon and Irish Elk. Date unknown, but before 1930 and probably before World War I, judging from the paucity of material in the hall. proximately 450 slide mounts were made for such training centers. During the year [1943] nearly 200 Army and Navy officers who were being assigned to malaria survey or control units, or to other activities concerned with human-health problems, have received some instruction or other help from personnel of this division." "

During the early days of the war, groups of six or eight servicemen would appear at the north door, having been given oral orders to report to the Museum, but no specifics. The guards would call Perrygo, who would take the men in hand and provide instruction on how to collect fleas and parasites from small mammals. They would go out in the field, set traps, and catch mice; the bodies were put in bags while still warmbefore the fleas hopped off. After a week or so of this, the official papers would arrive ordering the men to learn how to collect fleas. Some of these trainees went on to become professional biologists after the war.

\section{Survival Booklet}

An absolutely basic booklet in the war was the Navy's Survival on Land and Sea, to which every department of the Museum contributed data. The Smithsonian's War Background Studies was a major accomplishment, the first volume being published six months after the war began. For the first time, large numbers of American armed forces were in places where the general concepts of western civilization and culture did not apply. How much these studies helped smooth cultural shock on both sides can never be evaluated, but there is no doubt that they were important.

"Though it cannot be told here or now," Wetmore wrote in 1943, "the story of the Museum's participation in this war is one in which we can all take pride." the story has never been given in any detail, and those who participated are mostly gone, like Julia Gardner of the Geological Survey, who determined the launching site of a captured Japanese fire balloon by studying the microfossils in a bag of its sand ballast. Rumor has it that the migration routes of Pacific snapping shrimp were plotted so that American submarines could nestle up to them when threatened, for the sounds of these crustaceans confused the sonar on Japanese ships.

\section{A Sad Year for the Museum}

The year 1943 was not a happy one at the Museum. Miss Rathbun died, ending half a century of study of crabs. And "with the death of Dr. Leonhard Stejneger on February 28, the Department and the Museum suffered an irreparable loss. He had been head curator of the department of biology for the past 32 years. As man and as scientist, he was noted for his breadth of knowledge, depth of understanding, and, above all, for his clear thinking." ${ }^{10}$ Because Stejneger had held a presidential appointment, he was immune from Civil Service regulations and was still an employee at the age of 
Mammal groups in the central hall of the west wing (Hall 16) in the later 1930 s or 1940s. The Wapiti (Cervus) are still on exhibit; the glass eyes, painted with oil paint on the interior, are becoming opaque with age as the paint pulls away from the glass. Behind the Wapiti is the buffalo group assembled by William Hornaday. To the right, seen through the glass of the case, are the mountain goats (Oreamnos). Because one of them is lying down, this may not be the same group as is currently displayed.

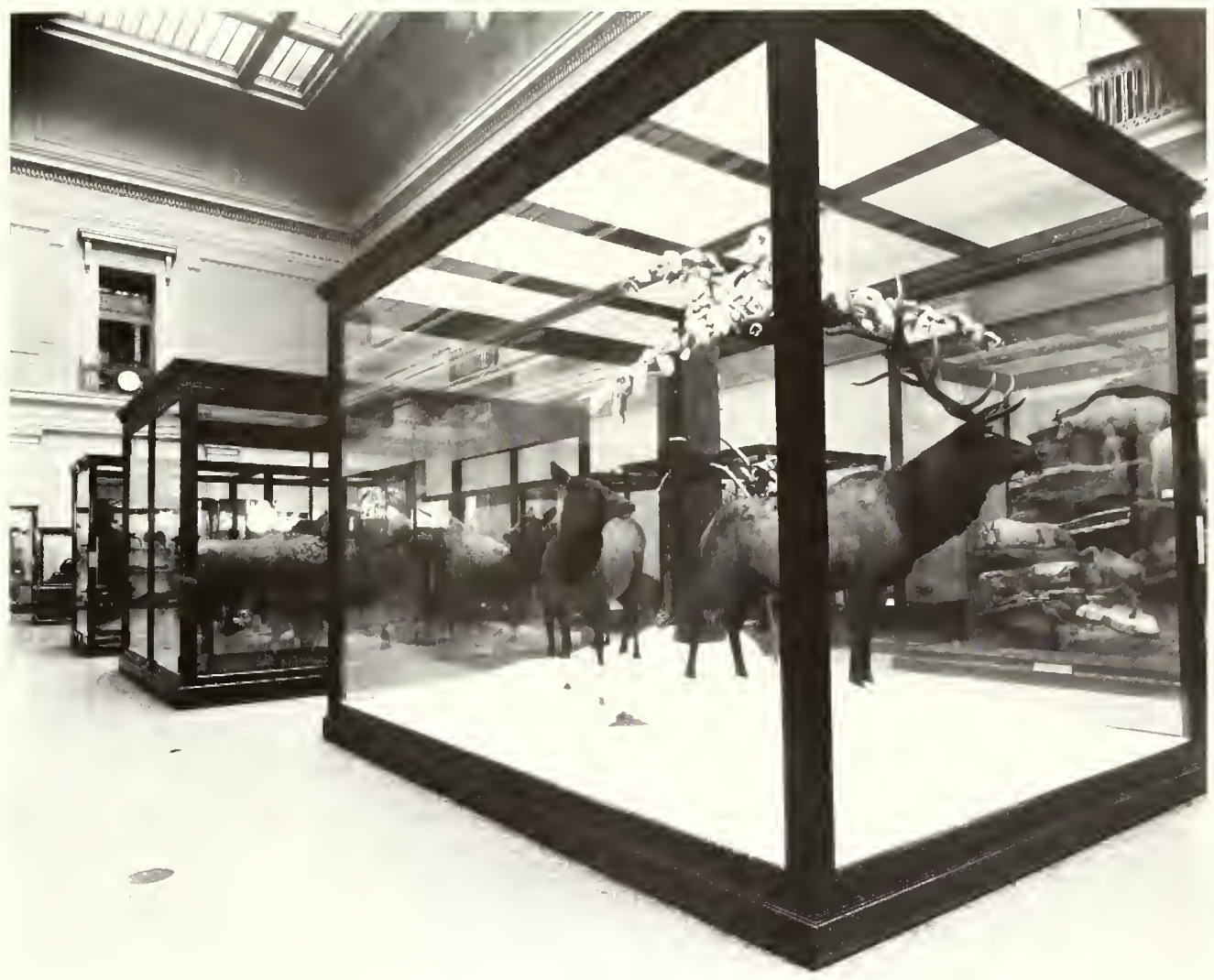

ninety-two. When he was in his eighties his doctor forbade him to do any more waltzing, as he became too dizzy. Had he not been injured by a car when crossing Constitution Avenue, he might have worked another decade. Waldo Schmitt took over as head curator of biology. Although a few old-timers continued to work during the late 1940s and the 1950s, the war essentially marked the end of the old-time naturalists who had joined the staff in the brick National Museum.

\section{Wetmore Succeeds Abbot}

In 1944 Charles Greeley Abbot finally retired after sixteen years as Secretary of the Smithsonian Institution. After six months under the formal title of Acting Secretary, Alexander Wetmore was appointed in 1945 as sixth Secretary of the Institution, making official what he had been for years as Assistant Secretary. For the next four years he continued to serve as director of the National Museum, and the Annual Report by the director was formally submitted by "A. Wetmore" to "The Secretary." After 1947, when items concerning the staff, the buildings, and a few other matters were transferred for economy's sake from the Museum report to the full annual report of the Secretary of the Institution, many details that harl cast light on day-today events were no longer recorded.

Just as the Anmual Report of the Museum never explicitly noted the beginning of World War II, it did not record the end of the conflict. In the latter part of 1944 times continued to be difficult, but by early 1945 victory was in the air, and by late summer the traumatic event was over. The staff finally could think of research unconnected with military work and devote some time to more basic activities.

Nineteen forty-six marked the 100th anniversary of the founding of the Smithsonian Institution. The Postal Service issued a commemorative stamp, and considering that the war had been over for less than a year, the Musemm's anniversary celebrations were not a bad effort. They included a special exhibition in the foyer from July 1 to September 27, 1946; a scholarly lecture by Matthew Stirling of the Bureau of American Ethnology on his excavations in Mexico; and, on October 23 , an evening ceremony followed by a reception in the rotunda attended by 1,021 guests. Lucile St. Hoyme, a physical anthropologist who was there, remembers that the Marine Band Orchestra played from the second floor around the rotunda. Wetmore surprised everyone by dropping his modesty and leading the dancing.

One thing that was lacking in the Smithsonian's centennial year was time to prepare a detailed written record considering what the Institution, and the Museum, had accomplished in one century, and what they hoped to accomplish in the next. Additional publicity would have been extremely helpful, for the problems of the thirties had not disappeared during the war. Funding still was short, and even with the return of workers from the armed forces, the Museum was unclerstaffed at every level. 


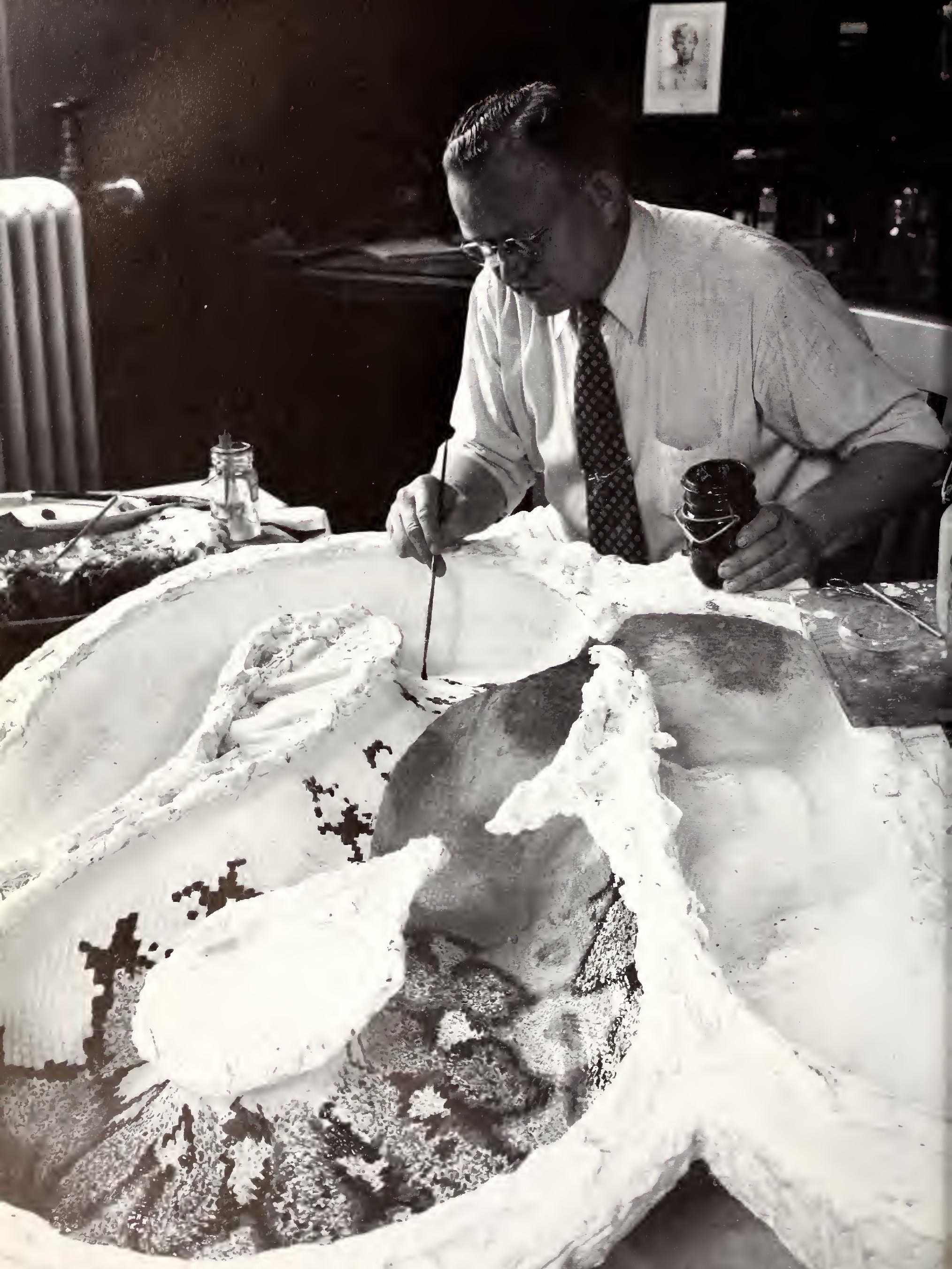




\section{New Faces, New Funds, New Exhibits}

$\mathrm{J}$ UST AS THERE WAS NO post-World War 1 increase in staff at the Museum, there was no significant change for at least a decade after World War II. If one counts the scientific staff members listed for the three Museum departments in 1946, the tally is: Anthropology, eleven; Geology, ten; Biology, twenty-eight. Of the twenty-eight in Biology, seven were botanists and one was Secretary Wetmore. In 1956 the figures were: Anthropology, ten; Geology, eight; and Zoology, twenty. Over in the Castle, the Department of Botany listed eleven on the staff. The number of aides in both years is unclear, but more exhibits specialists were listed in 1956.

Students of administration like to compile tables of age and grade distribution, but such exercises would reveal very little about the Museum. During its first four decades especially, the rate of change was slow. In 1930, for example, G. Arthur Cooper was hired as a bright young man of promise, and while he more than lived up to expectations, his first raise came thirteen years later. When C. E. Resser died in 1944, Cooper finally was promoted from the old Civil Service grade $\mathrm{P}-3$ to $\mathrm{P}-5$.

It is equally hard to define generations of scientific workers, since many scientists within the Museum had careers of forty to fifty years. Paul Bartsch retired in 1946 after fifty years' service; he died fourteen years later. After forty-seven years, R. S. Bassler retired as head curator of geology in 1948, but stayed around for thirteen years more. Nevertheless, by the 1950 s there was scarcely anyone still working who recalled the old days of the Museum before World War 1, with the exception of Waldo Schmitt. Schmitt was definitely not a stick-in-the-mud when it came to new ideas. 1t was he who in 1947 instituted the separation of Biology into

Edgar C. Laybourne painting the scales on a thin, transparent layer inside the cast of a python (Python) in the late 1950s or early 1960s. The model will be strengthened by additional fiberglass; this tedious technique gives iridescence to the scales. Chopped up by a visitor in 1969, the specimen was repaired and is back on display in Hall 29, near the Insect Zoo. departments of Botany and Zoology; as last head curator of biology, he became the first head curator of zoology. It was long past time that botany was given a voice of its own.

\section{A Brief Change from the Norm}

$1 \mathrm{t}$ was a rare event in the 1920 s and 1930 s for anyone to be hired, but even rarer for anyone to depart. During the first decade or so after World War I1, a strange thing happened: Some scientists left the Museum staff. Those in the shops, char force, and guards had come and gone, but the turnover rate of scientific staff from the inception of the Museum until World War 1I was essentially zero; no one ever left, whether he was paid or not.

Again in the 1960 s and 1970 s, very few of the permanent scientific staff left for greener pastures. It is a little hard to account for what happened in between. The war was followed by a tremendous boom in academic science, which led in turn to new opportunities in industry and greater mobility of society at large. Perhaps the stodginess and stinginess of the Museum and the life of a curator no longer appealed to those who had seen a lot of the world. Certainly the "young tigers" who joined the staff in the late 1940s were far more outspoken than their predecessors in their efforts to institute change.

\section{Cramped, Hot, Noisy Offices}

1t was not the Museum proper, but its affiliated organizations that showed the biggest growth in scientific staff during the decade after the war. Rock and fossil collections were moved once more, and in 1950 the Geological Survey modified the closed-off "Stone Hall" into office space. Noise droned in from the rotunda and from the balconies overlooking the dinosaur exhibit on the floor below. Specimen cases served as office partitions, and in summer it was miserably hot. Lloyd Henbest, who studied microfossils, kept a rat trap and obtained enormous specimens. Roland W. Brown, an eminent paleobotanist, used to come to the Museum on weekends when it was quieter. The Museum in- 
stalled an exhibit of a Geiger counter and a piece of uranium ore on the wall outside his office, but though he complained about the infuriating ticking noise, the display remained because of public interest in atomic energy in all its aspects.

The Geological Survey had already gained some exhibit space, formerly used for invertebrate zoology, in the northwest corner of the second floor. A "Coral Room" was buitt in 1947, and some of the studies of Pacific atolls that had been drilled and cored after World War II were conducted there. The Department of Agriculture entomologists also grew in number and occupied all of the west range on the second floor. Before World War II they had changed a few of the exhibit alcoves into cell-like offices; now there were individual cubicles on both sicles of the hall, with a passageway between allowing what few tourists wandered that way to walk from one side of the building to the other. Everyone who was in Hall 27 recalls the cases in the passageway containing the giant spider crab and the giant clam, the last remnants of the invertebrate exlibits that had been in the area

Eventually the east side of this row of offices, facing the west comrt, was decked over to provide needed storage space for insec cases. This made the little cubicles even worse, for there was no air circulation. During the summer, at least two of the entomologists took off their sloees and shints before stanting work. Among those who put up with these conditions was R. E. Snodgrass, from the Department of Agriculture. He exemplifies the remarkable Museum retirees, for he retired in 1945 and completed fourteen papers and a major book on insect morphology betore his deatlu seventeen vears later.

\section{Swamped with New Collections}

Bv the start of the 1950s, the slaff was being swamped with new collections coming in by the thousands. While the Museum's functions of record and research were going along about as well as might be expected with the funds available, its exhibit halls were dreadful by the standards of the larger American museums. George Brown Groode had warned that a finished museum was a dead museum, vet to too many minds, once a major exhibit had been installed nothing more needed to be done.

Secretary Wetmore had long been aware of the problems. As early as 1939 he had declared, "Much of our exhibition equipment is antiquated, and added personnel is required for its proper care and modernization." But despite his efforts, there was never money in the budget for major revisions. Frugality was as much a way of life as it had been during the Depression. Ernest Lachner, hired in 1949 as an ichthyologist, requested a pair of stainless-steel forceps and was refused because no funds were available. When Harold Saunders of the Geological survey asked the supply clerk for a pencil, she responded, "What are you going to use it for?" Whatever planning had been done for any new halls was lost in the shuffle of World War II.

Although all the Museum departments had made some changes in their exhibits since the 1930s, what little exhibit work was being done-with the exception of Perrygo's habitat displays-was in effect only adding a bit more of the same. From the tourist's point of view, nothing changed. One quick visit was more than enough, as the reactions of local citizens attested. One who had visited the Museum during this period likened it to a funeral parlor because of the dark mahogany cases and dim lights, and another thought the large, open hallways looked like a bowling alley. Another, taking a field trip with a university professor, suddenly became aware that the exhibits were arranged to present a logical story; but a visitor without a knowledgeable guide would have been unlikely to understand the presentation.

\section{Changing Exhibit Concepts}

In the late 1940s, several Museum committees suggested that the Smithsonian ask for additional funds specifically designated to improve the exhibits. Frank Taylor, a curator in the Arts and Industries Building and a "museum man" of the Goode mold, wrote a careful justification of the need for $\$ 300,000$ to fund a change in the public displays. He became chairman of an overall exhibits committee that changed the concept of exhibits throughout the Smithsonian. The others on this original committee were Paul Gardner, then with the National Collection of Fine Arts; Herbert Friedmann, the curator of birds; and John C. Ewers, associate curator of anthropology. Ewers, already an outstanding ethnologist of American Indians when he joined the staff in 1946, had made displays for the National Park Service and had planned, designed, and executed the Plains Indian Museum in Browning, Montana. The National Museum hired him with the expectation that because of his interest and experience, he might be able to do something to improve the displays in addition to his research. ${ }^{2}$

Another key appointment from the standpoint of exhibits was Clifford Evans, who came to the Department of Anthropology in 1951. In the thirty years before he died, he did a great deal of research on Latin America in partnership with his wife, Betty Meggers. He aroused not only his department but the Museum in general. He was a person of forceful opinions, and though some of his ideas were not accepted, they were never ignored. ${ }^{3}$

Evans and Meggers were intrigued by the new idea of possible human contact between Japan and South America, and they soon installed a case with a few objects and maps near the elevator in the second-floor west north hall, adjacent to the mummies. It was the first new scientific exhibit for anthropology in about forty years. Shortly thereafter, they went into the east 
Family group of Smith. Sound Eskimos from Greenland, in the Hall of Eskimo and Indian Groups (Hall 9) before 1916. The group is discussed in the Smithsomian Institution Annual Report for 1920. To the right, below the Catlin Indian paintings, is a case of Northwest Coast Indian artifacts, and between them and the totem pole is a house front, mostly obscured by the case. The totem pole is situated in Hall 10 , to the east.
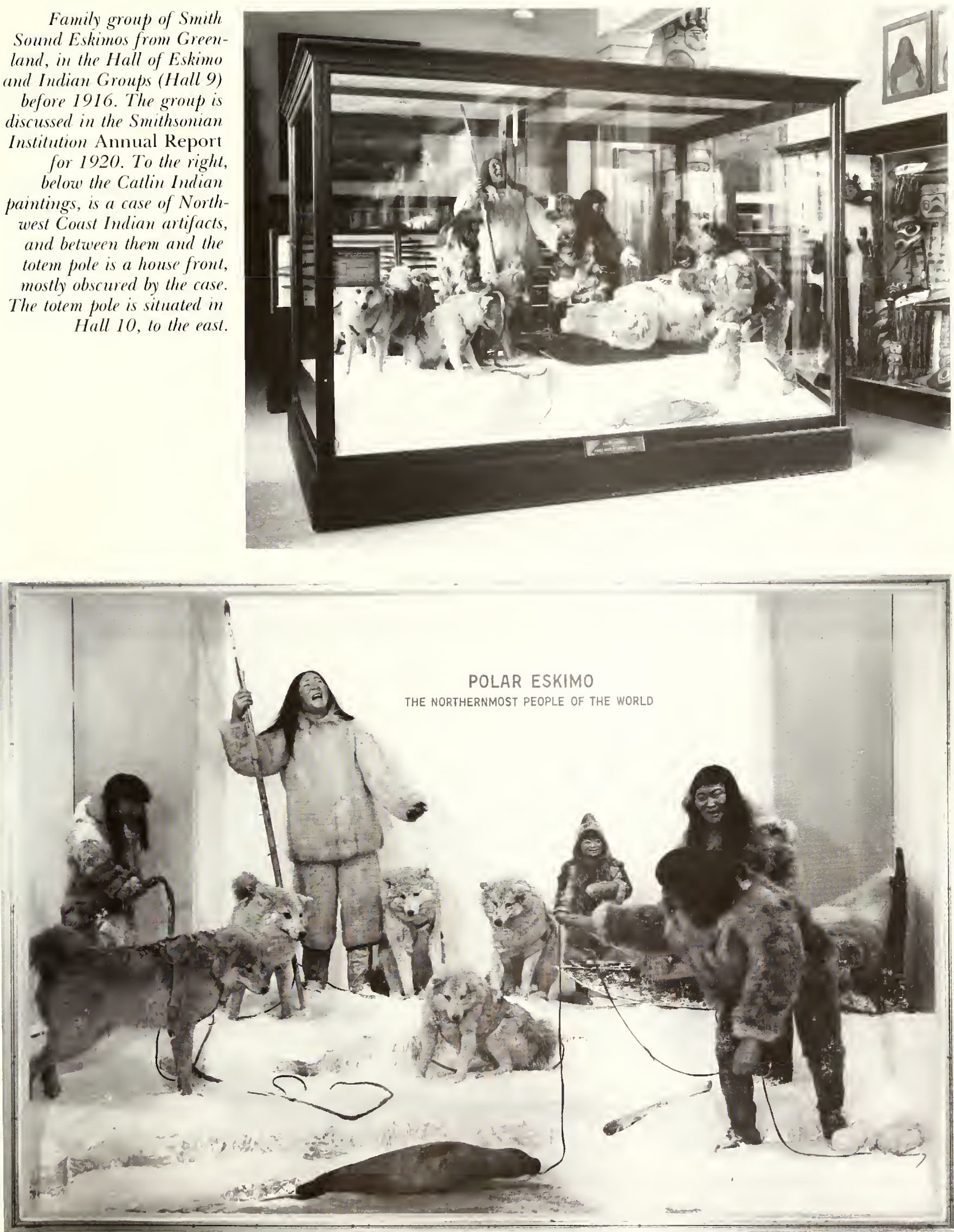

Polar Eskimo group, 1956 or 1957. The group has been renamed and reclothed since the 1920. Located at the south end of Hall 9, this high-visibility display is seen by anyone walking from the south door to the Museum Shop. 


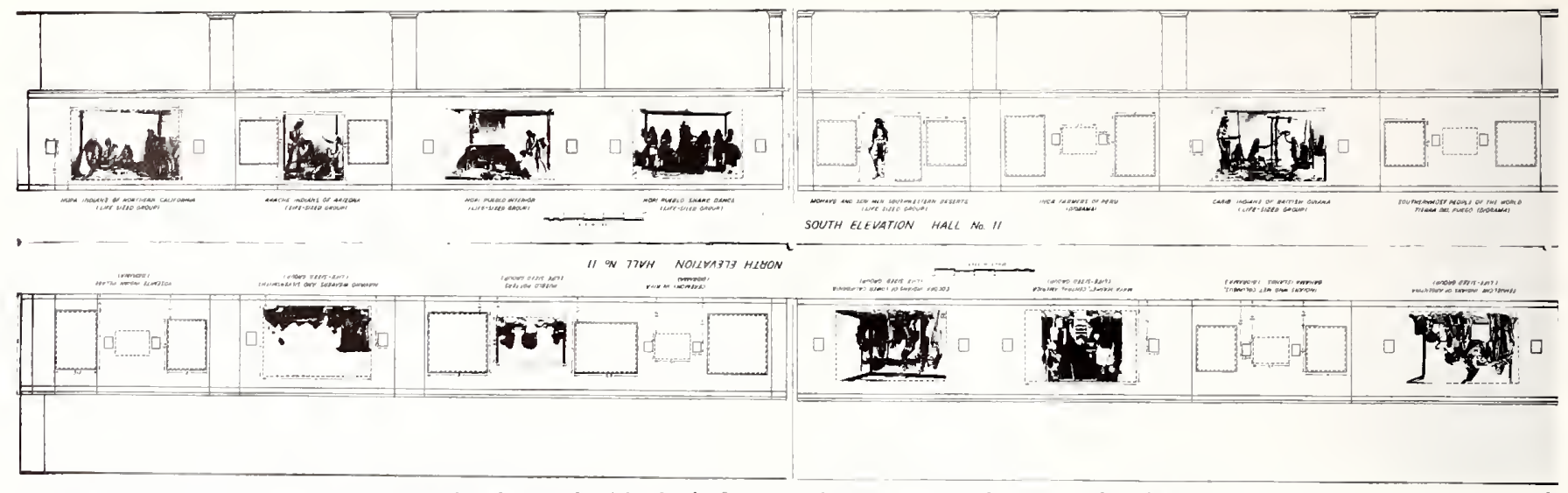

Design sketch for Hall 11, trawn in the early 1950s before the installation of new and refurbished exhibits. The Hopi snake dancers are on the south side near the center of the hall.

north hall on the second floor, devoted to South American Inclians, and planned a major revision. Because no one else dared to do it, they came down on a Saturday and painted the back of one mahogany case a striking blood-red. Assistant Secretary Kellogg stated that the red had to go, but there was a new Secretary coming in who, as a psychologist, liked colors and their effect on the public.

\section{Carmichael Succeeds Wetmore}

At the end of 1952 Alexander Wetmore voluntarily stepped down and went back to work full-time in his office in the Division of Birds. He commented that he had "seen the unfortunate results of clinging to positions too long and [that] he was resolved not to make that error." His successor, Leonard Carmichael, a distinguished scientist and educator, took office on January 2, 1953, as seventh Secretary of the Smithsonian Institution.

Carmichael had definite ideas about modernizing the exhibits and expanding the linstitution, and was able to set them in motion. By June 28, 1955, he had obtained congressional authorization to plan and construct, to the west of the Natural History Building, the Museum of History and Technology; it was opened to the public less than nine years later. (The structure is now called the National Museum of American History, and demonstrates that it is not a good idea to carve a name in stone hastily.) Carmichael was able to obtain significant increases in funding for the modernization of old exhibits in the Natural History Building, and for display halls in the new building. He studied the proposal for each new hall carefully, sometimes making curators squirm if their display concepts were fuzzy.

\section{Major Exhibits Program}

There is no question that a major exhibits program was finally starting at the Smithsonian in the early $1950 \mathrm{~s}$. Many of the staff did not want to be involved in any such things; for example, Jack Ewers quotes his boss,
Herbert Krieger, as insisting that there was no need for new exhibits, and that the staff need only "polish up the old Rolls-Royce." Yet the hall completed by Evans and Meggers had made every other antiquated hall look even dowdier by comparison. This convinced some of the staff that exhibits work could be done, and even convinced some of the old-timers that it should be done.

John E. Anglim, frustrated during his career as a pot restorer, now blossomed as a creative designer and display specialist. He juxtaposed stone tools with drawings of their present-day morphologic equivalents. His idea of painting the mahogany cases gray was upsetting to some curators, but this color emphasized the object rather than the case. When an electrician suggested that he could light certain objects better if their positions in the case were reversed, this was done. Anglim went on to become the head of the exhibits program.

Meanwhile, Evans and Meggers invented a first-rate technique for labeling. They would ask one of the painters to come down off his ladder and read the label; if he did not understand it, the text was changed. On the completion of the first new hall, they put up a plaque listing the names of the carpenters, painters, and electricians from the shops who had helped construct it. Despite the tensions built into this kind of work, the atmosphere was one of celebration. The biggest point of disagreement was that Anglim detested lavender and refused each time Meggers wanted it. (He was prompt to note that in an electrical fire years later, a doll case done in lavender was almost the only casualty. $)^{5}$

\section{New Exhibition Halls}

On April 14, 1954, according to the Annual Report, "the first wholly new exhibition hall to be completed in many years at the Smithsonian, 'Highlights of Latin American Archeology,' was opened to the public. ... This new hall shows many departures for us in modern museum techniques, in lighting, and in the use of color." press gave it excellent reviews, ${ }^{7}$ as did the experts and dignitaries attending its formal opening, the premier 


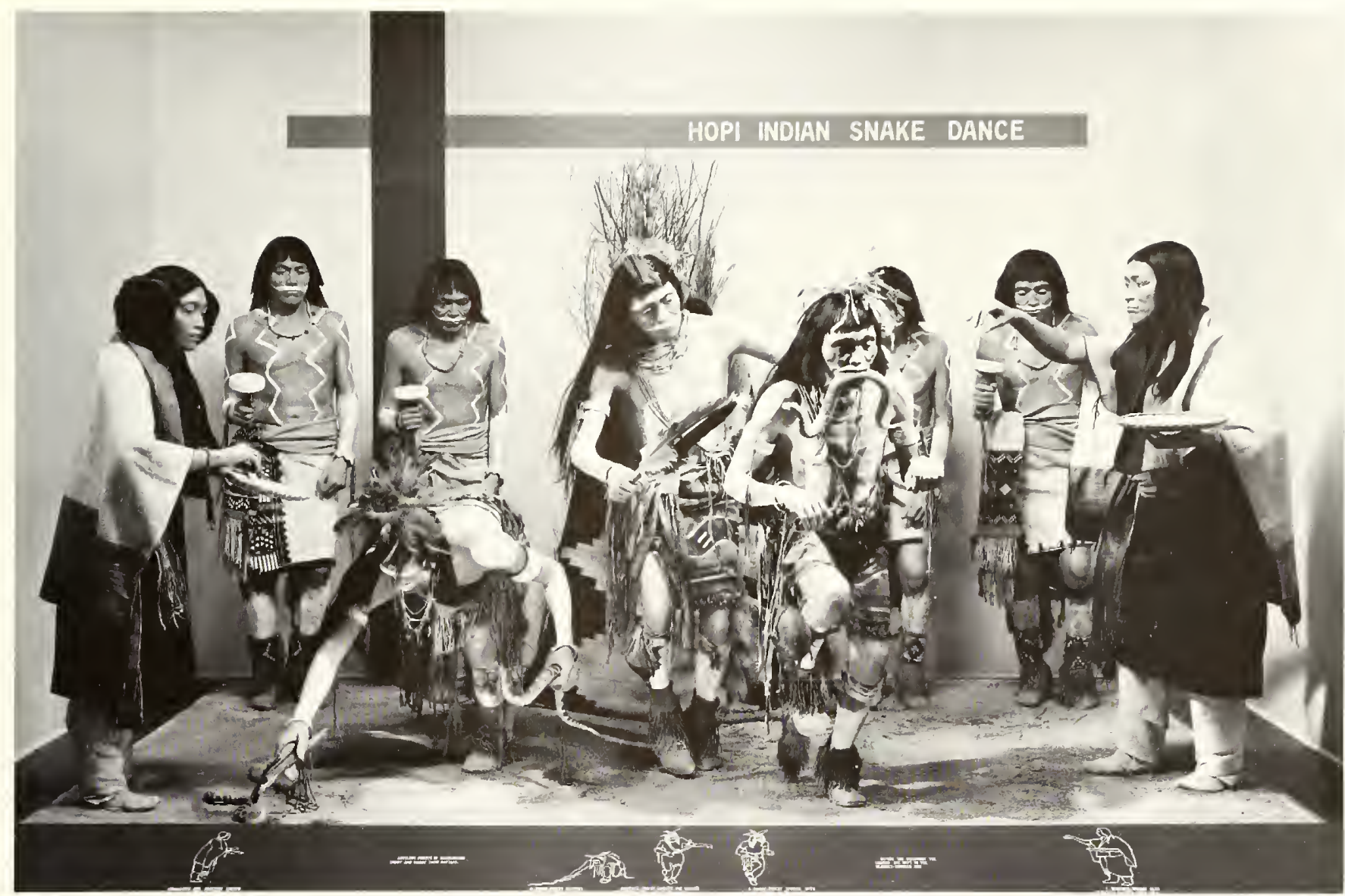

Hopi Indian snake-dance group in a modern case on the south side of Hall 11; the labels are below, at the fromt of the case. A similar photograph appears in the Annual Report for 1955.

cultural event of Pan-American week. Secretary and Mrs. Carmichael, in order to be present, gave up the voyage on the Queen Mary that they had planned and traveled to Europe by air instead.

The following year saw the opening of "Indians of the Americas" (Hall 11) on the first floor in the west north range. This was the first overhauling clearly under the aegis of Friedmann, chairman of the natural history exhibits group. Ewers, who did an excellent job on it, described the strong and weak points of the hall before its renovation:

Visitors to this hall used to be impressed by the sheer number of exhibits and objects on viewmore than 6,500 specimens. The magnitude of the collections could be sensed by merely walking through the hall without stopping to examine a single exhibit. But what did it all mean? ... Yet there were islands of interest in that uncharted sea of information that comprised the old installation.

These were the always popular, large groups of life-sized figures of Indians wearing real articles of clothing and engaging in typical activities demonstrating the making or uses of tools and domestic utensils, weapons and handicrafts. These exhibits were designed by the talented artistanthropologist, William H. Holmes, some of them more than half a century ago. They were some of the oldest exhibits in the museum. Yet they possessed human interest qualities which attracted the attention of museum visitors of all ages and both sexes. However these groups were glassed on four sides. Their effectiveness was hampered by inadequate lighting. Their realism was impaired by the distracting sight of adjoining cases crowded with unrelated materials showing through their plate-glass backgrounds.

Problems of modernizing exhibits in an old museum differ considerably from those of developing an entirely new one. The legacy of high ceilings, internal pillars, large windows, antiquated heating, lighting and ventilating systems impose very real problems. Still more obvious are overall space problems.

In addition to the old life-size figures, some miniature dioramas were prepared. (It costs far less to make a small figure than a large one, and only few new large 


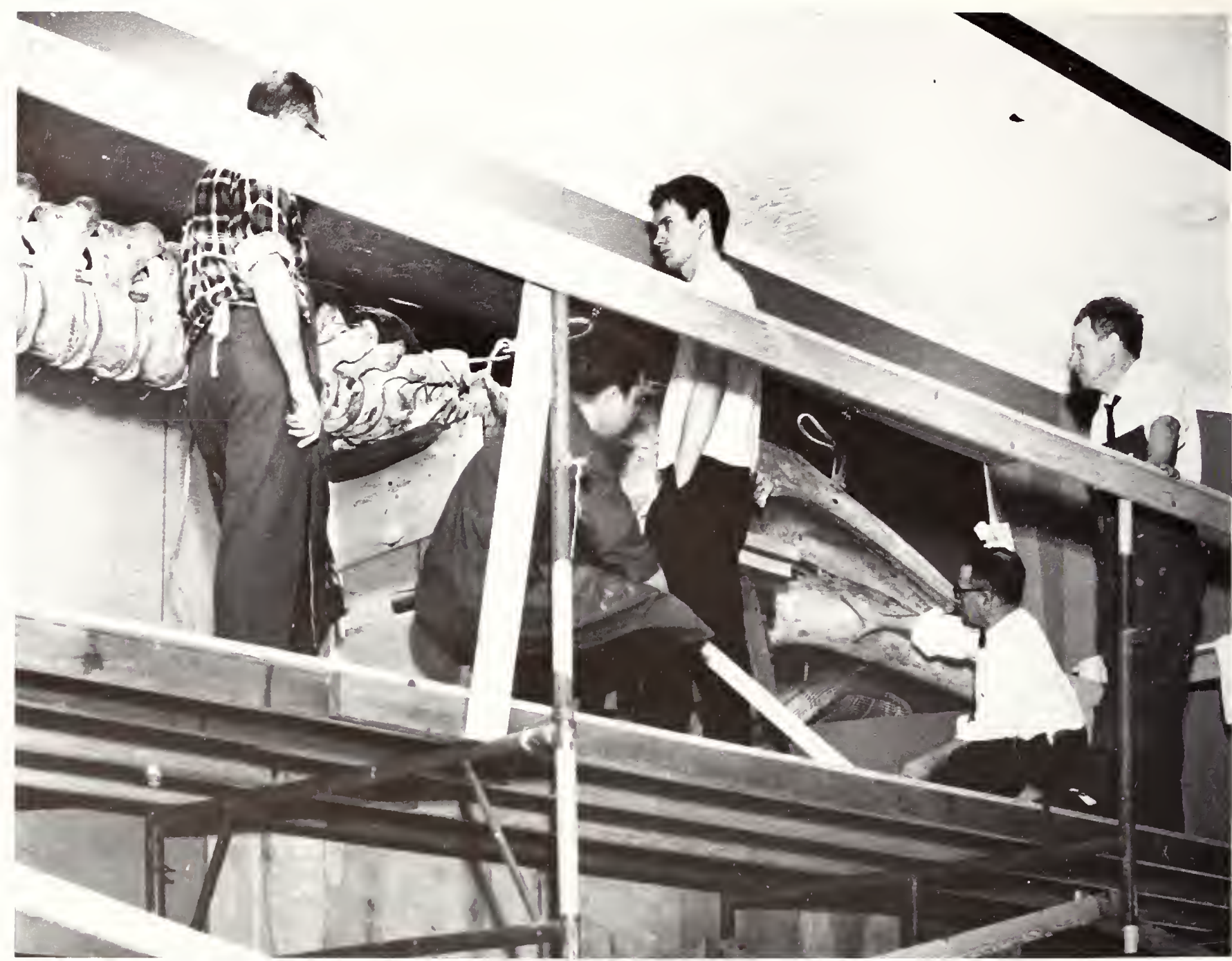

Insalling a whale sketeton in the Hall of Osteology (IIall 28), 1961 or 1962. This is the first exhibit at the roturda entrance to the hall. Left to right: Leonard Blush, Frank Greenadel, Leon Frederide, Wiatson Perngo, and Carleton

manikins have come into the exhibits in recent decades.) "Indians of the Americas," all in all, was a good hall in content, design, and display, and it attracted interest. Still, everything depends on the observer. One day when Ewers was walking through the hall, he saw a small boy standing entranced in front of the case of Hopi Indian ceremonial snake dancers. The boy yelled for his father to come. "So what?" said the father, taking a look. "It's just a fellow chewing on a snake."

Next to come was the bird exhibit in Hall 13, in the west wing on the first floor. Herbert Friedmann had been thinking about how he would like to change this display almost from the day he joined the staff. Watson Perrygo did most of the work-and did most of it within a year. The day before the hall was scheduled to open, in March 1956, a stepladder toppled into a case, and everyone worked all night to repair specimens and build a new case.
Lingebach; the three standing were temporary employees. A photograph of the completed exhibit appears in the Annual Report of 1964.

Next to open was Hall 26 on the second floor, above the American Indian Hall. "Everyday Life in Colonial America" displaced the lace and the chickens, and whether one called it ethnology or cultural history, it was a major improvement. Because of the ultraconservatism of head curator Setzler and curator Krieger, it had been impossible for Malcolm Watkins, hired in fiscal year 1949, to do anything that deviated one iota from the routine; but Friedmann, as exhibits chairman, recognized the problem and got around it by ordering Watkins in writing to prepare plans for a new hall immediately. This administrative ploy-Watkins's ideaworked, and the hall was started. The timing was not the best, since the contract for the new hall was followed in a matter of weeks by the authorization for building the new Museum of History and Technology. But although this hall thus ended up being dismantled and moved out within a few years, it was another fine ex- 
hibit, appreciated by the local press: "Advances in modern lighting and electronics, used by the Institution for the first time, unobtrusively make the hall come alive. The visitor entering the hall will automatically activate a 'proximity switch' to start a tape recording that briefs him on what he will see.",

One day, at the time "Everyday life" was being installed, the elevator shaft was found teeming with thousands of ants, and panic ensued. Remington Kellogg put out an emergency call for Jack Clarke of the Division of Entomology. Clarke was at lunch, and telephone messages arrived every few minutes in his office. After Clarke returned and took a quick look, he had a good laugh. The Museum was not being invaded by ants. These were carpenter ants from the dismantled old Colonial houses, and now that spring had come, they were trying to get outdoors to build a nest. As Clarke predicted, the ants were gone the following day.

\section{Exhibits Philosophy}

The new exhibits program was well under way before its philosophy was articulated by director Kellogg, or whoever wrote the Anmual Report for the year enching June 30, 1957. "The curators of the National Museum have twofold objective in planning their halls and ex- hibits," it read-_to give the Muscum visitor the experience of viewing objects of significant historical or scientific interest and rarity; and to show these objects in exhibits so effectively explanatory that they increase the visitor's knowledge, not only of the object, but atso of the history, science, technology, or art to which the object relates. The attainment of this objective and the authenticity, scholarship, and factual content which distinguish the exhibits reflect the devoted and timeconsuming work of many busy scientists and historians of the curatorial staff."

Even though Ewers was in charge of all exhibil planning for fifty-five halls in the yet-to-be-opened Museum of History and Technology, he completed a second display in the Museum of Natural History devoted to Indian and Eskimo cultures. Opened in December 1957 , this exhibit (Hall 9) was linked to Ewers's first anthropological hath by a map adjacent to the north elevators. The exhibits collectively were called "The Native Peoples of North America." A dramatic open case of wooden masks had to be removed later for security reasons after a few youngsters jumped into it.

When it came time for the biological halls to be revised, the American buffalo group Hornaday had prepared in 1888 was removed from public view and dis-

\section{Table 1: Openings of Major Natural History Exhibits: 1954-1967}

Hall 23

Hall 11

Hall 13

Hall 26

Hall 12

Hall 9

Hall 19

Halls 14 and 15

Hall 4

Hall 5

Hall 3

Hall 21

Hall 8

Hall 22

Hall 16

Hall 2

Part of Hall 19

Part of Hall 20

Hall 25

Hall 28

Part of Hall 29

Hall 7
Highlights of Latin American Archeology

American Indian Hall

Birds of the World

Everyday Life in Early America

North American Mammals

North American Indians and Eskimos

Hall of Gems and Minerals

The World of Mammals

Fossil Plants and Invertebrates

The Age of Mammals in North America

Fossil Reptiles and Amphibians

North American Archeology 1

Cultures of the Pacific and Asia

North American Archeology 2

Life in the Sea

Hall of Fossil Reptiles

Gem and Jade Halls (revised)

Hall of Meteorites

Physical Anthropology

Osteology

Cold-blooded Vertebrates

Cultures of Africa and East Asia
Aprił 14, 1954

June 2, 1955

March 22, 1956

January 26, 1957

April 30, 1957

December 8, 1957

July 31,1958

November 25, 1959

June 6, 1961

June 6, 1961

June 6, 1961

June 24, 1961

June 28, 1962

November 16, 1962

February 18, 1963

June 25, 1963

Summer, 1965

December, 1966

Spring 1965(?)

Fiscal Year 1965

Fiscal Year 1966(?)

August 25, 1967 
mantled. Buried in the plaster below the largest buffalo was a tin box containing two 1887 issues of the magazine Cosmopolitan, with articles by Hornaday. At the top of one article, Hornaday had written:

\section{To my illustrious Successor:}

\section{Dear Sir:}

Enclosed please find a brief and truthful account of the capture of the specimens which comprise this group. The old bull, the young cow and yearling call were killed by yours truly.

When I an clust and ashes I beg you to protect these specimens from deterioration and destruction. Of course they are crude productions in comparison with what you produce, but you nust remember that at this lime (A.D. 1888, March 7) the American Sehool of Taxidermy has only just been recognized. Therefore give the devil his due, and revile not.

\section{W.T. Hornaday ${ }^{\text {I }}$}

The specimens had faded over the years and were somewhat tattered. They could not be put into the new exhibit, and buffato obviously are large and hard to store, so they were given to the Montana State Museum. Their current status is uncertain. As the last wild Bison bison shot in America for display in a museum, the group has consiclerable significance. Any buffalo skins exhibited today are from domesticated herds, but it was primarily as a result of Homaday's concern that the American bulfalo was saved from extinction. The Institution lost a part of its history when the specimens left the building.

\section{More New Halls}

Major new mammal exhibits were badly needed. Leonhard Stejneger had been against habitat groups, according to Edward Henderson, because he wanted the visitor to be able to view the animals from all sides. He would not even permit a blue sky background to be instatled behind the mountain goats. While a few habitat groups had been installed in the early $1950 \mathrm{~s}$, after Stejneger's death, the halls as a whole reflected his prejudice.

The North American Mammals hall, completed in 1957. was done in segments, part of it having opened the year before. The hall included a display of Rocky Mountain sheep that Secretary Walcott had obtained for the Philadelphia Sesquicentennial exhibit, and which Perrygo had first worked on in 1925. During the interval before the mammal halls were finished, Secretary Carmichael held the annual dinner for the Board of Regents in the west wing of the main building, giving the regents a close-up view of the progress of the new exhibits program. The two halls comprising "The World of Mammals" were opened in 1959. That work was supervised by Henry W. Setzer, an outspoken mammalogist hired in 1948 whose principal interest was small mammals from Africa.

George Switzer and Paul E. Desautels were responsible for the Hall of Gems and Minerals, opened in the summer of 1958. Switzer, who joined the staff in 1948, became the first head of Mineral Sciences when the Department of Geology was split into departments of Paleobiology and Mineral Sciences. Desautels was hired in 1957, in part to assist with the new hall, and he later went on to increase the holdings of gems and minerals significantly. Rolland Hower of Exhibits designed the new display cases. Understatement being an old Smithsonian tradition, the case introducing the world's finest mineral collection was labeled simply "The Smit hsonian Mineral Collection." Five months after the hall opened, the Hope Diamond was presented to the Institution and installed in a safe specially built into the display. The Jarte Room, just to the north of the gem hall, also opened in 1958.

By this time the new exhibit halls had begun to crowd the old ones, and the National Collection of Fine Arts, while holding on to Hall 10 on the first floor, gave up some space on the second floor in Hall 22. "Twenty oil portraits of World War II leaders by John C. Johansen and pastel drawings of the Civil War Veterans by Walter Beck have been removed from the second floor gallery and are to be installed at the south end of the foyer together with the miniature portraits in specially lighted cases," read the National Collection's report for $1958 .{ }^{12}$ For what was supposed to have been a temporary gallery to have lasted more than thirty years does afford some perspective on just how badly the new exhibits progran was needed.

June 1961 was the crest of the wave. Waldo Wedel opened a hall of American Indian life on the east side of the second floor, "North American Archeology 1." On the east side of the first floor, a hall of invertebrates and plants, supervised by G. A. Cooper and opened on June 6, constituted a quantum jump over the old fossil hall; its stellar attraction was a series of wax reconstructions of sea-bottom life.

"The Age of Mammals in North America," which opened the same night, was the project of Lewis Gazin, who had joined the staff in 1932, spent a long time in the war, and returned in 1946, the same year Gilmore died. This hall included the first of a series of magnificant murals painted on plaster by Jay H. Matternes. Even twenty years ago it was difficult to find a plasterer who could prepare the proper rough coat and finish coat for a fresco surface, yet this specialized art is even more refined today; one can scarcely tell where the case ends and the background begins. W.H. Holmes would have appreciated the Matternes mural, a combination of excellent science and excellent art.

An alcove of fossil fishes and amphibians, opened informally a year earlier, was polished up by the addition of a diorama and included in the grand opening. The late David Dunkle, who had joined the Department 


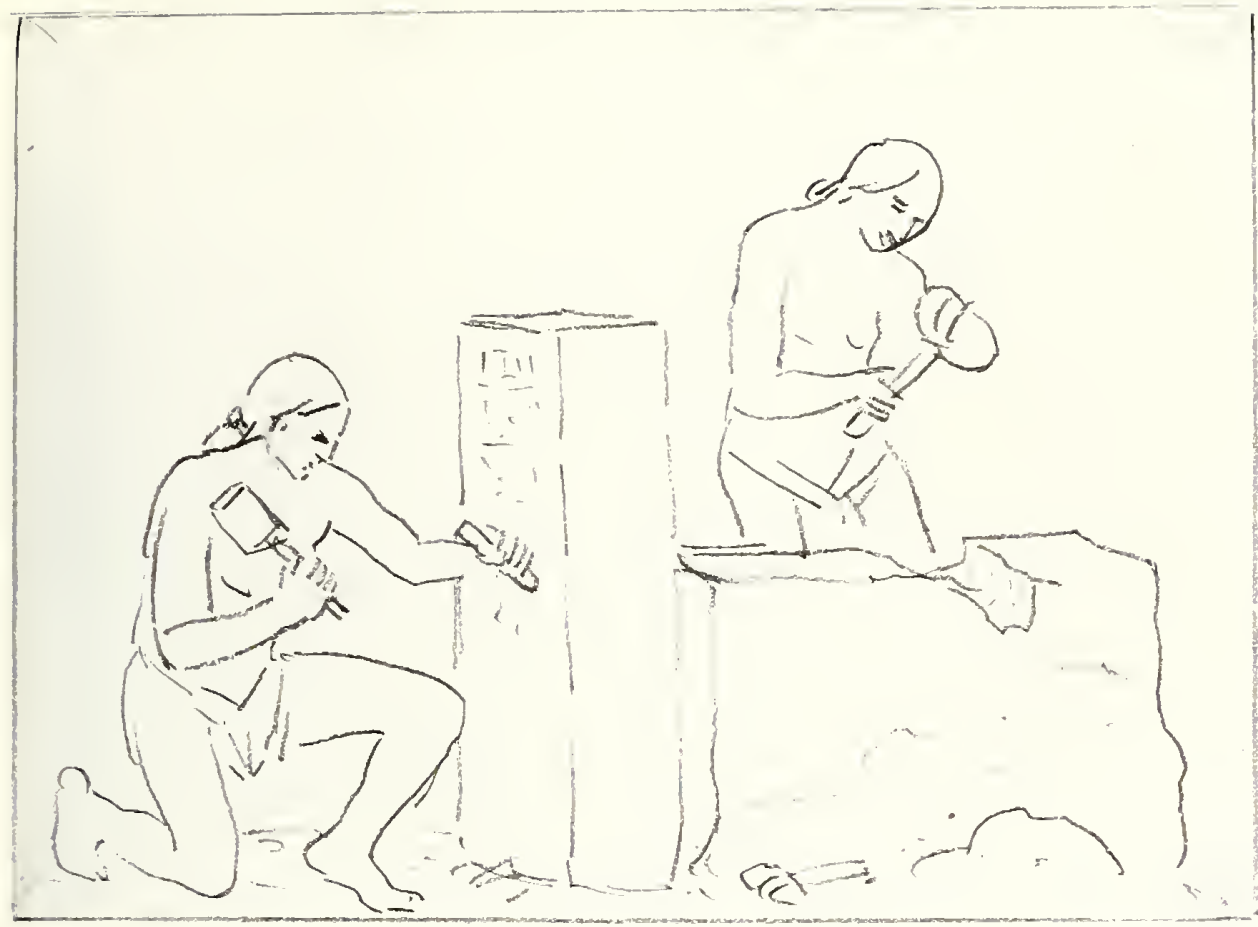

Piepacatory sketch for the Maya Sculptuer Group, portanying stoneworking al Milla. This group was made for the 1916 Panama-Catiformin Intermational Exposition ill San Dirgo. For many yerts, a case with these two figutes stood urar the nouth rud of Hall 23. Iu uotes arcompanying this pep-1915 sketrh. William IVeury Holumes wote detailed descriptions of the chothing, stour', aud lools to be depieted. Copied from au nupulhished sketch by Holmes in his "Random Recoids."

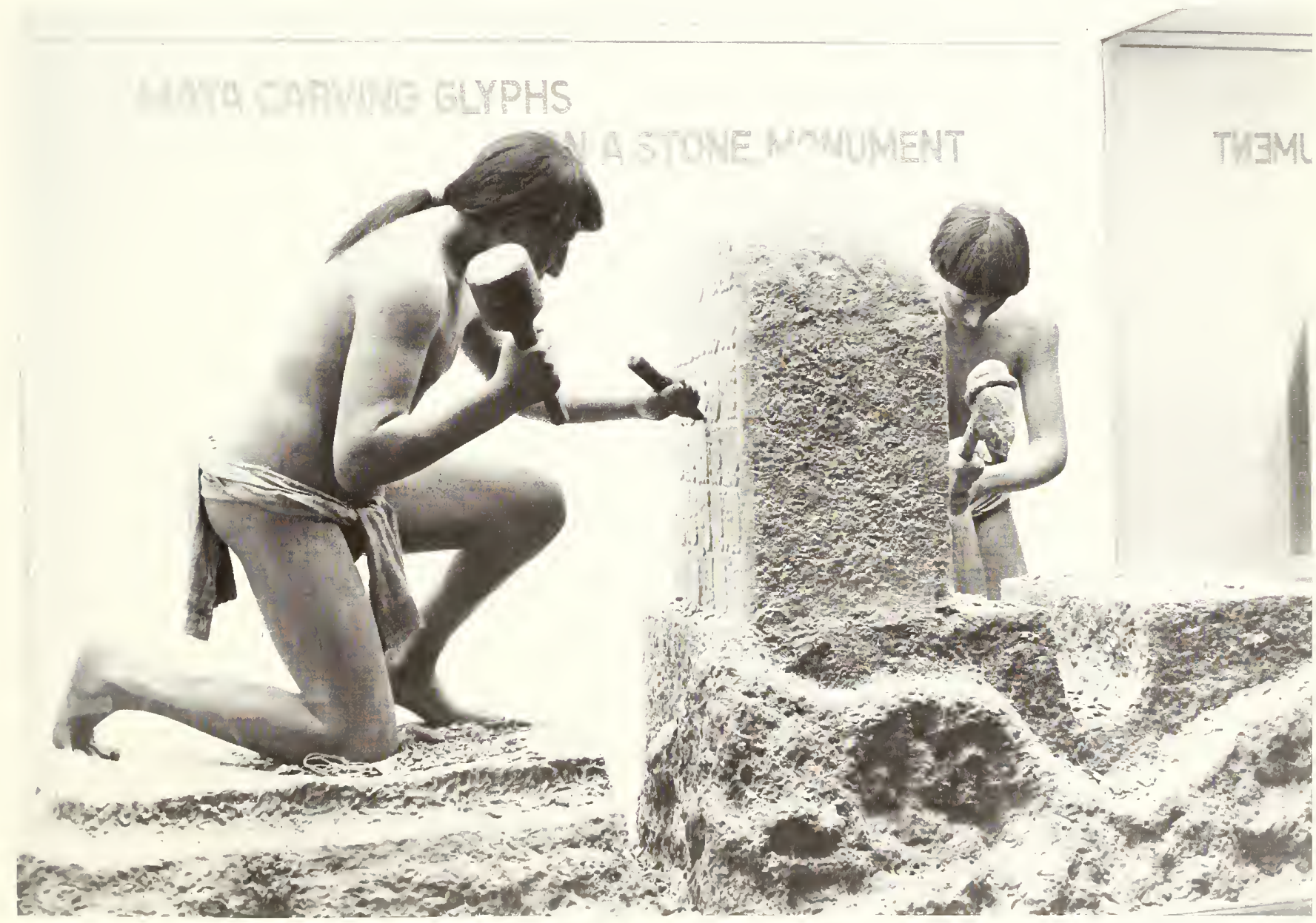

The Maya carvers, constructed from the sketch by Holues. The exhibit was refubished, as indicated by the harge, raised lelleriug ou the back wall of the casp. For many' yeas

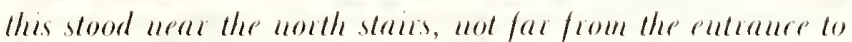
the secoud-floot hall (Hall 23) that was completed by Clifford Euraus aud Betty Meggers. 
of Geology in 1947, supervised this section. He estimated that in the week before the alcove was opened he was summoned there at least once an hour because someone had put down a model of a fish and could not remember whether it should point to the right or to the left when mounted. The fossil mammal hall was a long way from finished, and more Matternes murals were to come; but since the first days of the "New National Muscun" it had been standard practice to open a hall just as soon as there was something to show the public, and hope that later there would be time to add objects and correct mistakes. Of course this seldom happens, for curators and exhibits people always have more pressing concens than revising recently opened halls.

Eugene Knez and Gordon Gibson, both hired by the Department of Anthropology in 1959. were informed that they were expected to prepare halls promptly, and logether with Saul Reisenberg, who joined the staff in 1957, they established an informal group to review one another's ideas and exhibit scripts. Reisenberg's part of the "Culuures of the Pacific and Asia" project was finished first; it began with an Easter I sland head that had been on display in the original National Museum. The remainder of llall 8 was done by Knez.

\section{New Division, New Museum}

Development of the Muscum of History and Technology, although the building was sill incomplete, led 10 Makolm Watkins's transler 10 that staft. A new Division of Musical lnstruments was formed, and prochaced a temporarr exhibit in Hall 8 before the permanent instathation of the Pacific exhibit. The division then moved to History and Technology, but old-tiners in the Museum of Natural Historr will never torget the pianos of the priceless Worch Collection, a real treasure. Adjacent to the old mincrat hatt stood the timy piano built for the midge "General Tom Thumb," máde famous by P. T. Barnum.

Intil the 1960 s, unfortumately, there was no one on the staff to care for the instruments, and there was no space whatever for storing them properly except for one smatl spot on the second-floor rotunda bakcony. Pianos, harpsichords, clavichords, and virginals were stacked three and four high in the stairwells and all around the third-floor rotunda batcony. One particularly hot summer day, the glue holding the legs of one instrument gave way, and the sound of musical anguish when it crashed, amplified by the dome, was a noise that will not be forgotten by anyone who heard it. When offices on the third floor of the east range were vacated by employees migrating to the Museum of History and Technology, walls were torn down and space was used for storing human skeletons in drawers.

\section{Herbert Friedmann Moves On}

On May 31, 1961, Herbert Friedmann retired after thirty-two years at the Museum of Natural History; perhaps "retired" is not quite the proper word, for he left to become director of the Los Angeles County Museum. In a place that has housed many erudite and witty people, Friedmann stood out. Not only did he study birds directly, but he wrote on such subjects as the symbolism of the goldfinch in medieval art. One day he passed a youngish inhabitant of the building who had grown a beard over the summer. He said, "I see you are down to your secondary sex characteristics," and walked on. ${ }^{13}$

By the time of Friechmann's retirement, the Museum's "continuous modernization program" had been in effect for eight and a half years. As the Annual Report summed it up, "nine of the fifteen galleries on the first floor and four second-floor halls had been renovated and opened to public view. Each hall has presented distinct problems in exhibition because of the different subject matter interpreted in each. However, each renovated gatlery reveals marked improvements in the organization of topics, in the attractiveness of presentation, and in the simplicity of labelling that combine to make it a much more effective ectucational medium than was the series of exhibits that occupied the hall prior to modernization." "14 The general supervision of the exhibits program was taken over by A.C. Smith, and when Smith moved up to Assistant Secretary, T. Dale Stewart had the job. But the director of the Museum had many problems to worry about, and the exhibits chid not receive the same attention that Herbert Friedmann had given them.

\section{Three More Halls}

Fiscal year 1963 was again an important time for exhibits; three major hatls opened. Waldo Wedel completed his second hall of North American Archeology in the east north range of the second floor. While both these halls were far better than what had been there earlier, neither Hall 21 nor Hall 22 was dramatic or inspired, as Wedel, who never particularly liked exhibits work, will be the first to say. A superb field man and a member of the National Academy of Sciences, Wedel was hired in 1936, and like Cooper, was not promoted for thirteen years until Neil Judd, the person in front of him, retired. ${ }^{15}$ In 1983 Hall 21 was closed off to be used as a staging area for moving collections from the building, and in 1984 Hall 22 was closed off for the same purpose.

The Dinosaur Hall was done by Nicholas Hotton III, who joined the Department of Geology in 1959. This hall entailed major construction; a large balcony was built to increase the display area and to reduce the effect of the high ceiling. A stairway led from the balcony to the moon rock display in Hall 22, opened for the nation's bicentennial. Diplodocus longus was displayed in a smaller area than before because the east end of the hall, below the balcony, was walled off. A popular 


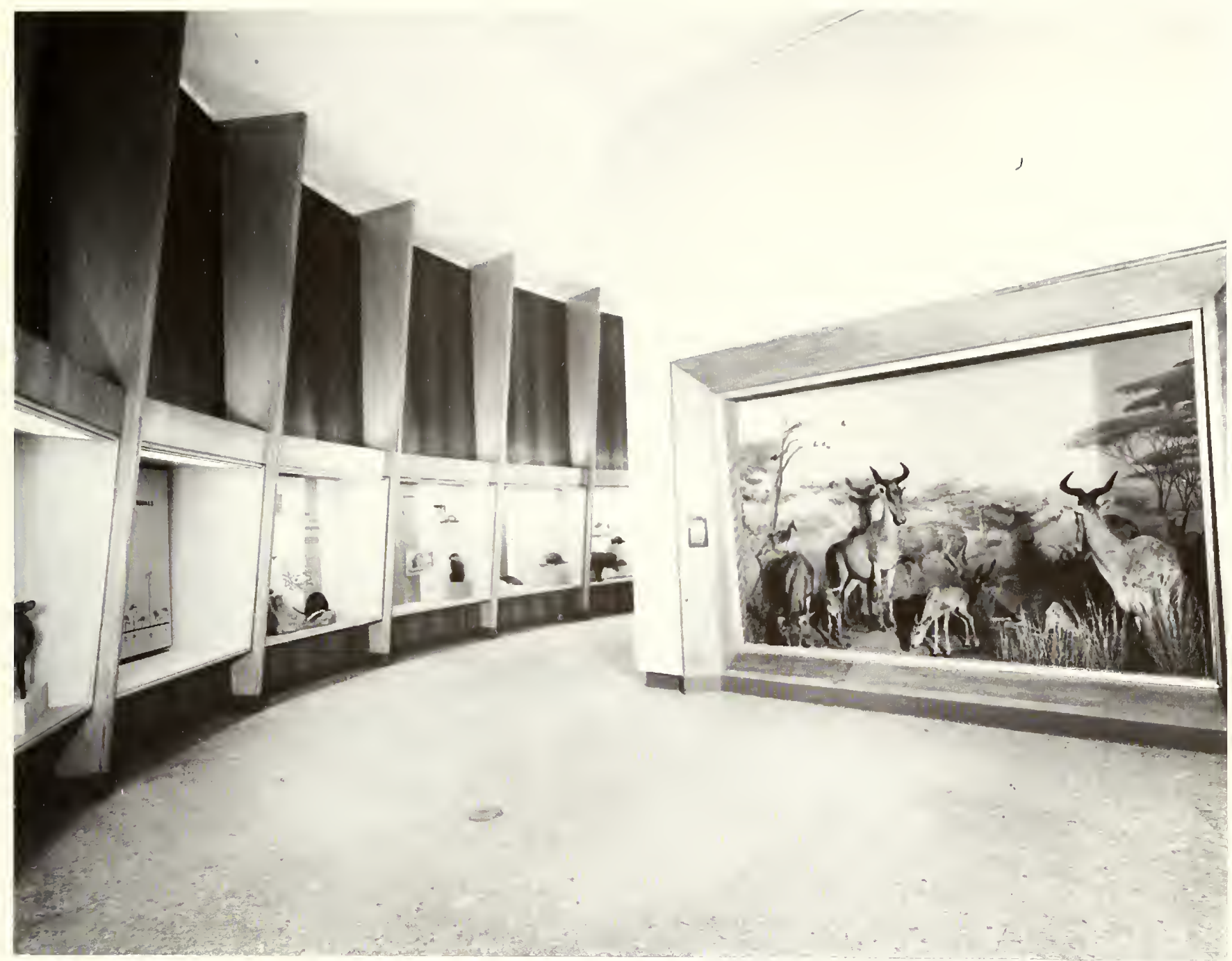

New mammal hall in the 1960s, with a habitat group of hartebeest (Alcelaphus) to the right - the first exhibit one sees in Hall 15 upon entering from the rotunda.

item was a large dinosaur bone that tourists could touch, but they could no longer walk under the specimen.

Across the rotunda, the Hall of Ocean Life was less than satisfactory, and some staff members still consider the term "disaster area" more appropriate for it. The old whale model, based on measurements taken of a beached specimen, left the impression that the creature was nearly as flat as a pancake. The prime feature of the renovated hall, "Life in the Sea," was the new, ninetytwo-foot model of a great blue whale. During its construction, someone removed the wrong rope and the head fell off with two people inside, but fortunately they were not hurt and only a small dent was put in the fiberglass. It was common practice for the director, Remington Kellogg, to stop by nearly every day and tell the whale-construction crew that he was going to retire as soon as the model was completed. One day he noted the slow rate of progressing by observing, "You sons-of-bitches will keep me working forever."
Kellogg did retire, and the hall, atthough it was incomplete, was dedicated and opened in February 1963. An elongate balcony had been installed opposite the whale, partly to simulate the side of a ship and allow a view of the whale from the side. The balcony was used for only a few months for one temporary exhibit, and none of the dioramas planned for it had been installed before the stairway to it was declared unsafe. The balcony has been closed off ever since.

In one incident, humorous only in retrospect, a visitor wrote to point out that a California abalone shell on display was not of legal size. He dondted a larger one, just in case the Museum did not have a proper specimen. A letter of thanks was sent, but a year later the same person wrote that he had visited again and the display had not been changed. One of the curators of mollusks replied by explaining how hard it was to have an exhibit changed-an accurate statement. About forty-eight hours later there was an inquiry from the 
office of one of the California congressmen, and almost immediately the display was corrected. In contrast to this rapid change, David Pawson, who joined Invertebrate Zoology in 1964, recalls being taken through the same hall when he first arrived and noting a sand dollar oriented upside down in a case. When he mentioned this, the person from Exhibits who was guiding him replied in ath seriousness that they were so backlogged, it would be nine years before any changes could be made. Pawson filed this fact away, and nine years later wrote a memorandum to have the error corrected.

\section{Exhibits Work Continues}

On January 22, 1964, the Museum of History and Technology was dedicated. Attention focused on it, not on Natural listory, and the year was one of only partial atcomplishment in exhibits. Knez got his part of a hath open; Wedel reinstalled a life-size diorama originally constructed by Holmes. A portion of the osteology hall was finished and opened informally; Jay Matternes completed another mural. Even if there had been more to record, the change from the Ammal Report to Smithsomian Yrar in 1964 resulted in much less cletailed style of accounting. For example: "Members of the curatorial staft panticipated in the planning and design of the hall of osteology, which opened during the year, and hath of cold-bloseded vertebrates. The latter is in process of consuruction, and considerable progress has been made in obtaining material for the tropical and habitat cases." to There is no indication in the departmental files when either displas was opened. A projected fish hall never materialized.

"Cultures of Africa and East Asia," which opened in 1967, was a hall that posed interesting problems. The first hurdle laced by Gorckon Gibson in installing the African portion of the hall was the Henry Ward bequest. Ward was a British sculptor who had lived in Africa as a plantation manager and then opened a studio in Paris. "When he died he left his collection to the Smithsonian, with the proviso that it be exhibited as it had been in his studio. Clearly there were some advantages in rearranging objects and moving some of the statues, and equally clearly there were tegal obstacles. Gibson eventuatly' got Kellogg's permission to look into the matter. At the time the Smithsonian had no legal counsel, so Gibson walked across the street to the Department of Justice and found an assistant attorney general willing to help. Gibson wrote to all of Ward's descendants and obtained permission for legal action. The case went to a judge for consideration under an obscure principle allowing speculation as to what the donor might have done had he known the present circumstances. The judge ruled that Ward would have been sympathetic toward a new display, and the director's permission to modify the donation was forthcoming.

For Knez's part of the hall, John Weaver of Exhibits had sculpted life-size figures of Chinese Opera actors that made men dressed in women's costumes still look like men, and he had prepared two-dimensional Korean manikins standing in a house cloorway so that they appeared three-dimensional. For Gibson, Weaver made a diorama of northern Cameroon showing half a dozen one-sixth-life-size figures engaged in smelting iron. From sketches left by Ward he sculpted a huge figure of a warrior brandishing a spear, which was cast in bronze for the display. The hall got rave reviews, and all the papers photographed the statue. ${ }^{18}$ Weaver wanted his name on the warrior, but the exhibits office refused because his Civil Service job title was model maker, not sculptor. Weaver quit.

The new exhibits program in the Museum, begun in the 1950s, had now run its course, so far as natural history was concerned. Progress in the last stages was by individual cases, not by halls. The Smithsonian's exhibits program had different outlets, partly because of the great amount of work needed in the new Museum of History and Technology. The lnstitution had new art galleries opening, and many temporary exhibits were being made for all its various museums and for the Smithsonian Institution Traveling Exhibition Service, launched in 1951.

After the mid-1960s, the staff of the Museum of Natural History gradually shifted its attention back to collections and research. Still, the new exhibits had pushed the Museum from the 1920s to the 1960s, in a single decade. 


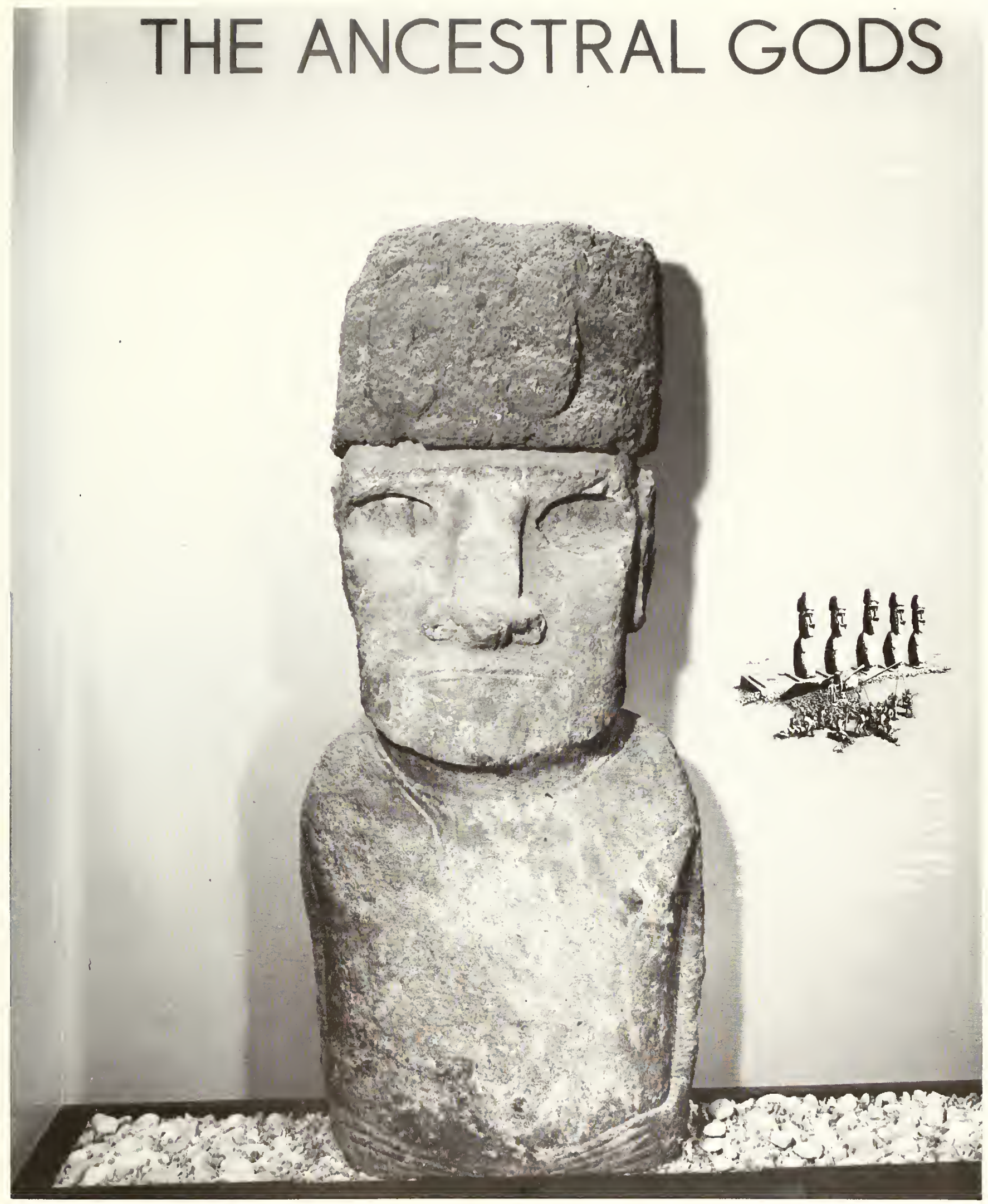

Easter Island head acquired in 1887 and installed in the U.S. National Museum the following year. This is the first display one sees in "Cullures of the Pacific and Asia" (Hall 8), entering from the rotunda. The Annual Report for
1962, where this pholograph was published, noted that the specimen is ten feet high. The headpiece, howeter, has a different catalogue number than the statue. 


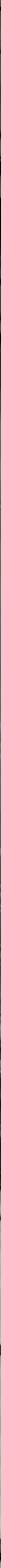




\section{New Wings and a New Elephant}

$\mathrm{T}$ HE ROTUNDA IS A GRAND architectural feature. However, no one seems to have known what to do with it. At first the architects had a skylight above the rotunda, but this gave a bizarre roofline to the building. Their next conception was a large clome with enormous bull's-eye windows, followed by the wingedstatue-topped model. Even though Hornblower and Marshall were overruled on the ornate French Second Empire-style dome, they persisted, and in $1909 \mathrm{rec}-$ ommended St. Gaudens's Victory as the statue for the center of the rotunda. Mercifully, this idea was rejected.

When the iron grilles were installed on the cloors in June 1911, and the public finally could use the main entrance to the building, cases of large mammals were in the rotunda. For a time a giraffe was centered below the dome. Later, various statues flanked the ambulatory. For a brief time in the 1940 s a giant blue vase stood in the center. During much of the 1950 s the rotunda was empty, save for the guards' desk and the benches under the ambulatory. It was not until 1959 that a proper rotunda-sized exhibit was installed: the largest mounted elephant in the world.

\section{An Awe-inspiring Sight}

While some staff members regard the elephant as just another animal on display, it is an awe-inspiring sight. Shot November 13, 1955, by J.J. Fénykövi near the Cuito River in Angola, the elephant was skinned in a single piece weighing over two tons. The 1,800 pound skull also was collected, along with the leg bones and the two tusks, each of ninety-six pounds' weight. Fénykövi wrote in 1956, "I have decided to let a big museum have him. There, reconstructed by their experts, he can stand in all the size and majesty he enjoyed in life-the biggest elephant ever shot by man." 'A larger specimen has since been reported.)

According to one story, Fénykövi first approached the British Museum (Natural History), but they de-

Building the manikin for the Fénykövi elephant in Hall 16, before the clay fell off, 1958. The entrance to the rotunda is behind the elephant. clined the specimen because they already had a group of elephants in the center hall. According to another story, a member of the American consular staff in Angola read about the animal's being killed and cabled the State Department, which informed the Smithsonian. Whatever the true story, the elephant arrived from the field. Although a truckload of salt had been dumped on the skin in the field to preserve it, the untanned hide reeked, and those who worked at the west loading dock, where it was stored for months, still remember it.

William L. Brown, the chief taxidermist, prepared an account of what was involved in mounting this elephant. It is worth quoting in full, for a similar procedure, although on a smaller scale, has been used for some of the mammal groups on display.

When the hide arrived at the Museum it was in one piece so it had to be cut into three parts for tanning. Then a wooden armature, two or three inches under life-size was so constructed as to be disassembled into three sections, head and neck, and two body halves. This supported the water clay used to make the life-size model. To support the armature four giant A-shaped trusses were made in order to take care of the heavy weight during construction. Because of the lack of humidity in the hall where the work was being done, a large plastic housing was built around the frame. Into this a steam line was inserted in order to maintain a high humidity, thus preventing any drying of the clay while modeling.

When the model was completed the hide was placed over it, adjusted, and worked on until every wrinkle was restored and a life-like appearance produced. After this, a plaster of paris mold, reinforced with sisal fiber, was made over each of the sections to hold the skin in exact position while the work proceeded. To strengthen each heavy plaster of paris mold, wooden beams were attached, to which hoists would be fastened later. At this stage the plastic housing was removed. 


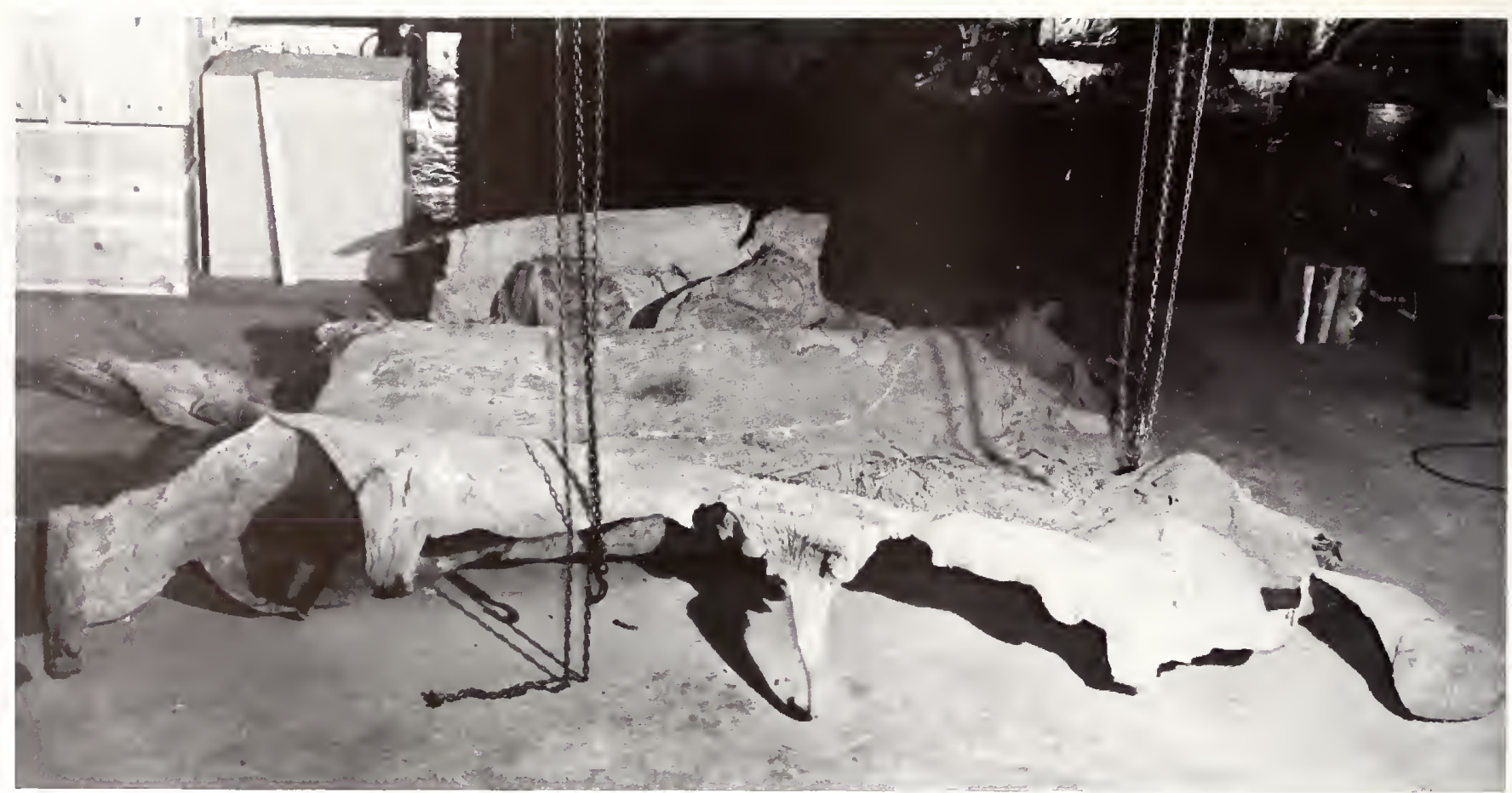

Taxidermy shop in Butler building, west court, with the Fengköne elephant skin on the floor. Probably 1958.

After this, each of the three sections was lowered to the floor by two two-ton hoists.

Then all inner armature, clay, wire, and so forth, were removed, leaving the elephant skin attached to the outside mold. When the skin had been thoroughly clemed, a layer of plaster of paris about $3 / 4$ inch thick was applied. This held the skin between two layers of plaster while drying. When thoroughty dry the inner coatting of plaster was carefully removed; three layers of burlap and two layers of ahmminum screenwire, each reinforced with papier mâché were laminated to the hide. This construction produced a thin manikin, very tough and durable, about $1 / 2$ inch thick.

Next, another internat armature of seasoned wooden ribs was built and fastened to the inside of the manikin for support. At this stage the outer wooden frame and plaster mold were removed.

After the molk was removed, the body halves were joined together from within by bolting. Papier mâché was then applied to the seams.

The head was treated the same as the two halves except for support. A wooden structure was made inside the head to hold a long beam from which the head would be supported when attached to the body. The tusks were inserted and the head was fastened to the body halves. After the seams had been sealed, the finishing touches, such as setting the eyes and restoring the color of the hide, were made. ${ }^{2}$

The elephant's blown-glass eyes were hand-painted, the legs were filled with sand, and the tusks were artificial- the originats weighed too much.

The mounting took about sixteen months and was done to the west of the rotunda in the Hatl of the Sea, which was closed for a number of years while the elephant and the whale were constructed. After most of the clay had been put on the manikin, the clay dried out and collapsed; it was only after that setback that the plastic tent and steam house were used. The taxidermists had to work in bathing suits because of the high humidity. When the elephant was moved into the rotunda, it cleared the door frame by one and one-half inches. For those who wonder how the head was attached, there is a trap door in the belly of the elephant, with the seams at folds in the skin where they cannot be seen.

There was a great deal more to the job on the elephant than just the mechanics. Neal Deaton, one of the taxidermists, also wrote an account, emphasizing the study that was done of living animals in zoos and of movies taken by hunting parties. "Selecting the final position came only after much deliberation and thought," he wrote. "There was some suspicion of an over-dramatic attitude, for fear it would cheapen the final effect and lessen its majestic quality. On the other hand, if the animal were mounted in a still position it might appear too statuesque. It was agreed to put the specimen in a fast walking shuffle, the head erect and slightly turned, scenting with its trunk. The ears were positioned to show their characteristic flapping motion. The position was planned to give an impressive picture of an active elephant in a somewhat suspicious attitude, displaying its massive bulk and strength." ${ }^{3}$ 
The Fénykövi elephant as decorated by the Women's

Committee of the Smithsonian Associates for a medieval Christmas, December 8 , 1978.

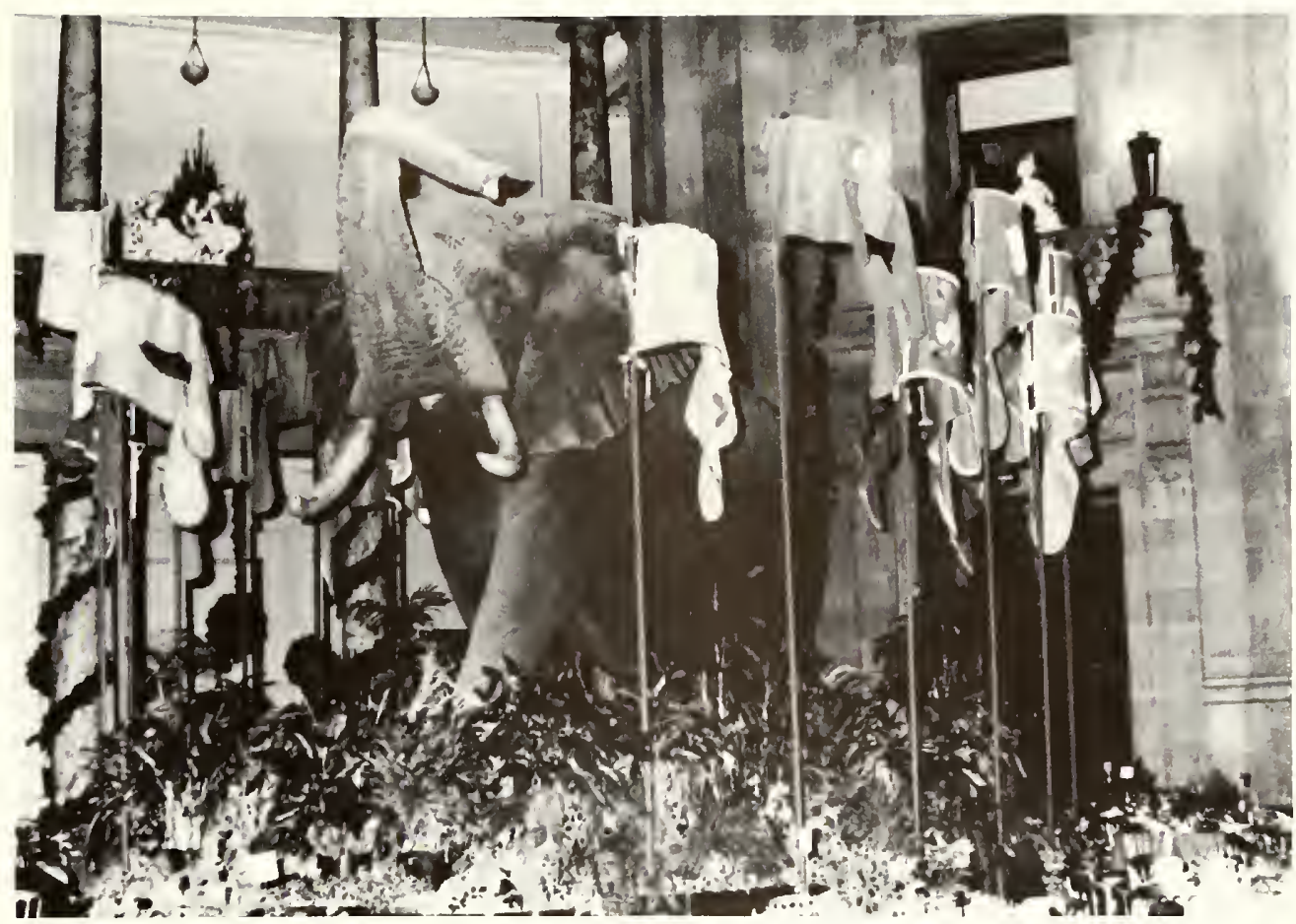

\section{Elephant Unveiled}

The elephant was unveiled in March 1959. Shortly thereafter, William L. Brown retired, leaving the animal to mark his career of almost half a century at the Museum, and Neat Deaton left to set up his own business. Frank Greenwelt remains as the only taxidermist who worked on the elephant-indeed, the only taxidermist left on the Museum staff. About twenty years afterward, Greenwell and his wife, Pat, spend six weeks repairing the skin. In 1983 Greenwell gave the elephant new fiberglass tusks made in the Exhibits Department model shop.

The platform around the elephant has been modified several times. For a few weeks a piece of elephant hide was placed on the railing so that tourists could feel it, but when the skin wore out it was not replaced, because the African elephant had become an endangered species. At one point the elephant was wired for sound, and trumpeting noises shook the dome every fifteen minutes; fortunately, this was discontinued. A recording about the elephant was added for those desiring more information than the label supplies. A skeleton of a pygmy elephant to place beside the big one was contracted for, but the skeleton turned out to be largely plaster reconstruction rather than authentic bone, and the contract was canceled.

The elephant is the subject of a couple of anecdotes that are part of the oral tradition of the Museum. As indicated, the animal is in a walking position with trunk and tail outstretched. No one will confirm it, but Secretary Carmichaet is supposect to have been so aghast at the sight of the large open anus that he issued orders

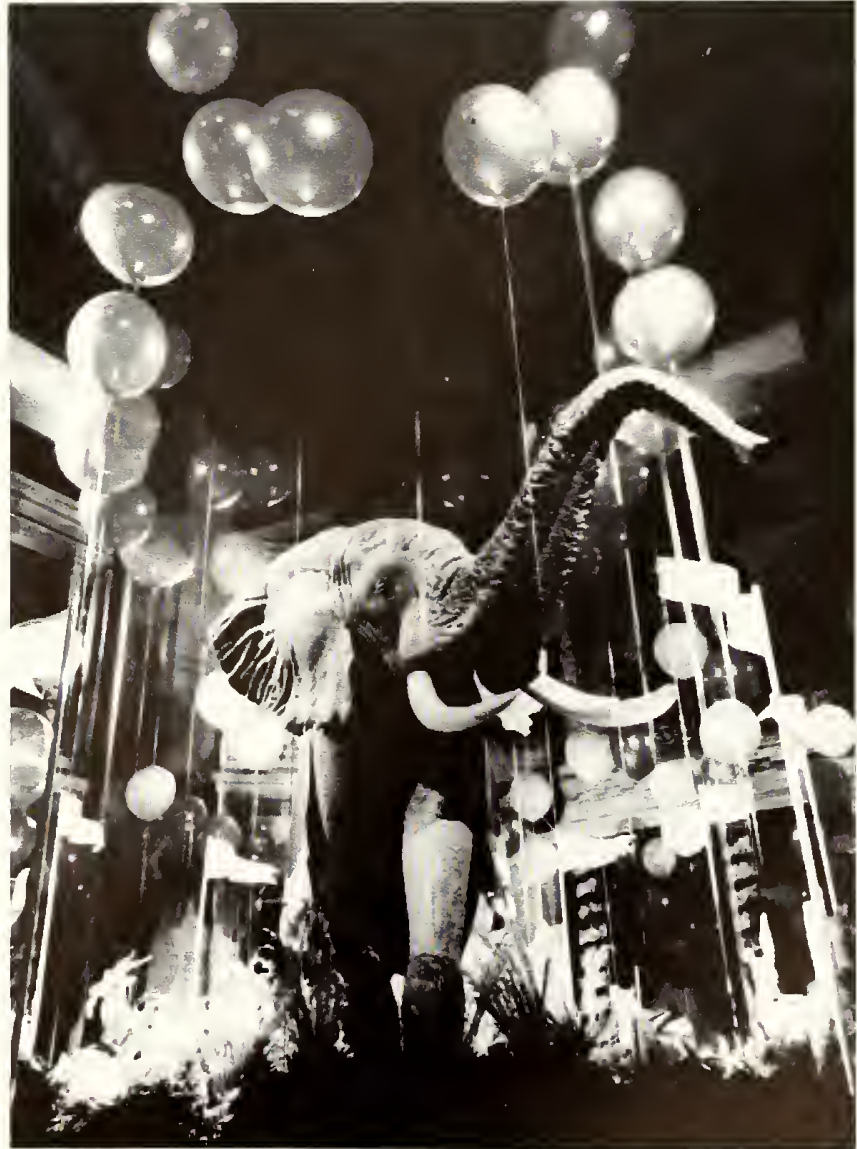

The elephant on December 14, 1979, when the Christmas dance of the Women's Committee had the theme of "Babar Visits America." 


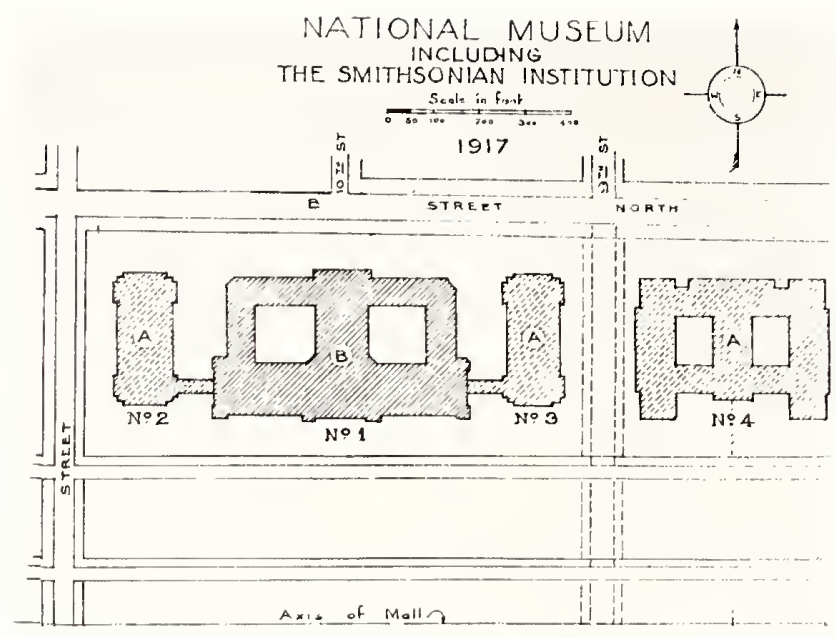

Proposal for wings to be added to the new National Museum; from Rathbun, 1918. The suggested building to the right is now the site of an ice-skating rink across from the National Archioes.

Lor it to be sewn up. The comments attributed to Assistant Secretary Kellogy are umprintable. It is a fact that when Porter Kier became director, he had taxidermists check into unsewing the elephant. After studying and photographing some elephants in the zoo, they reported that the African elephant's ants is hidden by skin wrinkles except when actually in use.

On April 1, 1960, an elephant-sized pile of dung was discovered under the animal shorty before the Museum opened for the day. There was considerable agitation, componnded when the laborer deaning up with shovel and broom objected to pictures. When the fuss was all over, the dung turned out to be a superb modeling job lone in clay by a member of the exhibits staff. The administration never considered this a humorous event and spent a long time trying to track down the model maker

It was coincidental that the dedication of the elephant occurred half a centurv after the building first opened. No one mentioned the timing at the dedication ceremonx. In 1966, for the celebration of the 200th anniversary of the birth of James Smithson, banners were designed for each of the Institution's bureaus; the one for the Museum of Natural History featured an elephant. The Museum's letterhead, more austerely, has stayed with a drawing of the dome.

\section{East and West Wings}

The east and west wings, the largest structural development of the building itself since the rotunda dome was completed, had existed in theory for over forty vears. In 1918 Rathbun gave his opinion that the greatest need of the Smithsonian Institution was a building for industrial arts and American history, and that this building should be followed by construction of a separate National Gallery of Art. He thought, nevertheless, that wings for the Museum ought to be started promptly. ${ }^{4}$

By the mid-1920s, Holmes had created considerable momentum toward a National Gallery of Art building. While this was still far from materializing, Wetmore in 1928 built on hopes for the gallery in campaigning for additional space for natural history. He wrote in the Annual Report:

The ultimate construction of a National Gallery of Art to which the art collections will be removed will free a certain amount of space in the Natural History Building, but that area will be automatically absorbed by the natural history exhibits retired to make room for art, and will not afford necessary relief. There should be added to the Natural History Building two wings, one on the east and one on the west, in accordance with the original plan of the architect for this structure. These, with the same height as the present buikling will give needed space for the tremendoush valuable research collections and will relieve crowded laboratories, which in the division of insects, for example, have become almost intolerable. ... [I]n some instances at present four persons depend upon the light from a single window for illumination for work requiring delicate examination, frequently uncler the microscope. The additional floor space would also afford a more logical arrangement of exhibits, a remodeling of many in more modern form, which cannot be attempted at present, and a relief from the present crowding, which is often tiring and confusing to the visitor. ${ }^{5}$

(It is ironic that Wetmore used the Division of Insects as an example; thirty-five years later, when the wings finally were completed, the entomologists still had the least satisfactory office space.)

Exactly the same words were repeated the following year in the Anmual Report on the Museum. Perhaps these words were reat on the Hill, or possibly the grave problems of slippage of the keystones of the rotunda arches (discussed in Chapter 21) focused attention on the building. A bill was introduced in Congress to authorize the wings, and to bring home its necessity, Secretary Abbot declared the building "as crowded as a woman traveler's trunk."

Whatever was the catalyst, "the Smoot-Elliott bill authorizing the extension of the Natural History Building .. was passed without a dissenting vote. The bill was approved by the president on June 19, 1930. Under this authorization it is planned to add to the present building so that it will extend from Ninth to Twelfth Street, in general duplicating the present structure, where the ground floor and third floor are given over to offices and laboratories and the two intermediate floors are devoted to exhibits." This concept of the wings as providing a major addition to the exhibit area was quite 


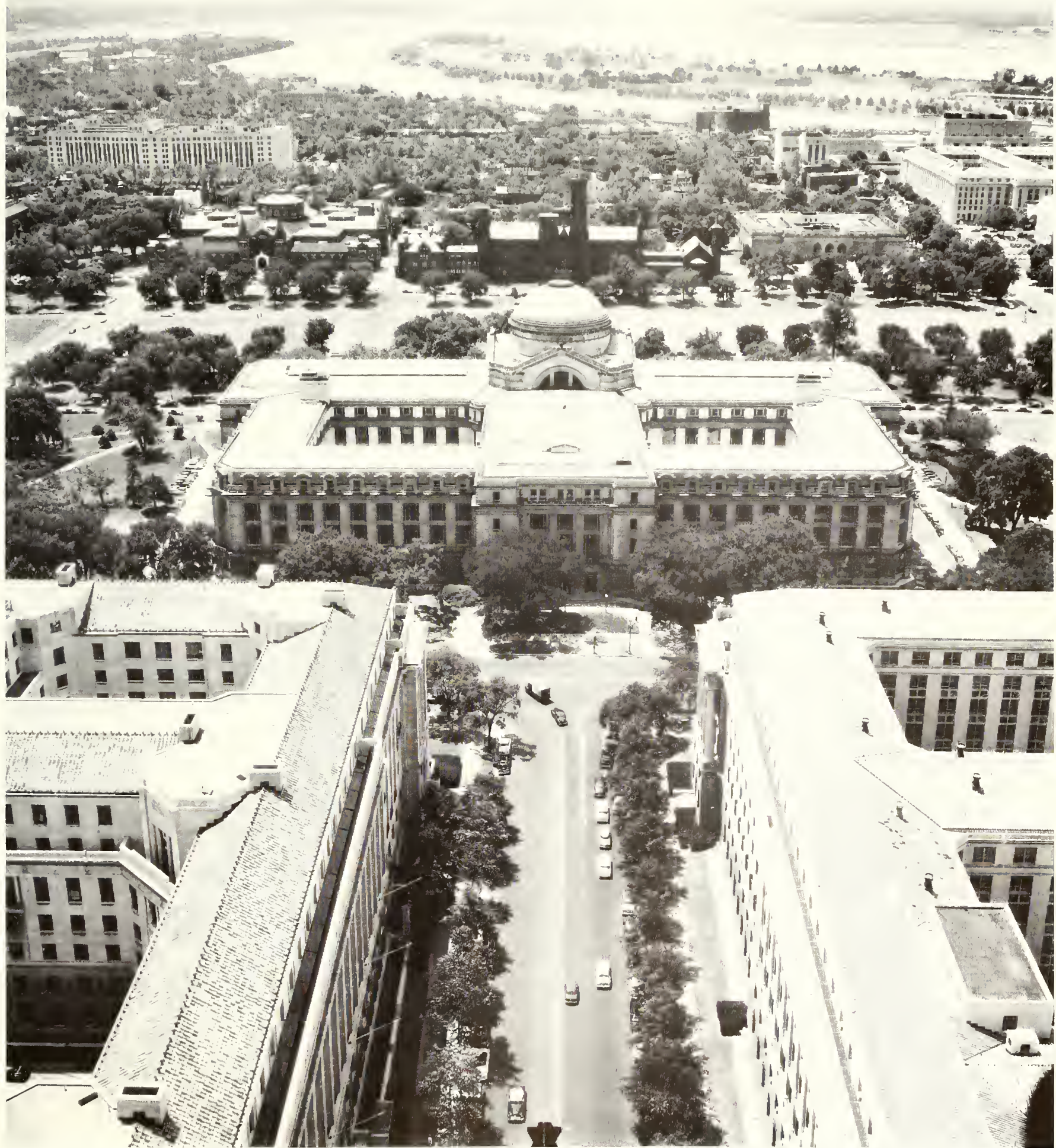

Aerial view looking south down Tenth Street, showing small parks on either side of the building, where the wings now stand. The projections on the south side, at the corner of each court, house the freight elevators. In the background are the Freer Gallery to the right of the Castle and the Arts and Industries Building to the left. Hams Point is in the distance, and National Airporl, across the river, is not particularly busy. The automobiles suggest a date in the early $1950 \mathrm{~s}$. 


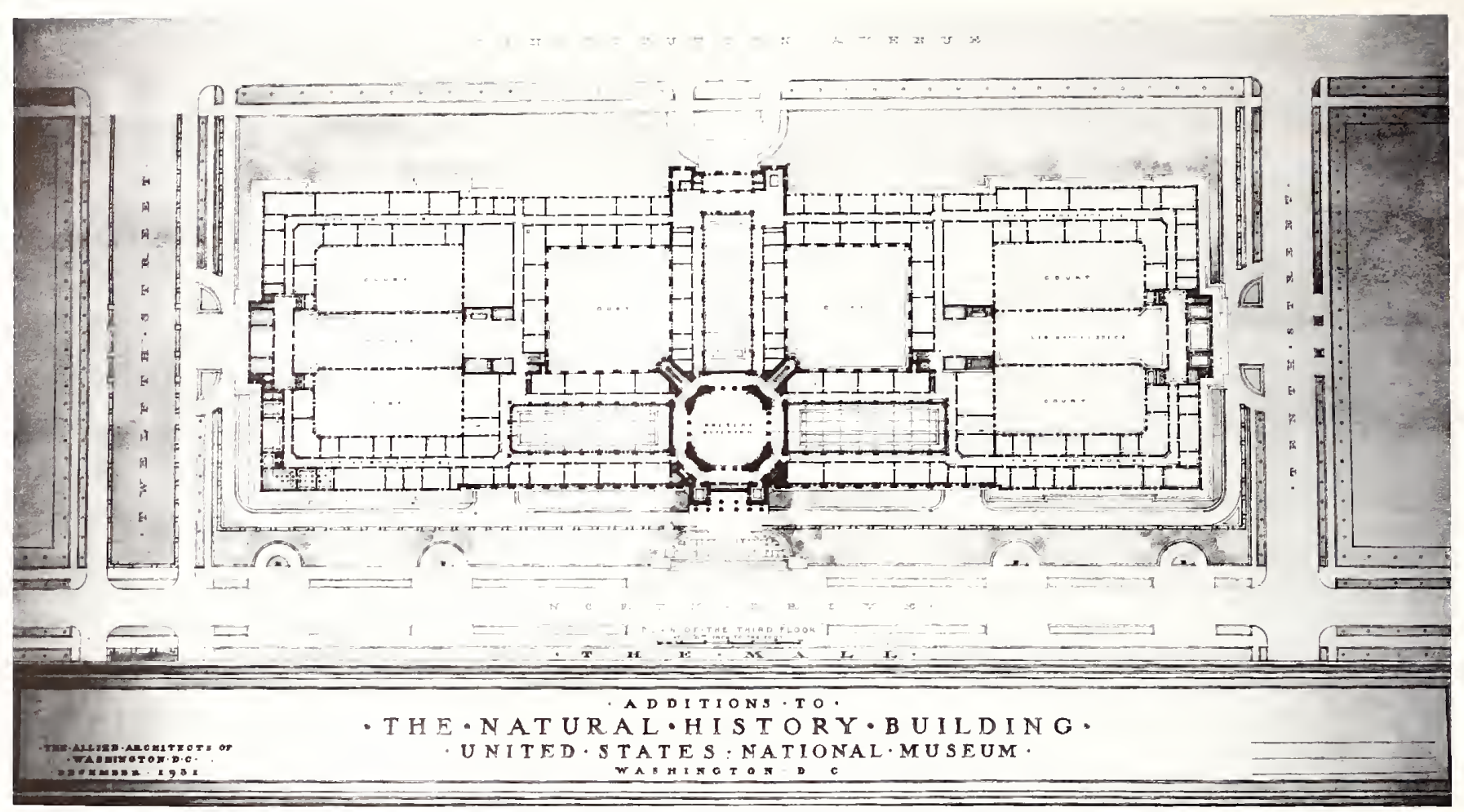

A 1931 architectural sketch for the tu'o wings, showing duat courts in each. The architects mislabeled Ninth Street, to the east of the building; the former $B$ Street to the north has become Constitution Avenue.

different from the offices and storage that were eventually constructed.

After the aluthorization for the wings was given, architectural sketches were prepared, and the staff offered suggestions. Hrdlička submitted a plan for an elaborate hall of physical anthropology; Wetmore had practical icleas about elevators, checking facilities, and stairways for this proposed new space. ${ }^{8}$ But those familiar with the methods of Congress know the relationship of that slippery duo "authorize" and "appropriate." Nothing may be clone unless it is authorized. However, even if permission to perform a particular action is given, nothing happens until money is granted. Ten thousand dollars for planning was appropriated in fiscal year 1931, and then momentum toward the wings stopped. The Ammual Report of the Museum delivered regular statements on the continually increasing need for space, but because of the Great Depression and then World War Il, nothing happened. For years the senior botanist, Conrad Morton, remarked that he would have wings before the building did.

\section{James Bradley to the Rescue}

The next key person in this account was James C. Bradley, first listed in the Annual Report for fiscal year 1959 as an assistant to Secretary Carmichael; Bradley later became an assistant secretary and finally under secretary. One of his first acts in his new position was to read the authorization bill passed years earlier. He noted how little other Smithsonian administrators at the time seemed to know of overall Congressional process. The authorization for construction had been given in 1930 with the proviso that the cost not exceed $\$ 6,500,000-$ which, incidentally, was nearly twice the cost of the original building.

Having digested the bill, Bradley called the General Services Administration and was advised that Congressional authorization would not have to be renewed if it could be shown that the new cost estimate was commensurate with the first, given the normal inflation that had occurred over the intervening years. Next Bradley went to Arnold Spaatz, a retired Air Force general who headed the Office of Management and Budget. Spaatz would have liked to help the Smithsonian, but the construction estimate of $\$ 19,000,000$ for both wings was just too high. Bradley then suggested that the construction start out with one wing. Spaatz agreed, and in May 1960 Congress appropriated a sum that was expected to cover the renovating and airconditioning of the existing building, plus the construction of the east wing. When construction finally began, the addition had overall dimensions of 190 by 180 feet and consisted of a basement, ground floor, and six upper floors.

Mills, Petticourt, and Mills of Washington, D.C., were the architects for both wings. The George Hyman Construction Company did a rapid job on the east wing, and finished the building faster than had been anticipated. Its bid for the east wing was actually lower than budgeted for. With these savings in the kitty, the Smithsonian requested and received an additional $\$ 4,336,000$ 
West wing and west side of the National Musenm of Natural History, looking east from the roof of the National Museum of American History, April 1984. The flagpole is to the left, on the north wing. The west-side loading dock and entrance to the mail room are in the parking lot on the lower right.

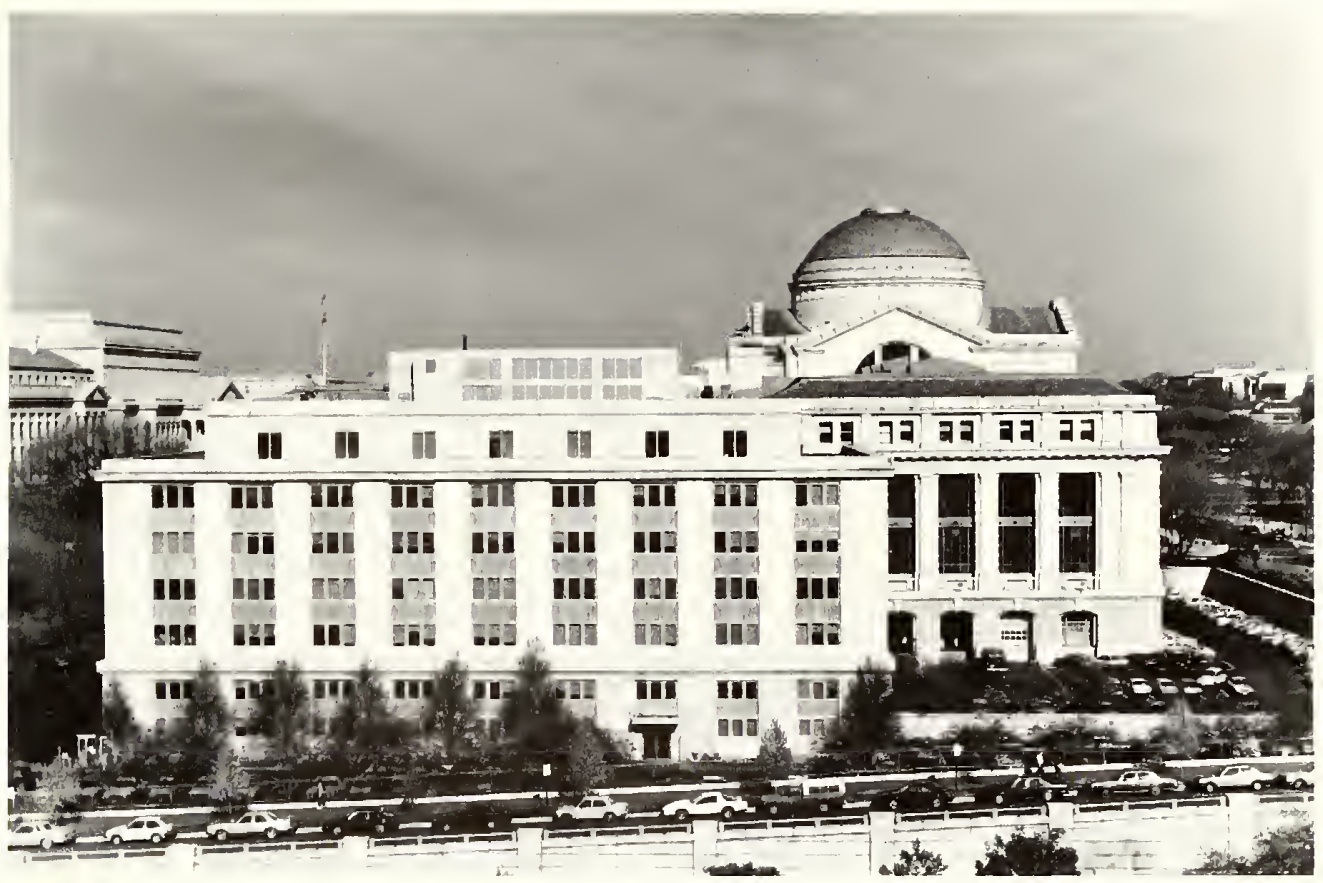

for the west wing, though no one can say exactly what each wing cost. Hyman Construction bicl on the west wing and was also awarded that contract. This was a lucky break for both the Institution and the company, since the same blueprints could be used; all the engineers had to do was reverse them. Mirror images often confuse people, and some of the staff who spent much of their time in one wing get lost when they venture into the other. The differences between the wings are minor. A different company supplied passenger elevators for the west wing, and whereas the east wing has mostly soapstone work sinks in each office, the west wing has mostly small porcelain hand basins.

Each wing was supposed to add 259,903 square feet to the building - a precise enough number to satisfy any bean-counter, though each time the wings are mentioned officially, a slightly different figure is given. Rathbun had estimated that the main building had 158,989 square feet for laboratories and collections, and 75,856 for all other nonpublic purposes. The wings almost doubled the laboratory and storage space, as the new National Museum had done half a century earlier.

"The general arrangement of each floor in the new wings is essentially standardized," ran a 1962 report. "There will be a central area for the appropriate reference collection, surrounded on the three outside walls of the wing by a series of workrooms and laboratories. ... All such rooms will have excellent daylight and will contain the facilities needed for the intended use as designated by members of the scientific staff, who in each case have designed the details of their own areas. On the average, each floor will have between 20 and 30 workrooms or laboratories, and each division will center its activities with a well-demarcated area."

\section{Lost Storage Space}

Fairly early in the planning, the curators thought that the support pillars would be one foot square. Instead, the piltars turned out to be round and nearly three feet in diameter. As a consequence, about 10 percent of the central space anticipated for storage cases was lost. Also, the Fine Arts Commission required that the top floor be set back, which pared the floor space in each completed wing to 209.000 square feet.

The architects did a good job on the exterior design in matching the wing to the old building, from which it is set back a few feet on the north side. At the lower level the granite has the same hue, but the surface is not so strongly rusticated as in the main structure. Unlike the ten-inch-thick granite of the main buitding, the stone of the wings is a veneer. The metal-framed windows pivot to open, and are placed in groups of three. These window groups are about as wide as the window openings in the main building. Rectangular metal pieces of the same color as the window frames and above each window add to the illusion of long windows, as in the main building. Because the top floor is set back behind a parapet, the windows there do not contrast with the prominent stone molding around the windows on the third floor of the main building. The freight elevator does not run to the sixth floor because the Fine Arts Commission juckged that its extension above the sixth floor woukl give an unacceptable appearance to the roof line.

At the east and west cnds of the wings there are double doors, locked except during fire drills. On the north side, sidewalks lead from Constitution Avenue to an entryway and lobby. During the first few months of occupancy these doors were open in the east wing, 
but because this required an additional guard, they were closed and have not been reopened. The doors in the west wing never have been used.

On the interior, the ground floor and the second, fourth, and sixth floors connect to the main building. The north side of each lobby contains two automatic elevators; each wing has one stairwell adjacent to the elevators and another near its south corner. Freight elevators on the south side of each wing open into both the wing and the main building. Every floor has two sets of toilets. Except for the polished limestone in the lobbies, never seen by the public, the wings are utilitarian.

Remington Kellogg, then director, insisted that the curators personally lay out and design office space, and this took a lot of time. Cooper drew the plumbing and sinks on the outside walls, as they had been in the main building, and was told to do it over because the plumbing had to be on interior walls. He grumbled, but redesigned. Fortunately tor everyone, Cooper had read the specitications of the General Services Administration and pointed out that these quarters were to be laboratories, not offices; an office is rather rigidly defined in terms of square feet, whereas a laboratory is not. Had the term "office" been used further in official correspondence, evervhing would have had to be changed. Parts of the west wing have much less space for the individual scientist because they are offices.

\section{Work Gets Under Way}

As with the original building, construction began on the east side. There was no ground-breaking ceremony; the contractor began work as early as he could in 1961. Shortly after the lirst buthlozer appeared to dig the foundation, the heary equipment broke into Tiber Creek. This creek had meandered across the swamp of the pre-Mall era to the barge canal that flowed where Constitution Avenue is now. Decades earlier, Tiber Creek had been enclosed in a massive brick tumnel and buried about wenty feet underground. Now it ran across the corner of the building site, so it was dug up, moved, and again sealed away from view, this time in concrete. Because there was some movement in the foundation of the main building, heavy collections of fossil plants were immediately moved from the east north range into the first story of the new wing, even before the walls were up. Later the plants were moved again, to the fourth floor of the wing.

Only one or two people on the ground floor lost their offices, and the vertebrate paleontology laboratory was able to continue work, despite the disappearance of all its windows. The breaking down of walls uncovered swarms of albino cockroaches, and one staff member remembers how eagerly the entomologists stalked these unusual specimens. Many people were temporarily inconvenienced by the noise and dust, but the work progressed rapidly. By wintertime, construction had reached the level of the third floor of the main Museum building. Several offices in the east range had to be sacrificed, and the construction crews hung canvas over the openings they had broken in the wall. One day it was so cold that ice formed in the sinks in adjacent offices.

The east wing had acres of cement flooring that remained vacant for weeks. After the cases were brought in, gray tile was laid around the perimeter and brown tile in the aisles between the cases. Every time a case is moved-admittedly a rare event-the bare cement floor is exposed, and tile that does not match either color has to be laid. The contractors did learn, however, and the floors of the west wing were tiled in one color, before the collections moved in. Raised phone jacks and electrical outlets put in the middle of the floor had been found objectionable in the east wing, yet the same design was used in the west wing.

\section{Moving into the East Wing}

By the end of June 1962, the east wing was nearly done-plastered on the inside and finished on the outside, except for some miscellaneous caulking and cleaning. On August 16, the new occupants began to move in. Nicholas Hotton believes that he was the first to establish an office in the new wing; he was on the north side of the first floor with the other vertebrate paleontologists.

The move itself went extremely well, and though it was hard physical work and the whole process took about six months, everyone who participated recalls the time with pleasure. Curators lugged cases along with workmen. Not a single drawer was dropped. One of the items that sticks in the memory was moving some cases of Geological Survey fossils in the third-floor hall and uncovering a door that had been hidden for decades. On it was lettered the name of E. O. Ulrich, then dead for twenty years. One social event was a party given by S. H. Manay to dedicate the paleobotanical library, in which he installed the painting Death Preferred. A lot of people marveled at all the empty space in the new wing. Cooper, ever the realist, is reported to have said, "It won't last long."

According to plan, the east wing was to accommodate the Division of Birds on the top floor, the Division of Mollusks on a large part of the fifth floor, and "practically all the functions of the Department of Geology and the activities associated with it" on the remaining four and one-half floors. ${ }^{10}$ This basic layout was not followed entirely, for the anthropologists were given about one-third of the fifth floor for a storage area. As a consequence, Tertiary fossils had to be distributed beween the fourth floor and the basement.

The basement was designed for indoor parking, and for about fifteen months many employees lived in the lap of luxury. It soon became obvious that the wing was full, and the cars were pushed out to make room for collections and some of the shops. The entrance to the 


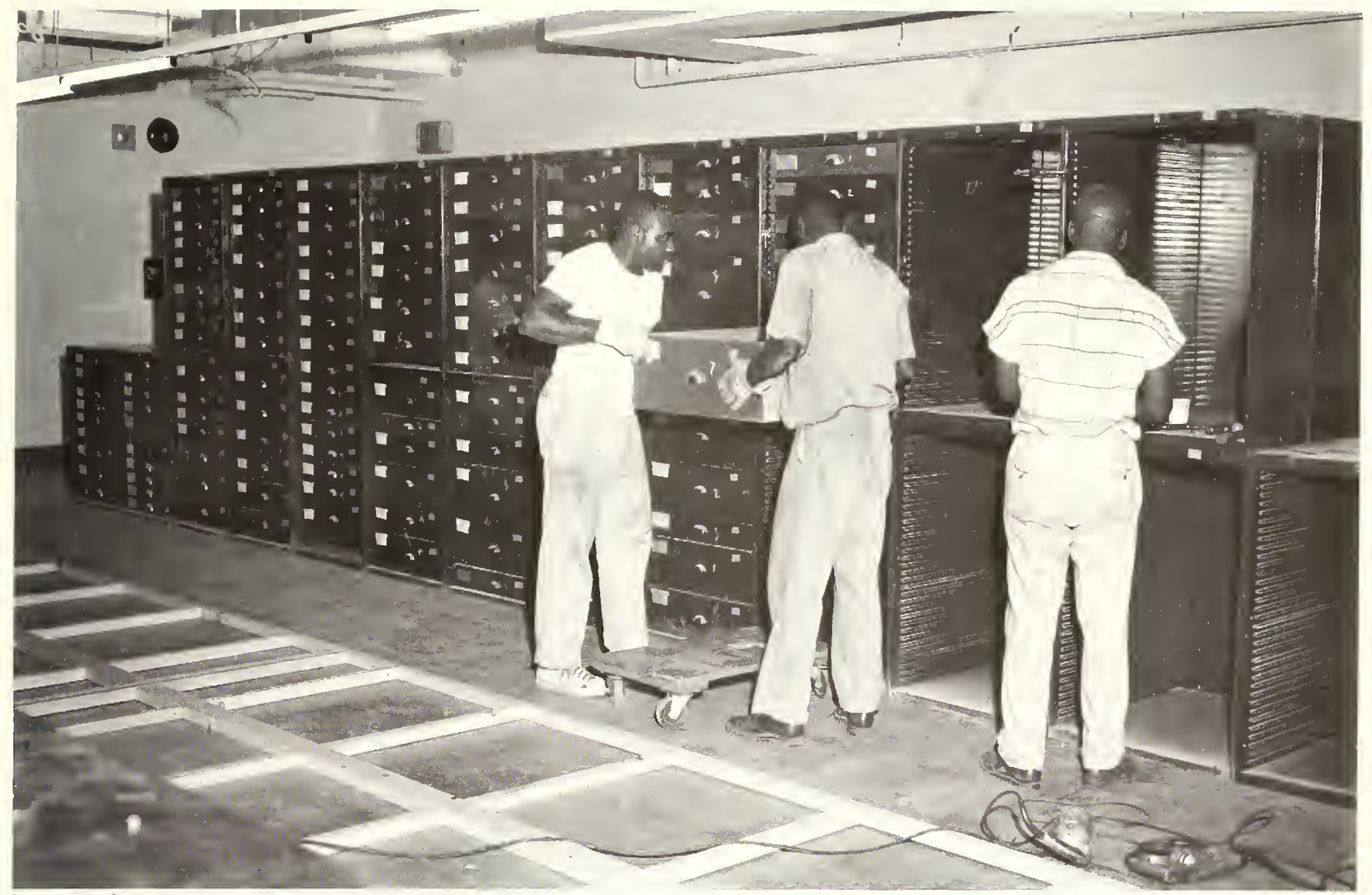

Moving drawers of fossil invertebrates into the east wing, 1962.

basement was too low to admit a large truck, and twenty years later, when the fossils were being moved to the new Silver Hill facility, this architectural oversight led to strong words.

\section{The Arrival of Air Conditioning}

Air conditioning came in with the new wing. Old-timers hailed it as a momentours break with the past, and Frank Taylor, then director of the United States National Museum, produced a nice homily on the occasion: "Visiting the Museum is now much more pleasant for the hundreds of thousands of summer visitors, who as a result, are induced to stay longer and absorb more of the instruction and inspiration that exhibits provide."11

But air conditioning was a new concept for the Museum, and the engineers could not get it to work properly. When members of the staff managed to contrive keys to open the pivoting winclows, the captain of the guards announced under orders that when rounds were made, "every damn window in the wing has got to be closed." An anonymous voice from the rear mentioned that Dr. Kellogg liked his winctow open, and the order was modified to, "Well, every other damn window in the wing has got to be closed." Despite perennial problems, the climate control eventually got somewhat better, but the north side of the building is atways too cold and the south side is always too warm.
During the early days in the east wing, the cleaning force could not cope with the extra work. One day a memoranchum from "Buildings Maintenance" appeared under every door, indicating how difficult it was for the cleaning staff to keep ahead of the sloventy scientists. It further noted that henceforth all scientists were expected to clean their own offices and that brooms woukl be placed on each floor. The scientists were incensed, and when the building superintendent found out about it he was incensed, and sent someone around to collect all copies of the spurious memo. Porter Kier still has the original copy he wrote.

\section{Entomologists Move Out}

There were many more scientists along the west sicle of the builcling than along the east sicle. The largest group was the entomologists in Hall 27 on the second floor. In 1962, when space was needed for construction of the west wing and renovation of the main building, they volunteered to move to the Bergman Latundry building in northwest Washington for what was supposed to be a couple of years, but turned out to be nearly a decade.

The contract for the new construction was signed in August 1963, and the digging began in November. Once again the work went quickly, and by the end of June 
1964 most of the west wing's granite facing was in place. During the latter stages of construction, a workman standing on some boards in the elevator shaft fell to his death when the boards broke. It was the only fatality associated with the building of the wings.

Renovation of the original building was going on at the same time. On the second floor near the south west corner, Waldo Schmitt, by then officially retired, occupied a mezzanine office that he had loaded with quite a lot of junk. When an opening was made on the side of the building, the decking began to sag, and the construction crew had to prop up the deck with timbers. Carolyn Gast, an artist for Invertebrate Zoology who had the office below Schmitt's, made a sign for the area: "The little city of Gustingdust. Population ten." The building manager saw this one day and tore it up. Gast then made a series of signs in Greek, Russian, Hebrew, Japanese, and a variety of other languages, expressing the resident scientists' opinion of the building manager. One day the building manager came through with a subcontractor who translated the Hebrew, but the signs stayed "1) anyway.

As with the east wing, construction on the west side was completed with no unanticipated problems, and by mid-1964 part of the wing was occupied. The scheme for the west wing-before the ground was broken, at least - was that it should "house the Division of Fishes on its ground floor, the Division of Marine Invertebrates on its first and much of its second floor, the Division of Reptiles and Amphibians on the rest of the second thoor, the entire Department of Botany on the third and fourth floors, and the Division of Insects on the lifth and sixth floors, a portion of which will also provide some storage space tor the Division of Mammals, which otherwise will occupy the adjacent top floor of the west pant of the adjacent building.,"12

\section{Moving into West Wing}

The Division of Fishes was lirst into the wing, with Leonard Schultz overseeing the move. Ernest Lachner employed a dozen high school students to help the Smithsonian labor force, and had the other curators and Fish and Wildlife biologists stationed at strategic places. A quarter of a million jars, totaling several million specimens, were moved in a month without a single jar being broken.

The visitors book of the Division of Reptiles and Amphibians, kept by Doris Cochran, records that there was a visiting scientist working in the old quarters in the main building on January 8, 1965. By January 26 , the next visitor was working in the new facility, on the first floor of the west wing.

The moving of Botany to the fourth and fifth floors (rather than the third and fourth) was more complicated. One of the gothic windows in the Castle was removed and a temporary elevator built outside to window level. The curators and laborers would move a long herbarium case up a ramp to the window, and then it would go down the elevator to a truck; the cases were too large to be taken down the stairway. Plans had been made to bring the National Fungi Collection to the Museum at the time of the move, but the then-new chairman of Botany, William L. Stern, decided against this, for it would have used up all the badly needed expansion room. One botanist recalls that he warned the director of the Museum there would be insufficient floor space, even without the fungi. He pointed out that on the balcony in the herbarium within the Castle, cases were stored three high, but in the new wings they could be stored only two high. Though he was assured that his fears were unfounded, the storage space that was to last for thirty years was filled in ten.

Much of the storage in the west wing is of wet specimens in bottles and jars. These alcoholic specimens were placed in large, closed-off interior rooms, considerably reducing the danger of fire. The curators had urged that there be positive air pressure in these rooms to help keep out dust, but the system was not up to this. Still, the new space for all the jars was a great gain, and allowed the collections to be properly organized for the first time in fifty years. Had the ceilings been just a few inches higher on most floors, an extra tier of cases could have been fitted in, affording about 30 percent more storage space.

The invertebrate zoologists filled their storage space with twelve-inch-wide shelving and needed more, so they were given room for additional wet storage on the third floor. The Division of Paleobotany, which also needed more space, was assigned to new quarters in the west wing. "For the first time, the entire paleobotanical collections of the Museum and those of the U.S. Geological Survey housed in the museum [were] located in a single area." 13

Only the sixth floor remained to be filled. Part of this was already designated for wet storage of mammals, but there were some vacant offices-later used by Entomology-and the mammalogists moved into them. After the renovation of the main building, they had moved from the ground floor to the west north range, and this was a logical extension of their territory.

Meanwhile, back in the main building, the groundfloor fur vault, which had been displaced by the doorway leading into the west wing, was moved down the west range a few feet. The National Anthropological Archives moved from the Castle to the ground floor on the west side of the range adjacent to the wing. The fisheries staff from the Department of Commerce moved into offices on the east side of that range and the south side of the west north range, all facing into the courtyard. The library got the area facing Constitution Avenue that the Division of Mammals had vacated, and improved the existing decking. The rearrangements on the ground floor were to everyone's satisfaction, unlike the shufflings higher up in the new wing. 
Construction of the east wing at fourth-floor tewel, 1961.

Ninth Street then went across the Mall, not under it. In. the distance, to the east, is the Army Medical Museum, now the site of the IIirshhorn Museum. A photograph of the east wing with all floors completed appears in the Annual Report for 1962.

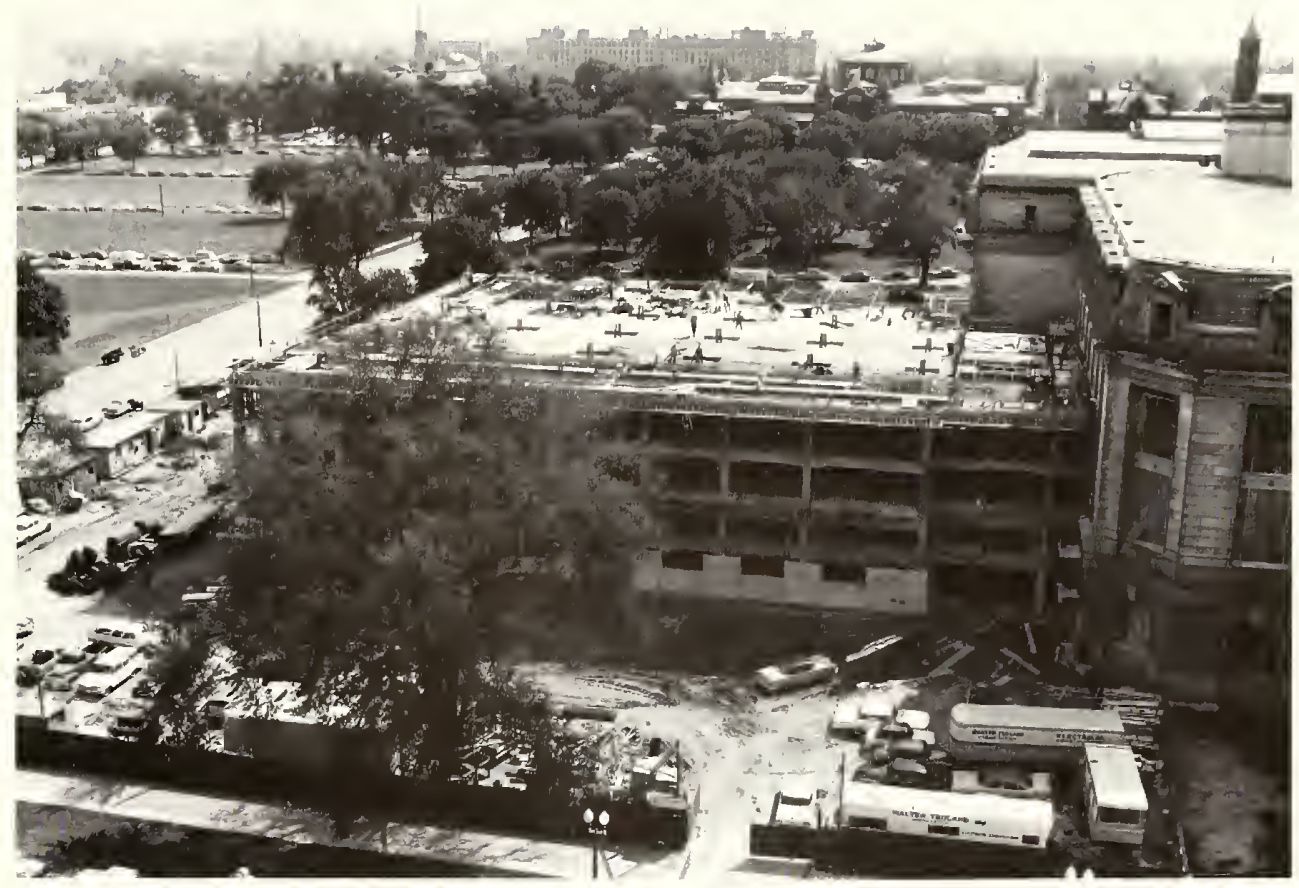

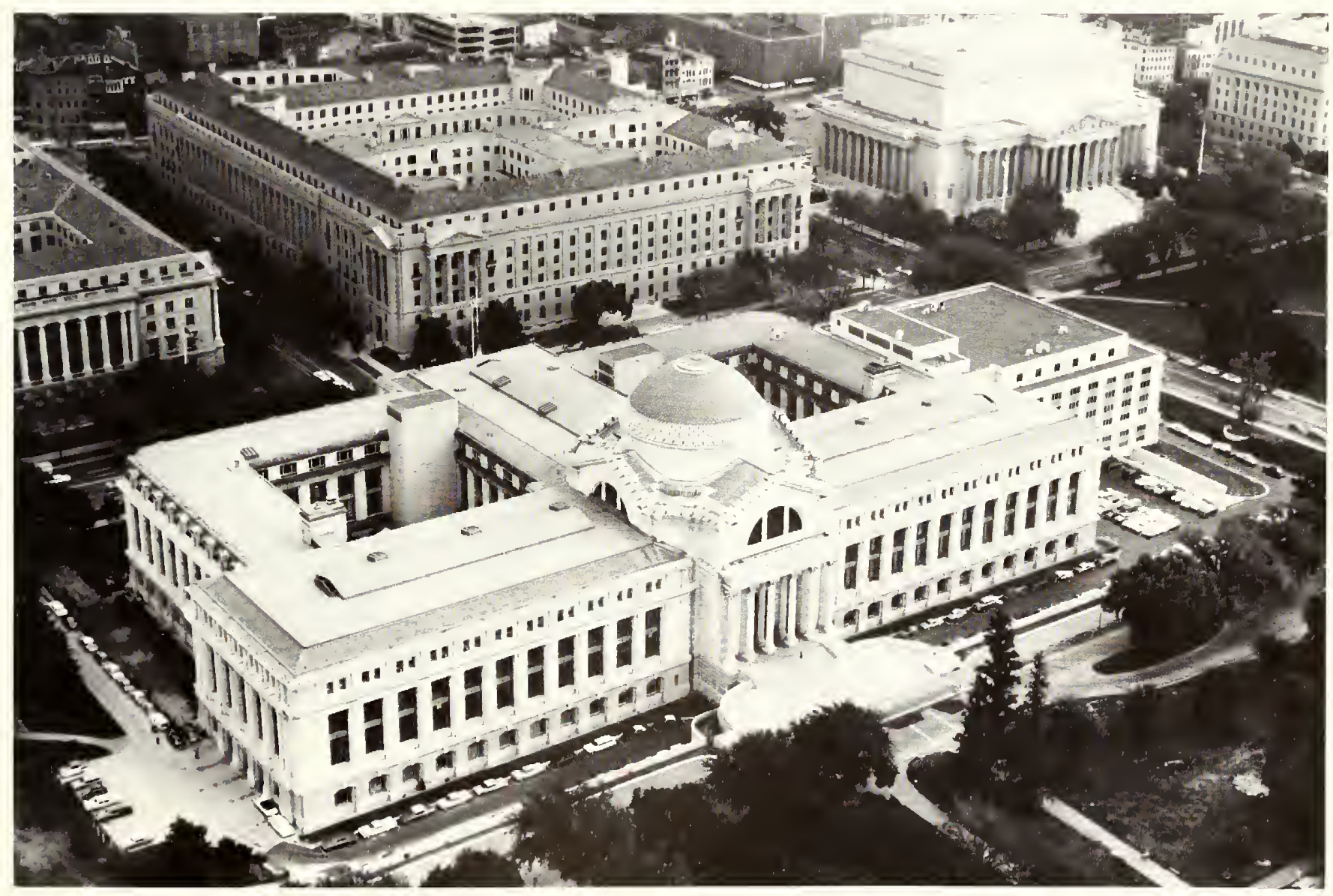

Aerial view looking north-northeast at the building with east wing attached, showing the setting-back of the sixth floor of the wing and the small-machinery building, for air conditioning, on top of that. The main air intakes are in the north corner of each court. On the north side of
Constitution Avemue are the National Archioses, to the right, and the Department of Justice, to the left. This photograph and several illustrations from ground level were published in the Annual Report for 1963 


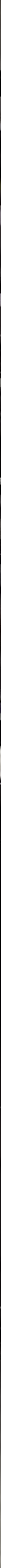




\section{Big Science: \\ Deep Space,

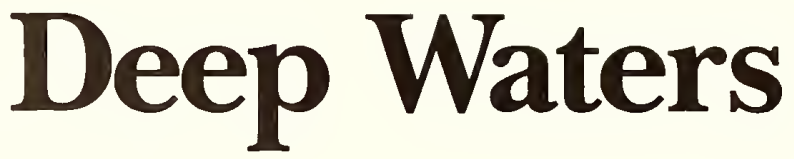

$\mathrm{E}$ VERYONE AGREES THAT THE postwar science bOOM in America began with the Russian launching of the first man-made satellite late in 1957. This satellite was one of the Soviet contributions to the International Geophysical Year, an eighteen-month, major investigation of the physics of the earth. For the first time since the end of World War II, the United States was in second place, and federal funds were poured into several branches of science.

The immediate result of Sputnik was a tremendous surge of interest in outer space-specifically, in what happened to an object when it came from space through the atmosphere to the earth's surface. Years before, Edward Henderson had been chided by Wetmore for spending his time only on meteorites. Suddenly it was realized that a meteorite is a space probe that has landed on earth, and everyone came to Henderson's office to find out about meteorites. Government agencies pressed money on him, awakening some of the staff to the possibility that the government might be interested in what the Museum could contribute to various other scientific programs.

With the increasing emphasis on outer space aimed at landing a man on the moon, the Apollo program had a direct impact on growth at the Museum. The National Aeronautics and Space Administration recognized the merit in detailed study of the Museum's large meteorite collection, and they agreed to purchase an electron probe and maintain it for three years, after which the Museum would be responsible for costs. This agreement led to the hiring of four additional people in Mineral Sciences and nearly doubled the professional staff of the department.

Kurt Fredrikkson seated by the electron probe on the fourth floor of the east wing, 1967. The probe itself is near the circular pillar that protrudes into the room; the rest of the equipment serves to detect and record. Charles Fiori, in the background, makes adjustments on the machine. The probe has been replaced by a later model and moved to an adjacent room.
The International Geophysical Year focused attention on Antarctica, and resulted in the establishment of permanent American stations on that continent. At the age of seventy-five, Schmitt went on an icebreaker cruise to investigate sites, and with virtually no equipment on hand, cajoled the ship's company into helping him make one of the largest collections of marine invertebrates ever obtained from the region.

\section{Expansion in Biology}

When it became clear that the International Geophysical Year was going to be a success, a group of biologists conceived the idea of an International Biological Program, to begin in the $1960 \mathrm{~s}$. Although this did not generate as much excitement or money, it was another step forward for "big science." Under this program, Setzer ran a major project for collecting small mammals, with field men working throughout Africa and the Middle East. At about the same time, the Pacific Ocean Biological Survey Project, supported by the Department of Defense, studied bird distribution and migration. Both programs added many specimens to the collections, but they were supported by grants and contracts-"soft money"-and with one or two exceptions, did not lead to permanent staff increases. The Office of Naval Research funcled some studies of sharks and shark attacks, again on a contract basis.

The atomic age, and particularly the development of the hydrogen bomb a few years before sputnik, indirectly stimulated expansion at the Museum, curiously enough in biology. Museum scientists had collected marine organisms at Bikini Atoll in 1947 and 1948, before and after atomic bombs were tested. With the hydrogen bomb experiments at Eniwetok Atoll during the early $1950 \mathrm{~s}$, it was even more critical to sample the biota. Travel money and funds for supplies and temporary assistants came to the Institution. The Atomic Energy Commission provided funds to build some decking on the south side of the ground floor of the main building; this was the first new space added inside the building since the decking of the 1930s. Some of it was used as offices for contract research associates. 


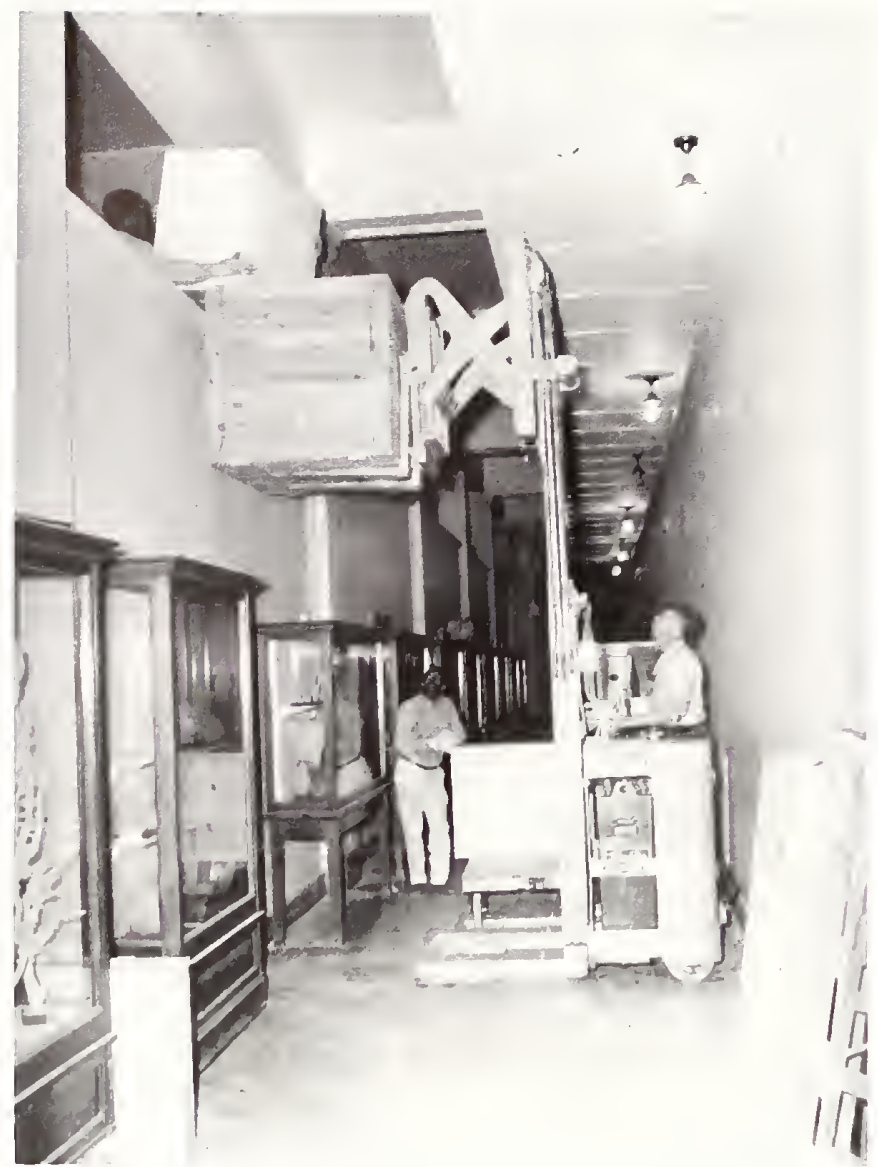

Moring insed cases from the deck on the west range, second floor (Ilall 27), 1962, aflet this Hall of Imerlebrales was comverted inlo offices for entomologists.

\section{Changes in Zoology}

Administrative dranges were taking place in the Department of Zoology. When Friedmann, who had succeeded Schmitt, retired in 1961, Fenner Chace served as acting head for a vear before stepping down to become the first Senior Scientist in the Museum. He was followed by Horton Hobbs, Jr., a specialist on freshwater crustaceans. Hobbs was the first scientist hired from outside the Museum specifically to be a department head. Promotion from inside, slow as it was, was no longer an antomatic event-a tremendous break with tradition.

Another big change within Zoology concerned the entomologists. The site they had been moved to in 1962 was the former rug-cleaning department of Bergman's Laundry, just off Georgia Avenue on Lamont Street in northwest Washington, about a mile from the Museum. The building was spartan but adequate, and because of the kind of operation that had been run there, floors were sturdy. There were no internal partitions, but the entomologists were experienced in building office walls from specimen cases. The move of specimens and peo- ple went fairly smoothly, and several people recall George Steyskal of the Department of Agriculture driving his car into the freight elevator, driving it off, and unloading directly onto his new desk. The entomologists had 55,000 square feet of space. For the first time they were able to get their collections in order and to have offices fairly close to one another.

This new space, as they had hoped, provided the opportunity for growth. On July 1, 1963, the Division of Insects was split off as the Department of Entomology, and J. F. Gates Clarke became the first head. The total departmental staff at that time consisted of fifteen people. Twent y years lat er the number was sixtyfive, including technicians and clerical support. The Department of Agriculture entomologists managed to add a position or two, but their number has been nearly constant.

There were a few wisecracks at first about living in a laundry, and it did not take long for this facility to be christened "Lament Street" by its inhabitants. The neighborhood was dangerous. No one associated with the Museum ever ran into trouble, but there was constant worry. On one occasion a murder victim was found on the parking lot, and during the entomologists' tenure several shopowners in the neighborhood were shot. After a gun store was robbed, the Federal Bureau of Investigation had a stakeout in the building before raiding an apartment across the street. During the 1968 riots in Washington, there was considerable concern for the staff and the collections, but again they came to no harm.

In 1968 and 1969 the entomologists returned to the Mall. Though they originally were slated for the fifth and sixth floors of the west wing, the fifth floor had gone to Botany, and because of the setting-back required by the Fine Arts Commission, the sixth floor was smaller than anticipated. Hall 27 on the west side of the second floor, which had been used for offices, was fully decked over, this time with steel plates, but that proved insufficient. Hall 30 on the south side of the second floor was also converted to offices and decked over. The Museum entomologists currently occupy about 36,000 square feet, far less than at Lamont Street. They have a few of fices in the west wing of the main building.

Nothing exists in a vacuum in the Museum, and one action affects another. Because these two exhibit halls were appropriated for offices, a partially completed hall of fishes was scrapped, and a projected hall of freshwater and marine invertebrates was dropped.

\section{Oceanography Program}

The real driving force for growth in the Museum during the early 1960s was oceanography. Using the International Geophysical Year as a model, a number of scientists set up an International Decade of the Oceans, in a way a water-based International Biological Program. After Stewart became director and Richard Cowan 
H. Adair Fekdmann and Beatrice Burch in the Smithsomian Oceanographic Sorting Center. This photograph was taken in the early 1970 s at the Nazy Yard in southeast Washington, where the Sorting Center moved before the Lamont Street building was vacated. Now the Sorting Center is in the Museum. Support Center at Sitver Hill, Maryland.

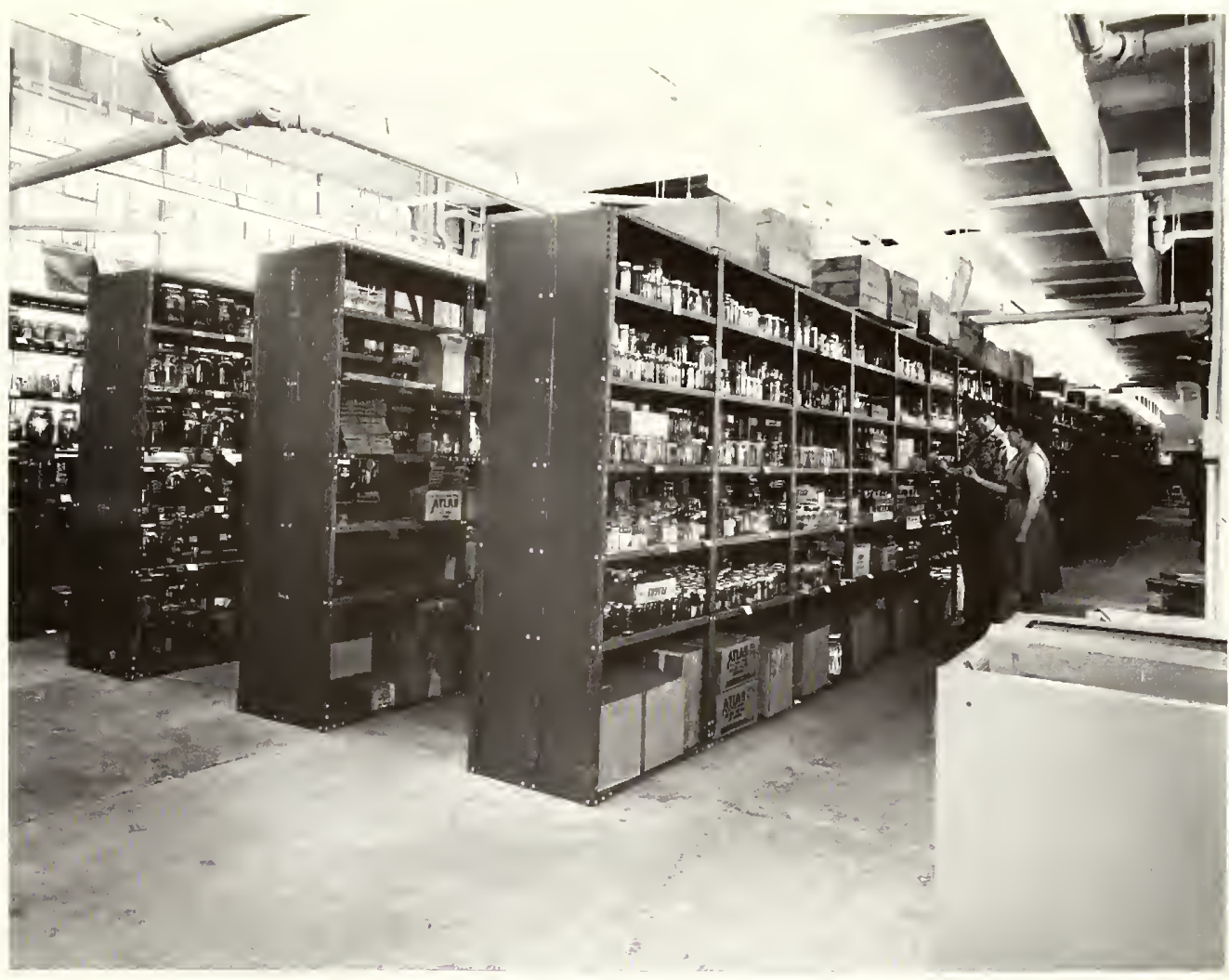

assistant director of the Museum in 1962, the special position of Assistant Director for Oceanography was created. Eugene Wallen transferred from the Atomic Energy Commission to the Museum to fill this post. While at the Commission he had been a strong supporter of the Museum, and had provided several large grants.

Wallen was an excellent organizer and wasted no time when presented with the opportunity to develop the Museum's oceanography program. "The establishment and functioning of the Smithsonian Oceanographic Sorting Center is perhaps the most important single accomplishment of the first year of the oceanography program," read the Annual Report published in 1964. "The Sorting Center is designed to provide assistance of several kinds to taxonomic specialists both in Federal and non-Federal establishments. A principal function is to sort to practical taxonomic level the multitude of plants and animals collected on oceanic cruises." The Sorting Center, opened in 1962, was on the second floor of the Lamont Street laundry building. Under the energetic direction of $\mathbf{H}$. Adair Feldmann, it soon became an effective and widely known unit. Before the entomologists left Lamont Street in 1965, the Sorting Center moved to a building in the old Navy Yard in southeast Washington. During the summer of 1985, another move was made to the Museum Support Center.

With so many organisms coming into the collections, the Museum could not hope to study them all. Nevertheless, there was good reason to increase the staff and hire specialists in groups that had not been studied by earlier curators. As one measure of growth, in fiscal year 1964 Zoology listed twenty-four names, even though a separate Department of Entomology had been established that year. The following year the old Department of Zoology was split into two, and the last of the seven departments of the present Museum emerged. In fiscal year 1965, when this division occurred, there were seventeen people in Vertebrate Zoology and sixteen in Invertebrate Zoology. Paleobiology also added specialists on fossils and marine sedimentology during these years.

"Perhaps the most obvious of the changes in the first three years of the Smithsonian's research effort in oceanography," Smithsonian Year for 1965 explained, "has been a large increase in staff involvement in biological and geological oceanography activities. Not only has the number of scientists involved in the oceanography program tripled in these three years, but the number of organizational units included in the program also has tripled. Whereas before, the Institution had extremely restricted capability to treat the nearly 100 major groups of marine organisms, selective recruiting has resulted in the addition of capabilities to examine and carry out research on groups which could not be inclucled in earlier oceanographic efforts."

A positive event of 1966 was the decision by Congress that "Public Law 480 funds"-foreign currency owed the United States that must be spent in the country repaying the debt-could be used for biological work. 


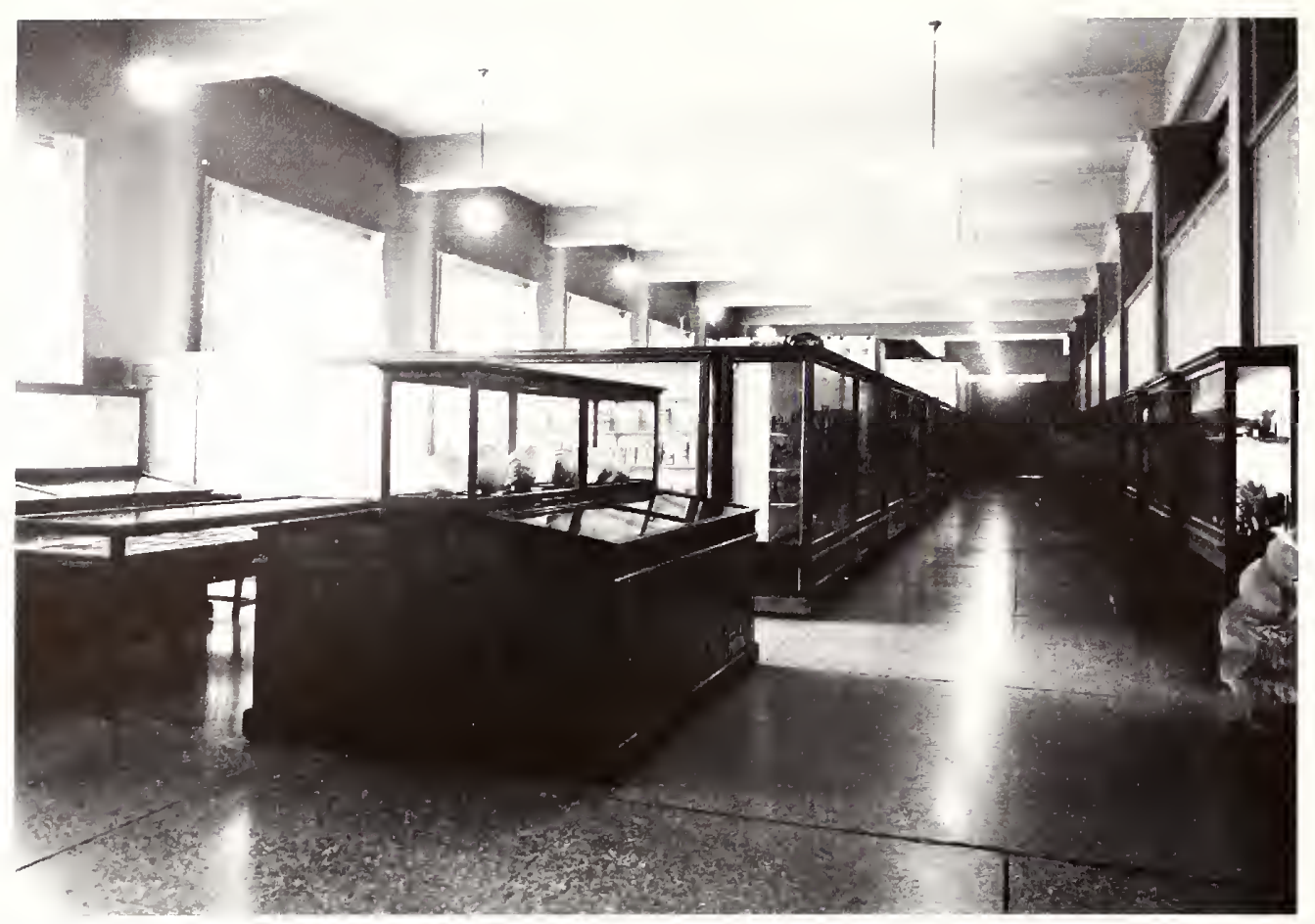

View looking north in Hall 27 , probably in the late 1950s. The giant clam (Tridacna) is to the extreme right. Beyond it, on the right side, the alcoves have been closed off to make offices for the U.S. Department of Agriculture entomologists. Some cases of invertebrates remain on the left, but behind them are more offices, with cases sticking up. Out of sight at the corner of the hall was the "Coral Room."

Both Musemn scientists and those from academic institutions received grants of PL 480 money, which contimue to be helpful to the pursuit of science at the Musellil.

By June 1966 the Smithsonian had formed a separate Office of Oceanography and Limnology (the study of lakes, ponds, and streams). Thus the Sorting Center was no longer part of the Museum. A Mediterranean Marine Sorting Center was established, supported by foreign-currency funds made available under Public Law 480 . Looking back, the impression one gains is of rapid expansion into a variety of fields. The lnternalional Biological Program embraced the total environment, not just the oceans. The Smithsonian established the Office of Ecology in July 1967, and Hehmut Buechner, as assistant director for ecology at the Museum, developed a modest staff. A Chesapeake Bay Center for Ficld Biology was started, and for its first year was under the administration of the Musemm.

\section{Fort Pierce Facility}

In 1968 Wallen became acting head of the Office of Ecology, and in October of 1969 it merged with Oceanography and Limnology to form the Office of Envirommental Sciences. Although Wallen continued for a time as an assistant director, increasingly he had more to do with oceanography overall and less to do directly with the Museum. In the early 1970s he went to Fort Pierce, Florida, to organize another Smithsonian bureau, and later left the Institution. In 1981, after several changes in administration, the Fort Pierce facility became part of the National Museum of Natural History. And when the Office of Environmental Sciences was closed in 1975, the Sorting Center again became part of the Museum-essentially, another department.

There was one other facet of big science that left a physical change in the Museum. Within the Department of Botany, the idea of a comprehensive "Flora of North America" in a series of publications was developed. Several feasibility studies were done, and momentum toward this major compilation began to build. This project helped lay the groundwork for automatic data processing, now a standard practice in the $\mathrm{Mu}$ seum. There were a few offices opening up in the north wing adjacent to the elevators. The exhibits people had left the area in terrible shape, but cleaned up and decked over, it would have made an ideal headquarters for the "Flora." The construction was completed, but in 1973, just before the move, the project expired. The "Handbook of North American Indians," big science in itself, moved into the area. When this group moved to the southwest corner of the ground floor, the public education staff inherited the space.

The volumes of Smithsonian Year for 1970 and 1971 combined are not as thick as the volume for 1969. "As in all research/education centers over the country, the year was one of retrenchment, deferred needs, and constantly revised priorities," the 1971 yearbook reported. "Rather than lose any of its excellent staff, this Museum chose to keep the people even though that decision meant drastically reduced funding for items other than salaries." ${ }^{3}$ This was a hard choice. The era of big science had dramatically increased the size of the staff, but when the cuts came, people were more important than travel or even cases for the specimens. $\square$ 


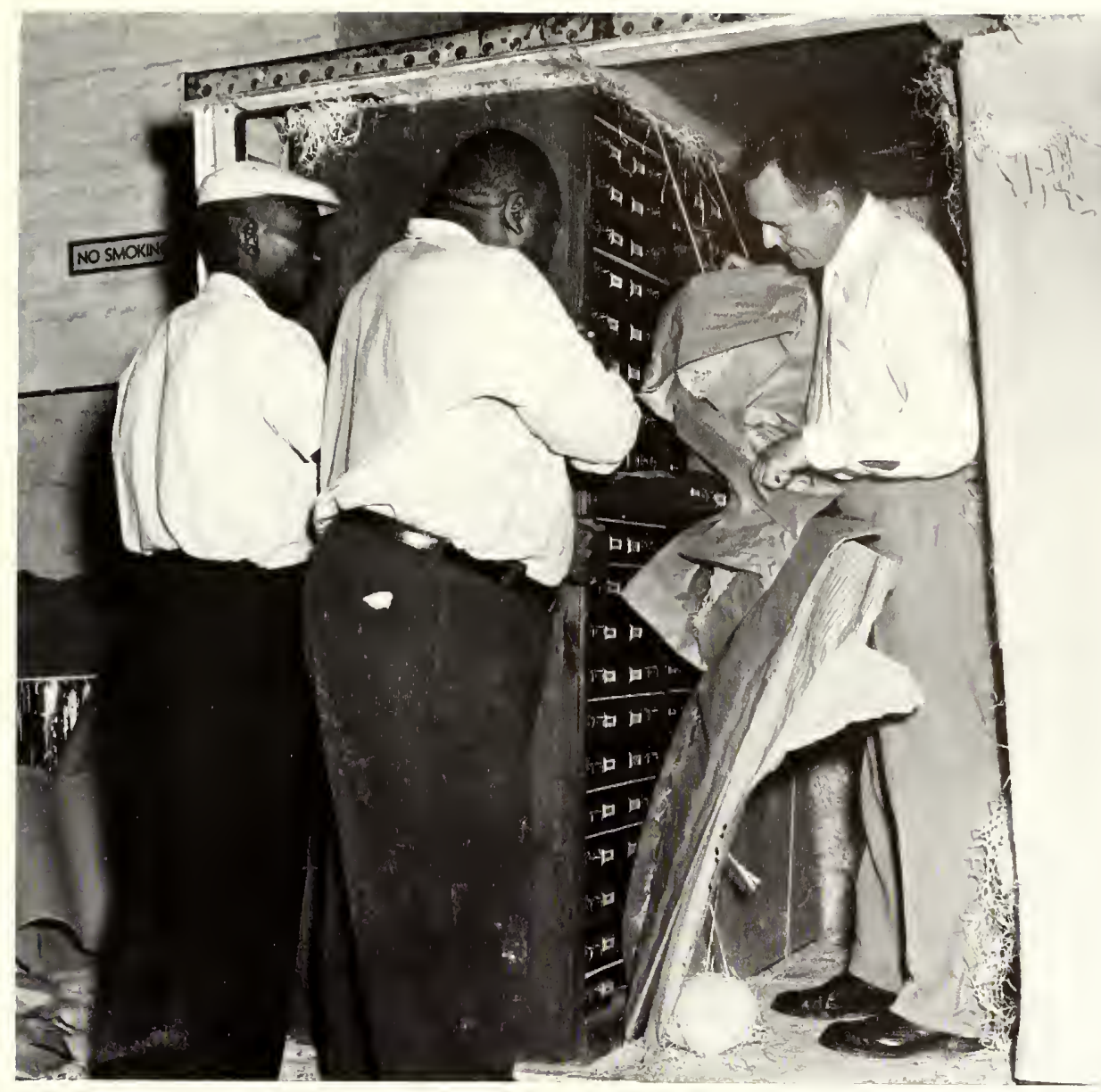

J. F. G. Clarke, Dizusion of

Insects, and two laborers

unpacking collections at

Lamont Street.

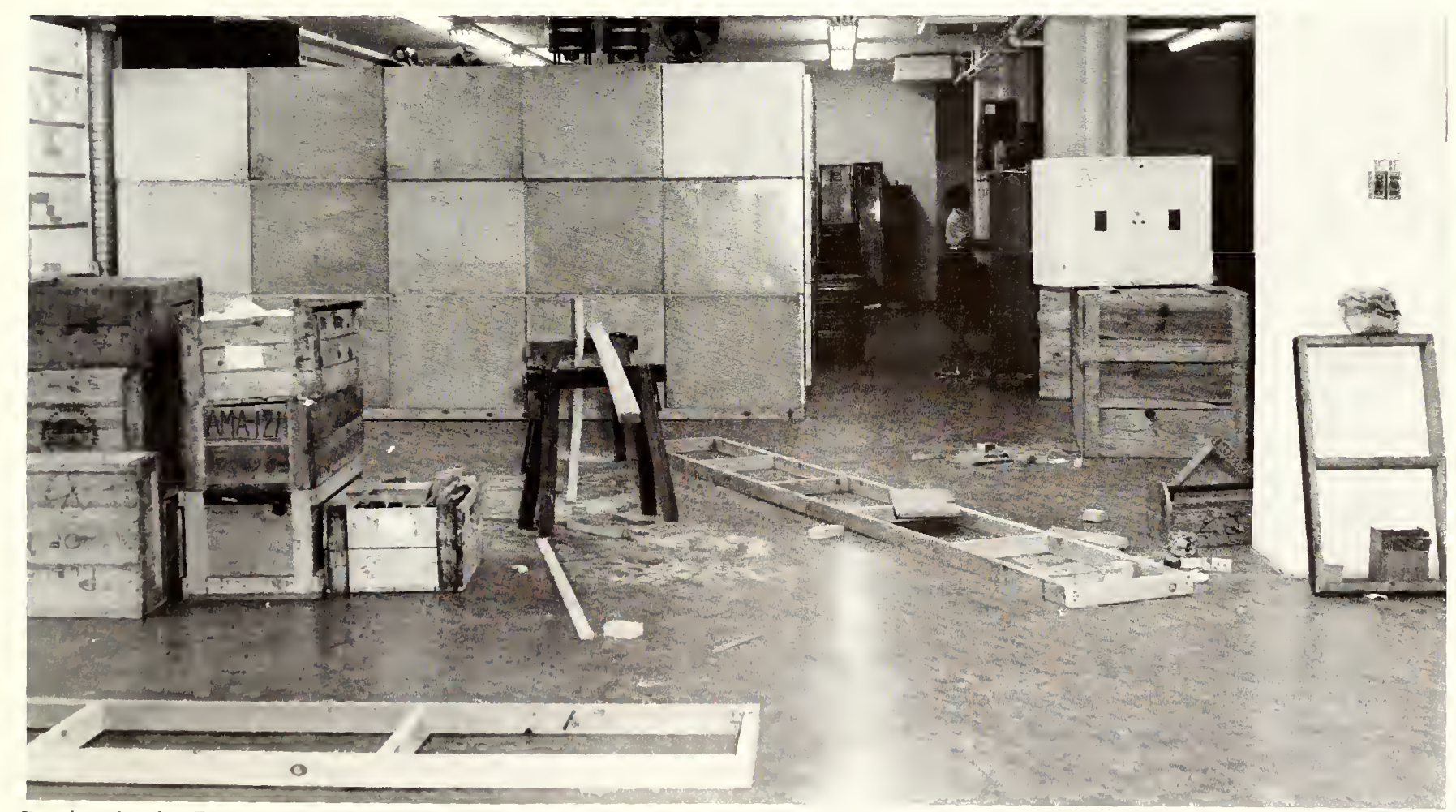

Putting in the floor supports for cases of insects at Lamomt Street, 1962. 


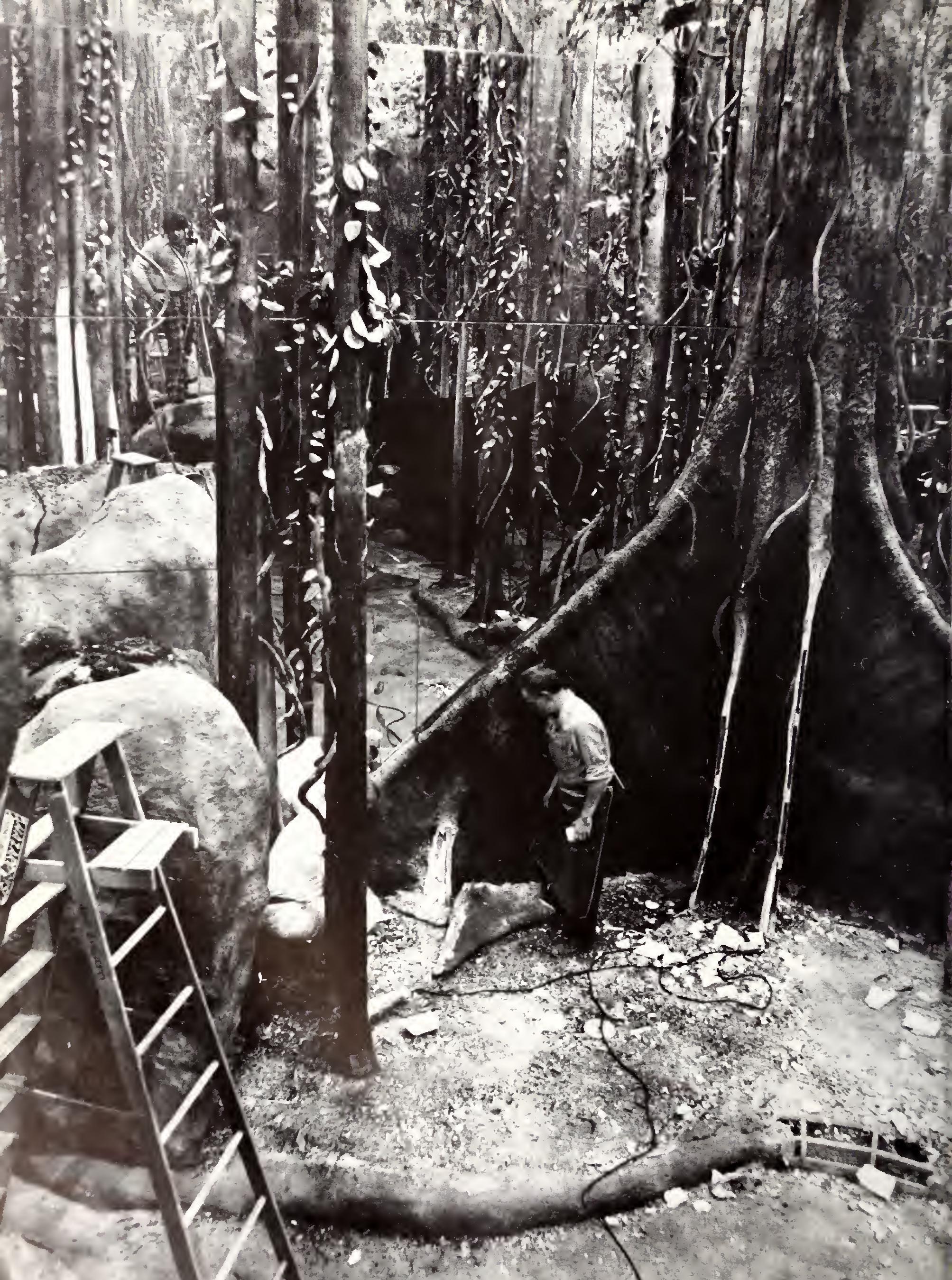




\section{"Modern Times"}

$\mathrm{T}$ HE OPENING OF THE Museum of History and Technology in 1964 marked a major change in the course of the Smithsonian Institution. It coincided with the start of the twenty-year tenure of S. Dillon Ripley as Secretary of the Smithsonian. During these two decades the Institution increased dramatically in both scope and diversity. For much of its history, one could well have described the Smithsonian as natural history with a few appendages; after 1964 the Museum of Natural History became simply one among a series of museums. In this sense alone the Museum lost significance, for staff and budget increased markedly during this era.

Leonard Carmichael, in reviewing the 1953-63 decade of his secretaryship, noted the development of the Museum of History and Technology, the increase in the collections from 34 million to 57 million specimens, the increase in field investigations, the formation of the Smithsonian Oceanographic Sorting Center, the construction of the east wing of the Natural History Building, and the appropriation for the west wing. 'The John F. Kennedy Center for the Performing Arts became a separate bureau, and the number of visitors to the buildings on the Mall nearly tripled.

Immediately after Secretary Ripley assumed office, the increase of staff and development of new offices in connection with oceanography and ecology accelerated. This resulted in new attitudes toward science at the Museum, and there were changes in attitude toward public affairs as well. In 1965 the Smithsonian's Annual Report was supplanted by a more popularized yearbook, Smithsonian Year. Because of the progressive growth of the Institution, with the addition of bureaus and functions, detailed information on individual events has necessarily been curtailed, although the yearbooks collectively give a sense of great happenings throughout

Removing a tree from It All Depends (Hall 10) for transplantation to the South American Hall (Hall 23), February 1975. The mirrors behind give an ithusion of great distance in the forest. They reflect photographer Roy E. ("Chip") Clark to the upper toft, and to the right, at the base of the tree, Reginald J. ("Bud") Sayre. the Institution. The yearbook itself has changed from year to year, even to alterations in cover illustrations of the Castle between 1972 and 1973 as the cupola, lost in the fire of 1865 , was restored to the north tower.

\section{Growth of the Museum Shops}

The publication of the magazine Smithsonian represented a large step in the Institution's becoming truly national in scope, rather than Washington-based; of its appealing to the public at large, rather than being bound to buildings in Washington. The development of the Museum Shops provides another example. Secretaries Abbot and Wetmore had been concerned that sales by the Institution might deprive local merchants, and as a consequence there was no shop in the Museum. Under Secretary Carmichael, steps were taken to satisfy the desire of tourists to purchase Museum-related items, and under Secretary Ripley the program expanded rapidly.

"The first year [fiscal year 1968] of the reorganized Smithsonian Museum Shop program saw the construction of a shop in the Museum of Natural History at the Constitution Avenue entrance and a book shop at the Mall entrance." From the start this shop was a hit with tourists, causing traffic jams in the lobby. It occupied a small office next to the marble stairway, but soon expanded, and the north end of Hall 10 on the first floor, in the area now occupied by Splendors of Nature, was partitioned off for storage. The Museum Shop, which moved to the West Court building in 1976, has become a major asset. It is never without customers; during the spring and summer it suffers from overcrowding. An accessory to each show in the Evans Gallery is a small separate sales desk in the foyer, selling books and objects related to the temporary shows. After the remodeled Hall 3 reopened in 1981 and a big thing was made of the return of the clinosaurs, a movable cart called "The Dinostore" was stationed in the rotunda for a time.

\section{Financial Problems}

Just as Museum Shop sales fluctuate seasonally, the fortunes of the Museum have fluctuated, though on a 
slightly longer cycle. Secretary Ripley recognized early that the Museum had financial problems. Access to National Science Foundation Funds had been cut off by Congress in the early 1960s, but while Ripley was able to persuade Congress to increase the appropriations for research to the Institution to compensate for the loss, these funds were removed by Congress in the early 1970 s.

Fiscal year 1970 was a downer, financially. "When I first came to the Smithsonian," Ripley stated in July, "I was concerned with our inability to compete with other institutions for highly qualified scientists because of salary levels. Now we have succeeded in attracting a number of highly competent, indeed distinguished scientists to our professional staff in the National Museum of Natural History." "Yet, he added in the 1970 Smithsonian Year, "If ivory towers existed here earlier, they have long since crumbled, spilling their occupants into the midst of concerns that involve us atl. .. . Decreasing resources in the past few years for carrying forward research-curation-education programs in the Museum becane a major preoccupation in the latter half of the year. Reductions in 'buying power' caused by near-level funding, inflation, and general pay raises, have been met in recent years by progressive reorganzation." According to one source, 98 percent of the budget in this fiscal year was allocated to salaries. One could pick almost any year luring the 1920s or 1930s and read similar stories of financial distress.

Nevertheless, in Ripley's view, much had been accomplished in change of attitude in the five years since he took over:

Scientists and scholars can only be appropriately treated as professionals; they must be accorded latitude in order to act responsibly as masters of their domains of subject matter knowledge. One of my first aims as Secretary was to provide that department chairman serve in rotation "from the ranks" so to speak, and for limited terms, in order to minimize the hazard of an internal seniority system that might block initiative and convert scientists into permanent administrators. Research support is made available to staff members in the form of grants and from appropriated funds, so that they will act responsibly as principal investigators treating scarce resources as wisely as they would funds of their own. I put an end to pre-publication review of professional publications by the Secretary, preferring to read them as reprints from colleagues rather than submissions for administrative clearance. We cancelled a burdensome annual report required of each staff member about his research because it served unnecessary and merely administrative purposes. Burdensome formal reporting can be no substitute for consultation and constant awareness by supervisors. Evaluation of professional accomplishment is now conducted by committees of peers formed in major research units, known as "Professional Accomplishment Evaluation

Committees." Staff members have been encouraged to teach in universities on official time (without added compensation) and to request changes of their duty station at intervals so as to be able to spend a year in study and research without distractions of daily office routine, an equivalent to a university sabbatical. Travel to professional meetings has been encouraged. ${ }^{5}$

All the items mentioned were important, but the two with the longest-lasting effects have been rotation of department chairmen and peer reviews. The change to chairmanship from lifetime head permitted more flexibility, though it also increased the paperwork, already swollen by the shift of administrative control from the divisional toward the departmental level. The peer review is the most important single factor in promoting research activities, for everyone on the staff knows that published papers are what one's peers evaluate.

\section{Research Vs. Service}

Under Wetmore and his predecessors, research certainly was considered important and was encouraged. However, the prevailing view appeared to be that the functions of the Museum were those of a service organization-to increase the collections and care for them, and to answer all public inquiries. John Ewers, an authority on American Indians, notes that Herbert Krieger would not allow him to forward any inquiries to others, so that he was forced to answer questions on subjects as far afield as African ethnology. Research could be done only in the time left after inquiries were answered. This view of the function of the Museum curatorial staff began to change in the 1950s. Today, the collections are not always cared for directly by the curators; the degree of curatorial involvement varies among the departments. Inquiries are often answered by assistants. The currently prevailing view is that the scientific staff should be involved primarily in research.

\section{Congressional Oversight}

Another milestone or millstone the Institution faced in 1970 was the general oversight hearings held by Congress. Previously the Institution had appeared only in connection with congressional appropriations hearings. No one knew what to expect. By dint of determined investigation, the General Accounting Office showed that some money appropriated for construction in the Museum, totalling just under $\$ 44,000$, had been used instead for construction in the Arts and Industries Building. This had been done so that the registrar could be moved and to provide an extra office for entomologists. The misapplication was viewed sympathetically by Congressman John Brademas, who said, "When I think of what goes on in the Department of Defense, 
Beth Miles installing a sundial shell (Architectonica) in Splendors of Nature

(Hall 10A), with Carl Alexander looking on, 1978.

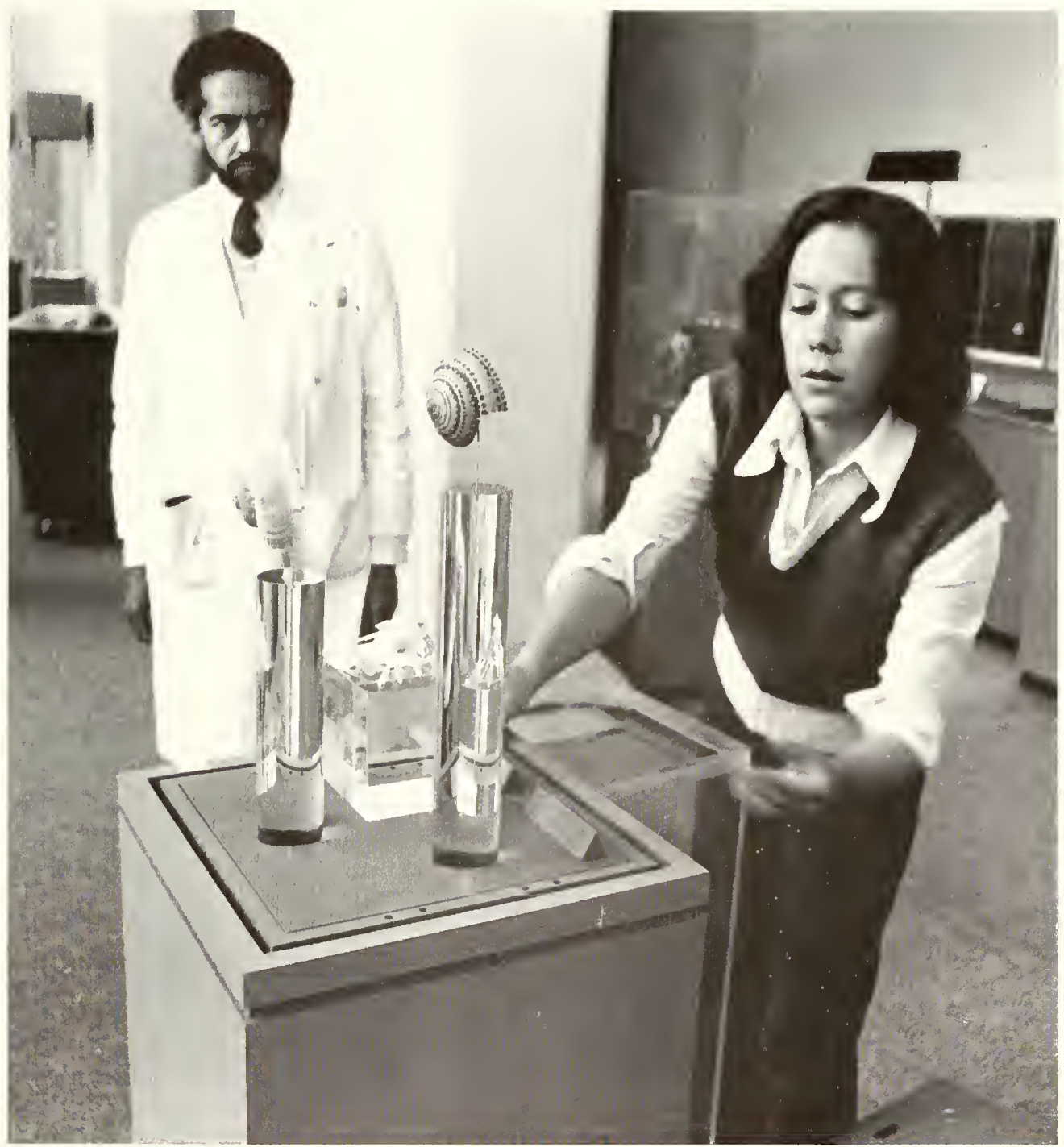

my blood does not boil very much about the Smithsonian's shortcomings." 6

The Museum got through the hearings satisfactorily, and possibly as a result of the experience tried a different budgetary approach. New research projects, mainly in environmental science, were specified in the proposed budget, and some of them were accepted by Congress. The early 1970 s thus brought additions to the scientific staff, though not on the large scale of the mid-1960s. About 105 professional scientists are now on the staff; the numbers fluctuate in reaction to various hiring freezes, but the last decade has not seen any dramatic change.

Growth by transfer, quite another matter, has occurred, with many services coming under the jurisdiction of the director in 1973. If one looks simply at budget figures, the Museum would seem to have expanded sixfold over the last twenty years. But if one allows for salary increases, effects of inflation, and transfer of people and services, little change in the available funds can be discerned.

\section{Exhibit Halls Undergo Change}

In 1973, after the "rearticulation" of various services, the Museum once again had its own exhibits group. Shortly thereafter a committee was formed to develop a long-range plan for the halls. Its chairman, Leo J. Hickey, a paleobotanist, is now director of the Peabody Museum at Yale, and the vice-chairman, Donald Duckworth, an entomologist, is now director of the Bishop Museum in Hawaii.

An article in The Torch, the Snithsonian's staff newspaper, outlined what the committee plannert to change: "In the past, NMNH seldom attempted to clearly identify the underlying concepts of its exhibit halls. Objects were arranged in cases by the curators because they were the best, or the prettiest, or because they came from the same South Seas island. Occasionally a case would be organized around an interesting idea but frequently it woukl not be closely related to the cases around it. The effect is that our halls clon't create a broad concept of natural history in a way the public can uncherstand."7 


\section{TABLE 2: Major Exhibits, 1971-1985, Still on Display}

Hall 20

Hall 6

Hall 23

Hall 29 (south)

Hall I0A

Hall 26

Hall 10

Hall 2 (center)

Hall 2 (east)

Hall 26 (west)

Hall 2

Hall 3

Hall 5 (west)
Our Restless Planet

Ice Age Mammals and The Emergence of Man

South America: Continent and Culture

Insect Zoo

Splendors of Nature

Western Civilization: Origins and Traditions

Dynamics of Evolution

The Conquest of Land

The Flowering Plant Revolution

The Living Coral Reef

Dinosaur Hall

Fossil Mammals

Origin of Life and the Early Atmosphere
November 1, 1971

September 13, 1974

Fall, 1975

August 23, 1976

October, 1977

June, 1978

May 18, 1979

April 17, 1980

April 17, 1980

October 15, 1980

December 4, 1981

Fiscal year 1985

Fiscal year 1985

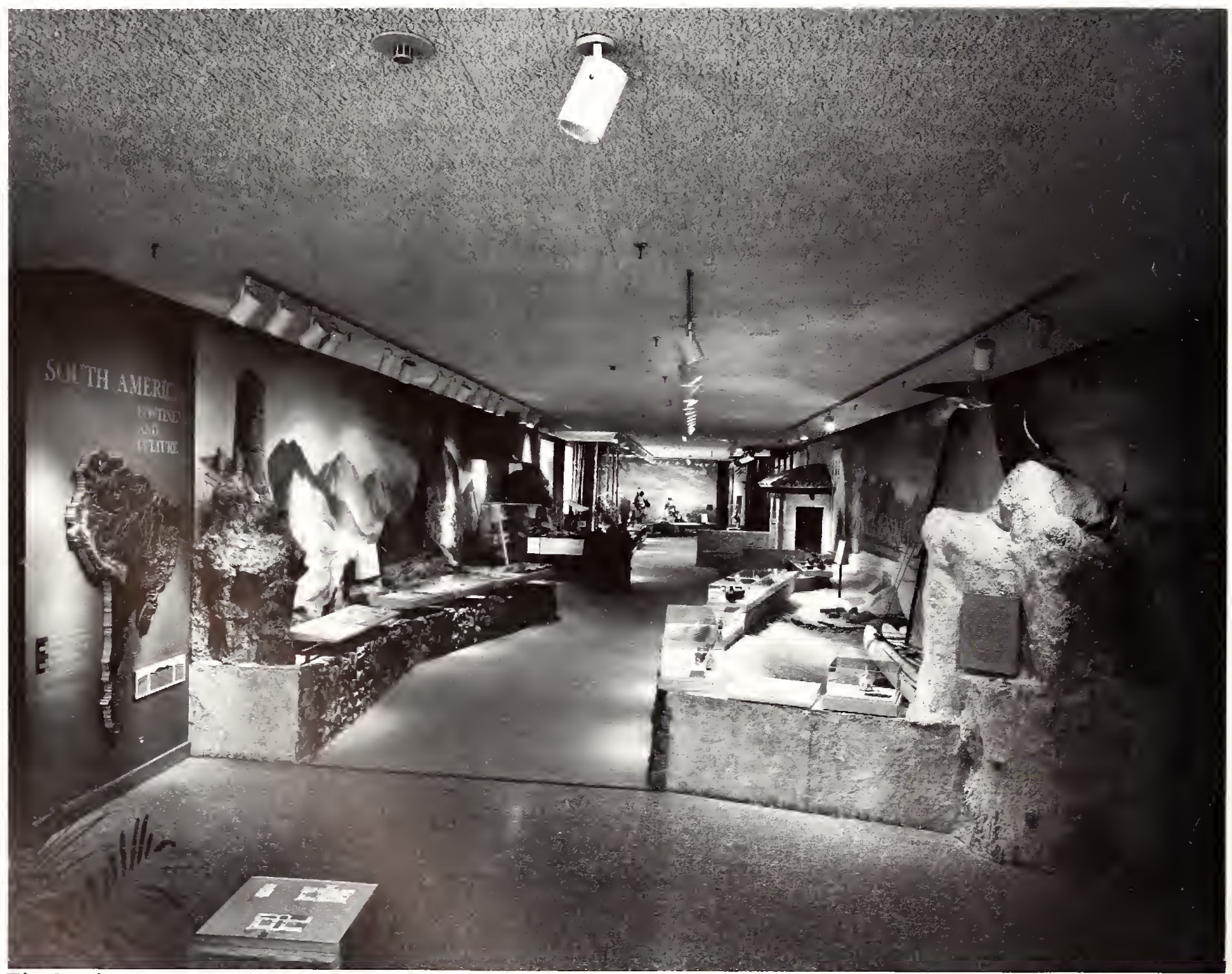

The South American Hall (Hall 28), photographed from the north steps looking south toward the rotunda, in 1978. The ceiling is lower and the lighting better than in earlier displays in this hall. This is an example of an interdisciplinary exhibit, for geology, plants, and animals are used to amplify the ethnology. 
Communicating ideas to the general public is difficult, especially when most of the information is to be conveyed through objects. Even a professional scientist should not criticize a hall until he has tried designing one of his own, for no matter how an exhibit is arranged, some viewers will respond to it and some will not. Because the Museum's new halls were to cut across several departmental lines, scientifically trained exhibits specialists were hired to serve as liaison between curators and designers. One aptly described her position as occupying the space between a rock and a hard place.

This third generation of exhibit halls is coming along more slowly than the second generation of the 1950 s and $1960 \mathrm{~s}$, but it is coming along. In Hall 6-the first to open, in September 1974 - -"the visitor can start out at the beginning of the Ice Age when the Eartlı was dominated by big mammals and end up in a cultural milieu dominated by man." 8 The hall, which includes two more Matternes murals, also featured two giant ground sloths nicely displayed on a central platform, behind piano wire strung from floor to ceiling. The specimens could be seen without obstruction, but visitors kept plucking the wires, and eventually the entire hall had to be closed and redesigned. One of the skeletons the vertebrate paleontology laboratory was particularly proud of was a woolly mammoth. The aim of the preparators is to make supports as unobtrusive as possible, and it took Leroy Glenn a full year to drill the limb bones and place supporting iron inside so that the specimen appeared freestanding. When the hall was temporarily closed, the mammoth was among the specimens that had to be shifted. Like all large elephants, it presented problems, clearing the ceiling by less than an inch. Decades ago this area was the hall of physical geology, and if there was ever a case of metamorphosis in the Museum, Hall 6 is it.

Physical geology still occupied Hall 20 on the second floor, but while a few of Merrill's stone cubes and slabs remained, this too was otherwise a total renovation. The exhibit was a long time in preparation, and a series of different designers were involved. Our understanding of geology changed dramatically during the 1960s, when plate tectonics became almost a household term; the hall managed to bring in these newer concepts. At its east end are the meteorites, and between them and the main part of the hall are moon rocks. These specimens may once have ranked third in interest after the Hope Diamond and the Insect Zoo, though they no longer attract the crowds they did at first.

\section{Some Exhibit Problems}

There were some problems with the bicentennial exhibit that opened November 19, 1975. Our Changing Land presented the concept of change through time of the Washington-area environment. The central corri- dor was a forest, but all the trees had uniformly large trunks more than four feet in diameter-the clesigner's effort to transform the brick supporting pillars of the building. The forest never looked real, and many people headed straight for the escalator. The exhibit stayed until the foyer was renovated to create the Evans Gallery.

On the first floor, in Hall 10 above the foyer, the ecological exhibit It All Depends had opened a few years earlier. It was in part tropical rain forest: "Modeled of papier-mâché and plastic, after sketches and photographs taken in Panama and South American jungles, the exhibit's trees, foliage, and vines were enclosed in a mirrored ceiling-high silo. Walking into this dimty lit enclosure, visitors had the illusion that they were in the center of a vast tropical forest-with trees rising 80100 feet above their heads." It was a great illusion. At the last minute there was concern that the silo would act as a chimney in the event of fire, and a special halogen gas system was installed in the attic above the hall.

"Earth Day" came to America in 1970, and the other part of Hall 10 was a response of sorts to public concern for the environment. Its exhibits dealt with various aspects of ecology apart from rain forests, with emphasis on man's impact on nature. The many pieces of audiovisual equipment in this hall kept giving trouble, which cooled enthusiasm for using so much such equipment in exhibits thereafter. When the hall finally closed, few were sorry to see it go. Later there was talk of modifying the hall to a display showing the interrelations of plants and insects. A giant model grasshopper was fabricted but never put on public display. The trees went to Hall 23. Some temporary shows were staged in Hall 10, including one by the Russian government, Siberia: Land of Promise. Still later it was used as a supply room and for temporary storage while a new exhibit was being planned.

Hall 23, the first new hall of the 1950s renaissance, had been done by Evans and Meggers. The first hall to be done for a third time-by Evans and Meggers again, plus a committee-it reopened quietly in the fall of 1975 . While it was closed for construction, a freezedried parrot was placed in one of the trees. One day someone noticed that nothing remained except the skeleton, moths and beetles having eaten it. The stuffed cormorants at the north end of the hall have been more successful in resisting infestation. Pampas grass was brought in from Argentina, though its arrival was delayed for a long time by the American Embassy's inability to understand why it should accept a shipment of hay for transportation to Washington. "1" A booklet to accompany the hall was planned, but funds were not sufficient for it. Later, booklets were printed to supplement the Insect Zoo and the Ice Age Hall, among others, and are sold at the Museum Shop. 


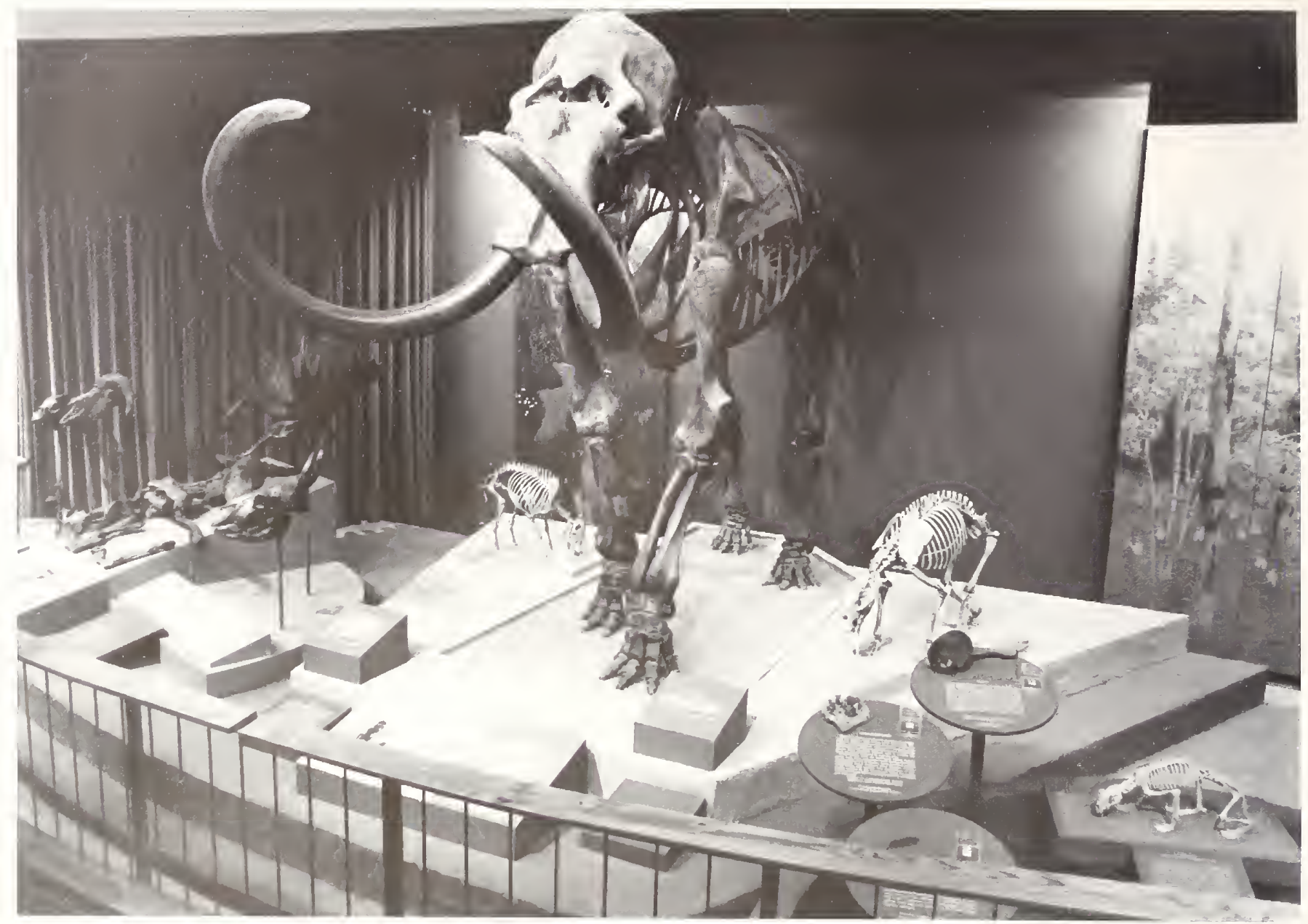

Part of Ice Age Hall (Hall 6) in March 1975, show'mg part of one of the murals by Jay Matternes on the right. The American Mammoth (Mammuthus) just clears the

ceiling. A slightly different view of the skeleton is in Smithsonian Year 1975.

\section{The Insect Zoo}

The Insect Zoo is a real success story. It began in the early 1970 s as an idea of Ronald Gore, then a special assistant to the director. For several years it was in operation during the summers only, in the northeast corner of the second floor at the junction of Halls 21 and 22. The life in the zoo provided a counterpoint and a welcome relief after the cases of archeology in the adjacent halls. The entire operation was run by volunteers supervised by the Museum staff. A number of the entomologists contributed insects, and one day a serious memorandum was issued from the director's office asking for volunteers to feed the mosquitoes. During the summer of 1975 , after the zoo closed, a vertebrate paleontology preparator worked on display in this area, and the tourists used to gather to watch him remove the matrix from a bone.

The Exhibits Committee decided to run the Insect Zoo year-round, and it reopened in August 1976, in time for the meeting of the International Entomological Congress in Washington. From the first day it attracted crowds. Although there are a number of behind-the- scenes problems in keeping these short-lived animals in cages, especially rearing more insects as replacement stock, the zoo is likely to remain in the Museum as a permanent display of living organisms. To reach it, one walks through the Hall of Osteology. If one waits in the right place in that hall, invariably an adult will be heard to say, "I didn't know snakes had bones."

\section{Other Exhibitions}

Splendors of Nature ${ }^{\mathrm{II}}$ in Hall 10A, where the National Collection of Fine Arts once spilled out of its bounds, has been another big success. "Museum Director Porter Kier's idea was not to provide any scientific message as the Museum ordinarily does in its exhibits, but rather each object was to be on view in the hall for just one reason-because it is beautiful," said the 1978 Smithsomian Year. ${ }^{12}$ Hall 10A, incidentally, represents the only addition ever made to Rathbun's original numbering scheme. This area at the north end of the north wing is noteworthy for one other feature. Except for the north stairway, it is the only public place in the Museum where visitors can look out of windows. 


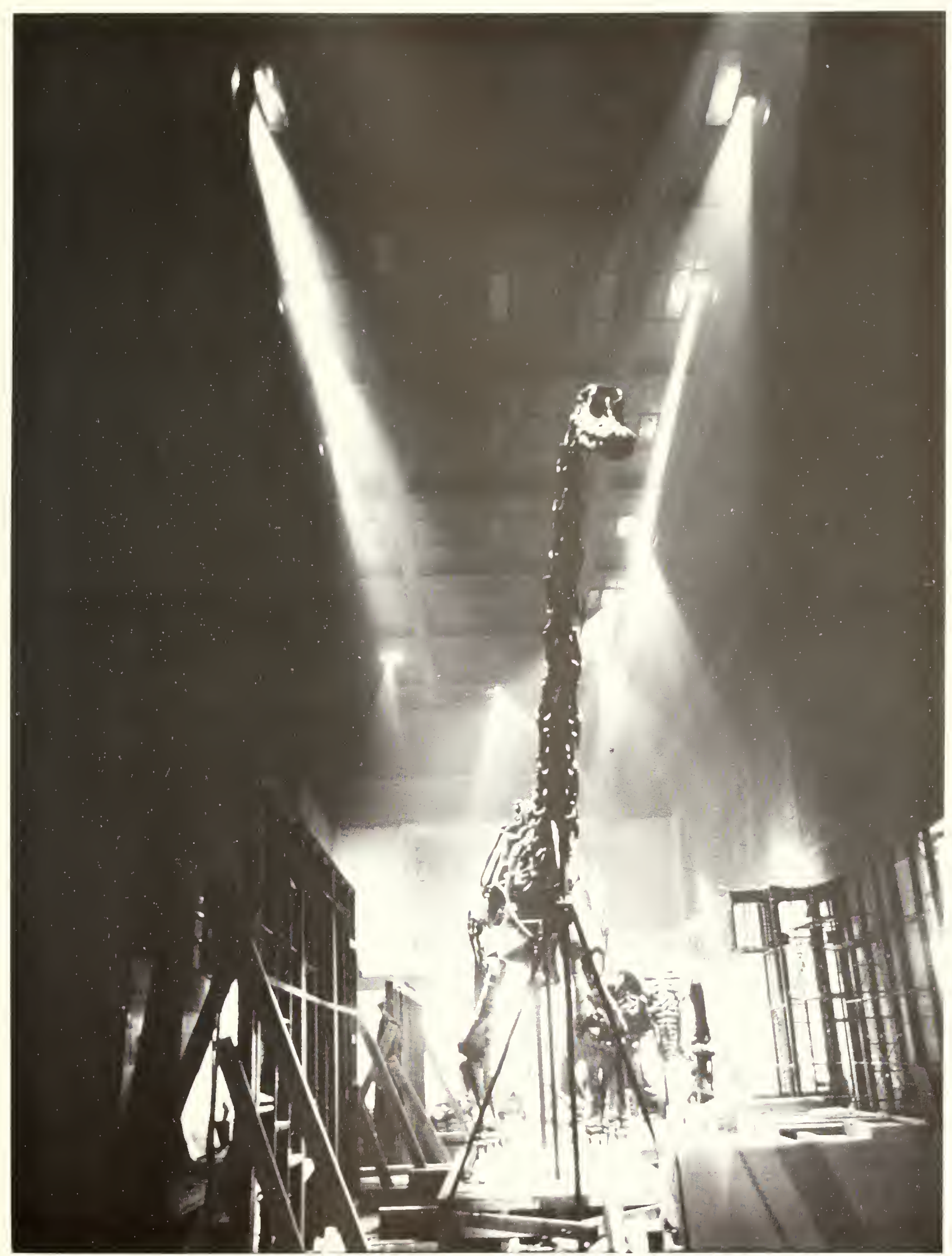

Construction in Hall 2 in the 1970s. Diplodocus is in the foreground, and Diana of the Tides is temporarily exposed in the distance above the balcony. Just off the picture to the left is a ramp to the second floor. An earlier view of Diplodocus in this hall is given in the Annual Report for 1963. 


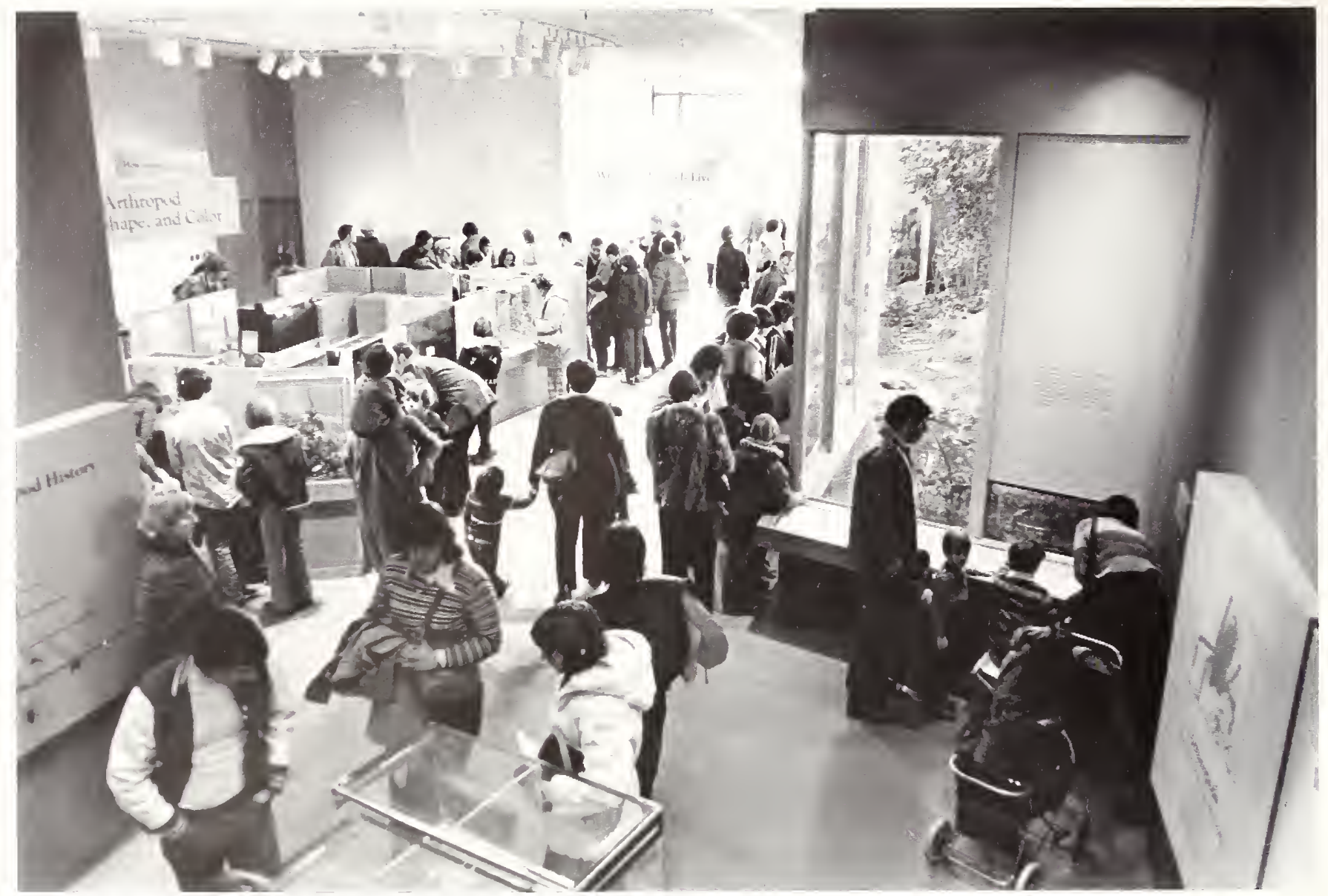

The Insect Zno on a quiet day in 1977. Formerly the Whale Hall, this is the only part of Hall 30 currently open.

Long after It All Depends, in Hall 10, was dismantled, a temporary show of Treasures of Mexico was installed. Even though this was on exhibit for only two months, it resulted in a permanent change in the building. A balcony leading off the second-floor rotunda was built out into the open space, and is now considered part of Hall 10.

Next in Hall 10 came Dynamics of Evolution, whose unveiling in 1979 ushered in a new set of problems. Some highly sophisticated concepts were being presented to the public, but in addition, it was the first time the word "evolution" had ever been used in a Museum display. This does not mean that the Institution had shied away from the subject. In the early 1920s, when anti-evolution laws were being passed by some states, Secretary Walcott had Abbot prepare a statement that was duplicated and passed around, though it is not certain whether these pages circulated outside the Museum. But while the old exhibits on the second floor were designed to convey ideas of individual variation and of change, the word evolution itself had not been used.

As might be anticipated, not everyone was pleased with the creation of this hall, and the Smithsonian Institution was sued. The United States District Court ruled that the exhibit came under the "increase and diffuse" mandate of the Institution, and that the evolution hall was not a religious display. The case was appealed, and the right of the Smithsonian was upheld. Justice Louis F. Oberdorfer of the United States Court of Appeals made an interesting observation: "Finally, appellants are under no compulsion to go to the $\mathrm{Mu}$ seum. If they choose to do so, they are free to avoid the exhibits which they find offensive and may focus on the other exhibits of which there are many." ${ }^{13}$ No one in the Museum argued with this decision.

In the late 1970s all the fossil halls in the east wing of the main building were closed for renovation. The concept of "Fossils: The History of Life" took shape, and the two segments dealing with transition from sea to land and with the appearance of the flowering plants opened in Hall 4 in April 1980. A year later the dinosaurs made it back into the limelight in Hall 2. In positioning of specimens and architectural style, the present dinosaur hall bears no resemblance to either the original one or the revamped model of the 1970s. A ramp was built from the balcony on the east end of the hall to another balcony extending off the secondfloor rotunda. The stairs from the east balcony leading to the moon rocks disappeared; a platform for speci- 
mens was hung on the south wall, and a giant pterosaur was suspended from the ceiling. At the grand opening, "dinosaur music" composed on a Moog synthesizer rumbled through the hall.

This dinosaur exhibit provides an excellent example of display recycling. The papier-mâché Stegosaurus now on the south side of the hall had been on view in both preceding dinosaur exhibits. The life-size beast was originally made for the 1904 St. Louis Exposition and paid for with funds appropriated for displays there. Somehow a wild rumor got started in the 1960 s that the papier-mâché was made from worn money withdrawn from circulation. The staff knew better, but to resolve the point, several people from the Bureau of Printing and Engraving did an "autopsy" and determined that ordinary paper was involved.

In 1983 fossils of ancient soft-bodied animals collected by Secretary Walcott in western Canada were installed in the entryway to Hall 2. An exhibit of extremely ancient fossils, opened late in 1984, finished off Hall 2, and fossil mammals in Hall 3 will complete the jigsaw puzzle. Once all the pieces fit together to make a coherent story, one will be able to start at the dawn of life just off the rotunda and encl up with the cave men at the north end of Hall 6 .

Used for both display and research, the coral reef installed in the Hall of the Sea in 1980 is an important addition to the Museum. ${ }^{14}$ Occupying the center of the hall is an exhibit consisting of a short movie and a display of specimens from the Pacific Ocean deep-sea vents. This too has received a great deal of attention, though there is widespread feeling that the full-scale model of a deep-water submersible, hung in 1983 as a complement to the hall's exhibits, is more of a detraction.

Four exhibit halls on the second floor are currently closed. Two are being used for offices by entomologists, and two for organizing collections to be moved to the new Museum Support Center. Despite this temporary loss of space, public display gained new importance in 1984 with the establishment of the position of Assistant Director for Exhibits.

\section{Educational Programs}

Aside from the exhibits themselves, efforts in public education broadened during the Ripley era, although several of them had been in place for years. The Museum always identified specimens and answered inquiries from the public. Under Secretaries Henry, Baird, and Langley, the Institution distributed "duplicate specimens" to schools and universities, as well as educational materials of a more general type. During the 1920 s a set of rocks and minerals illustrating the concept of weathering and soil formation was sent out. As late as the 1940s the Museum was distributing sets of common minerals to schools, and some schools, universities, and nature centers are still receiving speci- mens. The Museum has hung occasional displays of schoolchildren's work in the foyer. After World War I the Smithsonian started a weekly radio program, with Austin Clark, the echinoderm specialist, taking the lead in organizing the broadcasts. The current "Radio Smithsonian" is a later, independent development.

In 1955 the Junior League of Washington organized a docent program for the Museum and began to give tours for school groups. They were successful-indeed, the program grew to such an extent that the league could no longer handle it. In the late 1960s the Junior League donated money to the Smithsonian for a paid coordinator, on the understanding that in a few years the scheduling of tours and the training of docents would be handled by the Institution.

In the mid-1960s the Museum housed most of the education efforts of the whole Smithsonian. Rooms on both sides of the foyer served as educational offices, docent lounges, and class $\_$oms. The program was geared to all ages, from high school students to preschoolers. In the fall of 1973, the Smithsonian Office of Education was reorganized and decentralized. As had happened with exhibits and building maintenance, the Museum thereafter ran its own education program.

Tours of the halls led by docents have continued and expanded. The education staff offers Museum tours for the deaf, using docents who know sign language. They have also developed tours for the visually handicapped, and occasionally provide docents for tour groups speaking foreign languages. An outreach program for bringing natural history to elderly citizens resulted in a popular handbook.

During the 1970s the Museum added two new educational attractions. The Discovery Room in the northwest corner of the first floor opened March 5, 1974. There "elephant tusks, coral, petrified wood, woolly mammoth teeth, and hundreds of natural history specimens, ordinarily out of reach behind glass or railings in the museums, could be grasped, turned over in the hand at one's leisure, and studied with a magnifying glass." ${ }^{15}$ The Discovery Room, which incorporates some features of the Children's Museum in Boston, has been popular with the public, particularly with families. The docents observed during the first year that many guards came in to examine specimens and learn a bit more about what they had been protecting. More than 100 museums have now copied the Discovery Room.

In 1976 the Naturalist Center was opened in the West Court building. The aim of the Center is to provide a few references, appropriate synoptical collections, and some assistance. ${ }^{16}$ Amateurs interested in local natural history come here to see if they can identify for themselves the bug, leaf, or stone they have collected. Many of the simpler requests for identification are resolved on the spot; more difficult identifications or potentially novel specimens are referred to the staff of the appropriate department. The number of people using the 


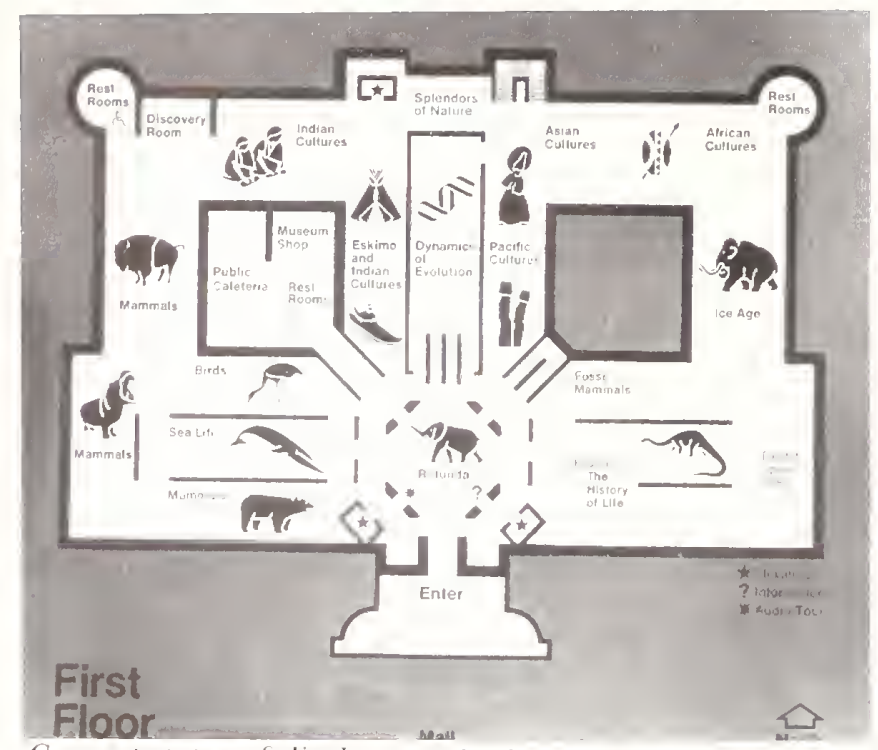

Current status of displays on the first floor and second floor.

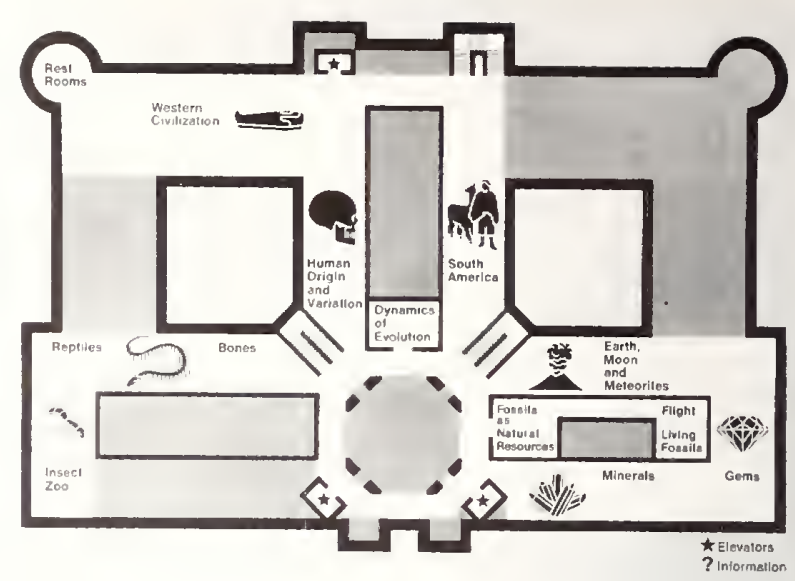

Second

Floor
Center has grown steadily, and when schools are in session it is in almost constant use. At least three local scientific societies hold monthly meetings in the Center.

Over the past twenty years, the side of the Museum dechicated to the public has more than held its own. Likewise, there has been considerable improvement from the scientist's point of riew. The collections are in far better condition than at any other time in the history of the Museum. The amount of support help is at an all-time high. Funding for research has always been a problem, but in addition to federal and Smithsonian funds, the Museum receires modest amounts from private endowments for certain types of research or collection-building

\section{Modifications to the Building}

The Museum buikling has been the site of almost continuous modification. The wings are increasingly being split up into tiny cubicles, some by temporary walls and some with cinderblock. The office ceilings in the wings and the main building were torn up to add smoke detectors. Then they were torn up again to add a sprinkler system. The main building is being tidied up with false ceilings to cover various wires, air ducts, and miscellaneous relics of improvement. Asbestos in the attics has to be removed, and unfortunately some of the relatively new air-conditioning piping was coated with asbestos. For the last five years, a significant hazard has been the danger of walking into stepladders scattered throughout the halls.

One place of great activity during the spring of 1984 was the northeast corner of the main building on the thind floor. Secretary Ripley had established research offices there upon his arrival in Washington; after his retirement on September 17, 1984, this became his headquarters. ${ }^{17}$ The area was rebuilt and repainted in an incredibly short time.

Down the hall from the former Secretary, on the east north range, Secretary Adams has an area reserved for his archeological research. ${ }^{18}$ Some skeletons had to be displaced to reconstruct office walls where they once hack stood two decades before.

There is one loose end: the enigmatic "Museum of Man." The name appears on a plaque at each entrance to the building, yet this is the only sign of it. During the days of the Smithsonian Office of Anthropology, a museum concentrating on man as distinct from natural history was discussed. It had both proponents and opponents, but the issue, so far, remains to be resolved. 


\section{Part Three}

\section{The \\ Museum}

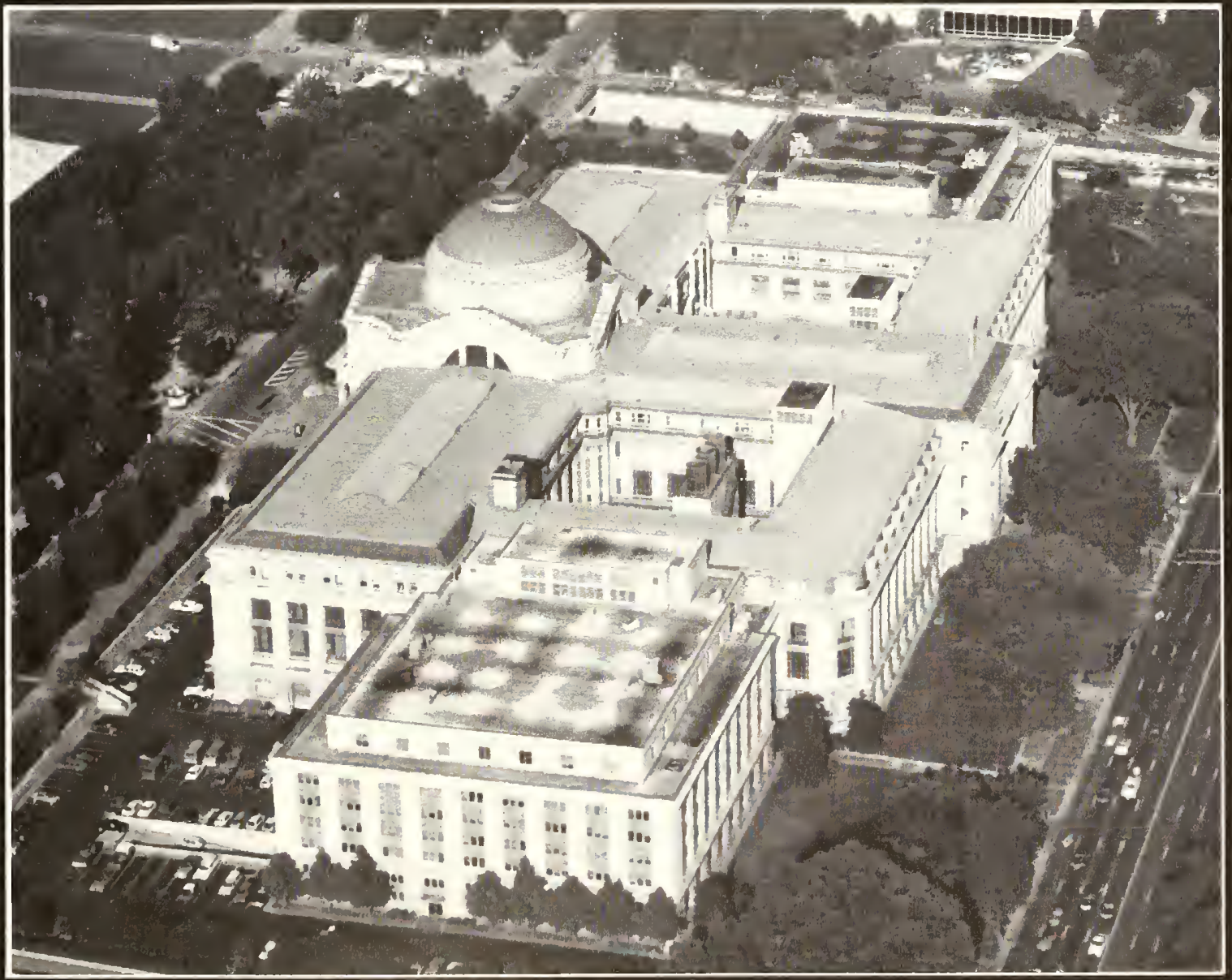



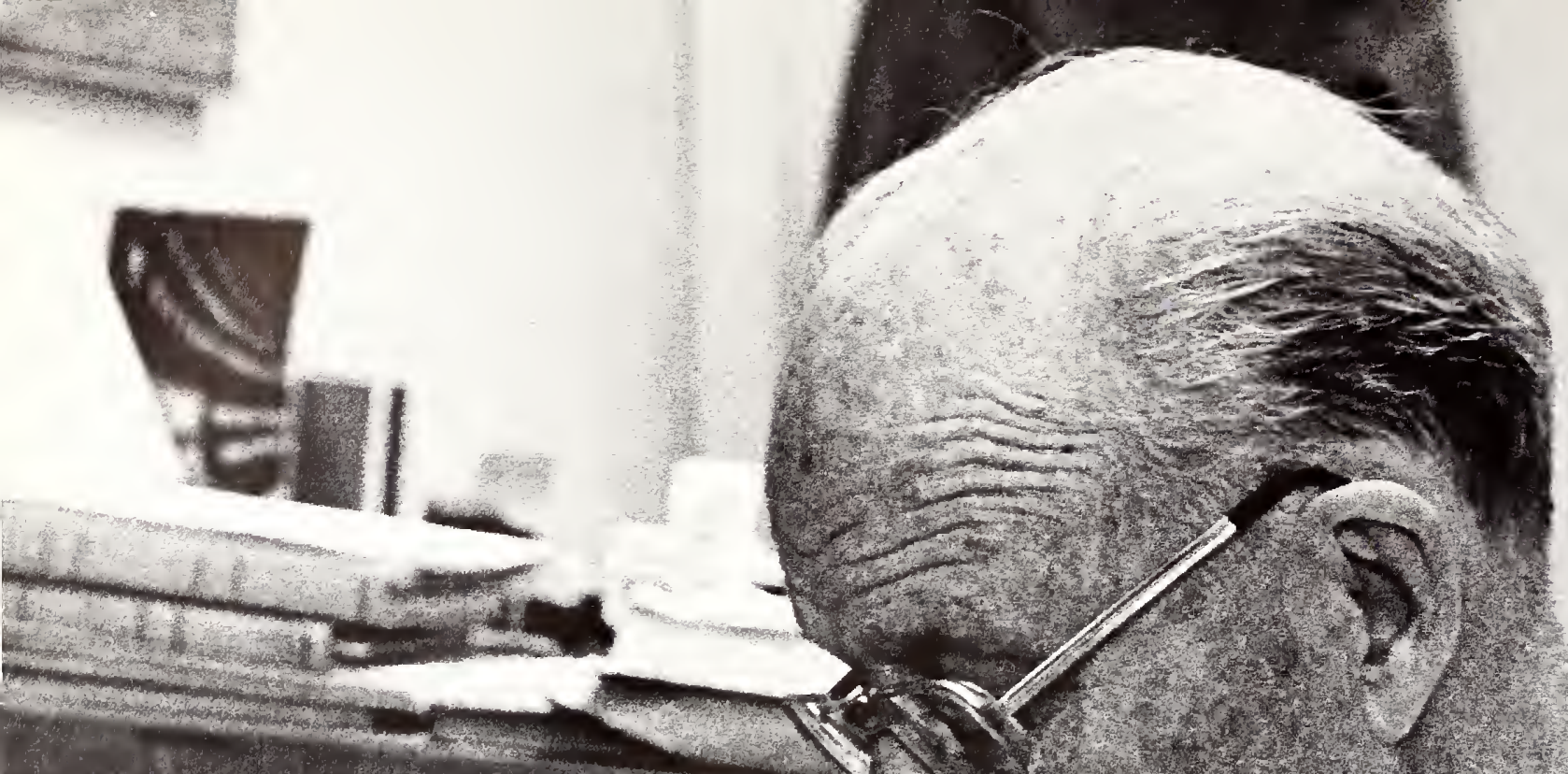

$+0$
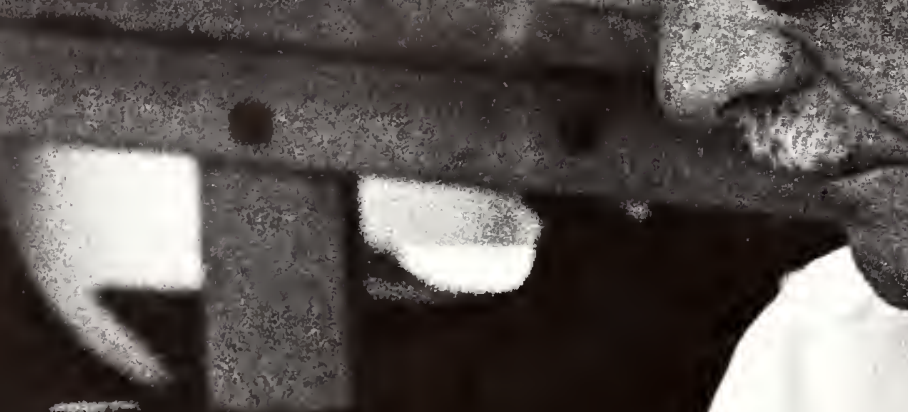

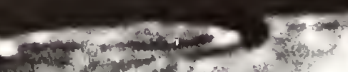

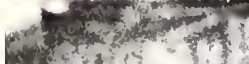

$=x^{2} y^{2} y+3$

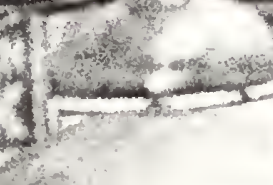

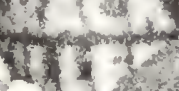

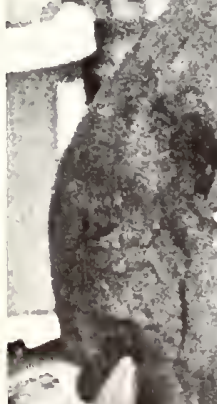

1)
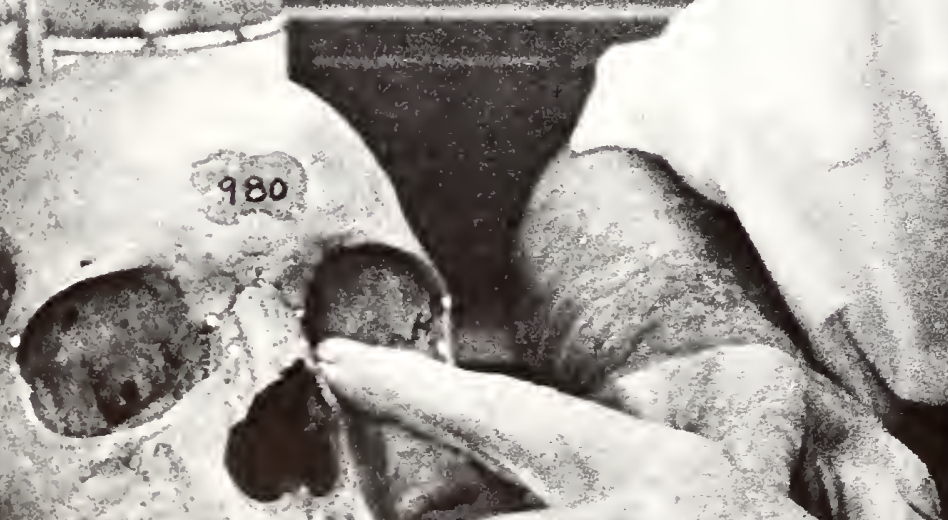

.

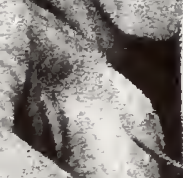

$2+4)^{4}: 1$ 


\section{Museum Administration}

$\mathrm{G}^{\prime}$ EORGE BROWN GOODE, WROTE: "GoOd administration is not to be had for nothing. As to the qualifications of a museum administrator, whether it be a museum of science or a museum of art, it is perhaps superfluous to say that he should be the very best attainable; a man of ability, enthusiasm, and withal of experience." 1

The office of the director is on the third floor at the southwest corner of the building, with windows facing the Mall and the Smithsonian Castle to the south, and Twelfth Street and the Museum of American History to the west. The room is spacious and airy, and according to many old-time Washington hands, it is one of the largest offices in town. For many years this was a fairly austere place, but over the last two decades it has been decorated to suit the tastes of the various occupants. When Porter Kier was director, he added a stuffed rhinoceros to the furniture.

A major amenity of the director's office was the large adjacent bathroom. During the 1960s, its claw-footed bathtub was replaced by the typical coffee kitchenette of the modern office building. The bathtub was a stark reminder of just how beastly hot Washington was in summer before the days of air conditioning. No high official could work all day and go to an official function at night without a bath, and the streetcars could not get one home and back in time.

\section{Richard Rathbun}

Richard Rathbun was the first to occupy this office. To recapitulate his career, he began as a geologist, but in 1878 became an assistant on Spencer F. Baird's Fish Commission. Later he became, as well, a curator of marine invertebrates, and did both jobs until 1914. A century ago there were few government scientists, and a lot of doubling-up was done to fill all the administrative positions. Rathbun transferred to the Museum full-time when Goode temporarily took over the Fish Commission after Baird's death; later he switched places with Goode again. In 1896, after Goode's death, Rath-

T. Dale Stewart with a human skull (Homo), 1982. bun became an assistant secretary, and was directly in charge of the National Museum from 1900 until his death in 1918. "Out of respect to his memory the flags on the buildings of the Institution were carried at halfmast. .. Business was suspended and the public exhibition halls were closed on the day of funeral."2 Considering his close involvement with the construction of the new National Museum, it is fitting that Rathbun's last published paper was a summary of the buildings of the Institution.

\section{William de C. Ravenel}

There is little personal information to be gleaned about William de C. Ravenel, who took over in 1918 as Administrative assistant to the Secretary (rather than Assistant Secretary) in charge of the United States National Museum. Paul Garber, historian emeritus of the National Air and Space Museum, describes him only as a pleasant man and a fine boss. While Ravenel did champion natural history's right to its own building, his major contribution to the Institution was the strengthening of the staff and exhibits in the old National Museum building. When he moved his office to the south side of the Mall after spending less than a decade in the new National Museum, Ravenel made the Arts and lndustries Building flourish as much as any part of the Institution flourished during the 1920s. He probably deserves the title of grandfather of the Museum of American History. He retired June 30, 1932, and when he died the following year, a memorial service was held in the auditorium. After Ravenel's retirement, Arts and Industries came close to becoming a "finished museum," mainly because of lack of funding, but crowds flocking to see Lindbergh's Spirit of St. Louis kept the building lively.

\section{Alexander Wetmore}

1n 1925, when Ravenel moved to Arts and Industries, Alexander Wetmore became Assistant Secretary in charge, and ran the Museum until well after World War II. Wetmore was the first to be titled Director of the United States National Museum. Throughout his 


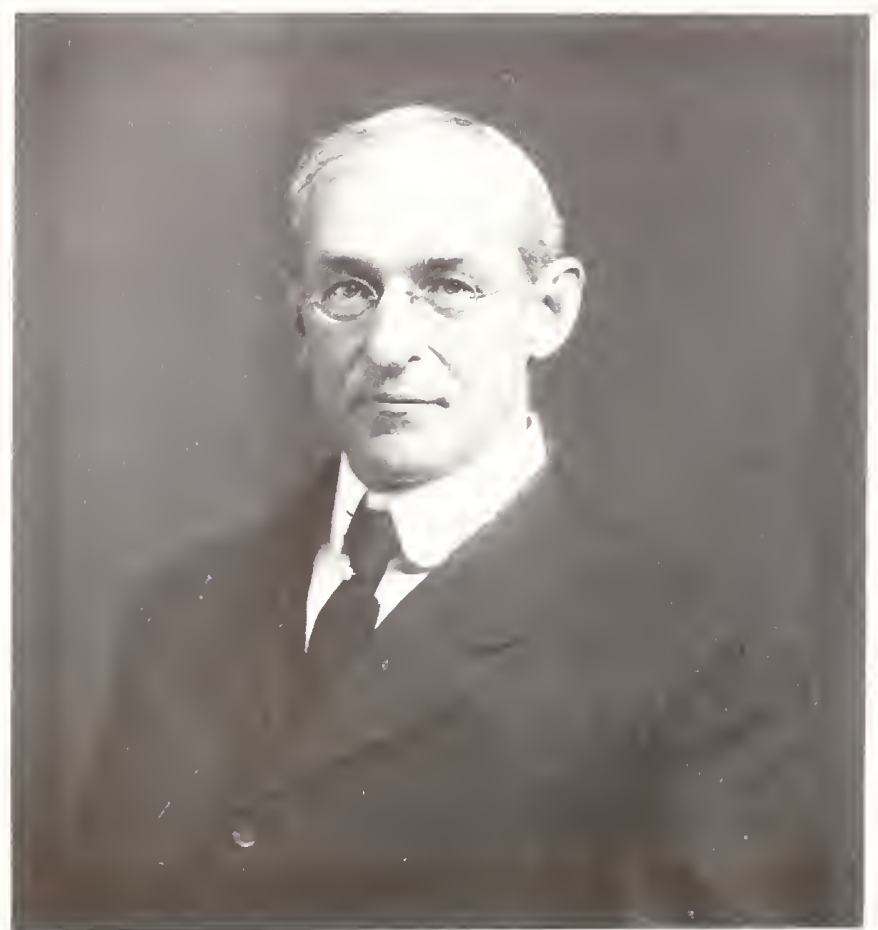

William de C. Ravenel, in a photograph published in local newspapers in 1918.

tenure he had to contend with inadequate funding and a limited statt, yet the collections grew and good research was published by those under him. One of the pieces of furniture in the director's office was the large desk once used by Secretary Baird: Wetmore was proud of this heirloom and its owner. Later the desk was taken back across the Mall and still later returned to the east wing. It is a prized piece of furniture, for display and not for use.

During this period it was customary for all inquiries from the public to be answered officially by the director. Inquiries were sent to the departments, which prepared replies for the director's signature. Over several years there had been a series of letters from a skilled amateur collector of Eskimo artifacts. One dav an embarrassed Wetmore brought a stranger to the ethnologist Henry Collins's office. The amateur had come to Washington anxious to meet Dr. Wetmore, for he was impressed that such a renowned ornithologist could also be so knowledgeable about Eskimo culture.

"Alexander Wetmore is so familiar a figure to scientists as the dean of American ornithology that it is difficult to realize that he has been directly associated with the Smithsonian Institution since 1924,"3 Ripley wrote of him in 1976, on the occasion of his ninetieth birthday. Wetmore's activity both in the office and in the field was only then coming to a close. After his death in 1979, a British colleague remembered him with affection and respect: "Dr. Wetmore was, in a sense, an old-fashioned ornithologist, museum-based, his field work centred round collecting-one who pro- vides the facts that others use. He did not originate new theories, seemingly distrustful of the sweeping generalization, as is often the case with those who are very familiar with the facts and see, more clearly than most, the exceptions and difficulties that need be taken into account."

\section{A. Remington Kellogg}

Wetmore was appointed Secretary of the Smithsonian Institution in 1945, but continued to run the Museum until May 1948, when A. Remington Kellogg was named director of the United States National Museum. Kellogg was the second person to hold this exact combination of title and position. He moved up to Assistant Secretary of the Smithsonian Institution in February 1958 and got a chuckle out of the fact that when he retired in 1962 , he was replaced by three appointees-an assistant secretary, the director of the United States National Museum, and the director of the National Museum of Natural History.

"The period of Kellogg's administrative appointments was an active one for the Smithsonian," wrote Frank Whitmore of the Geological Survey, Kellogg's fellow aficionado of fossil whales. The Museum's collections grew from 25 million to 56 million specimens; "almost all of the exhibit halls in the Natural History Building were modernized, the scientific staff of the Museum was enlarged, and many new research programs were initiated; and the new National Museum of History and Technology ... was built. Despite the demands of these and many other services, Kellogg managed to spend part of each day in research on fossil marine mannals.'

All this is accurate and yet not quite the whole story. Watson Perrygo stated, "One day A. W. [Wetmore] asked me who might make a good director and I suggest ed Kelly." Perrygo was an outgoing, diplomatic person who had a real way with people, and perhaps his suggestion did crystallize Wetmore's thoughts. Later, Perrygo said, Wetmore told him to ask Kellogg if he would take the position, but as anticipated, Kellogg immediately refused. Perrygo was told to persist, and eventually Kellogg said, "Tell the boss I'll do it." Kellogg became director, but he was a reluctant administrator.

Edward Henderson, who rode to work with Kellogg for years, speculated that the appointment was in part the result of a common background-both Wetmore and Kellogg were graduates of the University of Kansas and of the Biological Survey-and in part a recompense for the long delay in Kellogg's advancement within the Museum. Kellogg spent thirteen years as an assistant curator of mammals under Gerritt S. Miller, Jr., ${ }^{6}$ before being promoted to curator. This was a typical career pattern for staff members hired between the wars.

Once Kellogg assumed office, he immediately gained an unofficial title, "the abominable no man." He characteristically took a dim view of requests for travel funds, 
Richard Cowan, standing, examining material collected in South America for a plant

thall that never was constructed. Stooping is Reginald J. Sayre of the exhibits staff, and leaming forward is Thomas Soderstrom, curator of botany. This was in closedoff Hall 30-the whale hall on the south side of the second floor-as indicated by exhibits in the case behind. Late $1960 \mathrm{~s}$.

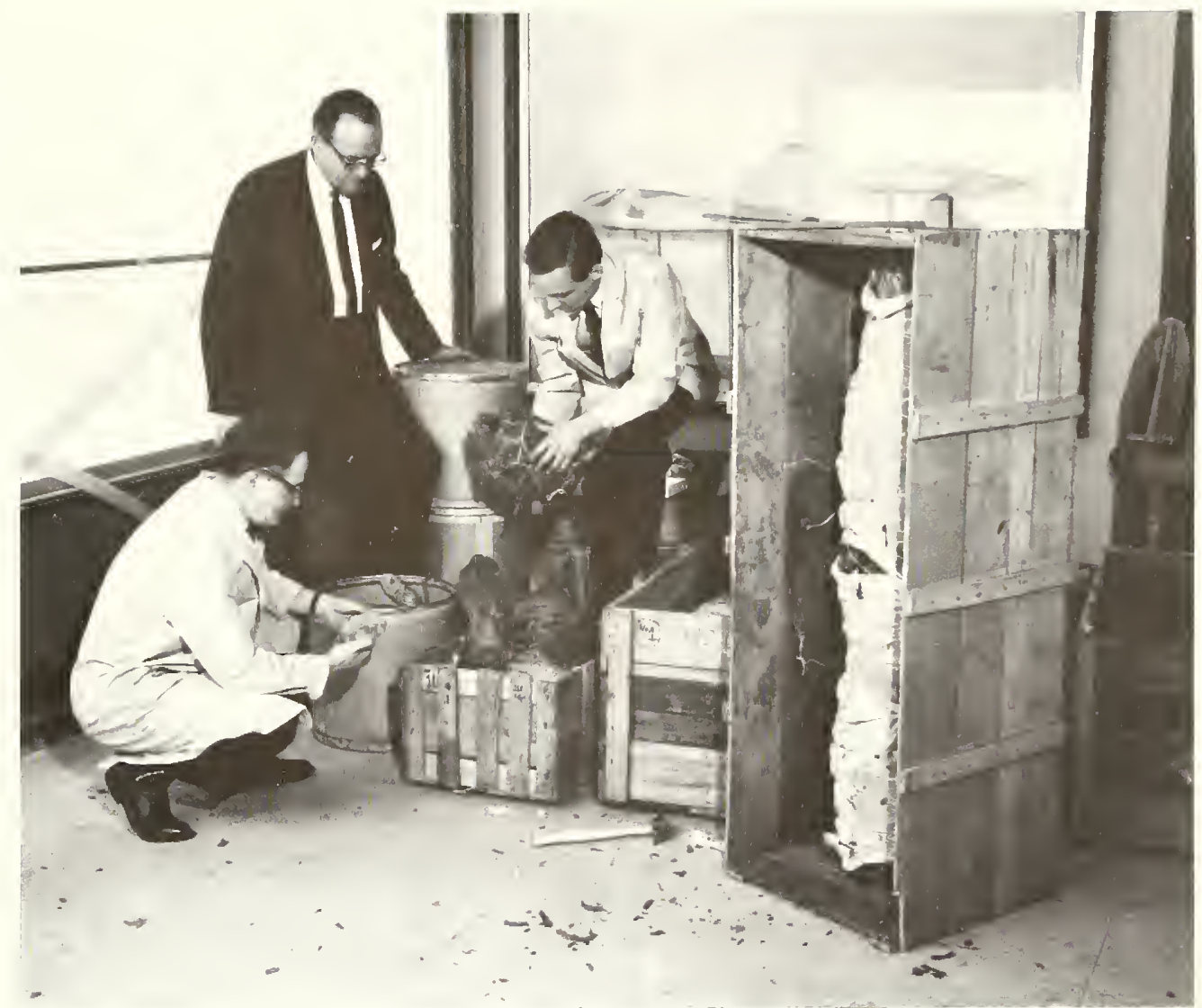

new ideas for research activities, and administrative changes, and while most were eventually approved, it took a long time for them to be argued through the system. Although exhibit activity reached a crescendo under Kellogg, he was far more interested in research. About the only exhibit work he participated in was supervising the fabrication of the great blue whale, and he had a terrible time making up his mind as to what he wanted and even what color the model should be painted. Fenner Chace, a crustacean expert, eventually decided what color to paint the eyes.

By any measure one wants to apply, Kellogg was a character. He swore. Indeed, he used profanity so constantly that for him not to use it in a sentence was a shock to the listener. One time the Smithsonian Institution made a short movie of scientists at work, dubbing in the voice of a narrator explaining what each scientist was doing. The film crew came back to Kellogg very apologetically and explained that they had to shoot again, for a lip reader had looked at his segment of the film and determined that it could not be distributed.

Kellogg was also an eminent scientist. For most of his career at the Museum he studied living and fossil whales, building on the work of his Museum predecessor in marine mammals, F. W. True. He was the American representative to the International Whaling Commission. Most of what we know of the early history of Leviathan was described by him in excruciating os- teological detail, and a great deal of the recent interest in marine mammals has come about as a result of his studies.

The Museum changed dramatically during the Kellogg years. To overgeneralize, about all that Wetmore was able to do, without funds and for nearly three decades, was to hold the Museum and the Institution together with little more than strength of character. Under Remington Kellogg, swearing all the way, a largely new staff, fueled by new money, remade the Museum.

\section{Albert C. Smith}

On July 1, 1957, the United States National Museum was divided into the Museum of Natural History and the Museum of History and Technology, with Kellogg remaining as overall director. John Graf retired at the end of 1957, and Kellogg was appointed an assistant secretary, while still acting as head of Natural History. Because of the administrative changes made in 1957 , the distinction of being the first director of the Museum of Natural History belongs to Albert C. Smith. He took office in August 1958, under Kellogg as director of the United States National Museum.

Museum life was definitely changing, and Smith's appointment was perhaps the first acknowledgement by the Institution that post-World War II science was quite different from science in the earlier days. Smith had begun his scientific career as a botanist at the New 
Director Richard S. Fiske in the vertebrate paleontology laboratory on the ground floor, east wing, receiving a donation of Miocene fossil shark teeth (Carcharocton) from Peter J. Harmatuk,

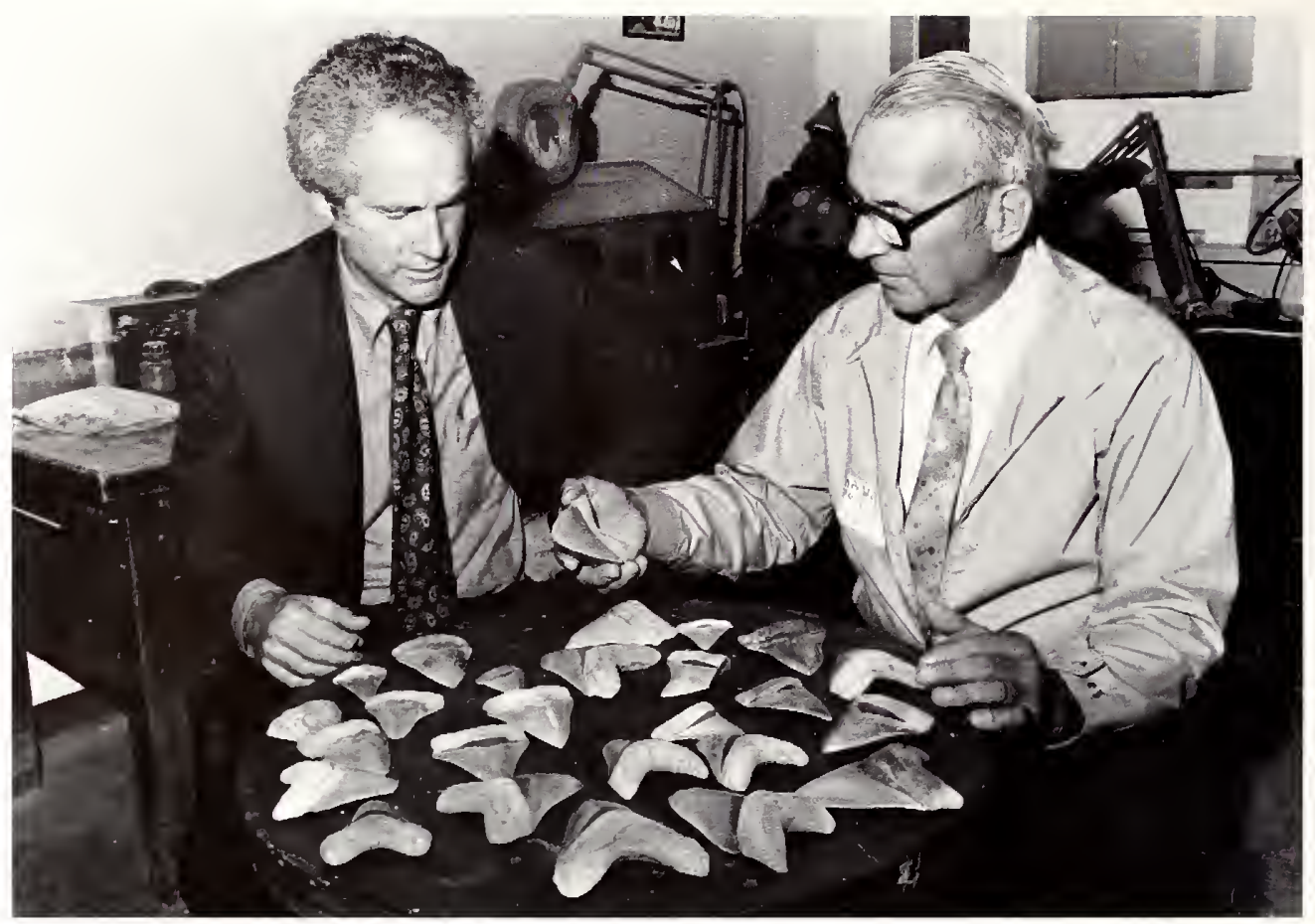
1981

York Botanical Garden while attending Columbia University. In 1940 he went to the Arnold Arboretum at Harvard for eight years. He came to the Museum as a new staff member in 1948, and for eight years curated phanerograms (flowering plants) in the Castle, crowded in with the other botanists. In 1956 he left for the National Science Foundation, where he was the program director for systematic biology. Having acquired considerable administrative experience there, Smith took up the directorship of the Museum with new perspectives.

For at least part of the time that Smith was director, Kellogg had a desk in the office, concealed behind a screen. Whenever anyone came to see the director, Smith would indicate by hand signal whether Kellogg was in the room. In spite of this, Smith was able to do a good job of administration, and always seemed to be quiet and self-contained, with a style quite unlike Kellogg's. Many of the staff found him easy to deal with and sympathetic toward new research ideas that required funds. When the National Science Foundation (NSF) came into existence, in the early 1950s, its relationship to the Smithsonian Institution and to the Museum was ambiguous. Under A. C. Smith the Museum staff was given permission to apply to the NSF for funds, and a number of scientists received grants. Smith was appointed an assistant secretary of the Smithsonian Institution in 1962, but left after a year for the University of Hawaii.

\section{Frank Taylor}

Also in I962, Kellogg retired. He was succeeded by Frank Taylor, who had started his career in the Arts and Industries Building in the early 1920s, but had an earlier, indirect connection with the Institution, working as a messenger in the new National Museum for the Bureau of War Risk Insurance. Taylor's five-year tenure as overall director of the United States National Museum ended July 12, I968, when the United States National Museum disappeared as an administrative entity. His office was never in the Museum, but in Arts and Industries. From 1968 until his retirement, Taylor served under the title of Director-general of Museums. One of two holders of a Smithsonian sixty-year pin, Taylor still comes to work and is currently planning a museum of the city of Washington.

It is expected, though nowhere explicitly stated, that the director of the Museum be a scientist involved in administration, not an administrator. The difference between a scientist serving as a leader of his peers and a professional administrator overseeing scientists need not be belabored, but perhaps the prime reason the Museum has functioned so well is that scientists have administered it. Rathbun, Ravenel, and Wetmore were listed as members of the scientific staff. Curiously, Kel$\operatorname{logg}$ and subsequent directors have not been listed under a department, but they are always thought of as coming from a particular department.

\section{T. Dale Stewart}

In any event, the botanist A. C. Smith was followed in early 1962 by the anthropologist T. Dale Stewart, the only head curator to become director. After a dinner of the Board of Regents attended by both Smith and Stewart, it was announced that both would move up simultaneously. Stewart's explanation of his selection 
was that he had served on several committees appointed by Secretary Carmichael, and that apparently the Secretary liked his approach. Stewart was named an assistant secretary in early 1966 and served briefly before returning to his first love, physical anthropology.

Stewart first came to the Museum in 1924 as a temporary aide to Alěs Hrdlǐcka. After working and going to medical school at Johns Hopkins University, he then spent more than five decades in the Department of Anthropology. Anyone who survived under Hrdlička had to be tough, and had to develop a sense of humor. Hrdlička did not like the staff to speak during working hours. He criticized Stewart one day for talking, but relented a bit when Stewart said that he was announcing the birth of his first child. Hrdlička asked what the sex was, and when told it was a girl, lost interest, remarking, "Vell, de first von is generally a veakling."

Stewart continued in the tradition of physical anthropology, developing great skill in forensic interpretations and applying this skill to skeletal remains recovered by police. His work for the Federal Bureau of Investigation would have won him a nod from Sherlock Holmes. Stewart's research, like that of many of the Museum's curators, has ranged into new fields over the years, and perhaps his key work has been his contributions to paleoanthropology, which have helped revise our notions of Neanderthal man. ${ }^{7}$

\section{Richard S. Cowan}

A. C. Smith pointed out to Stewart some of the advantages of additional administrative staff, and advised the appointment of an assistant director. It was he who suggested Richard S. Cowan for the position. Cowan, like Smith, was a postwar hiree, having come to the Museum in 1952 after four years at the New York Botanical Garden. He too was a tropical botanist, though he looked at different plants from those that interested Smith. Early in 1963 Cowan became the first assistant director of the Museum of Natural History, and in March 1966 was appointed director, succeeding Stewart. Cowan held the post until 1973, when, accompanied by his many office plants, he returned to the Department of Botany as a Senior Scientist. He continues to work on South American floras, especially tree legumes.

During the time that Cowan served as director, there was a great diversification in the administration of science within the Smithsonian, with the establishment of special offices for anthropology, ecology, oceanography, and systematics. In addition to being director, Cowan was head of the Office of Systematics. The Office held five memorable summer institutes in systematics, but the only tangible evidence of the Office was a large coffee pot.

Donald Squires, from Invertebrate Zoology, was deputy director for several years under Cowan. When he left, P. K. Knierim, an administrator who had trans-

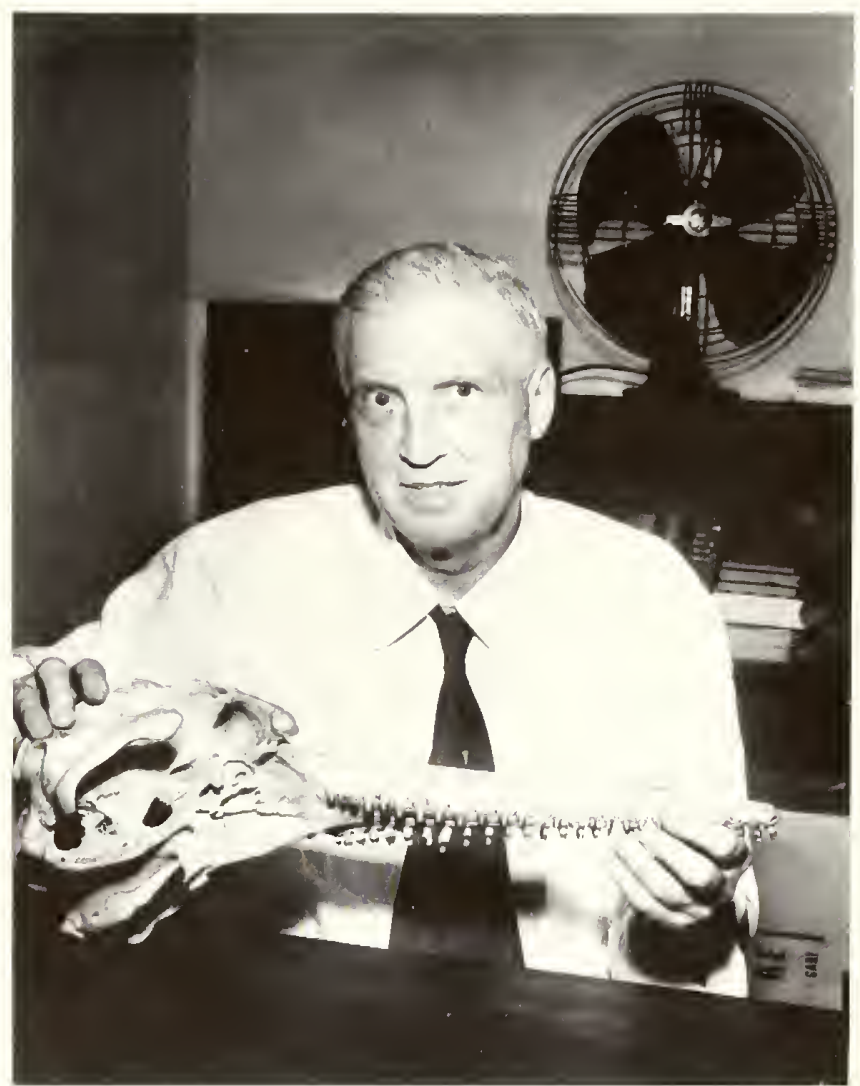

A. Remington Kellogg holding the skull of an Amazon River dolphin (Inia), October 1955.

ferred from the Department of Agriculture, served as assistant director until he retired in 1972. James Mello transferred from the U.S. Geological Survey to the Museum in 1970 to head up Automatic Data Processing, which had been developed by Squires. When Porter M. Kier of Paleobiology became director, Mello was appointed assistant director; he rose to associate director and then in 1984 gave up administration and transferred to the Department of Paleobiology to resume his long-interrupted study of microfossils. To date, Richard Cowan is the only assistant director to have become director.

During Cowan's tenure the name of the Museum was formally altered once again, to the National Museum of Natural History. For years, when referring to specimen numbers in a manuscript, the curators had used the prefix USNM. The Smithsonian Institution Press decided to adopt the change to NMNH, which lasted for about two weeks before the curators rose in wrath. USNM is still used to refer to specimens in the National Museum of Natural History, and mail addressed to the United States National Museum is still delivered.

\section{Porter M. Kier}

Porter Kier, described in a newspaper feature story as "a razor-thin, hawk-like . . man whose exuberance for his work is immediately discernable," took over as di- 


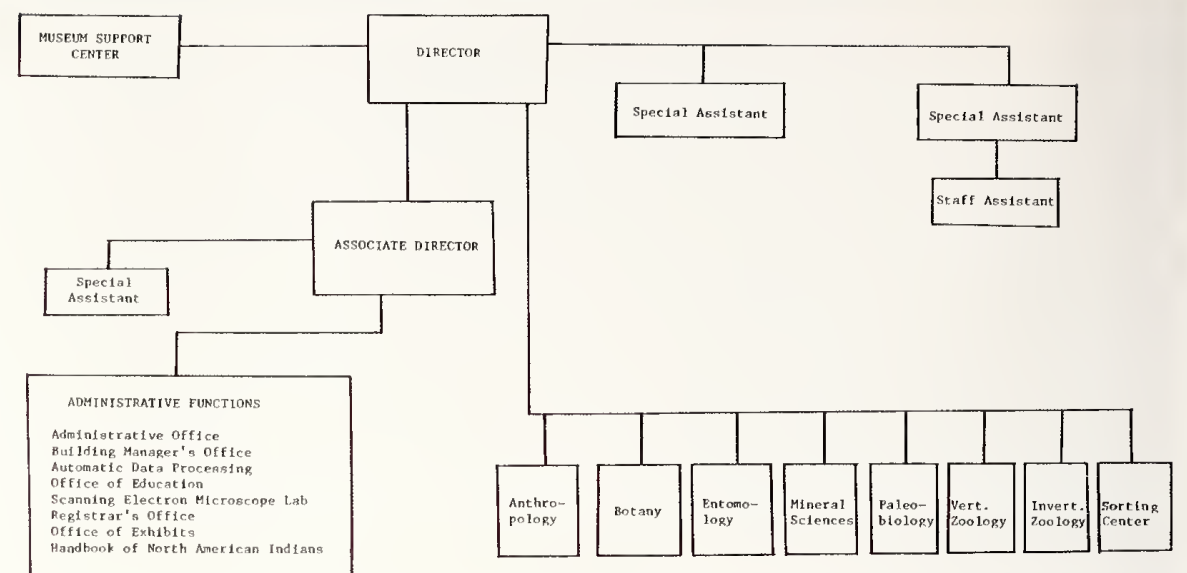

rector January 15, 1973, and served until mid-1979. After postgraduate work at Cambridge University, a two-year stint in the U.S. Army, and one year's teaching at the University of Houston, he arrived at the Smithsonian in 1957. "It was the dream of a lifetime. The Smithsonian's famed natural history museum. is the Mount Olympus of sea urchin paleontology." $A$ scuba diver and underwater photographer, Kier is one of those who have studied living animals to bring new knowledge back to the interpretation of fossils; Ripley characterized him as "an innovative researcher of almost indefatigable energy." ${ }^{9}$ A decade after joining the staff, Kier succeeded G. Arthur Cooper as the second chairman of the Department of Paleobiology. Following that term, he spent about a year as a full-time scientist before becoming director.

Kier was the first director to be selected through the mechanism of a search committee, an essential practice under present-day Civil Service regulations. He is also the first department chairman to have been appointed director. While one may quibble as to the distinction between Stewart as first head curator and Kier as first chairman to occupy the office, the difference between the old style and the new style is tremendous. A "green hornet" (so named because of the color of its paper and its thrust) issued by Secretary Ripley in the mid1960 s announced the abolition of the title "head curator." The term of a chairman is not to exceed five years.

The Museum's exhibits program regained its vigor under Kier. The most obvious public product of his administration, however, is the "Kier testimonial" escalator leading from the foyer to the rotunda. Its installation was opposed unanimously by the department chairmen. Kier was able to obtain money for it as part of the Bicentennial celebration, arguing-quite rightly, as it turned out - that the escalator would be needed to handle the large crowds.

\section{Richard S. Fiske}

Kier returned to his echinoids in mid-1979, and on January 14, 1980, Richard S. Fiske became the fifth director of the National Museum of Natural History, and the ninth man to occupy the southwest corner office. Fiske, like Stewart, received his final training at Johns Hopkins University. After a few years of postdoctoral study, he joined the U. S. Geological Survey in 1964. He spent the next twelve years studying volcanoes-live ones in Hawaii and presumed-dead ones in Washington State-but he gradually became ensnared in administrative duties. While his colleagues at the Geological Survey saw him as prime material for the administrative post of chief geologist, Fiske left the Survey for the Museum because he wanted more time for research in volcanology. ${ }^{10}$

Upon his arrival in the Department of Mineral Sciences, Fiske was swept into the exhibits program, and because of his interest soon became head of a revitalized exhibits committee. One of his early acts as director was to see that the rhinoceros was moved out of his office; the beast was replaced by a series of shelves holding American Indian pots. The eruption of Mount St. Helens in 1980, and the centenary in 1983 of the eruption of Krakatau kept Fiske busy combining administration and research with lecturing and writing on both events.

Nothing has been written about the term of the director of the Museum of Natural History, yet somehow it has come to be understood that this position, like a chairmanship, is not a lifetime appointment. On July 10, 1985, Dick Fiske stepped down; James Tyler, an ichthyologist who transferred from the National Science Foundation to the Museum earlier that year, stepped in as acting director. When the next major volcanic eruption occurs, Senior Scientist Fiske will be thereburdened with samples but untroubled by administrative cares. 
Some of those who ran the Museum of Natural History. Left to right: A. Remington

Kellogg, Director, U.S.

National Museum; A. C. Smith, Director, Museum of Natural History; Charles S. East, taxidermist; Alexander Wetmore, Secretary Emeritus; and Watson Perrygo, taxi dermist. The occasion was a retirement ceremony for Charlie East, held in 1960 on the second floor of the Castle.
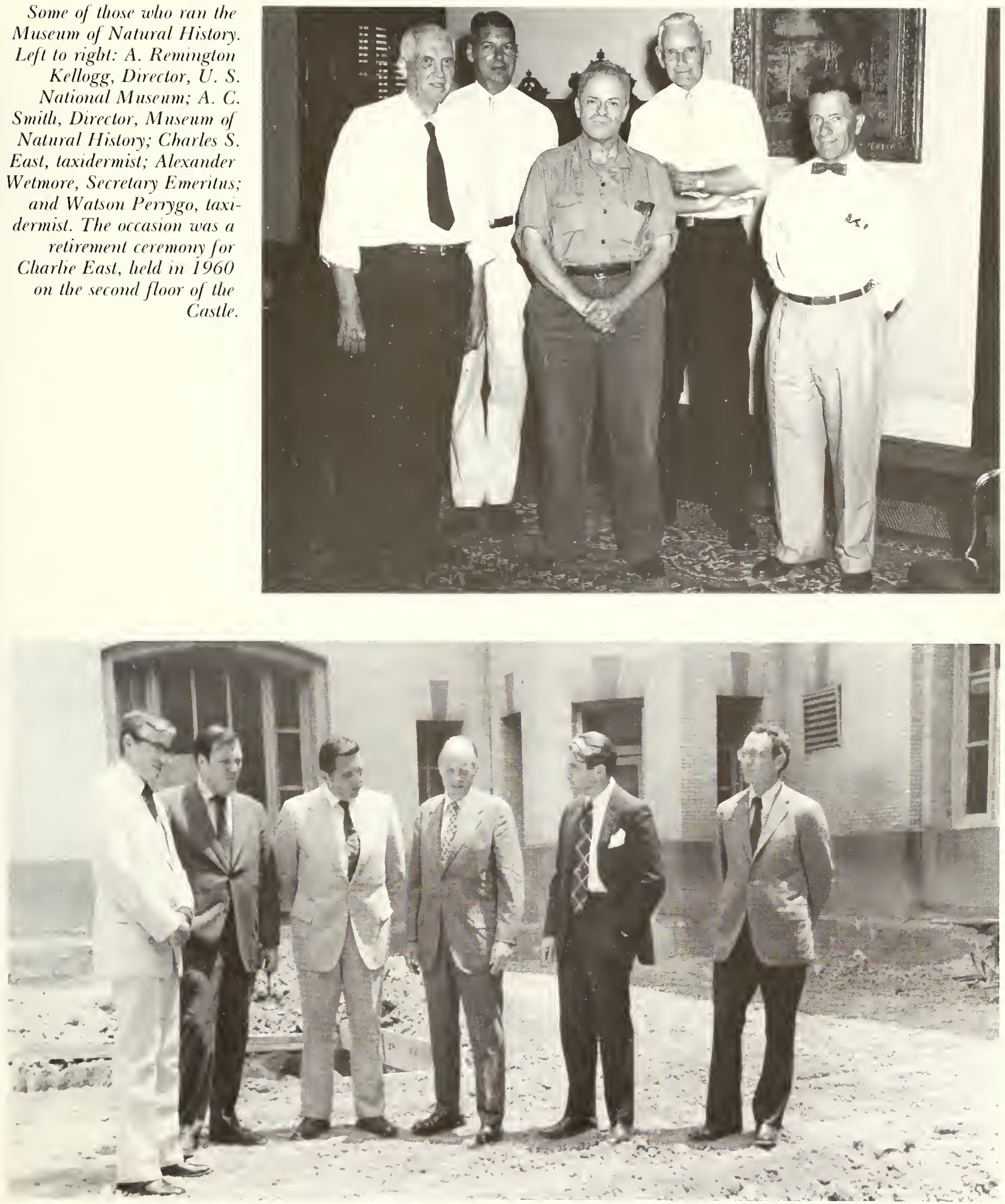

Group in the west court, just after the Buller buildings were torn down; the west stairwell is belind, projecting into the court. This is now the site of the West Court Building. Left to right: Porter M. Kier, Director, National Museum of Natural Mistory; Richard O. Griesel, Marager, Business Mamagement Office, Smithsoniam Institution; Richard $W$.
Kerman, Group Vice President, Marrott Corporation; Ames T. Wheeler, Treasurer, Smillrsomian Institution; Paul N. Perrot, Assistant Secretary, Museum Programs; and Jarmes F. Mello, Assistant Director, National Museum of Natural History. This photograph was published in Smithsonian Year 1975. 


\section{to, 00}

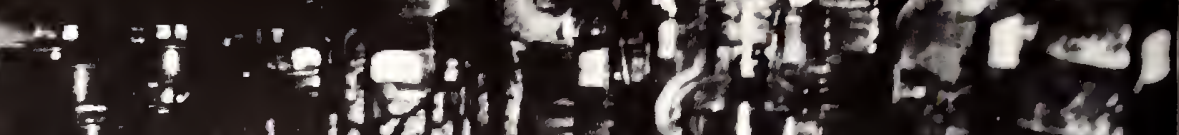

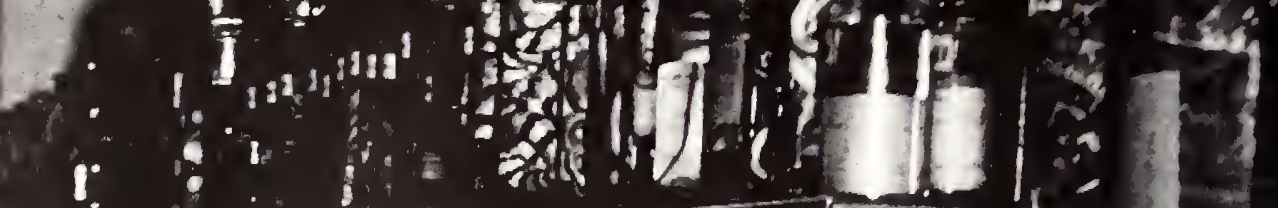

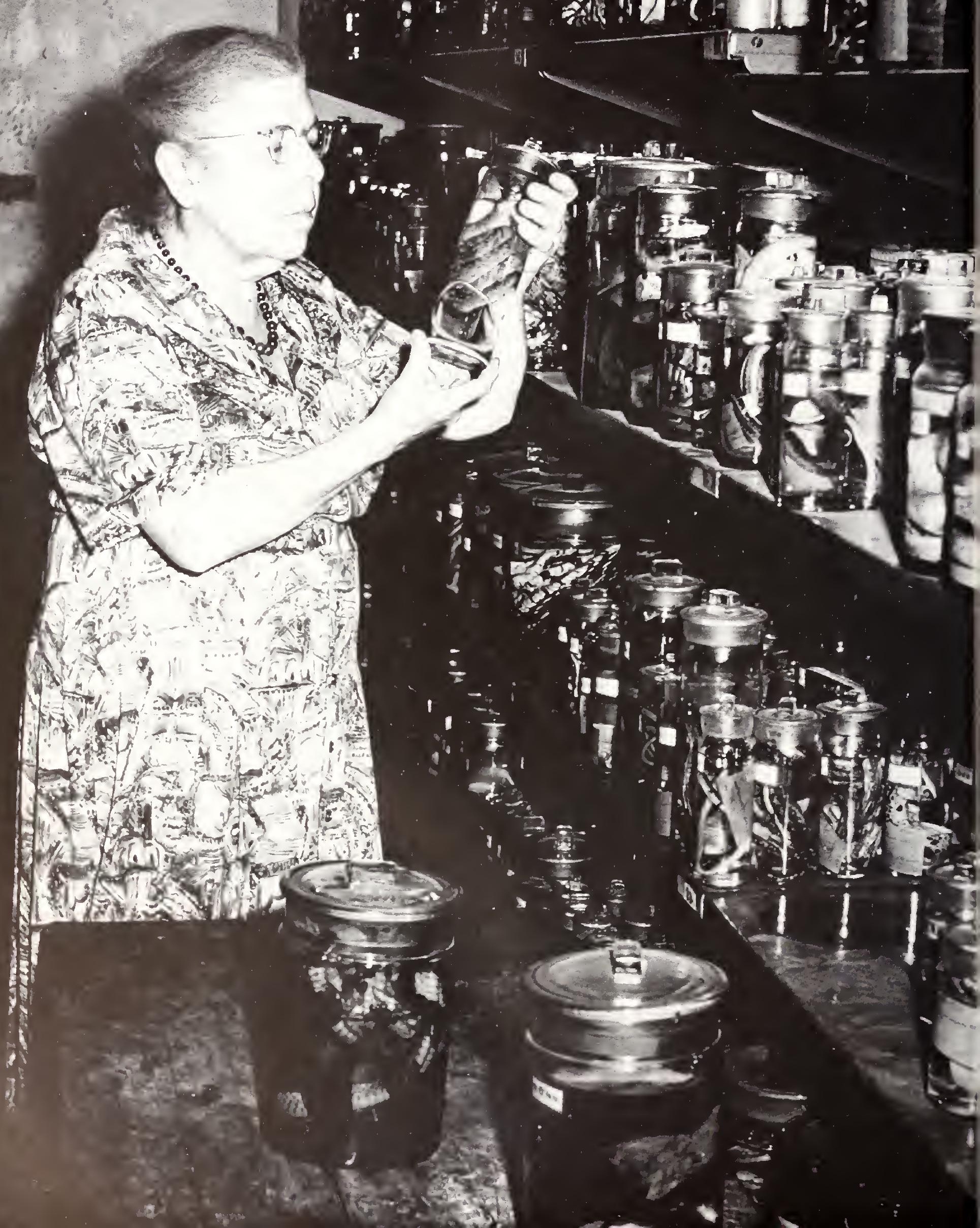




\section{The Scientific Staff}

$\mathrm{C}$

OUNTING EVERY LIBRARIAN, carpenter, and guard, $A$ it is nearly impossible to pinpoint the number of people currently employed in the Museum of Natural History. Given constant change and the very size of the building, that is no surprise. But it is extremely difficult to determine even the number of people pursuing research in the Museum during any given year, as critically important as this figure is to any museum director.

"At the beginning of the year the Assistant Secretary was placed in immediate charge of the Museum, the direction of which rests with the Secretary of the Smithsonian Institution, its keeper ex officio," Rathbun reported in 1901. "The scientific staff has consisted, besides the three head curators, of 18 curators, 12 assistant curators, 14 custodians, 10 aids [sic-the customary spelling in the early days], 4 associates, and 2 collaborators, making a total of 63 persons, of whom, however, only about one-half were under salary from the Museum, the remainder serving in a voluntary or honorary capacity, though nearly all of the latter were in the employ of other bureaus of the government." These figures included those in the Castle and those in the old National Museum, and thus encompassed more fields than natural history.

\section{Staff Numbers Low}

Just before the move to the new Museum building began late in 1909, the scientific staff for the Museum was given in the Annual Report as seventy-eight, and the listed administrative staff for the Institution was nine. ${ }^{2}$ However, the term curator was used for both those paid by the Museum and those paid by associated agencies; at least two of the curators recorded were not paid by the Museum and never had offices in either the old or new Museum buildings. In 1910, one may again count seventy-eight on the scientific staff (not duplicating those who held multiple appointments), and still an administrative staff of nine; eight of the scientific staff were designated aides and nine associates. ${ }^{3}$ From these figures one can see that moving to a huge new

Doris M. Cochran examining part of the snake collection preserved in alcohol, possibly in the 1950s. building did not result in employment of a huge new staff.

If the move across the Mall did not result in an increase, neither did World War I. In 1920, the formal managerial positions for the Institution had shrunk to eight. The staff list for the National Museum contained eighty-five names; of these eighty-five, nine were in the Department of Arts and Industries, and one, W. H. Holmes, was in the National Gallery of Art. ${ }^{4}$ Included in the seventy-five names for the three natural history departments, established by Walcott in 1898, are nine persons designated as aides. This hardly qualifies as a postwar boom, particularly when it is evident that almost half of the increase in staff since 1910 resulted from the addition of Department of Agriculture botanists.

By 1932 the administrative staff heads for the Institution had risen to ten; and as before, these people were responsible for libraries, correspondence, repairs, and similar activities for all the Smithsonian buildings. A count of the three natural history departments shows ninty-eight names. In the Department of Geology, seventeen persons were listed, of which one was a chief preparator and two were aides. Three associates listed were not paid by the Museum, nor were two custodians and one associate curator. The actual scientific staff of the Department of Geology was eight, and this included Paul Bartsch, who was really a specialist in modern mollusks, not fossil ones. Of course, there were Geological Survey paleontologists in the building, but except for two active members and one retiree, they were not listed. ${ }^{5}$ A decade later the scientific staff of the Department of Geology still consisted of eight people.

The 1920s and 1930s figures for the other two departments, Anthropology and Biology, were similarly inflated by the names of "staff" who were not paid by the Museum. Unless one knows the career of a particular person, it is risky to assume that a listing means that he was salaried by the Museum or even had an office on the premises. As in Geology, the staff in these two departments remained nearly static for two decades. During World War II, the staff declined in all departments. 
Mary Jane Rathbun working on fossil crabs, perhaps in the early 1920 s.

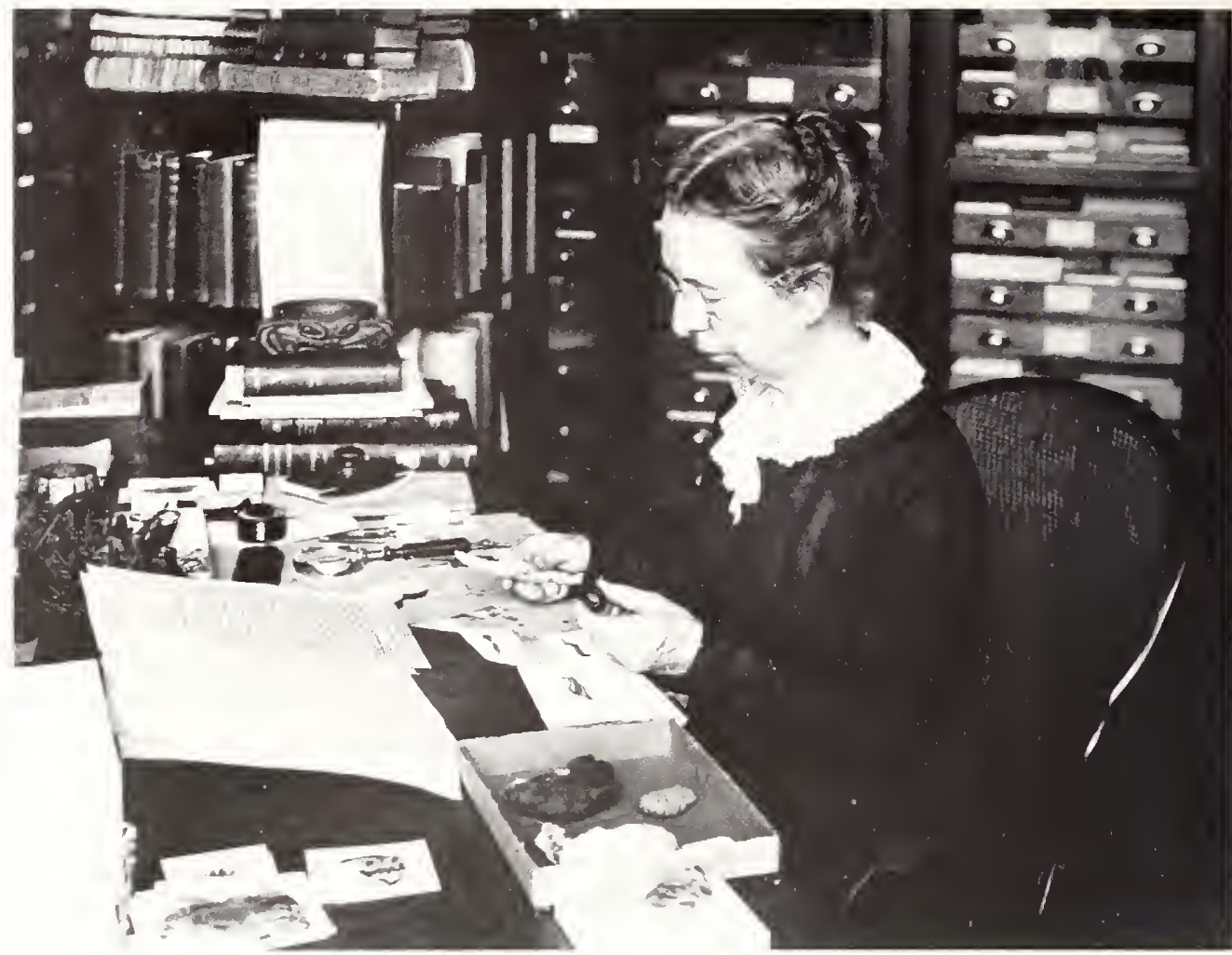

\section{Variations in Staff List}

Since the enty 1940s the staff list lras been published on a regular basis. One ought to be able to plot the growtl of staff since World War II, but this is more difficult than it seems. If one counts all the names listed under scientific staff for those in the Natural History Building during fiscal year 1955, the figures are: Anthropology, sixteen; Zoology, fiftr-four; and Geology, twenty-five. In 1960 these figures were eleven, twenty, and thirteen, respectively; what one sees here is the effect of a variation in the listing of exhibit specialists. collaborators, honorary associates, and others. In 1960 , for just about the first time, the stalf listing was a reasonably accurate indication of the number of scientists actually paid by the Mluseum. In 1965, just after the last of the present departments in the Museum of Natural History was organized, the count from the staff listing was: Anthropology, seventeen; Vertebrate Zoology, seventeen; Invertebrate Zoology, sixteen; Entomology, nineteen; Botany, nineteen (previously fourteen in 1955, and twelve in 1960); Paleobiology, fourteen; Mineral Sciences, six. Some of the departments, particularly Vertebrate Zoology, list exhibit specialists, but these figures mostly count only working scientists.

One may generalize that after the growth spurt in the mid-1960s and a smaller increase in the early 1970seffects of big science and the policies of Secretary Ripleythe scientific staff of the Museum has been close to static in terms of total numbers. In one department, the new curator hired in $197 \mathrm{l}$ remained the newest until 1981; the staff member added that year was a replacement for one who left. The changes in the 1970s were measured in terms of a few scientific positions a year. Since the late $1970 \mathrm{~s}$, as in most of the federal government, there has been essentially no growth in the Museum staff. The numbers of scientists paid by affiliated agencies reached a peak during the 1960s, but since then, in a few of those organizations, have declined. ${ }^{6}$

In recent years the Office of the Director has kept figures on the number of Museum scientists. These are compiled at irregular intervals, but have the advantage of being assembled by one person using consistent criteria as to who is considered to be on the scientific staff in a strict sense. The Archivist of the National Anthropological Archives, for example, is judged a historian, not a natural scientist. The director is counted, but an assistant, associate or deputy director may or may not be counted, depending on whether he is a scientist or an administrator.

In Table 3, the figures for Invertebrate and Vertebrate Zoology in 1964 show the makeup of the overall Department of Zoology, which still existed that year. Expansion of the mid-1960s and problems of the early 1970 s are evident in the totals. The large number in the Office of the Director in 1966 was a consequence of the assignment of Oceanography to the Museum. The small staff total in 1970 was an administrative artifact resulting from the separation of the Office of Oceanography from the Museum. In the compilation below they are returned to that office from 1976 onward. 
Under textbook administrative conditions, a pyramidal structure of many younger people below a few senior older staff is the model, but it seldom happens that way in the real world, certainly not in the Museum. Almost without exception, retirees are being replaced by relatively new graduates, rather than by highersalaried, middle-aged scientists, yet the rate of replacement is low. In 1966 the average age of the scientific staff was 44.0 years; in mid-1984 it had reached 49.6 years. Old-timers largely are of two classes: those few from the 1950s, who remember the building without wings and air conditioning; and those from the mid1960s. In a few years most of both groups will be gone, and a different staff with different memories will be in charge.

Just half a century ago, a Museum employee's salary was a tangible item, based directly on hours worked and distributed from a cash box brought over from the Castle. When someone went into the field, the Institution would send a salary check to his bank. In 1934 "a central disbursing agency for all Government establishments" was organized under the Treasury Department, and the Smithsonian's disbursing office was abolished. Beginning February 1, 1934, salary payments were made by check instead of by cash. ${ }^{7}$ For years, even after government checks were introduced, the staff hiked across the Mall to the Castle every two weeks and lined up to be paid. Today the Treasury Department prefers to mail salary checks to employees' banks.

\section{Salary Figures}

The Museum did not publish salary figures in its annual reports, but it is possible to draw some parallels from another agency. In 1894, when L. O. Howard took over what was to become the Bureau of Entomology in the Department of Agriculture, he received $\$ 2,400$. "In 1902 it was increased to $\$ 2,750$; in 1904 to $\$ 3,250$; in 1906 to $\$ 4,000$; in 1911 , to $\$ 4,500$, in 1919 to $\$ 5,000$; in 1924 , to $\$ 6,000$ and in 1925 to $\$ 6,500$. During all these years the salaries of principal assistants in the Bureau were being gradually raised from $\$ 1,200 .{ }^{\prime 8}$ One may approximately equate the position Howard held with that of the director of the Museum, and that of a principal assistant with a head curator.

In 1930 Howard wrote: "The salaries at the present time are in marked contrast to those of earlier years. The chief of the Bureau now receives $\$ 8,000$. There are two who receive $\$ 6,400$ a year each; one who has $\$ 6,000$, two have $\$ 5,800$, six have $\$ 5,600$, one has $\$ 5,200$, two have $\$ 5,000$, and forty-six have from $\$ 4,000$ to $\$ 4,600$, no less than twenty-eight of these receiving $\$ 4,600$ each. Of course, the compensation in other walks of life has also increased, either correspondingly or much more greatly. The vastly increased cost of living brought about largely by ... World War [1] is naturally responsible for much of these increases...."9

The general position of those who administered sci-

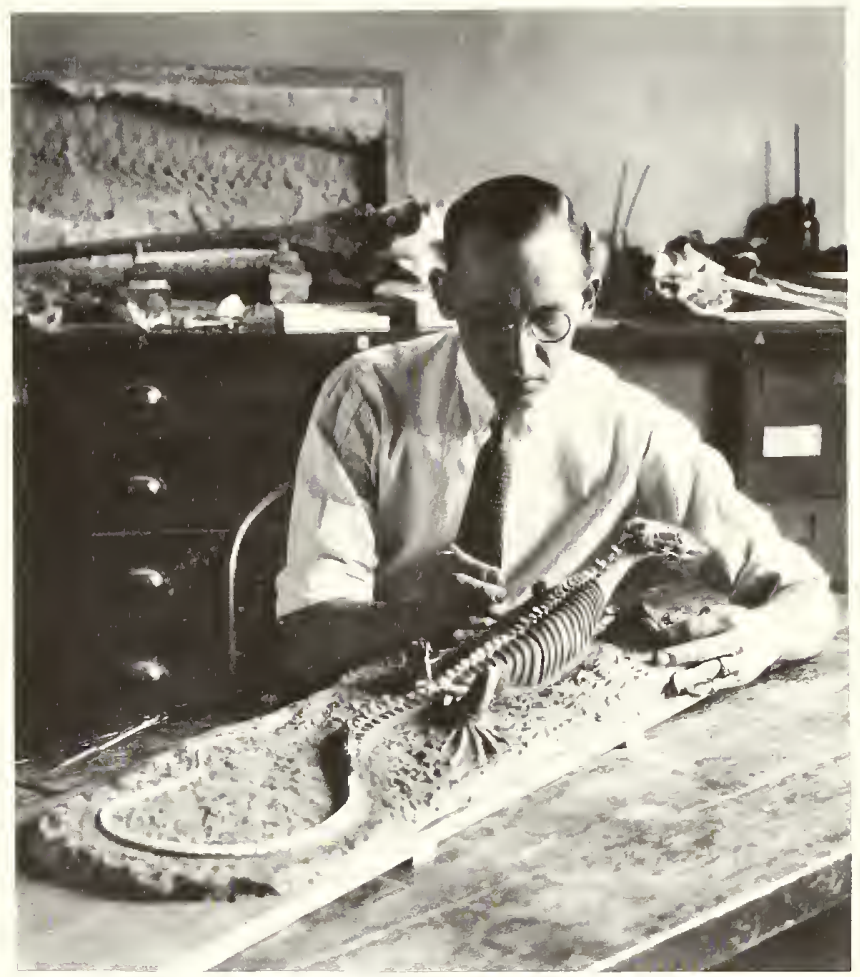

Norman Boss, chief preparator in the Vertebrate Paleontology division, preparing a fossil lizard (Saniwa), 1921 or 1922.

ence in the government was that the wisest course was to keep a low profile and not ask for too much money. For example, it was the often-stated policy of John B. Reeside, Jr., for many years chief of the Geological Survey paleontologists, that because paleontologists did what they enjoyed, they should be paid less than other geologists. Since World War I there has been a trickle of scientists from affiliated agencies to the Museum staff. Almost never were such transfers made for financial gain, but rather for slightly greater opportunities to pursue research.

Since the late 1950 s, performing scientific work for the federal government has become a recognized function, and salaries have become reasonably respectable. Government pay for scientists is more or less comparable to salaries in academia, taking into account the high cost of living in Washington, D.C., as compared to the average college town. Fifty years ago the life of the museum curator in Washington was that of genteel poverty. Today, if everyone on the suburban block lined up outside their houses, the museum curator could not be singled out, except by the parking sticker on the station-wagon bumper.

\section{Hiring Policies}

In the last seventy-five years, the scientific staff of the Museum has included few women and fewer black employees. Described by John F. Kennedy as a city of northern charm and southern efficiency, Washington 
may be the capital of the nation, but the District of Columbia is definitely south of the Mason-Dixon line. The hiring policies of the Smithsonian have been no more enlightened than those of the area and the times.

Neil Judd wrote in 1968: "My only assistant for this 1911 undertaking and for the accompanying laboratory work ... was a Civil War veteran who had joined the staff in 1878. ... In his later years failing health reduced the old gentleman's activities and a Negro, Charles $\mathrm{T}$. Terry, Jr. was employed as probational aide to mark specimens-the first to break the segregation barrier in our division of archaeology. From the beginning any nonwhite assistant gradually advanced to become an indispensible member of the organization. He not only numbered specimens but kept our records of the study collections so that any given object, if called for by a visiting scientist could be brought to the laboratory with minimum delay." ${ }^{16}$ Terry's name did not appear on the staff lists.

Another black employee, Ulysses Lyons, began as a laborer in the early 1950s at \$1.07 an hour. After a few months and some struggle, he was able to transfer to the Division of Ethnology in the Department of Anthropology as a GS-2, the second-lowest rating in the General Service scale. Shortly after Clifford Evans became chairman of the Department of Anthropology in 1970, he hired the first black female departmental secretary in the Museum. "Sophie Lutterlough, hired in 1943 as the first female elevator operator, eventually became a preparator in Entomology and stayed with the Museum for forty years. ${ }^{12}$ At the present time, though other minority groups are represented, there are no American blacks on the scientific staff.

For the first decade of the building's existence, there was only one female professional on the staff-Mary Jane Rathbun, the "crab lady." The geologist Julia Gardner had been in the building since before the start of World War I, during which she drove an ambulance, but she did not get a government position until the early 1920s. In 1919 Doris M. Cochran, the "frog lady," was listed as an aide, but it was not until 1927 that she was promoted to assistant curator. Doris Blake, the widow of an eminent botanist, was a volunteer in Entomology who for decades had an office in the rotunda just off the fourth-floor attics. For years, especially after Dr. Blake died, the two Dorises were the closest of friends, and it was the Division of Amphibians and Reptiles that provided office space for Mrs. Blake from 1962 onward, when the other entomologists left the building.

One interesting phenomenon, now slowly dying out, is the tradition of the volunteer wife. Perhaps Betty Meggers, who contributed so much to the anthropology halls, is the type example. One wife learned to read Russian so that she could make proper entries in a card catalogue of species maintained by her husband. There are nepotism rules, and occasionally wives work elsewhere in the Institution if husbands work for the Museum.

A very few women were added to the staff in the 1940s and 1950s; during the same interval, a slightly greater proportion of women appeared on the staffs of the affiliated organizations. Nothing changed until the 1970s, when some members of the "baby boom" generation began to be hired. Women scientists are still very much the exception, but the eight on the present Museum staff about equal the total that were on the staff for the first sixty years of the building's history.

One long-time feminine stronghold is the Office of the Registrar, first formally established in 1881. These people account for each specimen in the collections; currently the museum is approaching 69 million specimens. When the new building was ready, the registrar moved across the Mall, since most of the new accessions weie of natural history specimens. For decades the registrar's office was situated on the south side of the building near that of the director, and it was run by

\section{TABle 3: Scientific Staff by Department, 1964-1984}

$\begin{array}{rccccccccc}\text { Date } & \text { Off. Dir. } & \text { Ant. } & \text { Bot. } & \text { Ent. } & \text { I.Z. } & \text { M.S. } & \text { Paleo. } & \text { V.Z. } & \text { Total } \\ 9 / 1964 & 3 & 11 & 15 & 9 & 14 & 5 & 13 & 15 & 85 \\ 5 / 1966 & 12 & 17 & 15 & 10 & 16 & 5 & 15 & 15 & 105 \\ 6 / 1970 & 3 & 16 & 13 & 9 & 17 & 7 & 18 & 13 & 96 \\ 4 / 1973 & 2 & 16 & 19 & 12 & 17 & 9 & 18 & 13 & 106 \\ 4 / 1974 & 2 & 17 & 19 & 12 & 17 & 10 & 18 & 14 & 109 \\ 4 / 1976 & 7 & 17 & 19 & 11 & 17 & 9 & 18 & 15 & 113 \\ 4 / 1977 & 7 & 17 & 19 & 12 & 18 & 10 & 18 & 15 & 116 \\ 4 / 1978 & 8 & 18 & 19 & 12 & 19 & 10 & 18 & 15 & 119 \\ 4 / 1979 & 8 & 16 & 17 & 12 & 20 & 10 & 18 & 14 & 115 \\ 4 / 1980 & 5 & 15 & 17 & 11 & 20 & 9 & 19 & 15 & 113 \\ 4 / 1984 & 6 & 16 & 19 & 12 & 18 & 8 & 19 & 14 & 112\end{array}$


Staff of the Department of Anthropology, taken in the Arts and Industries Building in 1932. Standing, left to right: Charles Terry, museum aide, archeology; unknown, museum aide, physical anthropology; Walter Hough, curator, ethnology; George McCoy, secretary, head office; John $P$. Harrington, ethnologist, Bureau of American Ethnology; R. G. Paine, museum aide, archeology; W. G.

Egberts, chief preparator, Exhibits Office; Mrs. Loose, secretary, archeology-one of the two women to right. Seated, left to right: T. Dale

Stewart, assistant curator, physical anthropology; Frank M. Setzler, assistant curator, archeology; Neil M. Judd, curator, archeology; William Henry Holmes, head, National Gallery of Art; Aleš Hrdlička, curator, physical anthropology; Herbert $W$.

Kreiger, associate curator, ethnology; Henry B. Collins, assistant curator, ethnology.

Staff of the Department of Anthropology on the south porch steps in the early 1950s-not a great change in number from 1932.

Department of Zoology staff on the Mall steps, September

28, 1949. The fifty-four people shown include Secretary Wetmore, director Kellogg, two retirees, and six members of the Fish and Wildlife Service.
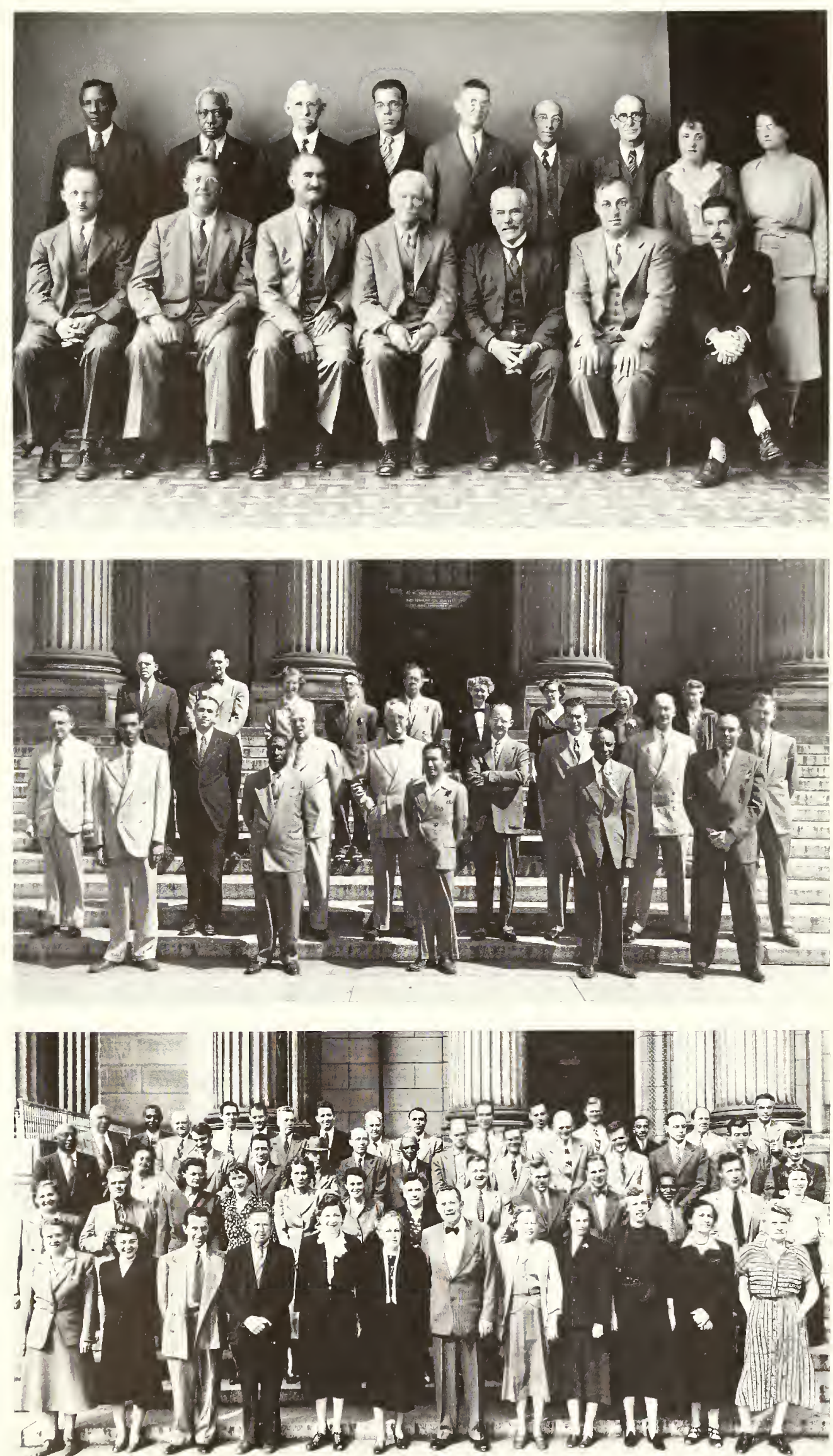
Helena Weiss, who retired in 1971 .

With expansion of the Smithsonian in the 1960s, the work of the registrar also expanded, and the office moved back to the old building, where there was more space. Finally, in 1976, accessioning and record-keeping were decentralized and the National Museum of Natural History gained its own registrar. The office was a rickety wooden balcony built into the shipping room. The files were one floor down and a hundred feet away. Later, the files were moved farther away; then the office was moved to where the files had been transferred, but the files moved again. In 1980, when this original area near the loading dock was decked over to make more space, the registrar thought that a ribbon-cutting ceremony was in order.

Because monover of the scientific statf is low, there is little prospect of major changes for blacks, women, or other minorities in the next decade, unless there is a substantial increase in the professional staff. The historical record is not one to be particularly proud of, but eftorts are being made to right the balance. In 1980 Secretary Ripley called for "fresh attitudes and stronger programs ... against discrimination ... whether intentional or not." He continued, "I an deeply concerned about this serious problem. An end to discrimination in all aspects of our atfairs is a fundamental responsibility of the old and honored institution."

\section{Matters of Dress}

In smaller matters such as dress and style the scientific staft is more difficult to characterize. In the $1950 \mathrm{~s}$ most people wore neckties and jackets to work; in the $1980 \mathrm{~s}$ most do not. The change has been gradual, although the appearance of Dennis Stantord, who joined the Department of Anthropology in 1972, was still attracting attention in 1977: "Dr. Stanford wears pearl-button cowboy shirts that may or may not be buttoned down. You can't tell because that part goes under the beard. He doesn't wear a tweed jacket with leather elbow patches. He wears faded denims. He doesn't smoke a pipe. He tucks a bit of snuff under his lip." "It The best word for the dress code at the Museum today is casual. About the only three-piece suits left in the place are on the repairmen for the copying machines.

\section{An Assortment of "Characters"}

In 1980 Henry Collins, then long-retired, commented wistfully that the staff did not contain the number of "characters" it once did. Certainly the Museum has seen its share of eccentrics, eccentric behavior, and practical jokes, many involving stuffed kangaroos, gorillas, or what have you. On publishing a scientific paper, Hrdlička would have his palm read to see how his latest work would be accepted by his colleagues. Evans once crammed the office of the archeologist Gus Van Beek so full of boxes that the door could not be opened; Evans left by way of the outside window ledge. Kier wrote a memo

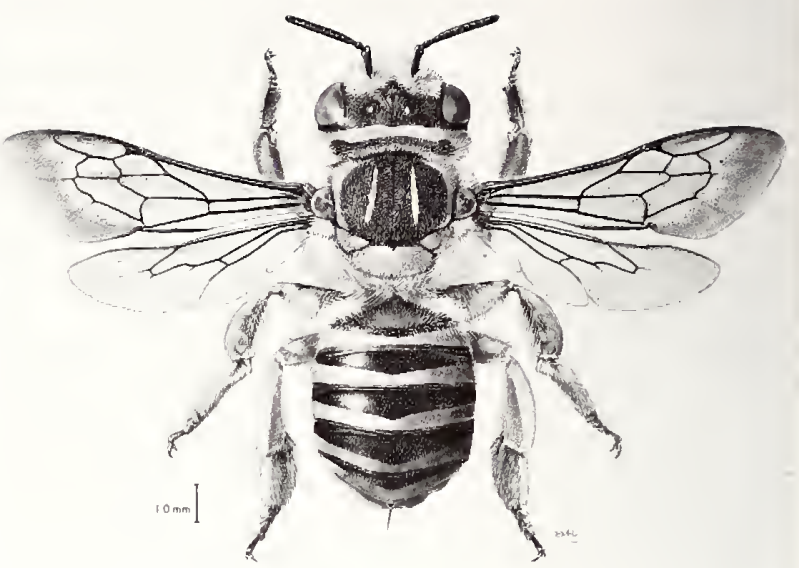

Bee, Heteranthidium bequarti. Carbon dust on 00 Ross board (Elaine R. S. Hodges, staff artist 1965-present).
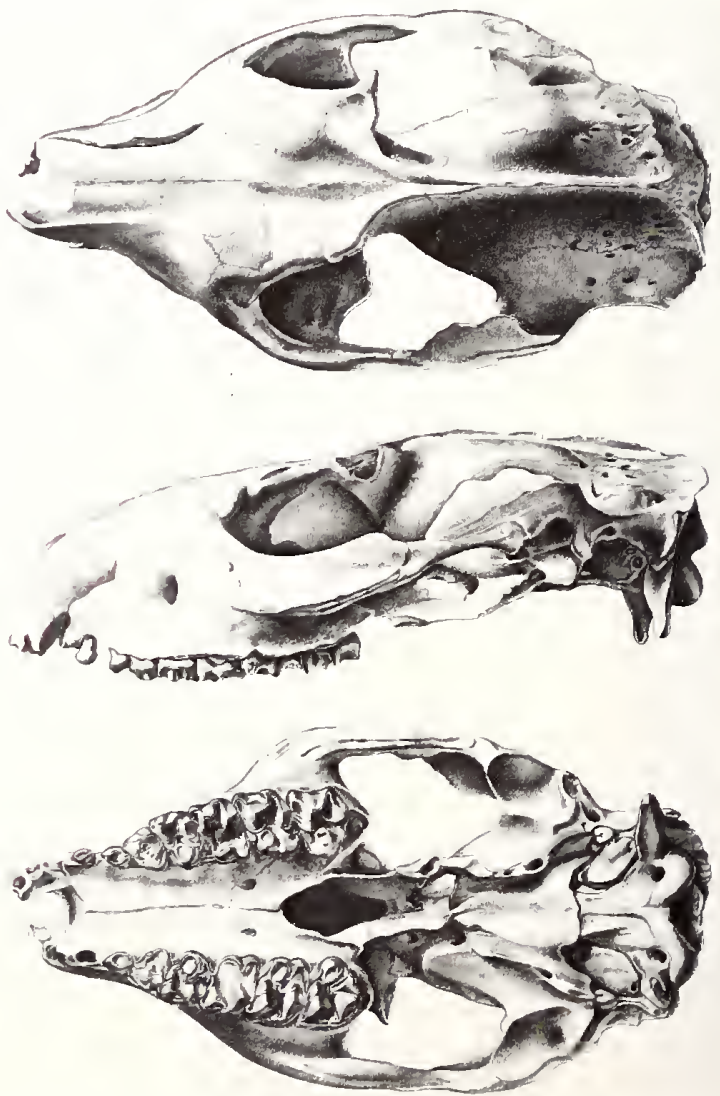

Fossil skull, Meniscotherium chamense. Graphite pencil on Bristol board (Lawrence B. Isham, staff artist 19531983). 


\section{Scientific illustrations prepared by Museum artists.}

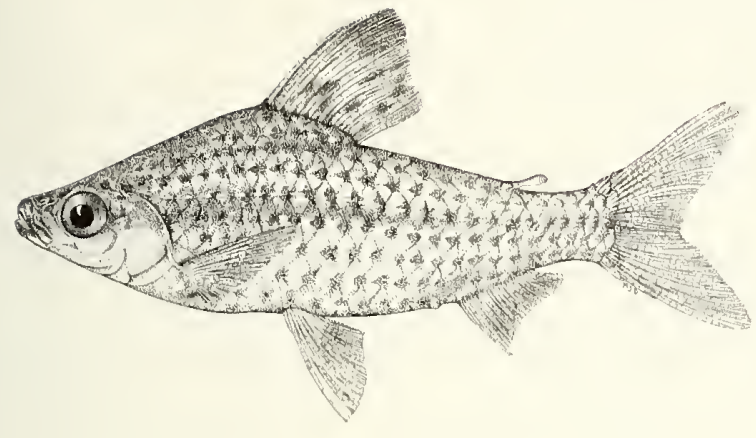

Spotted headstander, Chilodus punctatus. Technical pen on Bristol board (Marion J. Dalen, staff artist 19621970).

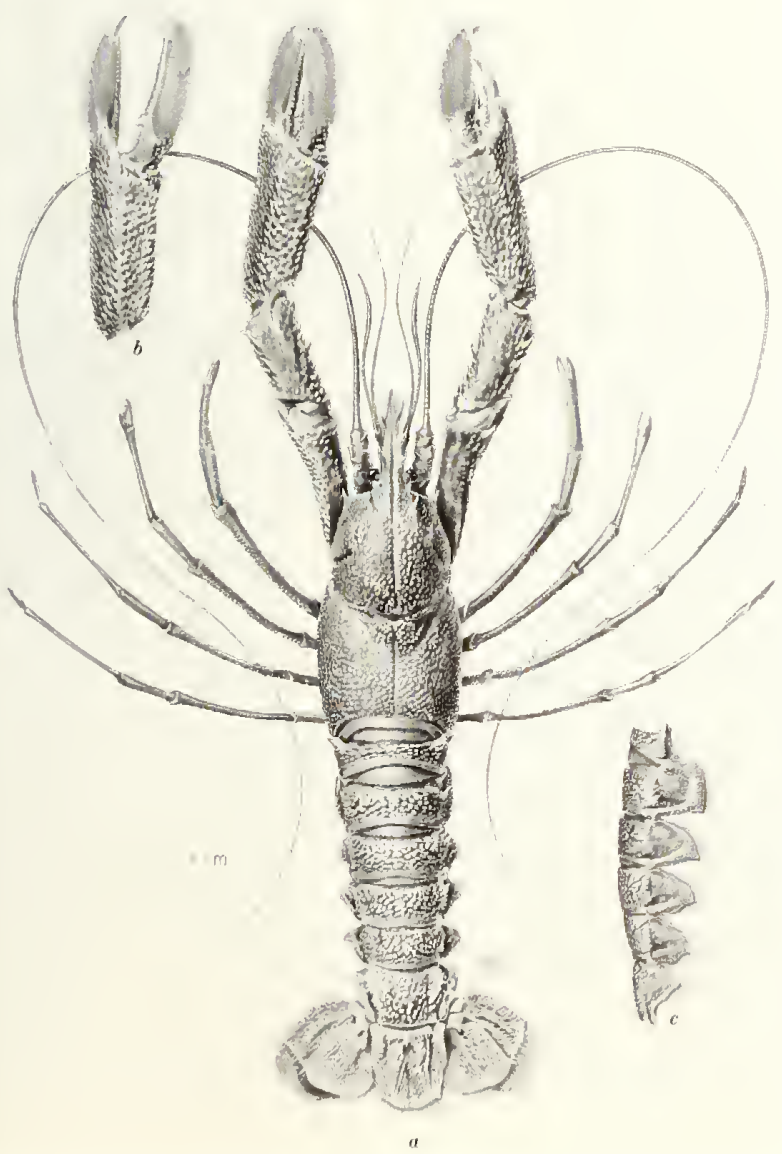

Lobster, Nephropides caribaus. Diluted India ink wash and graphite pencil on scratchboard (Carolyn B. Gast, staff artist 1959-1985).

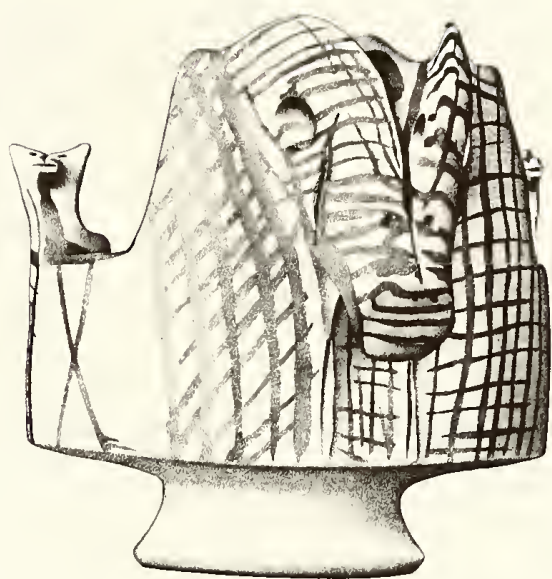

Painted pottery jar, representation of an ibex head. Crowquill pen and ink on Bristol board (G. Robert Lewis, staff artist 1959-1985).

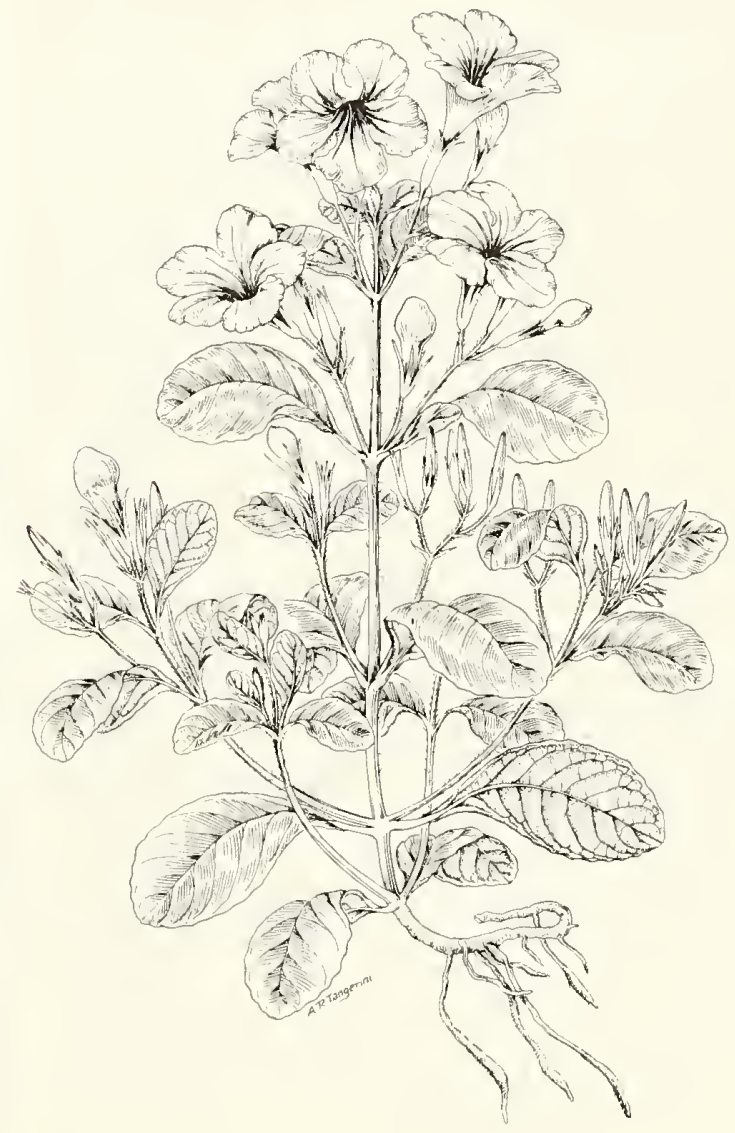

Spirit weed, Ruellia tuberosa. Crowquill pen and ink on plastic film (Alice R. Tangerini, staff artist 1972-present). 
Bird collections on the north side of the west wing, third floor, probably in the 1930 s, the windows open onto the west court. Herbert Fried mann is to the right and his assistant, to the left.

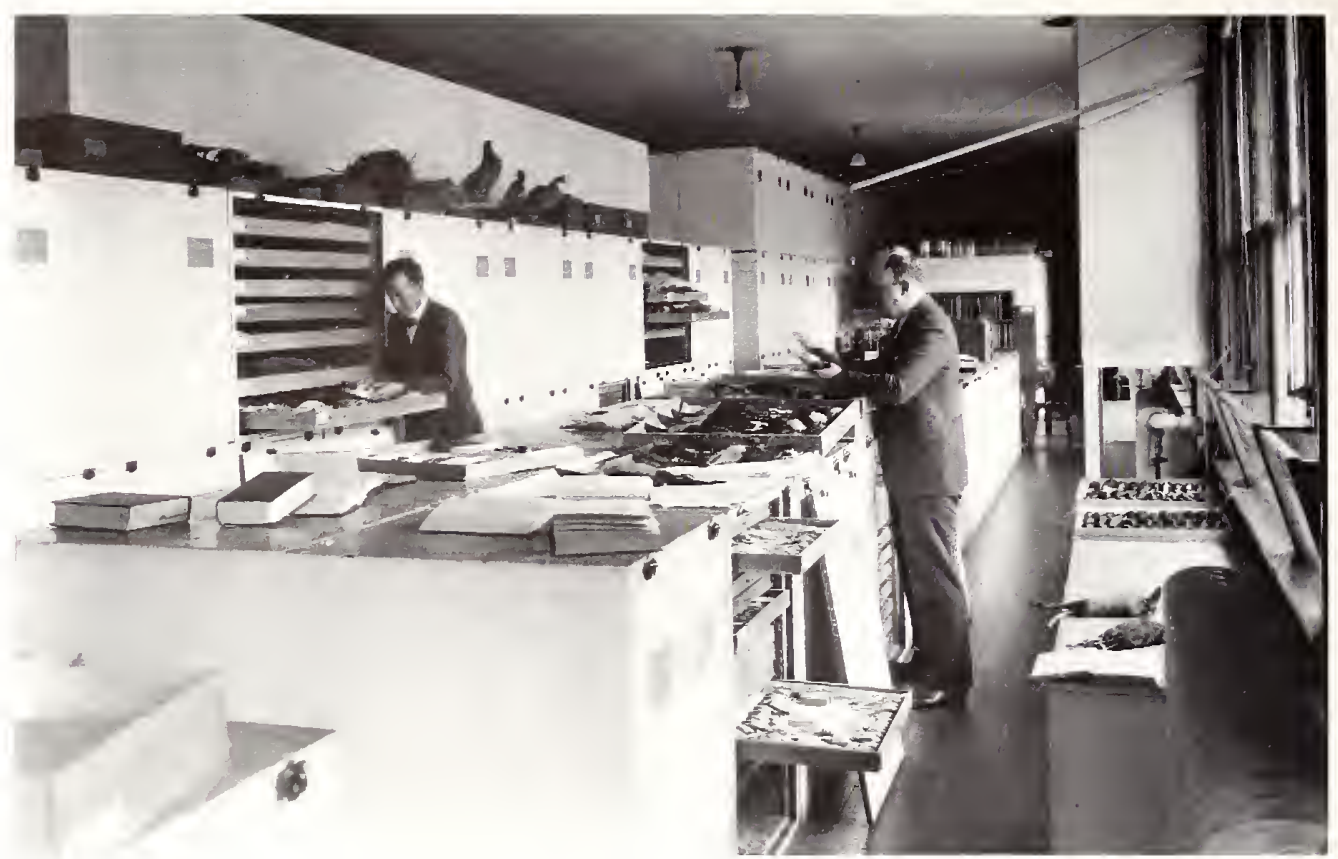

about a stucly of cockoach behavior in the Musemm and asked for information on sightings and if possible the anctual specimens. Then he signed Clarke's name and distributed it all over the Museum. Clarke was intmolated with specimens.

Roland W. Brown, the paleobotanist of the U.S. Creohogical Survey, was a charater by any definition. He cime from a very poor background and was one of the most frugal persons ever to grace the premises. Stories of his replacing a single shoelace and saving the other, or putting an edge on old razor blates found in a motel room, are all true. He cobbled his one pair of shoes himself, and when his pants becanne wo tight he added a gusset in the seat of a different color. Brown's great interest wis in Greek and I atin, and he compiled an invaluable etymological dictionany of the names of plants and animak. The book was witten on the bancks of old letters discanded from Geological Survey files. ${ }^{15}$

As in any academic setting, the label "character" sticks readily to a person who studies one narrow field in considerible depth throughout his career. Lately there is not so much monographic (some would say monomaniarcal) concentration on organisms about which few people are passionate. But it still is common. Perhaps to a younger scientist, the older specialist who considers himself Mr. Average is the real character.

One would assume that the number of characters of every kind would increase as the staff increased, but in the view of many staff members, this is not so. There are as many strong-willed individuats as in the past, but their impact is lessened by the size of the facility. Until 1960 ever yone came in the same entrance and everyone used the same toilet: any event or interesting comment spread rapidly. Size of staff and distance between offices have cut down on communication. In 1982, after a series of losses of Vienma sausages from his refrigerator, the sponge specialist Klaus Ruetzler painstakingly rigged a time-lapse camera to catch the culprit, but no one on the floor above, let alone in the east wing, even heard of this.

\section{Research and Publication}

Now, if the staff ches not spend its time being "quaint" so that there are humorous stories to pass on to future generations, what does the staff do? This is a serious question and it deserves a serious answer. The principal occupation of the scientific staff has always been research and publication. Investigation without publication is a sterile activity. The Smithsonian Institution issued its first major scientific publication in 1848 , and it has been dedicated to publication ever since. Until well into the 1950s, the Armual Report listed the papers published by members of the staff; they are listed now in Smithonian Year. There is no government agency that provides this degree of individual accountability to the citizens.

For many years there was a Bulletin of the United States National Museum, and one extremely crude but easy method of discussing productivity is to measure the shelf space it consumed. About ten feet of bound books were produced until 1909, and about twice that much chring the next sixty years. The Proceedings came a bit later, adding up to about seven feet before 1909 and sixteen feet thereafter. Both series included a bit more than natural history. A slight deduction must be made for the fact that the Museum also had quite a liberal policy on who could publish in the Proceedings, so that not every publication is from a paid staff member. Even allowing for this, a lot has been published. Papers by the Museum staff that were published in the now- 
G. Arthur Cooper typing and Josephine Cooper picking out fossils in his office on the third floor of the main building's west wing. The grinding wheel was used for sharpening needles to do precise preparation of fossils in rock. To the right, below a large tray, is a rock trimmer, hand powered by twisting the horizontal wheel. July 1954.

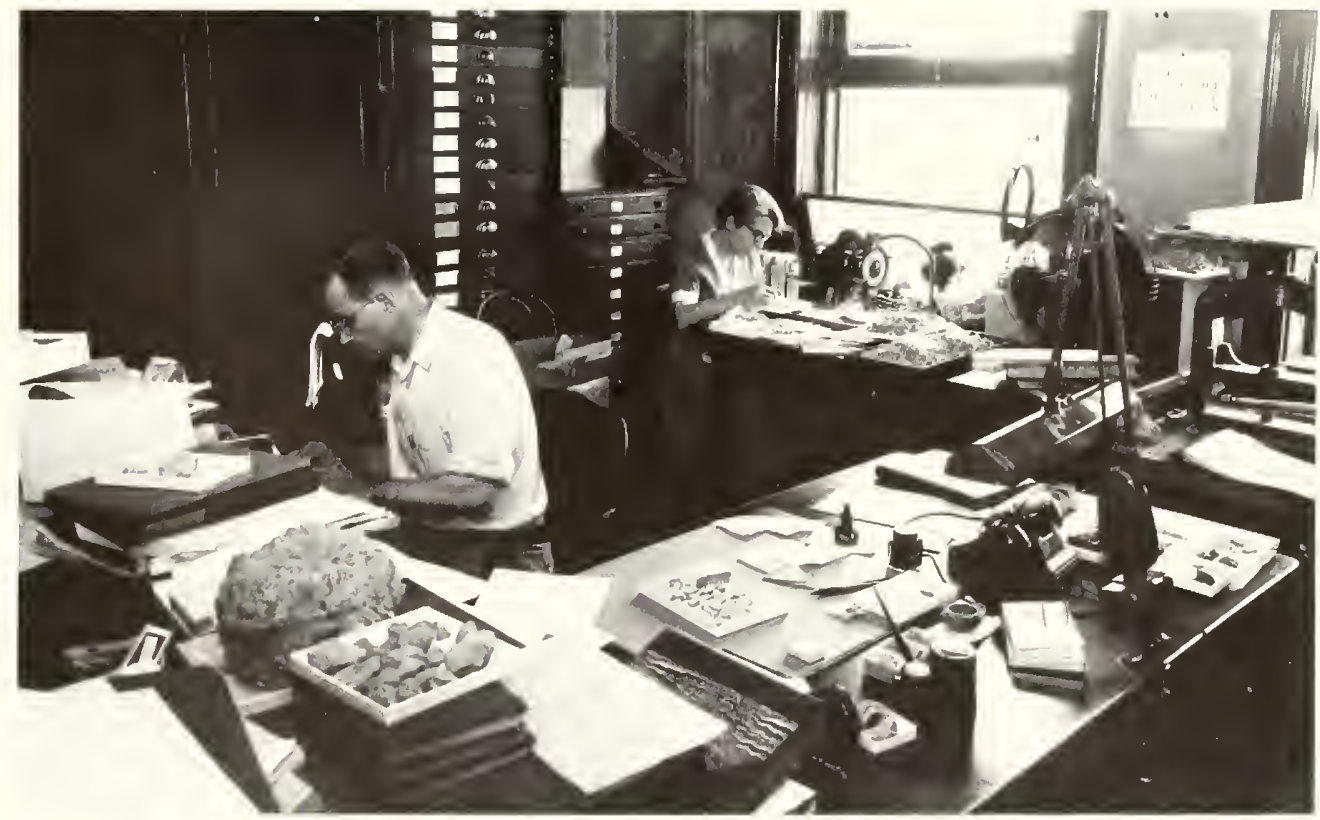

discontinued, Smithsonian Miscellaneous Collections would further swell the total.

In 1969 the Smithsonian instituted a series of Contributions in various fields. Those in the reahm of natural history have amounted to about twelve feet in fifteen years. None of these figures include publications in other scientific series or journals.

\section{Staff Organizations}

A handful of staff organizations deserve brief comment. The first is the Senate of Scientists, modeled on a similar organization at the National Institutes of Health. This group first met in 1963 in the basement of the ethnologist Saul Reisenberg's house with Gordon Gibson, another ethnologist, as the first chairman. Those who met felt almost like conspirators. One reason for organizing was that a number of actions, such as changes in parking regulations, were taking place without the affected parties' having any say. It was evident that Secretary Carmichael was soon going to retire, and it seemed more prudent to begin an organization before a new Secretary arrived than after. ${ }^{16}$

The senate is the one place where those from associated organizations can have a tiny voice concerning the building they inhabit. As the departments have become larger and the paperwork more complex, the senate provides a way of focusing on the problems that divert energy from the goal of research. The senate once challenged the Institution on its endowment practices and persuaded the treasurer to modify some of his policies. The dinner forums organized by the senate every other month or so are one of the few activities that cut across organizational lines within the Smithsonian complex.

The Smithsonian Museological Association, in spite of its name, has been confined to the Museum of Natural History. Technicians tend to be even more limited to associations in a single department than do the professional staff. Some of the ideas and concerns of the technicians have been expressed, through this group, and there has been exchange of techniques across departments. The organization began in 1974 and is now dormant. Both it and the senate in a sense are like volunteer fire departments-organized but not active until a crisis comes.

A quite different organization is the Guild of Scientific Illustrators. These people are not scientists, nor are they technicians. They are artists in a highly specialized field. The ilhustrators in the Museum founded the group, which is now an organization of more than 1,000 members, with shows at international scientific meetings to its creclit. The guild is one of the places where art and science are not in conflict. ${ }^{17}$

In the 1960s a small group calling itself the POETS Club met each Friday afternoon at Louie's Restaurant on the northeast corner of Ninth Street and Pennsylvania Avenue, NW. It was essentially the closest place to the Museum where one could get a beer and a sandwich. Ernest Lachner and the late James Peters from the Division of Amphibians and Reptiles could spend hours enlightening visiting scientists on this and that. During the days of the Summer Institute in Systematics, several members of the National Academy of Sciences were taken to Louie's. When Louie's closed in 1983, the POETS transferred to the Museum. Those who are newly into curating, the younger technicians, and the current lowest of the low, the packers for the move to the Museum Support Center, continue to gather for mutual support. As they might phrase it, this is the flip side of the Senate of Scientists dinmers. 



\section{Shared Facilities}

$\mathrm{T}$ HE LIBRARY OF THE Museum of Natural History has had a curious history within the Institution. In the vigorous congressional debate before the Smithsonian was formed, there were strong proponents of its taking on the duties of a national library-long before the Library of Congress assumed that role. In the early days of Secretary Henry's regime, the issue of the relative significance of the library within the Smithsonian was still hot. Arguments about what share of the Smithsonian endowment should go into library activities continued for years. Eventually the librarian, assistant secretary Charles Jewett, was discharged, and Henry, although buffeted by the storm of protest that followed, was able to prevail in his view that the Institution should be concerned primarily with research.

After Jewett left, most of the Institution's books were deposited in the Library of Congress, whence, in theory, they could be recalled as needed. In fact, "so urgent was the [Smithsonian's] need for more books that Secretary Spencer F. Baird in $188 \mathrm{I}$ donated his extensive private library, a valuable collection of standard works on biology and industry, to supplement the existing small nucleus of the Museum library." This library was devoted almost entirely to natural history, with a modicum of shelf space devoted to technology, art, and other pursuits.

In $191 \mathrm{I}$, when the new National Museum was conpleted, the library in the main moved in, leaving some of its holdings in the Castle and the Arts and Industries Building, and also leaving the chief librarian on the south side of the Mall. "In view . . . of the more ample accommodations afforded by the new building and the fact that the larger proportion of the publications were included in the transfer [to the new building]," it was decided in 1912 "that the library there established should be the central one for the receipt, recording, cataloguing and distribution of all books and for all other preparatory work."2

Taxidermy shop in the east courtyard. Left to right: Charles $R$. W. Aschemeier, Watson M. Perrygo (partially hidden between the two wolves), and William Goodloe. Probably taken in 1957.
Rathbun wrote the following year:

The space assigned to the library in the new building, located in the ground story of the northern section of the east range consists of what was originally a single room with northern exposure, 107 feet 7 inches long by 21 feet 1 inch wide, and a smaller room, facing on the east court. ... The former has been divided into three compartments for the book stacks, catalogue cases, and reading accommodations. ... All of the area is utilized to the full height of the story, this being accomplished by [a major internal structural change:] the introduction of a mezzanine floor in the stack room and of galleries in the reading rooms, which are at a uniform height of 7 feet 11 inches above the ground. . . The main reading room and consulting room has also a gallery continuous with that in the smaller room ... which extends along the three walls other than that occupied by the windows."

The gallery floors did not extend to the windows, so the exterior appearance of the building was unmarred. No doubt this gallery provided the precedent for later changes in the east range and on the west side of the building.

In fiscal year 1929, the library rooms were repainted, "new lights and ventilators were installed, a cork runner was laid the full length of the reference and stack rooms, and the two large, awkward reading tables were converted into four attractive, small ones." During the 1930 s, considerable free labor from the WPA and earlier organizations was utilized to improve shelving and cataloguing.

Despite the privations common to most librariesinsufficient staff, too little space, and inadequate funds for purchasing, binding, and repair-the Museum's librarians coped well with requests by users. They proved especially resourceful during World War II, when "representatives of about 35 different branches of the war agencies ... called for assistance or [came] in person to do research." Until after World War II, a messenger took the last elevator trip of the day to bring a book cart around, dropping off requested items and col- 
lecting loan slips. Later, one had to go in person to request a book, but the fibrary delivered all items until the early 1960s. In a few respects, the good old days actually were as good as they are remembered.

By the late 1950s the library had expanded slightly. All space on the north side of the east north range was occupied except the large corner office of the curator of vertebrate paleontology. On the south side, the library had the first office off the lobby; the National Collection of Fine Arts used the cooled storage room just down the hall for paintings. The area from this point to the anthropology laboratory on the corner was decked over, with bookshelves on both levels. The hallways on both sides of the range were filled with cases of fossil plants. The main catalogue, the serials record, and several desks all fitted into one office on the north side.

The portion of the Smithsonian library located in the Museum was treated in the Anmual Report as an integral of the United States National Musemm until 1948. Thereafter, information on the library in the Museum appeared in a separate library section of the Ammual Report. A major administrative event for the library occurred in November 1951, when the main office of the library moved from the Castle to the Museum, and the Natural History Branch was merged into the Smithsonian library.

\section{Additional Space}

In terms of physical change, the big event was the completion of the east wing, which freed a great deal of space. What had been the anthropology kaboratory, overboking the east courtyard, now became the main reading room. The card catalogue moved out into the hatl. Most of the west side of the east range was decked over for stacks; a sturcly but creaky catwalk crosses the reading room, connecting the south deck with the west one. The head tibrarian moved into the corner office occupied earlier by vertebrate paleontologists, and some open areas on the north side of the east north range were decked over to complete the stack area. In 1965 , after the Division of Mammats moved to the third floor, the library expanded into the west north range. The binding and acquisitions operations went downstairs, and rows of bookshelves stretching off into the darkness occupied the upper level.

In May 1983, in a reversion to the general setup of 1910, the Smithsonian Institution Libraries divided, so that there is now a Natural History Branch in the west north range, with a separate new-book shelf and checkout desk. Since the library filled up, many books have been sent to the general-purpose building on North Capitol Street and others to the Museum Support Center. Much as they prefer to hold a publication in their hands, the scientific staff will have to depend on the electronic transport of data to answer some of their questions.
Almost from the inception of the National Museum, sectional libraries were scattered throughout the building. During the 1920s the Annual Report listed thirtysix, twenty-one of which were directly associated with the activities of the Museum: "The 36 sectional libraries of the Museum are the immediate working tools of the curators and their assistants. Many of them contain rich collections of highly specialized material, some of which has never been catalogued."'

\section{Specialized Book Collections}

In the building today there are specialized collections in almost all the departments and in many divisions. Periodically an administrator suggests using the space for offices, and periodically the curators have apoplexy over the idea. These caches, not all of which qualify as libraries, range from 2,000 to 53,000 books. For ease of bookkeeping, some of these disparate groups are combined, while others, like hard-to-catalogue collections of reprints, are officially ignored. In addition to its departmental library, for example, Botany has a collection of reprints on grasses of which Agnes Chase was so protective that she stationed her desk right in the middle of it. Of course, most scientists have their own personal collections, usually including a lot of books checked out of the Museum library.

Only wo book collections in the building have plaques on the cloor. One is the Kellogg Library of Marine Mammals, in the east wing. The other, in the main building, is the John Wesley Powell Library of Anthropology. 1n 1981 John Ewers thought it was high time that something was named after Powell, so he decided on a plaque and a small ceremony. It seems that Powell had hat a bet with his colleague JW ("No Stop") McGee as to who had the larger brain. Both arranged for their brains to be saved, and when they were posthumously measured, Powell won. The point to all this is that John Wesley Powell's brain was brought in for the ceremony-a token of affection Powell would have appreciated, had more of him been present.

\section{Data Processing System}

While the library serves the entire Institution, the $\mathrm{Mu}$ seum has its own Automatic Data Processing system, a second common facility of great value to many scientists. Data processing in the post-carbon paper sense has a history of about twenty years at the Museum. In the early 1960s awareness of the new technology had grown to the point that a committee was formed to look into it.

Some scientists, such as James Peters, were immediately enthusiastic about sophisticated statistical techniques as aids to their investigations. "Peters and others have written programs ... which ... make it possible to carry out analyses previously impossible because of the amount of time required," Smithsonian Year observed in 1967. "Peters is also developing a computer- 


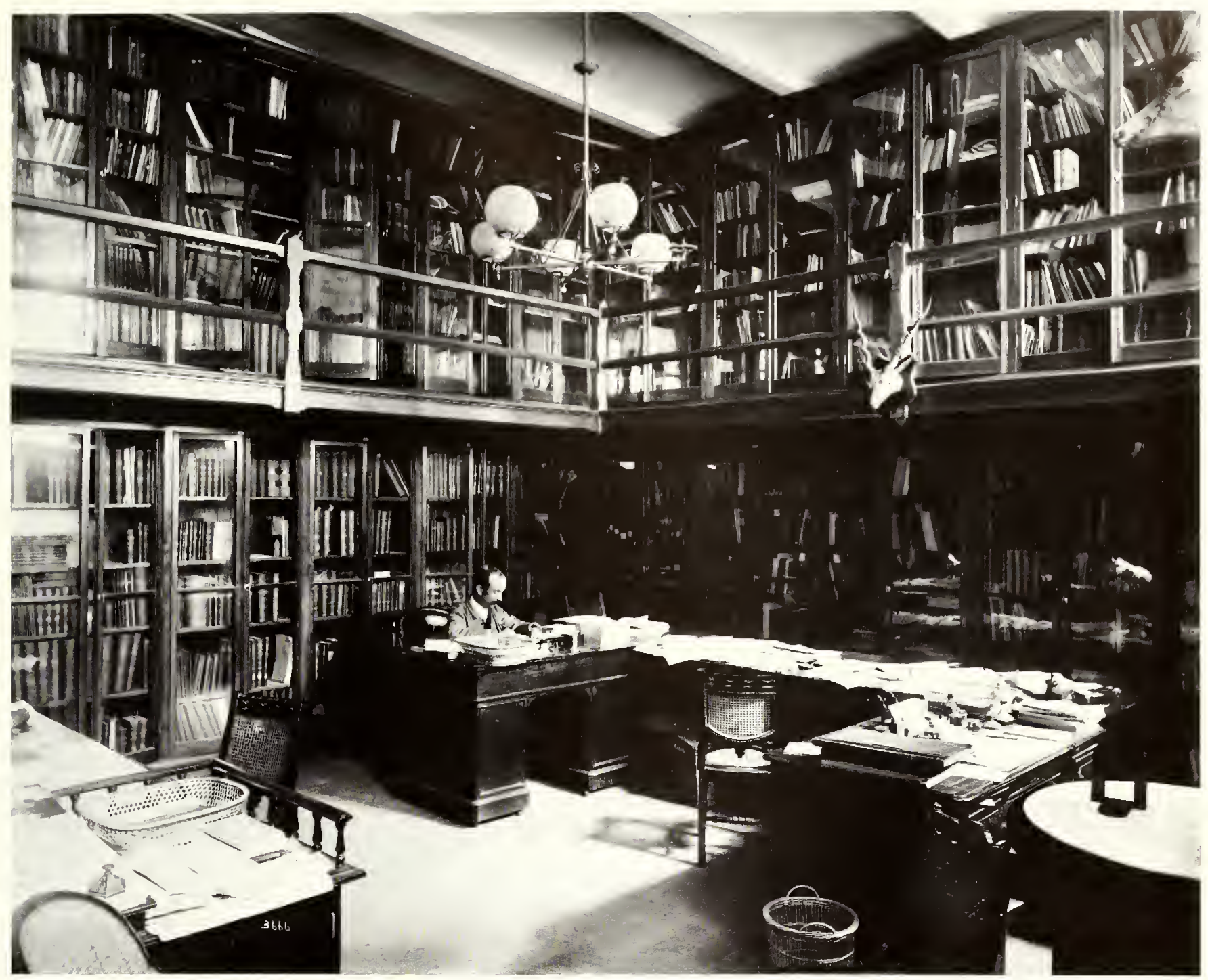

Librarian John Murdoch in the United States National Museum, before 1893. This is now the rare-book room for the Institution.

key to the snakes of Latin America.... Insertion of . . . basic data . . . results in a print-out of the correct generic name in less than four seconds."

The use of computers in individual research projects is of increasing importance throughout the Museum, but the greatest impact of data processing has been on general information processing and retrieval problems. In 1966 "funds provicled by the Office of Systematics enabled the department of invertebrate zoology to purchase equipment with which one operator can catalog all the very large number of collections being accessioned by the department, and which at the same time prints index cards on as many parameters as desired. In addition, the same operation automatically generates paper tape bearing the data from the collections, and these data may be inserted automatically in a central data center. It has been estimated that as much as 60 percent increase in the efficiency of the cataloguing operations is gained by having this equipment." ${ }^{\circ}$ The concept is fine, even if the language seems quaint in the light of today's machines. Paper tape machines were eventually declared surplus, though one probably should have been sent over to the Museum of American History as an artifact.

Data Processing had its first home in Room 206 on the second-floor balcony; people found the office by looking to where the elephant's trunk pointed. Next Data Processing went to the third floor, adjacent to the director's office on the west side of the building. In 1972 it moved several doors down the hall to offices vacated by oceanographers and ecologists. It is still in the same area, but the rooms have been partitioned and repartitioned. Even that has not made sufficient space, so an addlitional room has been built out into the main corridor.

During the mid-1960s cataloguing of selected minerals, sea birds, and crustaceans was tried as an experiment, using machines to alleviate the burden of routine 
work. After this success, Donald Squires obtained funds for a larger data system that might serve as a model for other Museums. Shortly after this program started he moved on, but the test was brought to a successful conclusion."

\section{Convincing the Staff}

In 1970, when James Mello transferred to the Museum to continue the Automatic Data Processing (ADP) program, his first problem was to convince the staff in general, not just the enthusiasts, that there was some merit to a new approach. One technician who favored leather-bound ledgers assured him that even though they cost sixty dollars each, her handwriting was so small that she could enter 50 percent more lines than anyone and still have it legible. Mello still recalls his first week at the Museum, when he was invited to have lunch with the Fish Division. Just before Mello started talking about his new program, Lachner wrote on a blackboard in capital letters, "EXPENSE" "UNPROVEN TECHNOLOGY" "MISALLOCATION OF RESOURCES," and said not a word during the presentation.

Despite some lack of enthusiasm, the program moved forward. In 1972 Smithsomian Year reported: "It is becoming increasingly evident that the care of such data is, in its own way, as important as care for the specimens themselves. The objectives are to capture, store, and retrieve collection-based information more efficiently than by conventional means and to produce ultimately a versatile, easily searchable dita base that will be more responsive to scientific inquiry than are current records in most of the departments." "The program still has not reached that goal, but records of millions of specimens are not assembled easily. Each year there are fewer problems with recording and retrieving data.

One early success story was a sequel to the Endangered Species Act passed by Congress in 1973. The Department of the Interior was required to produce a list of endangered species of animals and to arrange for the Musemm to make lists of endangered plants. The computer copy itself was eventually published in 1978, and the listing of plants was done far faster than anyone had anticipated, thanks to automation.

\section{Smithsonian-wide Inventory Ordered}

By the later 1970s an Institution-wide inventory program, discussed more fully in chapter 23, had been ordered by Congress. It officially began in the Museum in 1978, although some work had been done earlier. It made good sense for ADP to take on the chore for the Museum, and a whole raft of young temporary workers appeared to do the boring work of counting and recording data, often to the tune of rock and roll music. There was some trauma, but when the first phase of the inventory was completed in I983, the officials were pleased."
An inventory was an absolute necessity before collections could be moved to the Museum Support Center. The amount of computer paper required to make lists of objects and to assign moving schedules and locations is enough to make any tree nervous, yet there is no sense in storing an item that cannot be found on demand, as the scientific staff would have to agree. Naturally enough, the emphasis on automatic data processing and modern trends in systematics has led to widespread scientific literacy with computers. Not only is almost everyone who was hired from 1970 onward "into computers," some of the most senior curators use them.

\section{Word Processors Abound}

The most remarkable change in the Museum, and one not predicted by the black-box specialists, has been the spread of word processors. R. E. Grant recalls that when he joined the Geological Survey in 1962 he asked for a typewriter and was informed that because he did not spend 50 percent of his time typing, he was not entitled to one. In 1972, when he transferred to the Museum, he was able to obtain a typewriter officially. No one quite recalls the history of electric typewriters, but it took at least ten years for them to become moderately common in the offices. Word processors, on the other hand, swept the establishment in less than five years, and virtually every other scientist now has one. The Museum still requires justification for an electric typewriter, but no such paperwork is needed for a word processor, which for some reason is not classed as a typewriter. Typing on a word processor, while not exactly automatic data processing, is encouraged by the pro-ADP climate at the Museum. Electronic machines are here to stay. They have resulted in more sophisticated analyses of data on plants and animals, and they may provide the answer to the problem of linking scientists at the Mall with collections at the Museum Support Center.

\section{Scanning Electron Microscope Laboratory}

The Scanning Electron Microscope (SEM) Laboratory is a third shared facility. Developed at Cambridge University, the SEM brought a new dimension to science, and has led to breakthroughs in many fields in which the Museum is involved. The Museum acquired one in 1969-"a major step in the planned research activities of our staff," Smithsonian Year announced. "The marvelous new instrument is able to magnify the images of tiny objects from 20 to 140,000 times and several hundred times greater resolution than the conventional lightoptical system. ... In only four years since it became commercially available, it has become a dominant research tool in such diverse fields in biology as pollen analysis, microfossil identification, and textile fiber-wear studies. In one area of basic research being done at the Smithsonian, Dr. R[ichard] H. Benson is using the SEM 


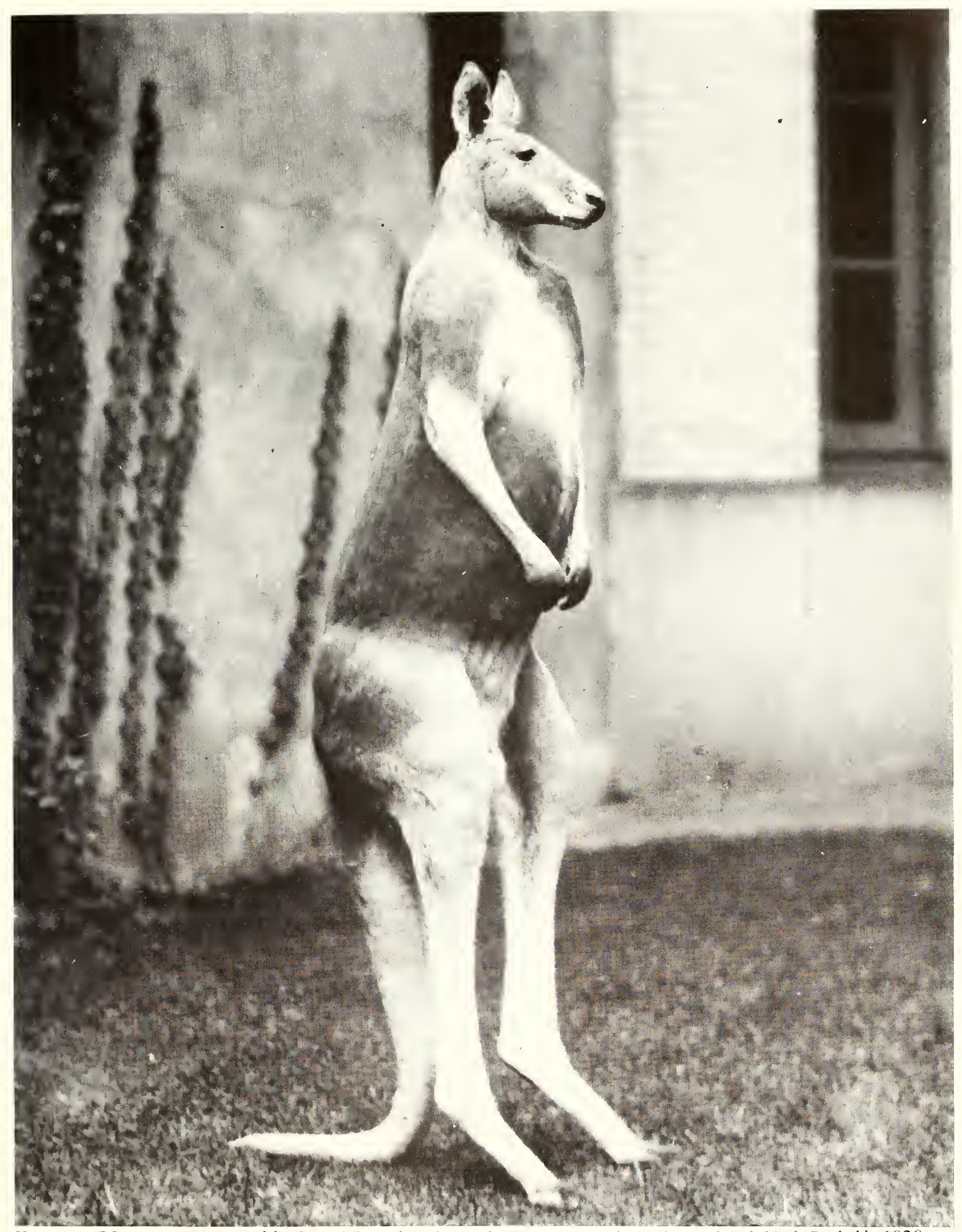

Kangaroo (Macropus), mounted by C.R.W. Aschemeier in the east court, with taxidermy shop behind. Probably 1920s1930 s. 


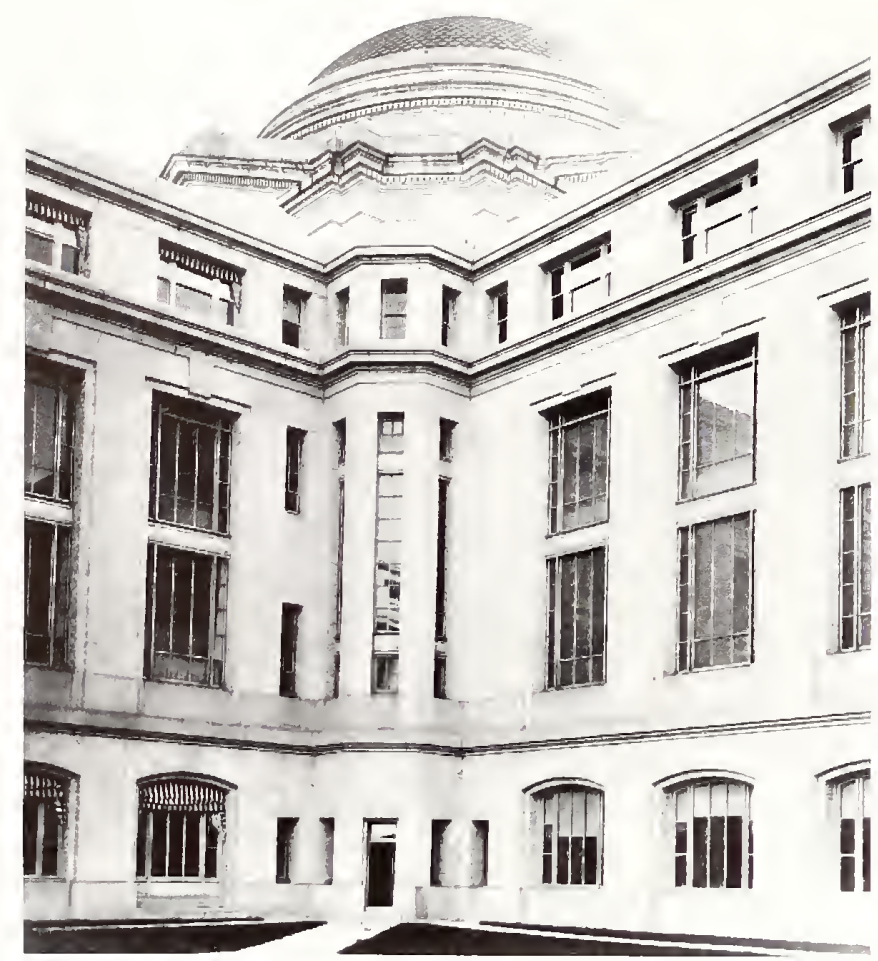

"West Court looking toward south pavilion and rotunda, and showing the projection of the stair towers," from United States National Museum Bulletin 80 (1913). Presumably the walkways were for strolling in the court, but no one recalls the door to the comut's being unlocked for the general publit.

for study of the histort of a minute fossil crustacean, the ostracod."

Benson, the first curator hired after Ripley was appointed Secretary, had worked with the second SEM sold commercially at the University of Leicester in England. He returned convinced that the Museum should have such an instrument, frightfully expensive as it was by the standards of the day. By this time several American companies had begun to manufacture them, and a "Buv American" policy was in effect. After convincing the Musem that a SEM would be a worthwhile investment, Benson was able to demonstrate, in a court trial with the Department of Commerce in regard to importation, that the depth of fietd of the Cambridge instrument was better than that of the new models being made in the United States.

Once the way had been cleared legally, a machine was purchased. Benson went around the ground floor with a pan of water, setting it on the floor and watching how much the reflection of the lights flickered as a way of determining the amount of vibration in different parts of the building. The SEM went into a former storage area in the northern half of the east range. There are no windows, but those who work under darkened conditions have no need for windows anyway. Walter Brown, who was hired to run the SEM, made such a success of it that later the U.S. Geological Survey put a second instrument in the laboratory under his charge. Still later a third was installed, along with many changes in the kinds of instruments, position of walls in the area, plumbing, wires, gas cylinders, and other details. As with ADP, the story of SEM is one of increasing sophistication of machinery.

There is a great deal of skill involved in making one of these brutes function, let alone function properly. By 1983, however, familiarity with the machine had reached the point that the Department of Agriculture could purchase an instrument for their scientists to operate themselves, with a minimum of assistance. Until that time a technician had always sat down with the scientist to operate the machine. Although one of the first three is no longer in use, the USDA's machine is functioning well, and the scientists seem to be enjoying running it themselves.

The SEM, again like ADP, is not for everyone or for every problem. But where SEM investigations are used, they provide remarkable new insight on morphological detail at a scale no one dreamed of two decades ago. The SEM is so popular that the biggest problem has been to accommodate all customers. For a time it was first come, first served. Then the system changed to signing up on Friday. When the lines in the hall got too long, a lottery was instituted. The SEM lab is a shared facility in the fullest sense of the term, for the USGS and USDA give Museum scientists part-time access to their machines in exchange for maintenance and technical assistance as needed.

One "first" at the laboratory was the making of a hologram-a three-chmensional picture-of a one-celled microfossil, the foraminifer, first cousin to an amoeba. This enlargement of about a thousand times was nearly a foot high, and suggests some interesting ideas for displaying tiny objects to the public. While holograms may not be the wave of the future, they should certainly inspire a few novel exhibits.

In 1984 the Museum produced a major temporary exhibit based on the work of the SEM laboratory. This show, Exploring Microspace, attracted a great deal of nationwide attention. ${ }^{13}$ Most of the exhibit consisted of greatly enlarged SEM photographs, but its most popular feature was probably the instrument itself. At certain times of day, visitors could watch it being operated by scientists or technicians. The three-month show was such a hit that a permanent exhibit is being planned.

\section{Travel Services Office}

Still another shared facility is the Travel Services Office, which like the library, serves the Smithsonian staff at large. Founded in 1966, the Travel Office is swift, efficient, and helpful, and the Museum staff has welcomed its presence in the building. The Museum is more involved in travel than any bureau of the Insti- 


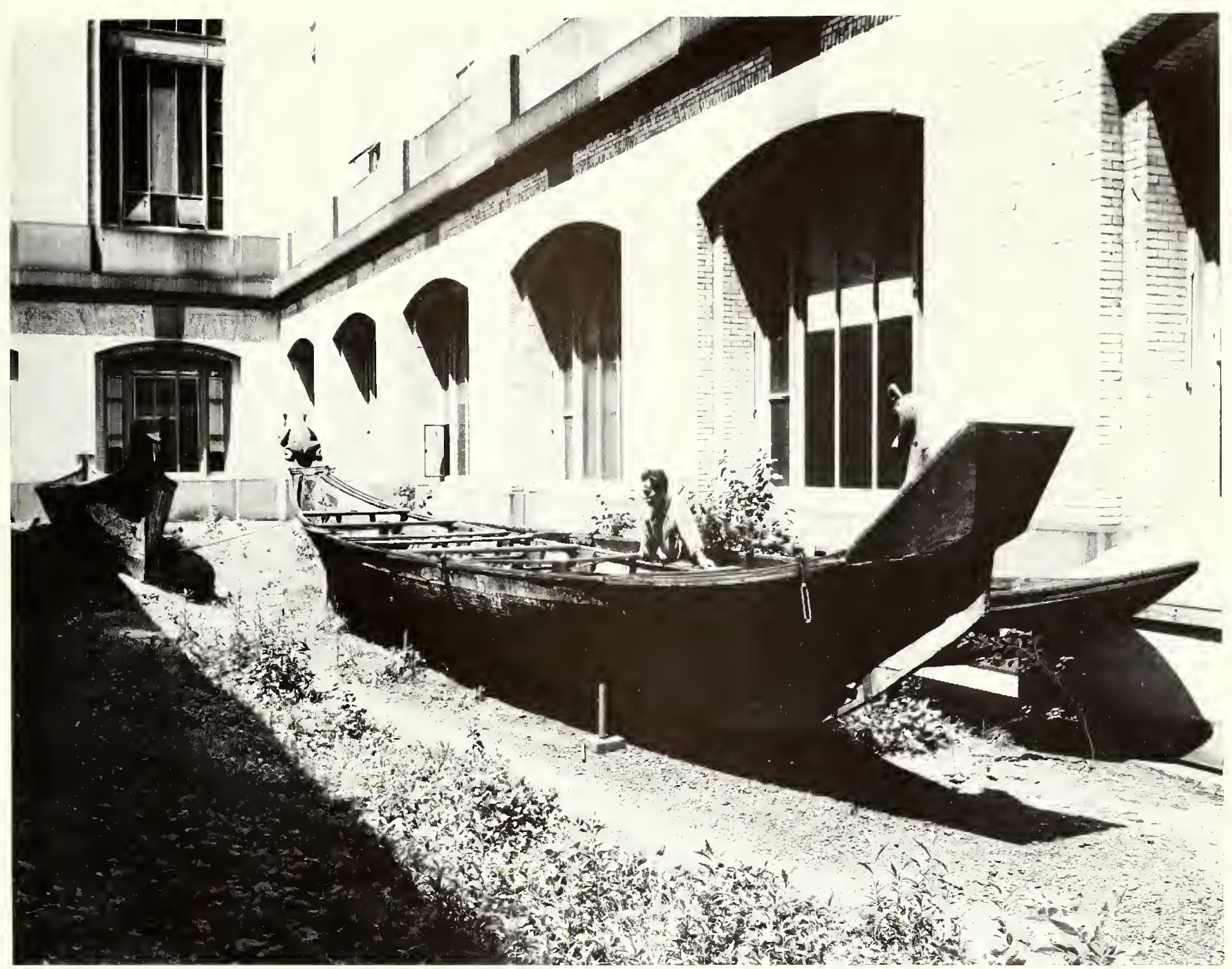

Northwest Indian (Haida) boats in the east courtyard before 1958. The shadow may be cast by the taxidermy shop.

tution, and the less distance people have to travel to a travel office, the better.

The peregrinations of this office give a capsule view of the changes caused by growth and construction over the last two decades. The Travel Service began in the Management Analysis Office in the Arts and Industries building, but almost immediately moved to the $\mathrm{Mu}$ seum. It was in one of the glorified closets on the second-floor rotunda balcony. Then there was a move to the third floor of the north wing, near the photographic laboratory; when the Travel Service left, the photo lab lapped up the empty space. Next the Travel Service was moved to the west side of the foyer on the ground floor. After a time it was hustled from there to an area on the second floor near where Hall 26, "Western Civilization," was being constructed. For its fifth move in ten years, it went back to Arts and Industries. Finally, in 1983, the Travel Service people returned to the Museum. They landed on the ground floor in the northwest corner of the main building-formerly Division of Fishes territory and before that the office of Remington Kellogg - where they have stayed ever since. By their standards, this is virtually a permanent home.

\section{East and West Courts}

The east court and the west court, in their way, have functioned as shared facilities. In Rathbun's account of the building, there is no indication of any actual or projected public use of courtyards; they were empty space, the single most valuable commodity in a museum. The courtyards, each in turn, were the strongholds of the taxidermists. Most of the taxidermists' work was for the Department of Biology, but for half a century they helped everyone with whatever exhibit work was done, and they formed the basis for the exhibits group of the 1950s. ${ }^{14}$

The courtyards are reached by two doors adjacent to the rotunda stairs on either side of the builching. The east court atso has, in its southwest corner, a large entryway from the shop area. Because of this large door 
Rolland Hower with freezedried animals. In the foreground are a sumfish

(Lepomis), a cedar waxwing (Bombycilla), and a muskrat (Ondatra); behind is a Pallas cat (Felis) and a

red-tailed hawk (Buteo).

This was taken in the west wing of the main building in Nowember 1967.

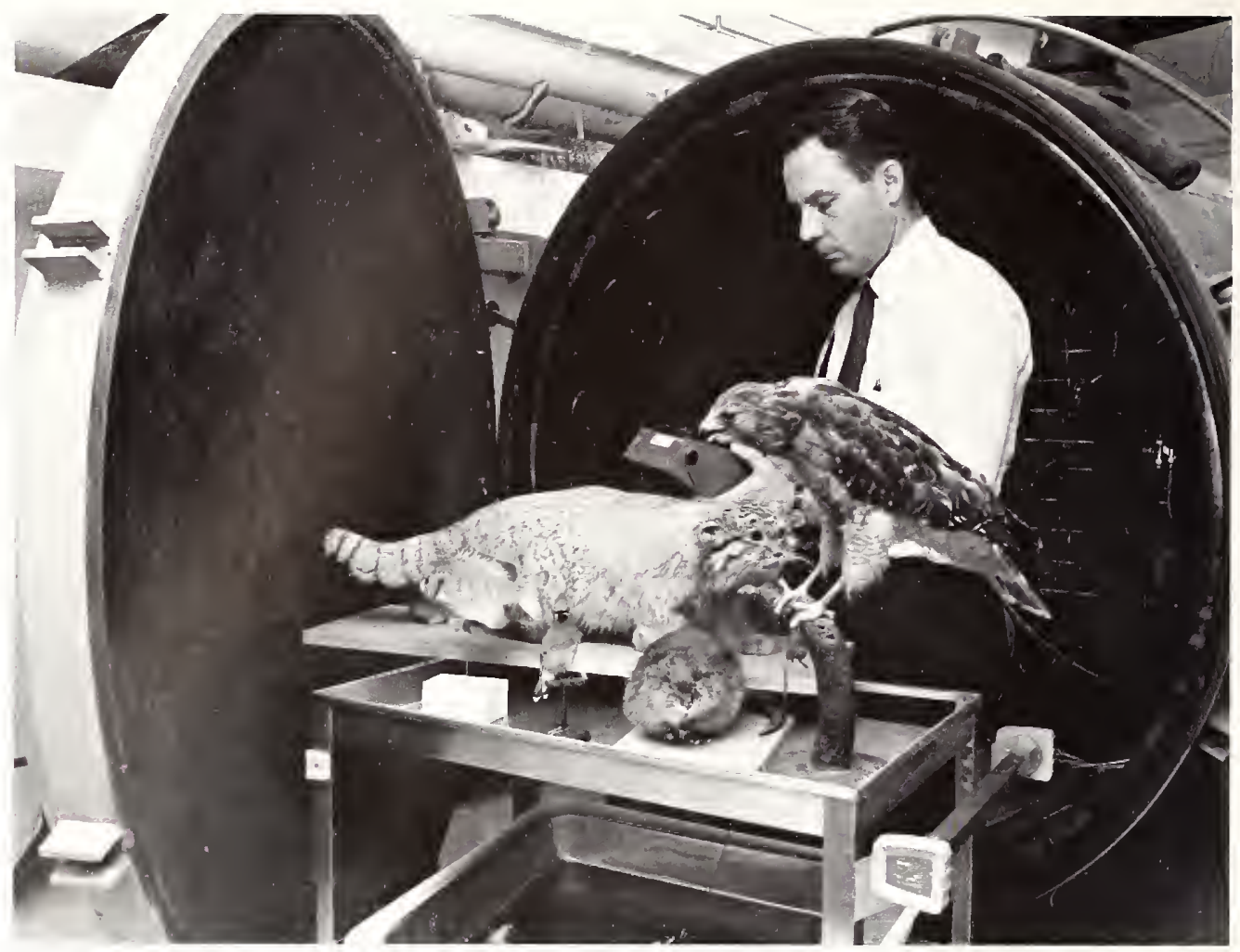

and its proximity to the saws, this comtyard first was used to store stone blocks and slabs awaiting cutting and polishing. G.P. Merrill solicited them from contractors who shipped building-stone samples to Washington, only to lose a bid. In 1915, for example, the Museum acquired stone sumples submitted for the Red Cross Building and for the Memorial Amphitheater at Arlington. ${ }^{15}$

During World War I, the east courtyard was partially occupied. The Museum's taxidermists had worked in a two-story brick structure built near the Castle in I875. When it was tom down to make room for the Freer Gallery, "the building erected in the east court of the Natural History Building by the Bureau of War Risk Insurance and turned over to the museum at the expiration of their occupancy of the building, part of which is intended for use as a taxidermist shop, was improved by the installation of a galvanized iron gable skylight on the roof and the replacing of ground glass in the west section with clear glass." 1920, "the building in the east court was remodeled by providing doors and portable glass transoms on the "west side." Natural History Building was extended to the concrete building in the east court."18

Judging from what was done to this building, it could not have won any architectural prizes, for it was erected to serve as a ladies' toilet when 3,000 clerks were in the building. Nevertheless, this temporary structure lasted for four decades, about as long as its predecessor behind the Castle. In addition to taxidermy, part of the building was used for storing whale bones, and part was used as the labor-force locker room. Numerous live animals were kept in the courtyard to allow the taxidermists to study their movements. A pair of tortoises lived there, too. While the vertebrate preparators on the east side of the east range watched girls sunbathe near the parking lot, the Geological Survey preparators on the west side climbed out of the windows to eat lunch in the courtyard and watch the tortoises make love.

Large objects that did not fit elsewhere went into the courtyard. Totem poles lay there for a time. Merrill's stones and slabs accumulated; one large slab of sandstone, propped against a wall, sagged after a few decades. Some war canoes that sat in the yard eventually were placed on rocks and finally had a roof built over them. Until the 1950s, large whale bones were parked here and there around the perimeter.

Eventually another temporary building was constructed in the east court. Shortly before World War II, G. Arthur Cooper had begun to collect limestone blocks in which the fossils had been replaced by silica. When the blocks were placed in hydrochloric acid, the limestone dissolved and the fossils remained. Magnificent collections were prepared by this technique. Cooper did the work in a tiny, unventilated third-floor room, and no one considered the effects of acid on pipe fittings. When a guard in the mineral hall below noticed that one of the suspended light globes was two-thirds full of an ugly brown liquid, Cooper had to find another lab.

During the early 1950 s the acid operations moved to 
Susann Braden preparing to mount a specimen on a SEM stub, July 1984. The ugly gray machine behind is used to apply a gold/palladium coating before placing the stub in the microscope. A few enlargements of SEM photographs decorate the far wall.

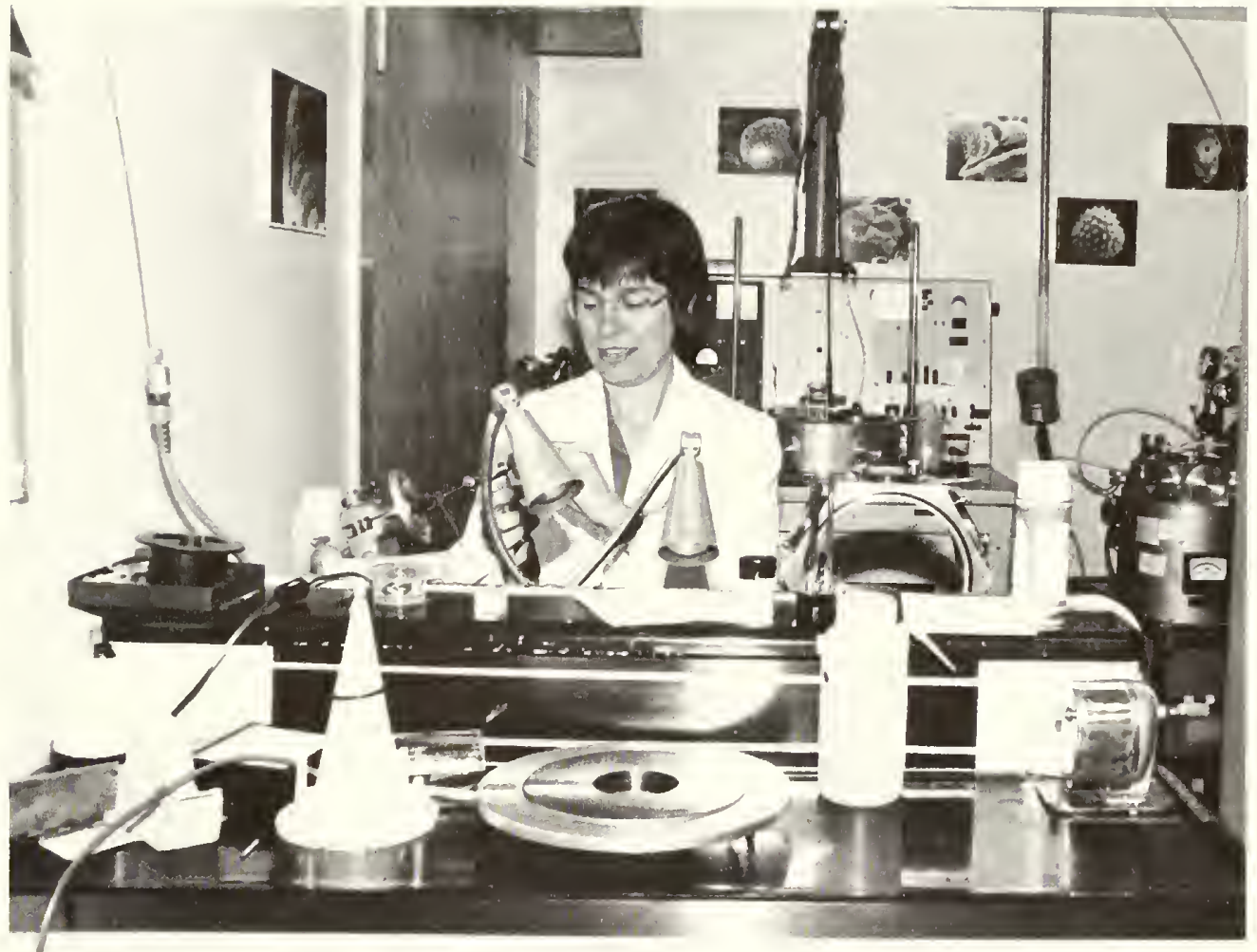

a high-roofed shed in the east court. The table, a magnificent slab of granite no longer needed for the exhibits, was its only impressive feature. The building was not much to begin with and rapidly became worse. Acid fumes corroded the nailheads, and occasionally a piece of wallboard fell down. Meanwhile, there was a continuing reaction between the gypsum of the wallboard and the acid fumes in the air, so that little piles of white powder accumulated around the walls.

When planning for the wings began in earnest, Cooper had to move again, and the taxidermy shop in the east court was vacated and torn down, probably in 1959. Its place has been taken by a large air-conditioning plant and cooling tower. This plant has been run continuously since the east wing was completed. On the northwest corner of the east court and the northwest corner of the west court, air-intake towers were constructed. Their boxlike shapes extend above the roof line of the main building and can be seen from Constitution Avenue.

\section{Building the Greenhouse}

There is another interesting component to the east courtyard: a greenhouse, constructed in 1976 atop the air-conditioning plant. A proper study of taxonomic botany requires, along with equipment and labs, a large dried collection in a herbarium, a good library, and facilities for live plants. The Museum was superb in the first two but lacked the third. In the early 1970s, a new fumatorium and drying room were built near the west loading dock, but $\$ 25,000$ of the money allocated had not been spent. Robert Read, who had come to the Department of Botany in 1972 to work on Flora of North America, was told to build a greenhouse with this money, and in all innocence he started.

All significant government construction in Washington has to be cleared through the Fine Arts Commission. Somehow the appropriate homework was not done when the air-intake towers were constructed, and the Institution was not in the good graces of the Commission. No one had told Read of this little matter, and his greenhouse plans were rejected twice before a design that would be acceptable when viewed from the air was finally approved. (The Museum lies in an area of airspace prohibited to fixed-wing planes, but the bird's-eye view had to be approved regardless.) Several years and a cost overrun later, the greenhouse opened. It has been an important research facility for the staff.

\section{All Quiet in the West Court}

The west court has had a nore placid history; for almost fifty years, practically nothing happened there. After World War I the Museum acquired the famous NC-4, the first airplane to cross the Atlantic, or at least part of it, but this aircraft could not be properly displayed in the corrugated shed behind the Castle. According to Paul Garber, there was talk of hoisting it over the roof of the Museum and into the west courtyard, but after extended discussion the plan was abandoned. Then 


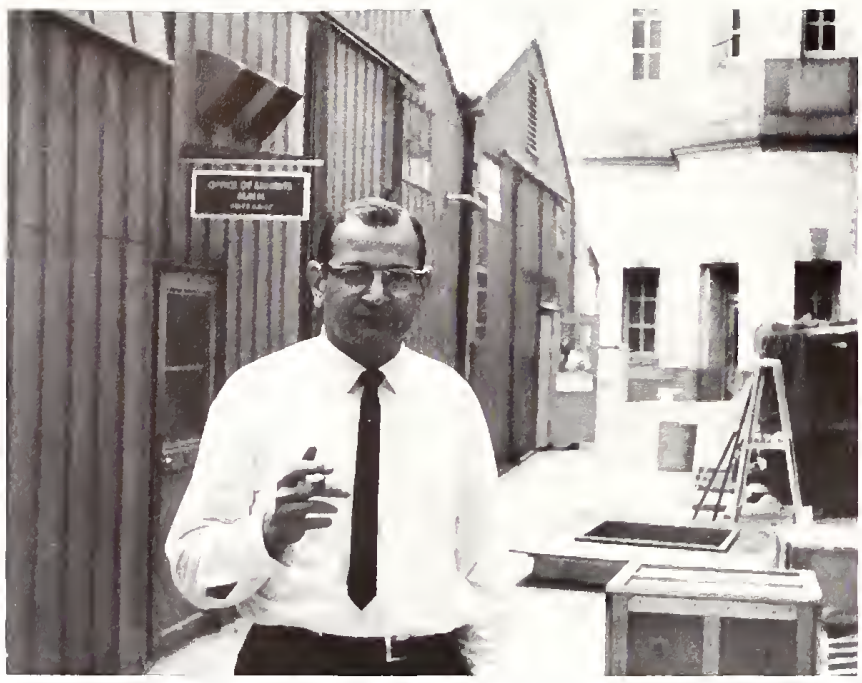

Victor G. Springer (without his usual mustache), curator of fishes, in the west court in fromt of Office of Exhibits buildings, October 23, 1963. The cigar is probably an El Producto.

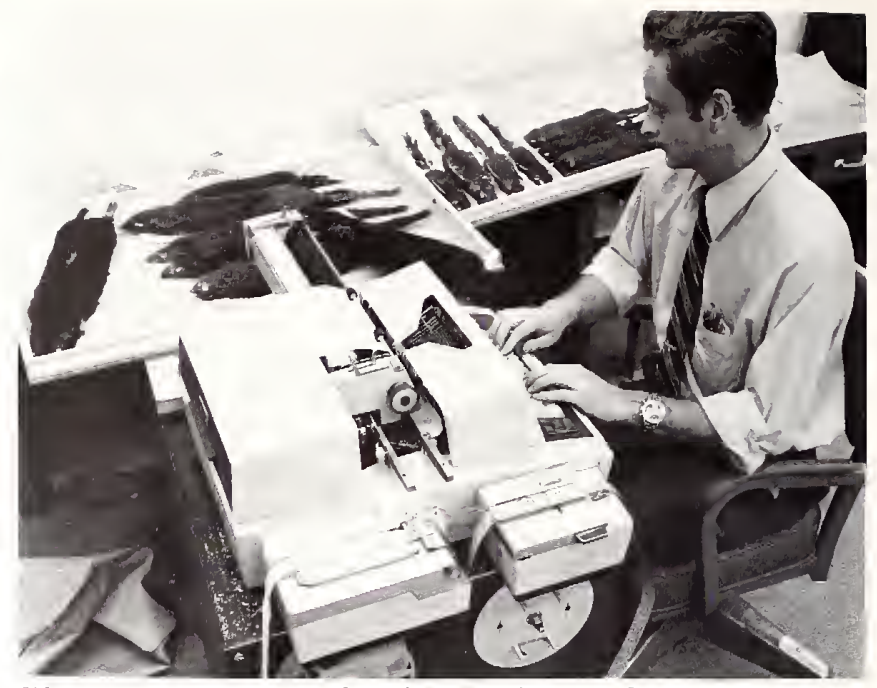

Thomas McIntyre cataloguing specimens of several genera of squirrels, September 1971. The cinderblock wall is in the west wing, and the paper tape machine today has value only as a collector's item. an an group in Philadelphia offered to design a founlain for the center, but this offer was kindly refused. A temporary hoist built in the west court in the late 1920 s was removed when it was no longer needed.

During the late 1940 s the only ativity in the courtvand-according to Lachner, whose office looked out on it - was the guice decaying of a few wooden boats. Charles Handley, the mammalogist, recalls that the grass was lush and the grasshoppers abundant. Pigeons ate the grasshoppers and sparrow hawks swept in to eat the pigeons.

\section{The "Butler Buildings"}

In 1957 a series of three connected metal "Butler buildings" was put up in the west coult, and this became the home of the rapidly expanding exhibits program. The west and center buildings housed the exhibits staff and the displays in preparation; the east one was used mainly for anthropological storage. When they moved from the cast-court toilet building to the west-court Butler building, the taxidermists were officially transferred from the Department of Zoology to the Office of Exhibits. Designers, carpenters, model makers, painters, and others were all busy with the new halls.

In these buildings, considerable effort was devoted to such projects as carving sticks into the shape of papyrus stems to go into the water-buffalo exhibit. Over about two years the stick-carvers turned out thousands, inspiring a local reporter to do an Arbor Day story on people who "made trees." Another day, a brown recluse spider in its web and the shed skin of another were found in a box of dried African mammal skins. Because this spider is so poisonous, the building was evacuated and fumigated.

One major technique was developed in the Butler buildings: the freeze-drying of specimens. The specimen, positioned by wires and other supports, is quickly frozen with liquid nitrogen and then kept cold until all moisture evaporates. For some mammals it works quite well, for some reptiles it is fair, and it requires great skill to work well with fish. Of course one is limited by the size of the cryogenic chamber, and no large animals have ever been freeze-dried. ${ }^{19}$

\section{Exhibits Staff Expands}

The exhibits group kept expanding. Some workers were moved into Stone Hall, abandoned by the Geological Survey when the east wing was completed; others were assigned to the high-ceilinged rooms in the north wing of the main building near the north elevators. A lot of casting of models for exhibits was done there, and excess plaster kept getting into the sink. Eventually the pipes were filled solid all the way to the ground floor, and new plumbing had to be installed when the area was renovated.

In 1962 and 1963, when the Museum of History and Technology was substantially finished, much of the exhibits staff went there, though there were still a number of people in the west courtyard and scattered in stillclosed exhibit halls. When the west wing was finally completed and the scientists moved in, the ground floor on the south side of the main building was modified. 


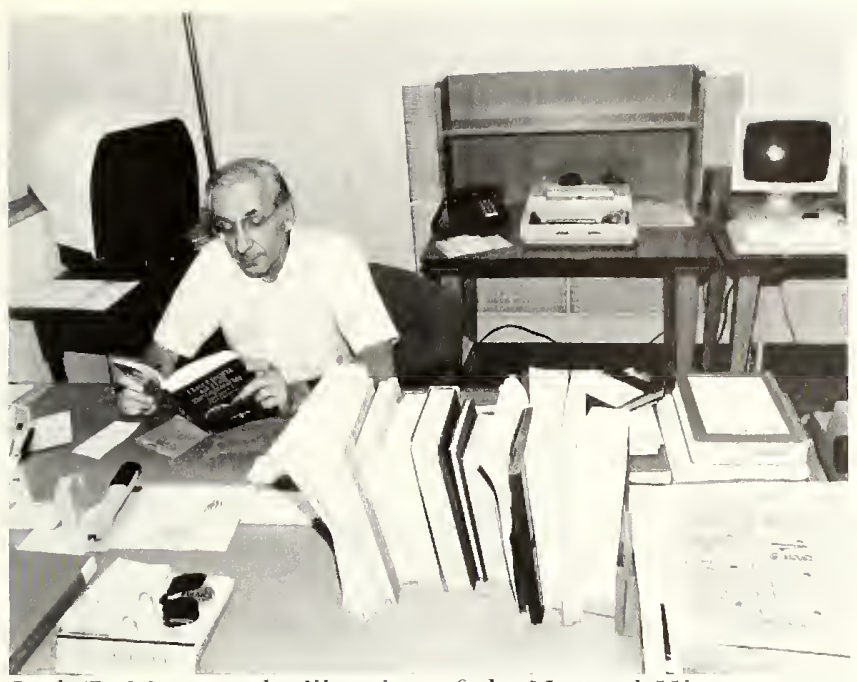

Jack F. Marquardt, librarian of the Natural History

Branch, in the decked area of the west north range, ground floor. Behind him are the various devices that librarians now use more commonly than pencils. Jack is on his lunch hour and is trying to keep ahead of staff requests by reading science fiction. July 1984.

While decking on the Mall side was extended, some decking on the north side, where the old offices of Fishes had been, was removed. This area became a large cabinet-making and paint shop for exhibits, and remains so today. Eventually a large share of the exhibits program moved to "Exhibits Central" at 1111 North Capitol Street, a catch-all building for a number of Smithsonian activities.

\section{James Mead's Project}

In 1972, when national concern about marine mammals was running high, James Mead arrived at the Museum from two years at a whaling station. Mead was to investigate strandings of mammals along the East Coast and to increase the size of the collections. The Division of Mammals had hoped to develop a center for the study of marine mammals in the Torpedo Factory in Alexandria, but this became an artists' center, so Mead moved into the Butler building along with a few remaining people from Exhibits. He set up a cooking system for boiling porpoise skulls in a former spraypaint booth. The exhaust fan moved the smell into the courtyard, whence it soon was picked up by the airintake tower. After that there was more removal of flesh by hand in preparation of specimens, and less boiling.

The best way ever found to clean bones for osteological investigation is to remove as much of the meat as possible by hand and then let dermestid beetle larvae eat the rest. This standard technique is, to many people, one of the most curious aspects of the Museum's work. For about twenty-five years the "south shed" behind

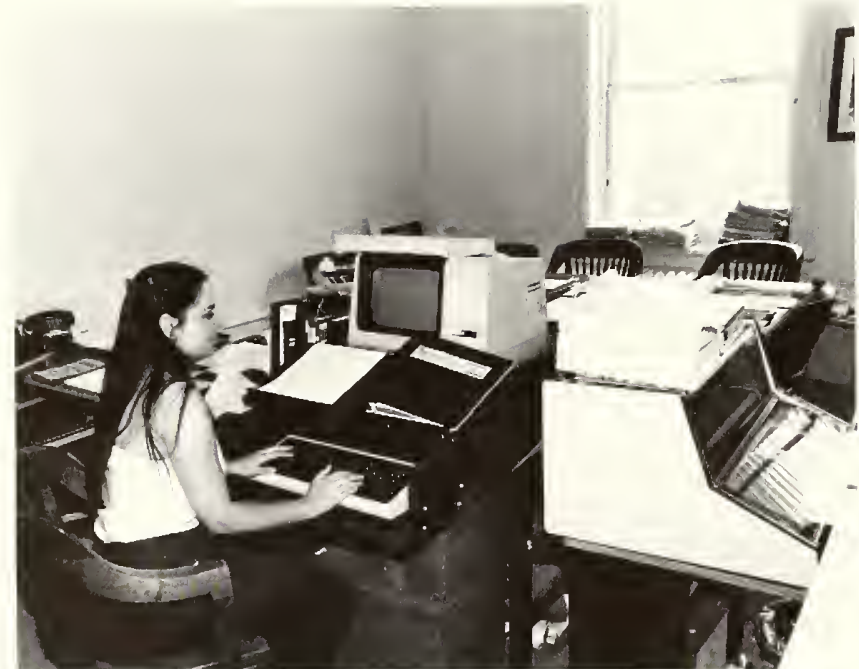

Madeline Tawney on the third floor of the main building, west wing, July 1984; the office was formerly part of the Division of Birds. The mowe to the Museum Support Center is accompanied by large amounts of computer paper from data processing.

the Castle was used for the beetles, the theory being that if they were kept away from the Museum, the collections would be safe from their scavenging. Over the years this facility became increasingly decrepit and smelly.

In 1975 the dermestid beetles and a laboratory for the preparation of large specimens, mostly from Mead's collecting, were moved into rooms in the Osteo-Preparation Laboratory, a small two-story building in the east court, between the courtyard wall and the air-conditioning plant. This was a major step up from the south shed and the Butler building. Not only did Mead appreciate it; everyone else in the Museum did too. One small whale being brought to the new lab did fall off a cart in the entryway to the courtyard, and because there was no way to move it, Mead and others prepared it on the spot. Air-conditioning engineers who had to walk past it going to and from work were cranky while the bones were being flensed.

By 1973, when the Butler buildings were vacated, the Museum's marvelous taxidermy staff had shrunk to one person, yet there was no space for skin preparation. On the third floor of the Museum, apart from the private facilities in the director's office and Holmes's old office, there was one large women's restroom and one men's room, each with marble floors, marble walls, and marble partitions. The decision was made to convert the men's room for work on skins; this facility is known as the "marble ballroom." In the game of winners and losers, male scientists in the main building now must walk great distances to the wings. 


\section{Shops and Maintenance}

$\mathrm{T}$ HE MUSEUM IS MORE THAN laboratories and exhibit halls, specimens and books. Without all its supporting parts it will not work, and without proper maintenance it falls apart. When the new Museum was planned, accordingly, the ground floor of the east wing was designed for equipment and shops. The people who worked there, reporting to the building superintendent rather than the director, were necessarily the first to be in the new National Museum.

The machinery must have been impressive. When Queen Marie of Rumania visited, Wetmore detailed Bassler to escort her around, and he showed her all the ground floor, suggesting that she seldom had a chance to see how a museum really worked. The new building's huge boilers and direct-current generators supplied heat and electricity for all the Smithsonian buildings by means of tunnels running under the Mall. ${ }^{1}$ Each annual report gave meticulous figures on the amount of coal used and the cost per kilowatt-hour of electricity. Rathbun, not surprisingly, offered details of every pipe and fuse.

He regretted, however, that the heating plant "could not have been located in a separate structure, on account of the annoyance caused by coal dust and soot and by vibration produced by certain parts of the machinery, troubles that can best be remedied by the establishment of a central power plant for the Government buildings in the western part of the city, as has been proposed." "Twenty-five years after the heating plant began operations, it was closed down; no one missed it. The six permanent and several seasonal workers whose jobs disappeared were resettled in other government positions. The government's power plant went into service in 1934, and the Smithsonian thereafter was content to purchase heat. ${ }^{3}$

It also stopped manufacturing its own electricity, but

Woodworking equipment in the new National Musenm, probably in the 1920s or 1930s. The belt-driven machinery was powered by the Museum's power plant until the mid 1930s. The carpentry shop is the only shop that has not changed its position on the ground floor. this was a different kind of story. The Institution customarily had purchased electricity for two months or so every summer, when its power plant was closed. By 1916 "the amount of electric current generated was greater than in previous years, as more lights were used and it has been found necessary to increase the size of the lamps in most of the exhibition halls." By the middle of the $1920 \mathrm{~s}$, some of the needed electricity had to be purchased year-round. In 1928, the year the small boiler for hot water to the offices gave out, the engineer obtained new pistons for his three 250-horsepower engines and was able to produce more current. Demands for light and power in all the buildings rose steadily. ${ }^{5}$ By 1931 the number of outside cables had to be increased, and it was evident that the plant could not cope with demand. In I934, 191 new light fixtures were installed in the third-floor laboratories. Judging from the lighting of the 1950s, it must have been as bright back then as the inside of a coal mine on a cloudy day.

The switch to purchased power in 1934 did not end all troubles. "The problem of obtaining additional electric supply becomes more serious each year, and it will soon be imperative either to increase the number of cables entering the Natural History Building or procure alternating current," Wetmore wrote in 1938. "The Smithsonian buildings are practically the only Government group in Washington not using alternating current, which may be purchased at more economical rates than direct current." In June 1940 the Museum finally began to convert to alternating power, a job that took about a year. The boilers were finally taken out of the building.

New passenger elevators were installed about this time. Ancient as they look today, the ones in the rotunda were completed in July 1941, and those in the north pavilion in December, just before the United States entered World War II. Whether it was lack of money or the start of the war, the freight elevators were not changed in 1941. They were still being rum by direct current until the wings were put on, and the converter had to be turned on before they conld be used.

An ice plant was authorized in 1911, ostensibly for 
Plan of shops on the ground floor, east wing of main building, from United States National Museum Bulletin 80 (1913). This was drawn before the icemaking plant was installed.

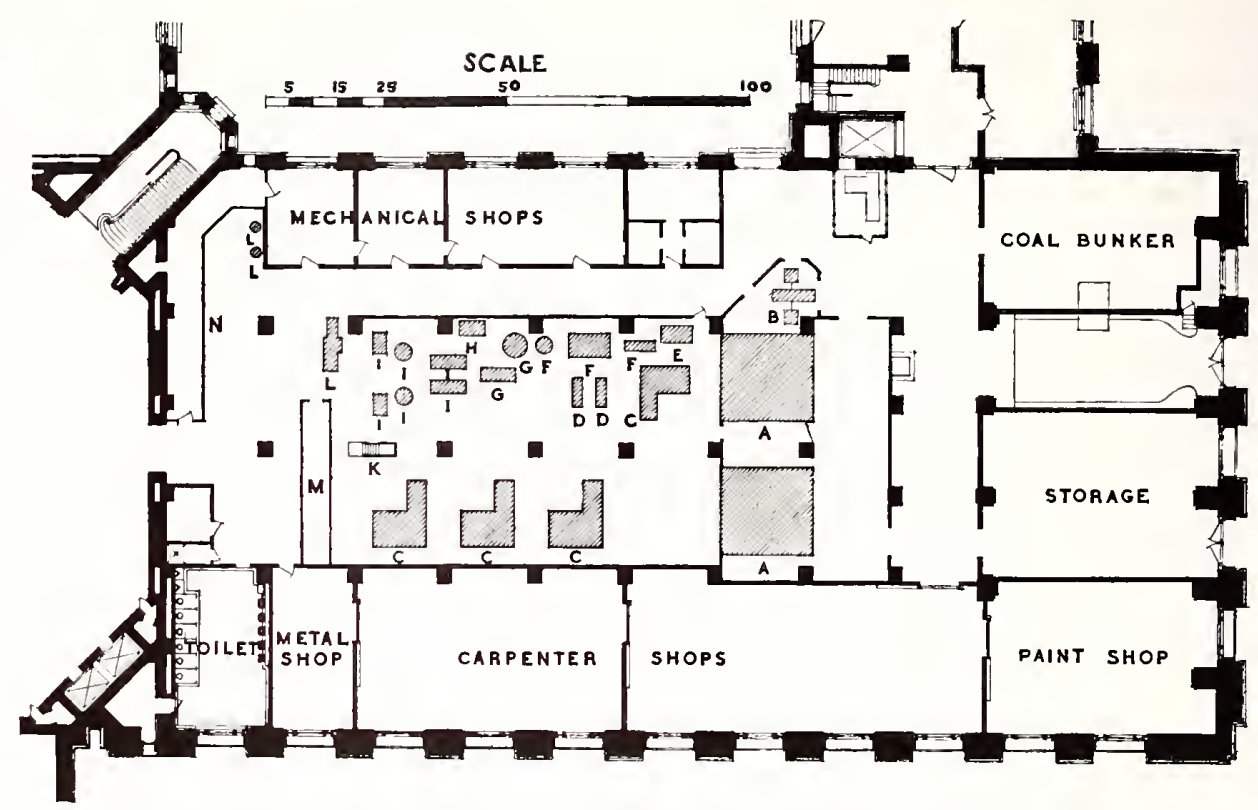

the preservation of collections, and was operated for decades. The Anmual Report of the Smithsonian Institution dutifully recorded that in fiscal year 1947, 186.7 tons of ice were produced at a cost, apart from labor, of $\$ 1.16$ per ton. After this entry, all the shops disappeared from the official records, and except for the opening of exhibit halls or major construction, the building is no longer mentioned. The ice plant functioned at least until 1948, but was gone by the early 1950 s. Ice was stored in two rooms behind the rotunda so that a wagon could drive into the tumnel and be loaded with ire for the other buildings. G. Arthur Cooper recalls the pitchers of ice he used to keep photographic solutions cool in the sweatbox of a darkroom in the corner of his office. For a time bottled water in iced coolers was provided for the staff during the awful Washington summers.

\section{Maintenance}

Contractors before World War I were no different from those of today in leaving problems behind. Consider this, for a building five years old: "Serious leaks in the upper story of the building were traced to and necessitated the repointing of joints in the three courses of stone adjoining the roofs in the west court, and also in the outer stonework of the west range above the main comice. The exterior metal framework and sills of all the first and second story windows in the courts were painted, as were the walls of the auditorium which had become defaced through the seepage of moisture. For the protection of floors showing wear, a part of the wood surface in the corridors of the third story was covered with a preparation of cork, while all of the cement paving in the corridors in the ground floor was treated with cement paint."

All this maintenance work was done by workers in the shops. While old-timers of the scientific staff think fondly of the days when the ground floor took care of everything from heat to ice, a look at salaries provides a rather jarring trip down memory lane. In 1918 the head of the paint shop got ninety-five dollars a month (fifty-five cents an hour), and the painters made three dollars and seventy cents per day. In the sheet-metal shop, two men made eighty-five dollars a month, one was paid sixty dollars, and another was paid fifty dollars. To give the wages of the plumbers at that time would bring tears to the eyes of any present-day home owner. In 1927 the Annual Report noted the great rate of turnover of labor, especially among the temporary help, who got the lowest pay and no leave.

Like everything else in the building, the shops have changed their locations. The carpentry shop is the last remnant of the old days, both in appearance and location, occupying much of the south side of the east wing in the main building. The sheet-metal and awning shops at the west end of the carpentry shop have gone, the awning shop falling victim to air conditioning and the sheet-metal work moving into the new east wing. The paint shop at the east end of the main building also moved to the east wing, and its former place was decked over for offices and locker rooms. Old-time cabinetmakers like Mr. Becker and Mr. Fischer are long gone, and their descendants are now in the exhibits shops. The area where the plumbing and mechanical shops once were has been decked over, mainly for offices. On the east end of the main building, where the electrical shop used to be, are more double-decker offices. The old furnace room now houses the saws used to section large meteorites and rocks, creating a new job for the chain hoist that was originally installed to move carloads of clinkers and ash.

On the courtyard side, an office now occupied by Buildings Maintenance was a supply room until the early 1960s. Clayton Ray, a vertebrate paleontologist, 
has a vivid recollection of Kellogg's taking him there and telling him to get whatever he needed in the way of office supplies. Billy Knowles was the building's original purchasing agent and supply clerk, stilt remembered by a few for his friendliness and efficiency. He never wore an overcoat, regardless of the weather, and one winter he caught a chill and died. Both Henderson and Perrygo remember what a contrast he made to a taxidermist who had been to the Arctic with Peary and could not wait for winter so that he could wear his furs to work.

Even with the new wings, there was insufficient space for the shops as the Institution and the Museum grew during the 1960s. In the 1970s, when the kinds of exhibit cases changed, the glass shop disappeared. The electric shop moved several times before ending up in the old awning shop. The plumbers dispossessed by sedimentologists who needed the ground floor for laboratories, moved to the basement, only to be dispossessed by ever-growing collections and by volunteer restorers of old pots. Today it is virtually impossible to find the plumbing shop. One must go into the east courtyard and through the air-conditioning building to enter their cinderblock lean-to. Perhaps the plumbers feel that if the scientists find out where they are hiding, they will be dispossessed again.

Painting is more complicated now than in the days of solid "government green." The liberalized $1950 \mathrm{~s}$ brought a choice of six colors, and now there are 1,200 possible color combinations. Repainting an of fice or touching up an exhibit can be a nightmare. The paint shop has calculated that if the Museum of Natural History were placed on, say, a three-year schedule of repainting, it would require more painters than are now employed to cope with all the buildings. The Institution's growth has not been reflected in a swelling maintenance force, only partly because of more-efficient machinery. Some work is contracted out. While it is generally agreed that work done by the Smithsonian shops is better, the waiting list is long.

Since the 1970s, when they started wearing uniforms, the shop employees have been color-coded. The labor force wears blue; painters and plasterers, the traditional white; groundskeepers, green. Mechanics, plumbers, sheet-metal workers, carpenters, and engineers are in brown. Anyone with a white shirt is a foreman or supervisor, just as any male guard with a white shirt is a sergeant or above.

\section{The Main Mail Room}

The Museum building remains the center for many support activities of the Institution, all very important and all occupying space that the curators would love to fill. For example, the area of the west loading dock is the main mail room for all buildings. Mail for the Museum has increased about 75 percent in the last fifteen years; mail for the Institution overall has more

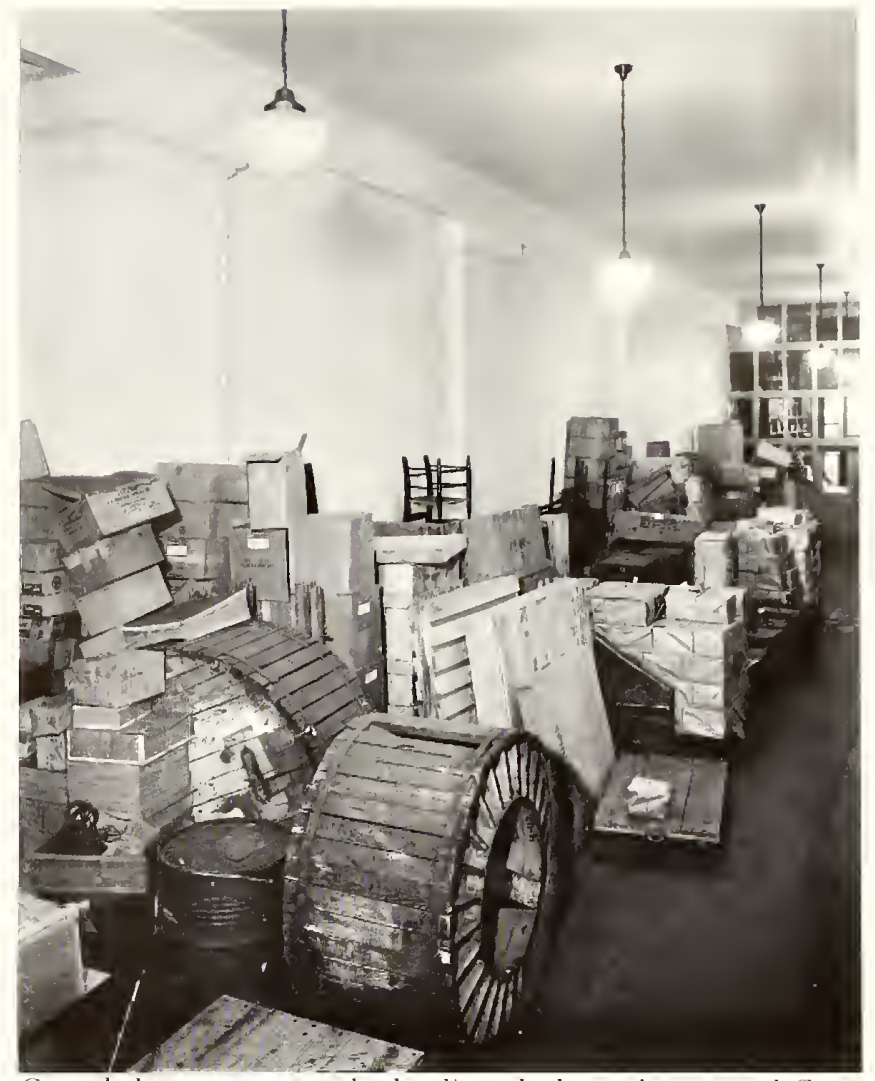

Crowded storage near the loading dock on the ground floor, west wing of main building. January 1950.

than doubled. The mailroom workers, who wear whatever they like, are always kind enough to reopen the last mailbag of the day for scientists running in late with manuscripts.

"Lanier," who delivered mail office-to-office in the 1930 's, felt that taking responsibility for the U.S. Mail was important enough to warrant a uniform. On his days off he played the trumpet at Laurel Raceway to signal the start of each race, and one day he showed up at work in his scarlet jacket. A few days later, Wetmore saw that he was issued a jacket and cap. In spite of a good memory, Lanier had a problem with his job in that he could hardly read. He judged names by length. When he walked in and handed a curator the mail, the person would shuffle through and hand back the pieces not addressed to him, being careful to say to whom those letters were to go.

\section{Housekeeping}

Not everyone on the ground floor is involved with the shops. As a result of reorganization in 1973, the responsibility for managing the Museum building was decentralized and came again to be under the director. Today the building is well managed, and this is no small task. Of the more than five million tourists each year, how many are likely to use the public rest rooms, and 


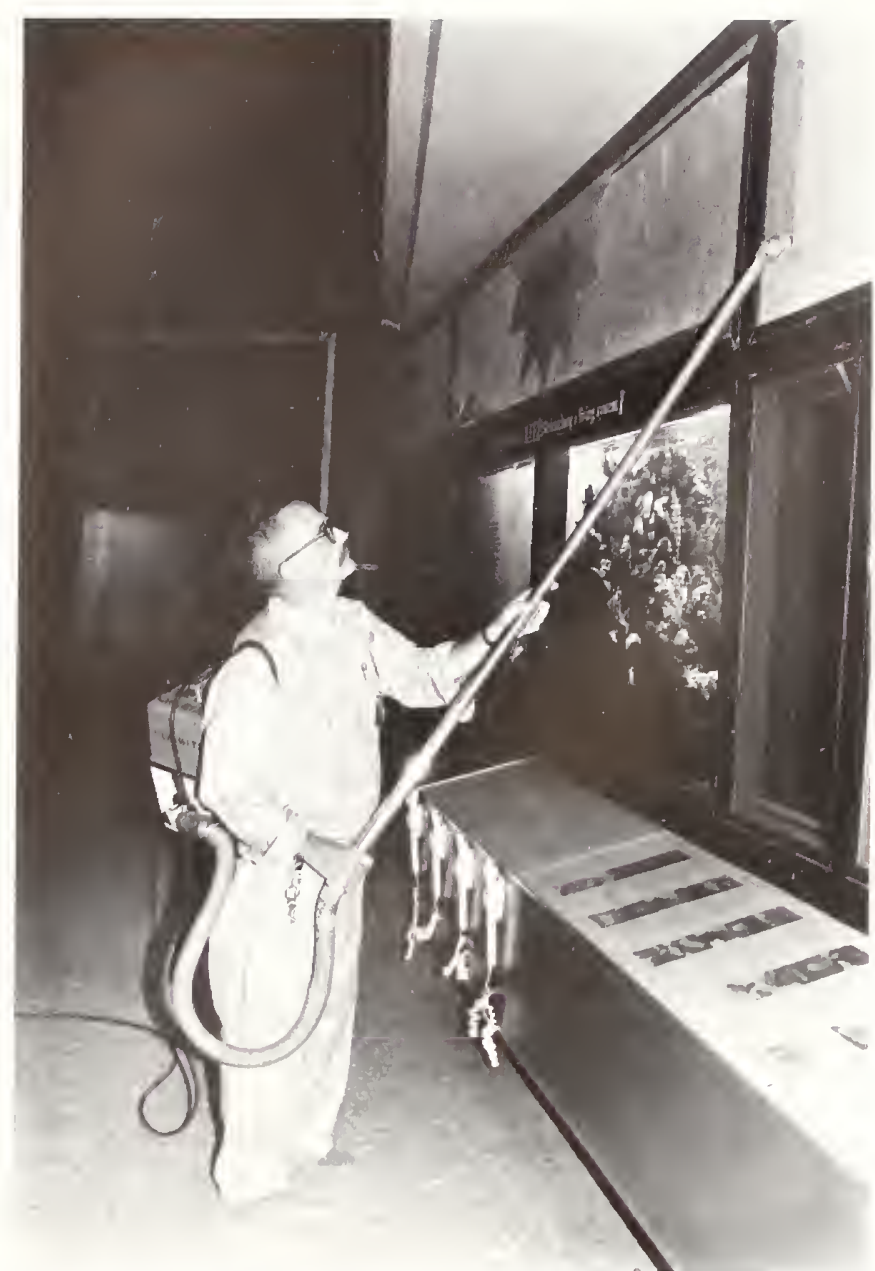

Frank Braisted cleaning the wall near the lizing coral reef at the entrance to Mall 16, July 1984.

just how many cases of paper towels are likely to be needed? There is a lot of building to be cleaned every single day. Public areas are cleaned betore 10:00 A M., and then offices and nompublic areas are taken care of.

A couple of amenities have faded out. Until at least the mid-1950), nickel-plated spittoons were regularly delivered to many of the offices, and the men's public toilet had one. There were none in the exhibit halls, and as late as the 1940 s some guards had to go to a window and spit before answering a tourist's inquiry. One of the people who delivered the spittoons walked in a stately manner from office to office. holding each ressel daintily between two fingers; he was a church deacon, and that was the way he held the collection plate. Towel service, a weekly ritual, was run by the Smithsonian in cooperation with the D.C. Prison laundry. In the early 1960s the jail doubled its prices, and the service was discontinued. A few hardy towels-white, with a blue stripe-are still in the hands of staff oldtimers who launder them at home. In at least two divisions, they are laundered and distributed regularly.

"There was a time," Judd wrote nostalgically, "when the National Museum prided itself on spotless exhibition cases, free from the imprints of sticky little hands and adult noses. In the archaeological halls, at least, this cleaning job was one for the 'bull gang', five husky Negroes who worked as a unit and found justifiable self-satisfaction in their results. Our big floor cases, each with its three-hundred-pound plate-glass side panels offered individual challenges despite their similarity. Two men would lift out the heavy glass and support it while the others cleaned. As they went about their daylong task these men frequently broke into song, country hymns sung with all the rich resonance and harmony of a church organ. Museum visitors stopped at a distance to listen, and I shall always believe we lost something unique and distinctive when 'the bull gang' was discontinued."

The Museum still prides itself on being spotless. The exhibit halls still contain plenty of glass that needs daily wiping, if not the acres of glass they presented in the past. Other changes besides the glass have been good news to the cleaning force. The big event, for them, was not the addition of the wings, but the replacement by terrazzo of the wooden floors, which had been made worse in some areas by cork coverings.

One last housekeeping tale is the story of the yellow wastebaskets. As a result of "Earth Day" in 1970, awareness of the environment and concern for conservation began to trickle through the nation, reaching even the General Services Administration. This agency announced, in some very obscure place, a program to salvage paper. One of the scientists in the building happened to see it, and suggested that the Museum might save a fair number of trees if a paper-salvage program were instituted.

The Museum had sponsored scrap-metal and newspaper collections during World War II, but the tradition of these had long since vanished. The new notion was for each office to have two wastebaskets, one for trash and a yellow one for salvage. It took an enormous amount of time to train some curators on the difference between carbon paper, which was not saved, and envelopes, which were, but eventually they got it. After a few weeks there was never an apple core in with the paper to be salvaged.

The only drawback was that this made extra work for the cleaning people, requiring them to carry two bags on their carts, one for regular trash and one for the salvage paper. It would have been easy enough simply not to bother, but when the program was explained to the maintenance crews, they agreed to do it. Not only did they agree, they did it for years. Long after the General Services Administration lost interest in the environment, the Museum continued to salvage paper until the GSA just stopped accepting it. Very few groups willingly make their daily job a bit harder. There are still a few yellow wastebaskets around, and the newer staff have no idea what they once meant. 
Charles Eblen cutting a metal strip in the machine shop, east wing, ground floor. April 1984.
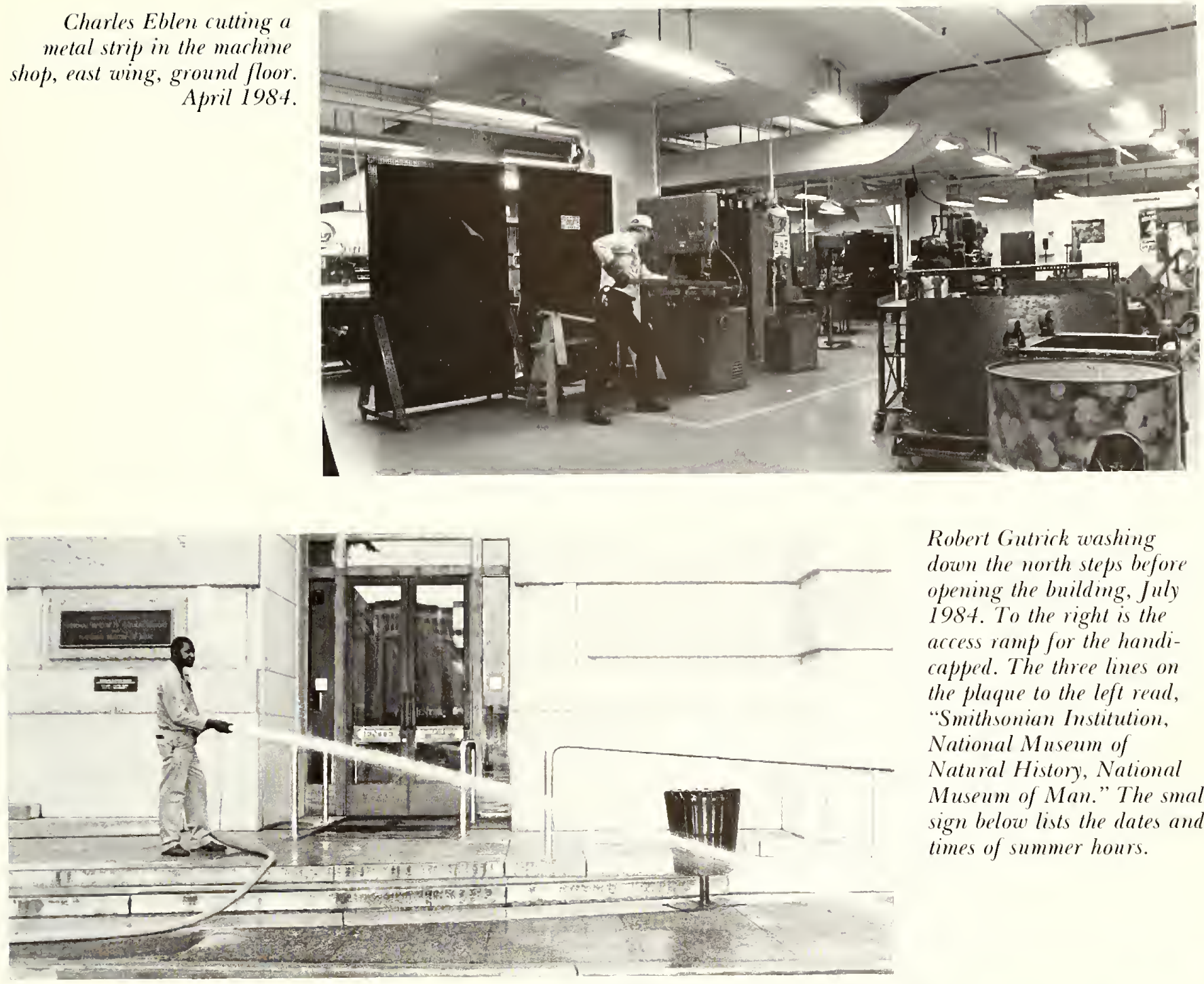

Robert Gutrick washing down the north steps before opening the building, July 1984. To the right is the access ramp) for the handicapped. The three lines on the plaque to the left read, "Smithsonian Institution. National Museum of Natural History, National Musenm of Man." The small sign below lists the dates and times of summer hours.

Building an exhibit case in the exhibits shop, west wing of main building; April 1984.

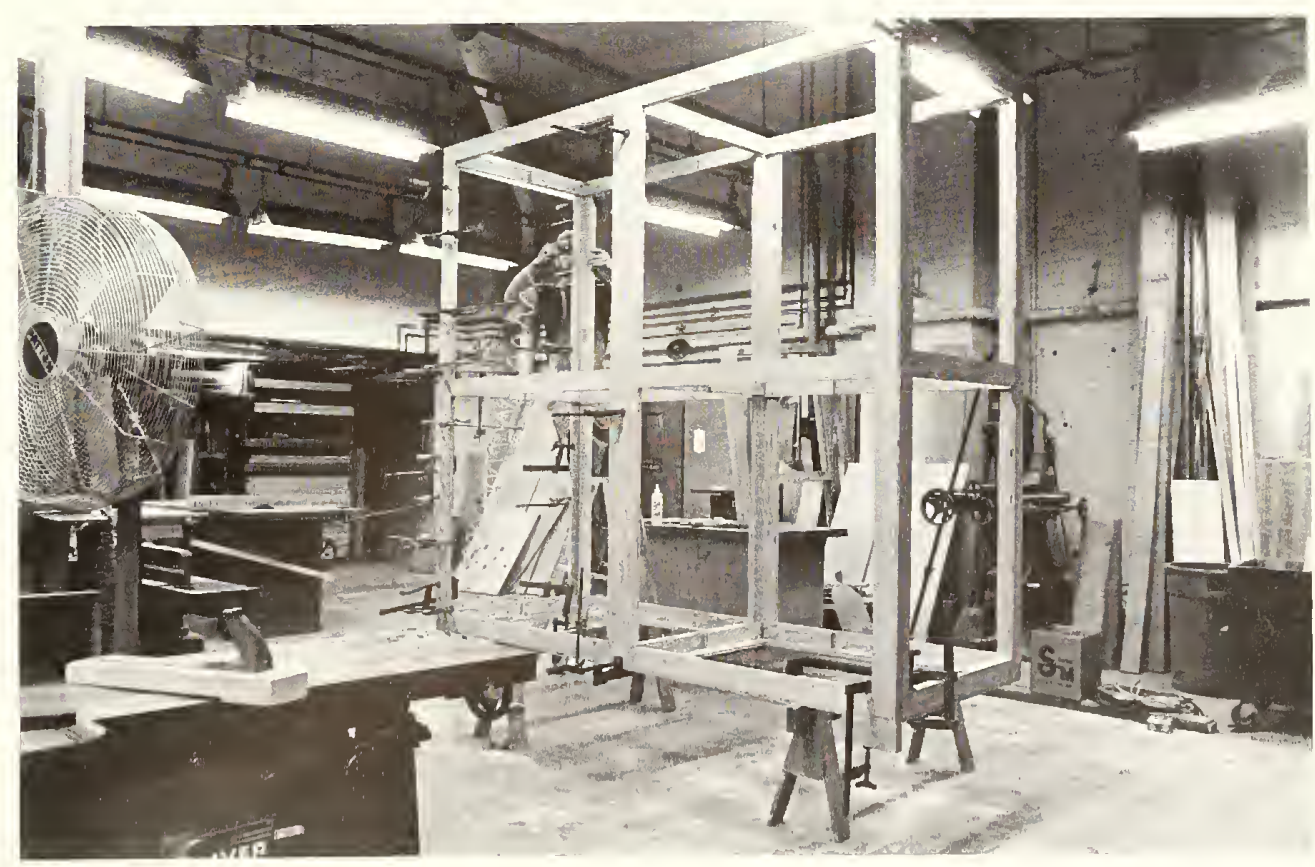




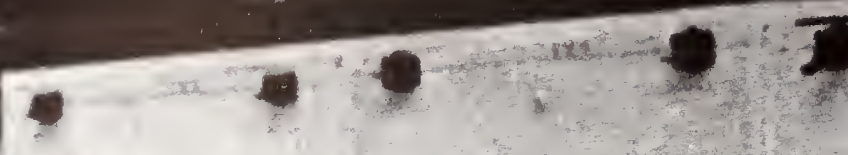

$-7$

928
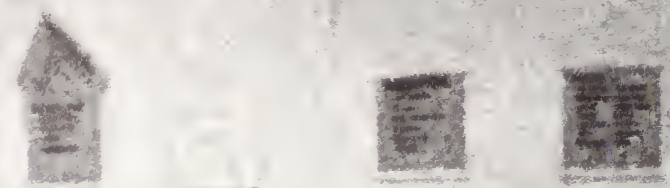

1.
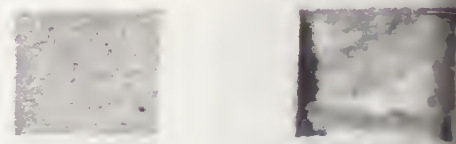

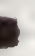

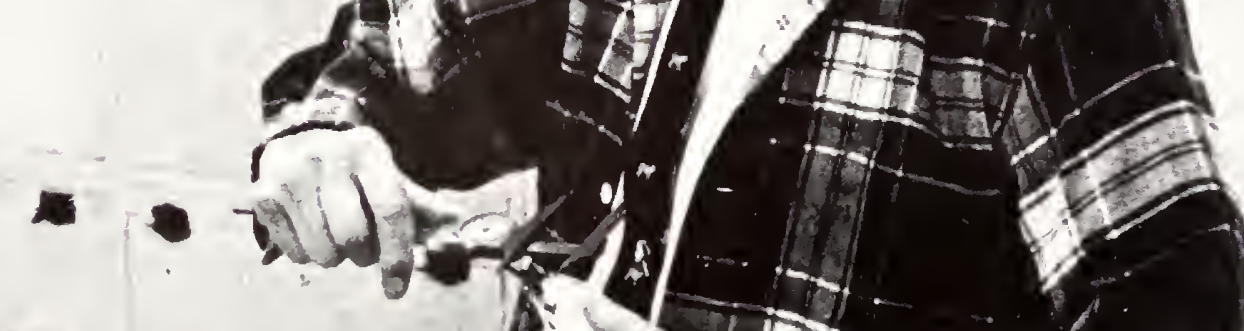

a $\mathrm{DS}$

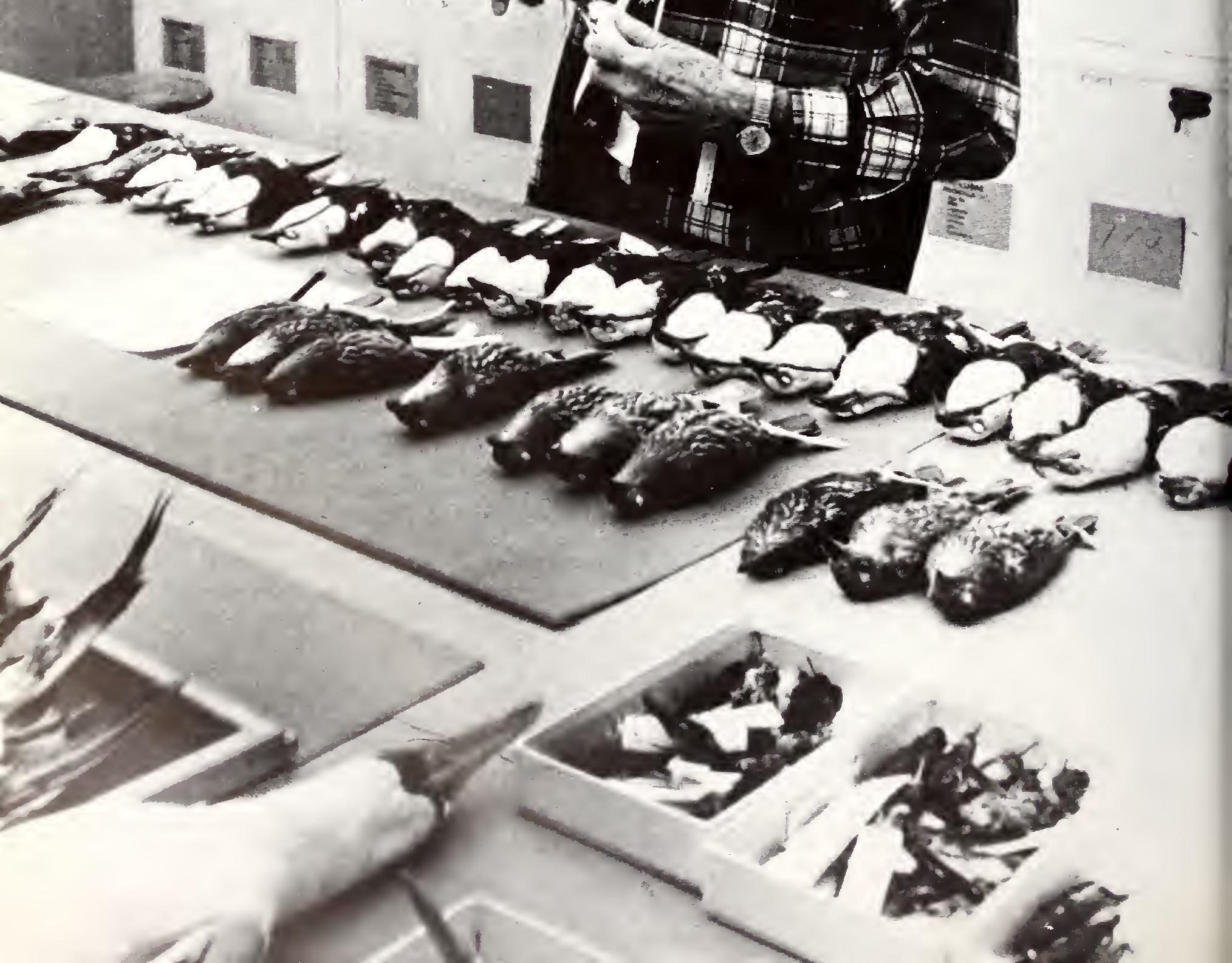

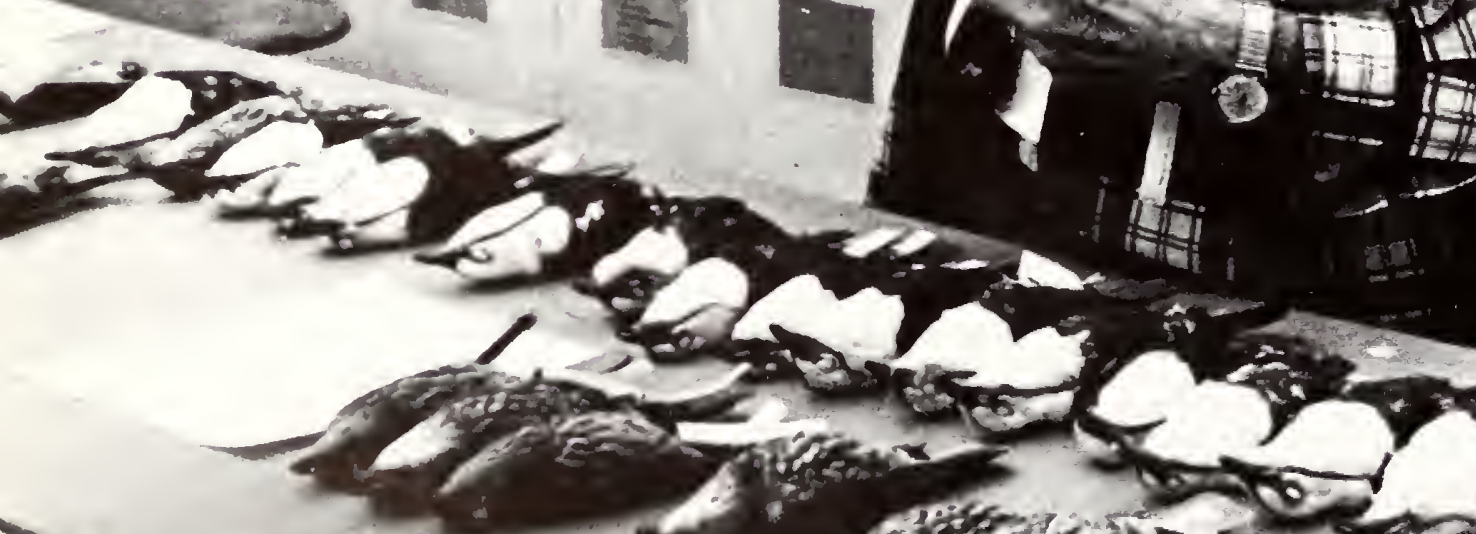
- 4 工

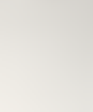




\section{Others in the Building}

$\mathrm{F}$ ROM THE WAY AFFILIATED organizations have figured in the story of the Museum, it must be clear that the building's various occupants all are part of the same Museum community and have interests in common. This concept certainly encompasses those who work in the shops. Between the systematists and the carpenters, however, lie several more groups of people who are important to the building and definitely part of the community.

This brings up again the persistent question of just how many people work in the building. The correct answer is that no one can be sure where the number stands at any given moment. The last time identification badges were made, about 1,700 were issued. Because some of those in the building have badges issued from other buildings, the number present each day is probably closer to 1,800 . The population fluctuates, with a few more scientific visitors in the summer than at other times of the year. At the moment just over 500 persons constitute the formal, paid Museum staff-less than one-third of those working there on an average day.

Because they are in uniform, the group of nonMuseum staff that are easiest to identify are the guards. The Smithsonian from its inception employed watchmen, whose job originally included running errands and, in winter, tending fires. By the time the National Museum opened, in 1881, it was established procedure to have a person on duty in the public areas. Employees had to supply their own uniforms, which were modeled in general on police uniforms of the time. Hours were long, commonly a twelve-hour shift, and it was not until 1907 that the watchmen were given one Sunday off per month. The forty-hour week did not arrive until 1945.

Alexander Wetmore, sixteen years after his retirement, studying birds on the sixth floor of the east wing, November 1969. The light is designed to simulate daylight as closely as possible. In the foreground is a blue-faced booby (Sula), but the principal interest is in the series of females and white-breasted males of the three-wattled bell bird (Procnius).

\section{The Guard Force}

Once the new National Museum opened, it became the headquarters of the Smithsonian's guard force. A small room to the west of the elevators in the north lobby was the guard office, and in spite of all the changes that have gone on in the building, it still is. In the 1950s the foyer, now occupied by the Evans Gallery, underwent extensive alterations. One exhibit on the east side was removed, and the area was decked over; the lower floor became a health room, and the upper floor was the locker room for guards. When the telephone room moved from the west north range to the Museum of History and Technology in the early 1960), this space was taken over by the guards and decked. The upper level became another locker room, and the lower floor is now a security area where Museum fire-alarm systems are monitored.

After the new National Museum opened, there were two companies of guards, one for this large new building and one for the Castle and the Arts and lndustries building. In 1964 a third company was established for the Museum of History and Technology. With each additional building, the company structure of the guard force has been modified. The Museum's guards do not report to the director. Formerly under the office of the Institution's buildings superintendent, they have been part of the Office of Protection Services since 1973.

The guards serve in three watches, the hours of which have changed slightly over the years. In the early $1940 \mathrm{~s}$ about thirty men were on the day shift in the Natural History Building, and about seven on each of the other two shifts. The guard force in the building has about doubled since then, in part because of longer hours during the summer. As the Smithsonian complex grew, the number of guards atso increased, and they now constitute the largest single group of employees that is active in every building of the Smithsonian.

There have been black officers on the force at least since the 1880s. For many years black officers were assigned to the night shift, ostensibly because they preferred it. In the very early 1950 s several of these officers indicated that they preferred to work days. They kept 


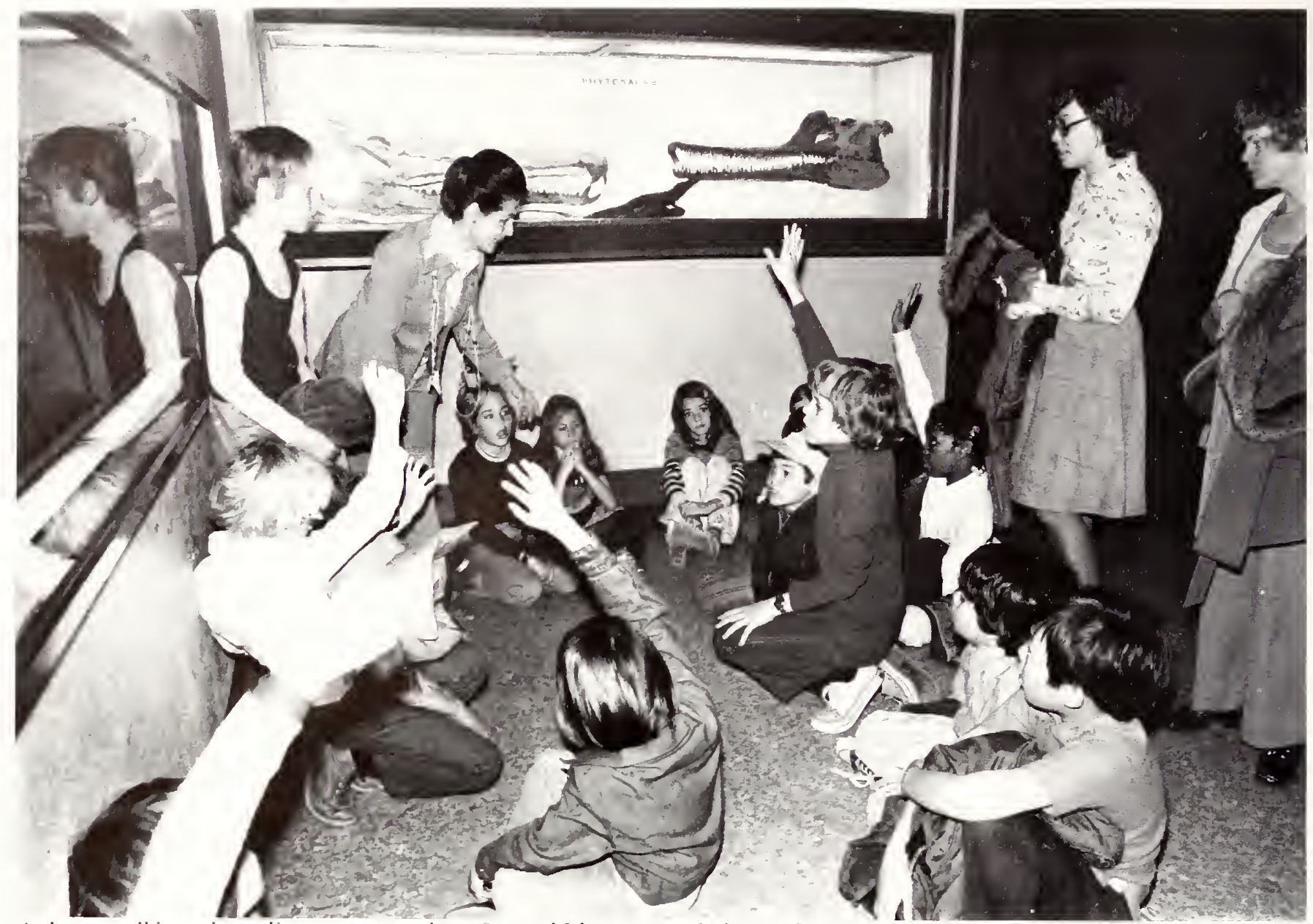

A docent talking about dimosaurs to a class. Several Phytosatu skulls are in the case behind. Although these still are on exhibit, this picture shows the retrised hall of the 1960 , not the current one.

indicating their preference, and finally they were given a fair share of dav work.

Guards must agree to work on any shift and in any building. In recent years there has been less shift rotation and less assignment from one building to another, and this has allowed the individual officers to increase their familiarity with a building. During the late 1930 s, Edward Henderson suggested that because many visitors asked questions about the gems, it might be wise to keep the same guard on duty in the gem and mineral hall so that he could become familiar with the collection and answer questions better. Wetmore agreed, and the mineralogists put together a reference book for the guard. Today the Smithsonian has a pocket guide for guards telling where the principal attractions are located in the various buildings. White the guards are reluctant to repeat some of the silly questions they have been asked, one does recall a tourist's looking at the world's largest crystal ball and asking if that was the Hope Diamond.

Being a guard has never been financially rewarding. Many good employees have been lost to higher-paying jobs and a few have joined the technical staff of the
Museum; yet some have retired after thirty or even forty years' service. There is a modest night-pay differential; the Museum is particularly drafty and gloomy late at night and the extra pay is earned. The fire alarms are tested on Friday nights at 3:00 A.M., and even if one knows the noise is coming, it still makes one jump. "Railroad" Harris, who had been on the force thirtyeight years, recalls taking a new man around to show him the alarm stations and warning him to stay away from the sword on "Kaiser Bill," the German officer manikin standing at one end of the attic. After one walk through the attic, the new man turned in his gun at the office and quit on the spot.

In the 1930s and 1940s each guard was equipped with a gas billyclub-a billy with a tear-gas canister at the tip. Since then, guards have been issued revolvers. In 1951 the Secretary was given legal authority to designate protection officers who have the right to enforce regulations and to arrest if necessary. Arrests are seldom made, but they are made.

While today's large volume of visitors probably provides extra security for the exhibits, it increases the problem of pickpocketing and purse snatching. The 


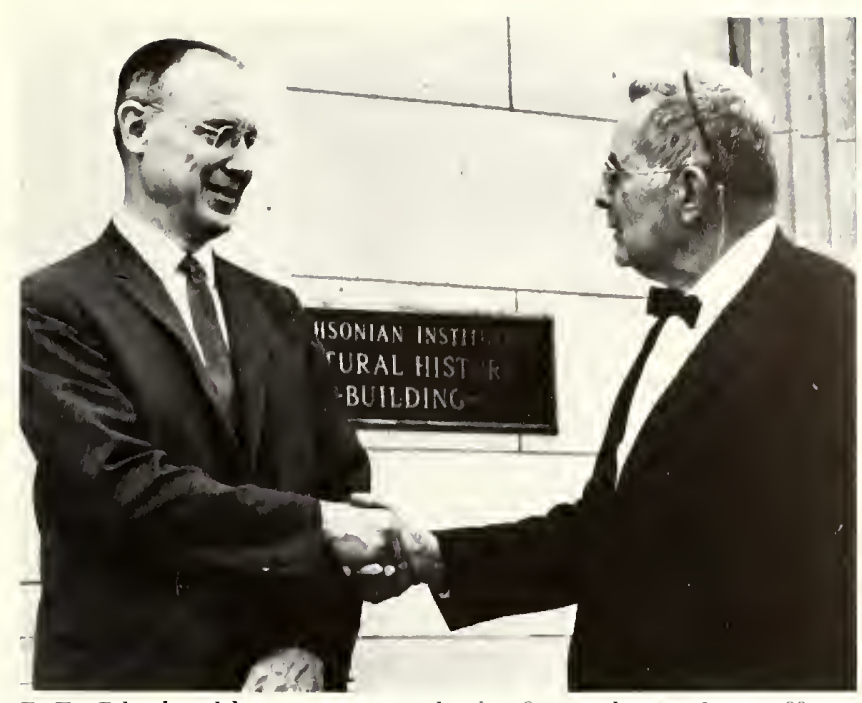

R.E. Blackwelder, an entomologist formerly on the staff, and Waldo Schmitt on the south steps, in 1976. At the time, "Uncle Waldo" was in his eighteenth year of retirement work at the office. The plaque does not mention the Museum of Man.

guards are always watching for this, but inevitably a few tourists do suffer losses. Once a young man found "operating" a self-service elevator and charging tourists twenty-five cents a ride was escorted from the building and advised not to come back.

Losses from the exhibits have been very few, and nothing noteworthy has disappeared. In one incident from the 1930s, a guard noticed that an African spear was missing from a wall display, and reported it. The next day he kept watch, and observed a man moving another spear slightly upward in its retaining brackets. Each day the spear was pushed a little higher. The guard was watching on the day the thief got it loose and hurled it out the window to an accomplice. Both were caught.

A few years ago a former employee tried to rob the museum shop before it opened for the day, but was caught before he reached the exit. In the 1970s a professional mineral thief was captured after he removed several screws from a case and set off the alarm. Not every case is equipped with an alarm, but most are. Security screws are also used on many of the cases.

One fairly new development is the appearance of women on the guard force. This was not so much a result of the women's liberation movement as a consequence of Civil Service reclassification. For about sixty years the elevators in the building were run by operators, and since the early 1940 s most of the operators were women. Guards were forbidden to operate the elevators during working hours, except in an emergency. Eventually, it was decided to abolish the separate classification of elevator operator, and these women became part of the guard force. For a time the elevators were viewed as "perimeter security" because they pro-

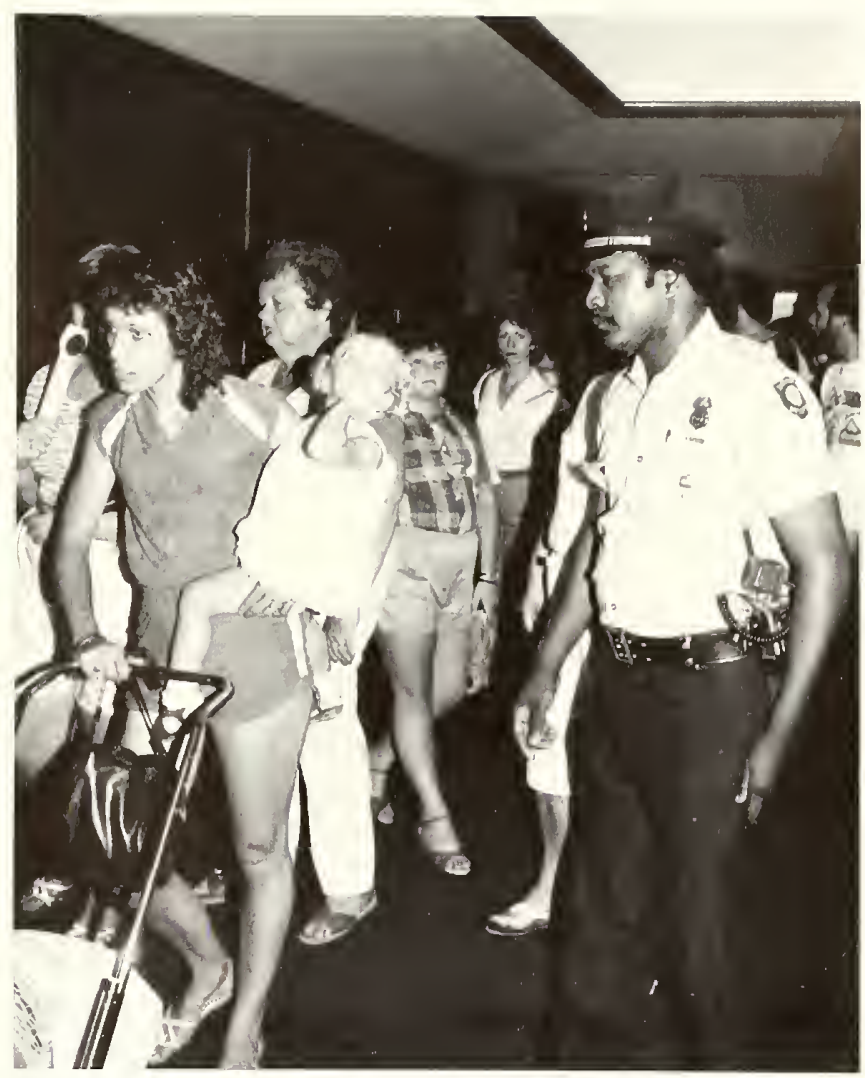

Officer Harrison McPhaul in the Gem Hall, at the west end of Hall 19, July 1984. Behind him are people lined up to see the Hope Diamond.

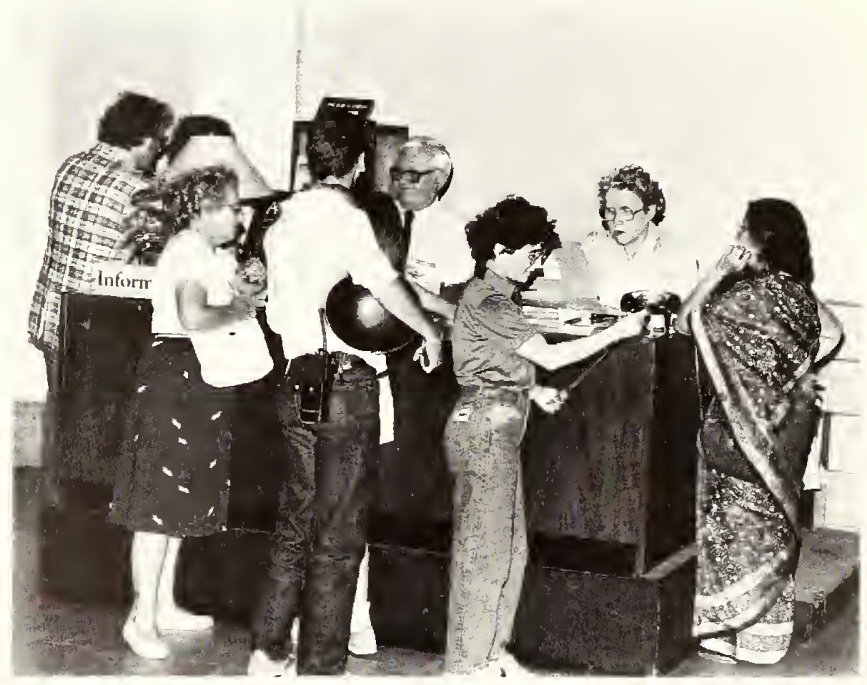

The information desk, manned by volunteers, on the west side of the lobby. This desk is normally by the entrance to the Evans Gallery but was moved for the "Aditi" show of life in India. July 1985. 


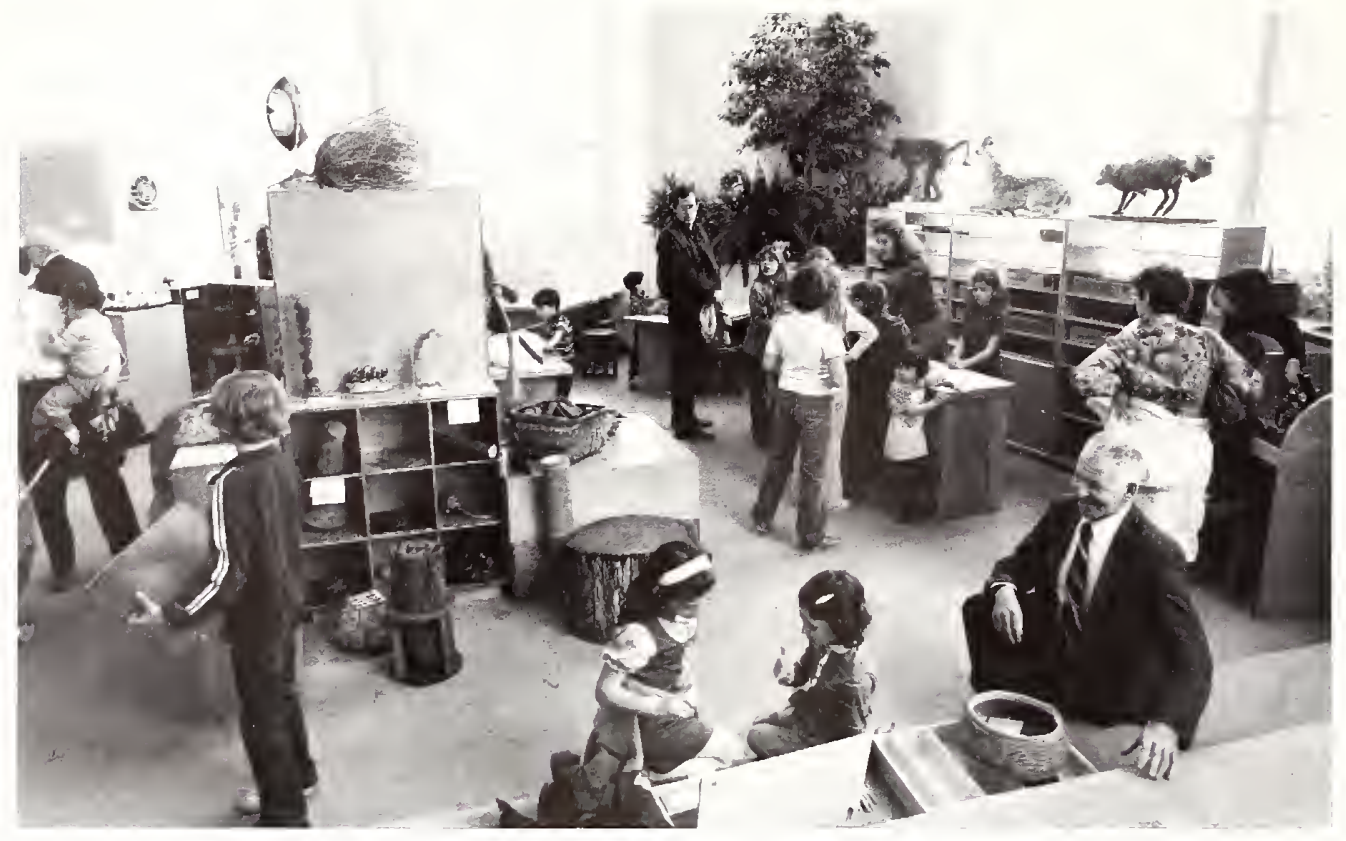

The Discovery Room, 1980. Amidst the children are a parent in the foreground, a volunteer midway, and $a$ staff member behind. Everyone seems to be enjoying learning.

vided access to the offices on the third floor, and a few tourists were flustered by the sight of a smiling female elevator operator packing a .32-caliber pistol. Other women have come directly onto the force as guards. In the recruiting of male and female guards alike, preference is given to velerans of the armed forces.

Another new development is the K-9 corps that began to be used in 1976. Some of the curators expressed dismay, fearing that the dogs might minate on specimens in the exhibit halls, but this concern has proved to be untounded. Using dogs in the Museum on an irregular schechule has added an extra measure of security.

An important recent event in the history of the building was The Precious Legacy, a temporary exhibit in the Evans Gallery in 1983. This was the first showing of objects from the Jewish Museum in Prague. Security was exceedingly important; should anything have been lost or damaged, it could have had political ramifications. When the Israeli ambassador toured the exhibit, the building was sealed.

Large crowds were expected, but they exceeded all estimates. Lines ran from the rotunda through Hall 8, down the Constitution Avenue steps, across the lobby, and finally into the Evans Gallery. Often the wait was more than an hour. In addition, a ticket system for admission at stated times was instituted. Throughout all this the guards remained poised, and no one was hurried through the exhibit. One of the officers commented that the Office of Protection Services had been involved in the planning from the beginning, and that this was the first time their view's and suggestions were seriously considered. The net effect has been that the guards, more than ever before, feet like part of the establishment.

\section{The Importance of Volunteers}

One of the remarkable aspects of the Museum and the Institution is the large number of volunteers. The Smithsonian is one of the few places in the world where people seem willing to stand in line to volunteer. The volunteer hours contributed over a year approximate those of paid staff. ${ }^{2}$

The Museum's information service, run from desks in the rotunda and the lobby, is entirely a volunteer operation. The desks are staffed from 10:00 A.M. to 4:00 P.M. throughout the year, with sixty-two time slots to be filled each week. This is a lot of hours, yet the desk is never unattended. All sorts of questions are asked and answered. Certainly the tourists, and the scientific and other visitors who have to be announced before proceeding to behind-the-scenes destinations, would put an overload on the guard force, were it not for these volunteers.

Another place where volunteers are extremely important in Museum work is the docent program. These volunteers lead school groups from one exhibit to the next and make certain the visit is a learning experience, not just a vacation from the classroom. For fiscal year 1983 , in the Museum of Natural History, 310 docents put in more than 30,000 hours. ${ }^{3}$ As a reflection of changing times in America, the docents now include a growing number of men.

In addition to docents who roam the halls when school is in session, there are two educational areas in the building that are staffed year-round by volunteers. The Discovery Room is staffed almost entirely by volunteers, about fifty-five of them in all. Two part-time paid staff members are responsible for the room and its specimens and for overseeing the volunteer program. ${ }^{4}$

The Naturalist Center attracts the even more scien- 


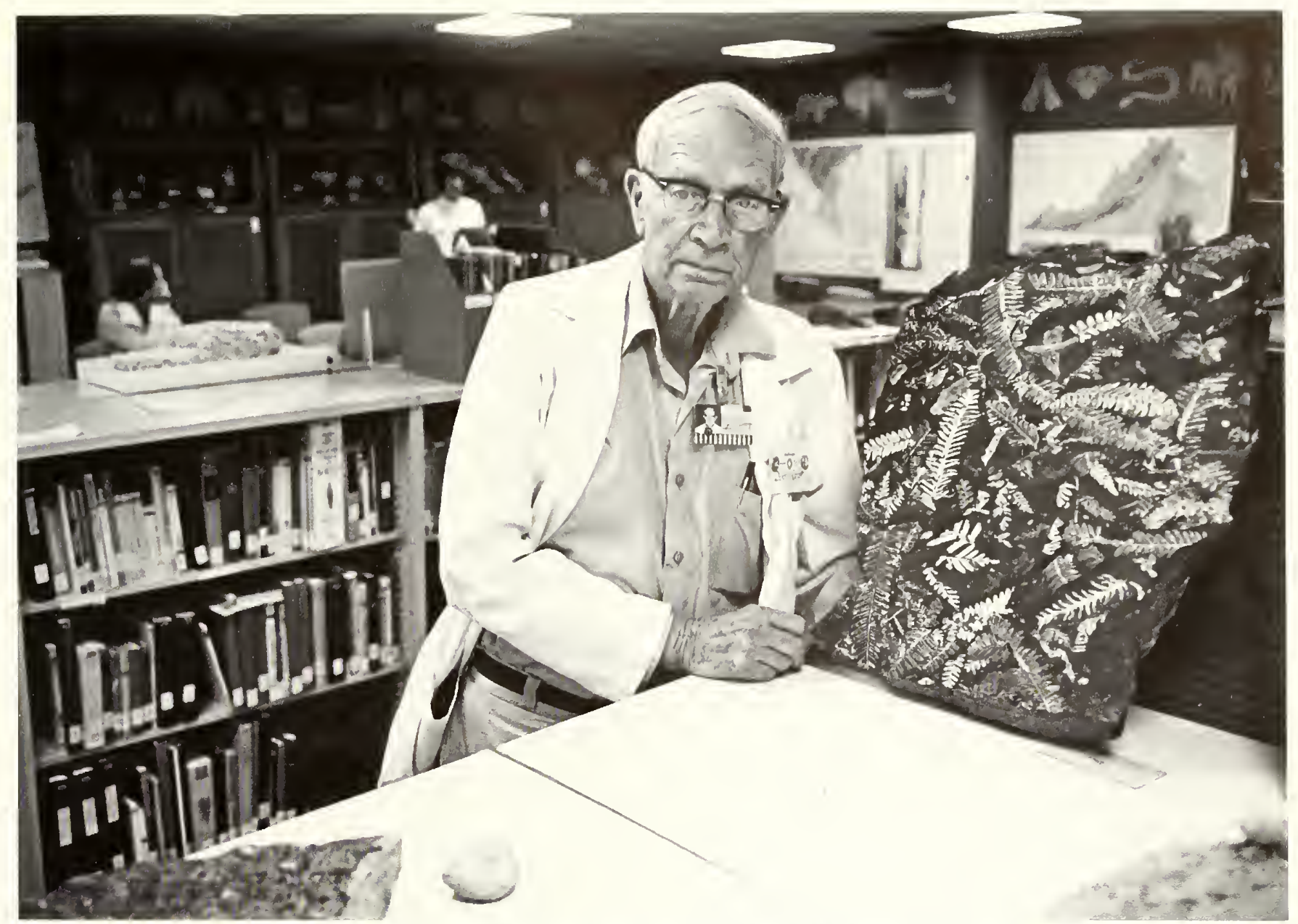

The Naturalist Center, 1982. Payson D. Carter is one of the oldest docents, a man in his eighties who comes in twice a week to teach. He is holding a slab containing fossil ferns (Neuropteris and Alethopteris).

tifically-inclined volunteer. In general, these workers are people who are interested in specimens and in sharing their interest with others. At least one member of the current staff, Donald Davis in Entomology, traces his interest directly to volunteer work done when he was in high school.

Gus Van Beek, a specialist in Middle Eastern archeology, has been extremely successful in obtaining volunteers to work at archeological sites. Reasoning that others might like to help even if they were not on a "dig," he put out a call for assistance over ten years ago, and got a volunteer group that has gathered weekly ever since to fit potsherds together. They met in one closed exhibit hall, then another; then in the basement of the west wing and finally in the east wing basement. This is the longest continuously running program of volunteer scientific work at the Museum, but some departments have received as much as eight years of parttime assistance from a constantly changing cast of volunteers. In fiscal year 1983, 247 behind-the-scenes volunteers contributed 59,043 hours of work. Annually they receive a pat on the back as their principal reward, plus a great deal of inner satisfaction. Volunteer work extends the efforts of the scientists and has become a significant facet of Museum operations in some departments.

From volunteers working in the collections, it is a short step to retired scientists, or, more correctly, unpaid scientists. Most retirees are from the staff or affiliated organizations, but retirees from the Department of Agriculture find a home in Botany or Entomology, and occasionally scientists from further afield come to the Museum for a year or more. Henry Collins has been coming in to the Museum for sixtyone years, as has T. Dale Stewart, if one counts the time Stewart took off to go to medical school. Edward Henderson has been coming in fifty-six years and G. A. Cooper for fifty-five.

At the other end of the scale are students. There are students of all ages in the Museum. About twenty-five each year are supported by the Smithsonian, ranging from lowly undergraduates to distinguished Regents Fellows. There are usually at least twice that many other students and special visitors in the building who have come to study the collections for a day or more. $\quad$ 



\section{The Visitors}

$\mathrm{T}$ He NATIONAl MUSEUm has AlWAy's BEen a public museum, and so far as one can cletermine, there never has been an instance of anyone's being refused admission during visiting hours. Because most museums in America either charge a fee or ask for a donation, visitors expect to pay admission, but no one's money has ever been accepted. This is not a trivial point, for some years ago, under a Conservative government, the British Museum of Natural History was ordered to install a turnstile and cliarge admission. At that time the Conservatives had already lost much support, but to charge for a public museum was the final straw. A few months later the Labor Party came in, and the turnstiles went out. After the Labor government lost and the Conservatives returned to power, no one attempted to reinstate the charge for entry into that government-supported museum.

If the National Museum of Natural History were to charge an admission fee of, say, three dollars, it would bring in enough money at least to maintain the building and exhibits. However, in exchange for a few cents apiece from their taxes, the people of America may enjoy for free the exhibits in all the Smithsonian museums, have their priceless national collections cared for, and, through scientific publication, reap the fruits of the Museum's research.

The American people seem to respect the Smithsonian Institution and all it stands for, judging from the behavior of the visiting public. There is virtually no trash on the floors, and graffition the walls are almost nonexistent. Some of the older staff members cannot quite get used to the casual dress of the tourists; when they were young, going to a museum was a serious business, requiring one's best clothing. Nevertheless, casual dress is now a way of life throughout the world. Some of the older guards have noted that the noise level since the 1950 s seems to be much higher, but this is probably a result of the great increase in tourism.

Visitors lined up along Constitution Averue to see the Dead Sea Scrolls exhibit in the foyer, March 1965. Behind the young man standing near the east driveway is the walkway to the east door of the wing, never opened.
The number of visitors to the Museum of Natural History and the other Smithsonian buildings has always been closely watched. When the Institution was still fairly young, an anonymous clerk compiled annual attendance figures for the Castle and the National Museum. These show the dramatic increase that resulted from the opening of the new National Museum, especially after Sunday hours were instituted:

One of the most important events of the year [1911], if not in the history of the Museum, was the beginning of Sunday openings to the public, whereby the privileges of the establishment were extended equally to all classes. First advocated by the Secretary of the Smithsonian Institution at least 50 years ago, the means required for the adchitional heating and watchmen only became available in the provisions made for maintenance since the completion of the new building. This innovation applies for the present only to the new building, with hours from 1:30 to 4:30 o'clock in the afternoon. ... On the first date of opening, October 8, 1911, the attendance reached the almost unprecedented figure of 15,467 . It fell to 4,570 on the second, to 3,885 on the third, and to 3,280 on the fourth Sunday, with an average for all Sundays of 1,666 visitors, as against a week-day average of 693 visitors. There is no doubt, therefore, that the step has been fully justified, and it is hoped that the provision of an additional place to which people may resort on Sundays for instruction and diversion has not been without some moral influence.'

The Sunday openings were a success from the very beginning, and for thirty years, in spite of its shorter hours, Sunday consistently drew more visitors than any other day of the week. When there were sufficient funds to open the other Sunithsonian buildings on Sunday, they too proved popular. During World War II Sunday became a full day, and eventually the Museum was open the same hours every day of the week. With the fiveday work week, Sunday is no longer the one big day, but shares the weekend crowds with Saturday. 
TABLE 4

\section{Museum of Natural History Attendance 1910-1984}

\begin{tabular}{|c|c|c|c|}
\hline $\begin{array}{l}\text { Fiscal } \\
\text { Year }\end{array}$ & $\begin{array}{r}\text { Number of } \\
\text { Visitors }\end{array}$ & $\begin{array}{l}\text { Fiscal } \\
\text { Year }\end{array}$ & $\begin{array}{r}\text { Number of } \\
\text { Visitors }\end{array}$ \\
\hline $1910^{1}$ & 50,403 & 1948 & 650,704 \\
\hline 1911 & 151,112 & 1949 & 689,233 \\
\hline 1912 & 281,887 & 1950 & 724,948 \\
\hline 1913 & 319,806 & 1951 & 757,126 \\
\hline 1914 & 329,381 & 1952 & 854,463 \\
\hline 1915 & 321,712 & 1953 & 830,775 \\
\hline 1916 & 381,228 & 1954 & 861,955 \\
\hline 1917 & 407,025 & 1955 & 905,292 \\
\hline 1918 & 401,100 & 1956 & $1,007,578$ \\
\hline $1919^{2}$ & 132,859 & 1957 & $1,160,041$ \\
\hline 1920 & 422,984 & 1958 & $1,401,772$ \\
\hline 1921 & 467,299 & 1959 & $1,957,747$ \\
\hline 1922 & 441,604 & 1960 & $2,218,747$ \\
\hline 1923 & 508,518 & 1961 & $2,047,973$ \\
\hline 1924 & 540,776 & 1962 & $2,113,053$ \\
\hline 1925 & 557,016 & 1963 & $2,288,397$ \\
\hline 1926 & 581,563 & 1964 & $2,512,306$ \\
\hline 1927 & 561,286 & 1965 & $3,051,472$ \\
\hline 1928 & 618,773 & 1966 & $2,988,006$ \\
\hline 1929 & 650,815 & 1967 & $3,409,957$ \\
\hline 1930 & 625,326 & 1968 & $3,257,957$ \\
\hline 1931 & 631,498 & $1969^{3}$ & $2,916,749$ \\
\hline 1932 & 600,535 & 1970 & $3,269,791$ \\
\hline 1933 & 519,977 & 1971 & $3,456,755$ \\
\hline 1934 & 507,948 & 1972 & $3,404,571$ \\
\hline 1935 & 606,145 & 1973 & $3,305,836$ \\
\hline 1936 & 635,561 & 1974 & $3,067,694$ \\
\hline 1937 & 702,657 & 1975 & $4,442,611$ \\
\hline 1938 & 750,307 & $1976^{4}$ & $6,435,654$ \\
\hline 1939 & 709,139 & $1977^{5}$ & $5,777,643$ \\
\hline 1940 & 809,661 & 1978 & $5,366,159$ \\
\hline 1941 & 803.466 & 1979 & $5,594,748$ \\
\hline 1942 & 622,989 & 1980 & $5,202,864$ \\
\hline 1943 & 424,055 & 1981 & $4,998,736$ \\
\hline 1944 & 493,239 & 1982 & $4,961,180$ \\
\hline 1945 & 531,712 & 1983 & $5,650,406$ \\
\hline 1946 & 606,310 & 1984 & $6,096,282$ \\
\hline 1947 & 637,917 & & \\
\hline \multicolumn{4}{|c|}{$\begin{array}{l}\text { 1. Government fiscal year July } 1-J u n e ~ 30 \text {, until } 19 \\
\text { 2. Building open for only three months of the yea } \\
\text { 3. Building closed Mondays October } 21.1968-\text { Ap } \\
\text { 4. Extra } 3 \text { months added to this fiscal year. } \\
\text { 5. Government fiscal year changed to October } 1- \\
\text { September } 30 \text {. }\end{array}$} \\
\hline
\end{tabular}

The Museum used to close on Christmas and New Year's days. During World War II a determination was made to keep the building open on New Year's Day, so that now the only day that it is closed is Christmas. The change from the original hours of 9:00 A.M. to 4:30 P.M. to the current hours of 10:00 A.M. to 5:30 P.M. took place in the $1950 \mathrm{~s}$.

From the fall of 1968 through the spring of 1969, the Smithsonian buildings were closed to the public on Mondays as an economy measure. There was not enough money to pay the guards needed to patrol the exhibit halls, and until the requisite funds were appropriated, many tourists who planned to see the Museum were turned away. In retrospect, it seems strange to spend millions of dollars on displays and not spend a few thousand to allow them to be seen, and it is tempting to trot out an epigram by Frank Wigglesworth Clark, an honorary curator appointed in the 1880s: "The government will spare neither time nor money in the pursuit of economy."

A happier development beginning in the 1970s has been the lengthening of visiting hours during the summer. Various combinations of months and hours have been tried. For a while a six-month extension of visiting hours was in effect. Then it was limited to the summer months, and finally a few weeks in April were also included. At the beginning of this experimentation the hours were extended until 9 P.M., but after several adjustments, closing time was fixed at 7:30 P.M. Because of the extra hours in the evening, one cannot exactly compare attendance figures from the pre-1960s with those of later decades, but the chances are good that had the evening hours not been added, the Museum would be even more crowded during the day. In the summer, it is better to visit the Museum of Natural History late in the day or in the early evening. By then most of the tourists who started out at the crack of dawn have collapsed either from the heat outside the buildings or from a nonfatal disease known as "museum fatigue" or the more localized "museum feet."

\section{Counting the Visitors}

The annual reports and Smithsomian Year have kept track of a variety of facts and figures, but the one item that has never been omitted is the number of visitors. The Smithsonian's officials all are very much aware of the importance of the public exhibits in maintaining public tax support for the Institution. If for some bizarre reason the Smithsonian should ever close forever, the last activity to stop would be the guards' clicking their mechanical hand-counters to tally each visitor entering each building. Visitor counts have been compiled since the National Museum first opened in 1881 .

It took five years for the new National Museum to $\log$ its first million visitors, the total by the end of fiscal year 1915 being $1,618,576$. It took another nine years to reach the five-million mark, the cumulative count by 


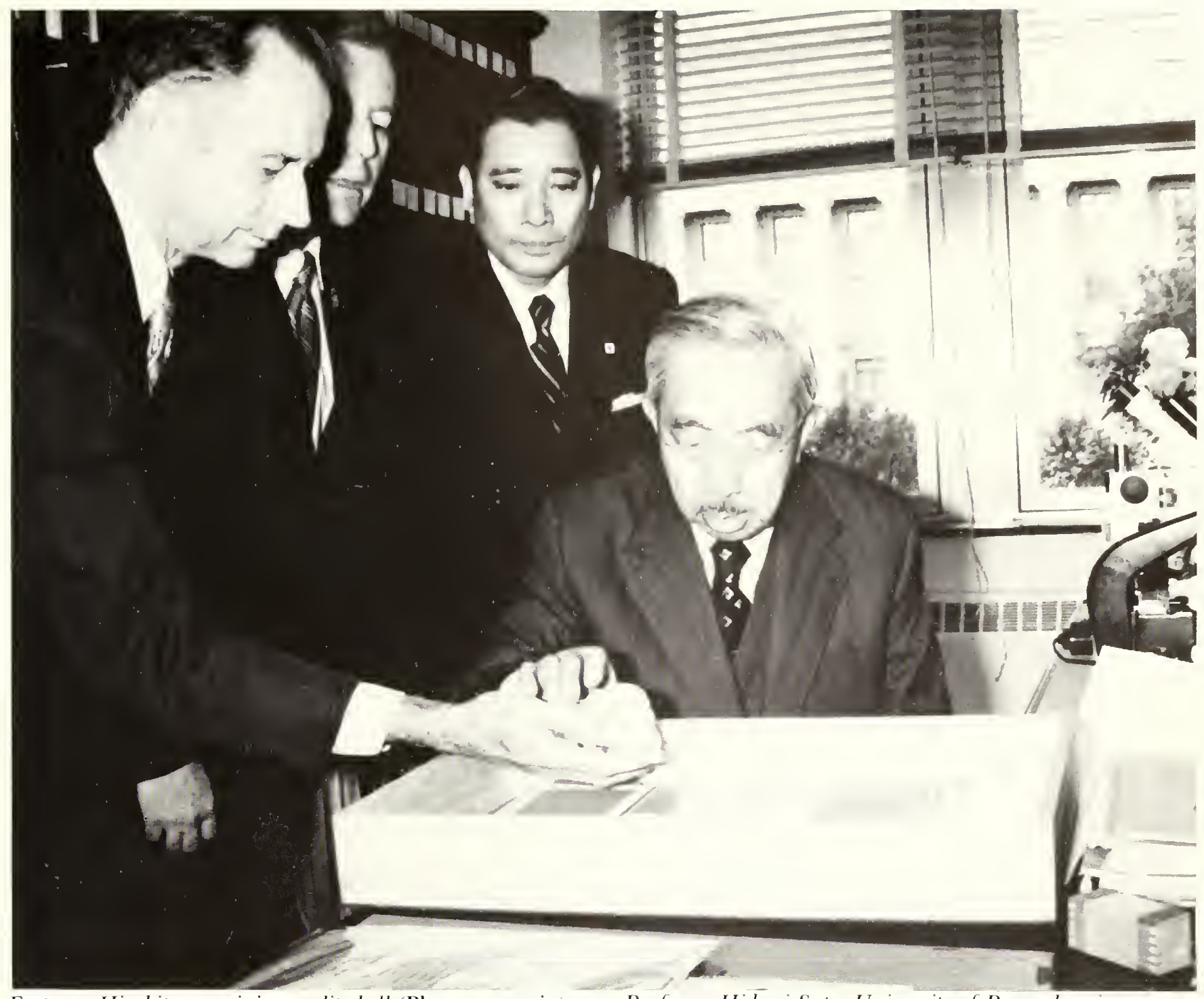

Emperor Hirohito examining a slit shell (Pleurotomaria) in the office of F.M. Bayer on the third floor of the west wing. The late Joseph Rosewater, curator of mollusks, and
Professor Hidemi Sato, University of Pennsyluania, are between them. This photograph appeared in Smithsonian Year 1976. the end of fiscal year 1924 being $5,157,694$; fiscal year 1984 alone drew almost a million more than that. In the early days of the Smithsonian there was a surge of visitors every four years as crowds came to Washington for the presidential inaugurals, but by 1910 this phenomenon was no longer evident in the annual attendance figures. Clearly transportation was improving so that people could vacation any year. By the late $1920 \mathrm{~s}$ the miracle of radio permitted people to hear the political speeches without making a trip.

By the end of fiscal year 1933, 10,504,483 visitors had been counted since the building opened. The public hours continued to be 9 A.M. to 4:30 P.M. Since most of the staff arrived by 8:45 A.M., a few guards accidentally counted staff members who came in after 9 , but by then the number of visitors annually was so large that the minuscule staff would not have adked significantly to the total, even if every one had been counted every day. By the close of fiscal year 1935, as the twentyfifth anniversary year began, a total of $11,618,576$ people had come through the doors. The small annual attendance figures for 1934 and 1935 reflect the Great Depression.

At the close of fiscal year $1955,25,620,085$ tourists in all had entered the building since it opened. In the annual figures one sees the dramatic impact of World War $1 \mathrm{I}$ in rechcing attendance, and the gradual postwar rise to prewar levels. Fiscal year 1956 marked the first time the buikling had received a million visitors in a year. After fifty years, at the close of fiscal year 1960 , a total of $33,365,970$ visitors had been logged, a threefold increase over the first quarter-century. 


\section{A Major Milestone}

By 1968 a major milestone had been passed: a grand total of $51,966,091$ by the end of that fiscal year. It had taken forty-five years for the first 25 million visitors to have come into the building, but only thirteen years for the second 25 million. America had become a nation in motion.

In only twelve more years the total doubled again. By the close of fiscal year 1980, the grand total of visitors to have entered the Natural History Building was $104,207,166$. In the midst of the general increase in numbers each year, one can see in the sharp decline of fiscal year 1974 the effect of the oil embargo. Attendance could reach 200 million by the end of the century, if present rates persist.

The figures alone do not tell the whole story, for they have to be taken in the context of visits to the entire Smithsonian complex. One might assume that from 1920 through 1960 the Natural History Building was the place to visit, but this was not so. The Arts and Industries Building consistently outdrew Natural History, with three visitors on the south side of the Mall for every two that came across to see the animals and the minerals. Three reasons are generally given for this. First, the instatlation of the Lindbergh airplane in 1928 had an enomous impact; everyone wanted to see it. Second, as interest in this phase of aviation waned, the interest in World War $\mathbf{I}$ aviation grew. Third, the First Ladies' gowns in Arts and Industries were the largest single draw in the Smithsonian.

During the 1950 s, visits to Natural History did pull ahead, but with the opening of the Museum of History and Technology early in 1964, attendance in the Museum of Natural History stagnated. Although visitors continued to pour in, there was a feeling that Natural History was no longer the drawing card of the Smithsonian. When the National Air and Space Museum opened in 1976, the pattern changed again. The number of visitors to the Smithsonian increased dramatically, for people flocked to Air and Space, and continue to fill that building to overflowing most of the time. The National Museum of Natural History is still number two in attendance, having edged ahead of the National Museum of American History (History and Technology). There has been no serious attempt to tabulate numbers of foreign visitors, but they are slowly increasing every year. Of the cassette tours recorded in Spanish, German, French, and Japanese, Spanish is requested more often than all the others combined.

\section{Mall Door Is Busiest}

The guards report that the Mall door is about twice as busy as the Constitution Avenue door. This is a pattern of long standing; most tourists visit more than one museum, and the easiest way to do it is by moving along the Mall. In the early days many visitors probably went to the Castle, Arts and Industries, and the National

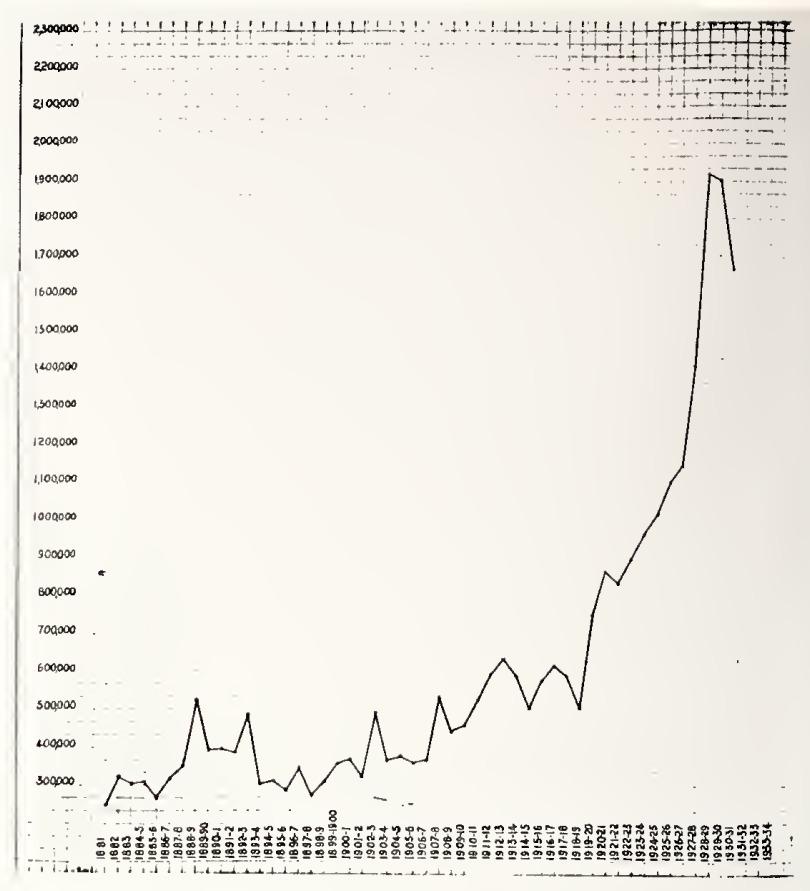

Graph of attendance from the opening of the United States National Musemm in 1881. The effect of the Great Depression is evident at the end of the line. Smithsonian Archizes RM 157, box 16.

Museum within a few hours and were counted in each building. Todlay there are more museums than can be covered in so short a time; the museums compete for the visitor's time, and the visitor must choose. Thus the great increases of the last decade may reflect some increase in interest in natural history, rather than just a general increase in tourism.

In the 1920s August was the busiest month, as a popular time for a family's major vacation of the year. August continues to be busy, but in the last two decades it has been beaten out by April. "T. S. Eliot notwithstanding, April this year was anything but cruel to SI museums, shops, and theaters," read an article in The Torch. "Always the first quarter's busiest month, April 1984 has outdone itself . . . [with] a 15 percent increase over April 1983. ... As usual, the crowds were largest during the week preceding Easter."2 The writer of this prose must never have spent time at one of the doors. While it is marvelous to see people coming in droves to explore the Museum, the noise level, after a few days' close contact, suggests a thundering herd of buffalo.

The abundance of tourists in April may be attributable in part to the growing custom of a senior trip for high school students across the country, as well as to the Cherry Blossom Festival. April is the most popular month, but all of the summer is busy, as is a good part of the fall. For some unknown reason, the busiest day of the year since 1978 has been the day after 


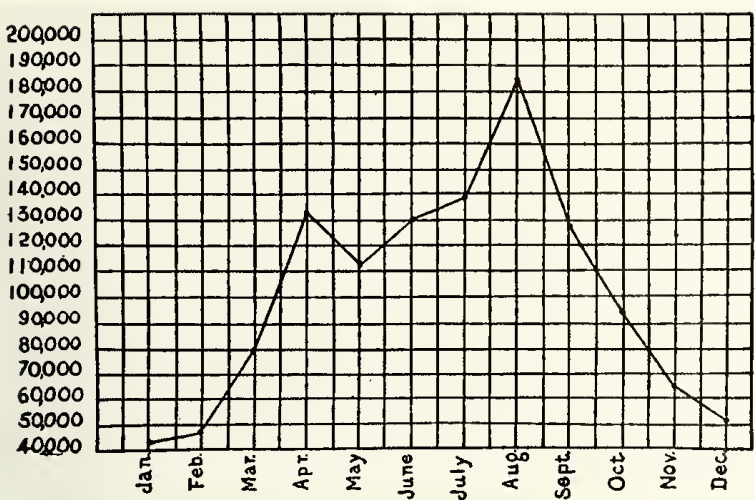

Average monthly attendance of visitors in United States National Museum (compiled from the period 1920 to 1931 inclusive). This graph, from the Annual Report for 1931, includes visits to the Arts and Industries Building and the Aircraft Building as well as the Natural History Building.

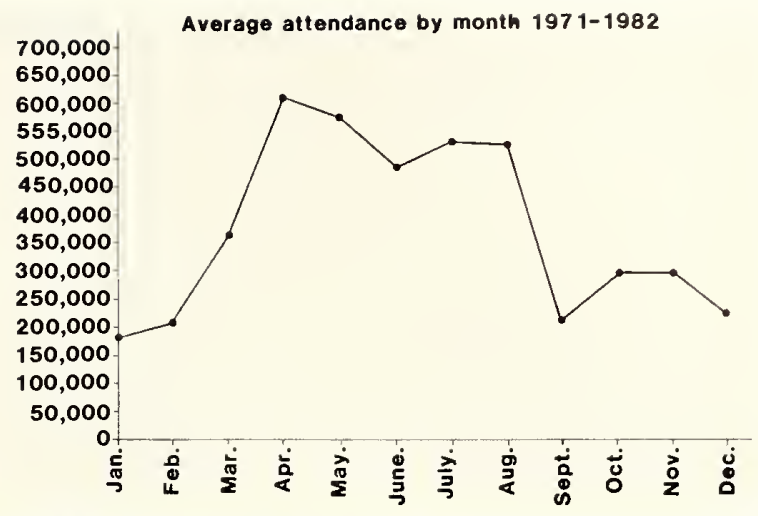

Average monthly attendance in the National Museum of Natural History (compiled from the period 1971 to 1982 inclusive). Not only has the attendance increased dramatically and the peak month shifted, but the difference between hand-lettering and more modern drafting methods is obrious.

During the Johnson administration, one Alfred C. Glassell, Jr., donated a record black marlin (Makaira indica) and provided funds for a reception at its unveiling. When he insisted that President Johnson be invited, there were gales of laughter from the staff at the notion that the President would come to see a dead fish, no matter how large. No one knew that Glassell was a Texas oilman and a friend of LBJ. When the President showed up for the unveiling, the Museum security people were in a panic.

One Sunday during the mid-1950s Senator Theodore Green of Rhode Island, who was then in his nineties, showed up in the north lobby. Only one elevator operator worked on Sunday, and she was on a break. Senator Green complained to a guard because he wanted to get to the exhibits. There are two versions of what happened next. In one the senator explained who he was and indicated that he was on the appropriations committee, and an elevator operator appeared in five minutes. In the other, more likely version, the guard listened to this disgruntled elderly tourist and then told him to write his congressman.

Perhaps the most famous visitor ever was Emperor Hirohito of Japan, who came to the building in 1975 on his visit to America. ${ }^{3}$ He was escorted to the office of F. M. Bayer. The Emperor happens to be a marine biologist, and when he is not on duty he studies coelenterates, which are also Bayer's specialty. After a half hour, the State Department officials indicated that it was time for the party to leave. The Emperor replied that he had not finished examining specimens to clarify some species in his own collection, and that he was not about to leave until that was completed. An hour later he finally left Bayer's office. This may be one of the few times that protocol has given way to natural history. 


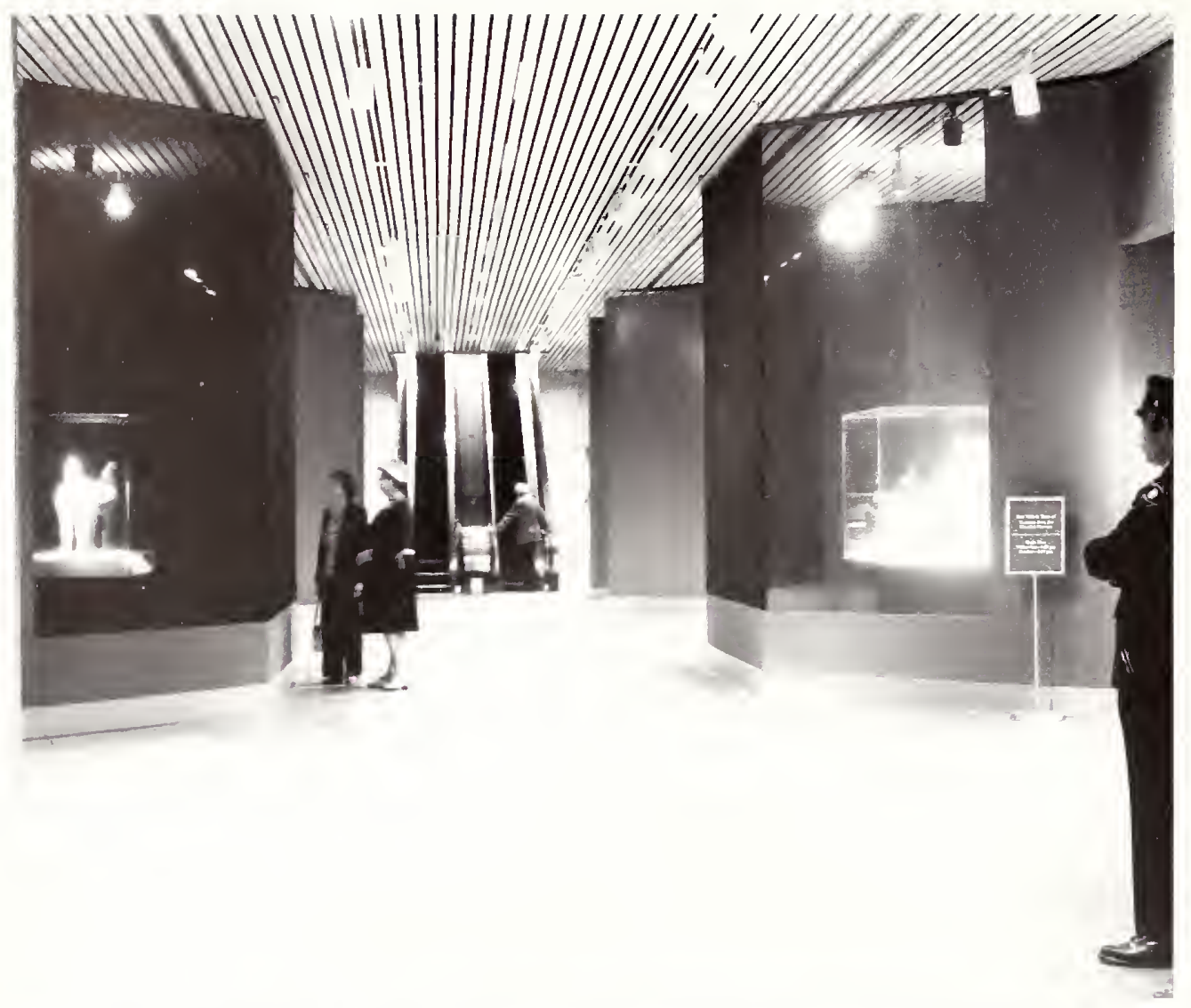

Officer Kenneth Wise observes early-morning tourists examining a porcelain horse in the Evans Gallery exhibit Treasures of the Shanghai Museum, November 1984. The escalator to the rotunda is in the background.

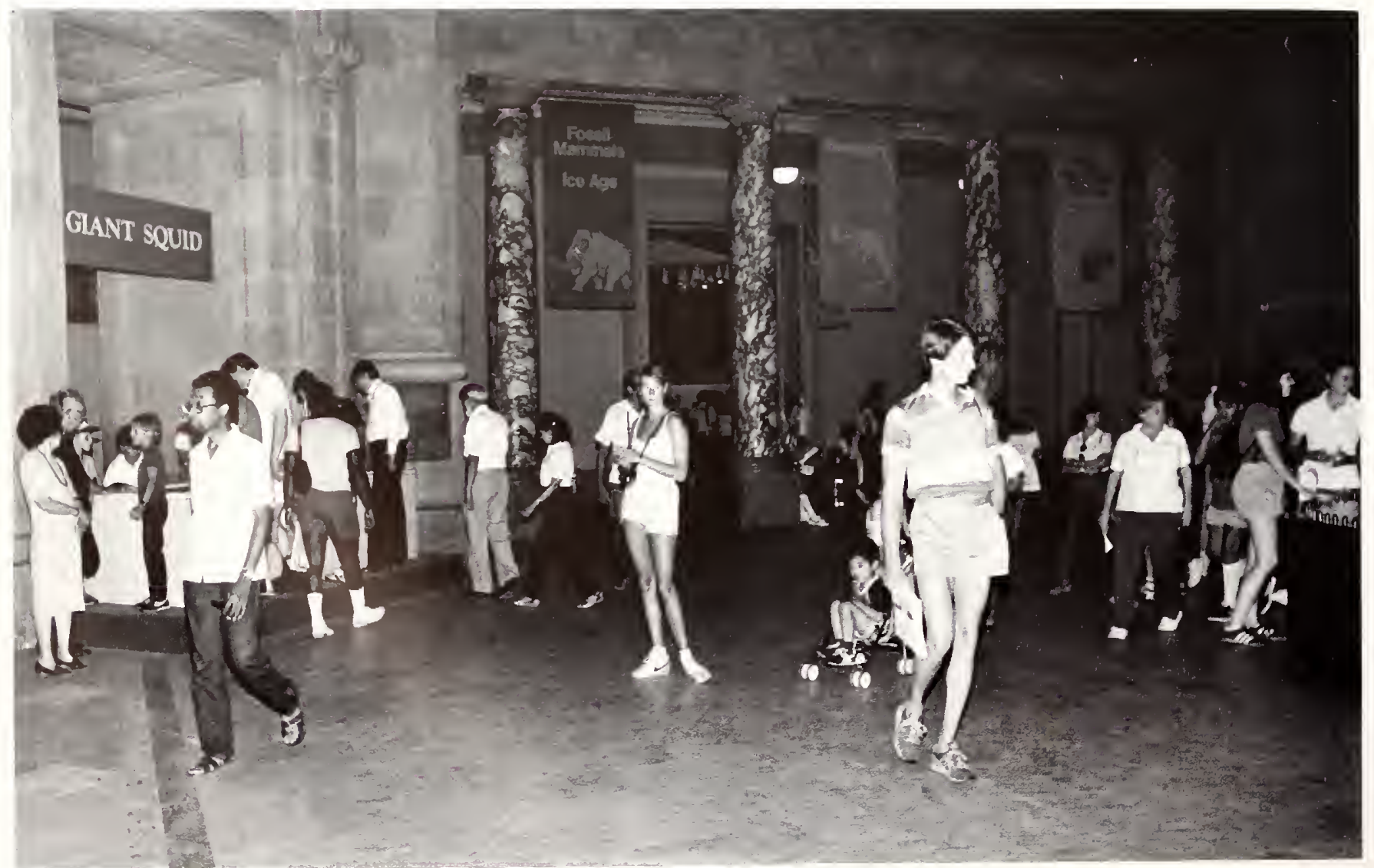

Tourists in the rotunda heading toward the giant squid, July 1984. 


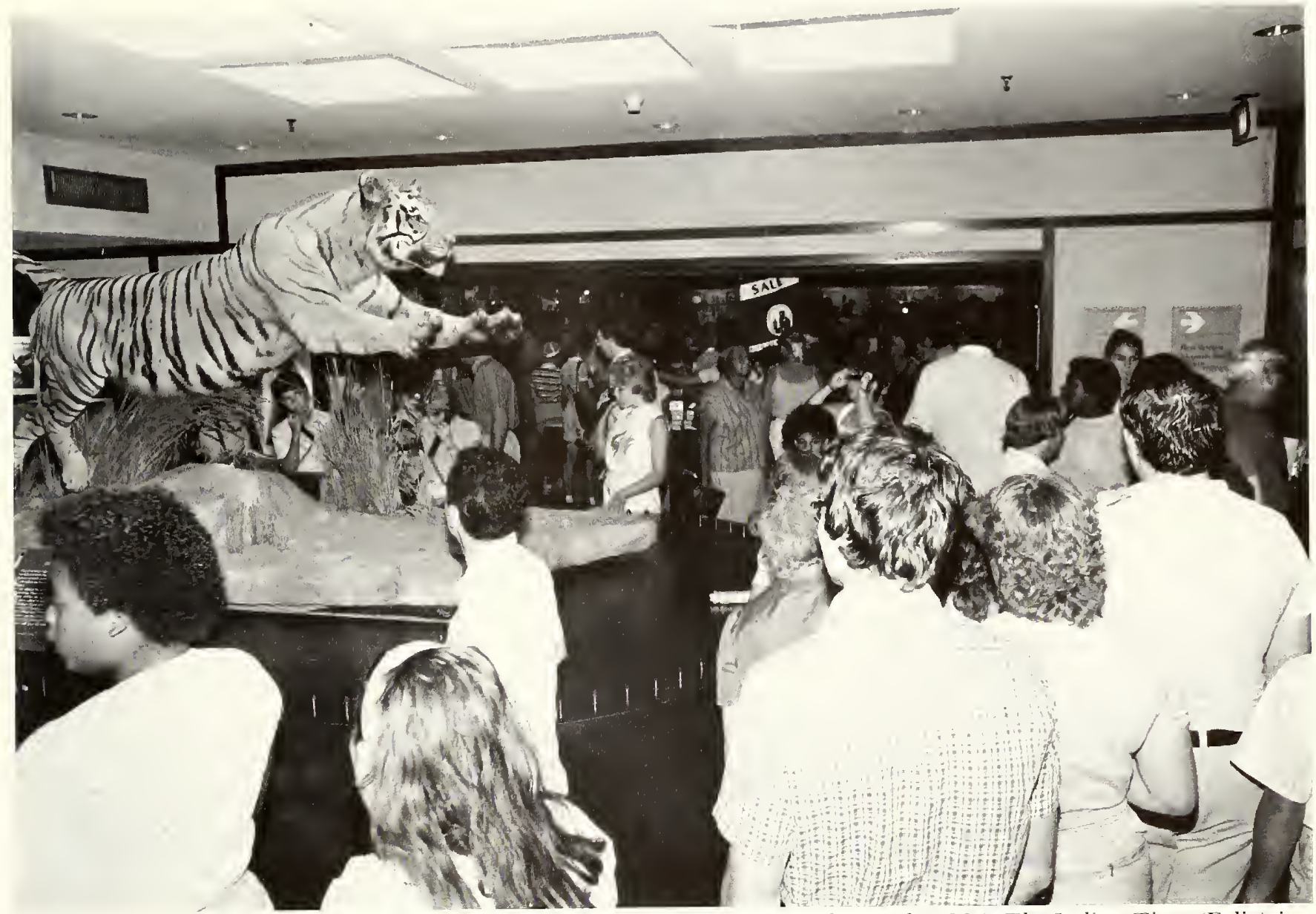

Tourists in the West Court building heading toward the sale in the Museum Shop, July 1984. The Indian Tiger (Felis) is to the left.

who comes into the building and why, but they have not revealed any surprises. Most persons visit either because they have an interest in natural history or because they want to see all the tourist attractions in Washington. Annual reports repeat the obvious: "Most of these visitors come to the Museum to be entertained, or to learn. All expect to see on display objects they have encountered at home or abroad, or heard about, or seen in the movies or on television, or read about in a book. Among the objects they come to see are many unique national treasures."

In 1969 one person came deliberately to do harm and decapitated the snakes in two exhibits, using a hatchet to break the cases and a butcher knife on the specimens. ${ }^{5}$ Afterward he told the guards that one of the snakes had borrowed $\$ 20,000$ from him the year before. In May 1984, some vandal decided that he needed to have the head of a tree sloth, and so destroyed a specimen in Hall 6, robbing all future visitors of the opportunity to see it. Still, the number of tourists each year is so large and the amount of damage done to specimens on exhibit is so small, that one must be impressed with the good sense and good manners of the visitors. 


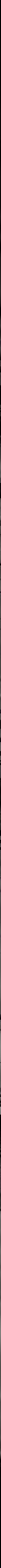




\section{Public Places}

N ADDITION TO THE SCIENTIFIC FACILITIES shared

by the staff, the Museum offers several special spaces for public use, apart from the exhibit halls themselves. The auditorium and, until fairly recently, the foyer on the ground floor of the north wing, have been available at the request of individual groups. The north lobby, the new West Court building, and of course the rotunda are invaluable starting, meeting, and resting places for one and all.

The International Congress on Tuberculosis that "christened" the Natural History Building well before its opening was in every way a success and an excellent start. One of those present at this most important meeting was Robert Koch, discoverer of the tuberculosis bacillus.

"[Tomorrow's] proceedings will begin with an assembly of delegates in the auditorium of the Museum building at 11:00 o'clock," the Washington Post reported on September 27, 1908. "The hall has been decorated with the flags of the countries represented. Music will be furnished by the Marine Band. . . . The diplomatic corps, the spokesmen of the various nations, officers of the Congress, honorary presidents, and section Presidents will meet in the office of Dr. Henry C. Beyer on the second floor of the building at 10:40 o'clock."1 There were numerous exhibits on hygienic products, such as pasteurized milk; five technical sections met in the various halls. For the finale on October 9, Bishop O'Connell of The Catholic University of America stated that "scientific men must walk hand in hand with the religious bodies of the world if the crusade against tuberculosis is to come to a successful termination." 2

The Anmul Report for 1909 noted that "about 100,000 square feet of the building on the first and second floors, exclusive of the south wings, were used for the

The rotunda (Hall 1), looking east into Hall 2 at the Zeuglodon, from United States National Museum Bulletin 80 (1913). The specimen was mounted for installation in the new building. Other views taken at the same time show that a giraffe was in the center of the rotunda. purposes of the congress. . . By November 3 all traces of the convention had been removed and the building was again ready for the resumption of construction operations. About $\$ 25,000$ was expended in fitting up the building for the congress"-\$15,000 less than had been appropriated. ${ }^{3}$

The next major event in the auditorium occurred two years later: "For the public sessions of the National Academy [of Sciences] at its annual meeting in Washington from April 19 to 21, 1910, temporary arrangements were made in one of the exhibition halls in the Museum building, accommodations for the business meeting being furnished in the Smithsonian building."4

There is a story behind these few words, for the National Academy of Sciences had had no home ever since it was founded during the Civil War. Joseph Henry was the first president of the Academy, and, like so many organizations, it just somehow got under the wing of the Sinithsonian. For practical purposes the Academy was a couple of file drawers and an annual meeting that wandered from hall to hall. In 1916, during their sessions at the Museum, the academicians elected Secretary Walcott as their president. After World War I, Walcott was among those who helped raise funds for the Academy building at Twenty-first Street and Constitution Avenue, NW. It is from this headquarters that the National Academy of Sciences has grown to be such an august body.

According to the Annual Report for 1911 , the Museum's auditorium was used that year for three meetings and two lectures. Thereafter it was a very busy place. In 1912 "the new building was used ... for a number of meetings and other functions held under the auspices of the Smithsonian Institution or of organizations having kindred objects. Besides the auditorium in this building, which has a seating capacity for 565 persons, two adjacent rooms have been fitted up for small gatherings." ${ }^{5}$ Despite its stuffiness and naked ductwork, one of these, Room 43, was heavily used for many years by local scientific societies.

It soon became evident that the foyer or the rotunda was the place in Washington to hold a reception for 


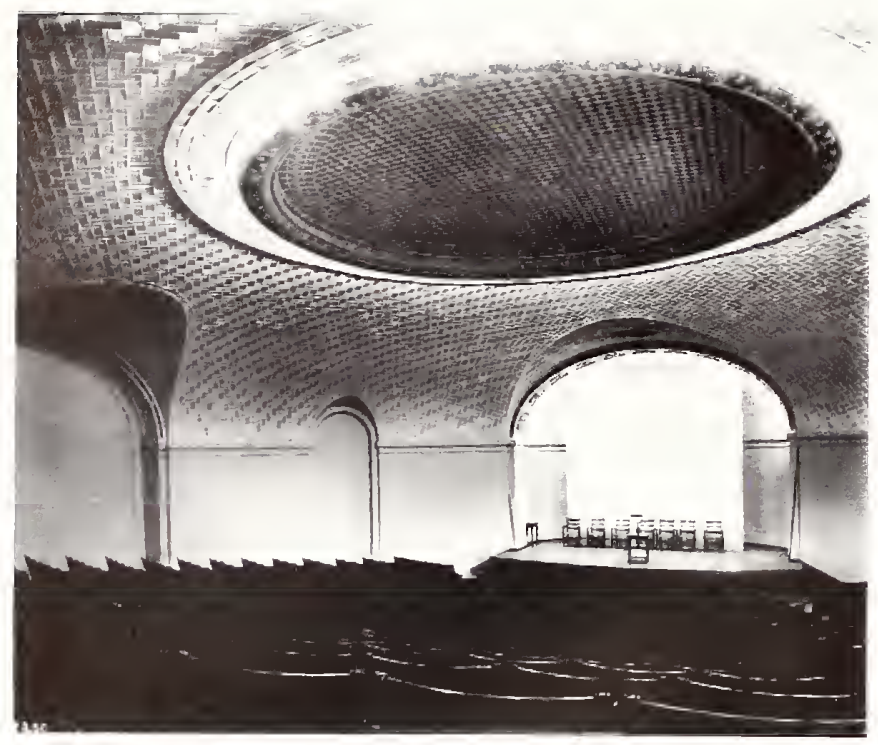

"Auditorium in ground story of the south parilion, looking toward the platform," from United States National Museum Bulletin 80 (1913). The seats are now somezhat more comfortable.

scientific or cultural events, particularly if a lecture was to be presented. The auditorinn, one of the few in Washington, was in such demand that by 1917 a special fireproof booth had been built for the motion-picture and stereopticon machines.

The auditorium was used not only by the scientific public; valous government deparments used it for neetings. As the First World War approached, the subject matter of governmental meetings gravitated toward food production and economics, and during the war the auditorium, like the rest of the buitding, was given over to ouher purposes.

After World War I the auditorium was back in full swing. During the 1990-2 I season, for example, there were meetings of groups from the Northem Nut Growers Association to the National Academy of Sciences to the Anerican Federation of Art. The Bureau of Public Health Service conducted an Institute on Venereal Disease Control, and the Bureau of Plant lndustry showed movies to its staff. The big event of 1922 was President Harding's appearance at the second annual meeting of the Business Organization of the Government. The meeting facilities were used on 110 occasions in fiscal year 1926, and on 131 in fiscal year 1930. Fifteen years later, the figure had doubled.

One of the developments after World War 1 was the use of the auditorium for memorial meetings. A tribute to Charles Doolittle Walcott on January 24, 1928, was one of the first. There were two in 1933, when Holmes and Ravenel died. The custom lapsed from the $1940 \mathrm{~s}$ to the 1970 s, but was reinstituted. Alexander Wetmore, Waldo Schmitt, and Clifford Evans were all accorded this mark of respect by the Museum, though Wetmore's memorial was held in the Castle.

\section{Auditorium Named for Baird}

The auditorium has been modified slightly on several occasions by the installation of better seats, improved lighting, and proper projection equipment. The room had its moment of glory in 1971, a year that marked the 100 th anniversary of the founding of the Fish Commission by Spencer F. Baird, ${ }^{6}$ as well as the 125 th anniversary of the Smithsonian Institution. In connection with the celebration of the role of fisheries, a bust of Baird and a brief account of his work were installed directly in front of the auditorium. On November 16, 1971, in a ceremony honoring Baird, the auditorium was named for him. When the installation of the escalator obscured the bust, it was moved inside and to the rear of the auditorium, where, unfortunately, not many people saw it. Subsequently the bust was put in storage, but it has been returned. Visitors seldom see the plaque on the low pedestal of the bust.

The Institution began a lecture series even before the Castle was built, and lectures in one form or another have been given ever since. The current weekly series of lectures and films, organized by the Office of Education, has been running in the Baird Auditorium for eleven years. Audiences vary with the subject and the time of year, but it is not unusual to find 250 people in the room during a weekend noon hour.

In the hallway outsicle the auditorium are several cases of Birds of the District of Columbia, a nice exhibit of some historical interest as the most-moved public display in the Museum. Originally Secretary Langley had a children's room in the Castle where local specimens were on view, including the largest and smallest local birds. Later the collection was installed on the second floor of the new Natural History Building. During World War 1 it was moved in with the whales, and then to at least one other location. After World War 1 three rooms not far from the auditorium were devoted to local fauna, including the birds-a sort of proto-Naturalist Center. The collection had to be moved again when the foyer was rebuilt in the 1970 s, and there may have been another move before the D.C. birds finally found their present roost.

The north wing that extends from the auditorium to the Constitution Avenue entrance has almost always had temporary shows in its central foyer. Most of these were not recorded in detail, so it is difficult to know the nature of the exhibits or how long they stayed. One significant exhibit of 1916 was in honor of the centennial of the Coast and Geodetic Survey. Another was "Safety First," to which many government bureaus contributed, and which one day drew 9,000 people. In 1917 a National Park conference, held under the auspices of the newly formed National Park Service, was accompanied by an exhibition of forty-five paintings. This led to the formation by Secretary Walcott of the $\mathrm{Na}$ tional Parks Association, a citizens' lobby.

Possibly the most important show of this time was 


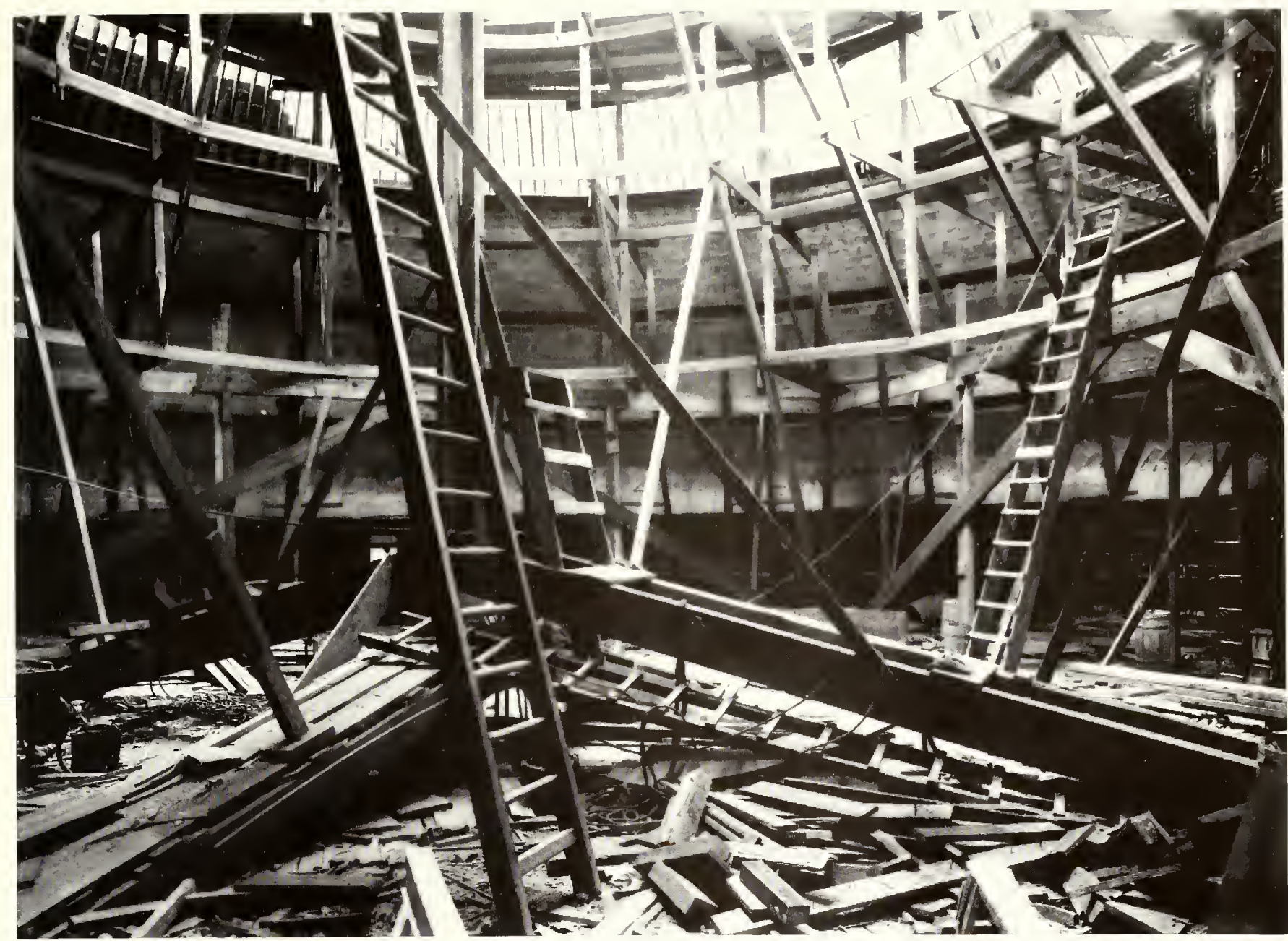

Building the dome, probably 1910. Workmen built this wooden floor and then erected scaffolding to construct the inner dome. The inner and outer domes rest on brick piers with spare hetween them. "Flying buttresses" of tile tie the two structures together. mounted in honor of President Wilson's inauguration: "Much space is devoted to aeronautics and aviation. This is enclosed in a large case, beginning with the early experiments of Langley, and his steam flying machine up to the Wrights, Curtiss, and others. A full-size copy of Langley's experimental steam flying machine is displayed." Although Langley's machine had been on display in the Arts and Industries Building, many more people were made aware of it by this exhibit.

The first phase of foyer exhibits ended with the closing of the building in 1918. After World War I much of the foyer, particularly on the east side, was devoted to the War Collection. As one case of uniforms was being installed, the Marine lieutenant supervising the work for some reason wanted the glass removed after it had been put on the case. The contractor warned that it might break in the process. The lieutenant insisted, and after the glass broke, berated the contractor and ordered him to pay for it. An elderly gentleman stepped up, explained that he had seen and heard the whole thing, introduced himself as Charles D. Walcott, and offered to talk to the Marine Commandant as to who was to pay for the glass. The contractor, who later joined the staff and worked his way up to assistant buildings manager, was forever grateful to Secretary Walcott.

\section{War Portraits Collection}

It is important to mention again the War Portraits Collection, which "comprised 21 canvases by American artists, portraits of distinguished leaders of America and of the Allied Nations during the World War, and is to form the nucleus for a National Portrait Gallery." "They were shown for three weeks in May 1921 in Hall 10 and then were circulated to a few other cities. After their return, some hung for almost a decade in the foyer.

After the War Collection left it in 1930, anywhere from twelve to sixteen shows a year were held in the foyer. Space was allocated by the building superin- 


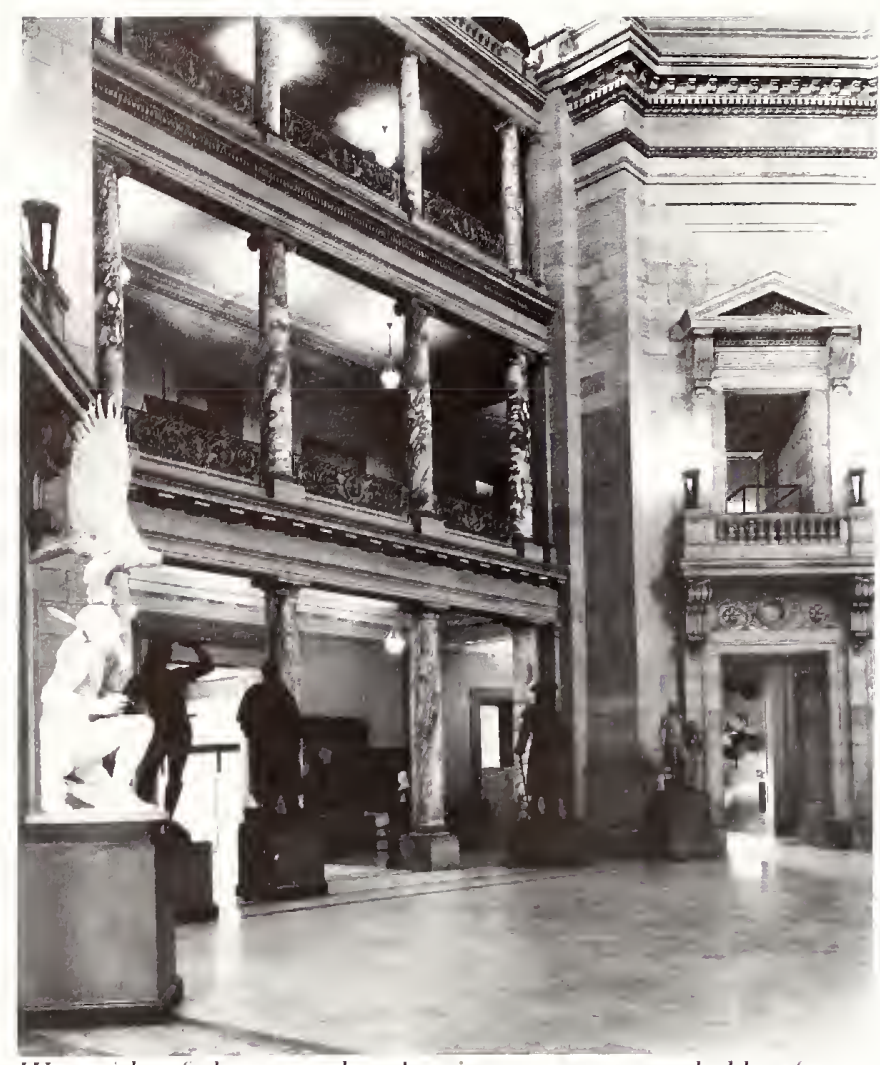

West side of the rotumda, shoaing statuary, probably after 1930. Note the mounted heads in the west stairway. To the left is a statue of an Indian with an eagle, titled Indian with Eagle.

tendent, and the rules were fairly simple. Each show had one month at most, which inchuded time to install and dismantle. Shows that signed up for space for two years ruming tended to become annual events. Thus, shows by local art groups were hung year after year. and often occupied half the available exhibit space.

In the early 1930s a colonial room donated by Mrs. G. D. Webster was installed on the east side of the foyer. Every item in the place had a large number in front of it, so that many of the objects were essentially hidden. When Matcolm Watkins arrived in the late 1940s and wanted to make some changes, he was told that he could not, because the donor came in periodically to examine the display. U pon investigation, Watkins found that for some years the donor's chauffeur had come in to look at it. Still further investigation turned up the fact that Mrs. Webster had died in the early 1940s. Watkins finally was given permission to dust and install smaller numbers. Later the exhibit was dismantled and included in "Everyday Life in Colonial America." The foyer space it once occupied was the area that later housed the health room and a guard's locker room.

Before this health room was put in, minor cuts and scrapes were treated by guards who knew first aid; Dr. Hrdlička or Dr. Stewart was called in the event of a serious problem. Eventually the Smithsonian hired a physician and a nurse. They were moved from the foyer to the second floor near the elevator, and then the doctor went to a proper dispensary in the Museum of History and Technology, while the first-aid room and nurse moved to the lobby. The service is available to anyone, but most of the people who go in are Museum employees, not tourists.

During World War II, the foyer was devoted mainly to shows concerned with the war. These included British war posters, photographs of the U.S. Navy in action, and a host of similar items. Some wartime exhibits were prepared in the Museum, beginning with one on the history of firearms, and soon including displays on exotic parts of the world where fighting was taking place. An exhibit that drew a particularly large crowd was one that showed survival gear.

After World War II the foyer reverted mainly to local art shows. A major exception was the four-day autumn show of the Potomac Rose Society, which was presented each year from 1932 until the late 1950s. Old-timers still remember the scent of roses that hung on for a day or two after the show closed.

\section{Noteworthy Foyer Shows}

During the 1960s the character of the shows in the foyer changed. Instead of local art shows, objects, photographs, and drawings were exhibited. The most noteworthy of these new shows was the Dead Sea Scrolls, a landmark exhibit for the Museum. It had taken almost four years for Gus Van Beek to arrange for the material, and when the display opened there was such incredible public interest that the foyer had to be kept open evenings. During three weeks in the winter of $1964,200,000$ people came to see the scrolls, standing in lines all the way to the corner of Ninth Street and Constitution Avenue. The Museum Shop quickly sold out of the book The Meaning of the Dead Sea Scrolls. There was a mistake in the replacement order, and the shop sold several dozens copies of the Russian novel, Dead Souls before the error was reported.

In 1967 the centennial of the Alaska Purchase was noted by a large display. The Right of Existence, opened in December 1968, focused on extinct and endangered species. The centennial of John Wesley Powell's trip in 1869 down the Colorado River was the subject of another major exhibit. Some of these new shows were from inside the Museum, and some were traveling exhibits from elsewhere. One of the most successful of the latter was Masada, an exploration of the last Jewish stronghold against the Roman army.

Just as the central display space of the foyer changed, the side rooms also changed in the late 1960s. The Travel Service moved into part of the area where the fauna of the District of Columbia had been. Most of the area on the east side was decked over and was used for classrooms. Much of it was taken over by the Smithsonian Office of Education, which remained until the 
Colonial furnishings on the east side of the foyer in 1949

These were moved to Hall 25, and later to the Museum of History and Technology.

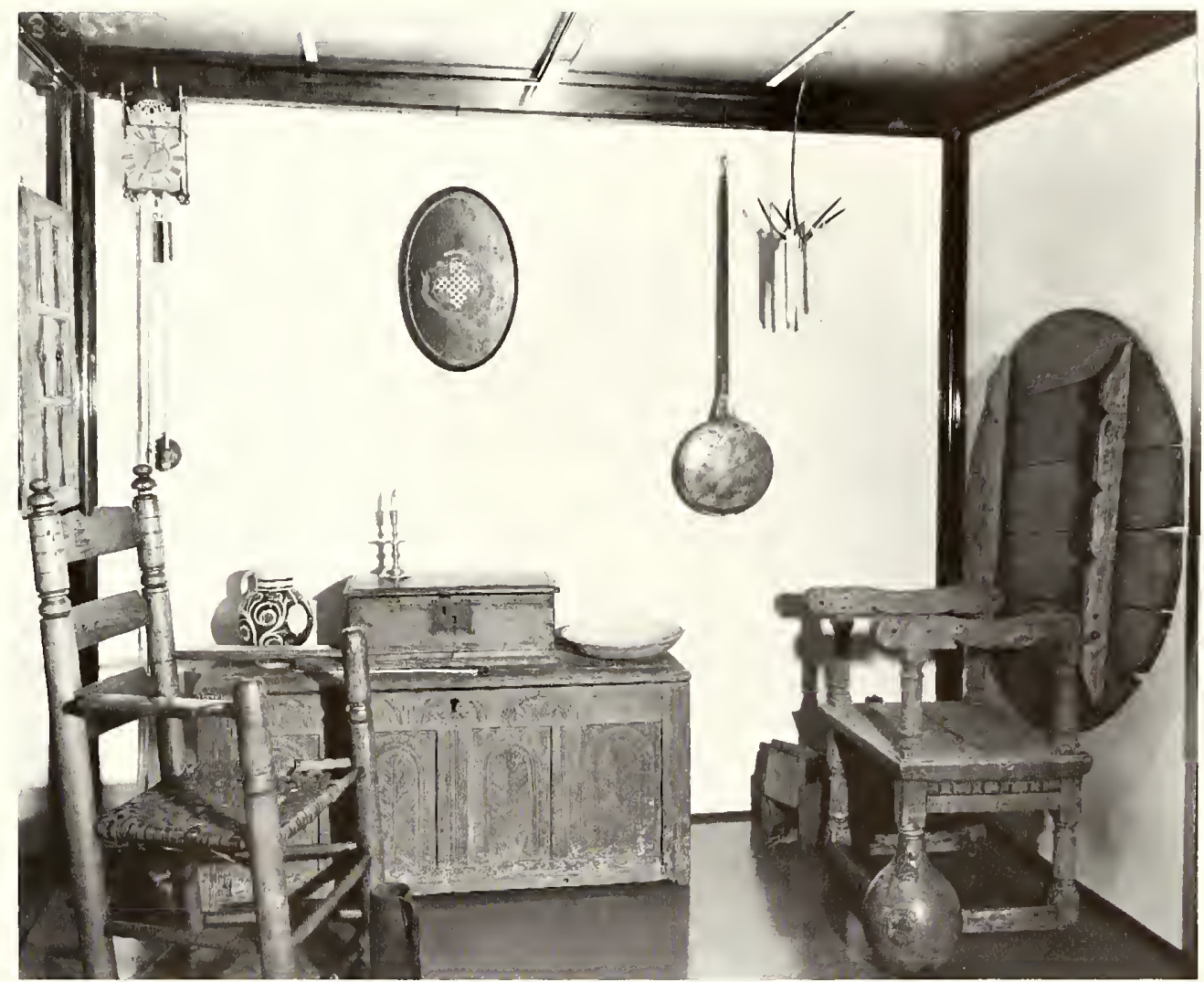

foyer was dismantled in the 1970s. In 1975 the foyer changed again, with the installation of the escalator and the permanent exhibit Our Changing Land. Room 43 and all the others disappeared. A large meeting room, the Ecology Theater, was installed on the east side.

Beginning in the 1980s, the character of the foyer was altered once more with the installation of the Evans Gallery. This is an excellent place for temporary shows, the largest such space within the Smithsonian complex. The Museum was concerned that the gallery might be deluged with shows not germane to natural history, but that has not happened.

Three major "in-house" exhibits have been prepared. First, in 1982, came Inua, a display and study of Eskimo artifacts collected a century ago by E. W. Nelson of the Biological Survey. The scanning electron microscope exhibition of 1984 was next. In 1985, a show celebrating Lieutenant Charles Wilkes's round-the-world expedition marked the seventy-fifth anniversary of the building. The Evans Gallery's handsome wood floor, worn by the feet of millions of visitors, has already been refinished twice, and may have to be replaced within the next few years.

\section{The Lobby}

Little has been recorded about the lobby, or portico, to the north of the foyer. For many years a huge painting by Thomas Moran, Grand Canyon of the Yellowstone, hung on the south wall of the west side, next to the men's restroom-where, incidentally, spittoons were cleaned. The painting of the World War I diplomats on the east sicle was not nearly so large or impressive as Moran's work.

There are occasional references to displays in the lobby. In 1929 "the two Feathered Serpent Column models, the mutilated originals of which are still in place in the portal of the Pyramid Temple known as the 'Castillo' or castle, in Chichen 1tza, Yucatán, were removed from the lobby to the second floor, thus taking their place with the archaeological collections to which they pertain." The columns were replaced by a striking holly-wood mantelpiece and fireplace that remained there until after World War 11. Tecumseh, a statue portraying the death of the Shawnee chief, stood near the stairs on the east side from the 1920s until the National Museum of American Art opened. Near the elevator, a couple of cases that did not fit in well anywhere else were filled with silver, or miniature paintings, or lace fans. During the 1950 s a few temporary cases replaced these relics. There used to be a clock on the west wall. This later was replaced by a grandfather clock, and still later that disappeared. "Can you tell me the time, please?" is another common question asked of the guards.

Today the lobby still contains the guard room and elevators in their original positions in the northwest corner. A tiny room on the northeast side of the lobbyonce a storeroom, then an education office-now functions as a checkroom. The stairway is unchanged, but 


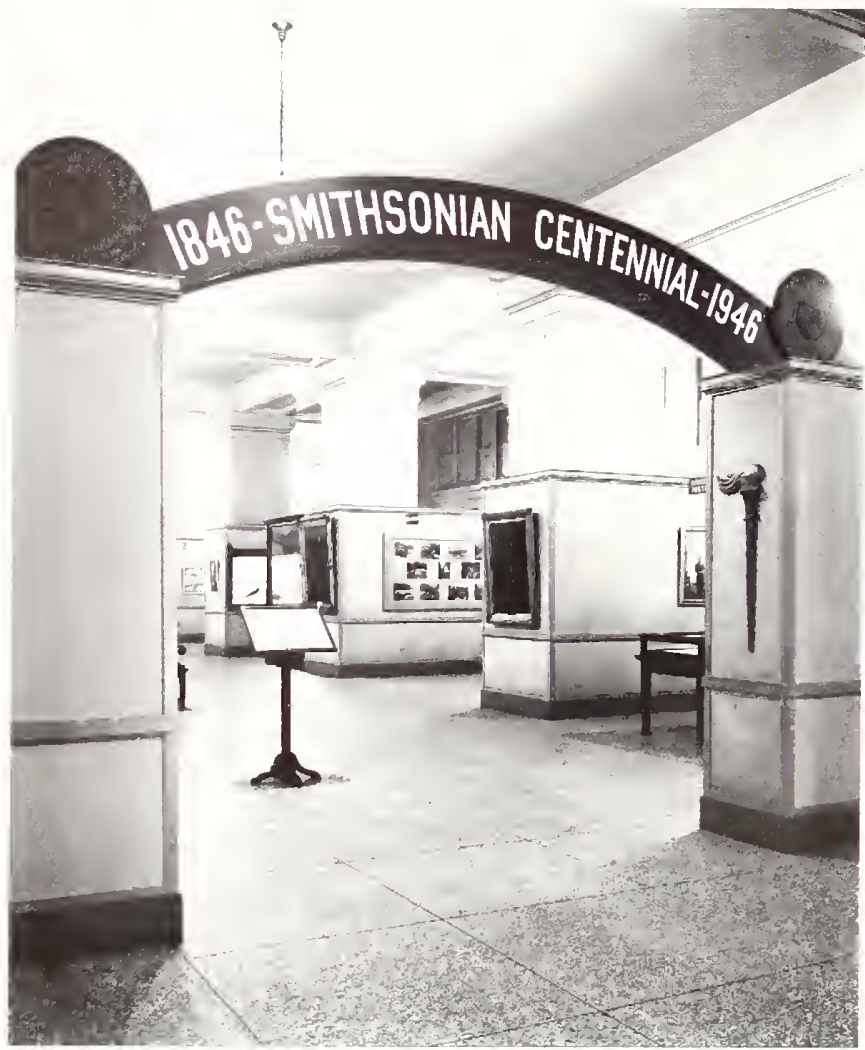

Entrance to the 1946 Smithsomian centemial exhibit in the foyer, looking south. Each alcove was devoted to a general area of activity, such as publications, research, or art.

what was for thirty years the only public telephone in the building has disappeared from under the stairs. Tucked against the wall at the foot of the stairs is a much-photographed floral display, emphasizing orchick from the Museum's living orchid collection. 'This garden, begun in 1980, has brightened up the lobby. The flowers are changed once a week.

On the east wall, where the fireplace used to stand, is a large case used to summarize the work of selected staff members. This changing exhibit, a nice touch, was instituted by the Smithsonian Women's Committee. On the east side of the lobby is a women's restroom, and the information desk is on the west, just at the entrance to the Evans Gallery.

\section{Public Amenities}

Public amenities were few when the Museum opened. There were public restrooms in the lobby, each with a large expanse of marbled space. This was good enough planning in 1910, but for the child whose parents had taken him to the second floor to look at a whale skeleton, it was torture to have to walk so far. In 1913 water faucets were replaced with what were called "sanitary bubbling fountains." Iced-water fountains did not come into the building until well after World War II. The
Museum Shop did not open in the foyer until the early 1960s. With the addition of the wings, rest rooms finally became available on the first and second floors at the north juncture with both wings.

In 1976 the Museum made some major Bicentennial gifts to the public. In the north-entrance lobby, which had previously contained a couple of hard wooden benches and an umbrella stand, "a spacious lounge area with comfortable sofas and soft rugs opened for footweary visitors." 10 The sofas and rugs move out from time to time when an Evans Gallery show spills over into the lobby, but when they are there they may be the inost appreciated objects in the building.

The West Court building, completed in 1976, filled up the entire courtyard. It gave some ground-floor offices in the main building a view of solid wall, but its three floors added 48,328 square feet of space and some long-overdue creature comforts. Sixty-six years after the Museum opened, it finally became possible for staff and visitors to sit down to a meal. There are two places to eat on the ground floor, which is entered by steps down from the ground floor of the main building. The employees' cafeteria, entered from the west range, serves about 700 staff members a day. That figure is slowly rising, a good sign for the outside concession that hancles the food service; the kitchen also does the catering for various affairs within the building, including, in 1981, the Inaugural Ball. The Associates Court, whose entrance is near the auditorium, is reserved for members of the Smithsonian Associates, and serves about 350 lunches a day in cool weather. In summer, breakfast too is served and the Museum is open longer, so the figure nearly doubles. Some meeting- and classrooms on the first floor are continually in use both day and evening.

The West Court builching's second floor, which houses the Naturalist Center, lies between the ground and first floors of the main building. The third story opens off the rotunda near the west stairway and is level with the main building's first floor, so that one is not aware of leaving one buikding and entering another. It is a measure of the traffic that the Mexican floor tiles installed in 1976 had worn down to the cement in spots before being replaced in 1984 . The third floor contains several attractions-another set of rest rooms; another lounge area; the Museum Shop, selling books on natural history, jewelry, postcards, toys, mineral specimens, and a whole host of things and a public cafeteria with plastic seats attached to tables in the "fast-food" architectural style of late-twentieth-century America. The food and the setting are not nearly as sumptuous as in the Associates Court below, but after a couple of hours of touring exhibits, this is an oasis.

Between the cafeteria and the Museum Shop is one other attraction that cannot be overlooked: a huge Indian tiger, presented to the Museum in 1969. ${ }^{11}$ The tiger, which formerly had been displayed in the foyer 
The rotunda decorated for the first annual Smithsonian Kite Festival, March 1967.

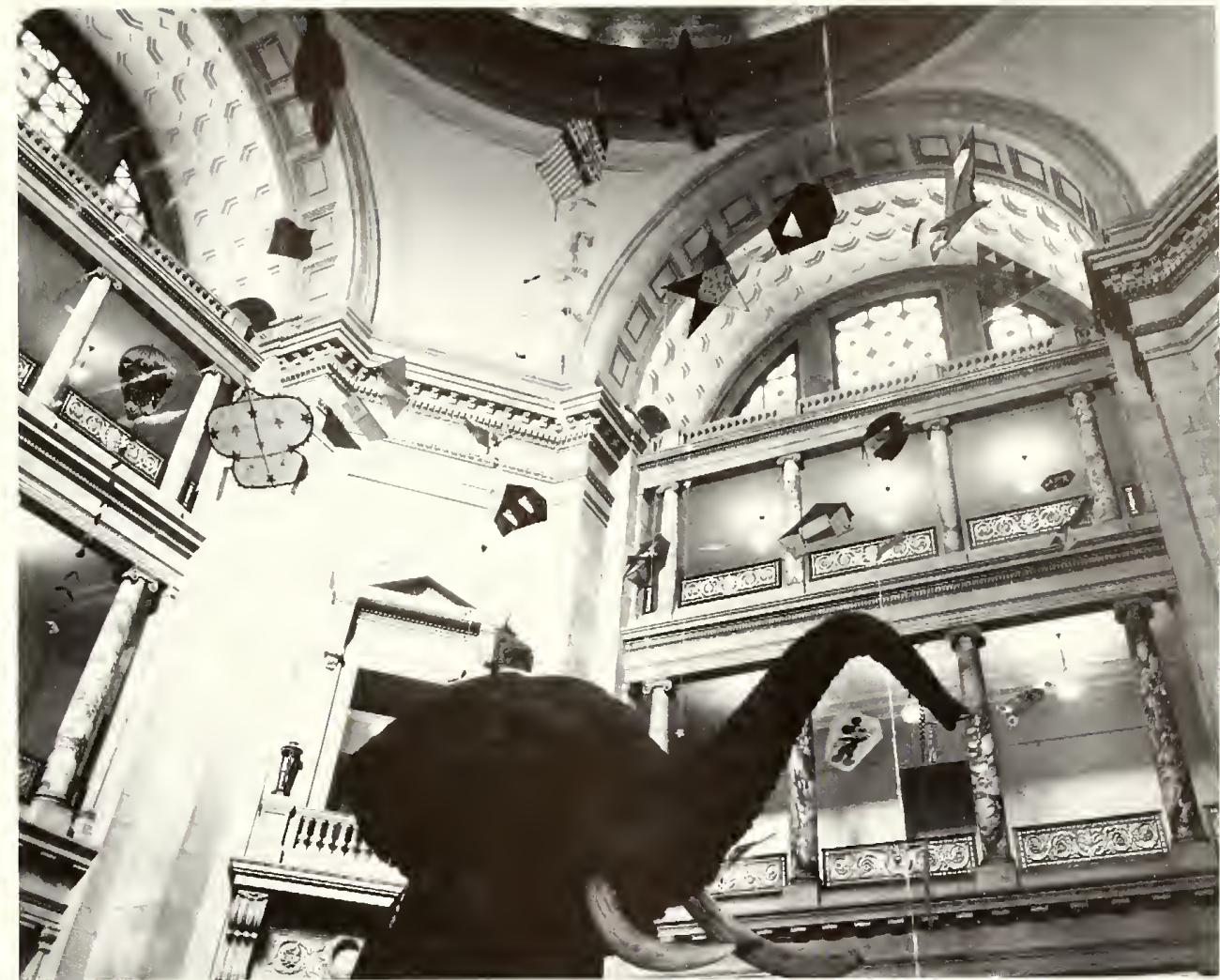

and in the lobby, is magnificently mounted, supported by only one hind leg and a small pipe. The animal had been a man-eater and had to be destroyed; yet, clelighted as the Museum was to receive it, public concern for endangered species made the dedication a slightly strained occasion. The mount originally showed the tiger pouncing on a frightened antelope, but the scene upset so many children that the victim was removed.

\section{The Story of the Rotunda}

What would the Natural History Building be without the dome, its most familiar feature? Hall 1 by Rathbun's number system, the rotunda floor beneath the dome is a favorite meeting place for both visitors and staff; the logical place to begin any tour; literally the heart of the Museum and its exhibits. It is true that this majestic space never "worked" until the installation of the elephant. But aesthetic points fade into quibbles before the real story of the rotunda-the fact that the great dome is still standing.

To catch up with its history, one must go back to the early years of the building. According to Rathbun's architectural description, "the covering of the rotunda consists of an inner and outer dome. ... the former constituting the ceiling, the latter the roof of this part of the building. Both of these domes rest, independently of each other, on the brick masonry of the drum which is concealed from view." 12 But trouble surfaced early, and Ravenel, in 1922, wrote about it in detail:
Shortly after the completion of the Natural History Building, it was noted that the keystone in the east arch of the rotunda was slightly out of place. As years passed the same thing occurred, in a lesser degree, in the west arch, and a slight separation appeared in the joints of the balustrade on the fourth floor, just below the stone arches. These joints were plastered up from time to time, but owing to the inaccessibility of the keystones, no steps were taken either to put them back in place or to fill the exposed openings. The condition of these keystones, although not considered dangerous, distinctly marred the appearance of the rotunda. The location of the east keystone continued to change, however, and it was deemed advisable this year to have a thorough investigation made. As a result of two examinations of the dome and the great piers supporting the dome, it was found that the displacement of the stone arches which span the piers, the opening of the joints on the end of the balustrades under these arches, and in the fourth story floor at the ends of piers have all been brought about by a movenent at the end of the piers in a direction away from the center of the rotunda. As there is no indication of movement of the piers in the lower portion of the building, it appears that they have simply leaned outward at the top, doubtless caused by the eccentric application of the weight of the dome. Since the piers are fully braced by a large number 
of steel beams to the walls of the building and no movement of the outer walls has been observed, it is assumed that the walls are successfully resisting the pressure from the piers and that the movement of the latter will probably not continue much farther, if at all. In the meantime an ingenious method of measuring the exact location of the keystones has been devised, and careful observations will be made at intervals of a few months to determine what, if any, further displacement occurs. ${ }^{13}$

Two years later, the report was that "the keystones in the four arches supporting the walls under the dome of the Natural History Building have been subject to periodical inspection, and recent measurements of the east arch indicate a further lessening of the downward movement." If If there was anything serious going on, no one really wanted to face it. In the east range on the first floor, a crack ran the length of the building, but when Edward Henderson suggested that a gauge be put on it to measure the rate of opening, the building superintendent objected that this would interfere with cleaning the floors.

A tew years after he joined the staff, while working in the west attic, Watson Perrygo saw the gap above one of the keystones and later noticed that the gap was getting larger. He and William $\mathrm{L}$. Brown, his supervisor in Taxiclermy, wrote a memorandum about the problem, and shortly thereafter a more serious investigation took place. Repairs were undertaken, but the work was far more complex than anyone had anticipated; as a further complication, the original contractor went bankrupt. The Anmual Report for 1929 described the process:

Two great bands of steel were placed around the four huge piers that support the dome, one at the level of the floor of the attic, and one near the tops of the piers in the ceiling above. Between them steel beams were installed extending vertically from band to band behind the piers, with a series of screw jacks between the beams and the bocties of the piers proper. Tension was placed on these jacks in such a way as to bring even strain all around, holding the piers from any possibility of spreading at the top. The delicate operation of adjusting the screw jacks required nearly three weeks for completion and was performed with the cooperation of a corps of engineers from the Bureau of Standards. The work was of a highly specialized nature and attracted considerable attention from engineers. ${ }^{15}$

A workman who did not know that the topmost part of the inner dome surrounding the central eye of the dome was only plaster started to cross the ceiling of the inner dome and broke through, but was able to hold on by his outstretched arms till other workmen got a rope around him. The fall to the rotunda floor 125 feet below would have been certain death.

By July 1929 the work was finished. After a thorough cleaning, the rotunda was reopened to the public on October 23, after being closed for nearly two years. The repair operation apparently was a complete success. When a similar dome on the main building of the Army War College at Fort McNair in Washington, D.C., developed comparable problems in the $1970 \mathrm{~s}$, an architect spent a few days peering into the Museum dome to see what had been done. A sheet of plastic has been inside the dome, under the skylight, since 1983 to protect the elephant from water leaking through the dome during heavy rains. There is a great deal more to the rotunda than what is on its floor. Because of the extension of the south portico, there are little offices to the east and the west on the south side of the rotunda. On the third floor, these two spots have been used as temporary offices by zoologists and anthropologists. They take some getting used to, since the greatest dimension in the office is height; the doors are taller than the office is long.

Adjacent to the elevators are two other rooms, used for dead storage. Within them are the data files on seabird distribution, the only sign of the considerable effort undertaken by the Pacific Ocean Biological Survey Project, financed by the Department of Defense. lt ultimately turned out that the department was concerned with distribution of animals as a facet of biological warfare. The issue of classified scientific work in the Natural History Building was fought on this battlefield, and now officially every study engaged in by the staff must be publishable in the open literature.

The rotunda offices on the second floor are as small as those on the thircl floor, but noisier and even more high-ceilinged. At least one of these rooms has been used to store whate bones. Currently they are occupied by some people involved in Information Resources Management, an office formed in 1981.

Following the modification of the will of Henry Ward, which permitted his collection to be rearranged, some of his life-size bronze statues were moved to the secondfloor rotunda balcony, where they are shifted from spot to spot. After the National Collection of Fine Arts removed its paintings from this balcony in the 1960 s, the area became a place for temporary exhibits. These exhibits, changing every few months, always have some sort of natural history theme. Most commonly they are photographs or scientific illustrations by nonSmithsonian artists; and because of the prestige associated with having a show at the Museum of Natural History, there is a considerable competition for the space. One exhibit of 1984 celebrated the fiftieth anniversary of the publication of Roger Tory Peterson's A Field Guide to the Birds; in 1979 the 100th anniversary of the U.S. Geological Survey was celebrated with a display of the scientific illustrations of William Henry 
Temporary exhibition case on east side of lobby. This case, changed from time to time, features the work of staff members. It is sponsored by the Women's Committee of the Smithsonian Associates.
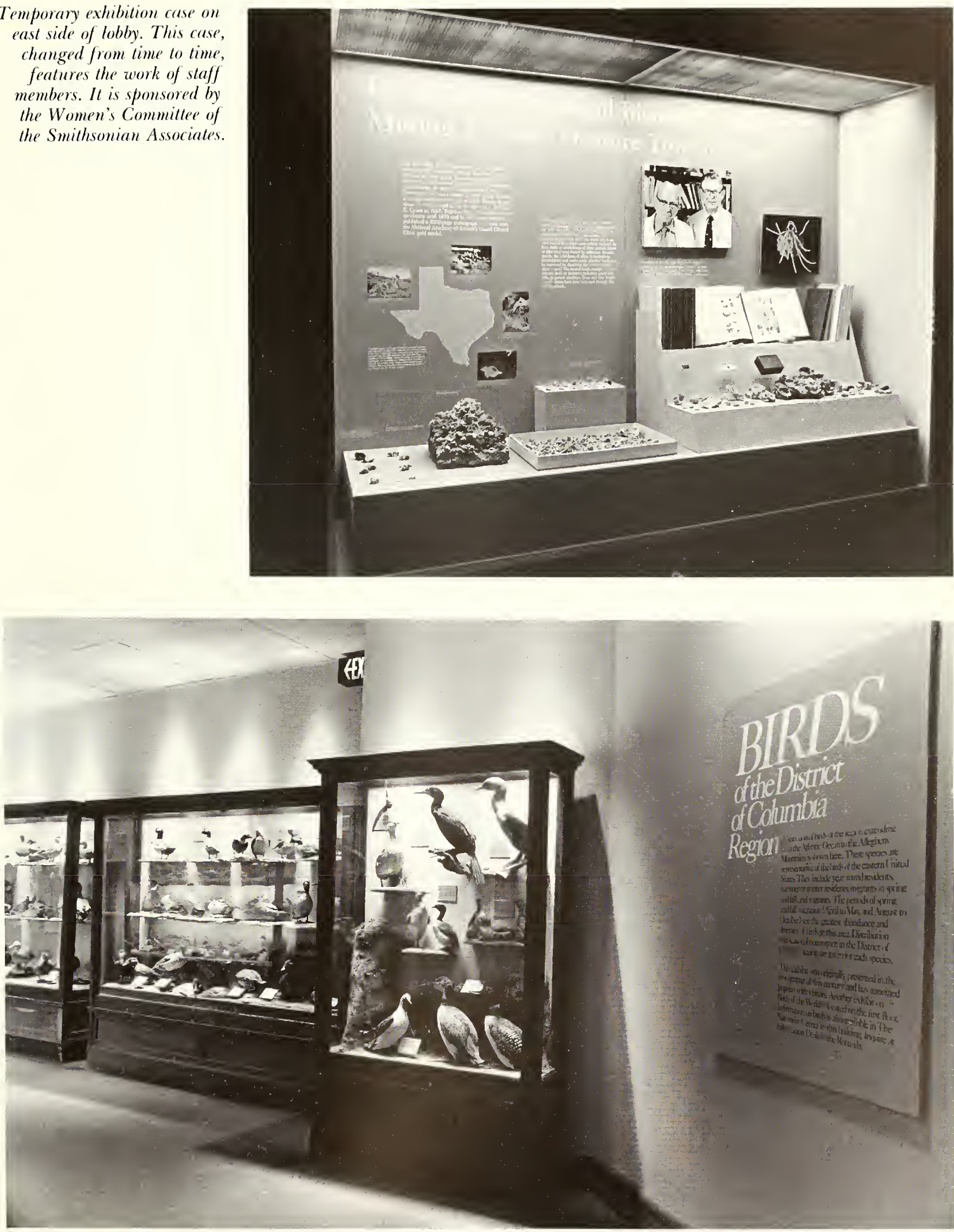

Behind Baird Auditorium on the east side, showing part of the most-moved exhibit within the Musenm. On the west side is the Associates Court, phus a lounge area for tourists. April 1984. 


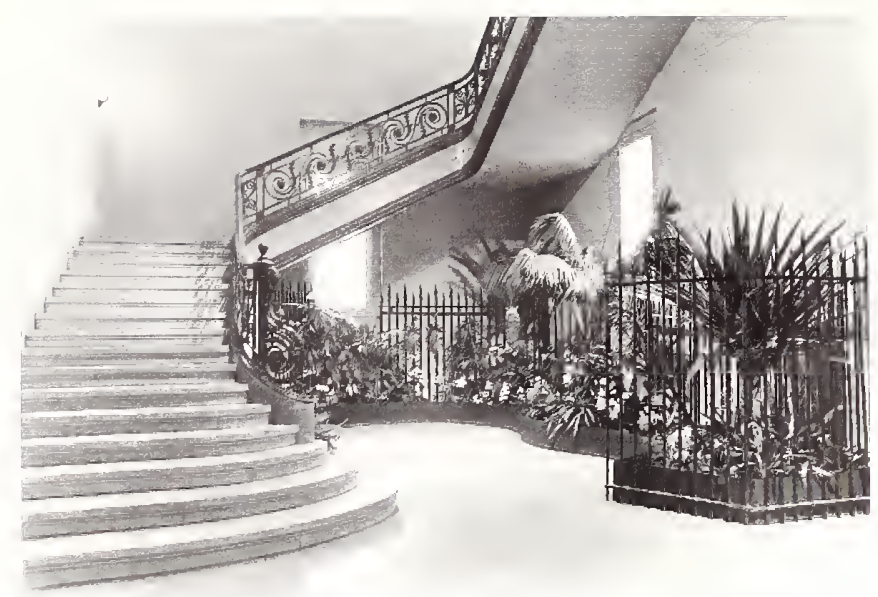

Stairway on the east side of the lobby, April 1984. The orchids and floral display were installed in 1980. Years earlier, the only public telephone booth in the Museum was under these stairs. The statue Tecumseh, now at the National Museum of American Art, stood near the foot of the stairs.

Holmes. Temporary exhibits are no different from permanent ones in that lhere is always a last-minute rush to open the show. While one person guided the directors of the Musem and the Geological Survey around the Holmes exhibit very slowly, the final two cases were installed by the rest of the crew.

The ambulatory on the first floor, under the balcony, also is used for occasional temporary exhibits, particularly when a number of halls are closed. Its moment of glory came in 1958, when for three weeks the Nalional Collection of Fine Arts, in connection with the Smithsonian Institution Traveling Exhibition Service, displayed a portrait of Sir Winston Churchill, together with thirty-five of Churchill's paintings. That year, for the first time, the Institution recorded over five million visitors. April was the busiest month ever, and on April 27, the first Sunday of the Churchill exhibit, 42,524 people visited the Natural History Building. ${ }^{16}$

There are small front offices off the rotunda as on the floors above, but with even higher ceilings. Not much is known of their early use, except that like most other corners of the place, they have been used for storage. During the early 1960s, Paul Gardner of the National Collection of Fine Arts occupied the west office, before leaving for the Division of Ceramics in the Museum of History and Technology. In 1969 the west office was used by "By-Word," a concession that offers self-guided recorded tours. ${ }^{17}$ The first season, the company hired dozens of college students on commission, and no tourist or staff member could enter the building without being approached by at least three of them. After that the operation became more sedate, and the concession is now run from a desk on the southwest side of the rotunda.

During the early 1970 s, the west office was used by

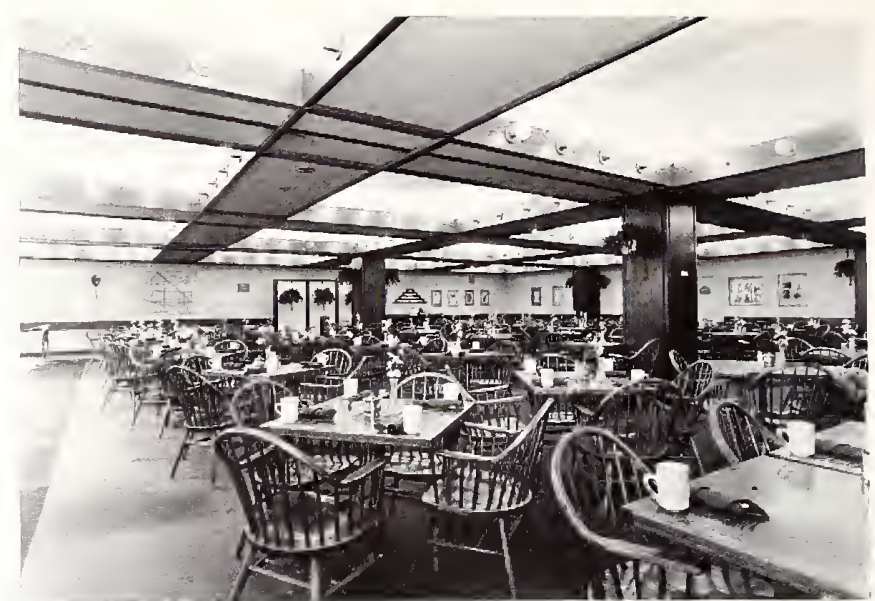

Associates Court on the ground floor of the West Court building, 1984. To the left on the wall are a paddle and a Polynesian navigation map.

the staff of the Discovery Room. It is now a cloakrooma much-needed improvement, since for years the only checking facilities in the building were wooden umbrella stands at the north cloor and in the rotunda. Although checking was at first a duty of the Museum guards, it was contracted out in the 1980s. Probably the single largest problem experienced by the checkroom staff is convincing some tourists that there really is no fee for the service.

In the late 1960 s the east office functioned briefly as a book store. Then it became a space-planning office for the Museum, and was decked over to provide more room. There is usually at least one employee in there poring over blueprints.

Also in the late 1960 s, two additional elevators were put in on the southwest side of the rotunda. This was something of a noisy process, but it was nothing compared to the echoing din of 1982, when two smaller doorways were drilled in the south facade on either side of the main entrance. These new doors are helpful as extra exits, though many tourists persistently gravitate toward the right-hand center door. Some of the granite cut away was saved, and when James Mello stepped down as associate director in 1984, he received "a piece of the rock." It may be appropriate to add the Rathbun-like detail that a metal shade is pulled down on these two new doors when the bronze gates are closed over the center doors.

In the southeast area of the rotunda is a large information desk staffed by volunteers. This installation was another positive step of recent years. Originally the desk was a doughnut-shaped affair in the northeast corner, where those on duty were confronted daily by the rear end of the elephant. In 1983 the former information corner was taken over temporarily by a giant 
A complete view of the rotunda, taken with a "fish eye" lens in the late 1970s. The banners to each of the halls are in place, and an information desk is on the floor. The mounting around the elephant has been changed-he now is walking through grass.

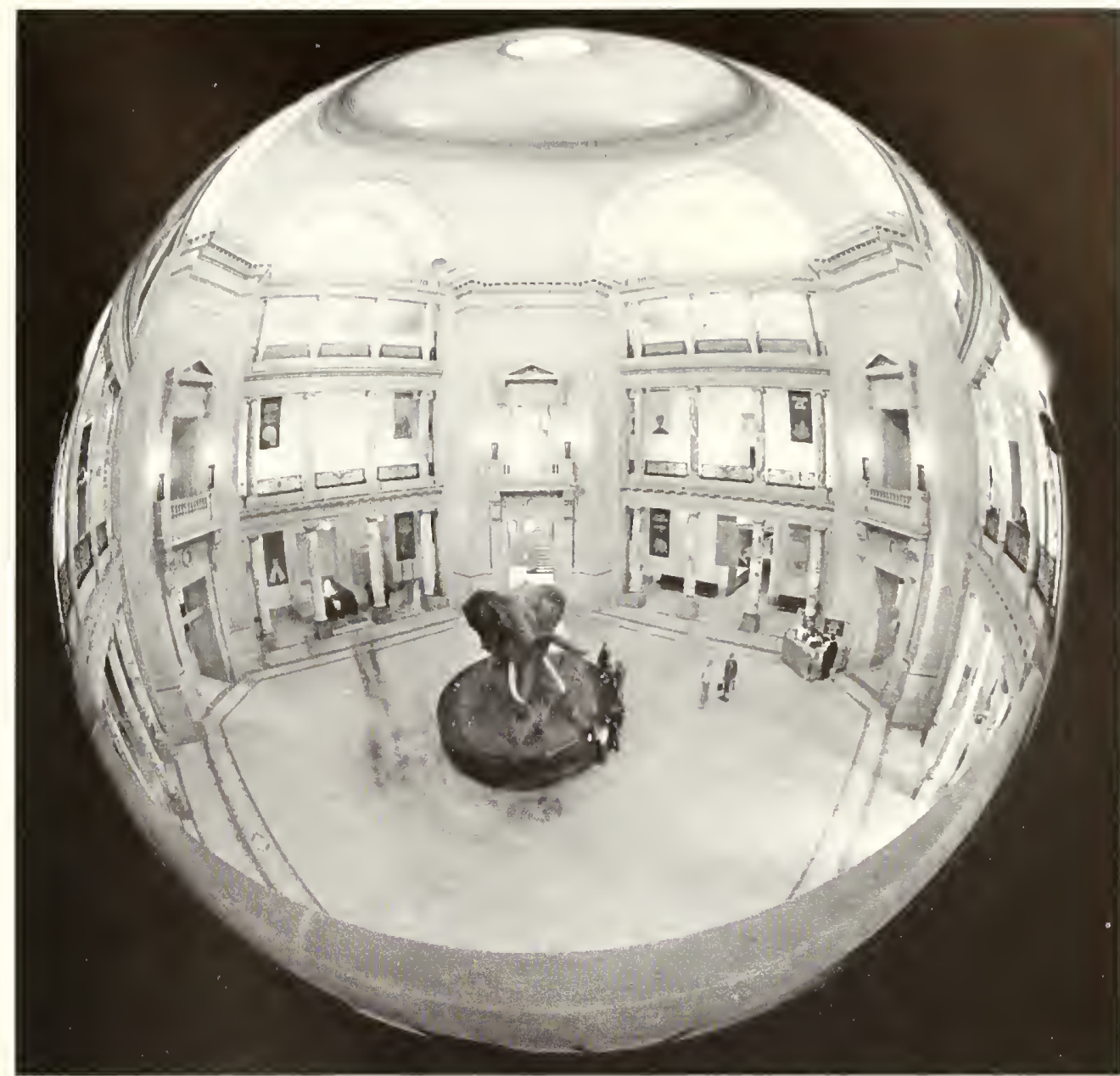

squid in a very large tank of alcohol-the first ever displayed in a museum.

Beginning with the first Smithsonian Christmas party, the rotunda has been the site of a number of memorable festivities held by many groups besides the Institution, especially the GOP. It has been common practice to decorate the elephant, and if it were not dead already, some of the garish displays might have killed it. One year when helium balloons were used, a few came loose and clung to the dome for several days before losing gas and descending. True scientists are tireless seekers after knowledge, and observers at the time noted that after a brief whiff of helium, one person's "Mickey Mouse" voice was much the same as another's.

In 1967 Paut Garber organized the first Smithsonian kite day, and the rotunda was festooned with kites. Ten years later, at the suggestion of Harry Hart, then head of Exhibits, "colorful banners showing the title and stylized symbol of a hall were hung at entrances to exhibit halls. The banners identify each hall, add a note of gaiety and warmth to the rotunda's gray granite facade, and make it easier for the visitor to find his way through the Museum without becoming lost or confused." 18 The rotunda is not granite-trimmed, and some tomists get confused no matter what, but the banners are a fine touch.

This leads to one last rotunda story, dating from the 1930s. At one time there was a revolving door into the rotunda, but during the summer it was removed and the other doors were propped open to let some air into the building. Many pigeons flew in and made themselves at home up in the dome. This nuisance was tolerated until the wife of a congressman got splattered by a pigeon passing overhearl. Something had to be done, and Perrygo was assigned the job of correcting the problem.

A few days later he appeared at the Museum very early, with his shotgun, and got a number of the bircls. One pigeon swooped into the gem and mineral hall with Perrygo in hot pursuit. Although the building superintendent was supposed to have notified everyone, the guard on duty there had not been told. When this man with a shotgun came running in, the guard went rumning out for reinforcements. Moments later, swarms of guards with pistols drawn were on the scene. Fortunately, one of the sergeants from the day shift recognized Perrygo before shots were fired by either side. 


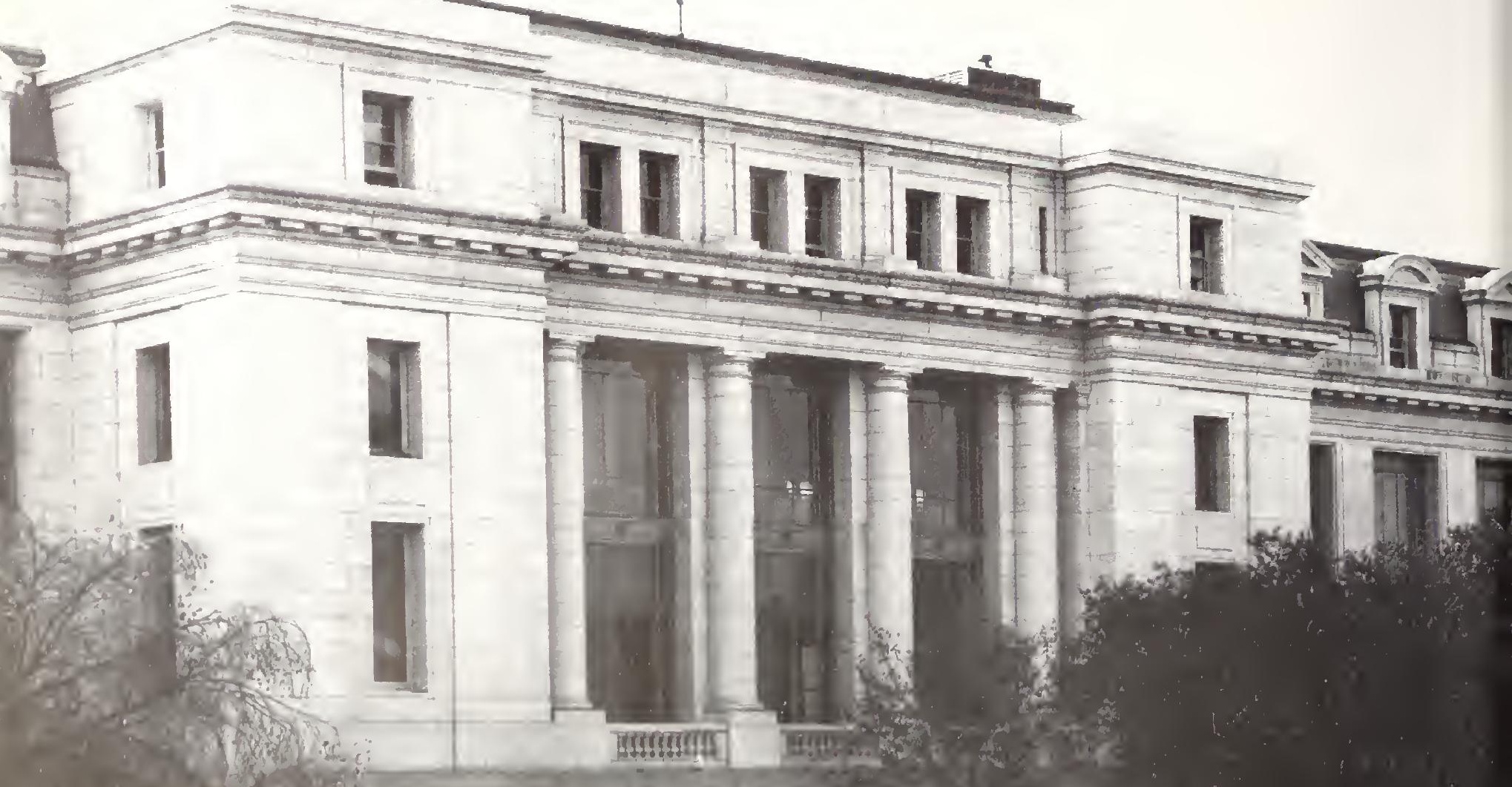




\section{Outside the Building}

$\mathrm{N}$ O PLACE, WITI THE EXCEPTION of the floating city of Gulliver's third trip, exists without a physical setting. When the walls of the Museum were in place and the collections moved, more remained to be done "for the completion of the new building of the United States National Museum and its surroundings, namely, the construction of roads and walks, grading and sodding, construction of a waterproof granolithic platform along the outer walls of the building, and the painting of the interior walls." Writing in the Annual Report for 1911, Rathbun stated the cost as seventy-seven thousand dollars. ${ }^{1}$

At the turn of the century, the Department of Agriculture had gardens on part of the Mall. These included grafted trees, and near the Museum was a tree that blossomed on only one side. Other areas of the Mall were moderately wooded, but during 1934 many of the trees except those adjacent to the Museum were cut down to improve the vista from the Capitol to the Washington Monument. Some of the largest and oldest trees remaining on the Mall side of the Museum are two bald cypress (Taxodium distichum) across Madison Drive from the south steps. They have not developed the "knees" typical of native cypress growing in southern swamps, and as a result many people do not recognize them.

\section{"Uncle Beazley"}

Not far away from the cypress trees stands "Uncle Beazley," a life-size model in fiberglass of the dinosaur Triceratops, made in 1967 for a television show that featured many Museum employees as extras in a few scenes. Uncle Beazley was presented to the Museum the following year, and except for one trip to the Anacostia Museum, he has remained in place on the Mall. It is a tribute to the strength of fiberglass that Uncle

Vendors at the B Street Centre Market, looking southwest from the present site of the Department of Justice building. The iron fence and large stone gateposts in front of the Museum may be seen. Post-1910 and pre-1931, the photograph was probably taken before World War I.
Beazley has withstood the effects of thousands of children climbing up and sliding down. A few years ago a Victorian-style metal link fence was put around him, but this was entirely for the aesthetic effect. Uncle Beazley is the only part of the Museum that can be visited by the public very late at night.

A sarcophagus that used to stand near this spot was moved to the south sicke of the Mall in the 1940s or 1950 s. It puzzled tourists, as did a monumental urn dedicated to Andrew Jackson Dowling, a landscape gardener generally given credit for the first attempts at beautifying the Mall. The inscription was badly worn, and tourists were left to wonder. The urn was removed in the 1960s, and now sits in front of the Castle.

Below the south steps of the Museum is a large storage vault, mostly used for drums of alcohol. Few people go into the vault, but the drums of atcohol are all carefully accounted for; years ago, one disappeared and the FBI was called in to catch the thief. In the early 1960s Buildings Management carted out of the vault a number of wooden boxes that belonged to the O. C. Marsh dinosaur collection. After several hours of heated exchanges and searching of files, Lewis Gazin found an agreement arranged by his predecessor Charles Gilmore, stipulating that the boxes were to be brought to the new building and stored under the steps. The boxes quickly were put back.

The vault opens into the side of a short auto passageway that runs below the south steps, connecting the east and west parking lots. Across from it, on the other side of the passageway, is a door into the Museum that has been usech occasionally to let dignitaries into the building, as in the case of President Truman. It was originally designed so that ice could be taken out of the adjacent ice rooms and moved to the other buildings. The passageway is called "the tunnel," and was designed for a horse and wagon. During the 1960s it became a macho event to drive a small car like a Volkswagen through it as fast as possible. The tunnel is short, but visibility is limited. After one close call, speed bumps ("Boardman bumps," in some circles) were instatled at either entrance to the tunnel, and the sport stopped. 


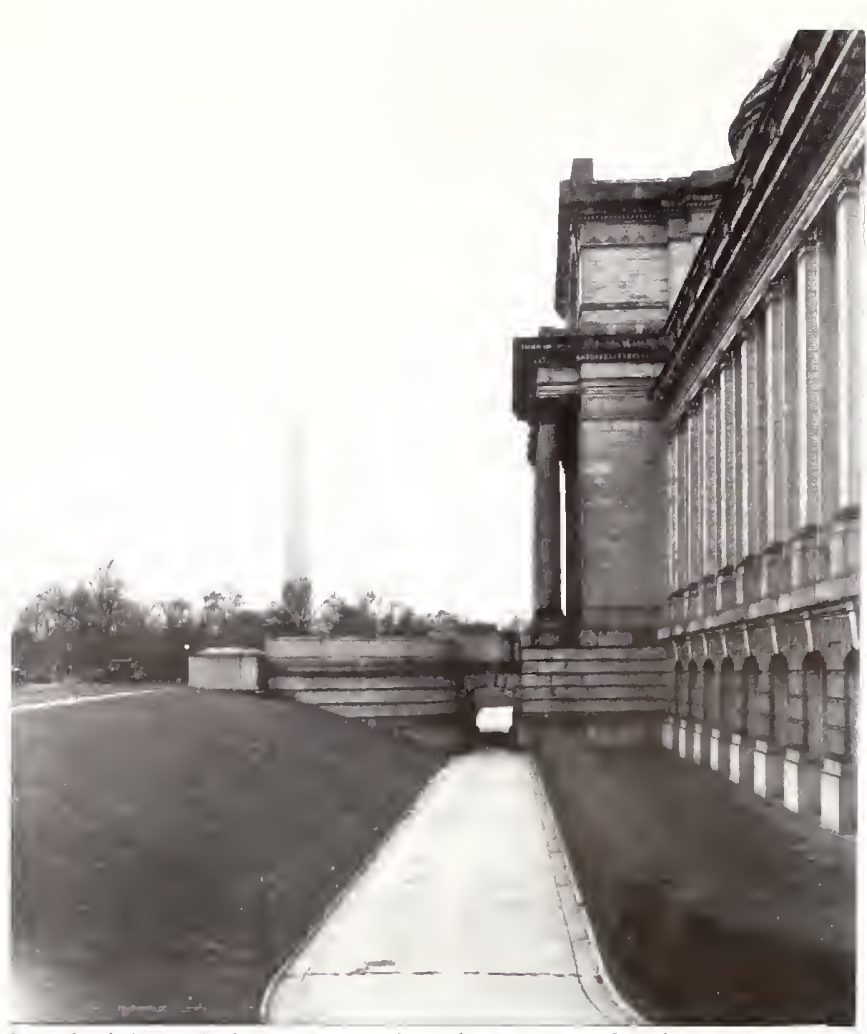

South drize of the newe National Museum in the 1930s, looking aeest into the lummel belowe the south steps. A boxwood hedge (Boxus) is to the right, and what parking there was aras parallel to the bank on the left.

As the Museum was originally built, the drivewav made a U-shaped loop around the building. Trash traditionatly was collected from the east side, but most of the supplies and the mail went to the west loading platform. All along the south side a boxwood hedge was planted, and what few cars were present parked parallel to the hedge. Because this area had been excavated well below the level of the Mall, the grassy slope from the Mall was steep, and most of the driveway was hidden.

In 1926 eighty-seven feet of the driveway running from B Street was repaired. More road work was done in 1930, and parking gattes were put on both the east and west entrances. Clearly, traffic control was becoming a problem. During the mid-1930s, parking became more difficult as a few of the younger staff finally managed to buy automobiles. Offering to pay for the necessary labor and paving, the staff petitioned to have the hedge removed so that the space could be widened and they could park at right angles to the building. The request was refused on the grounds that this would injure the appearance of the building.

When the wings were put on, the hedges clisappeared in the twinkling of an eye, and much of the area immediately surrounding the wings on the east and the west is now paved. No one objects, for one of the most desirable things in Washington is a parking space. More anguish has been suffered over who has parking and who does not than over any scientific problem. As one indication of the bustle and growth of the Smithsonian Institution, on one summer day in 1984, 695 exits and entrances by Smithsonian trucks, vans, cars, and Cushmans (powered carts used by the grounds people) were logged through the east gate. There is nothing remarkable about the vehicles, except that there are perhaps a few more pick-up trucks than on the average government parking lot. For a time one car whose owner worked with mollusks had the license plate SNAIL, and a paleontologist had PALEO. One truck bore a bumper sticker saying, "I'm proud to be an avian paleontologist."

In the great rainstorm of 1969 , water poured down the ramp into the basement of the west wing. Now each ramp has a "sleeping policeman"-an asphalt beadacross the top to slow down any further floods. Apparently these have some effect, for there has not been as severe a rain since they were installed. Unfortunately, in the event of a future torrential downpour they would provide little protection, and the staff hopes that specimens in the basement will be moved elsewhere before the next great flood.

\section{Outdoor Exhibits}

As noted earlier, the War Collection consisted in part of field guns placed on the west side of the building and the gun from the USS Magnolia on the east. Not much is known about how long this artillery stayed there, or what else was on clisplay, but it was not the first outcloor exhibit. Some large samples of ores were positioned on the east side of the building about the time it was completed. A giant copper boulder from Michigan was outside for a time. These large rocks were present during the 1940s, and then just vanished. Nothing is recorded of their installation, only one passing mention is made of labels for them, and nothing is recorded of their being moved.

On the west side of the building where the west wing now stands was a small park. This was the place where a Museum football team was organized in the 1950s. The lawns and the park were maintained by the National Park Service; it was only after the wings were constructed that the Museum assumed responsibility for the grounds.

\section{Cleaning the Outside}

In August 1922, the District of Columbia Fire Department washed the building. "The appearance of the building was materially improved as a great amount of dirt had accumulated, including nests of caterpillars and other insects not readily dislodged. . . In attempting to get water for this purpose the Fire Department discovered that all the fire hydrants in the Smithsonian Park were in bad condition and of an antiquated type, leaving the buildings practically unprotected in the case of fire." 


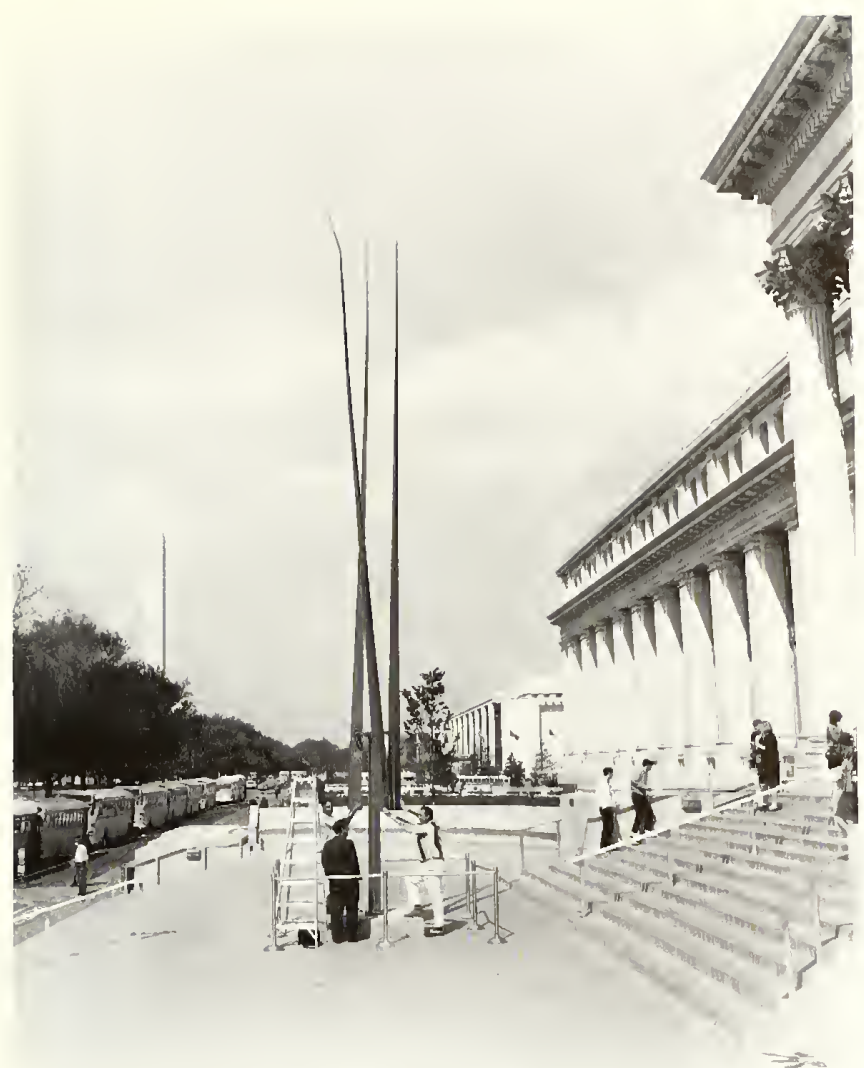

Three Red Lines, a mobile by George Rickey, on the south steps, probably in 1972. Earlier, this sculpture was on the east side of the National Musenm of History and Technology. It is made of lacquered stainless steel and sways in the wind; a gust unfortunately drove it to the ground, and two points were bent. The piece now stands on the north side of the Hirshhorn Museum.

The building was washed at least once more by the firemen before being professionally cleaned during the 1950s. As a result of that cleaning and the subsequent gradual darkening of the wings, the wings now match the main building quite well in color, although the lower stories of the wings are getting much dirtier than the upper two-thirds.

The windows in the main building are unsightly. Because they are no longer functional, they have been ignored. The edge of the steel decking that cuts across the window line on the ground floor of the north side is not seen by many people, but tourists walking along the Mall can see the windows that formerly opened into exhibit halls. A few are cracked, some have curtains, and there are several different hues of opaque glass. A covering material is now being tested on the outside of one of the windows to see how it looks and holds up. If the tests go well, the main part of the building will be given a uniform, if blank, appearance in the next few years.

The most interesting part of the environs of the building is the north side. The building originally had

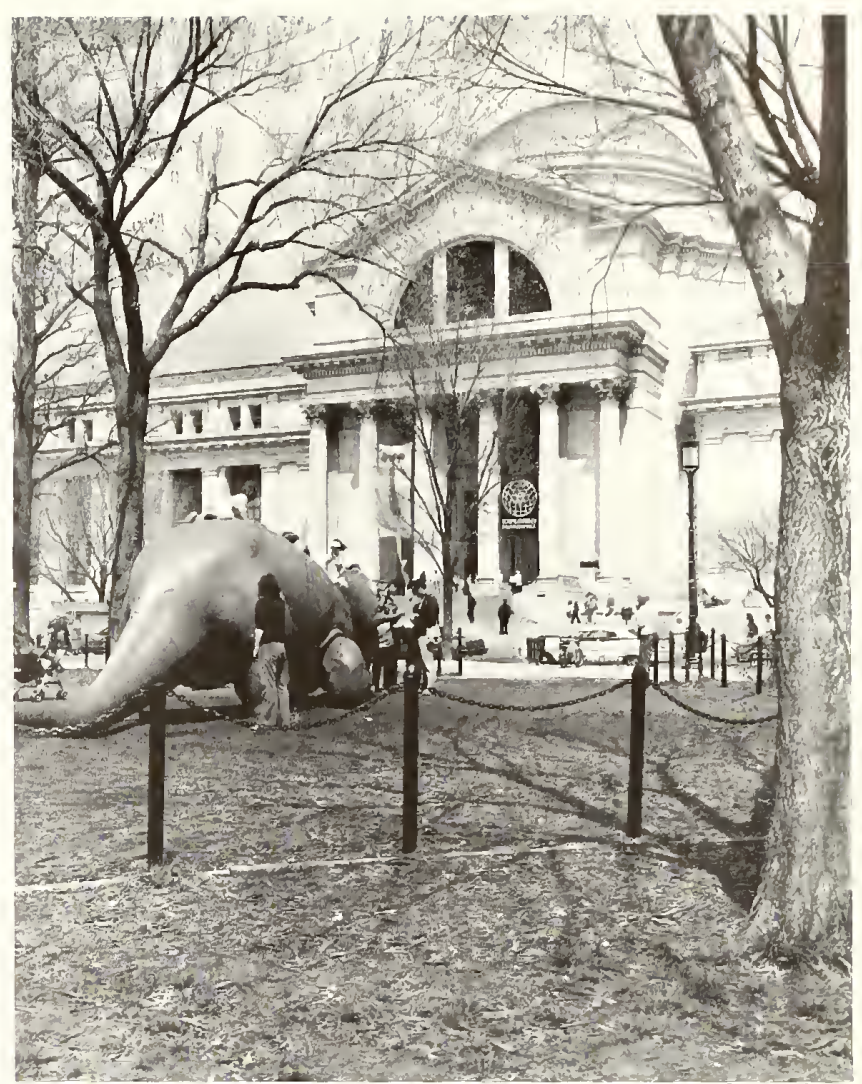

Uncle Beazley (Triceratops) on a fine day in early spring, before the crowds begin. The banners over the portico announce two shows in the Evans Gallery, The Art of Cameroon and Exploring Microspace. April 1984.

an iron fence, at least on the $B$ street side, with enormous stone gateposts in front of the north cloor. These disappeared before the end of the 1920s, and the only proof that they ever existed is found in a few old photographs. The National Zoological Park still has similar gateposts. Lieutenant Bell of the police force there recalls being told that the gateposts on Connecticut Avenue, and those formerly at the Harvard Street entrance to the Zoo, came from the Museum downtown.

\section{Outside the Museum}

Directly across B Street from the Museum was the old Centre Market. Although European museums were set in stately parks, the Natural History building had nothing that could be described as a formal setting. There were pigs and potatoes, horseradishes and horse-drawn wagons. A few of the old-time independent grocers in Washington got their start at this market. In the early 1930 s, G. A. Cooper saw a calf run from the market into the foundation of the Internal Revenue Service building.

Ohio Avenue, which cut diagonally through the market area, was chevoted to adult male entertainment. George P. Merrill, taking this shortcut one day, was shocked to be solicited by a young woman who was one 


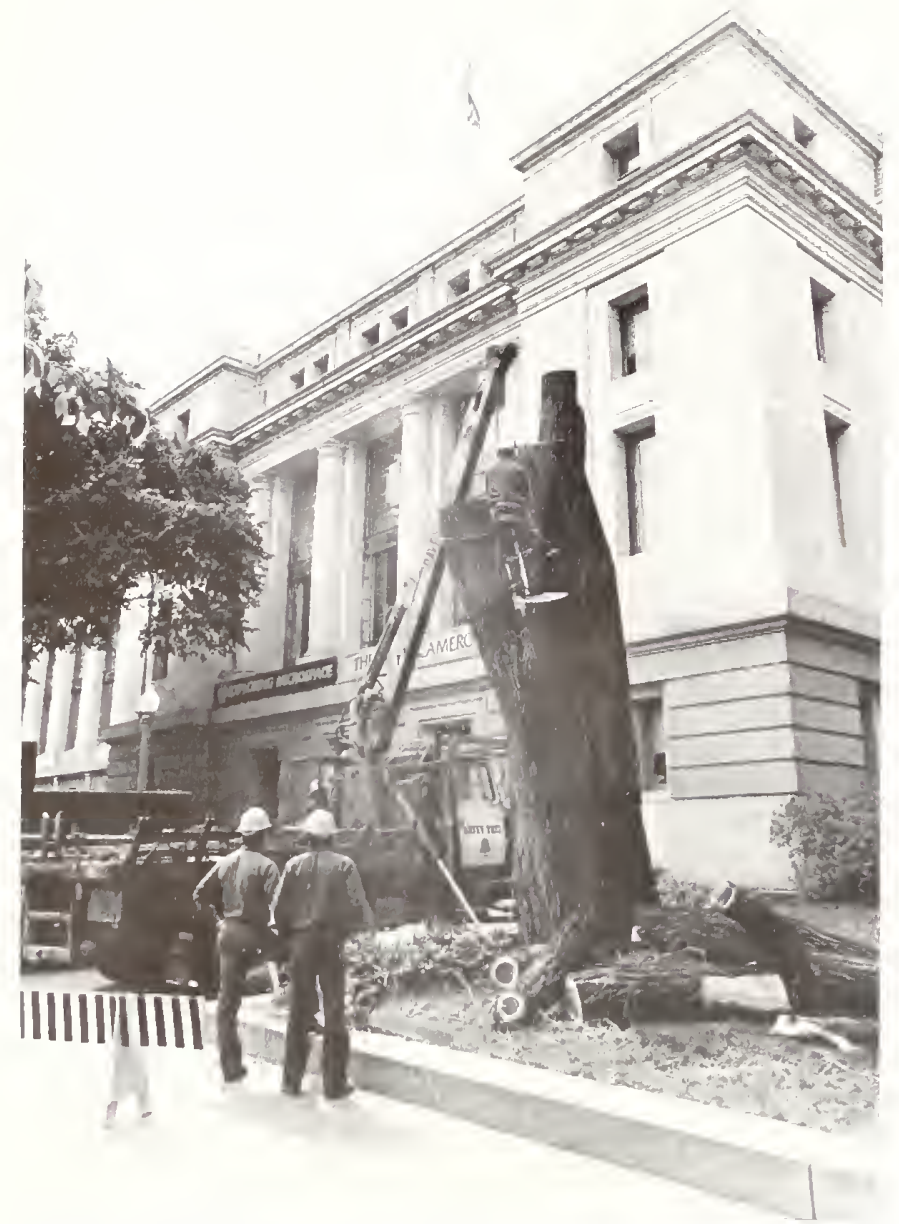

Loss of a large American elm on the west side of the north entrance, Mav 1984.

of his students at Ceorge Washington Universitv. Once when Edward Henderson was walking on Pennsvlvania Avenue, a very proper lads called out, "Young man, if you are a Christian, don't go down that street!"

In the early 1960s, there were not many plantings around the new wings. Shortly after Secretary Ripley arrived in Washington, he asked Richard Cowan to find specimens of the dawn redwood (Metosequora glyptostroboides). This is a rech wood tree originally described from a fossil and thought to be extinct, until a few living trees were discorered in China in 1941. Later the species was introduced into cultivation. Cowan found some trees in a Department of Agriculture nursery and had six planted-three each on the northeast and northwest corners of the Museum grounds. They were originally about seren feet high, and some are now approaching fifty feet. In the fall they shed their needle-covered branchlets, and the bare limbs in winter look much like those of the native bald cypress.

Between the main building and the wings are large southern magnolias (Magnolia grandiflora), and near the north corners of both the main building and the wings

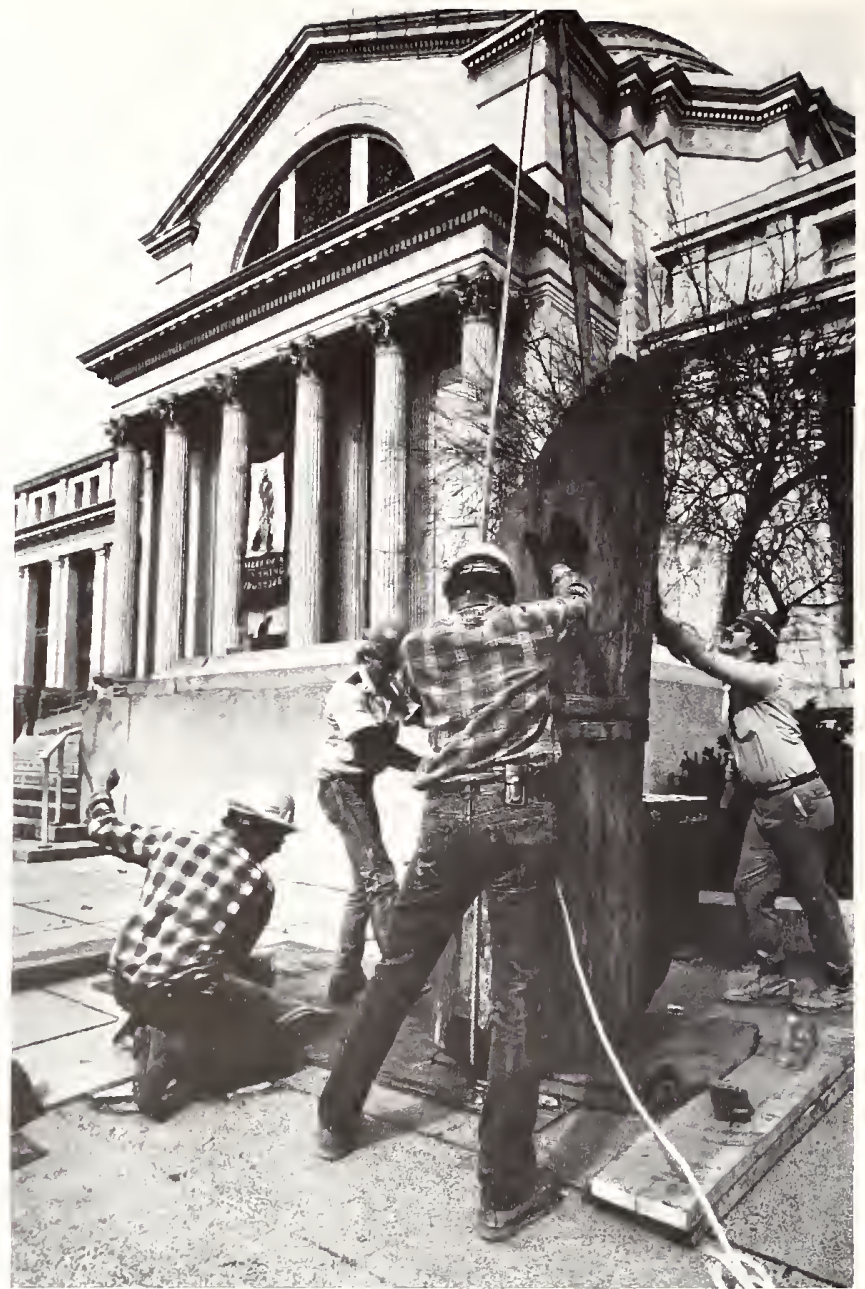

Riggers standing up a trunk of Araucarioxylon before raising it to the east plimth. On March 15, 1985, the United States Nayy Band played on the steps while the specimens on the plimtlis were formally unveiled to celebrate the seventy-fiftl annwersary of the building.

are handsome specimens of American holly trees (Hex opaca). A line of beautiful, pink-flowering crabapple trees (Crotaegus malus) borders both the east and west parking lots; most of them were planted in the 1970s. On the south side of the Museum, the steep slope between the Mall and the parking lot is lined with azaleas, two species of dogwood (Cornus), and magnolias. At the top of the slope are some oak (Quercus) and some sycamore maple (Acer pseudoplatanus) trees. In 1984 a few young gingko trees (Gingko Biloba) were planted adjacent to the east and west driveways into the basement.

The Museum's nice surroundings are a recent development, and stem from the hiring in 1972 of the Smithsonian's first horticulturist, James Buckler. On the east and west sides of the wings, katsura-trees (Cercidiphyllum japonicum) were planted, and the flower beds beneath them are used for spring bulbs and summer annuals. In April and May when the dogwoods and crabapples flower, the grounds are at their best. The 


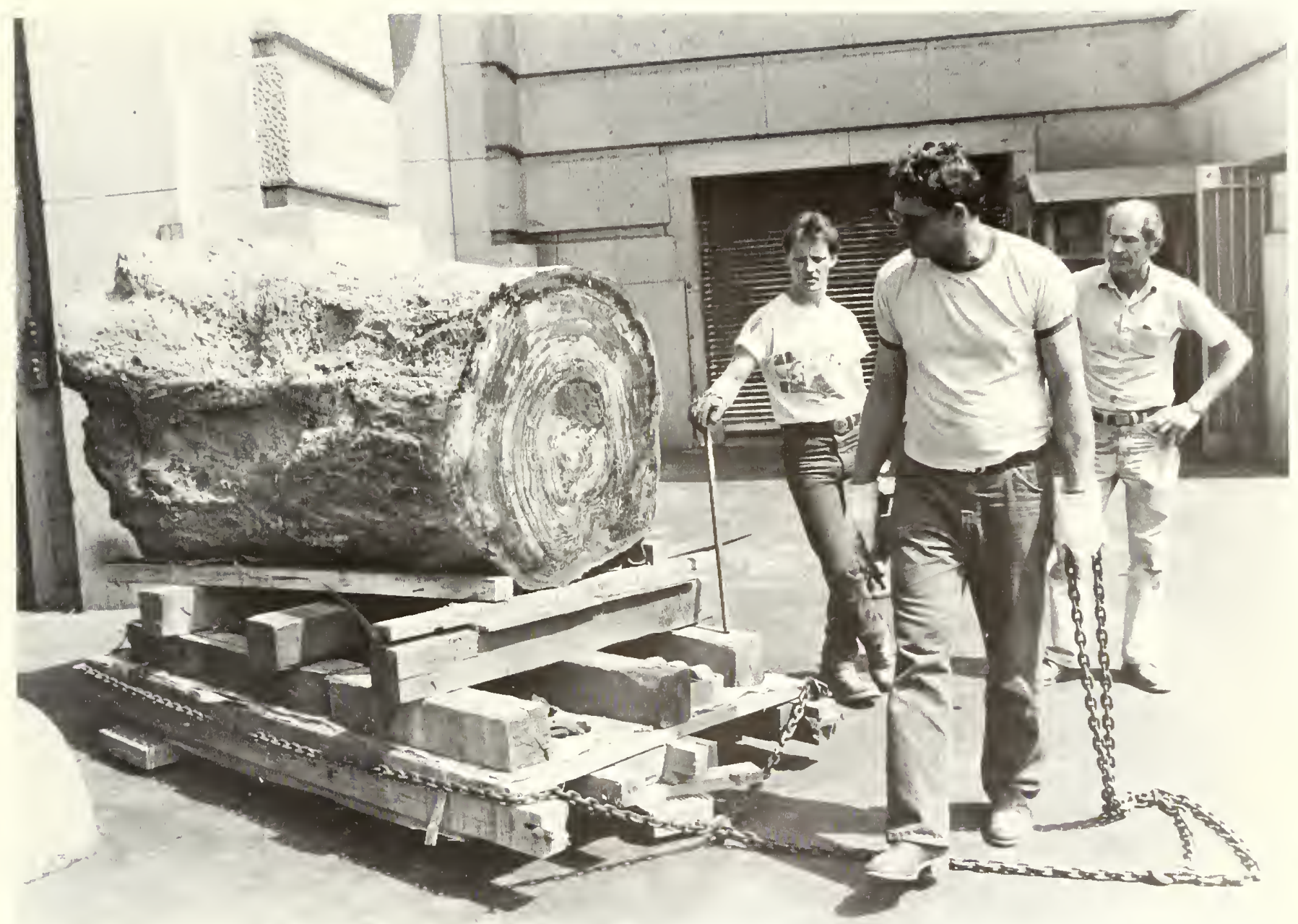

Riggers moving a cut and polished log of fossil wood (Araucarioxylon) onto the east parking lot, July 1984. The main building is to the left, with the east-wing freight entrance and guard's kiosk behind.

beds of summer annuals on the east, west, and north sides not only are pretty, but equally important, provide a source of nectar for the bees that fly out each day from the Insect Zoo.

A sad story is the plight of the American elm trees (Ulmus americanus) along Constitution Avenue. They are dying one by one from Dutch elm disease. In the 1960 s, one in front of the north entrance died. Late in the 1970s one died at the northwest corner, toward the National Museum of American History. In May 1984, another near the north entrance died. Before its stump was removed, one of the scientists counted the tree rings and found that it dated from about the time of the Civil War. In 1983, when the Washington Redskins won the Superbowl and thousands came to a victory parade on Constitution Avenue, Smithsonian guards had to clear people from the younger trees to save the trees from being damaged. Other elms along Constitution Avenue are about fifty years old. In anticipation of the death of a giant elm on the southeast corner, a hackberry (Celtis) has been planted nearby next to the dawn redwoods.
When the new Museum was erected, Rathbun noted that it was parallel to the axis of the Mall but at a slight angle to B Street. Constitution Avenue is now parallel to the north side of the building, but the building does not sit squarely on its lot. There is a bit more of a border on the west side of the building than on the east, though it is not obvious. Ninth and Twelfth streets used to cross the Mall but now pass under it in tunnels, which enhances the appearance of the grounds. A large copper European beech (Fagus syluatica) is on the southeast corner of the parking lot. The District of Columbia highway engineers had it marked to be cut down so that they could build their Nintll Street tumnel with a minimum of fuss, but the conservationists won, and the Museum kept its tree.

Next to the north entrance are Korean azaleas (Rhododendron mucromulatum). Buckler is particularly proud of these, for their very early, delicate purple flowers bring dozens of telephone calls from the public each year. The shrubs are deciduous, and flower each spring before any leaves develop.

Although the overall setting of the Museum has im- 


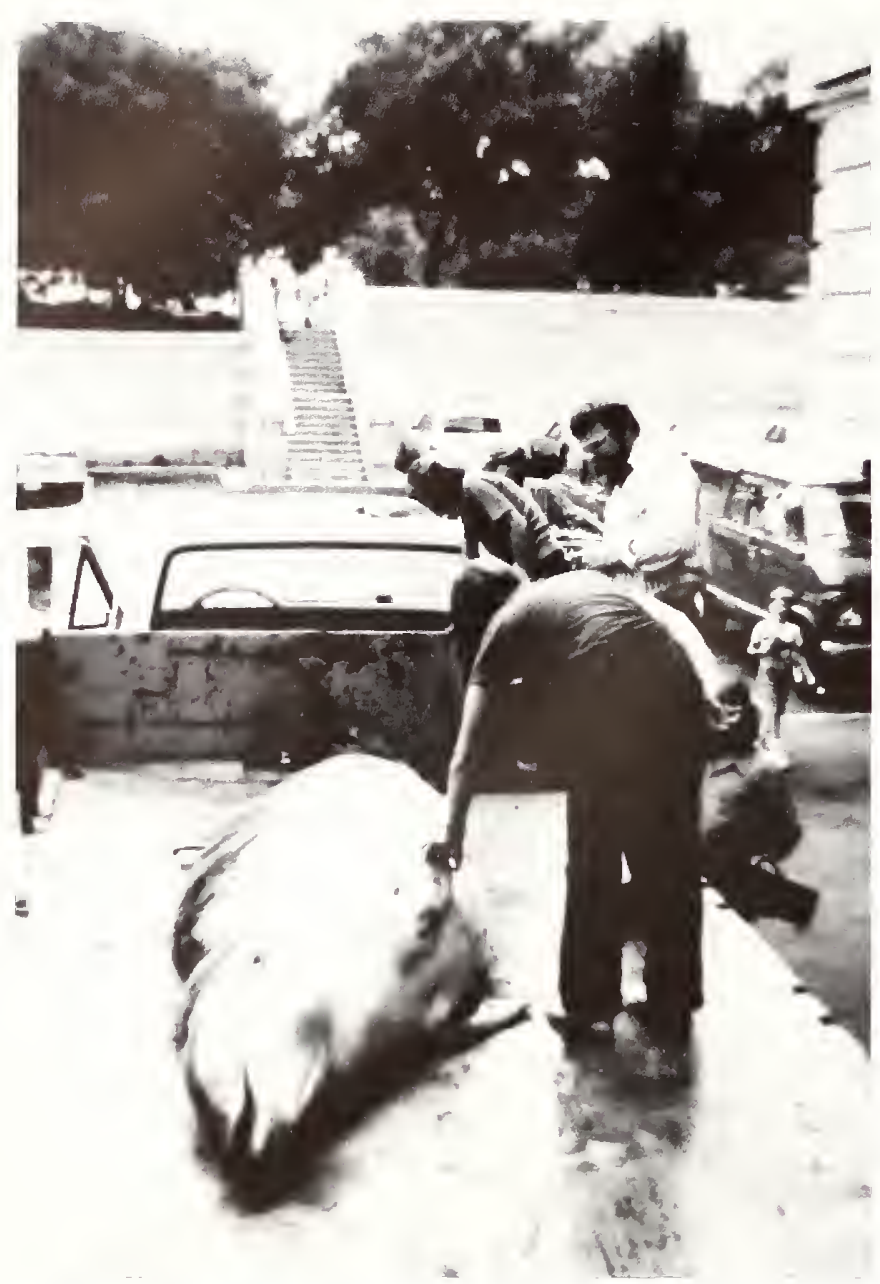

True's beaked whale (Mesoplodon mirus) on the east parking lot in August 1977.

proved with the development of the Federal Triangle across the street, the north entrance itself has deteriorated. Several lamp posts near the door have been moved. The curve of the steps has been filled in, and material of a different color extends to the driveway. Some of this was done during the Carmichael era. The latest modifications, on the other hand, have been for a good cause. There are now ramps from the sidewalk up the steps, and inside the entryway another ramp leads to the central automatic door. This entrance is fully accessible to the physically handicapped. Those in wheelchairs are a minute part of the tourist population, but their numbers have increased every year.

The north side of the building is the only place to see the flag. One has to stand back some distance from the north entrance to get a glimpse of it, a couple of stories up. This modest flagpole is the only one on the premises of the Museum, whereas many of the neighboring buildings have imposing flagpoles on their grounds. A number of picture postcards of the 1930s showed a huge flag flying over the east side of the building, but this never existed.

The north and south entrances are regularly festooned with banners announcing temporary exhibits. The banners, produced commercially, are handled by riggers employed by the Institution. Some say these banners give a tawdry appearance; some say they provide an air of gaiety. Good or bad, they are probably a permanent addition. The banners began during the Bicentennial when the Mall side flew one showing a dancing elephant balancing the Museum on its trunk.

One really must return to the south steps, the main entrance to the Museum. During the 1960s metal guardrails were added to assist people walking up or down. In the early 1970s a young man was walking on the outer ledge, showing off for some young ladies, and fell to the driveway below, breaking an arm. As a precaution against a similar event with a more unhappy ending, nets were slung on either side below the wall, extending out from the roof of the tunnel. Of course, these nets are full of beverage cans and paper trash, but there does not seem to be any cure for that.

The south entrance is closed by massive bronze gates that retract laterally into the walls; there used to be similar gates on the north side. Originally the gates were closed by steam power and later they were hydraulic. Now, in the electrified era, a guard simply touches a button. Few people see these gates, because they are out of sight during public hours, but they are impressive.

\section{Decorating the Plinths}

There is one last point to mention about the south entrance. Between the two runs of steps is a pair of large dies, the tops of which are level with the south entryway. In his description of the building, Rathbun indicated that they were designed to serve as pedestals for statuary. Except for the stone lions displayed on them during the George Washington bicentennial in 1932 , they seem not to have been used. With that preface, it is necessary to return for a moment to the developing exhibit on fossils in the west part of Hall 2.

In 1980 inquiry was made to a mining company in Minnesota to see if a large sample of red jasper could be obtained. This quite ancient rock, also known as banded iron formation, shows alternating darker and lighter layers. This layering may be related to consumption of oxygen from the atmosphere as the ancient iron was first oxidized. A slice of the rock was needed for the exhibit on early life and the origin of the atmosphere. After several letters and telephone calls, a large glacial boulder of this ore was located. The local Army Reserve unit helped bring it down a hill and place it on a truck. Eventually the eleven-ton rock arrived in 


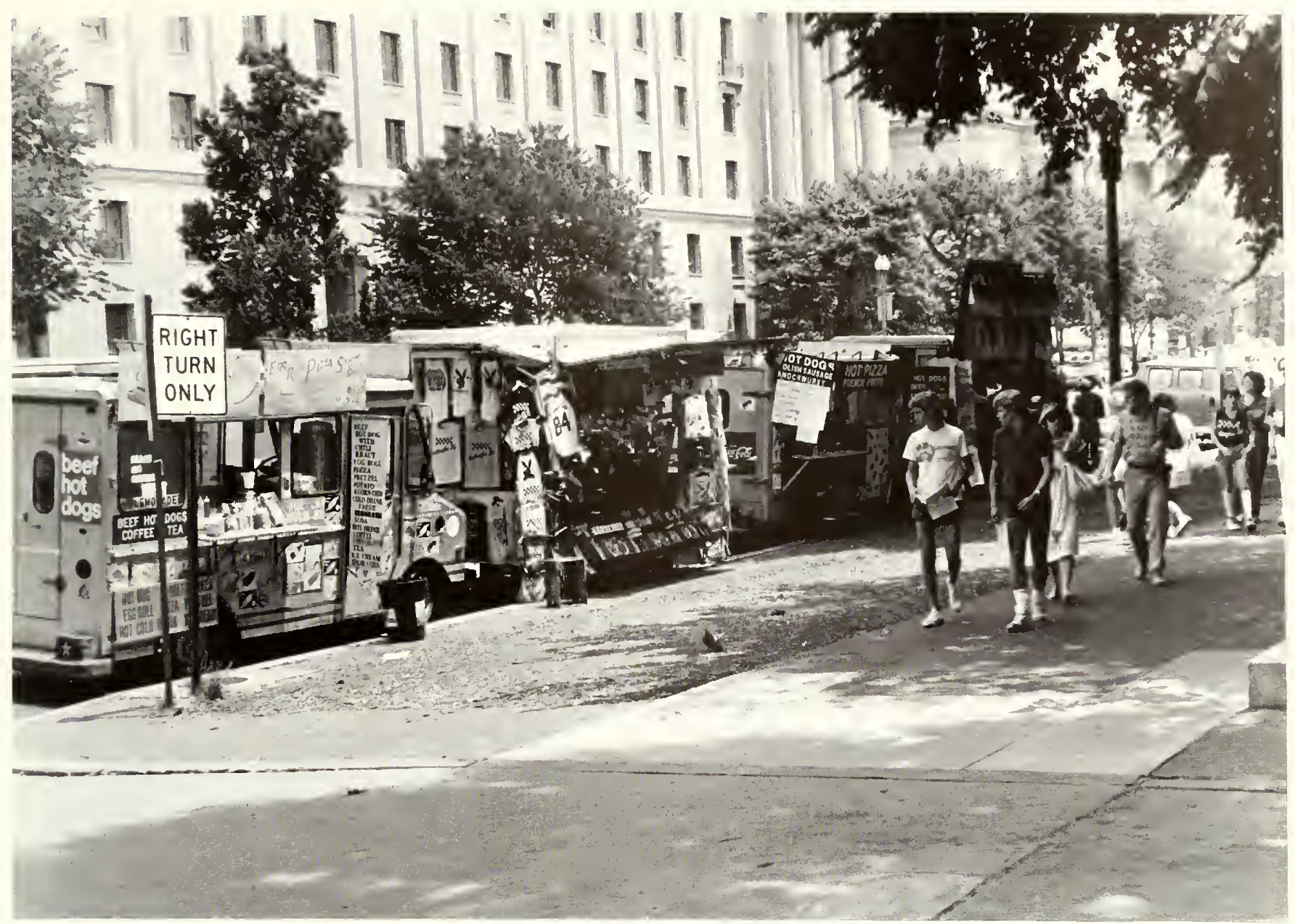

Vendors on Constitution Avenue on the east side of the Museum, looking northeast with the Department of Justice Building behind. July 1984.

Washington. It took about twelve hours of cutting with a large wire saw to prepare a slice. In this operation a slurry of water and abrasive is used; the wire simply carries the abrasive across the piece. The wires have to be replaced periodically, but because the iron layers are alternating hard and soft, cutting of the boulder went fairly fast.

There was some material left over after the necessary slice was taken out, namely a piece of about seven tons. Considerable discussion ensured as to the advantages of using this leftover as an outdoor display, in the general context of waste not, want not. Someone finally hit on the idea of placing the rock on the south steps. That immediately raised the question of whether the area would hold the weight.

Almost immediately that raised the next questionwhat to put on the other side for balance. Eventually this was settled by deciding on two logs of petrified wood. Frances Hueber, a paleobotanist, was dispatched to Arizona to obtain them. Adjacent to the Petrified
Forest National Monument, there are fossilferous beds exposed on private land that has been a source of petrified wood for decades. Hueber measured a number of specimens in the field but finally settled on two already collected from the area. One was donated, and the other was sold to the Museum for fifty cents a pound, the price the previous buyer had paid for it. The city of Holbrook, Arizona, offered its good offices, and a local rigger loaded the specimens at cost, throwing in the red carpet that they were wrapped in for the trip to Washington.

The larger piece of wood took twenty-eight hours of sawing time and used up fourteen wires. It took weeks more to polish the cut surface. The other tree was a bit smaller and took less time to cut. The Museum accessioned these three large specimens, including the rock. After the paperwork was completed and the preparation finished, the riggers moved them to the dies to be unveiled. One tree lies on its side, and the other stands again after nearly 200 million years. 


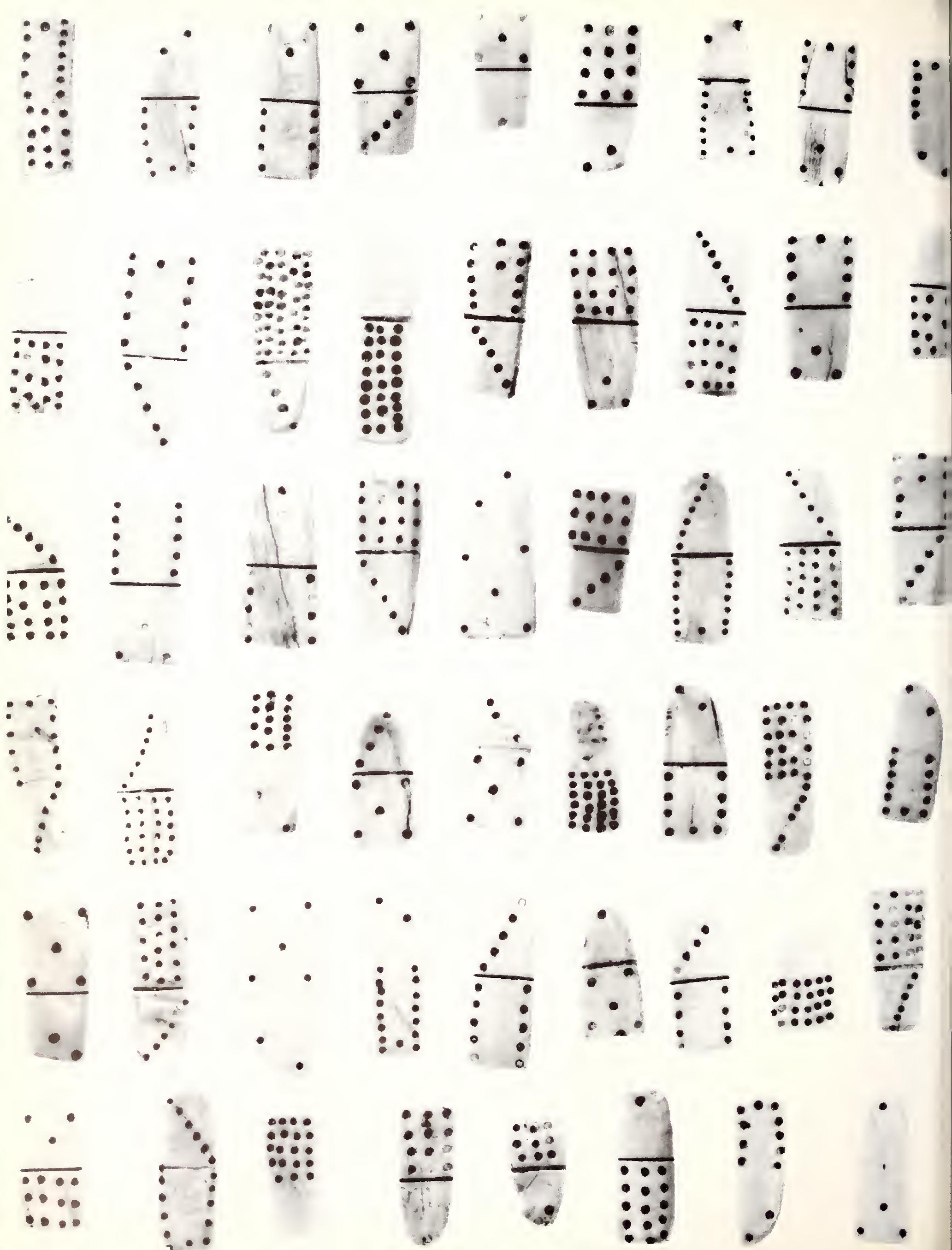




\section{The Collections}

$\mathrm{F}$ ROM WHATEVER ASPECT ONE CHOOSES to consider the Museum, one inevitably returns to the collections. James Smithson left a legacy to found the Institution, but this legacy even on the surface was mor'than money, for his mineral cabinet and library were included. From the time of the Institution's founding by Congress, the individuals associated with the Smithsonian have been collecting and preserving objects. The exhibits should not be considered as separate from the collections; they are just a tiny part of the Museum's holdings, put on display for the general public. Philosophical questions of what to display, how much and in what manner, whether originals or copies, and a host of other important issues, are, in the final analysis, secondary matters. No collections really means no exhibits.

Some aspects of science undergo periodic "revolutions." Once a new concept has been introduced, earlier concepts are discarded. One need only look at the value of last year's computer to be aware of the frenetic rate of change in some areas. In marked contrast, other aspects of science are cumulative. The study of history naturally has a cumulative approach, and historians aim in theory to save every scrap of the past, or at least representative samples of it. Natural history likewise is additive. Ideas and approaches change, but the objects of study themselves have a value that does not diminish through time.

\section{"The Nation's Attic"}

Spencer Fullerton Baird, the second Secretary, was a demon of a collector and infected many others with his enthusiasm. It was under his tenure that the term "the nation's attic" was first applied to the Institution. This was not meant to be a compliment and indeed it had a pejorative connotation, for it aptly characterized buildings bursting at the seams, unopened crates, and

Labrador Eskimo ivory dominoes for gambling, accessioued in 1886. While there is no "average" specimen, this is representative enough in terms of size, complexity, and problems of preservation. inadequately studied collections. For half a century, the press tended to view the Smithsonian, and especially its natural history endeavors, as a jumble. Those who worked with the collections never saw them in that light, but after all, the average person does not work in a museum.

A large part of museology, the study of museums, is concerned with the mechanics of arlequate storage of objects. Inadequate funding for collection storage brings with it a host of problems. The new National Museum provicled a typical example: "With ample basement storage available for the first time in many years, steel racks and drawers were ordered for the heavier stone specimens in geology and anthropology. But the contractor who submitted a low bid on the steel racks was too high in his bid for the accompanying drawers. Consequently, two bids were let, one for the racks and one for the drawers. And the low-bid storage drawers, too narrow and too light weight for their intended purpose, buckled and dropped off runners in the low-bid racks. I [Neil Judd] do not know how much our administrators saved on that transaction, but forty years passed before the last of that ill-advised purchase was surreptitiously replaced."

In the public mind, collections are kept in cigar boxes, and indeed a number in the Museum actually were; remember that for decades such boxes were abundant, and were free-the best possible price for a museum. Now these boxes are themselves collectors' items. As a piece of trivia in connection with containers, during the late 1940s A. R. Loeblich in Geology decided that the marine-bottom samples dredged years earlier by the Fish Commission steamer Albatross should be transferred to bottles of uniform size for easier storage and handling. Every evening he would discard old jars, and every morning Malcolm Watkins in Anthropology would carry a number of them away for his collections.

The fine points of collection storage have evoked some florid prose at the Museum, much of it concerning fossils:

With fossils, one is not troubled by evaporation. ... One is not conerned with material drying to 
powder. Except for rare specimens replaced by pyrite, fossils do not pick up moisture from the air. Fossils are not edible and though occasional labels and locality numbers may be lost to particularly desperate cockroaches or rats, such events have been fairly rare. . . Fossils do not change color after years of storage, nor do they smell.

About the only obvious and painful drawback to fossil storage is weight. The average collection of fossils, microfossils excepted, is heavier than the average collection of almost anything else in a museum. One drawer, 28 inches by 22 inches, full of particularly stony fossils .. . requires complete attention during a moving operation. Drawers of fossils can be stored to a height of 9 feet, but an administrator before making a decision for highlevel storage, should be required to carry at least one drawer to the floor. There is a general rule of nature (Gumperson's Law) that the heaviest drawers are always at the top; for any case over 5 feet high this may become hazardous. It is also well known that museums that stack drawers rather than place them in cases, keep a needed specimen in the bottom drawer of a stack (Saunders' Corollary).

The Saunders for whom the corollary is named came to the Museum in 1948 and has been curating collections for the U.S. Creological Survey ever since. Harold Saunders remembers the location of thousands of collections and hundreds of birthdays; almost every one of the old timers annually receives a birthday cigar or box of Cracker Jack from Harold Saunders. Cleaning and rearranging collections is a full-time job, and without those who do it the Museum collections would be in a sorry state.

Collections have to be stored, and they have to be stored in some meaningful way. A major preoccupation of any museum is files to keep track of specimens. One used to use a pen to write on the three-by-five-inch cards kept in the shoebox (shoeboxes are free); later the cards were typed. Today word processors produce enormous sheaves of paper printing the same datathat the camel-saddle rugs from Egypt are in aisle 3, case 10 , and those from Kuwail are in case 19.

It was not very long after the new Museum opened that the hallways on the third floor became the storage area for a large part of the collections. By the time the wings were built, there were collections in the offices, in the halls, in the attics-and wherever there was space. At one time there were some paleobotanical specimens in the east attic, some in Stone Hall, some on the first floor underneath exhibit cases, some stacked in the corridor of the east north range by the library, and some in the former boiler room. Simply finding out what was where, let alone getting one's hands on it, was not easy. When the exhibits were modernized in the
1950 s and 1960 s, the space between the new cases and the windows was used for storage by almost every department; soon these areas were full. Ten years after the wings were completed, space there was already at a premium.

Perhaps worst of all for storage are the three attics of the main building, which can be entered from the fourth floor of the rotunda or from a stairway in each wing. Originally the east attic was for Geology, the west attic for Biology, and the north attic for Anthropology, but they all contained a bit of everything. Paul Garber recalls finding Chinese kites from the Philadelphia Centennial. The attics were fantastically cold in the winter and incredibly hot in the summer; a large fan at one end of each attic provided only noise. The Old World archeological collections contained a round-bottomed pot in which some resin had solidified several thousand years ago. The attic was so hot that the resin slowly began to flow. Periodically Van Beek would roll the pot around so the resin would not flow out; eventually a stand was made to hold it upright. One need not explain what such conditions did to wood and fibers. Since 1960 the air conditioning has elevated working conditions from inhuman to umpleasant. Because of the space they provide, the attics are an important component of the building, but no one ever goes to the fourth floor with enthusiasm.

\section{Care of the Collections}

Care, along with storage and arrangement, is another facet of curating collections. What constitutes proper care depends on the kind of material being stored. Those who study plants and animals have problems of drying, evaporation of alcohol, and destruction by pests. Those who study ethnographic material have even more serious problems with deterioration. No collections, even rocks and fossils, can simply be stuck in a drawer and ignored; they all must be checked periodically.

Every museum in the world has stories about the technician who drank alcohol from specimens. Occasionally these stories are true, but it is not clear whether the Museum ever really had an alcoholic sharing the preserving liquid with the fish and the invertebrates. One time during the early 1930s, somebody experimented with adding sugar to inhibit evaporation and ended up with a few exploding jars. Newer jars and better storage limit evaporation, but somebody still has to "top off" or replace the liquid in the wet collections or the specimens will be ruined.

Everyone is afraid of pests, and fumigation and poisoning of collections, now more sparingly prescribed, were once carried out routinely. Harry Oberholser of the Biological Survey had a favorite moth-eaten wool shirt that he kept in a moth-infested office wardrobe when he was not wearing it. Wetmore pleaded with Oberholser to discard it because of the danger of moths to the collections. Oberholser refused, but when he 


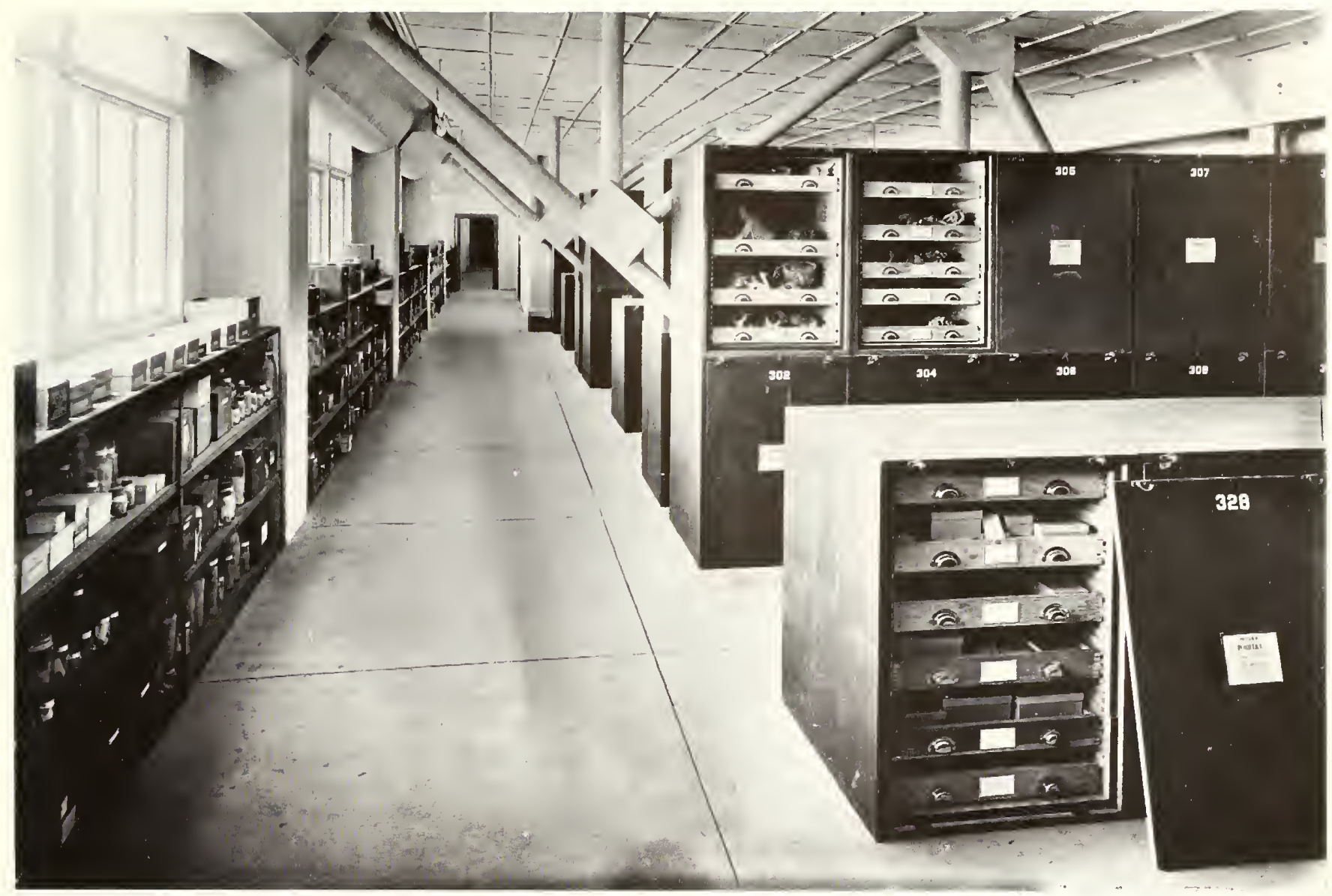

"Attic of west wing," from United States National Museum Bulletin 80 (1913). The specimens on view are sponges-specimens in alcohol to the left and dried specimens in three-foot-high cases to the right. Eiaporation from the alcoholics must have been formidable in the attic. went to the field the following summer, Wetmore had the whole wardrobe removed from the premises.

From time to time materials on display required repairing, and the taxidermists, who were called on for this, became fairly skilled at working outside their immediate field. It was not until the early $1960 \mathrm{~s}$, when the African hall was being constructed, that the anthropologists faced up to the issue of conservation and opened a laboratory for that purpose. It soon became apparent that a number of specimens of all kinds were in need of repair. The pianos were just then leaving the building for the Museum of American History, and they provided a glaring example of the need for conservation. The result of this new interest was that conservation became an important concern in both the Museum of American History and the Museum of Natural History, and analytical laboratories were installed. Conservation and restoration, well-established specialties in the art world, are now significant in the Museum of Natural History as well.

If collections cause such problems of storage and arrangement and preservation, why do museums go to the trouble they do? Part of the answer, especially from the perspective of Washington, is legal responsibility.
The Museum is the national repository for natural history objects. In presenting this point, the 1879 law clearly established one fundamental function or "mission" for the Museum of Natural History: Specimens to which the government has title are to be retained. Once a specimen has been accessioned by the Museum into the collection, it is a laborious formal procedure to have it deaccessioned and discarded. The national treasures are preserved, and will be preserved forever.

When George Brown Goode spoke of a museum of record, preserving government material was part of what he meant. However, he meant a great deal more than that, for he recognized the importance of a representative sample, no matter who obtained it. Records are of all kinds and for all purposes, and it is as important to record where elm trees once were as to find out where they are now. Goode would have been pleased with the uses to which old samples have been put. Determining mercury levels in old bird feathers and by the thickness of old eggshells is a well known example from the era of environmental awareness. No one can say what novel use might next be made of old Museum material.

Although the Museum is legally the official keeper 
of all collections made by government agencies, no one is particular about when and how custody is transferred. Since the inception of entomological studies in the Department of Agriculture, the collections have been turned over to the Museum. Each year, one piece of paper transfers title to hundreds of thousands of insects. Collections of the Biological Survey were always in the new National Museum, but until the 1940s they were kept separate. When Wetmore wanted to examine certain birds, he would approach Oberholser, who would unlock the appropriate case and later relock it. The Geological Survey retains large collections in the $\mathrm{Mu}$ seum and elsewhere. At irregular intervals it transfers large loads of fossils to the Museum, but it promptly transfers all"specimens illustrated for publication.

Members of the public often donate or sell specimens to the Museum. Donations are extremely important to the Museum, and a major reason for an annual report was to list the donors of specimens. The whole business of accessioning collections is to ensure legal itle and proper record-keeping. Periodically, people who liave donated material, or whose relatives have donated, come to the Museum to see those specimens, which will be found for them.

One of the sad trends of the last few decades is a decrease in the number of places in America that maintain natural history collections. A considerable amount of collection growth during the past few years has been by salvage of specimens from universities and other institutions going out of the business. Natural history material with proper documentation should never be discarded, and the Museum performs a valuable service in becoming the repository for these major collections suddenly thrown into limbo. Specimens that are described in a scientific paper assume international significance. Government scientists are required 10 place such specimens in the Museum, but there are no such restrictions on anyone else. Fortunately, many scientists have come to see the merit of a national center, and a large number of type specimens are presented annually to the Museum.

\section{The Issue of Value}

Purchase of specimens is an exceedingly delicate area. In the traditional view, each object, be it natural or man-made, is unique, and because it is unique is either priceless or valueless. Neither concept assigns it any monetary worth. Some objects do have value in the nommuseum world, but it was a tragedy for natural history when interior decorators began to frame slabs of fossil fish and hang them on walls. An unfortunate consequence of this fad of the decorator/collector crowd is that there is now a monetary interest in many natural history objects. Because of the possibility of theft, even the most humdrum of specimens are being put under lock and key. Security is important, but there is concern among some curators that overemphasis on security may inhibit scientific investigation.

Value created by scarcity, not "collectibility," is an even more serious problem. Many objects that once could be collected in profusion can no longer be readily obtained, and may not be obtainable at all. No amount of money or expense can produce additional specimens of the passenger pigeon.

To study passenger pigeons or anything else, it is necessary to see specimens. A large number of people now come to the Museum because they cannot make their own collections of what they would like to study, and for the same reason, lending specimens has become a big enterprise-perhaps twenty-five times what it was thirty years ago. Specimens sent on loan must be retrieved from the collections, listed, counted, and wrapped. When sent back, they must be unwrapped, listed, counted and returned to the collections.

Because of this whole issue of value, one major preoccupation of the Museum during the past decade has been an inventory program. The Museum of American History suffered some well-publicized losses, particularly in the pistol collection and the Early American silver collection. The loss drew attention to the fact that there was no proper inventory, and spurred Congress to order an inventory program throughout the Smithsonian.

\section{Benefits of the Inventory}

It is one sort of problem to count airplanes or even paintings, and another sort of problem to count beetles. Half the kinds of living things in the world are insects. Most curators were loath to be involved with the inventory, yet it had to be done. The program was conducted in a variety of ways by the different departments. Some inventoried almost every specimen, some inventoried only types, and some inventoried selected collections. On balance, most of those who participated see the inventory program as having been beneficial. It accomplished some improvements in the arrangement of the collections that would never have been financed otherwise. The curators now have more data on distribution to "massage" than would otherwise have been compiled. Were it not for the Automatic Data Processing system, the program could not have accomplished what it did.

One consequence of the inventory program is that there now are periodic audits in which auditors look for particular specimens. To move a specimen from one drawer to another now requires much filling out of forms, and some curators worry that desire to win an auditor's report that every jar is in the right place may overshadow the desire to investigate the contents of the jars.

One good consequence of the inventory was that some of the young helpers who survived it found permanent jobs in the Musem, and will be the next generation of technicians and research assistants. Another was that 
Mimi Kajencki inventorying skulls of Alaskan brown bears (Ursus) on the third floor of the rotunda, probably 1978 to 1980 . The inlaid floor is not seen by tourists.

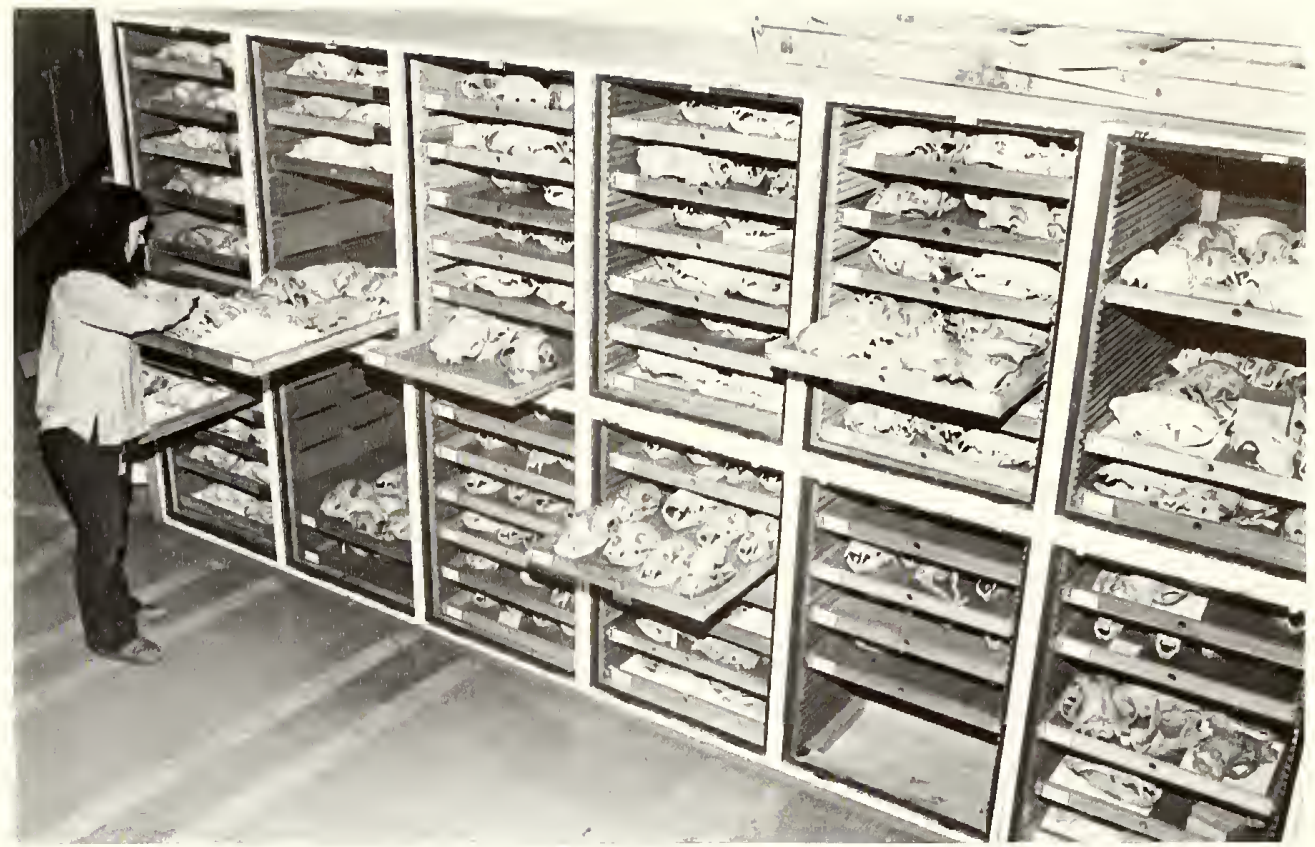

the program crystallized the concept of a collection manager. More interest in loans meant more filling out of loan papers. More specimens coming in meant more accessioning and more label-writing. More visitors meant more moving of material to and from storage. Twentyfive years ago curators handled all such transactions, but today this is not the case. The curators are expected to conduct research programs, and the collections are largely curated by technicians. The scientific visitor who wishes to study particular specimens can probably be accommodated more readily now than at any time in the past.

No matter what one writes about a collection, the true impact of the specimens is not fully communicable by the written word. There is nothing like seeing row upon row of jars or case upon case of fossils to impress one with the enormous amount of human effort that these specimens represent. Yet vast as the collections are, they are an inadequate sample of the world's diversity and the endlessly subtle complications it contains. It is the study of variation within these collections that is so important. Ripley has written, "The truth exists in objects. .. . They cannot lie. ... They can be handled, touched, thought about and reflected over, and in so doing convey a sense of truth beyond peradventure."

The curators do reflect on the objects and to varying degrees do look after collections, but increasingly they are concerned with a particular specialty, rather than a wider group of organisms. However, each curator contributes specimens, adding to the stock of the past. The activities of the present generation of "foragers" have been described in some detail, ${ }^{4}$ but generally speaking, collections obtained by staff members in the past were larger than those being made by present workers: Setzer's operations in trapping small mammals were like those of a field marshal; Cooper brought in seventy-t wo tons of rock to treat with acid; the Indian Ocean Exploration employed dozens of ships.

\section{Why Collections Grow}

With such large collections already in hand, why go out into the field in search of more? No matter what anyone says, one reason is that to most scientists, field work is more fun than being in the office. Another answer is that one cannot always solve new problems when limiting oneself to old collections; additional specimens and data on behavior and mode of occurrence must be obtained to resolve some questions. Also, curators are expected to add to the collections. If the research being pursued by a curator has nothing to do with collections, why should he or she be at the Museum in the first place? Collections will grow until collectors become extinct. New things always turn up.

The expansion of collections within the Museum is not an issue that many scientists care to belabor. All one can do, is to plead for adequate space and the money to support it. Fortunately, the collections have proven their worth so many times that Congress sees the merit of continuing research, even if this is linked to continuing growth.

The growth of the collections has been studied. ${ }^{5} \mathrm{An}$ nual reports provided solid information on the number of specimens accessioned each year, and the growth curves turned out to be exponential. On May 1, 1971, in advance of the inventory, the grand total of specimens in the seven departments in the Museum of Natural History was supposed to have been $54,215,643 .^{6}$ 


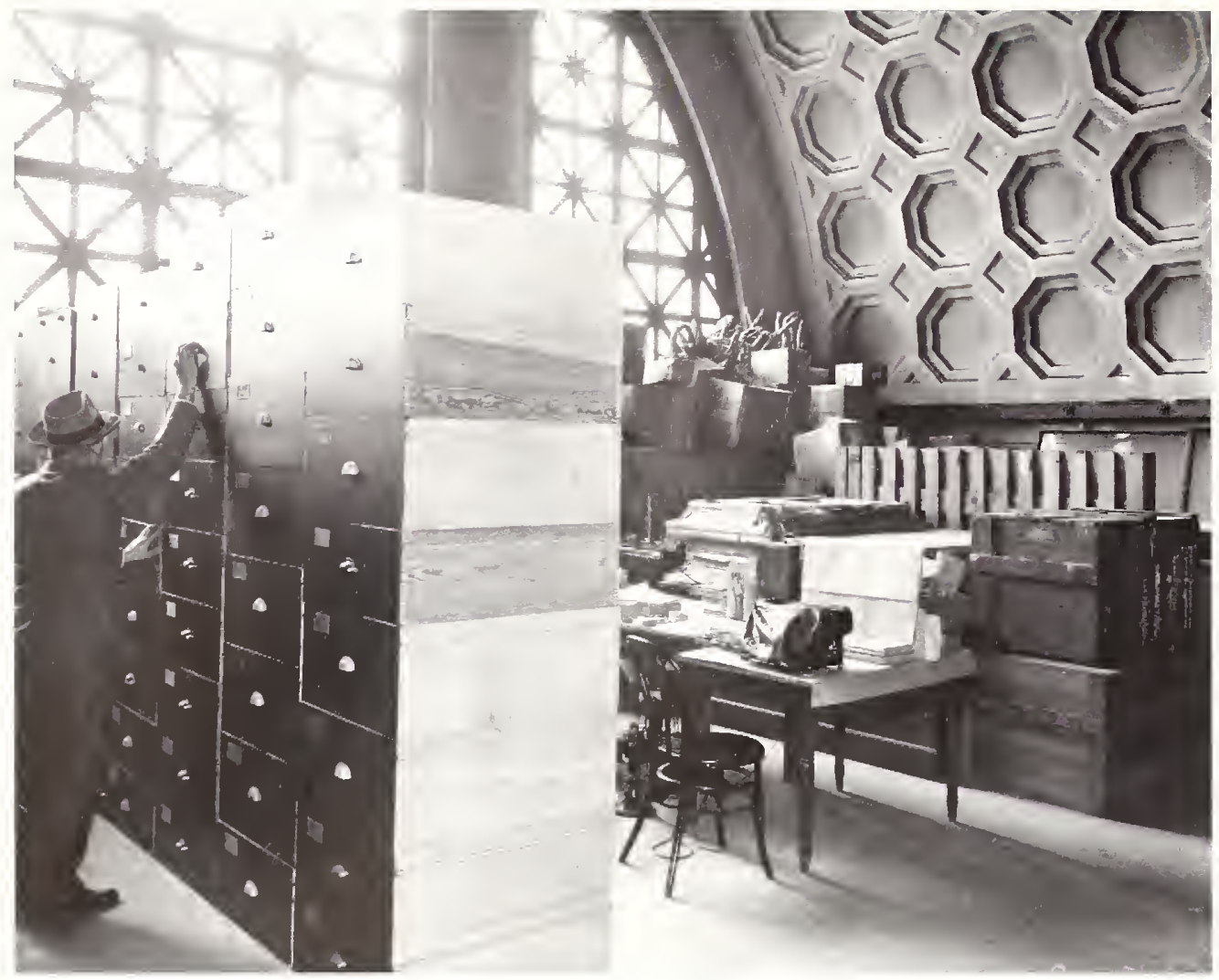

Storage of human bones and skulls on the fourth floor of the south pavilion, just off the rotunda; the hat gives some indication of temperature. Invariably the needed material is in the lowest of the stacked drawers. January 1950.

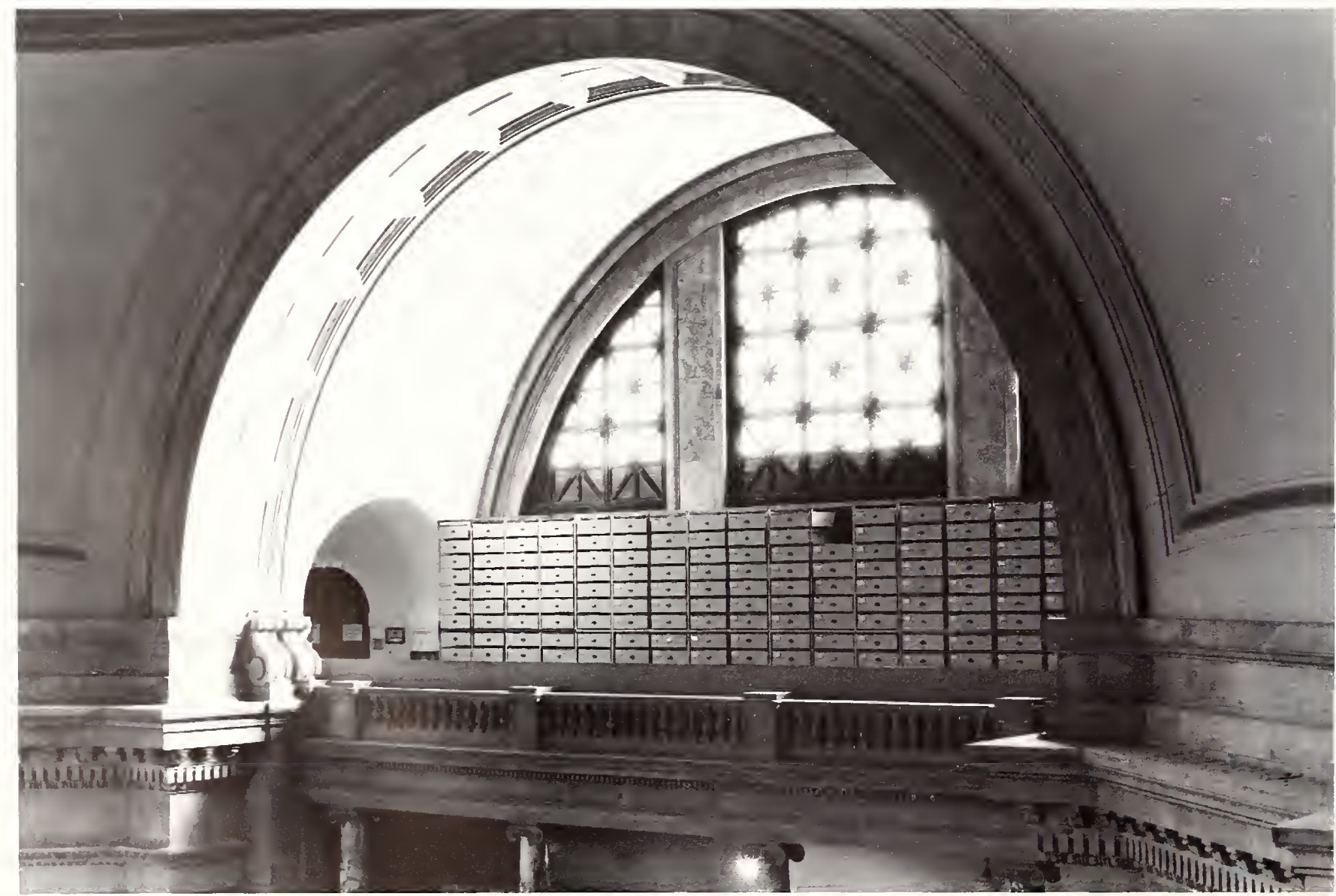

Storage of bones in the rotunda. February 1977. The drawers are in racks, a major advance over stacking them. 


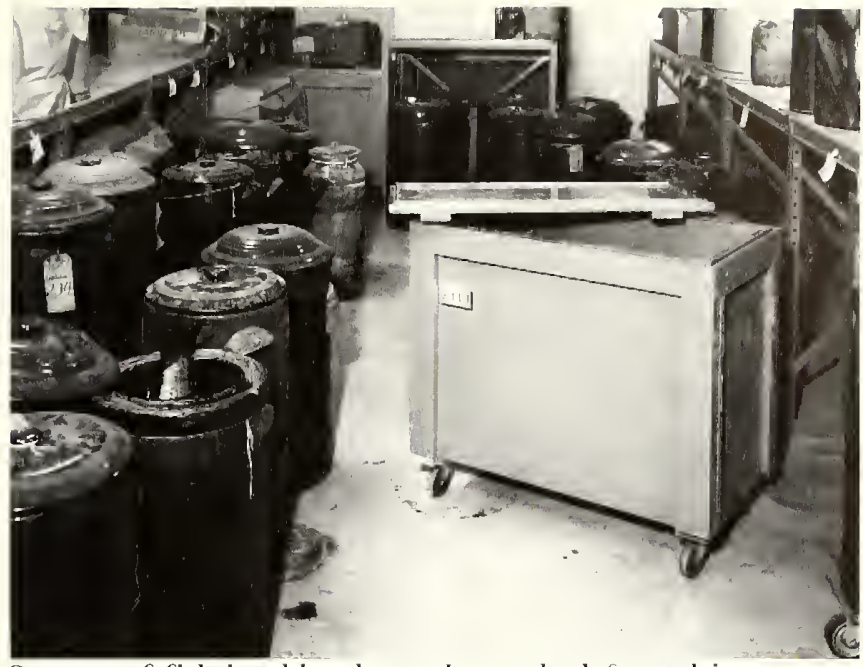

Storage of fish in old-style crocks, to the left, and in new tanks on wheels, to the right. There is little evaporation from the tanks. Late 1960 s or early 1970 s.

A realistic estimate in the light of the growth study was that by the year 2010,125 million specimens should be on hand. Whatever the exact numbers of specimens might be, it did not take much to realize that the building would not hold them.

During the 1960s, when Richard Cowan was director, there was considerable concern about future crowding in the Museum, in spite of the new wings. As one solution, Cowan suggested the idea of moving part of the staff and their collections to the Agricultural Research Center in Beltsville, Maryland, where there would have been space to construct a suitably large building to accommodate both staff increase and collection growth. The departments to be moved were those of Botany, Entomology, and Invertebrate Zoology. There were positive aspects to the plan, but it was not approved, in part because removing so many of the scientific staff from the Mall area would have meant splitting the Museum.

In the early 1970 s, committees studied the future space requirements of the Museum of Natural History and of all the Smithsonian museums. Eventually the notion evolved of moving some of the less-used collections, general facilities such as the Oceanographic Sorting Center, and the preservation and conservation laboratories to Silver Hill, Maryland, where the Smithsonian owned land and already had some storage facilities. During Porter Kier's directorship, this crystallized into what has now become the Museum Support Center. As Kier recalls the crucial conversation, he went with Richard Grant of Paleobiology, then head of the Senate of Scientists, to discuss the matter of a major new facility with Secretary Ripley. After extended discussion, Ripley summarized, "You mean to saddle the Institution with the incubus of ever increasing collections," to which Grant responded, "Yeah, I guess that's about it."

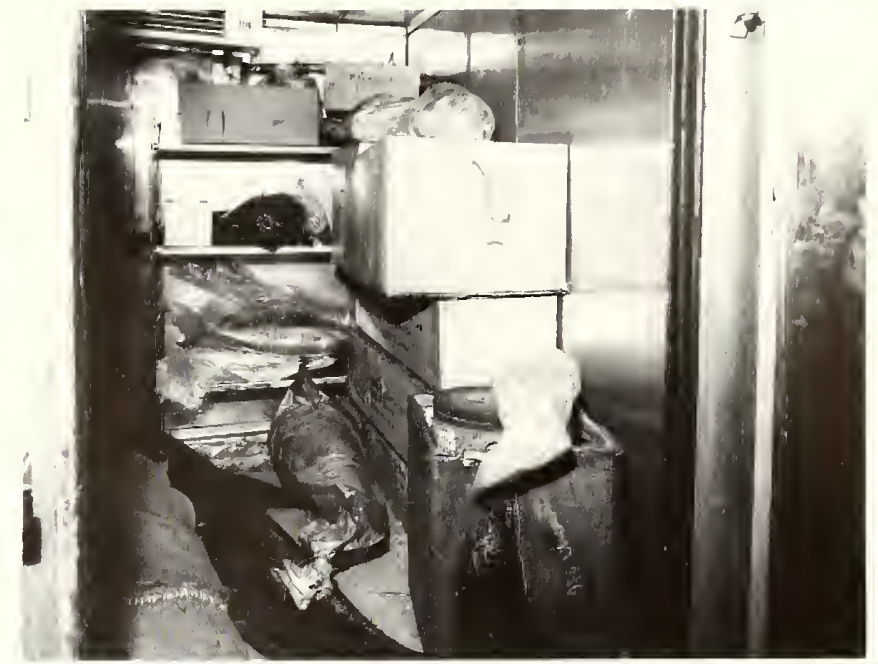

Frozen fish in a freezer in the basement of east wing.

\section{Museum Support Center}

Whatever was the deciding factor, the process of congressional authorization and appropriation was started. "The Museum Support Center, as it is titled, all 308,566 square feet of it, will be opened in 1983," Ripley wrote in Smithsonian Year 1981. "Say what one may, the 'trip' has been necessary. . . . the Smithsonian must realize its destiny to build a storage and retrieval center second to none."

The facility was dedicated on May 16, 1983. The building itself cost $\$ 29,000,000$, and storage and laboratory equipment will bring the total to $\$ 50,000,000$ about twice the cost of the wings, air conditioning, and refurbishing of the Museum during the 1960s. The newspapers got it right in dubbing this facility "the nation's closet" and not harping on cost. ${ }^{8}$ After all, no one keeps a mink coat in a hot drawer during the summer, and that was fundamentally what the Museum had been forced to do with the collections.

The Museum Support Center is two stories high and covers four and one-half acres, most of the area being taken up by four huge storage "pods." Each of the pods, described as "giant thermos bottles" by the center's director, Vincent Wilcox, is roughly the size of a football field. They are air-conditioned to seventy degrees and humidified to fifty percent by fourteen cooling units weighing twenty-five tons each. About 300 people work at the Support Center. Specimens are treated and studied in fifty-five laboratories fitted with special glass plumbing pipes which, unlike the old pipes in the Natural History Building, will not drip into the light fixtures.

An "Ode to the Museum Support Center" was read over the radio the day of the dedication. The third verse ran: 


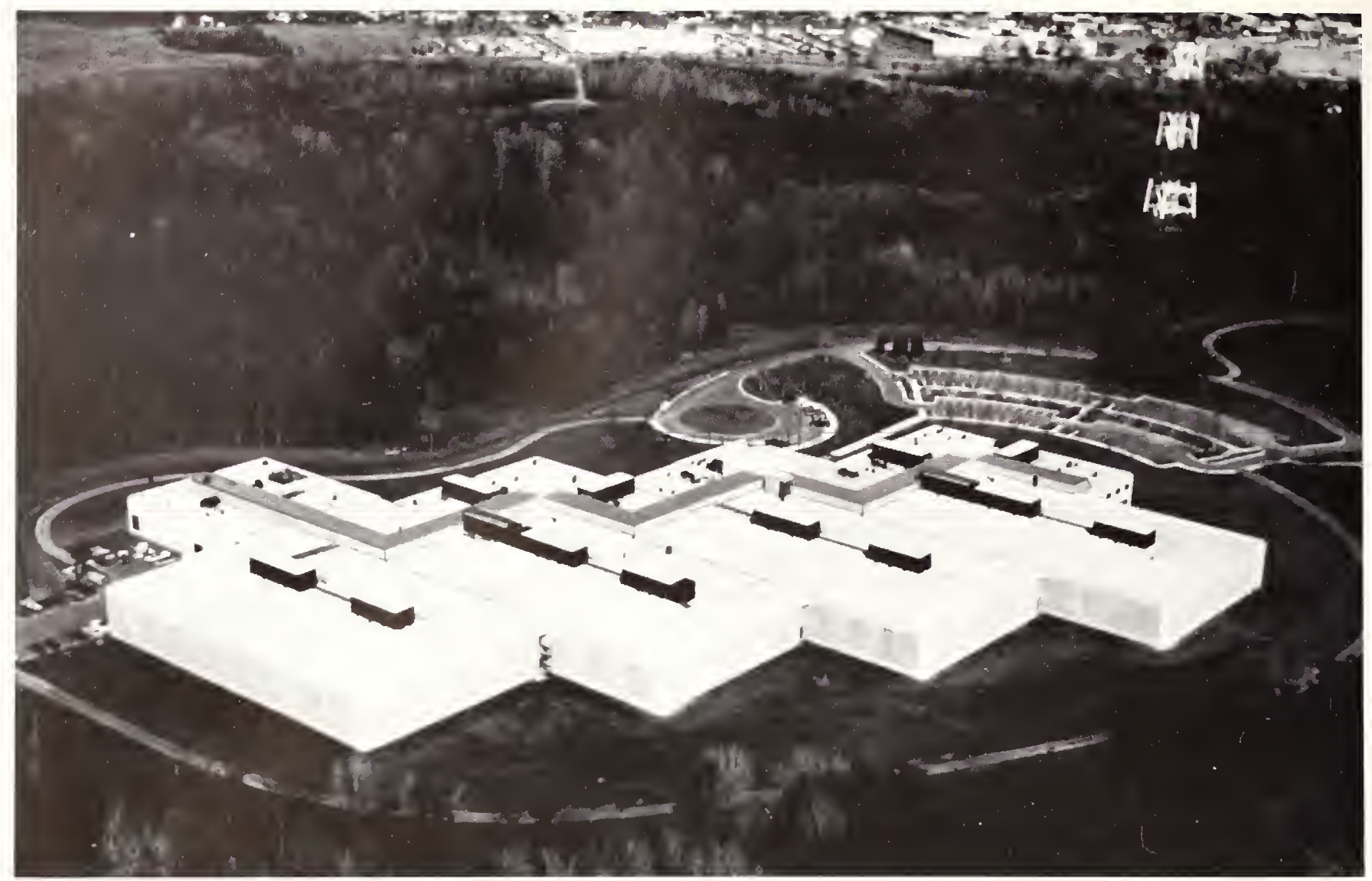

Museum Suppont Center, Silier Hill, Mandand.

The place at Suitland, Maryland, is made of concrete blocks,

And here now the Smithsonian will keep its extra stocks

Of everything it doesn't really need now right away

But thinks that very likely it will want to use some day."

The transfer of collections to the Smithsonian's Support Center is not the sime as the move from the Castle to the first National Museum, the journey across the Mall in 1910, or the spreading into the wings. The first three were expansions of previous activities; this is a new concept. It is a fairly safe prediction that the major events of the next twenty-five years in the history of the Museum of Natural History will be linked to his new facility.

New space provides new opportunities and presents new problems. The Museum Support Center will be a museum of record like none before. It will certainly bring out new approaches to the collections. The question of what is to be moved and what is to stay has already generated a great deal of controversy and will generate more, but the nation's treasures are being preserved for posterity in better condition than could ever have been realized in Rathbun's attics.

\section{Finale}

In seventy-five years, the Museum of Natural History has gotten bigger, and in many ways it has gotten better. Its halls have shaken out the hodgepodge of its first fifty years to achieve a steady focus on natural history. It is entertaining and educating over six million visitors a year. It gathers millions of fresh samples from nature every year, and has learned to keep track of them. During three-quarters of a century, the workers within its walls have given good service in performing the functions of record, research, and exhibit, and it "remains the nation's most important center for systematic research." "In the final analysis, because the Museum is a government bureau, the Congress must decide whether the taxpayers it represents have gotten their money's worth. On the other hand, it may be equally appropriate for the Museum to question the nation. Perhaps both nation and Museum would pass the twoway test proposed by George Brown Goode, again capitalizing as he did on the rare occasions when he thought it important: "THE DEGREE OF CIVILIZATION TO WHICH ANY NATION, CITY OR PROVINCE HAS ATTAINED IS BEST SHOWN BY THE CHARACTER OF ITS PUBLIC MUSEUMS AND THE LIBERALITY WITH WHICH THEY ARE MAINTAINED." 11 


\section{Notes}

\section{The United States National Museum}

\section{Goode, G. B. 1893. The genesis of the United States} National Museum. Report of the United States National Museum for 1891, part 2:273-380. Although there is a lot of quoted material in a fine type size that strains the eyes, this is an interesting historical account that demonstrates that the times and the resources have to be right for a good idea to succeed.

2. The question of just when the Museum began has been debated for decades. Smithsonian Deputy Archivist William A. Deiss provided a great deal of data in his memorandum to me of January 27, 1981. In my view, the National Museum began in 1858 when Henry convinced the Congress that support of a museum was an appropriate expenditure of public funds. An early sign over exhibits in the Castle is illustrated in Karp, W., I965, The Smithsonian Institution (Smithsonian Institution, Washington, D.C.). The book has considerable merit but is no longer in print.

3. Rathbun, Richard. 1905. The United States National Museum: An accoumt of the buildings occupied by the national collections. Report of the United States National Museum for 1903 , pp. 177-309. This is virtually the only information on the small brick building whose direct descendant is Exhibits Central, and on the Armory, whose direct descendant is the Museum Support Center.

4. Because the centenary of the Smithsonian lnstitution occurred shortly after the close of World War II, virtually nothing was written in a historical vein except a series of papers in a centennial issue of Science (vol. 104, August 9, 1946); this was curtailed because of a paper shortage. A brief general account was prepared for the public, with what were for its time profuse illustrations, by True, W. P., 1946, The first hundred years of the Smithsonian Institution, 1846-1946, 64 pp. True was an editor for the Smithsonian, the son of $\mathrm{F}$ W. True, Assistant Secretary at the time the Museum of Natural History was built. Since the 1950s, a great deal has been written and illustrated about the Smithsonian, much of it delightful to look at and a pleasure to read. A scholarly account of the early days that sheds a bit more light on federal funding is that of Washburn, W. E., 1977, "A national museum," pp. 20-27, in The Smithsonian Experience (New York: W. W. Norton \& Co.). The first fifty years of the Smithsonian Institution, including the early years of the United States National Museum, are chronicled in excruciating detail by Rhees, W. J., 1901, The
Smithsomian Institution, documents retative to its origin and history 1835-1899 (in two volumes). The sesquicentennial might provide an opportunity for later editors to put an approximate date on some of the old pictures, develop more precise chronologies, and offer some of the Rhesian type of detail concerning the great expansion of the Smithsonian between the 1950s and the 1980s.

5. Logan, Mrs. John A. 1901. Thirty years in Washington or hife and scenes in our national capital. Hartford: A. D. Worthing \& Co., 752 pp.

6. Rathbun, op. cit., 263.

7. I have drawn my account of the career of Goode from Oehser, P. H., 1949, Sons of science: The story of the Smithsomian 1ustitution and its leaders (New York: Henry Schuman). Oehser is a poet who for many years was the chief editor for the Smithsonian. Perhaps his view of the Smithsonian is a bit romanticized, but as one of those people dedicated to the Institution, he certainly is qualified to view it in this light. If Oehser writes that it happened, one can be certain it happened. His book is out of print, another loss that should be remedied.

8. Merrill, G. P. "An historical account of the Department of Geology in the U. S. National Museum." This is a rough draft of an incomplete manuscript prepared by Merrill and located in the Department of Mineral Sciences library. 1t includes material written at several different times. As there is mention of the appointment of Alexander Wetmore as director, it is probable that this copy was in preparation during 1926-27; Merrill died in 1929. Unfortunately, there is no comment on the death of C. D. Walcott, which occurred early in 1927. The manuscript is a mine of detail about the Department of Geology, and is one reason that department is mentioned more than others. A few additional drafts and other papers are associated with it. The quote, about how bad the old museum was, was taken by Mason (see note 2, chap. 2) from a pencil-written sheet; perhaps Merrill died before it was completed, or perhaps he decided not to include it, though he certainly spoke the truth.

9. Goode, G. Brown. 1895. The principles of museum administration. Armual report of the Museums Association for 1895: 1-73.

10. Rathbun, op. cit., 250.

11. Willis, Bailey. 1947. A Yanqui in Patagonia. Stanford University Press, p. 32. 
12. Rathbun, R. 1905. Report upon the condition and progress of the U.S. National Museum during the year ending Jume 30, 1903. For years Rathbun wrote the annual reports of the Museum, and I have read every one he wrote in this century, as well as those by his successors. Most of the information cited stems from these reports. Not every fact has to be documented, but I am old-

fashioned enough to believe that the sources of quotes should be cited. 1 also recognize that giving the full title and the number of pages in each report would be more than is needed. In fact, these should be cited as "Appendix to" the Smithsonian annual report, but that would incleed be sterite scholarship. Other annual reports by Rathbun and his successors are cited in a more abbreviated fashion. Further, some of the material is taken from departmental reports written by Hough, Merrill, True, and the various head curators who succeeded them, but it is expedient (even though not correct) to cite Rathbun or his successors.

\section{The New Building}

1. Rathbun, R. 1913. A descriptive account of the building recently erected from the departments of natural history of the United States National Museum. United States National Museum Bulletin 80:16.

2. Mason, B. 1975. Mineral sciences in the Smithsonian Institution. Smithsomian Contributions to the earth sciences 14:1-1I.

3. Girouard, M. 1981. Affred Waterhouse and the Natural llistory Museum. London: British Museum of Natural History.

\section{Building the Building}

1. Rathbun, R. I906. Anmual refort for the year ending June $30,1907, \mathrm{p}, 13$.

2. Ibicl., 12.

3. National Museum. Washington Sunday Stat, Aug. 13, 1905.

4. Cirouard, M. 1981. Alfred Waterhouse and the Naturat Iliston Museum. London: British Museum of Natural History, p. 7

5. Rithbun, R. 1906. Anmual report for the year ending June 30,1906, p. 7

6. Washington Post, October 28, 1906.

7. Rathbun, R. 1907. Anmuat report for the year ending Jume 30,1907, p. 15.

8. Willis, Bailey. 1947. A Yanqui in Patagonia, p. 32.

9. Rathbun, R. 1909. Anmual report for the year ending June 30,1908 .

10. Rathbun, R. 1909. Annual report for the year ending June 30,1909, p. 13.

11. Ibid.

12. Ibid., I4.

13. Rathbun, R. 1911. Anmual report for the year ending June 30,1910 , p. 13.

\section{Moving into Valhalla}

1. A history of the Division of Mollusks is being written by Harald Rehder, curator emeritus, who joined the staff in I932. He generously allowed me to examine his manuscript and draw from it.

2. Ibid.

3. Rathbun, R. 1909. Ammual report for the year ending Jume 30,1909, p. 15.
4. Ibid.

5. Gilmore, Charles W. 194I. A history of the division of vertebrate paleontology in the United States Museum. Proceedings of the United States National Museum 90:30577.

\section{The National Gallery of Art}

1. Rathbun, R. 1909. The National Gallery of Art: Department of fine arts of the National Museum. United States National Museum Bulletin 70.

2. Rathbun, R. I907. Anmual report for the year ending June 30, 1907, pp. 7-8.

3. Holmes, W. H. Quarters for the National Gallery of Art, undated seven-page typescript. Filed under National Collection of Fine Arts-History in the Library of the National Museum of American Art/National Portrait Gallery.

4. Walcott, C. D. 191 I. Annual report to the Board of Regents of the Smithsonian Institution showing the operations, expenditures and condition of the Institution for the year ending Jume 30, 1910.

5. Henderson, H. B. 1912. The art treasures of Washington. Boston: L. C. lage \& Co., p. 210.

6. Rathbun, R. 1913. Anmual report for the year ending June $30,1912$.

7. The "Random Records" of William Henry Holmes consist of fourteen volumes of documents, notes, watercolors, pictures, and other miscellanea that provide a wealth of detail on his life. Many facets of Smithsonian history not otherwise recorded can be found here. Why Holmes has not been the subject of a major biographical study is a mystery to me. I have not given references to the individual volumes, for all are carefully indexed, and the various items can be found easily.

8. Holmes, W. H. I926. Report on the National Gallery of Art including the Freer Gallery of Art. Annual Report for the year ending June 30, 1925, p. 52.

9. Holmes, W. H. 1931. Report on the National Gallery for 1931, pp. 43-44.

10. Holmes, W. H. 1924. Report on the National Gallery for 1927 , p. 57.

11. Taylor, J. C. 1978. National Collection of Fine Arts, Smithsonian Institution. 40 pp.

\section{Affiliated Organizations}

1. Bartlett, R. A. 1962. Great surveys of the American west. Norman: University of Oklahoma Press.

2. Hinsley, C. M., Jr. 1981. Savages and scientists: The Smithsonian Institution and the development of American anthropology 1846-1910. Washington: Smithsonian Institution Press.

3. Rabbitt, M. C. 1979. Minerals, lands, and geology, for the common defence and general welfare. Vol. I, before 1879 . Washington: U. S. Geological Survey. (Vol. 2, 18791904 , was published in 1980; vol. 3 is anticipated in 1985, and vol. 4 is in preparation.) Vol. 1, pp. 283-84, gives in full the text of the section of the act establishing the Geological Survey.

4. Dupree, A. H. 1957. Science in the Federal government: A history of policies and activities to 1940. Cambridge: Belknap Press of Harvard University Press. This is the reference for anyone who has a passing interest in how science and public policy interact. It should be required reading for all budding government scientists 
who wonder why the government does the variety of things that it does, and how that came about.

5. Chapin, Ray D. 1933. Science in the Department of Commerce. Scientific Monthly 36:193-99.

6. Sabrosky, C. W. 1964. Taxonomic Entomology in the U. S. Department of Agriculture. Bulletin of the Entomological Society of America 10(4):21 1-20.

7. Sterling, K. B. 1977. Last of the Naturalists-The career of C. Hart Merriam. New York: Arno Press, p. 70.

8. Howard, L. O. 1930. A history of applied entomology (somewhat aneclotal). Smithsomian Miscellaneous Collections, vol. 84:165. It is a pity that Howard was not in the Museum building, for he surely woutd have been a source of good stories. Between his history and the book by Sterling, one gets a fairly good notion of the difficult life of a federal scientist before World War I. It might be noted, in these days of advanced technology, that Howard's book was published in November 1930, and includes comments written earlier that year.

9. Spilman, T. J. 1984. Vignettes of 100 years of the Entomological Society of Washington. Proceedings of the Entomological Society of Washington, 86:1-10.

10. Sabrosky, C. W. 1964. Taxonomic Entomology in the U.S. Department of Agriculture. Bulletin of the Entomological Society of America 10(4):211-20.

11. Fisher, R. D. 1982. Museum section, U. S. Fish and Wildlife Service. Association of Systematics Collections Newsletter 10:29-31.

12. Judd, Neil M. 1967. The Bureau of American Ethnology, a partial history. Norman: University of Oklahoma Press, p. vii. Judd wrote in his preface, "The present writer, never a member of the B. A. E., knew most of its scientific staff from 1910 forward and held most of them in high regard. Because the majority of that staff have since passed to wider horizons and because their contributions will have more meaning in future years, it seems appropriate to record at this time at least a partial history of the Bureau and the people who made it what it was." This and Judd's later book are outstanding informal histories, preserving names and details that would otherwise be lost.

\section{New Exhibits, New Offices}

1. Rathbun, R. 1913. Annual report for the year ending June 30,1912 , p. 13.

2. Rathbun, R. 1912. Annual report for the year ending June 30,1911 , pp. 18-19.

3. New Exhibits Ready. Washington Sunday Star, Oct. 15, 1911 .

4. Merrill, G. P. An historical account of the Department of Geology in the U. S. National Museum (see note 8 , chap. 1), p. 56.

5. Ibid., 130 .

6. Ibid., 123.

7. J. E. Pogue, 10 May 1913. Division of Mineralogy and Petrology, U. S. National Museum, A record of its arrangement and activities, pp. 1-2. This is a twentypage manuscript found with the Merrill manuscript in the library of the Division of Mineral Sciences.

8. Ibid.

9. Lay figure ethnic groups of the National Museum. Washington Sunday Star, August 24, 1913.

10. Rathbun, R. 1913. Annual report for the year ending June 30,1912 , pp. 20-21.
11. Judd, N. M. 1968. Men met along the trail: Adventures $m$ archeology. Norman: University of Oklahoma Press, pp. $48-51$

12. Rathbun, R. 1915. Annual report for the year ending June 30,1914, p. 79.

13. Rathbun, R. 1913. Annual report for the year ending June 30,1912, p. 54

14. Ibid., 54-55.

15. Forbes, J. R. 1966. In the steps of the great American zoologists: William Temple Hornaday. New York: M.

Evans \& Co., p. 79. The account of the instatlation of the buffalo group in the National Museum is quoted in this book from the Washington Star, March 10, 1888.

16. Rathbun, R. 1915. Annual report for the year ending June 30,1914 , p. 114.

17. Ravenel, W. de C. 1919. Annual report for the year ending June 30, 1918, plates 1 and 2.

18. Blackwetder, R. E. 1979. The zest for life or Waldo had a pretty good run; the life of Waldo LaSalle Schmitt. Lawrence, Kans.: Allen Press.

\section{The Great War and Its Lingering Aftermath}

1. Rathbun, R. 1918. Annual report for the year ending June 30,1917 , p. 90.

2. Merrill, G. P. An historical account of the Department of Geology in the U. S. National Museum (see note 8, chap. 1), p. 62.

3. Ibicl., 70.

4. Rathbun, R. 1918. Annual report for the year ending June 30,1917, p. 14.

5. Ravenel, W. de C. 1919. Annual report for the year ending June 30, 1918, pp. 50-51.

6. 1bid., 14-15.

7. Ravenel, W. de C. 1920. Annual report for the year ending June 30, 1920, p. 22.

8. Ibid., 26.

\section{Interregnum}

1. Ibid., 15.

2. Ravenel, W. de C. 1923. Annual report for the year ending June 30, 1923, p. 3.

3. Walcott, C. D. I925. Annual report for the year ending June 30, 1925, p. 2.

4. Wetmore, A. 1925. Annual report for the year ending June 30, 1925, p. 26.

5. Snow, D. W. 1979. Obituary-Alexander Wetmore. Nature 278:490.

6. Stewart, T. D. 1982. Reminiscences. In Plains Indian Studies, a collection of essays in honor of John C. Ewers and Waldo R. Wedel, ed. D. H. Ubelaker and H. J. Viola. Smithsonian Contributions to Anthropology 10:40-42.

7. Wetmore, A. 1930. Annual report for the year ending June 30, 1930, pp. 30-31.

8. Wetmore, A. 1933. Annual report for the year ending June 30, 1932, p. 51.

9. Wetmore, A. 1931. Annual report for the year ending June 30, 1931, p. 34.

10. Wetmore, A. 1933. Annual report for the year ending June 30, 1932, p. 10.

11. Wetmore, A. 1935. Annual report for the year ending June 30, 1934, pp. 8-9.

12. Wetmore, A. 1936. Annual report for the year ending June 30, 1935, p. 9. 
13. Wetmore, A. 1939. Annual report for the year ending June 30, 1938, p. 10.

14. Wetmore, A. 1941. Annual report for the year ending June 30, 1940, pp. 10-11.

\section{World War II}

1. Wetmore, A. 1943. Annual report for the year ending June 30, 1942, p. 11.

2. Wetmore, A. 1946. Annual report for the year ending June 30, 1945, p. 7.

3. Wetmore, A. 1943. Annual report for the year ending June 30, 1942, p. 11.

4. Ibid., 59.

5. Wetmore, A. 1944. Annual report for the year ending June 30, 1943, p. 8.

6. Wetmore, A. 1945. Annual report for the year ending June 30, 1944, pp. 8 and 9.

7. Wetmore, A. 1944. Annual report for the year ending June 30, 1943, p. 8.

8. Wetmore, A. 1945. Annual report for the year ending June 30, 1944, p. 6.

9. Wetmore, A. 1944. Anmual report for the year ending June 30, 1943, p. 9.

10. Ibid., 29.

\section{New Faces, New Funds, New Exhibits}

1. Wetmore, A. 1939. Annual report for the year ending June 30,1938, p. 3.

2. Fenton, W. N. 1982. John Canfield Ewers and the great tradition of artists and ethnologists in the west. In Plains Indians Studies, a collection of essays in honor of John C. Ewers and Waldo R. Wedel, ed. D. H. Ubelacher and H. J. Viola. Smithsonian Contributions to Anthropology 10:218.

3. Van Beek, G. Unpublished obituary of Clifford Evans, in the author's files.

4. Ripley, S. D. and Steed, J. A. Alexander Wetmore. National Academy of Sciences: Biographical Memoirs. (In press.)

5. Fire damages Indian Exhibit at museum. Washington Post, May 26, 1965.

6. Carmichael, L. 1955. Annual report for the year ending June 30, 1954, p. 1.

7. Donnelly, T. 1954. The Smithsonian keeps up with the Joneses. Washington Daily News (April 13);

McDade, M. 1954. Institution shakes off old tradition. Washington Post and Times Herald (April 18).

8. Ewers, J. C. 1956. New ethnological exhibits United States National Museum Washington, D. C. Museum 9 (1):28.

9. Exhibit depicts early America. The Washington Post and Times Herald, Jan. 20, 1957.

10. Kellogg, A. R. 1958. Anmual report for the year ending June 30, 1957, p. 5.

11. Forbes, J. R. 1966. In the steps of the great American zoologists: William Temple Hornaday. New York: M. Evans, pp. 107-8.

12. Beggs, T. M. 1959. Annual report of National Collection of Fine Arts for 1958, p. 108.

13. I grew my beard in 1959, and was the subject of Dr. Friedmann's comment. 1 have pondered it often since that moment, but 1 have never been able to frame an appropriate reply.
14. Kellogg, A. R. 1962. Annual report for the year ending June 30, 1961, p. 11.

15. Gunnerson, J. H. 1982. Waldo R. Wedel, archeologist: Perspectives that grew in the plains. In Plains Indians Studies, a collection of essays in honor of John C. Ewers and Waldo R. Wedel, ed. D. H. Ubelaker and H. J. Viola, Smithsonian Contributions to Anthropology 10.

16. Ripley, S. D. 1968. Smithsonian Year 1965, p. 11.

17. Anonymous. Herbert Ward (1863-1919).

Unpublished four-page document in Department of Anthropology files.

18. Ross, N. L. 1967. Spirited exhibit opens, Washington Post (Aug. 26).

\section{New Wings and a New Elephant}

1. Fénykövi, J. 1956. The biggest elephant ever killed by man. Sports Illustrated, June 4.

2. Brown, W. L. Steps in mounting the Fénykövi elephant. Two-page typescript in the files of the Division of Mammals.

3. Deaton, N. N. "The Fénykövi elephant." Five-page typescript in the files of the Division of Mammals.

4. Rathbun, R. 1918. Appendix N. The Smithsonian lnstitution and National Museum, in Public buildings in the District of Columbia. 65th Congress, $2 \mathrm{~d}$ session. Senate Document 155:361-97.

5. Wetmore, A. 1928. Annual report for fiscal year 1928, p. 7.

6. Natural History Building wing enlargement sought. Washington Post, March 31, 1930.

7. Wetmore, A. 1930. Annual report for the year ending June 30, 1930, pp. 5-6.

8. Smithsonian Archives RM 157, Building Management Department, 1881-1973 records, Box 16, I 2.

9. Beggs, T. 1963. Annual report of National collection of fine arts for 1962, p. 4.

10. Kellogg, A. R. 1962. Annual report for the year ending June 30, 1961, p. 4.

11. Taylor, F. A. 1964. Annual report for the year ending June 30, 1963, p. 4.

12. Kellogg, A. R. 1962. Annual report for the year ending June 30, 1961, pp. 5-6.

13. Ripley, S. D. 1968. Smithsonian Yeaĩ 1965, p. 89. Priority of publications is a concern of many scientists, particularly those in taxonomy. For many years, the Smithsonian Library stamped the date of receipt in the front of books. This is how 1 know when the 1965 Yearbook was published. Such information is not of much use when matters of priority are not involved, so other yearbooks will be cited by the date given on the title page, except for one or two 1 have seen that are stamped with a different date of receipt.

\section{Big Science: Deep Space, Deep Waters}

1. Taylor, F. 1964. Annual report for fiscal year 1963, p. 86.

2. Ripley, S. D. 1968. Smithsonian Year 1965, p. 37.

3. Ripley, S. D. 1971. Smithsonian Year 1971, p. 34.

\section{4. "Modern Times"}

1. Taylor, F. A. 1964. Annual report for the year ending June 30, 1963, p. 3.

2. Ripley, S. D. 1969. Smithsonian Year 1968, p. 79. 
3. Smithsonian Institution. 1971. General hearings before the Subcommittee on Library and Memorials of the Committee on House Administration, House of Representatives (Hearings held in Washington, D. C., July 1970). 9 lst Congress, 2d session, 2 vols. p. 181.

4. Ripley, S. D. 1970. Smithsonian Year 1970, p. 30.

5. Ripley, op. cit., p. 9.

6. Park, E. 1976. Around the Mall and beyond. Smithsonian 7 (1): 1180 .

7. Harney, T. 1974. 'New Wave' of NMNH exhibits to show fundamental concept. Torch (January).

8. Ibid.

9. Ripley, S. D. 1974. Smithsonian Year 1974, p. 78.

10. Park, E. Around the Mall and beyond. Smithsonian 6 (8).

11. Exhibits such as the Splendors of Nature are best illustrated by color. By far the most lavish book on the present Museum exhibits, profusely illustrated, is by Kopper, P. 1982, The National Museum of Natural History (New York: Harry N. Abrams), 496 pp.

12. Ripley, S. D. 1979. Smithsonian Year 1978, p. 47.

13. 1980. Dale Crowley, Jr., Individually and in his capacity as Executive Director of the National Foundation for Fairness in Education, et al., Appellants, v. Smithsomian Institution et al. No. 79-1193.636 Federal Reporter, second series: 738-44.

14. Harney, T. 1980. Undersea creatures living in lab. Torch (October).

15. Ripley, S. D. 1975. Smithsonian Year 1974, p. 75.

16. Madden, J. C. 1978. Bridge between research and exhibits-the Smithsonian Naturalist Center. Curator 21 (2): 159-67.

17. It has been traditional that the Secretary of the Smithsonian be a productive scientist, and S. Dillon Ripley has maintained that tradition. His activities and accomplishments as Secretary have been much commented upon, but somehow little note has been taken of his work in ornithology. Probably the most balanced newpaper account of his activities as Secretary is given by Lardner, J., S. Dillon Ripley, Keeper of the Castle, Washington Post, November 7, 1982. An important record of some of the events during the first few years of the Ripley era is the book by Paul H. Oehser, 1970, The Smithsonian Institution (New York: Praeger Publishers). In 1983 a revised edition of 224 pages was written with the assistance of Louise Heskett, and published by the Westview Press, Boulder, Colorado.

18. Some of the prior research and field work of Robert McC. Adams is listed in Smithsonian Institution Research Reports number 42, Spring 1984.

\section{Museum Administration}

1. Goode, G. B. 1891. The museums of the future. Report of the United States National Museum for $1888-$ 1889, p. 437.

2. Ravenel, W. de C. 1920. Annual report for the year ending Jume 30, 1919.

3. Ripley, S. D. 1976. Appreciations, vii-viii, in Collected papers in avian paleontology honoring the 90th birthday of Alexander Wetmore, ed. S. L. Otson, Smithsomian Contributions to Paleobiology 27.

4. Snow, D. W. 1979. Obituary-Alexander Wetmore. Nature 278:490.

5. Whitmore, Frank C., Jr. 1983. Remington Kellogg
1892-1969, in Geology and Paleontology of the Lee Creek Mine, North Carolina I, ed. Clayton E. Ray, Smithsonian Contributions to Paleobiology 63:19-20.

6. A tribute to Miller was presented by a number of his colleagues who prepared vignettes of his life and encounters with them; appended to this is Miller's bibliography of 400 papers. 1937. Gerrit Smith Mitler, Jr. Joumal of Mammalogy 35 (3):317-29.

7. Angel, J. L. 1976. T. Dale Stewart. American Journal of Physical Anthropology 45:521-30. In onty two pages, followed by Stewart's bibliography, Angel summarizes nicely the work of this physical anthropologist for a Festchrift issue of the journal, an honor in any field. Additional information comes from Who's Who, where he is listed as starting with the museum in 1927.

8. Zinman, D. 1971. Fortunately for sea urchinsperhaps for all of us - there still exist many who want only to find out all there is about sea urchins. Washington Post, Potomac Magazine (Jan. 3).

9. Ripley, S. D. 1973. Smithsonian Year 1973, p. 3.

10. Churchman, D. 1983. Husband heads a museum in D.C., and so does the wife. Baltimore Sun (Nov. 24).

\section{The Scientific Staff}

1. Rathbun, R. 1901. Annual report for fiscal year 1901, p. 41 .

2. Rathbun, R. 1909. Annual report for the year ending June 30, 1909, pp. 63-64.

3. Rathbun, R. 1911. Annual report for the year ending June 30, 1910, pp. 73-74.

4. Ravenel, W. de C. 1920. Annual report for the year ending June 30, 1919, p. 8.

5. Wetmore, A. 1933. Annual report for the year ending June 30, 1932, pp. iv-vi.

6. Nelson, C. M., and Yochelson, E. L. 1980. Organizing federal paleontology in the United States, 1857-1907. Journal of the Society for the Bibliography of Natural History 4:607-18.

7. Wetmore, A. 1935. Annual report for the year ending June 30, 1934, p. 15.

8. Howard, L. O. 1930. A history of applied entomology (somewhat anecdotal). Smithsonian Miscellaneous Collections, 84:180.

9. Ibid.

10. Judd, N. M. 1968. Men met along the trail: Adventures in archeology, pp. 52-53.

11. Van Beek, G. Unpublished obituary of Clifford Evans.

12. From elevator to entomology. Torch, April 1983.

13. Maxfield, D. M. 1980. Smithsonian maps new hiring goals. Torch (June). The Smithsonian Torch began as a letter to Credit Union members. It expanded a bit and became an Institution-wide newsletter. It ceased publication at least twice because of a shortage of funds, but has been printed monthly for about a decade. Current circulation of about 6,000 includes news media, though probably no libraries carry this newsletter. 1t is useful as a source of dates and information not given in Smithsonian Year.

14. Park, E. 1977. Around the Mall and beyond. Smithsomian 8 (2):34; Thomson, Peggy. 1977. Museum People. Englewood Cliffs, N.J.: Prentice-Hall. A nice account, though mainly about parts of the Smithsonian outside the Museum of Natural History. The sections on Rolland Hower and Tom Simkin give a fair sample of the people involved in natural history. 
15. Brown, R. W. 1956. Composition of scientific words. Published by the author. Although Dr. Brown approached several commercial publishers, they wanted to modify his work to such an extent that he finally decided to publish it himself. The first edition was printed in 1954 and distributed before Brown realized it contained too many errors. He then had the book reprinted, again at his own expense. "Brownie" had kept track of purchases, and he replaced each copy he had sold of the first edition, an action that cost him about $\$ 25,000$. All copies of the first edition were taken to his farm and burned in his fireplace for heat. Upon Roland Brown's death, the remaining stock of the book was willed to the Smithsonian Institution for sale. After a few years, foolishly, the books were remaindered. Eventually there was such a demand for this unique work that the Smithsonian Institution Press reprinted it.

16. Pamela Henson, an oral history specialist at the Smithsonian Archives, has studied this organization in some detail and prepared a summary of its early history. She has also contributed information from various oral histories to confirm some of the items of human interest.

17. Elaine R. S. Hodges, wife of Ronald Hodges of the Department of Agriculture, played a leading part in forming the Guild, and I have drawn from a general short account she prepared of the organization.

\section{Shared Facilities}

1. Clark, L. F. 1946. The library of the Smithsonian 1nstitution. Science 104:143-146.

2. Rathbun, R. 1913. Anmual report for the year ending June 30,1912, p. 108

3. Rathbun, R. 1914. Anmual report for the year ending June 30, 1913, pp. 110-111.

4. Tolman, C. 1944. Annual report of the National Collection of Fine Arts for 1943, p. 27.

5. Wetmore, A. 1944. Ammual report for the year ending June 30, 19.43, p. 11.

6. Wetmore, A. 1930. Anmual report for the year ending June 30,1930, p. 29.

7. Ripley, S. D. 1968. Smithsonian Year 1967, pp. 29-30.

8. Ripley, S. D. 1968. Smithsonian Year 1966.

9. Squires, D. F. 1970. An information storage and retrieval system for biological and geological data. Curator 13:43-62.

10. Ripley, S. D. 1972. Smithsonian Year 1972, p. 53.

11. St. Thomas, L. 1983. First phase of inventory complete. Torch (July).

12. Ripley, S. D. 1969. Smithsonian Year 1969, p. 15.

13. Bond, C. 1984. It came from inner space. Smithsonian $15(3)$.

14. Very little has been written about the technicians and preparators at any period of time. An excellent reference is a short paper by Shufeldt, R. W. 1922, "Artisans of the National Museum," Museum Work, including the Proceedings of the American Association of Museums, vol. 5 (3):49-54.

15. Rathbun, R. 1916. Annual report for fiscal year 1915, p. 118.

16. Ravenel, W. de C. 1920. Annual report for the year ending June 30, 1919, p. 16.

17. J. E. Pogue. 1913. Division of Mineralogy and Petrology, U.S. National Museum, A record of its arrangement and activities, p. 18.

18. Wetmore, A. 1944. Annual report for the year ending June 30, 1943, p. 20.

19. In 1960 and 1961 Harold T. Merryman, the inventor of the technique wrote several articles in Curator. Rolland Hower, the perfector of the method, in 1962 prepared a small information leaflet, which grew into his book Freeze-drying biological specimens, 1979 (Washington: Smithsonian Institution Press).

\section{Shops and Maintenance}

1. Rathbun, R. 1909. Annual report for the year ending June 30, 1909, p. 13.

2. Rathbun, R. 1913. A descriptive account of the building recently erected from the departments of natural history of the United States National Museum. United States National Museum Bulletin 80, p. 79.

3. Wetmore, A. 1935. Annual report for the year ending June 30, 1934, p. 15.

4. Rathbun, R. 1917. Annual report for fiscal year 1916, p. 14.

5. Wetmore, A. 1928. Annual report for fiscal year 1928 , p. 31 .

6. Wetmore, A. 1939. Annual report for the year ending June 30, 1938, p. 16.

7. Rathbun, R. 1917. Anual report for fiscal year 1916, p. 13.

8. Judd, N. M. 1968. Men met along the trail: Adventures in archeology, p. 53.

\section{Others in the Building}

1. Kopper, P. 1982. Volunteer, oh volunteer-a salute to the Smithsonian's unpaid legions. Washington: Smithsonian Institution Press. 46 pp.

2. Volunteers of 1983, we salute you. Torch, January 1984. For the past several years the January issue has devoted four pages to volunteers.

3. These figures are compiled by the Independent Volunteer Placement Service, Smithsonian Institution.

4. Questions worth asking about the Discovery Room. Leaflet. April 1977.

\section{The Visitors}

1. Rathbun, R. 1913. Annual report for the year ending June 30, 1912, pp. 15-16.

2. Torch, April 1984.

3. Park, E. 1975. "Around the Mall and beyond. Smithsonian 6 (6).

4. Kellogg, A. R. 1962. Annual report for the year ending June 30, 1961.

5. Torch, April 1969.

\section{Public Places}

1. Washington Post, September 27, 1908.

2. Washington Post, October 9, 1908.

3. Walcott, C. D. 1909. Annual report for fiscal year 1909.

4. Rathbun, R. 1911. Annual report for the year ending June 30, 1910, p. 68.

5. Rathbun, R. 1913. Annual report for the year ending June 30, 1912, p. 78 .

6. Kask, J. L. 1971. Fisheries Service has of ten been foster child. National Fisherman 52 (2):4A, 13A. 
7. Washington Post, March 7, 1917.

8. Ravenel, W. de C. 1921. Anmual report for fiscal year 1921, p. 29.

9. Hohnes, W. H. 1929. Annual report of the National Gallery of Art for 1929.

10. Smithsomian year 1976, p. 101.

11. Seltzer, R. 1969. I ocal Nimrod gives tiger to Smithsonian. Philadelphia Inquirer, (Oct. 19).

12. Rathbun, R. 1913. A descriptive account of the building recently erected from the departments of natural history of the United States National Museum. United States National Museum Bulletin 80, p. 52.

13. Ravenel, W. de C. 1922. Ammal report for the year ending June 30, 1922, p. 18.

14. Ravenel, W. de C. 1924. Ammual report for the year ending Jure 30, 1924, p. 19.

15. Wetmore, A. 1929. Anmual report for the year ending June 30, 1929, p. 29.

16. Carmichael, L. 1959. Anmual report for the year ending June 30, 1958, p. 6.

17. Wetmore, A. 1929. Anmual report for the year ending June 30, 1929.

18. Harney, T. The National Museum of Natural History. Thirty-nine-page typescript in the files of the director's Office

\section{Outside the Building}

1. Rathbun, R. 1912. Anmual report for the year ending June 30,1912 , p. 17.

2. Ravenel, W. de C. 1923. Annual report for the year ending June 30, 1923, p. 17.

\section{The Collections}

1. Judd, N. M. 1968. Men met along the trail: Adventures in archeology, p. 49.

2. Yochelson, E. L. 1969. Fossils-the how and why of collecting and storing. In Natural History CollectionsPast-Present-Future. Proceedings of Biological Society of Washington, 82:585-602.

3. Ripley, S. D. 1972. On museum objects, truth, and education. Reflections of the Secretary of the Smithsonian Institution upon the one-hundred and twenty-fifth anniversary of its founding. Washington: Smithsonian 1nstitution Press.

4. Harney, T. 1978. The magnificent foragers. Washington: Smithsonian Exposition Books, p. 233.

5. Leslie, P. 977. "A report on the management of collections in the museums of the Smithsonian Institution." 131 pp., plus appendices; unpublished.

6. Ibid., A-47.

7. Ripley, S. D. 1982. Smithsonian Year 1981, pp. 3-4.

8. McCombs, P. 1983. The $\$ 50$ million closet. Washington Post (May 10).

9. The quote is verse three of a nine-verse "Ode to the Museum Support Center" read by Charles Osgood on the CBS radio network, May 16,1983 . The full text is in the Torch, July 1983.

10. A comment made in 1984 by David Challinor, Assistant Secretary for Science.

11. Goode, G. Brown. 1185. The principles of museum administration. Annual report of the Museum Association for 1895 , p. 73.

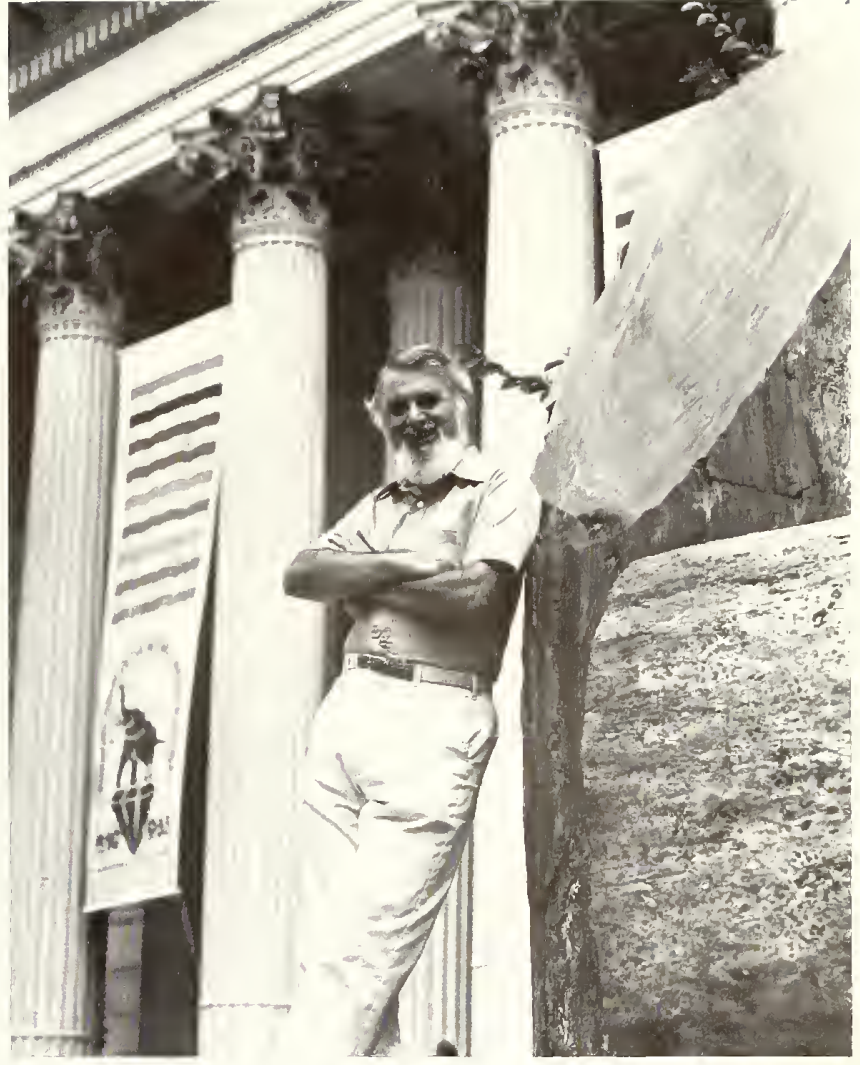

\section{About the author}

Ellis L. Yochelson, a paleontologist with the U.S. Geological Survey from 1952 until his retirement in 1985 , has had an office over the years in the National Museum of Natural History building; since 1967 he has been a research associate in the Museum's Department of $\mathrm{Pa}$ leobiology. A specialist in extinct mollusks, concentrating on the evolution of gastropods, Dr. Yochelson received B.S. and M.S. degrees from the University of Kansas and a Ph.D. from Columbia. He is a native of Washington, D.C., who attributes his interest in fossils to a mid-1930's trip to the Natural History Building where he saw the dinosaur exhibit for the first time.

Dr. Yochelson has written some 200 articles, reviews, and professional papers on paleontology. The many offices he has held include: president of the Paleontological Society; secretary of the Society of Systematic Zoology; organizer of the First North American Paleontological Congress; secretary-general of the Ninth International Carboniferous Congress; and, currently, secretary of the History of Earth Sciences Society. 


\title{
Index of Personal Names
}

\author{
Italicized numbers refer to illustrations
}

Abbot, Charles Greeley, 9, 37, 72, 83, $102,117,124$

Adams, Robert McCormick, 11, 126 , 211

Aldrich, Jolun M., 74

Alexander, Carl, 119

Anghim, John E., 88

Aschemeier, Charles R.W., 176

Baird, Spencer F., 9, 15, 16, 47, 48, 125, $129,130,147,180,199$

Bartsch, Paul, 35, 72, 74, 85, 137

Bassler, Ray S., 74, 80, 85, 159

Bayer, F.M., 173, 175

Bean, Barton A., 72

Becker, Ralph, 160

Benn, James, 74

Benson, Richard 11., 150, 152

Blackwelder, R.E., 167

Blake, Doris, 140

Blush, Leonard, 90

Boardman, Richard S., 191

Boss, Norman, 139

Brademas, John, 115

Braden, Susann. 155

Bradley, James C., 104

Braisted, Frank, 102

Brown, Roldnd W., 52, 85, 144, 212

Brown, Walter P'., 150

Brown, William L., 99, 101, 186

Buckles, James, 194, 195

Buechner, Helmut, 114

Burch, Beatrice, 113

Carmichael, Leonard, 10, 88, 89, 92, 101. $117,133,115,196$

Carter, Payson D., 169

Catlin, George, 14, 45

Chace, Femner, 112, 131

Challinor, David, 213

Chapin, Edward A., 74

Chase, Agnes, 50, 148

Churchill, Winston, 188

Clark, Austin H., 72, 125

Clark, Roy E., 116

Clarke, J.F. Gates, 81, 91, 112, 115, 141

Cochran, Doris M. 72, 108, 136,140

Cole, F.H., 57

Collins, Henry B., 72, 77, 130, 141, 142, 169

Cooper, G. Arthur, 74, 85, 92, 94, 106. $134,145,154,155,160,169,193,203$

Cooper, Josephine, 145

Cowan, Richard S., 10, 112, 131, 133, 194,205
Dall, William Healy, 35, 72

Davis, Donald R., 169

Deaton, Neal, 100, 101

Deiss, William A., 207

Desautels, Paul E., 92

Dowling, Andrew Jackson, 191

Duckworth, W. Donald, 119

Dunkle, David, 92

Dutton, C.E., 42

East, Charles S., 135

Eblen, Charles, 163

Egberts, W.G., $1+1$

Elliot, John, 45

Evans, Clifford, 86, 88, 121, 180

Evans, William T., 44

Ewers, John C., 86, 88, 89, 90, 91, 118, 148

leldmann, H. Adai, 113, 113

lenyövi, J.J., 99

Fiori, Charles, 110

lischer, Herbert, 160

Fishe, Richard S., 11, 132, 131

Foshag, William F., 72

Freer, Charles, 42

Frederick, Leon, 90

Fredrikkson, Kurt, 110

Freidmann, Herbert, 74, 86, 89, 90, 94, 112,144

Garber, Paul, 129, 155, 189

Gurdner, Julia, 82, 110

Gardner, Paul, 86, 188

Garfield, James A., 16

Gast, Carolyn, 108

Gazin, Lewis C., 92, 181

Gellatly, John, 44

Gibson, Gordon D., 94, 96, 145

Gilmore, Charles W., 36, 62, 75, 92, 191

Girault, A.A., 50

Glassell, Alfred C., Jr., 175

Glenn, Leroy, 121

Glover, Townsend, 50

Goode, George Brow'1, 9, 15, 16, 18, 19, $86,129,201,206$

Goodloe, William, 146

Gore, Ronald, 122

Graf, John, 72, 131

Grant, Richard E., 150, 205

Green, Bernard L., 24, 29

Green, Theodore, 175

Greenwell, Frank, 90, 101

Gutrick, Robert, 163
Handley, Charles O., Jr., 156

Harding, Warren G., 71, 180

Harmatuck, Peter J., 132

Harrington, John P., 141

Harris, Robert, 166

Hart, Harry, 188

Hayden, F.V., 42

Henbest, Lloyd G., 85

Henson, Pamela, 212

Henderson, Edward P., 72, 73, 75, 80, 92, $111,130,161,166,169,186,194$

Henry, Joseph, 9, 15, 16, 41, 42, 125, $147,179,207$

Hickey, Leo J., 119

Hirohito, Emperor, 173, 175

Hitchcock, A.S., 50

Hobls, Horton Ji ., 112

Hodge, F.W., 37, 53

Hodges, Elaine R.S., 212

Hodges, Ronald M., 212

Hogen, Helen, 45

Hollister, Ned, 72

Holmes, William Henry, 9, 42, 43, 44, 45, $53,58,61,62,63,72,89,92,96,102$, $137,1+1,157,180$

Hoover, Herbert, 75, 175

Hornaday, William T., 61, 62, 91, 92, 186

Hornblower, J.D., 24

Hormblower and Marshall, 19, 29, 99

Hotton, Nicholas $111,94,106$

Hough, Walter, 43, 1+1, 208

Howard, L.O., 50, 51, 139, 209

Hower, Rolland, 92, 154, 211, 212

Hrdlička, Alěs, 43, 62, 104, 133, 1 11, 142, 182

Hueber, Frances M., 197

Jewett, Charles, 147

Johnson, Lyndon B., 175

Johnston, Harriet Lane, 41

Judd, Neil M., 59, 63, 94, 140, 14l, 162, 209

Kajencki, Mimi, 203

Kellogg, A. Remington, 10, 72, 88, 91, 94, $96,101,102,106,107,130,131,132$, $133,135,141,153,161$

Kennedy, John F., 139

Kier, Porter M., 11, 102, 122, 129, 133, $134,135,142,205$

King, Clarence, 47

Knez, Eugene I., 94, 96

Knierim, P.K., 133

Knowles, William, 161

Knowlton, Frank H., 72 
Koch, Robert, 179

Kreiger, Herbert W., 72, 88, 90, 118, 141

Krombein, Karl V., 74, 79, 81

Lachner, Ernest A., 86, 108, 145, 150, 156

Langley, Samuel Pierpont, 9, 14, 16, 19, $19,24,29,43,57,62,125,180,181$

"Lanier", 161

Laybourne, Edgar G., 84

Lingebach, Carleton, 90

Loeblich, A.R., 199

Lutterlough, Sophie, 140

Lyons, Ulysses, 140

Mamay, S.H., 52, 106

Marquardt, Jack F., 157

Marsh, O.C., 191

Martin, Glenn, 45

Mason, Otis T., 14,19

Matternes, Jay H., 92, 94, 96

McCoy, George, 141

McGee, J W, 148

Mclntyre, Thomas, 156

McPhaul, Harrison, 167

Mead, James G., 157

Meek, Fielding Bradford, 42

Meggers, Betty J., 86, 88, 121, 140

Mello, James F., 11, 133, 135, 150, 188

Mellon, Andrew, 43, 44

Merriam, C. Hart, 50, 51

Merrill, George Perkins, 9, 24, 37, 57, 58, $61,62,65,72,74,80,154,194,207$, 208

Merryman, Harold T., 212

Miles, Beth, 119

Miller, Gerritt S., Jr., 130, 211

Mills, Petticourt and Mills, 104

Mirguet, John A., 35

Moodey, Margaret W., 38, 66, 73

Moran, Thomas, 183

Morrow, Dwight, 71, 72

Morton, Conrad V., 104

Muesebeck, C.F.W., 50

Murdoch, John, 149

Nelson, E.W., 183

Oberdorfer, Louis F., 124

Oberholser, Harry, 200, 202

Oehser, Paul H., 207

Osborn, Henry Fairfield, 19

Osgood, Charles, 213
Paine, R.G., $1+1$

Paridoso, John, 53

Pawson, David L., 96

Pell, Alfred Duane, 44

Perrygo, Watson M., 76, 79, 81, 82, 86, $90,90,92,130,135,146,161,186,188$

Peters, James, 145, 148

Peterson, Roger Tory, 186

Powell, John Wesley, 46, 47, 148, 182

Rathbun, Mary Jane, 39, 63, 74, 82, 138, 140

Rathbun, Richard C., 9, 19, 23, 24, 24, 27, 29, 30, 31, 35, 37, 41, 44, 59, 61, $62,67,72,75,102,105,122,129,132$, $137,147,159,185,191,195,196,208$

Ravenel, William deC., 9, 67, 71, 129, $130,132,180,185$

Ray, Clayton E., 160

Read, Robert W., 155

Reeside, John B., Jr., 62, 139

Rehder, Harald, 208

Reisenberg, Saul, 94, 145

Resser, Charles E., 74, 85

Ridgeway, Robert, 74

Riley, C.V., 50

Ripley, S. Dillon, 10, 81, 117, 118 , $125,126,130,134,138,142,152$, $194,203,205,211$

Roosevelt, Theodore, 62

Rosenbusch, Louise, 45

Rosewater, Joseph, 173

Ruetzler, Klaus, 144

Saarinen, Eero, 43

Saunders, Harold, 86, 200

Sayre, Reginald J., 116, 131

Schmitt, Waldo L., 63, 81, 83, 85, $108,111,112,167,180$

Schultz, Leonard, 108

Scollick, W.E., 69

Setzer, Henry W., 92, 203

Setzler, Frank, 80, 90, 141

Simkin, Thomas, 211

Smith, Albert C., 10, 94, 131, 132, 135

Smithson, James, 15, 102, 199

Snodgrass, R.E., 86

Soderstrom, Thomas, 131

Spaat 2, Arnold, 104

Springer, Victor G., 156

Squires, Donald, 133, 150

Stanford, Dennis J., 142

Stejneger, Leonhard, 9, 37, 61, 65, $76,82,92$
Stern, William L., 108

Stewart, T. Dale, 10, 72, 74, 77, 81, $94,112,128,132,133,134,141$, $169,182,211$

Steyskal, George, 112

St. Hoyme, Lucile, 83

Stirling, Matthew, 83

Sturtevant, William, 53

Switzer, George S., 92

Tawney, Madeline, 157

Taylor, Frank, 86, 107, 132

Terry, Charles, 141

Thompson, Eugene E., 65

Tolman, Ruel P., 43

True, F.W., 9, 61, 131, 207, 208

True, W.1'., 207

Truman, Harry S, I 75

Tyler, James C., 11, 134

Ulrich, E.O., 48, 62, 106

Van Beek, Gus, 142, 169, 182, 200

van Lerius, J.H1.F., 45

Vaughan, T. Wayland, 35

Walcott, Benjamin S., 65

Walcott, Charles Doolittle, 9, 18, 19, $42,61,65,71,92,124,125,137$, $179,180,181,207$

Walcott, Mary Vaux, 71

Wallen, Eugene, 113, 114

Ward, Henry, 96, 186

Washington, George, 76

Watkins, Malcolm, 76, 90, 94, 182, 199

Weaver, John, 96

Webster, G.D., 182

Wedel, Waldo, 77, 83, 92, 94, 96

Weiss, Helena B., 142

Wetmore, Alexander, 9, 10, 72, 74, $76,80,82,83,85,86,88,102,104$, $111,117,118,129,130,131,132$, $135,141,159,161,164,166,180$, 200, 202

Whitmore, Frank C., Jr., 130

Wilcox, Vincent D., 1I1, 205

Wilkes, Charles, 183

Willis, Bailey, 18

Wilson, Woodrow, 65, 181

Wise, Kenneth, 176

Yochelson, Ellis L., 210,213 


\section{Sources of Illustrations}

Plonographs were assembled from a variely of sources within the Institution. Unless otherwise indicated, the negatives are in the Smithsonian Photographic Services and are indicated by number. An asterisk indicates a copy negative made from a print. The current numbering system includes the date, but does not differentiate between views laken during the year and copy work. A double asterisk indicates a gloss-plate negalive.

Front cover, IINH 84-74; Back cover, $85-4046^{*}$; Half title page, MNH 19087; Title page, INH 823231 .

\section{Part One: The Structure}

13.2157I**; 14,57929**; 17 (top), 60190**; 17 (bollom), 2599*; 18, SA-742*; 19. Library National Museum of American Art; 20 (lop), $11305^{* *} ; 20$ (hollom), 2958**; 21 (lop), 9646**; 21 (hollom), 16846**; 22, MAl1-162999*;24, 85-402 l*; $25(t o p), 75-12392 * ; 25$ (muddle), 75-12388*; 25 (boltom), 75-12386*; 26 (tefl), Suithonian Arclives; 26 (right), Annual Repont for 1913, p. 16, 17; 27, Smithsonian Archives; 28, $18309 * ; 30$. MAII-16235*; 31. National Museum ol Amerlcall Art; 32 (lop), $17531 * * ; 32$ (bellom), $18546^{* *} ; 33$ (lop), 29(2)207**; 33

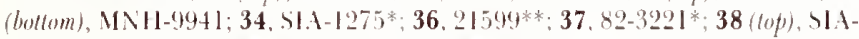
I273*; 38 (hollom), SIA-127I*; 39 (top). MNH1-26552; 39 (bollom), 1272; 40 31122-C; 42 (left), National Nuseum of American Art; 42 (nght), 23752**; 43, Nationd Vusenm of Amerit an Art; 44. National Museum of American Art;

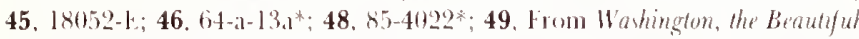
Capial of the Nation, O 1922 by William Olsen, National Acro-View Publishing Compan, Washington, 1).C.; 50. 85-4023*; $52(t o p), 85-4024^{*} ; 52$ (bottom), 85$\left.41)^{2}\right)^{*} ; 53,85-4025^{*}$.

\section{Part Two: The Exhibits}

$\mathbf{5 5}, 45429 ; \mathbf{5 6}, 28589^{* *} ; \mathbf{5 8}, 28196 * * ; \mathbf{5 9}, 28596^{* *} ; \mathbf{6 0}$ (top), 24872**; 60 (bollom), $28600^{2} * * ; 61,27073^{* *} ; 63,285\left(42 * * ; 64,85-4027 * ; 66(t o p), 85-4028^{*} ; 66(\right.$ bottom), 23904**; 67, 23905**; 68, Library National Museum of American Art; 69 (lop left), 9716-D; 69 (top nght), 26914-C; 69 (botlom), Division of Amphibians and Reptiles; 70. 85-4029; 73. National Museum of American Art; 74, 85-4035;
75 (left), 85-4030*; 75 (right), 85-4032*; 76, 85-4031*; 77, 28259**; 78, 28537; 80, Smithsonian Archives; 81, 41942; 82 (top), NH 33835-C; 82 (bottom), 28537; 83, MAH 30634-A; 84, 36818-A; 87 (top), 24875**; 87 (boltom), MNH 035; 88, John Ewers; 89, 27073; 90, 85-4034*; 93, Library National Museum of American Art; 93, Betty J. Meggers; 95, MNH 200; 97, MNH 893; 98, 85-4037*;

100. 85-4035*; 101 (lop), Women's Committee; 101 (bottom), Women's Committee; $102,85-4038 ; 103,43047 ; 104,85-4039 * ; 105,85-4040 ; 107$, MNH-955-C; 109 (top), MNH-776; 109 (bottom), P 63336-B; 110, MNH-783-C; 112, MNH 837-D; 113, MNI1-I448-B; 114, 85-4041*; 115 (top), 85-4042*; 115 (bottom), MNH 837; 116, 76-1260-7; 119, 78-9817-8; 120, 78-I5802; 122, 76-5049-34; 123, 85-4043*; 124, 77-3249-10; 126 (left), 85-4044; 126 (right), 85-4046.

\section{Part Three: The Museum}

127, 85-12069/26; 128, Thomas llanney; 130, 21314; 131, 1819-C; 132, 85. $4071-10 ; 133,78-3701 * ; 134$, Office of Director NMNII; $135(10 p), 436 \mathrm{~A} ; 135$ (bollom), 75-6027-2; 136, MNH-1092; 137, 85-4047*; 138, 85-4049*; 141 (lop), 85-4050*; 141 (middle), 42016; 141 (hottom), 85-4048*; 142, Elaine Hodges; 143 (top left), Aurhor original; 143 (boltom right), Author original; 143 (top right and bottom (efl), Elaine Hodges; 144, 11055-C; 145, 85-4051*; 146, 85-4052*; 149, $3666^{* *} ; 151,85-4053^{*} ; 152$, S1A-1276; 153, 85-4054*; 154, 85-4056*; 155, 85-4074-0; 156 (left), 85-4055*; 156 (right), 71-310; 157 (left), 85-4075-13; 157 (righit), 85-4075-12; 158,85-4057*; 160, U.S. National Museum Bulletin 80; $1613885 \mathrm{I}-\mathrm{F} ; 162$ 85-4072-20; 163 (top), 85-4077-17; 163 (middle), 85-4076-5; 163 (botlom), 85-4077-10; 164, 85-4058*; 166, 85-4059*; 167 (left), 85-4060*; 167 (top right), 85-4074-14; 167 (bottom right), 85-4079; 168, 85-4059*; 169, Naturalists Center; 170, 3669; 173, Thomas Harney; 174, 85-4061; 175 (left), 85-4062; 175 (nght), 85-4063; $176(10 p), 85-4036 ; 176$ (bottom), 85-4074-17; 177, $85-4074-5 ; 178,85-4065^{*} ; 180,28235^{* *} ; 181,21258^{* *} ; 182,85-4066^{*} ; 183$, WAH $388801-\mathrm{C} ; \mathbf{1 8 4}, 37443-\mathrm{D} ; \mathbf{1 8 5}, 85-4064^{*} ; 187(t o p), 85-4077-82 ; 187$ (bollom), 85-4077-15; 188 (left), 85-4077-4; 188 (right), 85-4077-14; 189, Victor Krantz; 190, 24939; 192. MAH 30680-B; 193 (left), National Museum of American Art; 193 (right), 85-4067; 194 (left), 85-4071-5; 194 (right) 85-6370-25; 195, 854072-11; 196, 85-4068*; 197, 85-4073-10; 198, MNH-778; 201, 27I $84^{* * ;}$ 203, Thomas Harney; 204 (top), MNH 3885 I-N; 204 (bottom), 77-2089-27; 205 (left), 2477-A; 205 (right), MNH 2477; 206, 85-4069; 213, Roy Clark. 



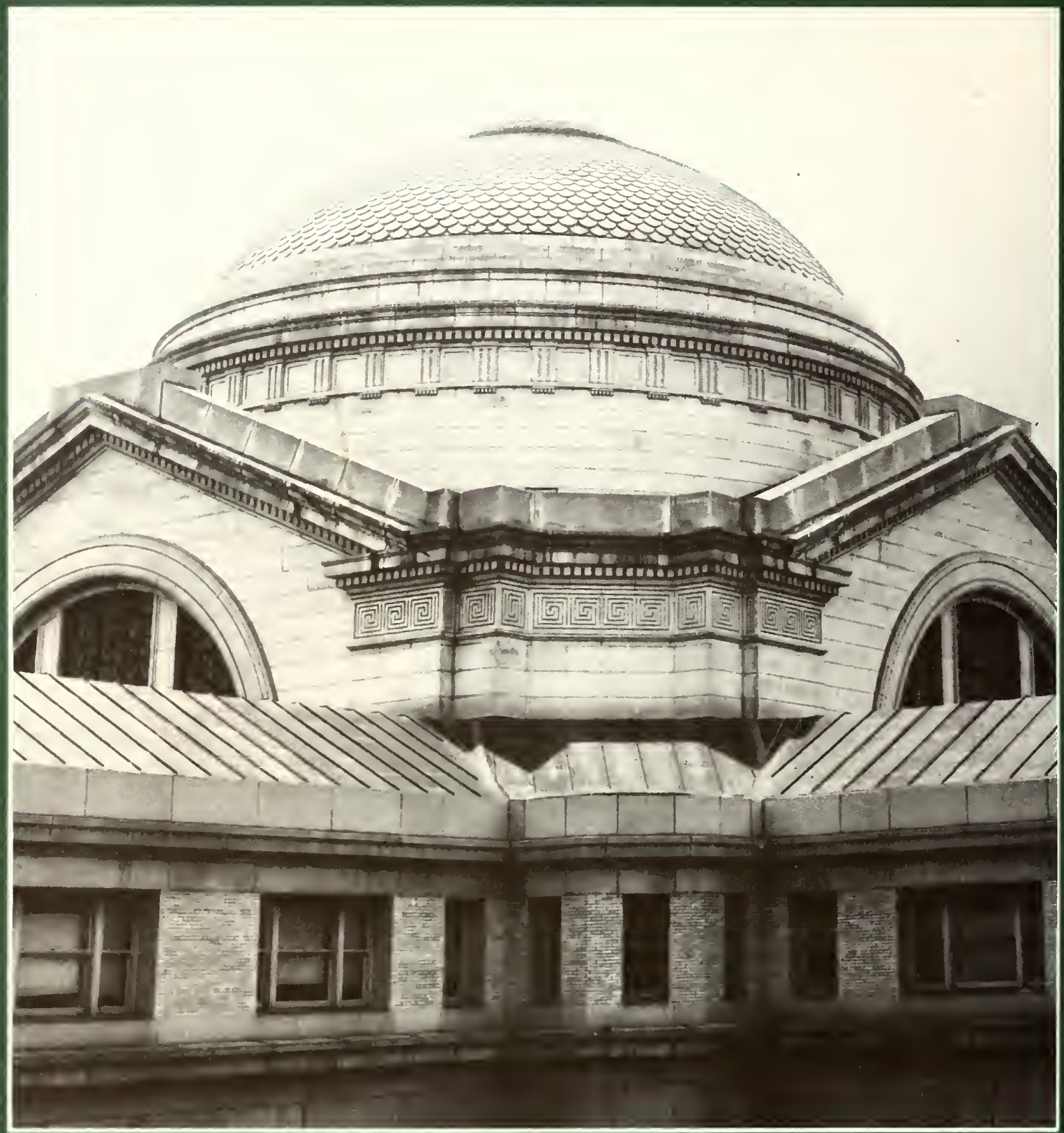





\section{$x^{2}+x^{2}$}

